UNITED STATES DEPARTMENT OF THE INTERIOR

Harold L. Ickes, Secretary

GEOLOGICAL SURVEY

W. C. Mendenhall, Director

Professional Paper 200

\title{
GEOLOGY AND ORE DEPOSITS OF THE \\ MAGDALENA MINING DISTRICT, NEW MEXICO
}

\author{
BY \\ G. F. LOUGHLIN AND A. H. KOSCHMANN \\ Prepared in cooperation with the \\ STATE BUREAU OF MINES AND MINERAL RESOURCES \\ NEW MEXICO SCHOOL OF MINES
}

UNITED STATES

GOVERNMENT PRINTING OFFİCE

WASHINGTON : 1942

For sale by the Superintendent of Documents, Washington, D. C. . . . . . . . . Price $\$ 2.00$ 



\section{CONTENTS}

Abstract..

Introduction

Field work and acknowledgments

Bibliography

Geography

Location of the area

Relief _...........

Valleys and drainage

Climate _. _

Vegetation_...

Geology _...

Pre-Cambrian rocks_._._.

Argillite ("greenstone") and schist_........

Distribution and structure

Lithology

Gabbro

Distribution and occurrence...........

Lithology _. _ .

Felsite

Distribution and occurrence...........

Lithology _...

Granite_._.

Distribution and occurrence...........

Lithology_...........

Chemical composition and classification

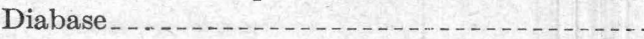

Distribution and occurrence...........

Lithology ..............

Biotitization of the pre-Cambrian rocks

Correlation__._.

Carboniferous system, by V. T. Stringfield, A. H.

Koschmann, and G. F. Loughlin

Kelly limestone (Mississippian) _.............

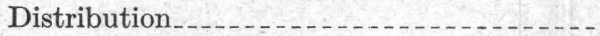

Age and correlation

Magdalena group (Pennsylvanian) _.........

Sandia formation .....................

Lower quartzite member........

Lower limestone member............

Middle quartzite member..........

Shale member.

Upper limestone member............

Upper quartzite member..........

Madera limestone..................

Age of the Magdalena group

Abo sandstone (Permian)

Tertiary (?) sedimentary rocks _........ Quaternary system

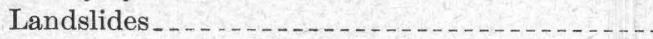

Alluvium _. _...

Talus _._

Tertiary (?) effusive igneous rocks _.............

General statement.

Lower latite tuff _._.

Lower andesite..............

Upper latite........

Purple andesite

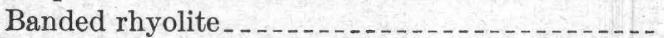

Red andesite.
Page Geology-Continued Page

Tertiary (?) effusive igneous rocks - Continued.

Red rhyolite $\ldots \ldots$

Upper andesite $\ldots \ldots \ldots \ldots$

Pink rhyolite_.....

White felsite tuff__._.

Tertiary (?) intrusive igneous rocks _._._. _ _._. 32

General statement_...

Latite porphyry _.....

Latite dikes_._.

Rhyolite porphyry _.................... 33

Typical facies_......

Magnetic facies____

Hornblende andesite . . . . . . . . . . 35

Augite andesite

Monzonite group _._......... 36

Typical facies.....

Other facies_..........

Chemical composition and classification.... $\quad 39$

Tertiary (?) granite $\ldots \ldots \ldots \ldots \ldots$

Distribution and occurrence_._._._. _. $\quad 39$

Lithology _._

Aplite dikes_...... 40

Pegmatitic material_....... 41

Granophyre _... 41

Hybrid granophyre _...

Pitchstone ............... 42

Lamprophyre dikes . . . _

White rhyolite $\ldots \ldots \ldots$

Differentiation_... _............ 44

Rock alteration and its significance _._._.

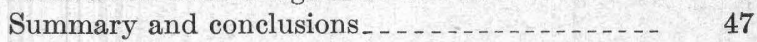

Alteration near intrusive contacts__._._._. 49

Alteration of pre-Cambrian rocks_._._... 49

Alteration of shale

Alteration of limestone _...... 50

Marbleization ......... 50

Silication

Alteration far from intrusive contacts _. . . . . . . 51

Alteration in the northern area_....... 51

Alteration in the southern area

Silicification

Hematitization _............. 54

Alteration to clay minerals and celadonite

Structure _ _

Summary of deformation

Pre-Cambrian structure $\ldots$

Paleozoic and Mesozoic structure___._._._. 56

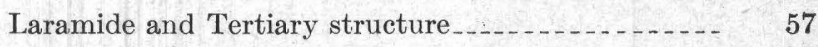

Folds

Faults_...

Faults south of the Nitt stock

East-dipping longitudinal faults_..... 58

Germany fault zone

Stonewall fault zone_._._._._. 59

Crest fault_._._._. 59

Other east-dipping faults_._._._. 60 
Structure-Continued.

Laramide and Tertiary structure-Continued.

Faults-Continued.

Faults south of the Nitt stock-Continued. Vertical or steeply dipping longitudinal

faults ...........................

Kelly-Graphic fault .............

Mistletoe fault

Young America fault............

Grand Ledge fault ................

East Slope fault ..............

Waldo fault

Faults between Kelly and South

Camp

Transverse faults . . . . . . . . .

Bedding faults........................

Faults north of the Nitt stock

Faults within Tertiary (?) granite $\ldots$

Vindicator fault...................

Stendel fault ..........

Faults in the Granite Mountain area .....

Interpretation of Laramide and Tertiary structure

Deformation before volcanic eruptions...-

Deformation between the first and second stages of volcanic activity

Deformation after the second stage of volcanic activity

Local faulting during the intrusion of stocks_

Minor adjustments after stock intrusion but before ore deposition.................

Minor adjustments after ore deposition ....

Physiographic development ....................

Ore deposits

Historical sketch

Production.

Minerals of the Magdalena district, by S. G. Lasky and G. F. Loughlin

Iron minerals

Sulphide zone

Pyrite

Pyrrhotite

Oxidized zone

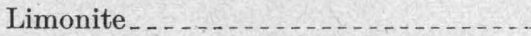

Jarosite or natrojarosite ...............

Melanterite .......................

Zinc minerals

Sulphide zone.

Sphalerite (zinc blende)

Oxidized zone

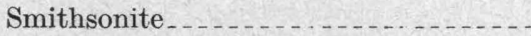

Hydrozincite ........................

Aurichalcite........................

Chalcophanite

Hemimorphite (calamine)

Willemite

Goslarite

Zinc-bearing clay or "tallow clay"...

Copper minerals_.......................

Sulphide zone (hypogene)

Chalcopyrite

Bornite

Chergene)

Covellite.
Page

Ore deposits-Continued.

Minerals of the Magdalena district-Continued.

Copper minerals-Continued.

Malachite

Azurite

Chrysocolla.

Native copper.......................

Cuprite

Tenorite

Chalcanthite .....................

Antlerite...........................

Spangolite

Cyanotrichite .........................

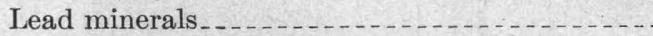

Sulphide zone $\ldots . . . . . \ldots \ldots \ldots$

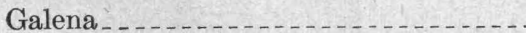

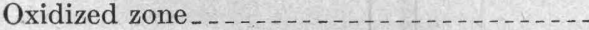

Anglesite . . . ....................

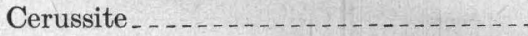

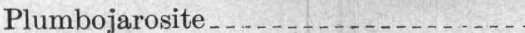

Vanadinite

Silver minerals

Sulphide zone (hypogene)

Sulphide zone (supergene) _................

Argentite (?)

Native silver .....................

Oxidized zone $\ldots \ldots \ldots$

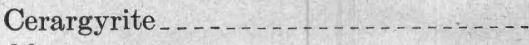

Native gold

Manganese minerals

Sulphide zone

Oxidized zone.

Pyrolusite, psilomelane, and wad _.... 99

Cadmium mineral greenocite

Gangue minerals ..........................

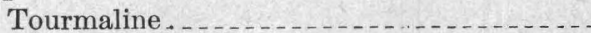

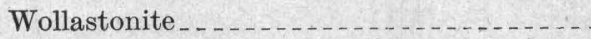

Andalusite.

Diopside..

Hedenbergite

Tremolite and actinolite

Garnet.................

Epidote

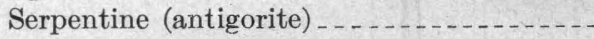

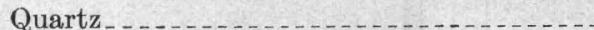

Sericite

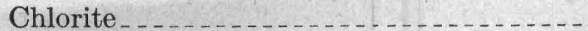

Thaumasite

Siderite

Dolomite

Calcite ..............

Aragonite

Barite

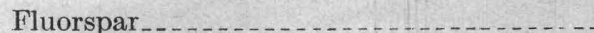

Clay minerals _...

Celadonite

Distribution and classification of mineral deposits

Deposits formed at high temperatures ..............

Deposits formed at moderate temperatures

Large barren quartz veins in igneous rock......

Sulphide deposits

Hotter mesothermal ores..................

Iron and copper (pyritic) ores........

Zinc blende, galena, and mixed sulphide ores

Cooler mesothermal (leptothermal) ores _. -
96 
Ore deposits-Continued.

Deposits formed at low temperatures

Genesis of original (hypogene) ores

Processes in limestone.....................

Early, silicate-forming stages............

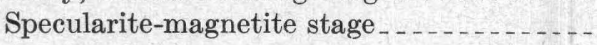

Ore-forming stages _._.

Processes in igneous rocks

115

Oxidized iron and iron-manganese ores_...... 115

Lead carbonate ores....

Zinc carbonate ores...........

Oxidized copper ores_.................. 117

Oxidized gold ore $\ldots \ldots \ldots \ldots \ldots \ldots$

Oxidized silver ore $\ldots \ldots \ldots \ldots \ldots$

Zones of alteration $\ldots \ldots \ldots \ldots \ldots$

Processes of alteration _................... 120

Alteration of country rocks _.._.

Alteration of sulphide ores _._._.

Solution of primary sulphides _.......... 121

Redeposition as products of oxidation _.... $\quad 121$

Zinc carbonate stage _............ 121

Iron-manganese oxide stage $\ldots . . . \ldots . . .122$

Lead carbonate stage

Final base-metal stages......... 122

Precious metal stage ........... 123

Mines_._. _..._.

Mines in the main ore zone _..._.

Nitt mine _._.

Graphic-Waldo or Ozark mine_........... 124

Main workings _._.

Small tunnels east of Graphic tunnel_..... 131

Mitchell tunnel_._._.

Kelly mine

Juanita mine_...

South Juanita (Juanita Extension) mine.......
Mines-Continued.

Mines in the main ore zene-Continued.

Black Cloud and Mistletoe mines............ 141

Young America, Imperial, and Enterprise claims_ 143

Linchburg tunnel_...................... 144

Woodland mine......................... 145

Cavern and Grand Ledge mines _........... $\quad 145$

Connelly tunnel_............ 148

West Virginia tunnel _._.

Victor tunnel_.................... 148

Mines and prospects east of the main ore zone _..._. 148

Sampson claim _..._.

Grand Tower and Legal Tender claims_....... 148

Germany mines_._.

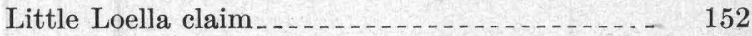

Tip Top and Key mines _._.

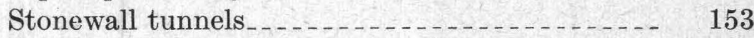

Ambrosia mine _...

Sleeper tunnel_.._

Prospects west of the main ore zone _.......... 156

Mines north of the Nitt monzonite stock_._._._. 158

Hardscrabble mine .................. 158

Anchor mirie . .

Vindicator mine _............. 161

Outlying prospects

Cavalier claim_.......

Magnetite on Medley ranch _._._._._._. 163

Heister prospect

Future of the district_..._.

Main ore zone south of Nitt stock _._.

Area east of main ore zone

West ore zone

Ore zones north of Nitt stock _._.

Granite Mountain area_._._.

139 Index $\ldots \ldots$

\section{ILLUSTRATIONS}

Plate 1. Map of region surrounding the Magdalena district, showing general geologic features

2. Geologic map of the Magdalena district, Socorro County, N. Mex _._. In pocket

3. A, Kelly, Magdalena Mountain, and Elephant Butte, looking west from dump of Juanita tunnel; $B$, Northern part of Magdalena Range, looking east from Magdalena Mountain

4. Geologic cross sections of the Magdalena district _

5. $A$, Cliff of silicified Kelly limestone resting on argillite, which is cut by a granite dike; $B$, West slope of Magdalena Range, showing its relations to dips of sedimentary rocks

6. A, Photomicrograph of pre-Cambrian granite; $B$, Pre-Cambrian granite showing somewhat rounded quartz grains embayed by interstitial microperthite; $C$, Quartz vein cutting aplite, and in turn being replaced by an irregular veinlet of biotite and calcite (?)

7. $A$, Lamellar structure in weathered latite tuff on the east slope of Granite Mountain; $B$, Photomicrograph of preCambrian granite, showing plagioclase and other salic minerals partly replaced by green biotite and hastingsite; $C$, Ramifying veinlets of biotite partly altered to chlorite and ealcite replacing feldspar in pre-Cambrian granite. _.

8. Generalized columnar section of sedimentary rocks in Magdalena Range

9. Columnar sections showing the variations in character and thickness of the Kelly limestone, the Sandia formation, and part of the Madera limestone

10. A, Photomicrograph of purple andesite, showing mesh of hematite, which probably represents resorbed and oxidized amphibole needles; $B$, Photomicrograph of purple andesite, showing hematite pseudomorphs after amphibole; $C$, Red andesite with groundmass thoroughly obscured by red iron oxide.

11. A, Upper andesite, showing relatively large phenocrysts of plagioclase and smaller phenocrysts of former hypersthene bordered by hematite and internally replaced by what appears to be a clay mineral; $B$, Red andesite, showing groundmass obscured by red iron oxide; $C$, Plagioclase phenocrysts and microgeodes of a zeolite with opal or chalcedony core in glassy portion of upper andesite. 
Plate 12. $A$, Vitrophyre in upper andesite, showing celadonite as vermiculate traces and ringlets around zeolite blebs; $B$, Typical rhyolite porphyry, showing partly resorbed phenocrysts of quartz and feldspar; $C$, Photomicrograph of typical magnetic rhyolite porphyry; $D$, Photomicrograph of magnetic porphyry

13. $A$, Intrusive augite andesite with phenocrysts of altered plagioclase and augite; $B$, Typical hornblende andesite; $C$, Photomicrograph of magnetic porphyry from lower part of the formation.

14. A, Micrographic intergrowth of augite and magnetite with a border of augite and a core of magnetite; $B$, Monzonite showing graphic intergrowth of orthoclase and quartz in sharp contact with orthoclase; $C$, Typical monzonite $\ldots$

15. $A$ and $B$, Intergrowths of orthoclase and quartz with numerous hornblende fibers; $C$, Photomicrograph of mixed rock from a contact between pre-Cambrian gabbro and monzonite; $D$, An enlargement of the fine-grained matrix in $C$

16. A, Photomicrograph of norite from the apophysis on Stendel Ridge; $B$, Photomicrograph of monzonite from west side of mass northwest of Stendel Ridge; $C$, Photomicrograph of facies of typical monzonite from the west side of the mass northwest of Stendel Ridge; $D$, Fibrous hornblende impregnating epidote

17. A, Outcrop of pre-Cambrian granite on north end of Magdalena Range east of Anchor Canyon; $B$, Outcrop of Tertiary (?) granophyre northwest of Stendel Ridge

18. A, Polished surface of Tertiary (?) granite; B, Photomicrograph of "granophyre" from mass west of Granite Mountain; $C$, Photomicrograph of Tertiary (?) granite

19. A, Photomicrograph of metamorphosed sandstone from an inclusion in granite west of Granite Mountain; $B$, Photomicrograph of Tertiary (?) sandstone west of Granite Mountain partly replaced by a micrographic intergrowth of orthoclase and quartz; $C$, Photomicrograph of Tertiary (?) sandstone from mass west of Granite Mountain partly replaced by orthoclase.

20. Map showing distribution of faults .

21. Topographic map showing the limits of pediment $\mathrm{B}$ and the approximate limits of the older dissected pediments $\mathrm{C}$ to $\mathrm{H}$

22. A, Foothills of Magdalena Range, looking north from low rhyolite hill three-quarters of a mile west of Kelly; $B$, Upper Patterson Canyon, looking west...

23. A, Magnetite encasing specularite; $B$, Specularite-magnetite aggregate, showing partial replacement of specularite by magnetite; $C$, Magnetite pseudomorphs after specularite; $D$, Magnetite and partly replaced sheaf of specularite blades in a polished crystal face of pyrite.

24. $A$, Banded mixed-sulphide ore from Kelly mine; $B$, Enlargement of part of $A$; $C$, Interfingering pyrite and specularite with sphalerite in a carbonate gangue; $D$, Pyrite crystals and specularite-magnetite blades in quartz gangue .

25. $A$, Pyrite crystal with a zone of small specularite blades; $B$, Cellular smithsonite ("dry bone ore"); $C$, Massive zinc carbonate that has replaced the "silver pipe" bed of the Kelly limestone

26. A, Crustiform fibrous smithsonite; $B$, Concentric amethystine, white, and yellow layers of smithsonite surrounding a cellular mixture composed mainly of brown iron oxide, green malachite, and white smithsonite; $C$, Photomicrograph of ore from Stonewall mine

27. $A$, Chalcopyrite interstitial to light-gray blades of specularite and partly replaced by dark-gray covellite; $B$, Inclusions of chalcopyrite in sphalerite segregated near contacts with specularite (Nitt mine); $C$, Inclusions of chalcopyrite in sphalerite segregated near and parallel to contact with a continuous area of chalcopyrite; $D$, Inclusions of chalcopyrite in sphalerite parallel to its contacts with galena and quartz

28. A, Parallel banded silicified Kelly limestone; $B$, Brecciated silicified Kelly limestone recemented by later milky quartz

29. A, Photomicrograph of ore from Graphic-Waldo mine; $B$, Photomicrograph of metamorphic limestone from a bed in the shale member of the Sandia formation east of Granite Mountain

30. Map showing distribution, sizes, and forms of ore bodies mined south of the Nitt monzonite stock

31. Plan of Graphic-Waldo and Nitt mines, showing geologic features and stopes

32. Cross section of the Ida Hill, Waldo, and Graphic workings, looking N. $77^{\circ} \mathrm{E}$

In pocket

33. Plan, longitudinal profile, and cross sections of main ore shoot north of Waldo tunnel, Graphic-Waldo mine

34. Geologic sketch of 200 - and 275-foot levels of the Nitt mine

35. Surface plant of Kelly mine in 1916, looking north

36. Geologic map and workings of the Kelly and Juanita mines_-

37. Plan and longitudinal profile of South Juanita (Juanita Extension) mine

38. Geologic map of the Hardscrabble mine

FIGURE 1. Columnar sections showing variations in character and thickness of the Kelly limestone

2. Sequence of effusive igneous rocks and associated rhyolite sills in the Magdalena district.

3. Bedding faults in Graphic-Waldo mine

4. Diagrammatic interpretations of structural development in the vicinity of the Stendel and Vindicator faults_.--

5. Diagram showing interpreted relations of east-dipping and vertical faults to relative uplift in the main Magdalena Range, and beneath the valley surface between the main range and Magdalena Mountain

6. Diagram of Kelly fault block

7. Diagram showing the Roll fault and an associated bedding fault along the "silver pipe" bed -

8. Profiles showing concordant altitudes of spurs and foothills interpreted as dissected pediments...

9. Generalized section in Graphic-Waldo mine showing relations of specularite-magnetite aggregates to sulphide ore and gangue....

10. "Tallow clay" replacing limestone along a fissure beneath a cap of silicified limestone and passing downward into black manganese-stained material. 
FIGURE 11. Microdrawing showing four distinct stages of growth of a quartz crystal in a drusy cavity in jasperoid ......... 101

12. Generalized cross section through Nitt mine

13. Geologic section along Mitchell tunnel

14. Cross section through Traylor shaft of Kelly mine

15. Cross section along level 10 of Kelly mine

16. Cross section through middle part of Kelly mine

17. Cross section of South Juanita (Juanita Extension) mine _.

18. Map of Linchburg tunnel and shallow workings in the Young America, Imperial, and Enterprise claims

19. Section through main raise near breast of Linchburg tunnel

20. Plan and cross section of Cavern and Grand Ledge tunnels

21. Plan of Grand Tower mine

22. Section from the Germany fault through the Grand Tower shaft, looking N. $74^{\circ}$ E_.........................

23. Map of the Germany mines showing geology of accessible parts

24. Geologic map of Tip Top and Key mines and adjacent Stonewall tunnels

25. Vertical projection of Stonewall tunnels

26. Geologic map of Sleeper tunnel workings _ _

27. Plan and profile of part of Anchor mine

28. Geologic map and cross section of Vindicator mine, looking S. $77^{\circ} \mathrm{W}$ 

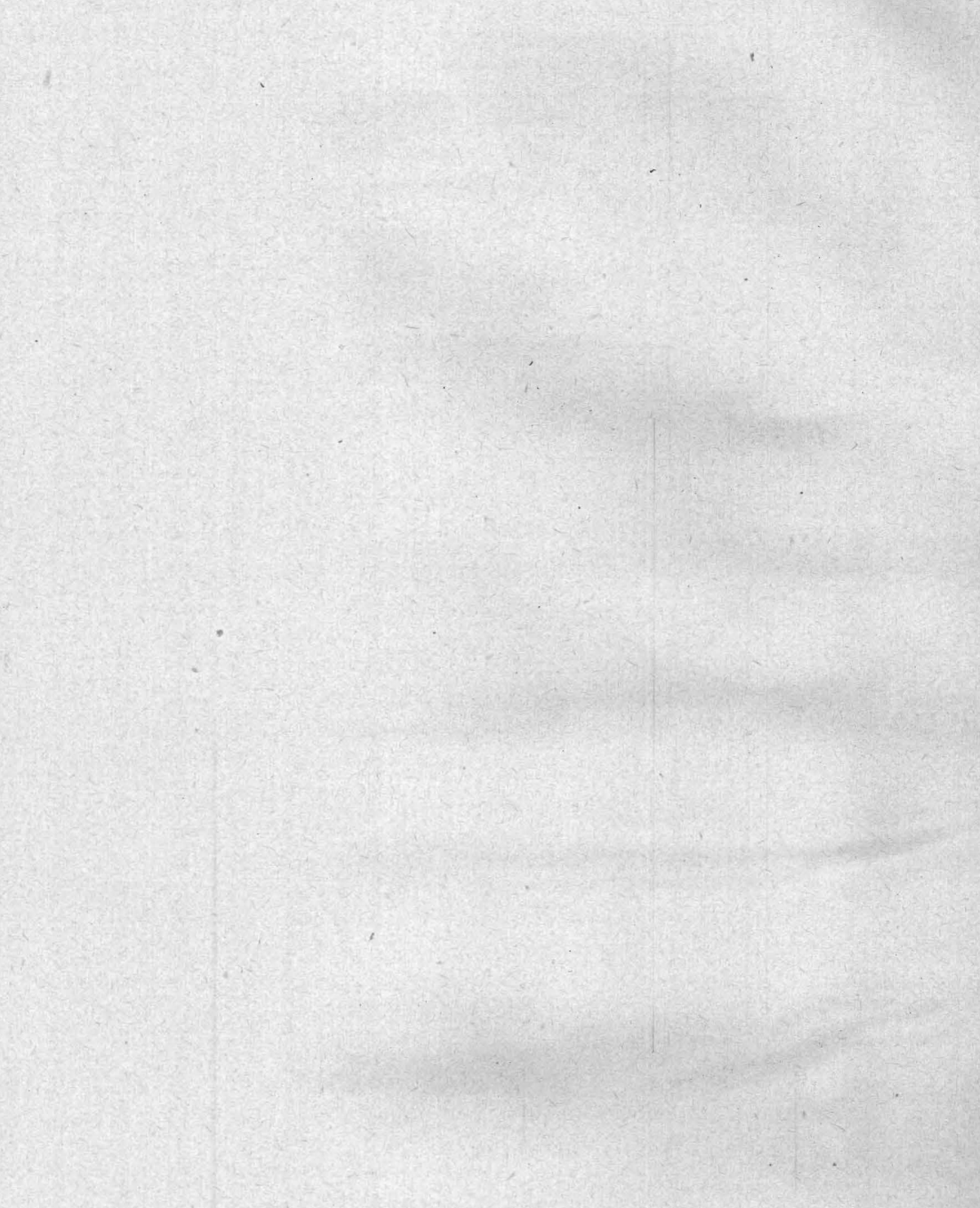


\title{
GEOLOGY AND ORE DEPOSITS OF THE MAGDALENA MINING DISTRICT, NEW MEXICO
}

\author{
By G. F. Loughima and A. H. Koschmann
}

\begin{abstract}
The Magdalena district, in Socorro County, central New Mexico, is about 65 miles south of Albuquerque and 28 miles west of Socorro. It comprises Granite Mountain and the northern part of the Magdalena Range. It has been one of the more productive mining districts in the State, but owing to declining prices in lead and zinc and the depletion of the largest developed ore bodies, its largest mines have been closed or worked on a small to moderate scale by lessees since 1930 . Its early production was chiefly of lead and silver, but since the discovery of zinc carbonate ore in 1903 and the erection of mills to treat sulphide ore a few years later, zinc ore has been the most valuable product.
\end{abstract}

Geology.-The Magdalena Range and Granite Mountain are of the Basin and Range type. They consist of westward-tilted and faulted Carboniferous sedimentary rocks that lie on a basement of pre-Cambrian rocks and are covered with volcanic rocks in part if not wholly of Tertiary age.

The oldest pre-Cambrian formations are argillite and schist. They were invaded successively in pre-Cambrian time by masses of gabbro and felsite, a granite batholith, and many diabase dikes.

From the end of pre-Cambrian igneous activity until Mississippian time the region was subjected to erosion, which exposed the granite batholith. On this erosion surface the Kelly limestone, of Mississippian age, was deposited. This formation, which is $\mathbf{1 3 0}$ feet thick, is the principal ore-bearing formation of the district. The Sandia formation, of Pennsylvanian age, with a total thickness of about 550 feet, overlies the Kelly limestone in apparent conformity, although the two formations do not represent successive periods of time. The Madera limestone, also of Pennsylvanian age, overlies the Sandia formation in apparent conformity. During Permian time the Abo sandstone was deposited on the Madera limestone, without conspicuous angular unconformity, although its basal beds locally contain Madera pebbles, and it is known that some interval elapsed between Madera and Abo time.

No Mesozoic rocks are present.

Tertiary(?) rocks are represented almost entirely by flows, tuffs, and breccias of latite, andesite, and rhyolite, stocks of granite and monzonite, and dikes of lamprophyre and white rhyolite. The volcanic rocks within the district are divisible into two groups, separated by an unconformity. The lower group comprises relatively local basal members of latite and andesite, which overlap the sedimentary rocks unconformably and are overlain by a persistent flow of banded rhyolite, which in the southern part of the district is overlain by more andesite and rhyolite. Northwest of the district the banded rhyolite overlies a Tertiary(?) sandstone and may divide the lower group into two subgroups. The upper group within the district includes andesite and a pink rhyolite which are prominent in the hills west of the main Magdalena Range. South of Kelly the lower group is cut by a sill of latite porphyry, whose relation to the upper group is not known. Both groups are cut by sill-like masses and dikes of a rhyolite porphyry that is considered the youngest member of the upper group, as it is separated from the intrusive stocks by a period of pronounced faulting.

The main granite stock is at the north end of the main range. As it is almost entirely surrounded by pre-Cambrian rocks and Quaternary alluvium, its relations to the monzonite stocks and to structural features are not clear. The sedimentary rocks are flexed along its concealed western margin, but as they were somewhat flexed and eroded before the first volcanic period there is no evidence that the intrusion of the granite was accompanied by thrusting. It is more likely that intrusion took place along a zone of weakness related to earlier flexing.

The main stock of monzonite, the Nitt stock, is of irregular form, and its general position indicates that it was intruded along a zone weakened by intersecting major faults. Minor stocks, in and beyond the northwestern part of the district, are arranged in a zone of north-northwesterly trend in line with the principal zone of faults along which ore-forming solutions rose. The later facies of monzonite are feldspathic and granitic, and one of the smaller monzonite stocks is cut by a granite dike. This evidence suggests that the granite as a whole is later than the monzonite, but there is no direct evidence to determine the relative ages of the main stocks of granite and monzonite.

The lamprophyre and white rhyolite dikes, like the monzonite stocks, also lie for the most part along the structural zone of north-northwesterly trend.

Rock alteration.-Rock alteration is extensive and of different grades. Pure limestone, particularly the Kelly, adjacent to the stocks has been replaced by such silicate minerals as wollastonite, diopside, and garnet (grossularite), which may have been formed during the late, feldspathic stage of monzonite intrusion; somewhat farther away, along ore zones, the limestone has been replaced by hedenbergite, garnet (andradite), and platy calcite; and still farther away by immense masses of jasperoid, which are regarded as equivalent to the silicates in time but which formed below silicate-forming temperatures. Limestone containing hedenbergite and andradite was later replaced by specularite and magnetite, and still later by sulphide ore, which extends far from any intrusive stocks or centers of mineralization.

Siliceous rocks, both sedimentary and igneous, contain a little tourmaline and andalusite close to the stocks and much epidote farther away. Impure limestone is also epidotized. The siliceous rocks are cut by a few large quartz veins, which are thought to be equivalent to the jasperoid masses in limestone. Epidotized volcanic rocks are conspicuous in the northern and central parts of the district. The epidote varies in quantity and is accompanied by varying amounts of chlorite, sericite, and calcite. Sericitized rock is most conspicuous where the 
rocks are veined or impregnated with sulphides. In the southern part of the district the volcanic rocks are impregnated with much red hematite, and some of them contain conspicuous amounts of chalcedonic geodes and quartz veinlets. A few contain small amounts of clay minerals and celadonite, which are believed to have been formed by rising hot water.

Structure.-The principal structural features-homoclinal faulted masses-were formed in Laramide time. Deformation began with flexing, expressed by a change of strike from $\mathrm{N}$. $15^{\circ} \mathrm{W}$. in the Magdalena Range to N. $30^{\circ} \mathrm{E}$. in the Granite Mountain area. Flexing was accompanied by minor reverse faulting and followed by the initiation of normal longitudinal and transverse faulting through gravitative adjustment. The major longitudinal faults dip eastward. Movement along them produced essentially vertical faults on their hanging-wall sides and permitted the settling of intervening wedge-shaped blocks. The transverse faults mark the north and south boundaries of subsided blocks. Renewed movement accompanied by pronounced tilting took place along the east-dipping faults after the first period of volcanic eruption. The second period of eruption was followed by vertical faulting along well-defined zones, especially on the west slope of the main range, and caused renewed movement along vertical faults and associated east-dipping and transverse faults. The valley west of the main range was depressed at this time. This stage of vertical faulting was followed by the intrusion of stocks. The monzonite stocks especially were guided by fault intersections along the main zone. Subsequent recurrent movements within the district were small. They afforded openings for the intrusion of lamprophyre and white rhyolite and the deposition of ore. Movement within the district since ore deposition was trivial, but it was more conspicuous along the northeast base of the range.

Physiographic development.-Physiographic development of the Magdalena Range took place in as many as eight stages of erosion, each defined clearly or obscurely by remnants of rock pediments. Three stages, better defined than the others, are represented by the alluvium-covered pediment at the base of the range, alluvium-covered and other benches about 200 feet higher, and relatively long spurs and summits about 200 feet still higher, including those on Stendel Ridge. The second of these three stages was the one in which practically all of the oxidation of ore took place. Restoration of the surface that represents the oldest of these three stages shows that the main Magdalena Range was then continuous with Granite Mountain, whose summit had just begun to appear above the pediment. Drainage from the west slope of the range may once have been into a closed basin, but rapid erosion of the soft volcanic rocks that filled the valley between the main range and Granite Mountain permitted the heads of tributaries of the Rio Grande system to cut westward and divert drainage from the west slope into its present form. The different stages of erosion may be correlated with the varying rates at which the principal tributaries to the Rio Grande cut their channels through volcanic flows and tuffs of different hardness; lut the youngest pediment and its present dissection may be related to a recent fault along the northeast base of the range.

Economic geology.-Ore was discovered in the Magdalena district in 1866, but so far as known very little ore or bullion was shipped before 1881. From that year to 1939, inclusive, the total value of shipments from Socorro County, which were mainly from the Magdalena district, was $\$ 29,410,112$. Until 1900 the output of the district consisted of lead, with subordinate silver and a little gold. Then copper became the principal metal until 1903, when the zinc-carbonate ores were first recognized. Zinc then became the dominant metal, coming mainly from carbonate ore until 1908 and thereafter mainly from complex sulphide ore. The metal output of Socorro County from 1881 to 1939 comprised $\$ 1,690,096$ in gold, $4,039,459$ ounces of silver valued at $\$ 3,532,705,11,632,843$ pounds of copper valued at $\$ 2,292,217,88,548,427$ pounds of lead valued at $\$ 4,513,649$, and $233,701,399$ pounds of zinc valued at $\$ 17,381,445$. Practically all of the lead and zinc and most of the copper have come from the Magdalena district, but most of the silver before 1903 and of the gold before 1911 came from elsewhere. The district was especially active during the first World War, reaching its peak of production in 1916. Operations almost ceased during the depression of 1921, and since then the district has been a minor producer, at times practically dormant. The largest developed deposits appear to be practically exhausted, but some unexplored ground awaits attention whenever economic conditions justify it.

The mines and prospects lie mainly in three general zones that trend southward from the principal monzonite stock, but the output has come almost entirely from replacement deposits in the Kelly limestone in the central or main zone. A small quantity has come from replacement deposits in other limestones and very little from veins in siliceous rocks.

The primary minerals were deposited at temperatures that ranged from high to rather low. The high-temperature minerals are represented by "contact-metamorphic" silicates that are present in areas adjacent to intrusive stocks and by specularite-magnetite aggregates that are closely associated with minerals formed later at moderate temperatures. The moderate-temperature minerals are represented by the sulphide ores, which are divisible into two groups of deposits that represent the hotter and cooler parts of the mesothermal range. The first group is characterized by massive sulphides with siliceous gangue. It includes the largest ore bodies and lies mostly along the northern part of the Kelly-Graphic fault zone, which is also the main ore zone; but other members of the same group are present in the southern part of the same zone, along the Waldo fault of the western zone, and in the limestone inclusion in the Tertiary (?) granite at the Hardscrabble mine. The second group, characterized by barite and fluorite accompanying massive to disseminated sulphides, includes all the other deposits of the main zone and the ores of all the other zones, both in limestones and siliceous rocks. It is largely associated with enormous masses of barren jasperoid, which replaced limestone during a presulphide stage of deposition and may be an outlying equivalent of the hightemperature or contact-metamorphic silicates.

The three ore zones south of the main monzonite stock, correspond to major zones or groups of faults. Deposits in other parts of the district are too small and scattered to be correlated with well-defined zones. The largest deposits have replaced limestone, mainly along networks of minor faults, fissures, and bedding planes that have been subjected to tensional movements in the main ore zone. The smaller deposits have similar structural relations, although those in siliceous rocks have replaced only the immediate walls of fissures and therefore maintain a veinlike rather than blanketlike form.

The original ores are classified according to mineral composition as pyritic (of no present value), pyritic copper, zinc, lead, and mixed sulphide or zinc-lead. The pyritic copper ores are practically confined to the basal members of the Kelly limestone in the Nitt, Graphic-Waldo (Ozark), and Kelly mines. The reason for this restricted distribution is not clear. The zinc, lead, and mixed-sulphide ores are present throughout the Kelly limestone but mainly above the basal members. The mixed ores predominate, and the zinc ores, which differ from them mainly in the ratio of zinc blende to galena, form local lenticular shoots, some close to the main monzonite stock and others far from it. The lead ores in part form similar but 
much smaller shoots and in part larger masses of originally mixed sulphide ore from which the zinc blende and part or all of the pyrite and chalcopyrite have been leached. Chalcopyrite also forms small streaks of high-grade ore that has little value except as the original sources of certain oxidized copper ores. The silver and gold contents of unenriched sulphide ores are very small, and enriched sulphides in shoots approaching commercial size are exceptional.

The ores are believed to have been derived from the same deep sources as the intrusive stocks and the later lamprophyre dikes. Three local centers of mineralization along the main ore zone are recognized-the Graphic fault block, the northeastern part of the Kelly block, and the Young America and adjoining faults in the southern part of the district. The first two account for the bulk of the district's output. Other centers in the main Magdalena Range are indicated along the Waldo fault west of the Graphic block, the Vindicator fault, which is a continuation of the main ore zone north of the main monzonite stock, and the Hardscrabble mine. Another center, east of Granite Mountain, is obscurely indicated by the presence of high-temperature minerals.

Processes of oxidation have produced iron and ironmanganese oxides in small to rather large masses but of no commercial value; oxidized copper ores, some of unusually high grade, and associated enriched sulphide ore; lead carbonate and zinc carbonate, which constituted the main output of the district until 1906; and gold and silver ores in a few highgrade bunches. As the processes of oxidation and sulphide enrichment were generally similar to those of the Leadville district, Colo., which have been fully described, ${ }^{1}$ only a summary account of them is presented in this report.

Oxidation and enrichment took place, for the most part, during the development of an old pediment surface, called pediment $\mathrm{D}$ in the section on physiographic development. They were limited by local ground-water tables, which in turn were controlled by major faults that served as barriers to underground circulation.

Mines accessible to the authors are described in as much detail as available data permit. Although the principal mines of the district have been practically exhausted under present economic conditions, it is understood that an appreciable reserve of mill ore is still available whenever the outlook for the zinc market is sufficiently favorable. There is also a considerable undeveloped area in the southern part of the district, where the Kelly limestone along the west side of the main fault zone deserves exploration. The future of the district is largely dependent on the results of such exploration.

The ground beneath Hardscrabble Valley, north of the main monzonite stock, is also entitled to further consideration, as the ground-water level there is remarkably deep and the Kelly limestone, if adequately replaced by ore, can be mined without excessive pumping. West of the Waldo fault the Kelly limestone is so deeply buried and the probable quantity of water to be handled so great that there is little to encourage deep development. In the Granite Mountain area also, the shallow ground-water level and the small size of the scattered prospects offer little promise of important discoveries.

\section{INTRODUCTION}

\section{FIELD WORK AND ACKNOWLEDGMENTS}

Subsequent to the publication in 1910 of Professional Paper 68, The ore deposits of New Mexico, the United States Geological Survey had planned a detailed study

\footnotetext{
${ }^{1}$ Emmons, S. F., Irving, J. D., and Loughlin, G. F., Geology and ore deposits of the Leadville district, Colo.: U. S, Geol. Survey Prof. Paper 148, pp. $248-272,1927$.
}

of the Magdalena district, and G. F. Loughlin was assigned to the work. In the fall of 1915 he made a preliminary visit to the district, mainly to study mine workings that were soon likely to become inaccessible. A year later he began a detailed study of the district, but the war activities of the Geological Survey and the consequent shifting of its personnel during and after 1917 made it necessary to transfer Mr. Loughlin to administrative work, where the demands upon his time prevented his completing the report on the district.

In 1928 the newly organized New Mexico Bureau of Mines and Mineral Resources undertook to finish the work. Activity in the district had greatly declined, but the complexity of the geology and its bearing on possible ore reserves justified the completion of the work for both scientific and commercial purposes. During July and August of that year Messirs. A. H. Koschmann and V. T. Stringfield, then connected with that organization, restudied the area mapped by $\mathrm{Mr}$. Loughlin, whose maps and other data were placed at their disposal. During June and July $1929 \mathrm{Mr}$. Koschmann, assisted by Merz Black and Gordon Wells, mapped the geology of the area north of parallel $34^{\circ}$ $07^{\prime}$ and the strip west of meridian $107^{\circ} 13^{\prime}$, and Black mapped the topography of this area. Mr. Loughlin spent about 3 weeks in the field during 1928 and 1929 with the members of the State Bureau reviewing the essential features of the geology.

During the field season of 1916 W. O. Hotchkiss spent 3 weeks in the district tracing formation contacts underneath the alluvium, especially that of the monzonite, by means of the dip needle. In the summer of 1928 Messrs. Don E. Wilson and F. G. Boucher, of the State Bureau, checked a few topographic details, and Messrs. Koschmann and Stringfield revisited the field several times after the regular field seasons of 1928 and 1929 to check questionable points in geology as the report progressed. S. G. Lasky, then of the State Bureau, studied the Nitt mine in 1929 and spent the winter of 1929-30 in Washington assisting Mr. Loughlin in the study of ores and the preparation of mine maps and descriptions. Several chemical analyses were made by the State Bureau and are duly accredited in the text.

Help of various kinds has been received from several persons both in the field and in the office, and the authors are indeed grateful for this assistance. They are especially indebted to the late C. T. Brown and Philip B. Argall, and to J. A. Macdonald, John A. Weir, Paul B. Moore, Ian D. Mactavish, V. Carl Grubnau, F. H. Gordon, Sim Exter, B. A. Statz, G. L. Brooks, and Roy Stendel, who generously gave of their time and supplied many of the mine maps; also to C. M. Glasgow, superintendent in $1915-16$ of the Kelly mine and $\mathrm{Mr}$. Pressler, superintenden in 1915 and Philip H. Argall, 
superintendent in 1916 and later, of the Graphic-Waldo (Ozark) mine; also to C. S. Ross, W. T. Schaller, C. F. Park, Jr., and M. N. Short, of the United States Geological Survey, who kindly determined several minerals, discussed some of the problems involved, and critically read parts of the manuscript, and to T. B. Nolan, who critically read the entire manuscript.

\section{BIBLIOGRAPHY}

Very little detailed geologic work has previously been done in the district, and the literature pertaining to the area consists chiefly of brief articles on some mine or some special problem of geology of the region. In the list of publications below only those articles are given that contain information on the district; articles dealing with adjoining areas or related problems are duly recognized in the footnotes at appropriate places within the text. This bibliography is in part taken from that of Gordon, ${ }^{2}$ and brought up to date.

1882. Silliman, Benjamin, Jr., Mineral regions of southern New Mexico: Am. Inst. Min. Met. Eng. Trans., vol. 10, pp. 424-444; Eng. and Min. Jour., vol. 34, pp. 199-200, 212-219. Describes the geology of the region west of the Rio Grande from Socorro southward and comments on the ore and minerals found.

1897. HERRICK, C. L., The geology of a typical mining camp in New Mexico: Am. Geologist, vol. 19, pp. 256-262. Describes the general geologic features of the Magdalena Range and the fault phenomena of the region.

1898. Herrick, C. L., Papers on the geology of New Mexico: Denison Univ. Sci. Lab. Bull., vol. 11, pp. 87-92; re print, New Mexico Univ. Bull., vol. 1, 1899, pp. 87-92 Describes the geology of Magdalena Mountain and includes an account of the basic eruptions of the Magda. lena district.

1901. Herrick, C. L., Applications of geology to economic problems in New Mexico: Internat. Min. Cong. Proc., 4th sess., pp. 61-64. Describes some of the geologic features and the occurrence of economic minerals.

1903. Johnson, D. W., Block mountains in New Mexico. Am. Geologist, vol. 31, pp. 135-139. Discusses the phenomena of block faulting and describes the occurrence of examples of this type of structure in the central New Mexico region.

1904. HerRick, C. L., Laws of formation of New Mexico mountain ranges: Am. Geologist, vol. 33, pp. 301-312, 393. Describes the geologic structure and physiographic features of several mountain ranges of New Mexico.

Keyes, C. R., Note on block mountains in New Mexico: Am. Geologist, vol. 33, pp. 19-23. Believes the block mountains of central New Mexico to be the result chiefly of one great fault along a single plane.

KEYES, C. R., Remarkable occurrence of aurichalcite: Iowa Acad. Sci. Proc., vol. 11, p. 253. Describes an occurrence of aurichalcite in the Magdalena district.

Jones, F. A., New Mexico mines and minerals: (World's Fair Ed.) Santa Fe, N. Mex., 349 pp. Includes a brief account of the general geology and observations on the occurrence, geologic relations, and character of ore deposits, and mining and production of minerals. Gives a list of minerals occurring in New Mexico.

${ }^{2}$ Lindgren, Waldemar, Graton, L. C., and Gordon, C. H., The ore deposits of New Mexico: U. S. Geol. Survey Prof. Paper 68, pp. 214-217, 1910.
1905. KEYES, C. R., Zinc-carbonate ores of the Magdalena Mouutains: Mining Mag., vol. 12, pp. 109-114. Describes the geology of the range and the occurrence and relations of the zinc ore deposits.

KEYEs, C. R., Northward extension of the Lake Valley limestone: Iowa Acad. Sci. Proc., vol. 12, pp. 169-171. Mentions the occurrence of Lake Valley limestone in several ranges north of the Lake Valley area and gives a section of the Carboniferous formations in the Magualena Range.

1906. Brinsmade, R. B., Kelly, New Mexico.-A zinc camp whose ores have been made available by modern metallurgical methods: Mines and Minerals, vol. 27, pp. 49-53. Gives an interesting historical sketch and brief descriptions of the geology, mine workings, and mining and milling operations; discusses the nature, occurrence, and origin of the ores. Regards the intrusive rhyolite porphyry as the source rock.

HadDon, R. W. Zinc mining in New Mexico : Eng. and Min. Jour., vol. 81 , pp. 845-846. Briefly summarizes geology and descriptions of mineral deposits.

Lindgren, Watdemar, and Graton, L. C., A reconnaissance of the mineral deposits of New Mexico: U. S. Geol. Survey Bull. 285, pp. 74-86. Briefly describes the general geology and structure of the State and then outlines the ore deposits, giving their geographic and geologic distribution. The most productive deposits are post-Cretaceous, and are correlated with an earlier series of intrusions of possibly early Tertiary and a later epoch of effusion of middle or late Tertiary age.

1907. Gondon, C. H., Notes on the Pennsylvania formations in the Rio Grande Valley, New Mexico: Jour. Geology vol. 15, pp. 805-816. Discusses the character and classification of the Pennsylvanian formations in the Rio Grande Valley, with special reference to the lower division, for which the name Magdalena group is proposed.

GoRDon, C. H., Mississippian (Lower Carboniferous) formations in the Rio Grande Valley, New Mexico: Am. Jour. Sci., 4th ser., vol. 24 , pp. 58-64. Describes the occurrence of Mississippian rocks at Lake Valley, Hillsboro, Kingston, and Cooks Peak, and gives lists of the fossils found in them. The name Graphic-Kelly applied by Herrick to these rocks in the Magdalena district is changed to Kelly limestone.

Johnston, W. M., The Kelly mine, New Mexico, and treatment of its ores: Min. World, vol. 27, pp. 267-269. A brief description, with emphasis on the character of ore, which was mostly carbonate but passed into the sulphide zone.

1908. Argatl, P. B., The ore deposits of Magdalena, New Mexico: Eng. and Min. Jour., vol. 86, pp. 366-370. Discusses chiefly the relationship of the ore to the geology, its character and origin.

1910. Lindgren, Watdemar, Graton, L. C., and Gordon, C. H., The ore deposits of New Mexico: U. S. Geol. Survey. Prof. Paper 68, 361 pp. A summary account of the ore deposits of the State, giving the general geologic features and generalizations concerning the ore deposits, followed by a more or less detailed description of the mining districts.

1911. Keyes, C. R., Sulphide ore bodies in oxidized zones: Eng. and Min. Jour., vol. 92, pp. 793-794. Discusses origin of sulphide bodies and argues that they are not remnants of primary deposits but that they are "largely of vadose origin - contemporaneous with the oxidic ores." The ores at Magdalena are given as an example. 
1912. Tutrue, E. G., The Magdalena mining district, New Mexico: Mines and Minerals, vol. 33, pp. 275-277. A brief historical review of the district, followed by a brief description of the geology and the six most important ore horizons.

Statz, B. A., Geology of the Magdalena district, New Mexico: Min. Sci., vol. 66, pp. 406-407. A very brief summary of the geology and origin of the ores.

1915. Jonks, F. A., The mineral resources of New Mexico: New Mexico School of Mines, Min. Res. Survey, Bull. 1, 77 pp. Very briefly describes the distribution of commercial minerals in the State with their geologic occurrence, character, and production; a catalog of all minerals found in the State and their location is appended at end.

1916. RICKARD, T. A., Philip Argall and metallurgical progress (an interview) : Min. and Sci. Press, vol. 112, pp. 119131. Metallurgical problems of Magdalena ore are mentioned on pp. 129-130.

1917. Darton, N. H., A comparison of Paleozoic sections in southern New Mexico: U. S. Geol. Survey Prof. Paper 108-C, pp. 31-55. Gives the distribution and a comparison of the Paleozoic formations in the southern part of the State.

1922. Fintay, J. R., Report of appraisal of mining properties of New Mexico: New Mexico State Tax Commission, 1921-22, pp. 52-54. Gives brief general comment and information regarding the Empire Zinc Co. (Kelly mine), Ozark Smelting \& Mining Co. (Graphic mine), Mines \& Metals Co. (Ambrosia and Juanita mines), and TriBullion Smelting \& Development Co. (Nitt mine).

1923. Нотснкіss, W. O., Magnetic methods for exploration and geologic work: Am. Inst. Min. Met. Eng. Trans., vol. 69, pp. 36-47. Discusses general principles of magnetic methods and then gives instances of practical application in the field, including results obtained in the Magdalena district.

KeYEs, C. R., Brass ore in nature: Pan-Am. Geologist, vol. 39 , pp. 75-76. A popular brief description of aurichalcite in the Graphic mine.

1928. DARTon, N. H., "Red beds" and associated formations in New Mexico: U. S. Geol. Survey Bull. 794, 356 pp. Discusses first the general stratigraphy of the State and then the local geology of many areas.

1933. Sснмтт, HARRIson, Structural associations of certain metalliferous deposits in southwestern United States and northern Mexico: Am. Inst. Min. Met. Eng. Contr. 38 (Class I, Mining Geology), February 1933. Contains a short paragraph attributing localization of ore to replacement along auxiliary faults cutting Kelly limestone on the hanging-wall side of a master fault of east-northeast trend and south-southeast dip.

\section{GEOGRAPHY}

\section{LOCATION OF THE AREA}

The Magdalena district lies in Socorro County in the central part of New Mexico about 65 miles south of Albuquerque and 28 miles west of Socorro (see pl. 1). It possesses features typical of the Basin and Range province and lies in the southeast extension of that province. ${ }^{3}$ The area included within the district that has been mapped in detail (pl. 2) contains the north end of the main Magdalena Range and, to the

\footnotetext{
${ }^{3}$ Fenneman, N. M., Physical divisions of the United States, map published by U. S. Geol. Survey, ed. 1930.
}

northward, Granite Mountain and its eastern foothills. A western member of the range, separated from the main part by a broad valley of northerly trend, lies about 2 miles west of the area and includes Magdalena Mountain (pl. 3, A). This is also called Picture Mountain, because the distribution of talus and brush on its northeast slope resembles the profile of a human head. The area studied is about 7.2 miles long and ranges in width from 2.7 miles in the north-central part to 2.17 miles in the northern and southern parts, thus covering about 17 square miles.

The main productive area is on the west slope of the main range, but considerable prospecting has also been done in the outlying northern and northwestern parts of the district in the Granite Mountain area. The principal mines are in an area of about 8 square miles in which the town of Kelly, near the base of the range, is centrally located. South of the main producing area the Magdalena district adjoins the Water Canyon and Hop Canyon districts, from which small intermittent shipments have been made.

Magdalena, the principal settlement, lies about 3 miles northwest of Kelly and about 2 miles west of the area mapped, on the east-west State highway that leads westward from Socorro across the San Agustin Plains and Datil Mountains. The terminus of a branch of the Atchison, Topeka \& Santa Fe Railroad that leaves the main Albuquerque-El Paso line at Socorro, Magdalena constitutes the main shipping point for ore as well as for cattle and sheep from an extensive grazing country. A spur track from this branch extends to a loading point for ore nearly $1 \frac{1}{2}$ miles due west of Kelly.

\section{RELIEF}

The major features of relief are the Magdalena Range (pl. 3, B) and Granite Mountain, which are bounded by bedrock floors (pediments) and alluvial plains on the east and west.

The Magdalena Range, like typical ranges of the Great Basin, has a northward trend and consists of tilted and faulted sedimentary and volcanic rocks on a pre-Cambrian basement. The stratified rocks as a whole form the western slope of the range, and their westerly dip largely determines the western slope of the range, as shown in plates 4 and $5, B$. The eastern side of the range consists mainly of pre-Cambrian granite. Its slopes are decidedly more steep and rugged and are cut by gulches that head abruptly along the crest of the range. The mapped area ranges in altitude from 6,025 feet at its northeast corner, along La Jenze Creek, to 9,650 feet at the southeast corner on the crest of the range, but summits of volcanic rock beyond the south limit of the area are considerably higher. The crest of the range, characterized largely by cliffs of silicified limestone, is 
gently undulating. The upper western slope is also comparatively gentle in the southern part of the area mapped, owing to the low angle of dip of the strata, and is good grazing land; but the lower slopes are deeply cut by dry gulches.

Directly north of the Magdalena Range, but separatè from it by a hroad gap, is Granite Mountain, which reaches an altitude of 7,200 feet. Its crest is composed of rhyolite porphyry and latite and at the highest point intrusive andesite. The Paleozoic sedimentary rocks with some volcanic rocks form the low foothills to the east, and intrusive and extrusive rocks with some Tertiary (?) sandstone form the low hills on the west.

\section{VALUEYS AND DRAINAGE}

The largest valley within the area studied is the transverse valley of northeasterly trend that separates the main range from Granite Mountain and connects the broad lowlands to the west and east of the district, as shown on plate 1 . South branches of this transverse valley include the valley between the main range and Stendel Ridge, which will hereafter be referred to as Hardscrabble Valley after the abandoned Hardscrabble Camp which is located in it (pl. 2), and the longitudinal valley that separates the main range from Magdalena Mountain and is mostly just west of the area mapped. Both of these valleys are in downfaulted areas.

There are no permanent streams in the area mapped. Runoff from rains and cloudbursts in excess of that which is absorbed by the alluvium is disposed of by La Jenze Creek (pls. 1 and 2). This creek heads in the southern part of the Gallina Mountains, in general flows eastward, passing north of Granite Mountain, and enters the Rio Salado, which is in turn tributary to the Rio Grande. Its chief tributary within the district is the arroyo that extends along the south and east sides of the Granite Mountain area and has one branch heading at the south end of Harscrabble Valley.

Although there are no permanent streams in the area, the abundant shaly beds and volcanic rocks maintain a shallow circulation of ground water that emerges in intermittent springs either at the outcrop of some impervious bed or where a fault along the western foothills affords escape to water that has traveled downward along westward-dipping beds. North Camp was favored by a permanent spring that rose along a large though obscure fault until the tapping of the fault on level 10 of the Kelly mine diverted the flow. Springs at the head of Patterson Canyon are sufficient to maintain a small stream for a considerable part of the year, and in Hop Canyon, south of the area mapped, water is sufficient to supply Magdalena, except in prolonged dry seasons, as in the early summer of 1928 , when the town had to depend upon water pumped from the lower levels of the Graphic-Waldo (Ozark) mine. Kelly obtains its water from the extensive workings of the Germany mine.

\section{Climate}

The climate of the district is rather mild and is very pleasant during the summer. The following table summarizes the climatic conditions at Magdalena.

Temperature and precipitation at Magdalena, N. Mex. ${ }^{1}$

[Altitude at Magdalena, 6,556 feet]

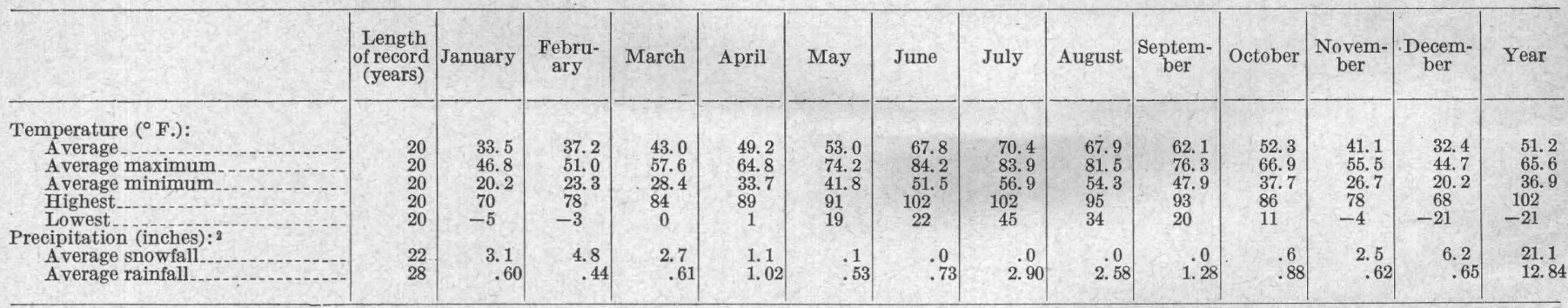

1 U. S. Dept. Agr., Weather Bur., Climatic summary of the United States [from the establishment of station to 1930, inclusive], sec. 27 , Northwestern New Mexico, pp. 12 $17,18-19,1933$.

2. Maximum annual precipitation, 23.84 inches in 1914; minimum annual precipitation, 4.25 inches in 1922; maximum monthly precipitation, 11.70 inches in July 1914

Extreme temperatures are unusual, and the daily and seasonal variations are moderate. The relative humidity is low and, with the aid of an occasional gentle breeze, mitigates the heat of the few hot days. The evenings are usually cool and pleasant. As in other parts of the Rocky Mountain belt, relatively strong winds prevail for about 6 to 8 weeks in spring.

The precipitation is not abundant, but this region has a well-defined rainy season, which usually comes in July and August. During this season daily showers at noon and early in the afternoon are common. On the west slope of the range precipitation is probably greater than that shown in the table. The temperature in winter is sufficiently low for snow to cover the range, and the upper northern and protected slopes may be white from early fall to late spring. 


\section{VEGETATION}

The upper slopes support small clusters of yellow pine, which attain heights of 30 feet or more, but the most abundant trees are the piñon or nut pine, the Rocky Mountain juniper or "cedar," the alligator juniper, and mountain mahogany. The alligator juniper attains a maximum diameter of 3 feet and a height of more than 15 feet, and the mountain mahogany in favored places also attains a height of 15 feet. Tall aspens and other trees are thickly clustered in Patterson Canyon near the spring. The upper, northern and more moist slopes are thickly covered with oak brush and "thorn bushes" or with short grass, which affords grazing, especially on shaly ground. On the lower, more arid slopes sagebrush and cactus, including the cane cactus, and species of flat-leaved and melon-shaped prickly pear are prominent, together with Spanish bayonet and soapweed.

\section{GEOLOGY}

The geologic formations of the district comprise four main groups-sedimentary and igneous rocks of pre-Cambrian age; limestones, shales, and quartzites of Carboniferous age; extrusive and intrusive igneous rocks probably of early and middle Tertiary age; and landslides and alluvial deposits of Pleistocene to Recent age. A little Tertiary (?) sandstone is present southwest of Granite Mountain. The bedrock formations have been tilted and thoroughly broken into fault blocks, and their surface distribution is accordingly complex in detail. But with few exceptions the preCambrian rocks form the east slope of the main Magdalena Range and a few small areas on the west slope, the Carboniferous sedimentary rocks cover most of the main west slope, and the Tertiary(?) igneous rocks form the foothills as well as the lower western slope in the south part of the district. Farther south the Tertiary (?) rocks extend eastward across the summit of the range. In the Granite Mountain area in the northern part of the district pre-Cambrian rocks are limited to a few small outcrops at the eastern end of the exposed bedrock, the Carboniferous rocks are confined to the low hills farther west, and the Tertiary (?) rocks form the higher hills in the central and western part, including Granite Mountain itself.

\section{PRE-CAMBRIAN ROCKS}

Pre-Cambrian rocks form the basement of the district. As the oldest rocks that overlie them in the district are of Mississippian age, their pre-Cambrian age cannot be proved, but it is inferred because of their general structural similarity to pre-Cambrian rocks elsewhere in the State. They include in the order of relative age, argillite and schist, early gabbro or diabase, felsite or aporhyolite, granite, and late diabase. Of these the granite is exposed over the greatest area. An outstanding feature of these rocks is their regional impregnation by green biotite associated with smaller amounts of chlorite, hastingsite, epidote, zircon, allanite, apatite, and magnetite and rarely with fluorite. Solutions depositing these minerals mark the final episode of pre-Cambrian activity in the district and will be discussed at the end of this section.

\section{ARGILLITE ("GREENSTONE") AND SCHIST DISTRIBUTION AND STRUCTURE}

The rocks included under the heading "argillite and schist" on plate 2 comprise argillite and hornblende and mica schists. These rocks and the early gabbro, which is intrusive into them, have been locally called "greenstone" and have been described by Gordon as "greenstone schists." ${ }_{4}$ The argillite forms several small to fair-sized areas chiefly on the west slope in the main range from the vicinity of the Hardscrabble mine to the southeast corner of the district. All these areas represent upthrown fault blocks, although this relation is not so evident in the northernmost area as in the others. Gordon states ${ }^{5}$ that "greenstone" is also exposed north of Water Canyon on the east slope of the range, beyond the south limit of the area mapped.

The mica and hornblende schists crop out on the north end of the Magdalena Range and on the east side of the Granite Mountain area. They are also found as small inclusions in the granite. Their relations with the more abundantly exposed argillite have not been determined, but it seems reasonable to regard them as roughly equivalent in age. The argillite and schist are clearly the oldest rocks of the district, as they are cut by all the pre-Cambrian igneous rocks, which also contain many inclusions of argillite and schists. Such inclusions are well-shown in both the gabbro and granite east of Kelly.

The argillite in general strikes northward and dips vertically or steeply to the east. In the southernmost exposure it strikes N. $20^{\circ}$ E., in the exposure northeast of Kelly N. $25^{\circ}$ W., at the Graphic tunnel N. $2^{\circ}-16^{\circ}$ W., and east of Hardscrabble Camp N. $25^{\circ}-30^{\circ}$ E. There is no evidence of local folding, and the different exposures are regarded as parts of one thick formation, neither the top nor the bottom of which is defined. The thickness exposed in any one area may be as much as 2,000 feet.

Where considerably sheared along premineral faults, the argillite is converted into sericite schist. The best exposures of schist, however, are at the north base of the main range and across the valley at the east end of the bedrock exposures in the northern or Granite Mountain area. At both places the schist is similar in atti-

${ }^{4}$ Lindgren, Waldemar, Graton, L. C., and Gordon, C. H., The ore de posits of New Mexico U. S. Geol. Survey Prof. Paper 68, pp. 243-245, 1910.

Idem, p. 245. 
MAGDALENA MINING DISTRICT, NEW MEXICO

tude to the argillite; in the first exposure it strikes N. $25^{\circ}$ E. and dips $87^{\circ}$ E., and in the second it strikes N. $3^{\circ} \mathrm{W}$. and dips $43^{\circ} \mathrm{E}$. The schist, like the argillite, is cut by granite, pegmatite, and diabase, but the exposures are too few to permit a clear explanation of its higher degree of metamorphism. It is also locally sheared and faulted.

\section{IITHOLOGY}

The typical argillite is prevailingly rather light greenish gray, fine-grained to microgranular, and rather thin bedded. Local varieties are dark gray. Weathered surfaces show distinct banding of relatively light and dark layers, mostly less than an inch thick. Cross bedding on a small scale is commonly present. The mineral grains are too small to be identified without a miscroscope, but the rock has a distinctly siliceous appearance in contrast with the darker-green gabbro and diabase. It is free from cleavage but full of small intersecting fractures, and thus weathers into small angular blocks. At the southern exposure, where shattering along a strong fault zone is excessive, these blocks are so small that the local talus resembles crushed stone. Much of the argillite in this area is bleached and silicified and forms cliffs and pinnacles. The argillite close to the monzonite contact near the Graphic tunnel is also bleached and has the appearance of hornfels.

Microscopic study indicates that the principal minerals are quartz and sericite, with smaller amounts of orthoclase, green biotite, and chlorite. In some specimens clear quartz and feldspar in irregular grains are as much as 0.06 millimeter in diameter; but in others, which contain less mica, they are only 0.01 millimeter in diameter, indicating that the larger size is probably a result of recrystallization. Some quartz and orthoclase grains are clear, but other orthoclase grains and even some of the quartz grains are largely or even wholly replaced by sericite. Biotite and chlorite that is probably derived from biotite form evenly distributed small flakes and, together with a little epidote, also form veinlets, which will be discussed later. The minor constituents are magnetite, plagioclase, apatite, zircon, and locally calcite that forms small irregular patches.

The schist, which is micaceous with the exception of a small inclusion of hornblende schist in granite near the Anchor mine, ranges from banded siliceous rock in the exposure on the north end of Magdalena Range to a very schistose sericitic rock in the Granite Mountain area. The siliceous variety consists of alternating lightgray layers one-fourth of an inch thick and thinner brown and green layers. Its weathered surfaces show distinct cross bedding. In thin section it consists mainly of quartz, orthoclase, chlorite, and muscovite, with minor amounts of magnetite, zircon, and rutile. The quartz and orthoclase grains are irregular and interlocked and have a maximum diameter of 0.02 millimeter but average much less. The quartz grains are free from strain. The orthoclase grains are in part clear and in part sericitized. Chlorite and muscovite with associated magnetite are segregated in rather poorly defined bands and account for the brown and green layers of the rocks. The zircon girains are rather abundant and well-rounded. Rutile forms radiating needles in chlorite.

The sericitic schist is silvery gray and finely foliated. Quartz grains are visible on surfaces across the foliation. In thin section irregular interlocking grains of quartz with oriented muscovite predominate, and biotite, magnetite, chlorite, apatite, and rutile are accessory. The quartz has strain shadows, which indicate shearing subsequent to the crystallization of the schist.

\section{GABBRO}

DISTRIBUTION AND OCCURRENCE

Altered gabbro or coarse-grained diabase that is intrusive into the argillite but older than the granite has been mapped in several areas. The largest mass and the one showing age relations best is that just northeast of Kelly. This mass is bounded in part by faults, so its original outline cannot be readily interpreted; but its western boundary, which roughly parallels the strike of the argillite, and its northerly trend suggests that it is a sill-like mass intruded before the argillite was upturned. It is doubtless continuous beneath the overlying rocks with the smaller areas on the slope to the east. The exposure 2,000 feet northeast of the Graphic tunnel is an altered dike 250 feet thick, of northwest trend. It is cut off on the northwest by monzonite and on the southeast by faults, but it may be continuous underneath the Pennsylvanian formations with the remnant of a much larger dike exposed just east of the crest of the range.

\section{LITHOLOGY}

The gabbro is very similar, except in coarseness of grain, to the diabase that forms dikes in granite. On fresh surfaces it is dark green to black but on weathered surfaces is bleached to gray. Cleavage surfaces of a dark prismatic mineral can be recognized. A thin section of the altered gabbro dike northeast of the Graphic tunnel shows a confusing mass of plagioclase and uralitic hornblende with accessory green biotite, magnetite, leucoxene, apatite, chlorite, epidote, and some calcite. The plagioclase forms about 70 to 90 percent of the rock and consists of microgranular oligoclase in laths 2 to 3 millimeters long Much of it is untwinned, but some grains still show twinning and zoning of the original more calcic plagioclase, which has been altered to oligoclase. Much of the oligoclase is peppered with fine-grained magnetite, which may represent iron enclosed in the original plagioclase or 


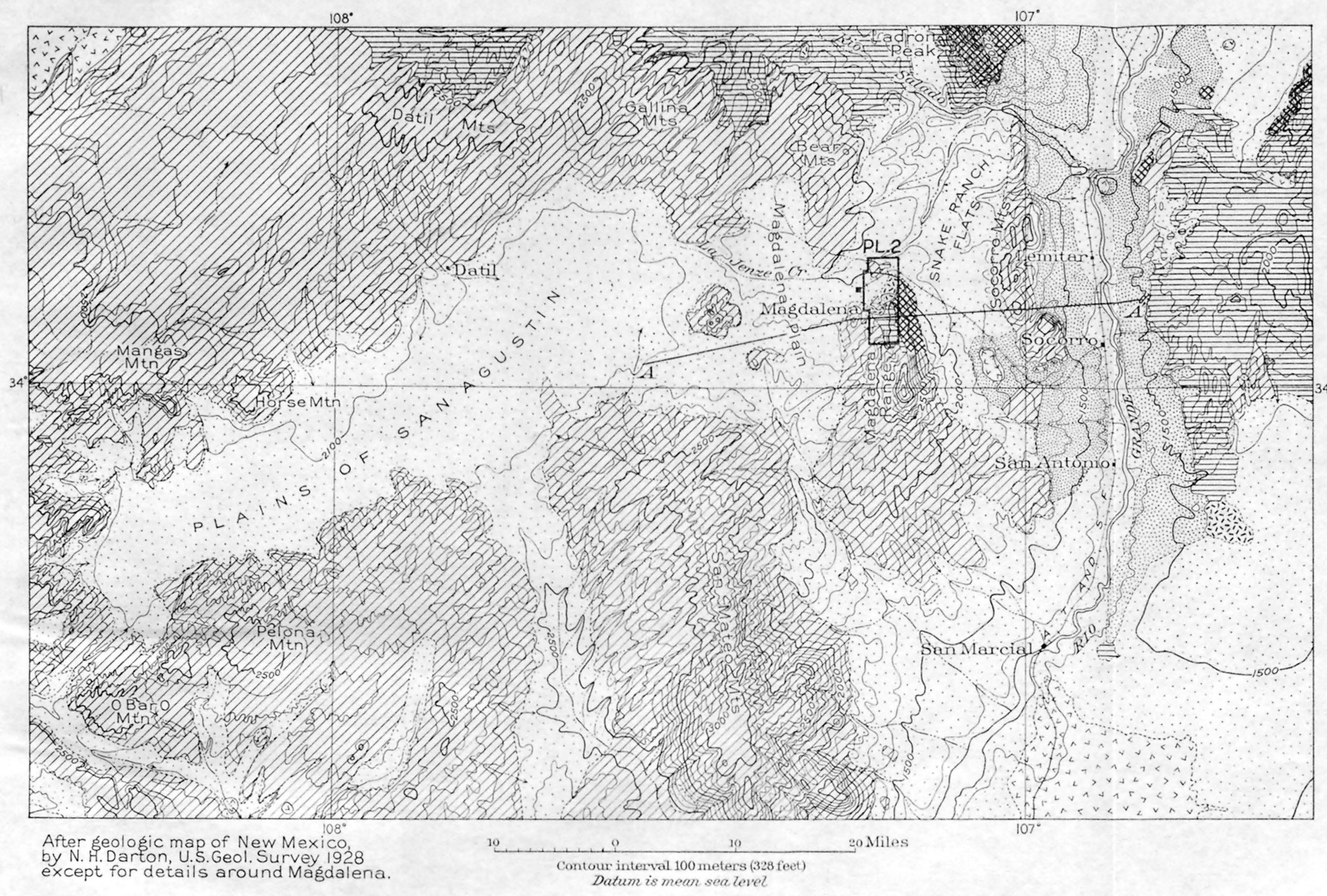

EXPLANATION

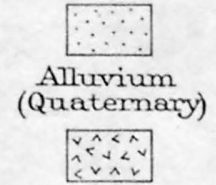

Late basalt
(Late Tertiary to Quaternary)

Tiocene and Pliocene sediments 经湿晹

Intrusive rocks (Tertiary(?)) UIIA

Cretaceous and Tertiary

Carboniferous and Mesozoic sediments m

Pre-Cambrian granite and. argillite

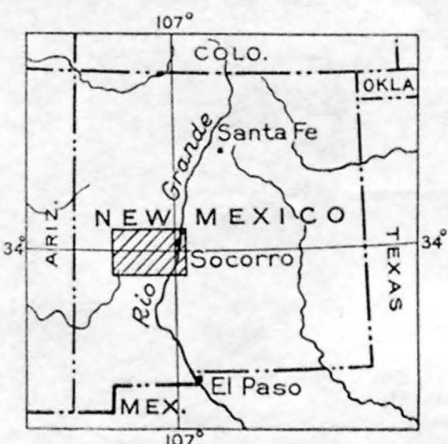

INDEX MAP

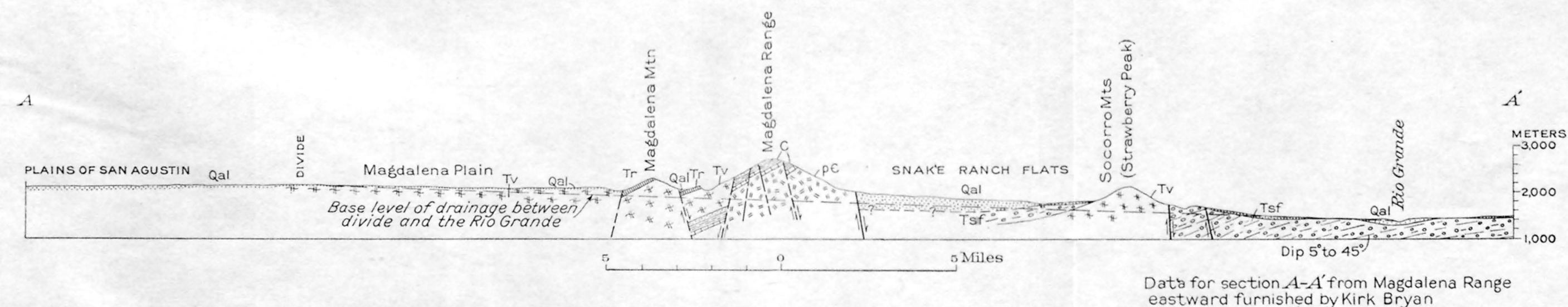

MAP OF REgION SURROUNDING THE MAGDALENA DISTRICT, SHOWING GENERAL GEOLOGIC FEATURES.

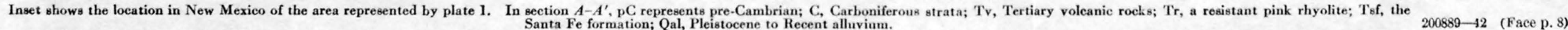




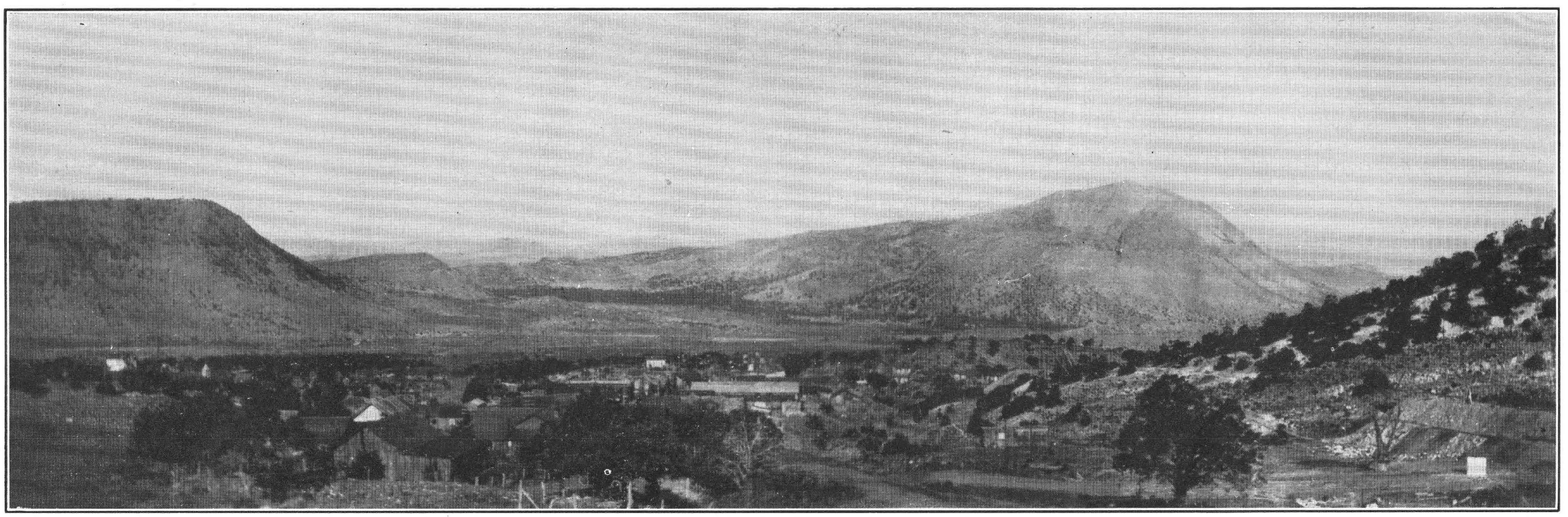

A. KELLY, MAGDALENA MOUNTAIN, AND ELEPHANT BUTTE, LOOKING WEST FROM DUMP OF JUANITA TUNNEL.

Magdalena Mountain, in right middle ground, is also called Picture Mountain because the round patch of talus surrounded by brush on the northeast slope resembles the profile of a human head. The mountain is capped with pink rhyolite, which merges into the dike that forms the high cliff on the east slope. The dike strikes north, parallel to the plane of the picture. The horizontal layers to the left of the dike represent the glassy
top of the upper andesite. The same formations constitute Elephant Butte, on the extreme left and the hill in the southwest corner of the district (see pl. 2 ). The low mounds in the valley between Magdalena

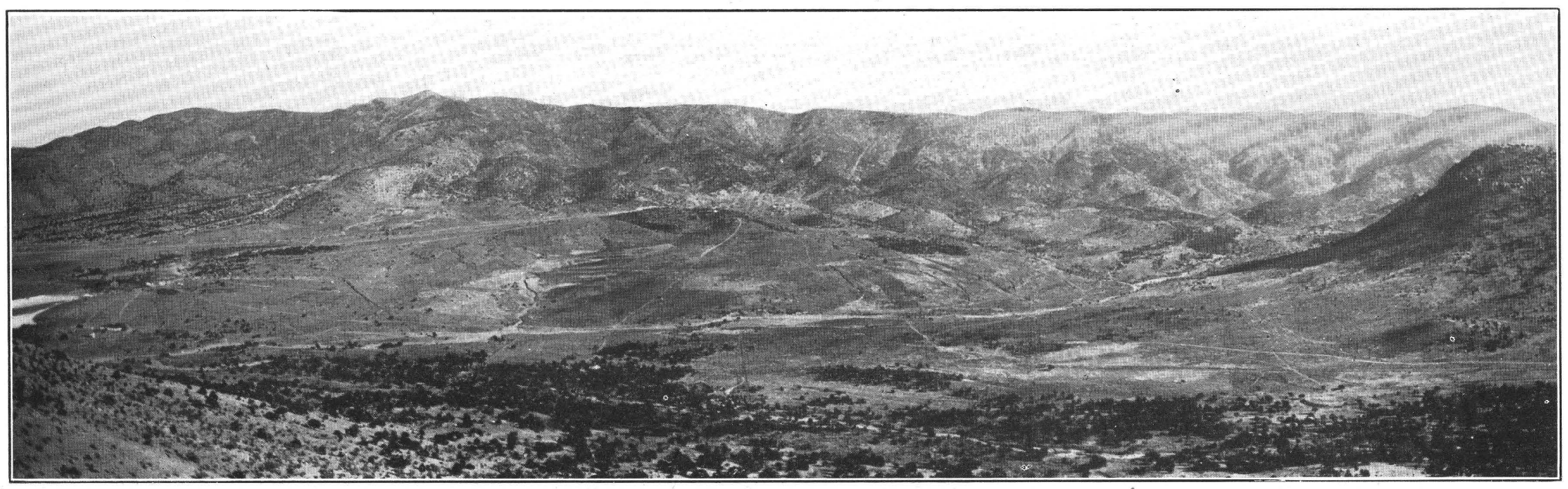

B. NORTHERN PART OF MAGDALENA RANGE, LOOKING EAST FROM MAGDALENA MOUNTAIN.

Shows west-sloping spurs and foothills with a broad alluvium-covered rock plain or pediment in the foreground. Town of Kelly in center. 
1 
introduced during alteration. The uralitic hornblende forms roughly rectangular grains as much as 2 millimeters in length and, together with enclosed grains of magnetite, may be secondary after augite. Much hornblende is also found in microscopic needles that impregnate the plagioclase. Leucoxene forms irregular grains as much as 2 millimeters long and evidently represents original grains of ilmenite.

\section{FELSITE}

\section{DISTRIBUTION AND OCCURRENCE}

Felsite (aporhyolite) is found principally in a triangular area east of Hardscrabble Camp, but small areas of it are also found just northeast of Oak Spring and near the extreme southeast corner of the district; and a few dikes, or faulted parts of one dike, cut the argillite and gabbro near the Germany mines, east of Kelly. The southernmost mass is too poorly exposed to deserve further attention.

The two northernmost masses are evidently parts of an intrusive plug in argillite partly concealed by a cover of Kelly limestone, which there, as elsewhere, rests on a nearly plane erosion surface. The contact of this plug with argillite is nearly vertical, and its intrusive character is best shown near the 7,700-foot contour where small obscure felsite dikes of east-northeast trend, too small to be shown on plate 2, cut the argillite. Inclusions of argillite, some of considerable size, are found near the tunnel at the 7,600-foot contour in the west-central part of the felsite mass, and other remnants of argillite are found close to the contact with overlying limestone along its south boundary. The main felsite mass is cut off on the east by preCambrian granite, which is clearly intrusive into the felsite, although the contact is nearly horizontal. The northernmost part of the felsite is cut by Tertiary (?) granite, and along the southwest it is cut by Tertiary (?) monzonite.

As the steep to vertical contacts between the felsite mass and argillite are nearly at right angles to the strike of the upturned argillite beds, the sequence of the felsite intrusion and of the upturning is obscure; but, as the relations of felsite and argillite to the preCambrian granite are identical, the intrusion of the felsite before upturning seems likely.

\section{LITHOLOGY}

The fresh felsite is dark purplish to black, dense to extremely fine grained, and finely porphyritic; but along the veins on the 8,721-foot summit north of the Ambrosia mine it is bleached almost white. On weathered surfaces it bleaches to light gray and locally to pale pink. Its appearance on both fresh and weathered surfaces is much like the argillite, but it can be distinguished by its porphyritic texture and by the absence of banding, which is usually present in the $200889-42-2$ argillite. Its phenocrysts are feldspar and quartz in grains as large as 3 millimeters in diameter.

Thin sections show phenocrysts of quartz, oligoclase. and perthitic orthoclase embedded in a microgranular groundmass of feldspar and quartz. The quartz phenocrysts are in general well-rounded by resorption and show embayments and reaction rims. They are also much fractured and are sealed with fine-grained quartz. They show strain shadows, and in some sections the greater part of the quartz phenocrysts have been recrystallized into mosaics. The oligoclase is much sericitized in most sections and is the only feldspar present among the phenocrysts in some sections. In others orthoclase, clouded with dustlike particles and less sericitized than the plagioclase, is the only feldspar.

The groundmass is a very fine grained mosaic. The principal minerals are quartz and feldspar with accessory apatite, ilmenite, magnetite, and very little zircon. In some sections the groundmass is much sericitized and silicified. It is crisscrossed by many veinlets that contain green biotite, chlorite, iron oxide, apatite, and sericite. Green biotite is also disseminated and in local segregations. Apatite forms irregular grains associated with green biotite and magnetite and is distinctly secondary. Epidote is very scarce.

The local dominance of plagioclase phenocrysts suggests that the original rock was dacite, at least in part; but the uncertainty as to whether most of the irun, magnesia, and titanium, as well as some silica, have been largely introduced or merely rearranged renders an exact classification impossible. So the rock is designated by the field name felsite rather than aporhyolite or apodacite.

\section{GRANITE}

DISTRIBUTION AND OCCURRENCE

The pre-Cambrian granite covers the largest surface of any formation in the district and closely resembles pre-Cambrian granite found elsewhere in New Mexico. ${ }^{6}$ It forms the east slope of the main Magdalena Range from the extreme north end southward beyond the limits shown on plate 2, and small patches of it have been uncovered in fault blocks on the west slope by erosion of the Carboniferous rocks. The westernmost exposure is near the Germany mines, east of Kelly. None is found in the Granite Mountain area.

The relations of the granite to argillite, schist, gabbro, and felsite are shown to be intrusive, although locally the presence of fine-grained granite near the finely granular facies of the felsite at first gives the impression that the two rocks grade into each other. The northern outcrop of schist is cut by a poorly exposed pegmatite dike composed of white albite, quartz, and small flakes of mica, the only granite pegmatite found in the district. Aplitic stringers cut the gabbro dike northeast of the Graphic tunnel, and inclusons of

' Lindgren, Waldemar, Graton, L. C., and Gordon, C. H., The ore deposits of New Mexico: U. S. Geol. Survey Prof. Paper 68, p. 247, 1910. 
argillite and gabbro are found in the granite that forms part of the pre-Cambrian block east of Kelly.

Small dikes of granite, one of which is shown on plate $5, A$, cut the argillite in the southeastern part of the district and are cut off sharply at the basal contact of the Kelly limestone. These dikes are relatively coarse grained, some grains being as much as 6 millimeters in diameter. The dikes have a maximum width of 4 feet, but most of them are only a few inches wide and are parallel to the banding in the argillite. South of the Germany mines a dike of fine-grained granite or aplite about 40 , feet thick extends beside a diabase dike in gabbro.

The contact of the granite with the older rocks is remarkably regular on the whole, although many short apophyses extend upward from its general level. Along the northern part of the range the contact along the east edge of the felsite is nearly horizontal, and scattered exposures of the contact with older rocks on the west slope near Kelly and in the southern part of the district indicate a westerly slope approximating the dip of the younger sedimentary rocks. (See pls. 4 and $5, A$.)

The abundant fractures in the granite belong to three principal sets-one of northerly trend, one of northeasterly trend, and one about parallel to the upper contact. The more conspicuous fractures of the northtrending set dip east, about normal to the upper granite contract, and in many places they are so closely spaced as to form sheeted zones, which when viewed from a neighboring spur strongly resemble an eastdipping stratified rock. The plane to slightly curving steep, east slopes of spurs in the main granite area have resulted from erosion along these fractures. The more conspicuous fractures of the northeast-trending set dip steeply to moderately northwestward, but fractures with southeasterly dips are conspicuous in places. Gulches of northeasterly trend have been formed by erosion along this set. The set parallel to the upper contact is not so conspicuous on the east side of the range, as it has large angles to most of the slopes and is obscured by debris; but some of the slopes on the east sides of north-trending gulches are evidently controlled by it. Fractures of westerly and northwesterly trends are also present and coincide with the prevailing trends of pre-Cambrian diabase dikes and some of the transverse gulches. Besides these sets there are many minor fractures that break the granite into small blocks of various shapes.

Some fracturing obviously took place in pre-Cambrian time, as some fractures are filled with pre-Cambrian diabase dikes; but intense fracturing also took place during the disturbances that produced faults in Laramide and Tertiary (?) time (pp. 57-73). Many of the more conspicuous fractures are so closely associated with clearly defined faults cutting the Carboniferous rocks that they are consistently correlated with those faults. The set that parallels the top of the granite. however, suggests that it may have been formed in preCambrian time in the same way as the nearly horizontal fractures in granite quarries-by expansion in response to the decrease of load through erosion or in response to superficial temperature changes. Erosion along such fractures may account for the smooth granite surface on which the Kelly limestone rests. The minor fractures, which have no apparent relation to fractures in overlying limestone, suggest at once that the granite surface was much fractured before the limestone was deposited; but deformation of massive granite may produce minor fractures that do not extend into adjacent bedded limestone. In short, the only fractures that can be called pre-Cambrian with any assurance are those that contain diabase dikes and veinlets of minerals attributed to deposition at the end of pre-Cambrian igneous activity (see pp. 12-13).

This failure to recognize different fracture sets of pre-Cambrian age, especially any that have been called primary joints by Cloos ${ }^{7}$ adds to the difficulty of recognizing the form of the granite mass and the process of its intrusion. Its contacts with older pre-Cambrian rocks imply that the upper surface of the granite was determined by fractures (the " $Q$ " joints of Cloos ${ }^{8}$ ) nearly at right angles to the upturned bedding of the argillite. This regularity of contact, together with the scarcity of granite dikes or apophyses that extend upward into the older rocks, suggest that the granite has a sill-like or tack-shaped form; ${ }^{9}$ but the failure to find a floor to the granite mass weakens this suggestion. As the granite mass, so far as known, forms the entire east slope of the range, it is apparently very thick; but, owing to steplike downfaulting to the east, its apparent thickness is somewhat exaggerated. Further speculation should be deferred until a much larger area has been carefully studied.

\section{LITHOLOGY}

The pre-Cambrian granite is prevailingly pink and fine grained, even a long way from its intrusive contacts, although it contains some small, rather coarse grained patches near those contacts. On the lower slopes east and southeast of Tip Top Mountain its grain is not quite so fine. On weathered surfaces it has faded to pinkish gray and may even be stained yellow and buff, and some weathered surfaces have a resemblance to feldspathic sandstone. It consists essentially of pink feldspar and colorless quartz with small to negligible amounts of biotite in small, dark,

${ }^{\imath}$ Cloos, Ernst, in Balk, Robert, Primary structure in granite massives : Geol. Soc. America Bull, vol. 36, pp. 679-696, 1925.

8 Idem, p. 686.

${ }^{9}$ Chamberlin, R. T., Whittling down the batholiths: Geol. Soc. America Bull., vol. 38, p. 109, 1927; Pan-Am. Geologist, vol. 47, p. 65, 1927. Chamberlin, R. T., and Link, T. A., The theory of laterally spreading batholiths : Jour. Geology, vol. 35, pp. 319-352, 1927. 
knotty aggregates. Biotite is almost entirely absent at the north end of the range, where the granite exposed is close to its pre-Cambrian roof, but is more conspicuous in the central part of the district, where the roof and uppermost part of the granite have been removed. Because of the fineness of grain, scarcity of biotite, and abundance of fractures, the granite characteristically weathers into sharply angular blocks, in marked contrast with the coarser-grained Tertiary (?) granite, which weathers into spheroidal blocks, as shown on plate 17. On the lower, eastern slopes, where the pre-Cambrian granite is not so fine grained, its weathered fragments have somewhat rounded corners but still maintain a marked contrast with the weathered Tertiary (?) granite.

The microscope shows the essential constitutents to be quartz and microperthitic orthoclase, in large part micrographically intergrown, as shown on plate $6, A$. Albite-oligoclase amounts to less than 5 percent of the rock. Conspicuous in the rock are secondary green biotite and several minor minerals, which are discussed below.

Only a few quartz and microperthite grains are free from micrographic intergrowth. The independent quartz grains are irregular to rounded, 1 millimeter and less in diameter, and many have undulatory extinction. In places quartz forms clusters, as if remnants of quartzite. Quartz is apparently the earliest of the minerals. It forms rounded inclusions in the albiteoligoclase as well as in the microperthite; and in the quartz clusters the grains are commonly separated and some are even cut and partly replaced by interstitial microperthite, as shown on plate $6, B$. The amount of replacement in this granite is not evident. Graphic intergrowths of quartz and albite are believed by Gilluly ${ }^{10}$ to be a product of replacement in the albite granite near Sparta, Oreg., and the clusters of quartz vith interstitial microperthite likewise suggest that the pre-Cambrian granite at Magdalena is a product in part at least of replacement of some earlier quartzose rock. No such rock, however, was recognized in the pre-Cambrian rocks within the district.

A striking feature of the granite is the secondary green biotite, which occurs disseminated, in clusters of small flakes, in veinlets, and in stringers that are interstitial to quartz and feldspar. In only one section was pale-brown biotite found, and it also occurs in clusters. Many of the clusters grade into veinlets. Biotite is commonly in association with magnetite, and some clusters and veinlets also contain one or more of the following minerals: hastingsite, apatite, zircon, epidote, allanite, calcite, and fluorite. Hastingsite is commonly present though scant. The mode of occurrence of biotite and its associates in veinlets and clusters and the absence of any trace of a former ferro-

\footnotetext{
10 Gilluly, James, Replacement origin of the albite granite near Sparta, Oreg. : U. S. Geol. Survey Prof. Paper 175-C, pp. 72-73, 1933.
}

magnesian mineral show that they are secondary rather than original constituents. One thin section showed a cluster of biotite flakes replaced by a network of iron oxide and muscovite.

A thin section from an aplite dike shows the aplite to be similar to the main mass of granite and to consist chiefly of quartz in irregular grains and in poorly developed graphic intergrowth wth microperthite. However, the primary minerals have been largely replaced by secondary quartz, which forms rosettes of radiating structure and has produced a well-developed micrographic intergrowth of quartz and feldspar that now predominates throughout the rock. The radial quartz is accompanied by green biotite and a small amount of calcite. A quartz veinlet that cuts the rosettes has been itself fractured and recemented by biotite and a noteworthy amount of calcite. (See pl. $6, C$.) Sericite is present only in negligible quantities.

The replacement of quartz by feldspars, the presence of clusters and veinlets of green biotite, hastingsite, epidote, allanite, calcite, and apatite, and the replacement of aplite by quartz, largely grouped in rosettes, which in turn were subsequently fractured and recemented by biotite and calcite, are clear evidence of partial replacement and probably profound alteration of the original granite. The clusters and veinlets of green biotite and associated minerals in the argillite and felsite, and, to anticipate, in the diabase dikes that cut the granite, as well as in the granite, show that this kind of hydrothermal alteration was regional rather than formational. This regional alteration will be discussed after the diabase has been described.

\section{CHEMICAL COMPOSITION AND CLASSIFICATION}

A chemical analysis of a sample of the pre-Cambrian granite from the head of Anchor Canyon, south of its contact with the Tertiary (?) granite, is recorded below. In the quantitative classification it corresponds to I.3.1.2., but the amount of secondary changes in the rock prevents a definite classification. The high silica content is expressed mineralogically by the unusually large amount of quartz, and the large amount of ferric iron is accounted for by the green biotite and associated magnetite. The titania $\left(\mathrm{TiO}_{2}\right)$ is also probably present chiefly in the biotite. The high ratio of potash to soda reflects the marked predominance of orthoclase microperthite over albite-oligoclase.

Analysis of pre-Cambrian granite

[A. R. Ferguson, analyst, New Mexico School of Mines, 1929]

\begin{tabular}{|c|c|c|}
\hline $\mathrm{SiO}_{2--}$ & 75. 73 & $\mathrm{~K}_{2} \mathrm{O}$ \\
\hline $\mathrm{Al}_{2} \mathrm{O}_{3-}$ & 11. 93 & $\mathrm{H}_{2} \mathrm{O}-\ldots$ \\
\hline $\mathrm{Fe}_{2} \mathrm{O}_{3-}$ & 2. 19 & $\mathrm{H}_{2} \mathrm{O}+\ldots$ \\
\hline $\mathrm{FeO}$ & .67 & $\mathrm{TiO}_{2-}$ \\
\hline $\mathrm{MgO}_{-}$ & .29 & $\mathrm{CO}_{2-}^{-}$ \\
\hline $\mathrm{CaO}_{-}$ & .83 & \\
\hline $\mathrm{Na}_{2} \mathrm{O}$ & 2. 57 & \\
\hline
\end{tabular}


DIABASE

\section{DISTRIBUTION AND OCCURRENCE}

A large group of diabase dikes with a general westerly trend is present on the east slope of the range and also in the small areas of pre-Cambrian rocks east of Kelly. There are other small groups with dominant westerly trends near the Hardscrabble mine, in the north end of the range, and near the southeast corner of the district. Diabase that cuts schist is exposed in the arroyo on the east side of the Granite Mountain area. The main group of dikes lies transversely to the strike of the argillite and presumably to the major axis of the domed or upwarped area from which the preCambrian cover of the granite was largely removed before the deposition of Carboniferous rocks.

The prevalence of debris in the pre-Cambrian areas renders it difficult to trace the diabase dikes for any considerable distance, or tc correlate exposures on opposite sides of faults; nevertheless, the discontinuity of some of the larger dikes is remarkable, especially that of the largest dike found. This dike is about 4,000 feet south-southeast of Tip Top Mountain. It is 200 feet thick and can be traced eastward for a few hundred feet from its contact with the overlying Kelly limestone without appreciably diminishing its width, but all traces of it abruptly disappear. Its possible westward continuation through granite on the west slope of the range may be concealed by debris, and it may be represented by the remnants of dikes in the small pre-Cambrian areas east and northeast of Kelly. Such a correlation would help to show the amounts of heave or horizontal offset along intervening faults, but the evidence is too meager to be reliable.

LITHOLOGY

The diabase comprises coarse-grained and finegrained varieties, both of which in a few dikes have been sheared into chlorite schist. Both varieties form small as well as large dikes and have no apparent regularity in distribution. The coarse-grained diabase is dark greenish gray, and none of its minerals are identifiable megascopically on unweathered surfaces, although dark-green prismatic cleavage surfaces of a hornblendic mineral are conspicuous. On weathered surfaces the bleaching of altered or replaced feldspar brings out the diabasic texture except where alteration is extreme. The fine-grained variety is grayish black to greenish gray, and the darker facies shows minute glistening cleavage surfaces of biotite.

Thin sections show that the dikes are almost completely altered. In the specimen apparently least altered, collected on the blunt east spur of the peak eastsoutheast of Tip Top Mountain, the microscopic diabasic texture is distinct; but plagioclase is represented mainly by albite-oligoclase in well-developed twinned laths up to 2 millimeters long. It is intererystallized with hornblende and in part replaced by it; the hornblende in turn is in part chloritized. More commonly the diabase consists of a confusing mass of green hornblende, with smaller amounts of chlorite, epidote, and zoisite, granular aggregates and ramifying veinlets of albite, and leucoxene. The diabase shows only small scattered remnants of the original pyroxene and ilmenite and the usual unaffected crystals of apatite and zircon. Sericite was prominent in only one thin section. Green biotite, similar to that in the other pre-Cambrian rocks, was present in another. The thoroughly sheared dikes consist mainly of chlorite, with irregular stringers of sericite and quartz. Impregnating grains and veinlets of quartz and calcite have been noted in some thin sections. A thin section of the grayish-black, finegrained diabase consists essentially of zoisite, green biotite, chlorite, hornblende, and epidote, with only a scattering of granular feldspar, probably albite, ilmenite replaced by leucoxene, and probably quartz. This rock is distinctly different both megascopically and microscopically from the diabase dikes and may be an altered pre-Cambrian lamprophyre dike.

The green biotite in these rocks is also of interest. It is disseminated in two of the specimens studied and shows no evidence of its age relations to the other minerals; but its green color is indicative of its relationship to the green biotite found in the other preCambrian rocks and, in view of the association of epidote with the biotite in the granite, it is probable that the epidote and zoisite in the diabase, as well as the general alteration of the diabase, are contemporaneous with the biotite.

\section{BIOTITIZATION OF THE PRE-CAMBRIAN ROCKS}

A striking feature of the pre-Cambrian rocks of the district is the general presence of green biotite in veinlets as well as in disseminated grains. The biotite and associated minerals are probably secondary in origin. The presence of this biotite in all of the pre-Cambrian rocks and its absence from the Paleozoic and Tertiary (?) formations show that it was formed in preCambrian time, and its unusual but uniform character points to its probable development at one time, after the intrusion of diabase. It is most commonly associated directly with magnetite, but in the granite it is also accompanied by hastingsite, epidote, zircon, allanite, and apatite and rarely by fluorite. Apatite associated with green biotite and magnetite was unusually abundant in one section of felsite. Chlorite, which is also abundant in the felsite and argillite, may represent altered biotite. In the argillite and felsite the especially common mineral is sericite, and in the gabbro and diabase the common secondary products are epidote and zoisite.

Development of green biotite in so many different kinds of rock evidently required uniformity of temperature, pressure, and composition of the source ma- 
terial. These rocks in general show no signs of dynamic metamorphism, other than the conversion of a few diabase dikes into chlorite schist; the biotite is therefore to be attributed to solutions that acted under uniform physical conditions throughout the area. To the unaided eye the granite and felsite appear unaltered except along Tertiary (?) veins. Allanite, hastingsite, zircon, apatite, and fluorite in association with biotite are commonly ascribed to a higher temperature of deposition than the common hydrothermal minerals. Biotitization is one of the common modes of rock alteration in the Engels mining district, California, ${ }^{11}$ and its origin is similarly ascribed. Knopf and Anderson ${ }^{12}$ point out that rocks in which biotite, actinolite, and plagioclase have formed metasomatically "are bound to look fresh and unaltered." Judging from the wide distribution of the green biotite in the Magdalena district, these high-temperature solutions under great pressure permeated even the most minute cracks and thoroughly soaked the country rock. The biotite and associated minerals are therefore found in veinlets, clusters with small apophyses, and disseminated grains that have replaced the primary minerals. Furthermore, the distribution of the disseminated and clustered biotite is .irregular (pls. 7, $B, C$ ) and in marked contrast to the primary biotite of ordinary granite. Nowhere in the granite was residual material such as spongy iron oxide found to show the former presence of original ferromagnesian minerals, and it is not very likely that residual iron oxide could have been completely removed. The evidence as a whole, therefore, clearly indicates the secondary origin of the green biotite and associated minerals.

Whether other secondary minerals disseminated through the rocks, but not found with the biotite in veins and clusters, are contemporaneous with the biotite is not certain. It seems probable that the composition of the solutions that first deposited the veinlets and clusters of biotite and associated minerals was sufficiently changed by reaction with the original rock minerals to produce different groups of disseminated secondary minerals, depending upon the character of the permeated country rock; thus in argillite and felsite the most abundant disseminated secondary mineral is sericite, whereas in the gabbro and diabase the most abundant are epidote and zoisite. These disseminated minerals may also be interpreted as the products of an earlier stage of hydrothermal alteration from that represented by the biotite. The evidence of their relations to the biotite is not conclusive, but the association of epidote with the biotite in veins at least suggests that the silicate veinlets and the disseminated secondary minerals are contemporaneous.

\footnotetext{
11 Knopf, Adolph, and Anderson, C. A., The Engels copper deposits, California : Econ. Geology, vol. 25, pp. 14-35, 1930.

12 Idem, p. 33.
}

In the gabbro and diabase it was evidently hornblende, in which the biotite is enclosed, and chlorite that furnished most of the constituents for the development of biotite except potash, which must have been introduced; in the granite, and perhaps in the argillite and felsite also, the bulk of all the constituents of biotite must have been introduced. The presence of hastingsite and of the quartz rosettes and veinlets in the aplite dikes indicates that the high-temperature solutions introducing these constituents probably represented the final stage of the pre-Cambrian igneous activity.

The pre-Cambrian rocks and their succession in the Magdalena Range are so similar, except perhaps in degree of metamorphism, to those found in other parts of the State and in the Front Range of Colorado that there can be little question of their direct correlation. Lindgren, Graton, and Gordon ${ }^{13}$ found in their investigation covering the State that the oldest rocks everywhere are sedimentary and include quartzite, mica schist, limestone, and slate. They also report ${ }^{14}$ that some of the "greenstone schist" or argillite in the Magdalena district was "derived from apparently tuffaceous" sediments, but in our microscopic work we have not recognized pre-Cambrian rocks of tuffaceous origin. They suggested correlation with the quartzitic Pinal schists of southeastern Arizona. Tentative correlation may also be made with the Idaho Springs formation of the Front Range of Colorado, ${ }^{15}$ which has a similar range in composition.

The early gabbro of the Magdalena district may correspond in age to the Swandyke hornblende gneiss of Colorado, ${ }^{16}$ which, according to Lovering, represents originally gabbroic and basaltic rocks in part at least intrusive into the Idaho Springs formation, although it may also represent originally calcareous sedimentary rocks. The felsite is not so readily correlated. Metamorphosed volcanic rocks of rhyolitic character are present in the Gunnison River series of Colorado, but they are older than the basic rocks of the series, whereas the reverse order holds at Magdalena.

Regional metamorphism in Colorado was accompanied by the early stages of granitic intrusion, which was followed in turn by the main batholithic intrusion of Pike's Peak and equivalent granites and later more local granites. ${ }^{17}$ On the basis of general structural

\footnotetext{
13 Lindgren, Waldemar, Graton, L. C., and Gordon, C. H., The ore deposits of New Mexico: U. S. Geol. Survey Prof. Paper 68, pp. 26-29, 1910.

${ }^{14}$ Idem, p. 245.

${ }^{15}$ Lovering, T. S., The geologic history of the Front Range, Colo.: Colorado Sci. Soc. Proc., vol. 12, No. 4, pp. 64-65, 1929.

${ }^{16}$ Lovering, T. S., op. cit., pp. 65-66; Geology and ore deposits of the Montezuma quadrangle, Colo.: U. S. Geol. Survey Prof. Paper 178, pp. 10-11, 1935. Colorado geologic map, U. S. Geol. Survey, 1935.

${ }_{17}^{17}$ Lovering, T. S., The geologic history of the Front Range, Colo.: Colorado Sci. Soc. Proc., vol. 12, No. 4, pp. 67-74, 1929.
} 
evidence, the granite at Magdalena is more nearly equivalent to these local granites, which were intruded in the zone of fracture after regional metamorphism had ceased, although they contributed in some degree to the injection of the older rocks with granitic material. The almost negligible amount of typical schist in the Magdalena district implies that the district could have been only on the outskirts of an area of intense regional metamorphism.

Diabase dikes with structural relations similar to those in the Magdalena district are found in the Cripple Creek district of Colorado, ${ }^{18}$ and Gruner ${ }^{19}$ reports late "basic" dikes intruding the pre-Cambrian granite in the southern part of the Taos Range, N. Mex.

The metamorphosing influence of the granite was not extreme and may have been masked in part by later metamorphism. Only in the northern part of the district, where the argillite has been converted into schist and cut by pegmatite, has pre-Cambrian metamorphism been strong. Comparison with other pre-Cambrian areas, notably the Front Range of Colorado, ${ }^{20}$ suggests that the local granite intruded into the zone of fracture represents the latest stage of a complex cycle of metamorphism and batholithic intrusion. Final adjustments after the granite intrusion produced profound fractures normal to the top of the granite and admitted the diabase dikes. The subsequent biotitization of all pre-Cambrian rocks marked the latest expression of pre-Cambrian activity.

\section{CARBONIFEROUS SYSTEM}

By V. T. Stringfield, A. H. Koschmann, and G. F. Loughitn

Although older Paleozoic sedimentary rocks are widespread in southern New Mexico, only the Carboniferous system is represented in the Magdalena district. During pre-Carboniferous time the surrounding region was evidently subjected to continuous erosion; and the pre-Cambrian rocks were worn down to a nearly level surface, upon which the Carboniferous rocks were deposited. These rocks comprise four formations - the Kelly limestone, of Mississippian age; the Sandia formation and Madera limestone, of Pennsylvanian age; and the Abo sandstone, of Permian age (pl. 8).

\section{KELLY LIMESTONE (MISSISSIPPIAN)}

The Kelly limestone, originally called the "GraphicKelly limestone" by Herrick, ${ }^{21}$ after the two leading

\footnotetext{
${ }^{18}$ Lindgren, Waldemar, and Ransome, F. L., Geology and gold deposits of the Cripple Creek district, Colo.: U. S. Geol. Survey Prof. Paper 54, p. $56,1906$.

19 Gruner, J. W., Geologic reconnaissance of the southern part of the Taos Range, N. Mex. : Jour. Geology, vol. 28, pp. 731-742, 1920. ${ }^{20}$ Lovering, T. S., op. cit., pp. 61-74.

${ }^{21}$ Herrick, C. L., Laws of formation of New Mexico mountain ranges: Am. Geologist, vol. 33, p. 311, 1904.
}

mines of the district, was later renamed the Kelly limestone by Gordon, ${ }^{22}$ after the town of Kelly. It is by far the most productive ore zone in the district. It is from 90 to 135 feet thick, but this variation in thickness is due, in large part at least, to bedding faults that commonly escape recognition except in mine workings. The Kelly limestone rests directly upon the very gently undulating pre-Cambrian surface, as shown in figure 1 .

\section{DISTRIBUTION}

The Kelly limestone is exposed almost continuously in two narrow sinuous bands along the crest and the upper western slope of the Magdalena Range from the southeast corner of the district to the Ambrosia mine, near the north end of the range. Where the overlying rocks have been removed these bands broaden into dipslope areas of considerable width. A shorter broken band crops out in the group of small downfaulted blocks in the upper eastern slope due east of Kelly; and small exposures, which represent the most productive part of the formation, are scattered along the western slope between the Juanita and Graphic-Waldo mines. A large metamorphosed block is enclosed in Tertiary (?) granite at the Hardscrabble mine, and one rather large mass is poorly exposed near the east side of the Granite Mountain area.

The Kelly limestone for the most part is a light bluish-gray, medium- to coarse-grained, thick-bedded, high-calcium limestone with a persistent bed of dense argillaceous limestone in its middle part known as the "silver pipe" or "indicator," because of its close association with ore shoots. The name has also come to signify a dense or microgranular texture and has been applied to thinner, less persistent beds both above and below the original "silver pipe." The importance of the Kelly limestone as an ore zone has led to its subdivision into beds that may be readily recognized and followed underground, within a single mine, though some may not persist from one mine to another. These subdivisions are represented in figure 1. Although the Kelly limestone ranges from 90 to 135 feet in thickness, in most places it exceeds 110 feet. The unusually reduced thickness of 90 feet in the Traylor shaft reported by C. M. Glasgow, superintendent of the Kelly mine in 1916, may be related to a bedding fault. The basal beds, from 6 to 16 feet in aggregate thickness, are characterized by grains and small pebbles mostly of quartz, with some of pink feldspar, argillite, and gabbro or diabase. In places they contain sufficient detrital epidote to have a distinct green color. They are best exposed along the crest of the range east and northeast of Kelly, where the very base, which rests on granite and locally on diabase dikes is commonly represented by a bed of pink

\footnotetext{
22 Lindgren, Waldemar, Graton, $\mathrm{C}$, and Gordon, C. H, The ore deposits of New Mexico; U. S. Geol. Survey Prof. Paper 68, p. 229, 1910 ; Am. Jour. Sci, 4th ser., vol. 24, pp. 62-63, 807, 1907.
} 


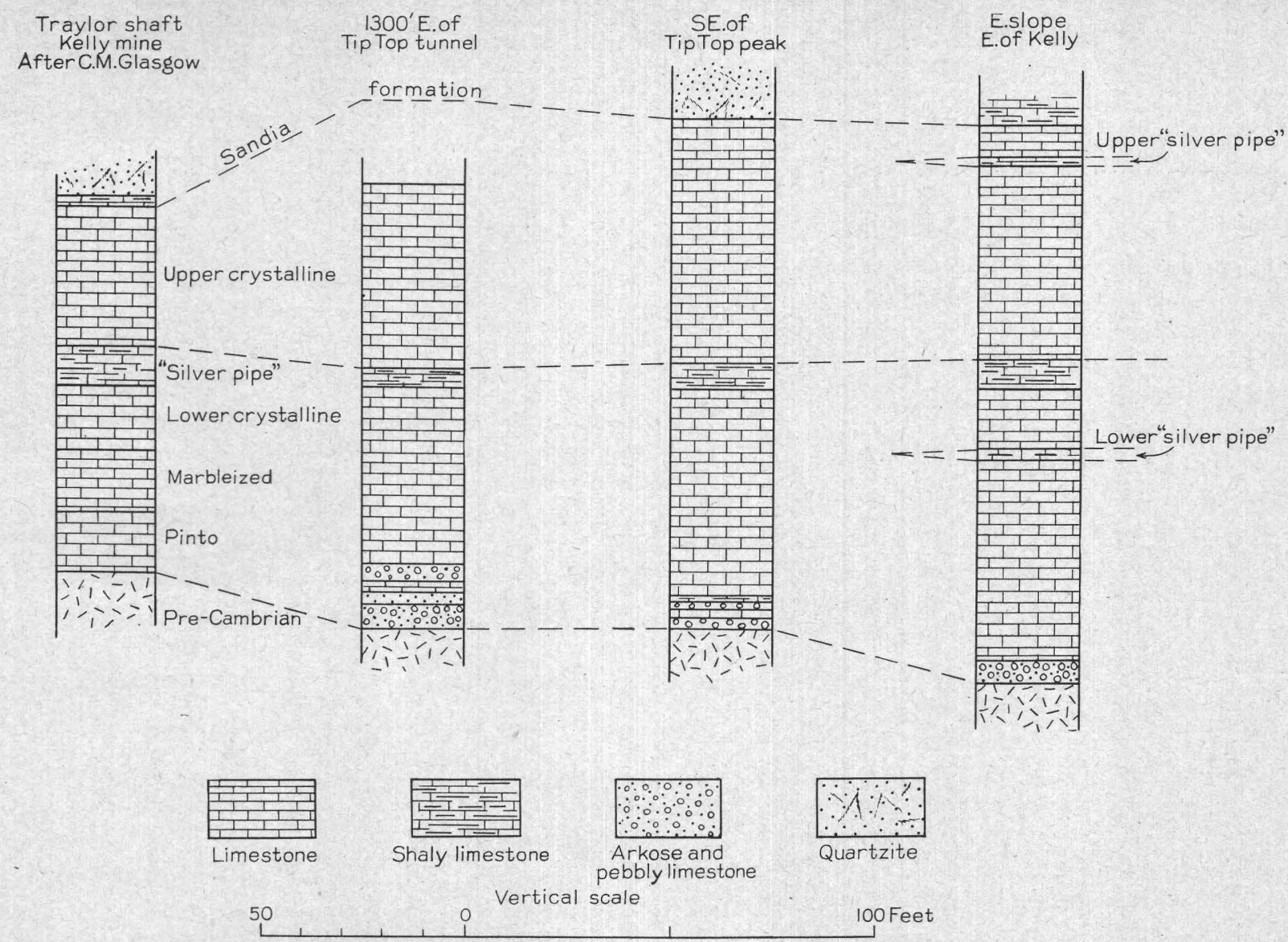

Figure 1.-Columnar sections showing variations in character and thickness of the Kelly limestone.

felspathic sandstone 3 or 4 feet thick overlain by a greenish to dark-gray bed 2 feet thick. Thin beds of limestone alternate with sandy or pebbly beds between these very basal beds and the overlying continuous limestone. At some places, notably the 9,389-foot peak in the southeastern part of the area and at Oak Spring, in the northern part of the range, the basal beds are almost pure limestone; but in the Nitt mine the basal bed is quartzite from 2 to 6 feet thick. In the principal mines of the district the basal beds rest on argillite, but where the basal beds are dark gray and fine-grained the contact with argillite is obscure. The constituents of the basal beds are not of strictly local origin, as large fragments of pink feldspar, characteristic of coarse-grained or porphyritic granite, and pebbles of argillite and diabase have been found directly above fine-grained granite, and fragments of dark-colored rock may be absent directly above argillite, gabbro, and diabase.

The limestone above the basal beds is mainly bluish gray and medium-grained and is sometimes called the "lower crystalline" limestone. Beds with conspicuous crinoid stems and chert lenses are exceptional. In the Kelly mine (fig. 1) the typical "lower crystalline" limestone is immediately underlain by a nearly white finegrained bed called the "marbleized lime," which contains scattered glistening calcite grains, and this in turn by a discolored bed called the "pinto lime." The "lower crystalline" limestone also commonly contains in its lower part one or more dense, lithographic lenticular beds, sometimes called "lower silver pipe." The "lower crystalline" limestone is overlain by the main "silver pipe," which is of similar dense texture and from 4 to 8 feet thick. The lower two-thirds of the "silver pipe" is dark gray to nearly black but weathers nearly white or buff; the upper third is light gray to white on both fresh and weathered surfaces. Single layers range from a few inches to 2 feet in thickness. Locally the dense, lithographic texture is not well-developed, but on the whole the "silver pipe" is the most reliable horizon marker in the district, especially underground. The "upper crystalline" limestone, above the "silver pipe," is bluish gray, prevailingly mediumto coarse-grained, and cherty. The coarser-grained beds consist largely of fragments of crinoid stems, and the uppermost of them are remarkably thin, giving weathered outcrops a platy appearance. This platy structure has rendered the uppermost beds especially permeable and replaceable by gangue and ore minerals. Single beds range from an inch to 2 feet in thickness, and the chert lenses and nodules are as much as 6 inches thick and several feet long. This upper member also contains thin lenticular beds of dense limestone, which are sometimes called the "upper silver pipe." 
From Tip Top Mountain southward the Kelly limestone has been extensively silicified (see pl. 28, $A$ and $B$, and pp. 53-54). Silicification is most persistent in the upper beds but may also be present just below the "silver pipe" and in a few places near the base. At a few places near the southeast corner of the district practically the entire thickness is silicified.

The lower half of the Kelly limestone mass enclosed in Tertiary (?) granite at the Hardscrabble mine has been bleached, thoroughly recrystallized, and in part replaced by garnet and other silicates. It is also replaced by silicates in the vicinity of Oak Spring, near the east contact of the main monzonite mass, and above the breast of the Linchburg tunnel, south of Kelly.

The one exposure in the Granite Mountain area is obscured by faulting and a thin covering of weathered debris. The "silver pipe" is exposed in a trench near the north end of the outcrop, and the silicified basal heds are doubtfully recognized along the contact with pre-Cambrian schist.

The Kelly limestone throughout the area, except the layers known locally as "silver pipe," appears to be essentially a calcareous formation with little or no dolomite present and a very little insoluble residue. Microscopic study of the residue from the "upper crystalline" limestone member from the Stonewall tunnel shows it to consist of minute doubly terminated quartz crystals; and the residue from an unreplaced remnant from the third level of the Kelly mine consists of kaolinic material, irregular quartz grains, sericite, and pyrite. All these minerals are attributable to mineralizing solutions and are of no value in stratigraphic correlation. Chemical tests of the "silver pipe" and microscopic study of its insoluble residue show it to be an impure dolomitic limestone containing considerable claylike material.

\section{AGE AND CORRELATION}

Although fragments of crinoid stems are abundant in some beds and small fragments of other fossils are numerous in places, identifiable index fossils in the Kelly limestone are disappointingly few. One small poorly preserved lot, from the very base of the limestone was tentatively regarded by the late Dr. G. H. (Girty as early Mississippian. Another lot, also poorly preserved, from the top of the limestone was insufficient to show whether the upper part was of the same age or appreciably younger. The fossils listed below have been identified by Dr. Girty.

Lot 6817 . Base of Kelly limestone close by fault, southeast of Young America mine:

Stenopora? sp.

Schizophoria? sp.

Schuchertella aff. S. chemungensis

Camarotoechia aff. C. chouteauensis
Lot 6818. Top of Kelly limestone, crest of main ridge, 1,200 feet south-southeast of Tip Top Mountain:

Triplophyllum sp.

Cyathaxonia? sp.

Rhipidomella aff. R. dubia

Spirifer aff. $\mathbf{S}$. pellaensis

Spirifer aff. S. missouriensis

Composita? sp.

Of these Dr. Girty says:

The faunas as represented by these two small lots are markedly unlike, thus suggesting a marked difference in age. These faunas contain so little that is identifiable or distinctive that a definite correlation cannot be made with known Mississippian faunas of the West. Thus, their relative ages in geologic time cannot be determined by reference to other faunas that are better known. Incidentally, as just implied, neither of these faunas is closely related to that of the Lake Valley limestone, which they might be expected to resemble. Indeed, from our present inadequate knowledge, the fauna of the Kelly limestone is rather strikingly different from the fauna of the Lake Valley limestone, though it is not necessarily of a different geologic age.

One fossil plant (lot 7984) was collected from the sinuous band of Kelly limestone east of the Germany mine and was determined by the late Dr. David White as Asterocialamites scrobiculatus, a Mississippian species.

\section{MAGDALENA GROUP (PENNSYLVANIAN)}

The name Magdalena group was introduced by Gordon ${ }^{23}$ in 1907 to represent the Pennsylvanian rocks in the Magdalena Mountains.

These rocks, which comprise limestones, shales, and quartzites, have an average total thickness of about 850 feet, although the thickness of single members varies considerably, as shown on plate 9 . They rest upon the Kelly limestone with apparent conformity but are very probably separated from the Kelly by a considerable interval of late Mississippian time. They are unconformably overlain by the Abo sandstone, of Permian age, ${ }^{24}$ throughout much of New Mexico, although no good exposure of an angular unconformity has been found in the Magdalena district.

The Magdalena group is divided into two formations, the Sandia formation below and the Madera limestone above.

The Sandia formation was named by Herrick ${ }^{25}$ in 1900, after the Sandia Mountains, Bernalillo County, N. Mex., where it was first studied. The name was applied to the shales, limestones, and sandstones that constitute approximately the lower half of the Magda-

${ }^{23}$ Gordon, C. H., Jour. Geology, vel. 15, pp. 805-816, 1907 ; op. cit. (Prof. Paper 68), p. 231.

${ }^{24}$ Lee, W. 'T., and Girty, G. H., The Manzano group of the Rio Grande Valley, N. Mex. : U. S. Geol. Survey Bull. 389, p. 13, 1909 . Lee, W. T., General stratigraphic break between Pennsylvanian and Permian in western America: Geol. Soc. America Bull., vol. 28, pp. 169-170, 1917; Notes on Manzano group: Am. Jour. Sci., 5th ser., vol. 4, p. 325, 1920. Darton, N. H., "Red Beds" and associated formations in New Mexico: U. S. Geol. Survey Bull. 794, pp. 20-28, 1928.

${ }^{25}$ Herrick, C. L., The geology of the white sands of New Mexico, Jour. Geology, vol. 8, p. 115, 1900; The Coal Measure forest near Socorro, New Mexico, vol. 12, pp. 237-251, 1904; Laws of formation of New Mexico mountain ranges, Am. Geologist, vol. 33, p. 310, 1904. Herrick, C. L., and Bendrat, T. A., Identification of an Ohio coal measures horizon in New Mexico: Am. Geologist, vol. 25, p. 235, 1900. Gordon, C. H, in op, cit. (Prof. Paper 68), pp, 232, 234, 235. 


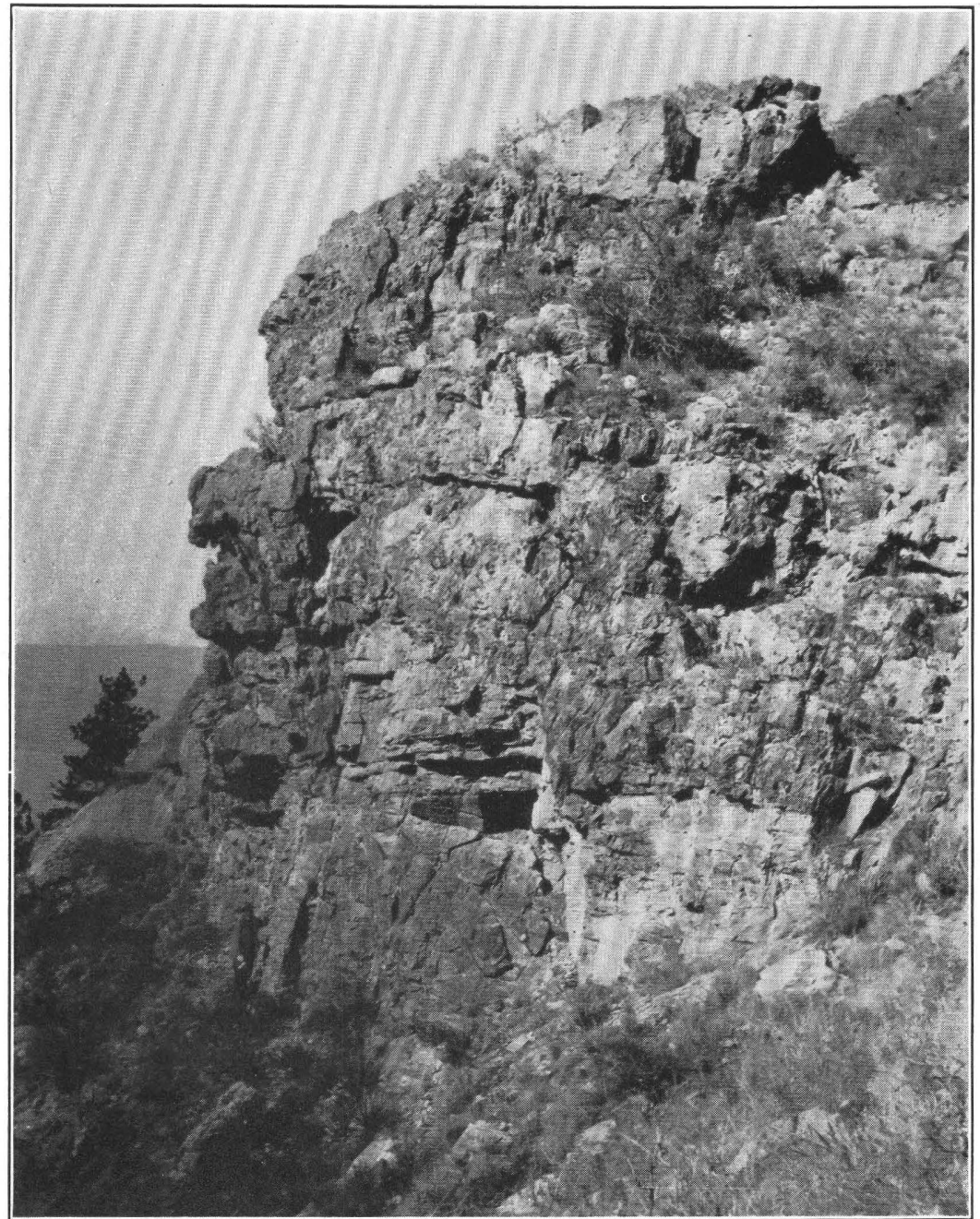

1. CIIFF OF SILICIFIED KELLY LIMESTONE RESTING ON ARGILLITE, WHICH IS CUT BY A GRA NITE DIKE. The dike, shown beside man in lower left corner, is cut off abruptly by the limestone. Head of north branch of Patterson Canyon.

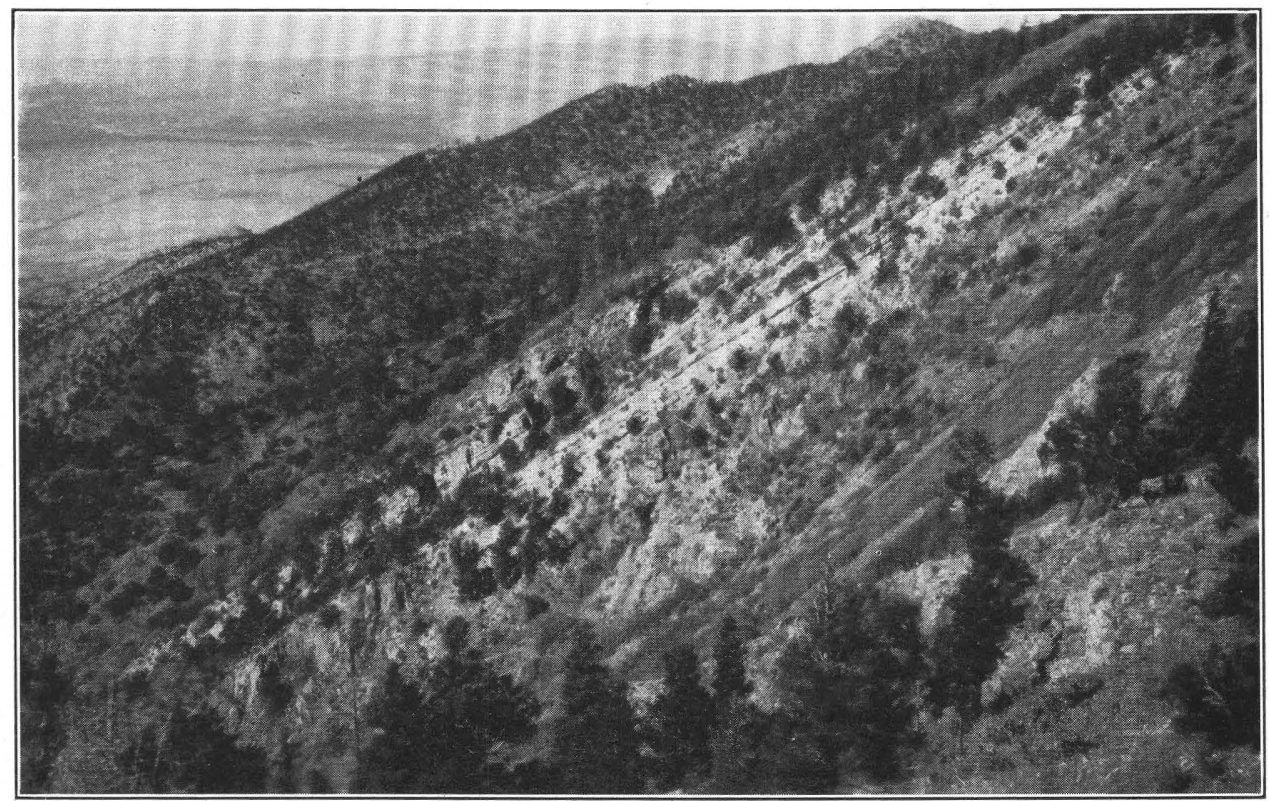

B. WEST SLOPE OF MAGDALENA RANGE, SHOWING ITS RELATIONS TO DIPS OF SEDIMENTARY ROCKS.

Pre-Cambrian granite in foreground overlain by west-dipping Kelly limestone (light-gray). East slope of western ridge consists of Sandia formation; its crest an: west slope consist of west-dipping Madera limestone. Looking north from crest of range N. $80^{\circ} \mathbf{E}$. from Kelly. 


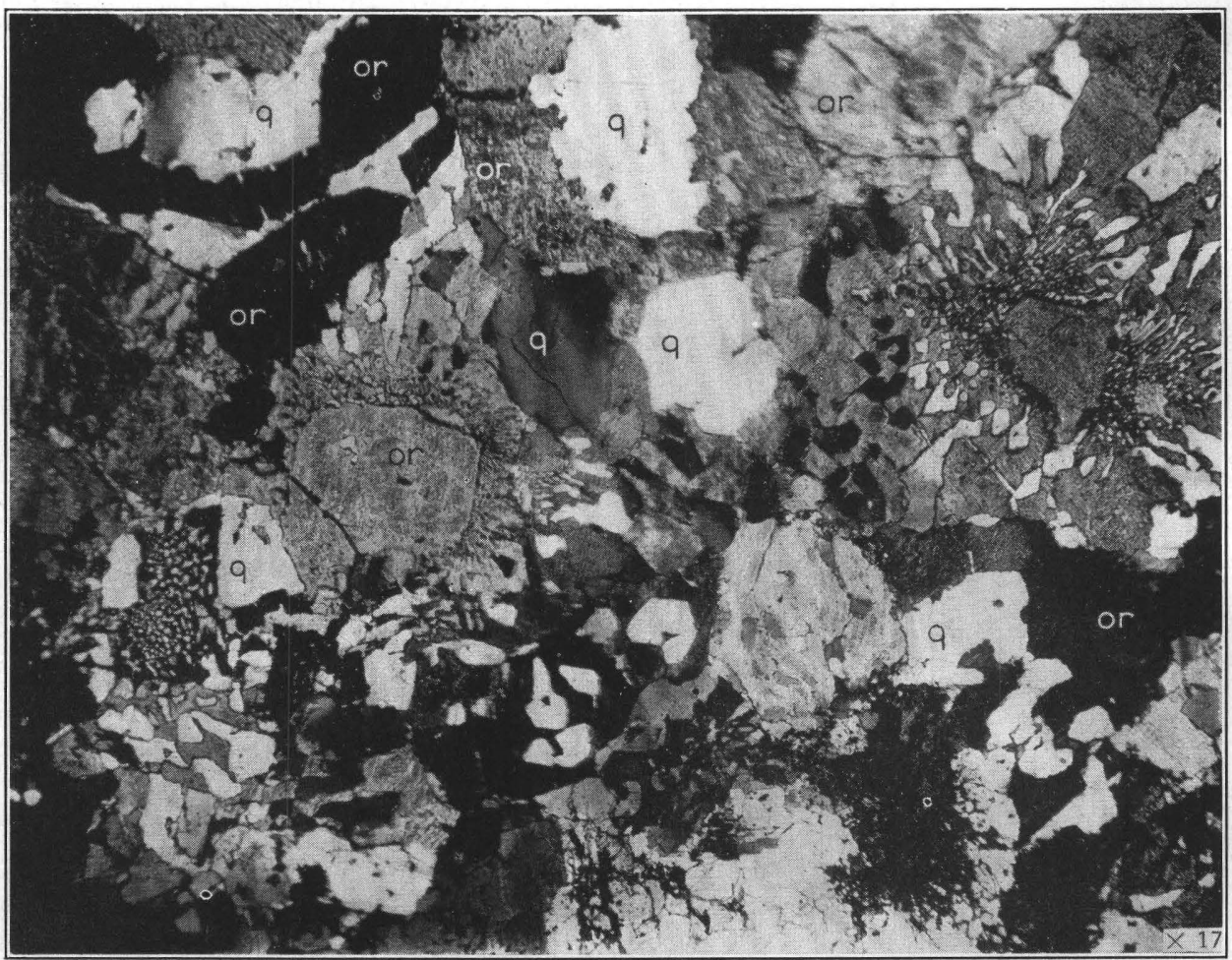

A. PHOTOMICROGRAPH OF PRE-CAMBRIAN GRANITE.

The rock consists essentially of quartz (q) and microperthitic orthoclase (or), which are in large part micrographicaliy intergrown. Green biotite, with magnetite, apatite, zircon, allanite, epidote, hastingsite, calcite, and fluorite, is present in certain black areas. Crossed nicols.

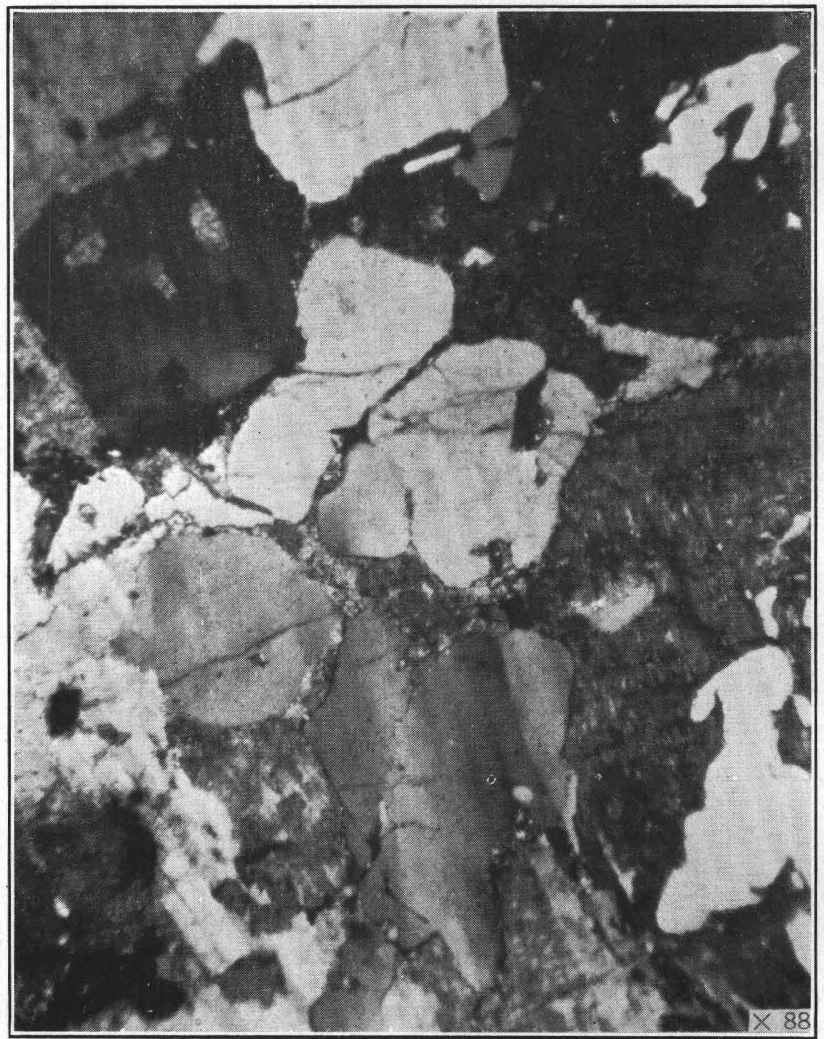

B. PRE-CAMBRIAN GRANITE SHOWING SOMEWHAT ROUNDED QUARTZ GRAINS EMBAYED BY INTERSTITIAL MICROPERTHITE. Plagioclase with included quartz remnants is shown in lower left corner. Crossed nicols.

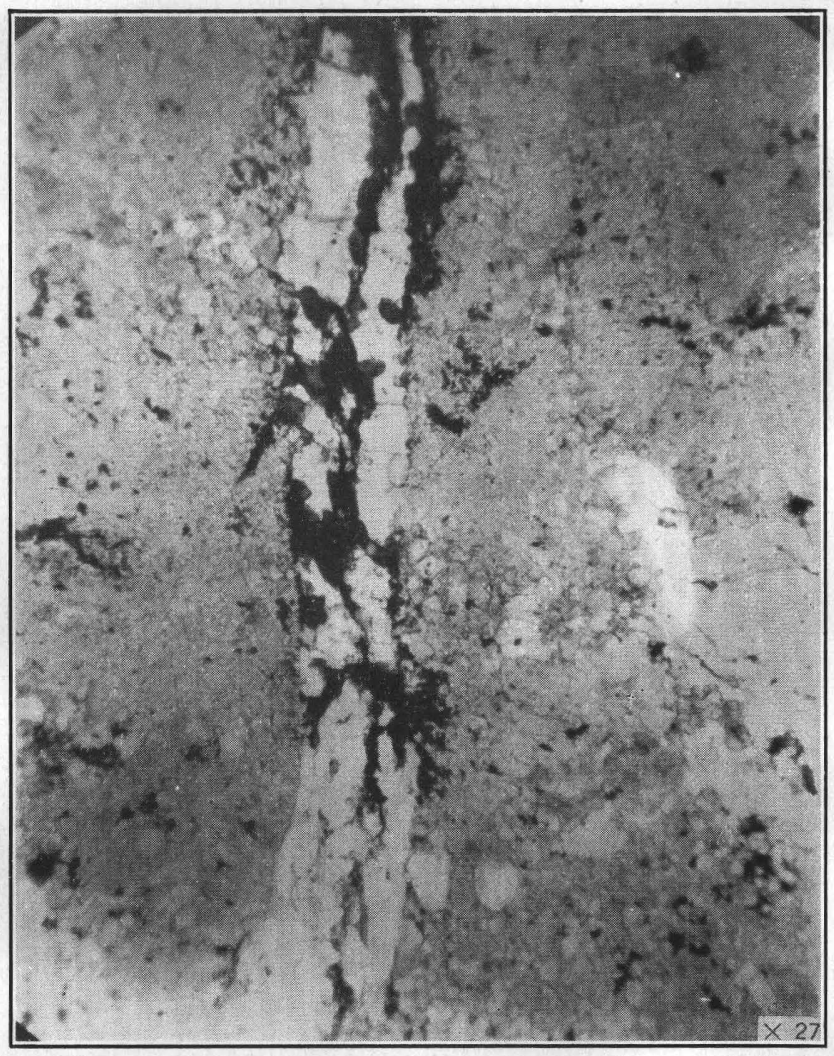

C. QUARTZ VEIN CUTTING APLITE, AND IN TURN BEING REPLACED BY AN IRREGULAR VEINLET OF BIOTITE AND CALCITE (?). Plain light. 
lena group in Socorro and Bernalillo Counties. Although the formation consists largely of shale, several members of limestone and quartzite are present.

The formation is exposed along the crest and upper west slope of the Magdalena Range in a broad belt that extends northward from the south boundary of the district to a point half a mile south of the Hardscrabble mine. Faulted outliers of this belt are prominent along the lower west slope between the Kelly and the Graphic tunnels, and isolated outcrops are present at the east base of Stendel Ridge and at the Vindicator mine. A shorter belt on the east slope of the range, due east of Kelly, represents the most complete and diversified, though not the thickest, section of the formation in the district. The Sandia also forms the low hills in the eastern part of the Granite Mountain area. Gordon ${ }^{26}$ gives the approximate thickness as 600 feet, which accords closely with our measurements in the main range; but in the Granite Mountain area, only 3 miles away, the apparent thickness, which is doubtless considerably exaggerated by strike faults, is about 2,300 feet. The exposures there are poor and afford little opportunity to estimate the amount of faulting, but different members of the formation are clearly much thicker than in the main range. The features described below indicate that sedimentation during Sandia time took place under near-shore conditions, which favored the thickening and thinning of beds within short distances.

We have divided the formation into six members, which, beginning with the oldest, are designated lower quartzite, lower limestone, middle quartzite, shale, upper limestone, and upper quartzite. The members vary considerably in thickness, and the smaller of them are lenticular and locally absent. The geologic age of the Sandia formation and the overlying Madera limestone is discussed on pages 19-20.

Lower quartzite member.-The lower quartzite is a persistent member of the formation in the main range, but in the Granite Mountain area it is either absent or has been concealed by strike faults. It consists of gray, greenish-gray, and brown quartzite with subordinate interbedded shale and limestone. It is, for the most part, about 90 feet thick, but the exposure on the east slope is apparently 165 feet, although concealed strike faults may reduce that total to 130 feet. Its character varies considerably as shown on plate 9 . In some outcrops it appears to be almost entirely quartzite, as shaly beds are concealed beneath quartzite debris, but where exposures are most continuous considerable shale is interbedded with quartzite, and in some places thin limestone beds are present. The shale and limestone beds are locally silicified.

The quartzite beds range in texture from fine to coarse-grained and in places become conglomeratic

\footnotetext{
${ }^{28}$ Gordon, C. H., in op. cit. (Prof, Paper 68), p. 246.
}

and contain many pebbles of quartz as much as an inch in diameter. Their cementing material is in part calcareous and in part siliceous. In general they have a greater color variation than the quartzite beds in higher members of the formation. They are notably resistant to erosion and tend to form ridges and dip slopes.

The only fossils found in the quartzite beds of this member are a few plant remains (lot 7985). They were determined by Dr. David White to be the species Lepidodendron clypeatum, which he described as a "Pottsville species and essentially confined to the middle an 1 upper Pottsville." Invertebrate fossils (lot 6804 ) collected from a shaly bed near the top of the lower quartzite south of Tip Top tunnel were determined by Dr. Girty and are shown in the list on page 20.

Lower limestone member.-The lower limestone member, which persists throughout the extent of the formation except where eroded in the southeast part of the district, is predominantly medium-grained bluish-gray argillaceous limestone with subordinate amounts of shale and quartzite (pl. 9). Typical varieties of limestone are nodular or lenticularly banded with mottled weathered surfaces, rather coarse grained with many fossil fragments, and thin-bedded with thin layers and partings of black shale. West of the Ambrosia mine, where the coarser-grained variety has been metamorphosed to a white crystalline limestone, it closely resembles the similarly altered Kelly limestone nearby. The approximate total thickness of this member is 65 feet throughout much of the range but exceeds 80 feet near the head of Kelly Gulch, south of Tip Top Mountain. In Kelly Gulch and on the east slope of the range the contact of the lower limestone with the lower quartzite appears unconformable, as the contact is undulating; but the bedding is not sufficiently distinct to show its true relation to the undulating contact.

The lower part of the limestone especially is also characterized by thin, very fossilliferous, shaly beds, in which species of Productus are prominent. Fossils from this member have been identified by Dr. Girty and are listed on page 20.

Middle quartzite member.-In some places a brown to gray, medium- to coarse-grained, lenticular bed of quartzite with a maximum thickness of about 18 feet separates the lower limestone member from the shale above. It has been mapped, wherever distinct, as the middle quartzite member. One lens about 100 feet wide in the outcrop and 1,000 feet long is exposed near Tip Top tunnel. Near its south end it is separated from shale by a thin limestone bed that farther south and in the Kelly mine cannot be separated from the lower limestone. Another quartzite lens caps the range between two faults near the south- 
east corner of the district. Its outcrop is approximately 1,000 feet long and 500 feet wide. There are other exposures on the east side of the range and on the west slope about 1,000 feet southwest of the Mistletoe mine and about 1,500 feet southeast of the Graphic tunnel. No coresponding quartzite has been found in the Granite Mountain area.

Shate member.-The shale member, which constitutes more than half of the Sandia formation, is about 300 feet thick in the main range, and about 1,100 feet thick in the Granite Mountain area. It is overlain either by the upper limestone or upper quartzite members or, where these are missing, by the Madera limestone. It is predominantly blue or black and in part highly carbonaceous, with several interbedded layèrs of limestone and quartzite. On the east slope of the range its upper 100 feet consists dominantly of thinbedded limestone, whose quantity elsewhere may have been underestimated because of poor exposure. The quartzite beds are fine-grained to pebbly and some are cross-bedded and ripple-marked. In the Granite Mountain area the shale appears to be more siliceous than in the main range but has fewer beds of coarsegrained quartzite and limestone. Sections of the shale member are given on plate 9 . The bleached metamorphosed shale near the Sleeper tunnel so closely resembles the bleached pre-Cambrian argillite, against which it is faulted, that the two are not readily distinguished.

Fossils collected from the shale member and identified by G. H. Girty are listed on page 20.

Stein and Ringlund ${ }^{27}$ report the following plant fossils from the shale, which were identified by David White:

Neuropteris aldrichi (Lesquereux); ferns represented by rachises, species not determinable; Lepidophyllum lucidum (Lesquereux) ; Sigillaria sp.; Cordaites $s p$. Concerning the age of these, David White stated: ${ }^{28}$ "The forms represented are characteristic of the Pottsville group and leave no doubt as to the age of the beds from which they were obtained."

Upper limestone member.-The upper limestone member, which is bluish-gray and medium-grained, is lenticular. It has been mapped in only four placesjust north of Kelly, 1,000 feet southeast of the Young America mine, on the east slope of the main range, and in the Granite Mountain area. North of Kelly the bed reaches a thickness of 30 feet and is characterized by spherical concentric algal growths as much as 2 inches in diameter. West of the Paschal shaft it lies on shale, but to the north and south it forms lenses in the upper quartzite. A thin bed of it forms a dip slope southeast of the Young America mine. Fossils collected from it and identified by G. H. Girty are

${ }^{27}$ Stein, Paul, and Ringlund, Soren, Geology and ore deposits of Kelly, N. Mex., unpublished thesis, New Mexico School of Mines, 1913.

${ }_{28}$ Idem. listed on page 20. A little further south algal limestone similar to that north of Kelly is present in the upper quartzite member along the Water Canyon trail just northeast of the Grand Ledge tunnel. The algal limestone appears to have originally contained small limestone pebbles, around which the algal growths dereloped in concretionary fashion. This concretionary structure has not been found in other parts of the district.

The upper limestone member on the east slope is thin-bedded, and its lower boundary and total thickness must be arbitrarily determined. About 70 feet below its top, which is marked by quartzite, it is cut by a fault with a dip-slip of 35 feet, which exaggerates its thickness by that amount. The thin-bedded limestone is underlain by 26 feet of alternating beds of shale and limestone, 3 feet of pebbly quartzite, and 100 feet of thin-bedded black limestone that appears to be locally equivalent to the upper part of the shale member. The entire thickness of 200 feet or more could be as consistently mapped in a unit as some of the other members have been, but the drawing of the boundary 70 to 100 feet below the top maintains a more uniform thickness for the shale member.

The bed in the Granite Mountain area has an apparent thickness of more than 400 feet.

Upper quartzite member.-The upper quartzite member, composed of gray quartzite beds with interbedded shale and limestone, is also lenticular and has a maximum thickness of about 65 feet in the main range. It appears to rest unconformably on the upper limestone in some places and should perhaps be regarded as the basal member of the overlying Madera limestone; but, because of the numerous thin quartzite beds that characterize the Sandia formation, this quartzite member is also included in it. The quartzite beds are thicker near the base and upper part of the member; they constitute about 30 feet of the total thickness of the member, each stratum having a thickness of about 15 feet.

In the Granite Mountain area the upper quartzite, like the lower members, has an abnormal thickness. It is cream-colored to white and well-sorted in contrast to the less pure beds in the main range.

\section{MADERA IIMESTONE}

The Madera limestone is evidently named after the town of La Madera, on the east slope of the Sandia Mountains. Herrick ${ }^{29}$ states that the town "seems to be upon a plateau of limestone," but he did not definitely name the formation. Keyes ${ }^{30}$ was the first to apply the name to the "upper part of the great limestone formation-the blue to gray beds," in the Sandia Moun-

${ }^{29}$ Herrick, C. L., The Geology of the San Pedro and Albuquerque districts: New Mexico Univ. Bull., vol. 1, p. 104, 1899.

${ }^{30}$ Keyes, C. R., Geology and underground water conditions of the Jornado Del Muerte, N. Mex. : U. S. Geol. Survey Water-Supply Paper 123. p. 22,1905 . 
tains, but he went no further in defining it. Later Gordon ${ }^{31}$ adopted the name and says that "overlying the Sandia beds in Socorro and Bernalillo Counties is a dark-blue limestone, for the most part in thick beds alternating with other thin shaly beds and blue shale."

The Madera limestone is almost continuously present on the upper west slope of the range from the south end of the district as far north as the Ambrosia mine. Between Kelly and the Nitt mine it is the most prominent rock along the lower slope, and farther north it is exposed along the east edge of the valley at Hardscrabble Camp. It also forms a prominent band along the higher foothills of the Granite Mountain area. Exposures near the Nitt mine and at Hardscrabble Camp are considerably metamorphosed; but those near the Nitt mine are continuous with the unaltered rock, and some of the less altered beds near Hardscrabble Camp are identified by the presence of Fusulina.

The limestone includes two members that have not been separated on the geologic map. Approximately the lower 300 feet consists of relatively thin bedded bluish-black limestone with some thin beds of bluishgray fissile shale and gray, medium-grained quartzite. These lower beds are somewhat similar in general character to those of the Sandia formation and could consistently be included in that formation, but, as limestone beds dominate and are continuous upward with a much greater thickness of limestone, they have been assigned to the Madera limestone; furthermore, the upper quartzite member of the Sandia formation marks a convenient horizon for the arbitrary drawing of the formation boundary. The gradational relations of the two formations accord with those elsewhere in central New Mexico. The dominant, upper member, at least 300 feet thick, is characterized by bluish-gray fine to rather coarse grained, massive limestone beds, which form cliffs as high as 10 feet. The irregular grain of some of its beds is caused by patches and veinlets of dolomite. Other beds have streaks and lenticular bands of yellow argillaceous material, and a few contain gray to black chert nodules as much as 8 inches in diameter. These cliff-forming beds alternate with subordinate thin-bedded, mottled, shaly limestone and a few thin lenses of gray shale, gray to brown quartzite, and limestone conglomerate. Prominent lenses of limestone conglomerate as much as 500 feet in length and 15 feet in thickness have been mapped near the base of this member at three places north and northeast of Kelly. They contain pebbles of quartzite and Madera limestone and grade into thin quartzite beds. They lie in distinct unconformity on typical Madera limestone beds and evidently mark repeated uplift and erosion between stages of limestone deposition. In the southernmost part of the district the highest beds are mottled and shaly and are stained reddish by material derived

\footnotetext{
r Gordon, C. H. Notes on the Pennsylvanian formations in the Rio Grande Valley, N. Mex. : Jour. Geology, vol. 15, pp. 805-816, 1907.
}

from the overlying Abo sandstone. Where metamorphosed near the monzonite stock, the Madera limestone is either colored green by diopside and epidote or is bleached to a white crystalline rock not distinguishable from other metamorphic limestone in the district.

The true thickness of the Madera limestone cannot be determined within the district, and a composite estimate may be misleading because of faults and the unconformable contact with the overlying Abo sandstone. The top of the limestone has been eroded north of Kelly. To the south it is marked by a sill of latite-porphyry intruded between it and the Abo sandstone, with only a few small scattered patches of the sandstone on the underside of the sill. One of these is at Kelly, where the base of the limestone is also exposed, and the calculated thickness is about 360 feet without allowance for possible minor faults. The base and top are both exposed just south of Chihuahua Gulch, but the irregularity of the dip and the presence of faults would render an estimate of thickness still more uncertain. Its thickness is apparently between 200 and 400 feet. The mass on Tip Top Mountain, even though its top has been removed, apparently exceeds 600 feet in thickness and may be as much as 1,000 feet thick, but the apparent thickness there is probably exaggerated by concealed strike faults.

Fossils collected at several places in the Madera limestone have been determined by G. H. Girty and are listed on page 20.

\section{AGE OF THE MAGDALENA GROUP}

Fossil plant remains (lot 7985) found in the lower quartzite member of the Sandia formation were determined by David White to be the species Lepidodendron clypeatum, which he describes as a "Pottsville species and essentially confined to the middle and upper Pottsville." Plant remains were also found in the shale member by Stein and Ringlund ${ }^{32}$ which David White determined as "Neuropteris aldrichi (Lesquereux) ; ferns represented by rachises, species not determinable; Lepidophyltum lucidum (Lesquereux) ; Sigillaria sp.; Cordaites sp." Also, according to White, these fossils are "characteristic of the Pottsville group and leave no doubt as to the age of the beds from which they were obtained."

With the exception of the fusulinids the invertebrate fossils listed on page 20 afford little basis for separating the Madera and Sandia formations. According to G. H. Girty :

Lot 6800 stands out as something rather distinct from the other collections made in the Madera limestone and scarcely more distinct from the collections having their source in the Sandia formation. Apart from this lot, which colors the composite fauna, the Madera limestone apparently does not differ

32 Stein, Paul, and Ringlund, Soren, Geology and ore deposits of Kelly, N. Mex., unpublished thesis, New Mexico School of Mines, 1913. 
much in its fauna from the Sandia formation. A few species in each formation are peculiar to it, so far as our records go, but not many of these are suggestive of an older age for the Sandia and a younger age for the Madera, though such suggestion is not wholly wanting. I am tentatively regarding the Sandia formation as of Pottsville age, but I am tentatively regarding the Madera limestone as post-Pottsville, although this last needs corroboration.

Specimens of fusulinids from the upper Madera strata were submitted to Mr. John W. Skinner, ${ }^{33}$ who has determined them as an

"undescribed species of Triticites which show a close relationship to Triticites ventricosus (Meek and Hayden). Their general aspect is suggestive of upper Pennsylvanian age, probably upper Wabaunsee."

\section{Invertebrate fossils in the Sandia formation and Madera limestone}

[Numbers refer to different lots collected at places shown below]

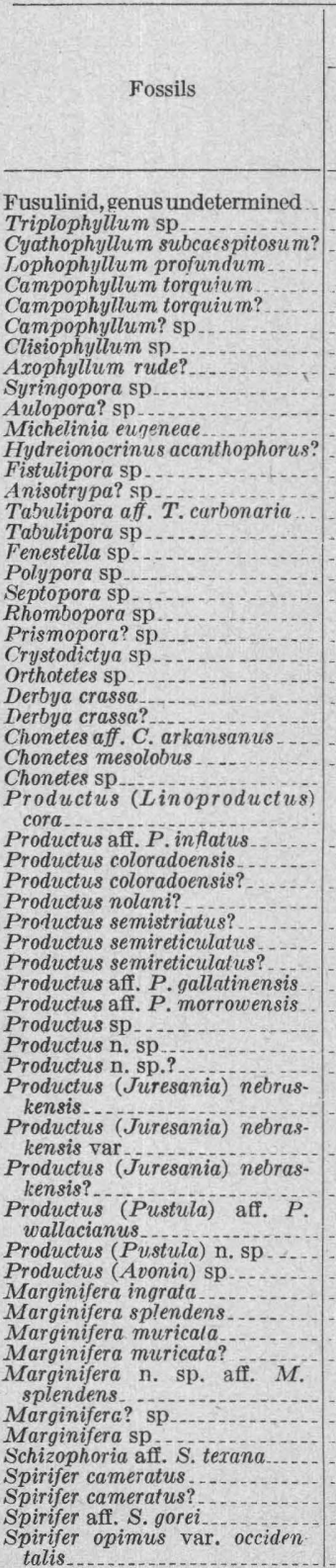

33 Personal communication.
Invertebrate fossils in the Sandia formation and Madera limestone-Continued

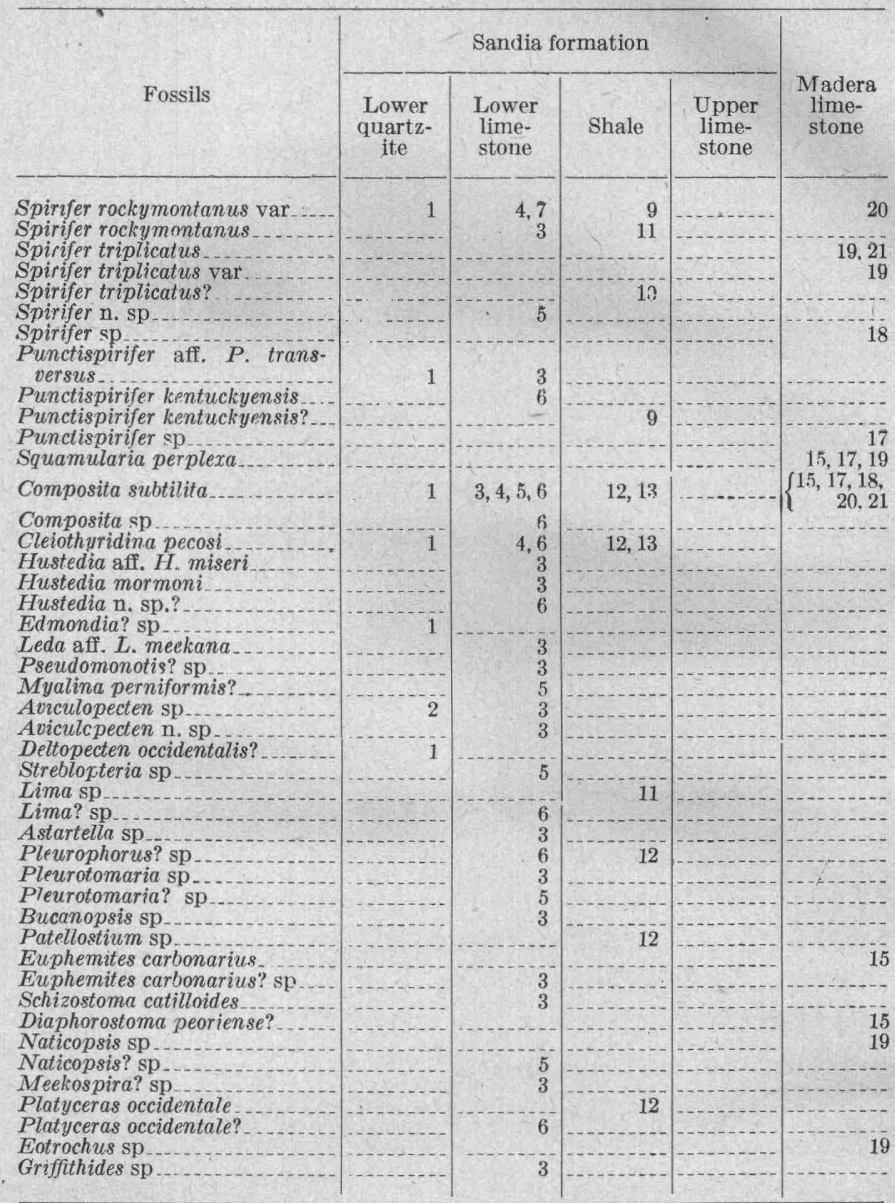

1. Lot 6804 , from a shaly bed near top of the lower quartzite member south of Tip Top tunnel.

2. Lot 6805 , about 100 feet east of Woodland mine.

3. Lots 6904,6906 , and 6907 , east of Mistletoe tunnel on west side of range.

4. Lot 6811 , about 1,000 feet northeast of Cimarron tunnel.

5. Lot 6825 , about 700 feet northeast of Cimarron tunnel.

6. Lots 6828 and 6829 , about 700 to 1,000 feet south of Tip Top tunnel on west side of gulch.

7. Lot 6810 , on spur with saddle on east slope of range east of Kelly.

8. Lot 6807 , near north end of lower limestone exposure on east slope of range due east of Kelly.

9. Lot 6809 , just east of Paschal shaft.

10. Lot 6816 , from thin-bedded limestone just below quartzite bed at first bend in road southwest of fork in Tip Top road.

11. Lot 6808 , west of Young America mine.

12. Lots 6820 and 6823 , west and north of Tri-Bullion mill.

13. Lot 6827,500 to 800 feet southwest of Tip Top tunnel

14. Lot $6803,1,000$ feet southeast of Young America mine.

15. Lot 6822 , Basal shaly bed in gulch 700 feet west of Paschal shaft.

19

16. Lot 6824,500 feet north of Cimarron tunnel.

17. Lot 6800,800 to 1,000 feet northwest of Tri-Bullion mill.

18. Lot 6802,600 to 700 feet west of Tri-Bullion mill.

19. Lot 6821,700 feet west-northwest of Tri-Bullion mill

20. Lots 6812 and 6815 , west-southwest of Grand Ledge tunnel.

21. Lot 6826,800 feet west of Tip Top tunnel.

22. Lot 6905, about 100 feet north of Mistletoe tunnel.

\section{ABO SANDSTONE (PERMIAN)}

The youngest Paleozoic formation in the Magdalena district is the Abo sandstone, the lowest member of the 
Manzano group, of Permian age. ${ }^{34}$ It unconformably overlies the Madera limestone. Although the Abo and Madera formations are in contact at only a few places, lecause of faults and of the intervening sill of porphyritic latite, there is apparently little angular discordance between them. The unconformable relation is most strongly suggested near the south boundary of the district, where the Abo sandstone overlies a beveled surface of the Madera limestone that slopes $24^{\circ} \mathrm{W}$., whereas the Madera strata dip $17^{\circ} \mathrm{W}$. The unconformity has been recognized in other parts of the State. ${ }^{35}$ Darton ${ }^{36}$ states that "in most places the Abo formation appears to lie unconformably on the Magdalena group, but the nature, duration, and extent of the hiatus are not known." The Abo, in turn, is unconformably overlain by Tertiary volcanic rocks.

The Abo sandstone, which is exposed at intervals from Kelly southward, consists of dark-red to locally gray fine- to coarse-grained shaly sandstone beds, mostly less than a foot thick, which alternate with dark-brown to red or locally green sandy shales. The red color is bleached to light gray along quartz veins and to gray or greenish gray in occasional baked inclusions in the adjoining sill of porphyritic latite. In some places the sandstone grades into sandy shale along the bedding. Cross bedding, ripple marks, and mud cracks are common. Locally the basal bed is a limestone conglomerate, the limestone pebbles of which were apparently derived from the underlying Madera limestone. However, near the south end of the district the basal bed is arkose with prominent pink feldspar grains.

The maximum thickness of the Abo sandstone within the district is about 175 feet, but most of the sections studied are less than 100 feet thick. The thickest is at the 7,800-foot hill just south of Mistletoe Gulch. One of the best exposures, just south of the old aerial tramway near Patterson Canyon, is represented below; however, it is in fault contact with porphyritic latite and the basal beds are not exposed.

\section{Section of Abo sandstone south of the old aerial tramway near Patterson Canyon}

Sandstone, pale red; overlain unconformably by

Sandstone, red, fine-grained, with fragments of light-green and gray sandstone

Sandstone, red, ferruginous, micaceous; irregular bedding planes 2 to 4 feet apart, partly weathered to thinly bedded material. Cross bedding on large and small scale

${ }^{34}$ Herrick, C. Y., Geology of the white sands of New Mexico: Jour. Geology, vol. 8, pp. 112-128, 1900; also New Mexico Univ, Bull, vol. 2 pp. 1-17, 1900. Lee, W. T., and Girty, G. H, The Manzano group of the Rio Grande Valley : U. S. Geol. Survey Bull. 389, pp. 10-13, 1909.

${ }^{3}$ Herrick, C. L., A coal-measure forest near Socorro, New Mexico Jour. Geology, vol. 12, p. 244, 1904 ; Lee, W. T., Note on the Red Beds of the Rio Grande region in central New Mexico: Jour. Geology, vol. 15, pp. 52-58, 1907 ; Lee, W. T., and Girty, G. H., The Manzano group of the Rio Grande Valley, New Mexico: U. S. Geol. Survey Bull. 389, pp. 12-13, and 39, 1909

s6 Darton, N. H., "Red Beds" and associated rormations in New Mexico : U. S. Geol. Survey Bull. 794, p. 20, 1928.
Section of Abo sandstone south of the old aerial tramway near Patterson Canyon-Continued

Feet

Pebbly sandstone containing fragments of the light and dark-red members up to 4 inches in diameter; weathers to irregular surface

Sandstone, red, coarse-grained, micaceous, with calcite veinlets

Sandstone, red to brown, weathers to thin irregular beds; grades into a red arenaceous shale

The age of the Abo sandstone was formerly believed to be Pennsylvanian, ${ }^{37}$ although Herrick ${ }^{38}$ originally believed the lower member of the Manzano group to be Permian and the upper members younger. Its age is now established as Permian. ${ }^{39}$

The following fossils from the Abo sandstone have been identified by Dr. Girty:

Lot 6801. On trail just south of district close to basal contact :

Fusulina secalica.

Derbya aff. D. multistriata.

Marginifera splendens.

Pustula symmetrica?

Composita subtilita.

Of these, Dr. Girty makes the following comment:

Qualified by the fact that this lot contains only 5 species, this fauna marks a distinct departure from the Madera collections, though perhaps no more of a departure than lot 6800 , which is proper to the Madera. Its stratigraphic position together with certain suggestions contained in the fauna itself seem to make it advisable to class the horizon of lot 6801 as basal Red Beds.

A fossil plant horizon was found in the saddle just north of the old aerial tramway. Probably the same stratigraphic horizon is exposed to the northwest in the southeast corner of sec. 1, T. 3 S., R. 4 W. Specimens in lot 7983 were determined by David White as species of "Walchia, intermediate between Walchia piniformis and Walchia hypnoides"; another species of "Walchia that is probably undescribed," and "a small fragment that is possibly referable to Walchia piniformis." Darton ${ }^{40}$ reports that G. E. Anderson "collected a slab of red sandstone ${ }^{41}$ that showed a fine impression of a plant, on which David White has furnished the following report:

The fossil plant on the slab of red sandstone from the Abo formation near Kelly, N. Mex., was considerably worn and slightly macerated before fossilization, and some of the criteria essential for its absolute paleontologic determination are lacking. However, it appears to be a representative of the Callipteris

${ }^{37}$ Lee, W. T., and Girty, G. H., op. cit., pp. 12, 16-17.

${ }^{38}$ Herrick, C. L., op cit. (Jour Geology), pp 112-128 and (New Mexico Univ. Bull.) pp. 1-17.

${ }^{39}$ Lee, W. T., General stratigraphic break between Pennsylvanian and Permian in western America: Geol. Soc. America Bull, vol. 28, pp. 169170, 1917; Notes on Manzano group: Am. Jour. Sci., 5th ser., vol. 4, p. 325, 1920. Darton, N. H., "Red Beds" and associated formations in New Mexico : U. S. Geol. Survey Bull. 794, pp. 16-28, 1928.

${ }^{40}$ Darton, N H., op. cit., p. 137.

41 Lost in the New Mexico School of Mines fire in 1928. 
group, of distinctly Permian type, and probably belongs to the genus Glenopteris, described from the Wellington shale, which in Kansas is considerably above the base of the Permian. Though the evidence is not conclusive, because the identification is somewhat uncertain, it is probable that this is a Permian plant.

\section{TERTIARY (?) SEDIMENTARY ROCKS}

Along the west edge of the Granite Mountain area are a few small exposures of gray fine- to mediumgrained sandstone of probable Tertiary age. Similar sandstone, however, has been found, by reconnaissance, to be rather extensively distributed in the Bear Mountains to the west and north of the area. There are many inclusions of it, ranging from an inch to tens of feet in diameter, in the adjoining Tertiary (?) granite.

The prevailing gray color is locally modified by buff and brown banding, especially next to joints. The constituent grains are well-rounded to subangular and consist almost entirely of quartz. They are poorly cemented in the unaltered rock, but the inclusions in the granite and the sandstone near the contact have been hardened and in part converted into quartzite.

In general the sandstone is much fractured so that its bedding and structure are obscured, but an exposure in the arroyo about 3,200 feet east and 600 feet south of the northwest corner of sec. 14, T. 2 S., R. 4 W., shows it to have at least locally a strike of $\mathrm{N}$. $7^{\circ}$ W. and a dip of $62^{\circ} \mathrm{W}$. This steep dip, which is much greater than the general dip of the underlying volcanic rocks, is undoubtedly due to local drag produced by faulting, which may also account for the excessive fracturing of the sandstone.

The age of the sandstone cannot be closely defined. It is older than the granite, as shown by the numerous inclusions in the granite, but nowhere within the district is it in contact with the volcanic rocks. Just northwest of the district, however, it is clearly overlain by banded rhyolite, and as it dips westward it apparently overlies the older volcanic rocks, which also dip westward. Winchester ${ }^{42}$ described a formation in the Alamosa Creek Valley about 12 miles northwest of the district as "consisting of a series of tuffs, rhyolites, sandstones, and conglomerates, which is probably of late Tertiary age, although no fossils were found that lend evidence for this assumption." This formation he named the Datil formation, as it is the most prominent component of the Datil Mountains, in the southern part of the region that he studied. It seems probable that the sandstone in the northwest corner of the Magdalena district is to be correlated with the sedimentary members of the Datil formation, as it is similarly associated with volcanic formations and is found in hills that are the southern extension of the Bear Mountains of the Alamosa district.

42 Winchester, D. E., Geology of Alamosa Creek Valley, Socorro County, N. Mex.: U. S. Geol. Survey Bull. 716, p. 4, 1921.

\section{QUATERNARY SYSTEM}

The Quaternary formations of the district include landslides, alluvium, and talus. The oldest of them may be of Pleistocene or even Pliocene age, but there is no basis for distinguishing between Pleistocene and Recent deposits.

\section{LANDSLIDES}

The landslides, reduced to mere remnants by erosion, are mainly confined to the southern part of the district, where they cap a few spurs and upper slopes of sedimentary and volcanic rocks. The most pronounced areas are immediately north and south of the Young America mine. One just south of Patterson Canyon is almost surrounded by a high bench of alluvium.

The landslides consist of Carboniferous debris. The one south of Patterson Canyon is made up essentially of large blocks of Madera limestone and Abo sandstone, but those farther up the slope to the east contain also blocks from the Sandia and Kelly formations. Some boulders are as much as 100 feet long and 25 feet thick, and some may be even larger. A prospect shaft 30 feet deep has been sunk in a block of cherty Kelly limestone, and about 4,000 feet east of South Camp a 1,200-foot tunnel has been driven in landslide material. $\Lambda$ small amount of ore was mined by F. A. Gordon from a block in the slide south of Patterson Canyon.

Scars indicating the breaking away of a landslide are still recognizable near the crest of the range, especially in the Kelly limestone in the vicinity of the Young America and Woodland mines. The landslides probably took place during a period when relief was greater than at present and undercutting and oversteepening were prevalent. It is quite probable that the erosion of downfaulted shale beds west of those mines permitted rocks to the east of the main fault zone to break away and to slide down the dips of shale layers at the base and top of the Kelly limestone. Subsequent erosion has deepened the transverse gulches, leaving landslide debris as caps to the spurs, but has not reproduced conditions favorable to the recurrence of appreciable landslides.

\section{ALLUVIUM}

Alluvium flanks the western slope of the range and completely surrounds the Granite Mountain area. Within the district it is represented by fans that spread over a gentle rock slope and grade into valley fill. The covering of the rock slope ranges in thickness from a veneer, as is well shown just west of Kelly and south of Stendel Ridge, to 125 feet or more. It consists of angular to rounded pebbles, cobbles, and small boulders that have accumulated intermittently over a considerable time. The older accumulations, which range in altitude from 7,225 to 7,850 feet on the west slope of the range and from 7,900 to 8,275 feet on the east slope, have been considerably eroded 
and in places only remnants of them are left; but where they have been protected from erosion they grade imperceptibly into the more recent accumulations. An attempt to show them separately on the map has therefore been abandoned.

\section{TALUS}

The only areas of talus shown on the geologic map are those on the east slope of Granite Mountain, where the talus is sufficient to conceal considerable bedrock and thereby seriously interferes with the interpretation of local structural features. The talus, where not in contact with exposed bedrock, grades into alluvium, and its boundaries have therefore been drawn rather arbitrarily.

\section{TERTIARY (?) EFFUSIVE IGNEOUS ROCKS GENERAL STATEMENT}

The effusive rocks of the district-latites, andesites, and rhyolites-are found in the foothills and lower slopes on the west side of the main range of the belt of Paleozoic sedimentary formations. In the Granite Mountain area they predominate, but here also they are found west of the sedimentary formations.
The different formations represented on the geologic map can in general be distinguished by their characteristic colors or textures and have been named accordingly. They trend northward and have a general dip of $25^{\circ}-30^{\circ} \mathrm{W}$., but locally they dip as much as $50^{\circ} \mathrm{W}$. or, as shown by the pink rhyolite, as little as $10^{\circ} \mathrm{W}$.

Figure 2 shows the sequence and relative ages of the formations in each part of the district. It also expresses the restricted distribution and probable interfingering and overlapping of the lower formations, which were derived from at least two centers of eruption probably beyond the limits of the area studied. It is only by means of the banded rhyolite, which is present throughout the district, that the sequences in different parts of the district have been correlated. The earliest eruptions evidently took place in the northern part of the region. The large volume of pyroclastic material shows that the eruptions were chiefly violent, but the mode of extrusion, whether by fissure or by central eruption, is nowhere shown within the district.

The volcanic rocks, on the basis of local geologic structure, are divisible into an earlier and a later group, whose eruptions were separated by a period of fault-

N.
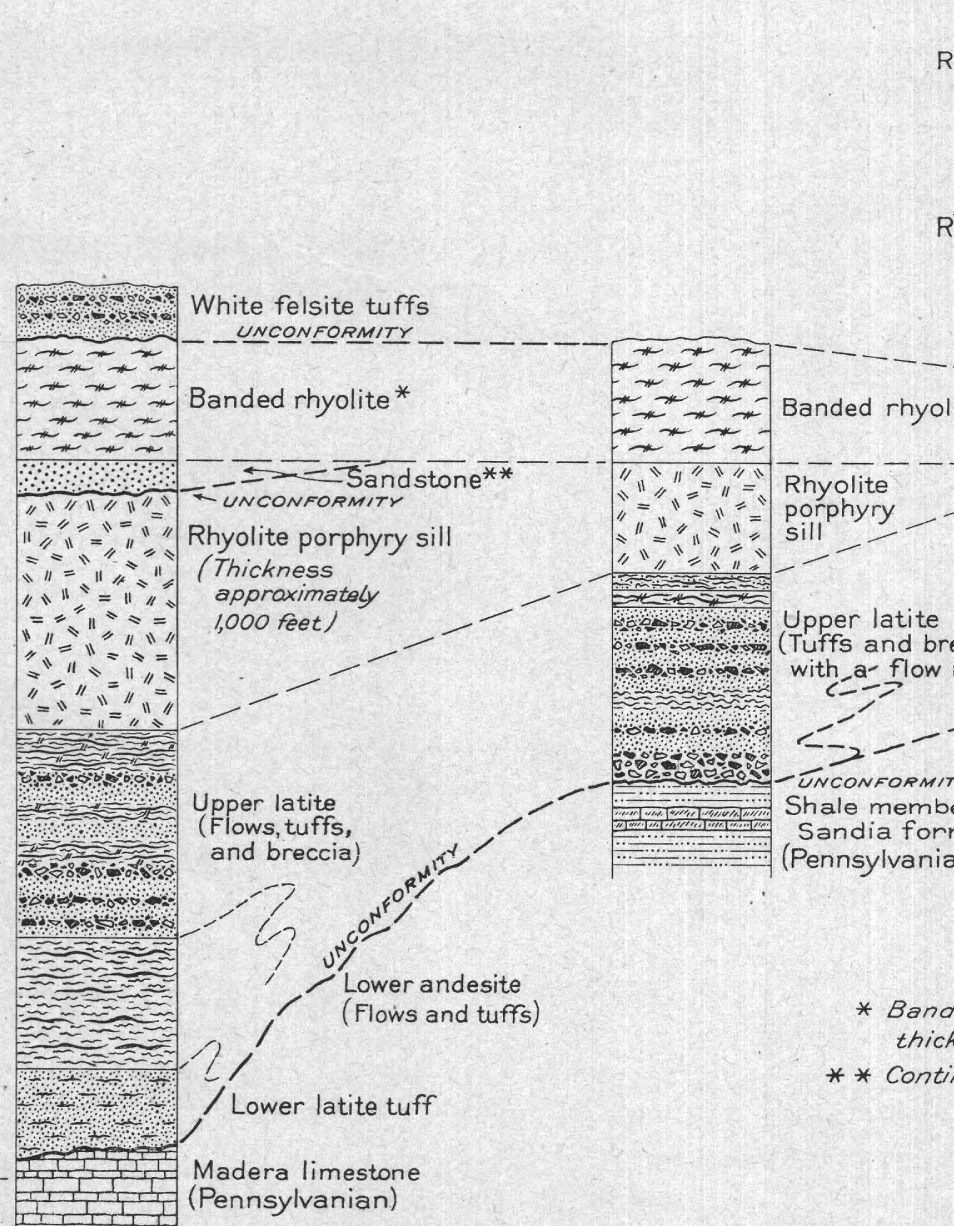
MAGDALENA MINING DISTRICT, NEW MEXICO

ing, tilting, and erosion, but the earlier group may be divided into two subgroups separated by a stage of erosion and sedimentation. Rocks of the earlier group include the latites, lower andesites, and the banded and red rhyolites. The lower members of this group overlapped southward on an irregular erosion surface of somewhat deformed Carboniferous rocks, and south of Kelly they interfinger with or are overlain by the purple andesite, which was evidently erupted from a different center. In the Granite Mountain area the eruption of upper latite was separated from that of banded rhyolite by a substage of erosion and sedimentation represented by Tertiary (?) sandstone which is well-exposed west of Granite Mountain beyond the area represented on plate 2 . Winchester ${ }^{43}$ describes interbedded sedimentary and volcanic rocks in the valley of Alamosa Creek to the northwest, where the sedimentary rock is more prominent and may represent a greater interruption to the volcanic sequence than it does in the Magdalena district. In the southernmost part of the district, however, the banded rhyolite and the underlying andesites are in apparent conformity. The members of the earlier group, both below and above the sandstone horizon, dip from $30^{\circ}$ to $50^{\circ}$ westward and appear to be conformable throughout, but any angular discordance in dip that might be correlated with this substage is obscured by a large sill of rhyolite porphyry that was introduced along the contact between the upper latite and the overlying rocks. South of Kelly the rocks of the earlier group are cut by a sill of latite porphyry.

Members of the later group include white felsite tuffs in the Granite Mountain area and the upper andesite and pink rhyolite south and west of Kelly. These members dip westward at very low angles and overlie members of the older group unconformably. The unconformity in the Granite Mountain area is distinct. In the southwest part of the district the pink rhyolite overlaps the upper andesite eastward and northward onto the more steeply dipping red andesite and red rhyolite, but the relation between the upper andesite and the older volcanic rocks is obscure.

The later group also is cut by sill-like masses and dikes of rhyolite porphyry identical with that in the large sill within the earlier group. This porphyry, therefore, is clearly the latest member of the volcanic series, but it may conveniently be included in the later group, as it was intruded before the major period of disturbance that separated the volcanic period as a whole from the later periods during which stocks of granite and monzonite were intruded and ore deposits were formed.

The volcanic rocks of the main Magdalena Range are limited to the lower western slope. They gradually

${ }^{4}$ Winchester, D. E., Geology of Alamosa Creek Valley, Socorro County, N. Mex.: U. S. Geol. Survey Bull. 716, pp. 4-5 and 9-10, 1921. extend up the slope as they are followed southward, reaching the crest a little beyond the south boundary of the district; and from there they cover the entire range for a distance of 20 miles. $^{44}$ This distribution, together with the thickness and dips of the volcanic rocks within the district, leaves no doubt that the volcanic rocks at least of the first stage once covered the entire district.

The volcanic rocks are considerably altered, and the original character in some has been destroyed. Insofar as possible, however, the original minerals are noted. Because of the altered character of the rocks the classification of each must necessarily be based on a microscopic study. The alteration products are included in the rock descriptions, but the interpretation and significance of the alterations are discussed in the section on rock alteration.

\section{LOWER LATITE TUFF}

The lower latite, the oldest and least extensive of the Tertiary (?) volcanic rocks, marks the beginning of volcanism within the district. It is found only east of Granite Mountain in a narrow irregular band of northerly trend that covers about 20 acres. It rests unconformably on the Madera limestone, with the exception of its southernmost outcrop, which overlies shale of the Sandia formation. Its exposures are so poor that nowhere can its strike and dip or thickness be accurately determined, but as the overlying andesite dips about $30^{\circ} \mathrm{W}$., the dip of the latite is inferred to be similar; and its thickness is estimated to be about 500 feet.

The rock is greenish gray and appears minutely porphyritic because of the abundant grains of white and pale-pink feldspar, which average about 1 millimeter in diameter, and the green specks of epidote. No dark mineral can be recognized. Crystal fragments, as shown in thin section, are estimated to constitute from 50 to 70 percent of the rock. Their diameters attain a maximum of 2 millimeters but are more commonly 1 millimeter or less. They have the random distribution characteristic of a crystal tuff and are embedded in a matrix too fine grained to be positively identified. Most of the fragments are plagioclase and orthoclase, but a few are felsite. Quartz forms small irregular grains and scattered bunches that are probably secondary. Typical grains of magnetite, apatite, and zircon are also present. Ferromagnesian minerals are now represented by chlorite full of finegrained magnetite.

Other secondary products are epidote and calcite, and in one section sericite. Orthoclase, which appears as typical microperthite, and plagioclase are partly

44 Lindgren, Waldemar, Graton, L. C., and Gordon, C. H., The ore deposits of New Mexico: U. S. Geol. Survey Prof. Paper 68, p. 248, 1910. Darton, N. H., "Red beds" and associated formations in New Mexico: U. S. Geol. Survey Bull. 794, p. 136, 1928 ; Geologic map of New Mexico; U. S. Geol. Survey, 1928. 


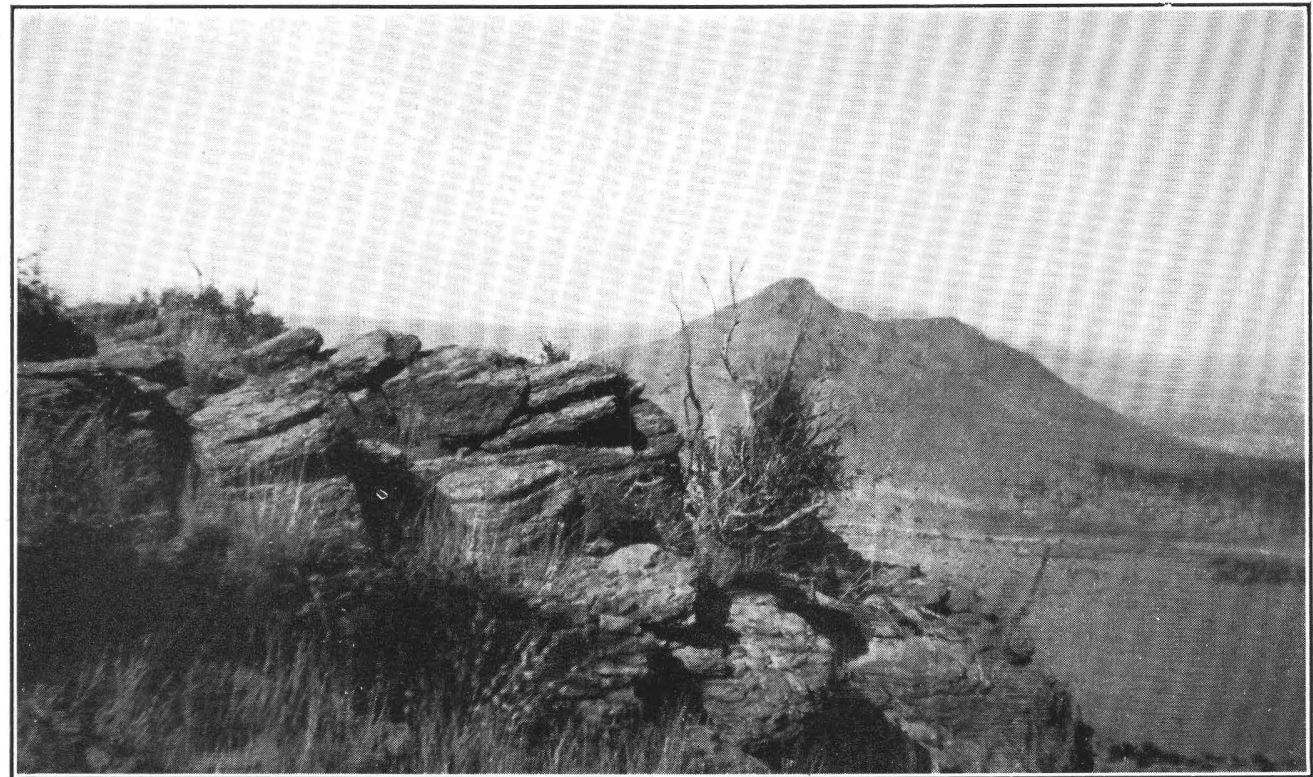

A. LAMELLAR STRUCTURE IN WEATHERED LATITE TUFF ON THE EAST SLOPE OF GRANITE MOUNTAIN.

The sheeting dips about $10^{\circ} \mathrm{W}$., whereas joints dip steeply to the east. La Jenze Creek is seen on the right. Nipple Mountain, to the north, lies outside the area mapped.

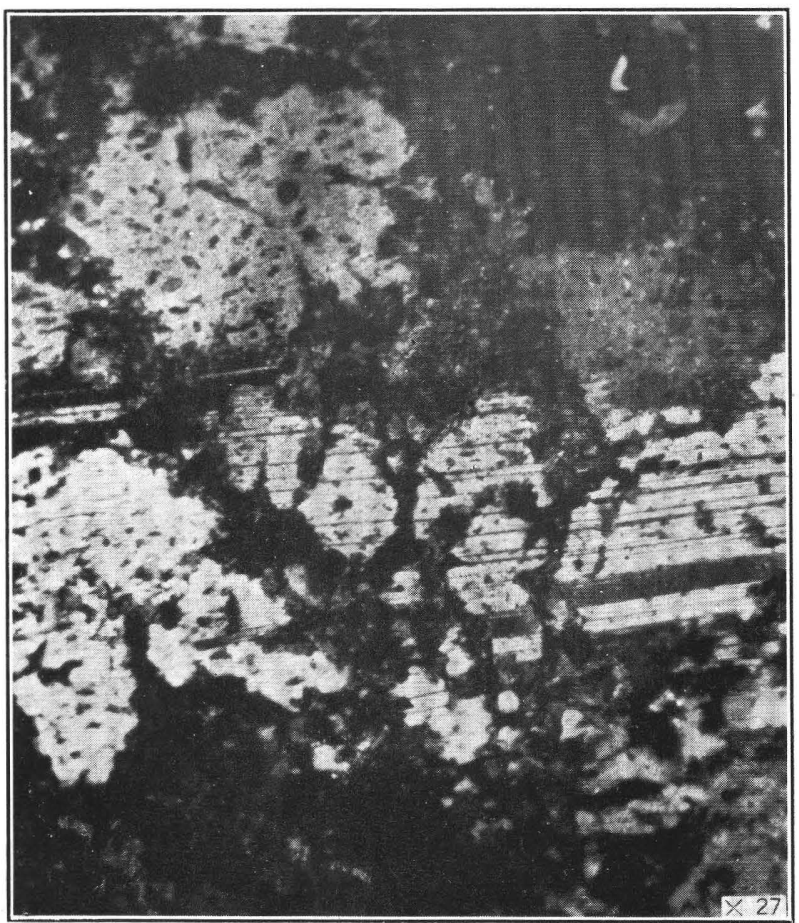

B. PHOTOMICROGRAPH OF PRE-CAMBRIAN GRANITE. SHOWING PLAGIOCLASE-AND OTHER SALIC MINERALS PARTLY REPLACED BY GREEN BIOTITE AND HASTINGSITE (DARK AREAS).

Crossed nicols.

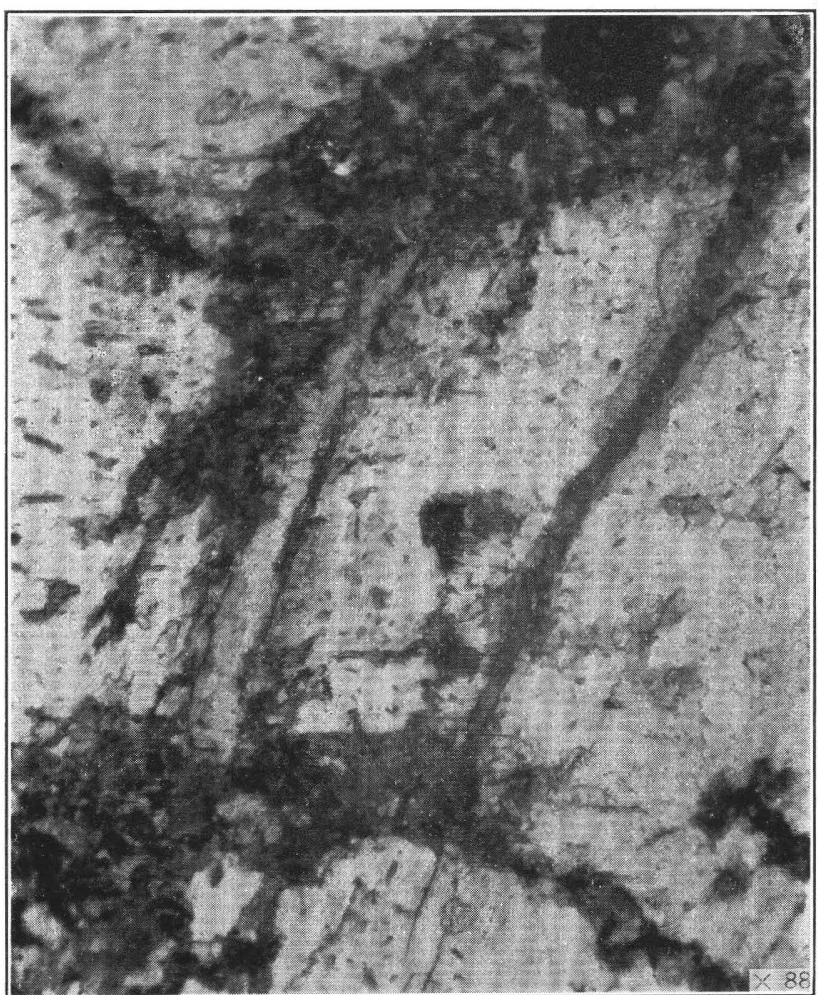

C. RAMIFYING VEINLETS OF BIOTITE PARTLY ALTERED TO CHLORITE (DARK AREAS) AND CALCITE REPLACING FELDSPAR IN PRE-CAMBRIAN GRANITE.

Minute veinlets are especially common along cleavage cracks in feldspar. Plain light. 



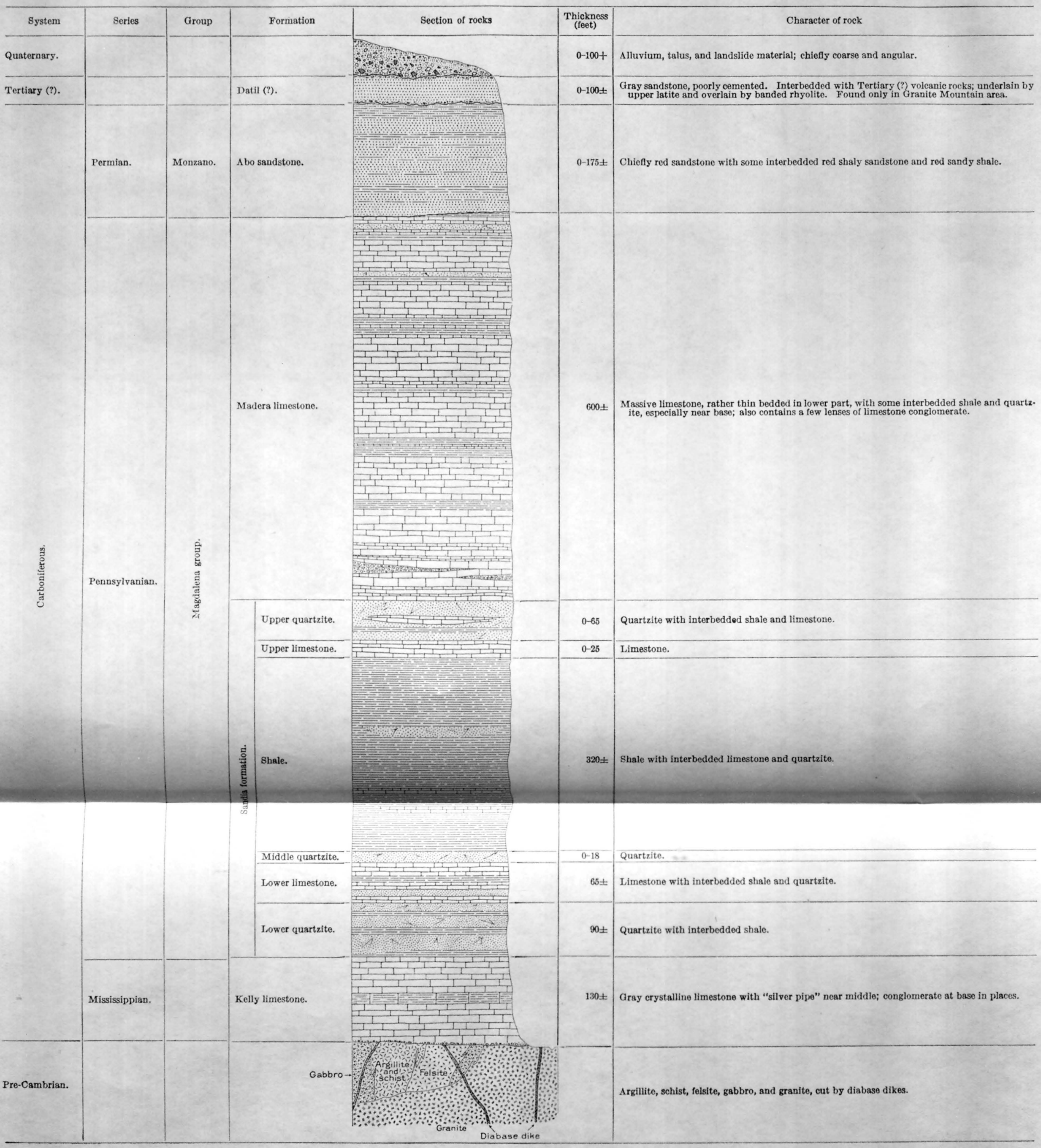


GULCH JUST NORTHWEST
OF PASCHAL SHAFT

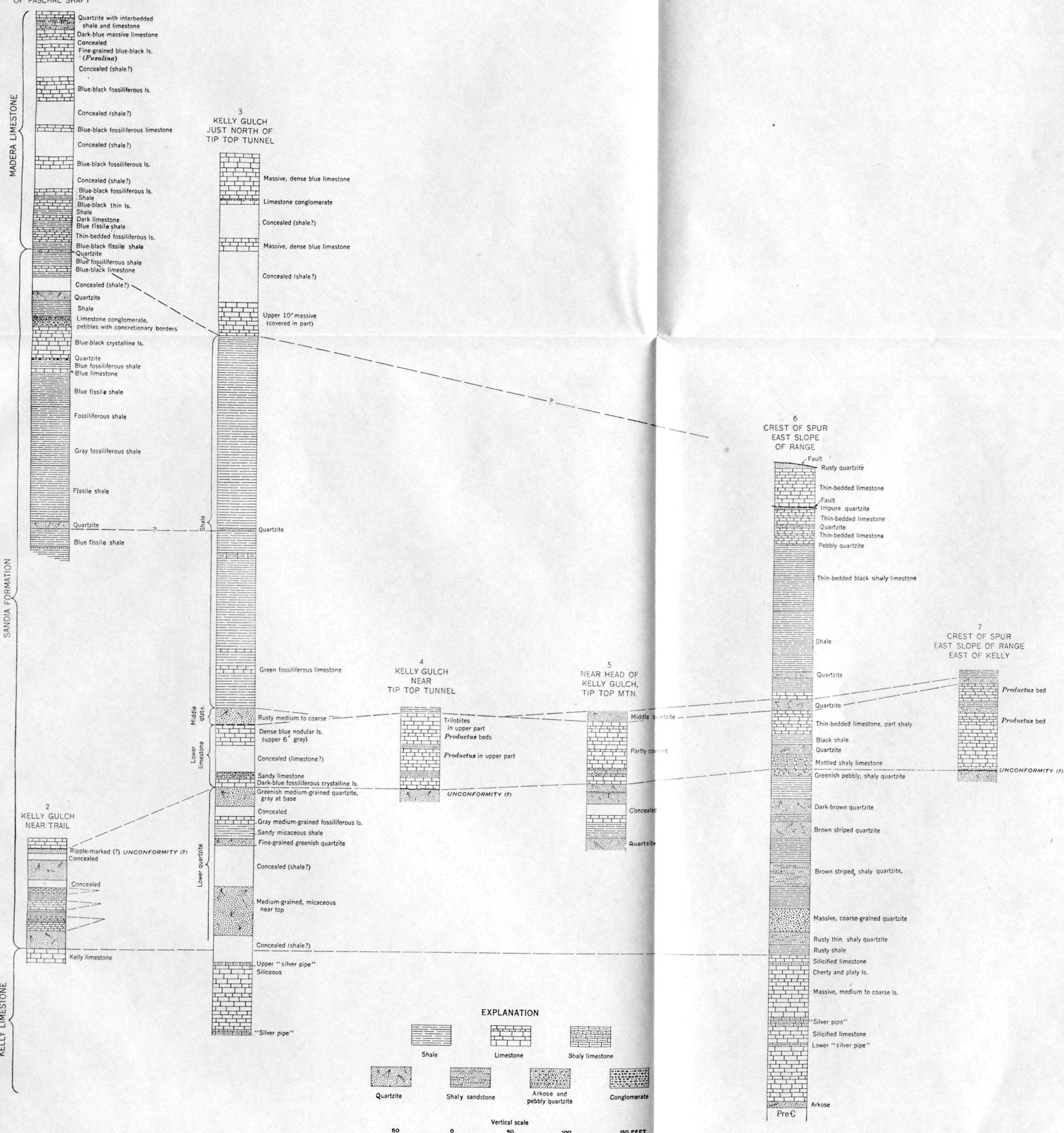


replaced with irregular blebs of albite. The abundant epidote, which accounts for the greenish color of the rock, forms irregular grains or radiating bunches up to 2 millimeters in diameter and occasional well-formed crystals. It indiscriminately replaces both the crystal fragments and matrix. Calcite in irregular masses up to 5 millimeters in diameter is found mainly in the matrix, but it also replaces in part some crystal fragments. Sericite partly replaces the feldspar. The matrix may consist in part of quartz and other secondary products.

\section{LOWER ANDESITE}

The lower andesite, like the lower latite tuff, is found enly in the low hills east of Granite Mountain, where it covers about 70 acres. Its northernmost exposure is west of its general trend and has evidently been offset along concealed faults, as suggested on plate 2. The northernmost part lies on the lower latite tuff, but the southernmost part overlaps onto shale of the Sandia formation. In places white rhyolite has been intruded along the lower contact, probably in the form of sills. The lower andesite is overlain by the upper latite. It consists chiefly of tuff with a few interbedded flows or sills and is about 750 feet thick. The tuff is sheeted, whereas the flows or sills are massive and are 2 to 3 feet thick. The tuffs and flows strike a little west of north and dip about $30^{\circ} \mathrm{W}$. The dip is considerably less than that of the limestone and shale to the east and clearly marks an angular unconformity.

The lower andesite as a whole is more variable in appearance than the latites both below and above it. The tuffs are dark green and differ in color from all the other andesites of the district. Only occasional fragments can be seen with the unaided eye. Some of the flows also are green and resemble the nonporphyritic lamprophyre dikes, but others near the middle of the formation are dark purple where fresh and dark gray where weathered. The texture of the flows ranges from nonporphyritic in the green to decidedly porphyritic in the dark-purple flows, whose prismatic phenocrysts, which are as much as 7 millimeters in length, are altered to a black material embedded in a dense groundmass. Green specks of epidote are common.

The tuffs, as seen in thin section, consist chiefly of two kinds of rock fragments, a small amount of interstitial epidote and calcite, and smaller amounts of quartz and chlorite. The most common fragments are andesite with rare altered feldspar phenocrysts in a felty, very fine grained groundmass. They are only slightly replaced by epidote and calcite. Less common are somewhat coarser and more altered fragments that consist of an intimate intergrowth of altered feldspar, quartz, epidote, calcite, and chlorite. A few fragments of altered hornblende are present and are now represented by chlorite, quartz, and calcite.
The purple rock, as shown in thin section, originally consisted of brown hornblende phenocrysts in a microgranular groundmass of plagioclase laths and is therefore called hornblende andesite. The hornblende phenocrysts have been in part replaced by chlorite and in part by pseudomorphous rims of fine-grained hematite with cores of calcite, chlorite, and quartz, and represent the black prismatic phenocrysts seen megascopically. The plagioclase laths in the groundmass are considerably altered to sericite and calcite. Small aggregates of secondary quartz and abundantly scattered grains of hematite, epidote, and chlorite are also present.

\section{UPPER LATITE}

The upper latite forms the east slope of Granite Mountain, where it rests on the lower andesite, and the eastern portion and crest of Stendel Ridge, where its rests uncomformably on shale on the Sandia formation. It is overlain by the rhyolite porphyry sill, which so closely resembles the latite on weathered surfaces that it can be distinguished only by its abundance of large quartz phenocrysts. For this reason the contact between the upper latite and rhyolite porphyry is somewhat arbitrary where exposures are poor. The upper latite consists mainly of tuffs and breccias, with a massive, interbedded flow near the top of the formation on Stendel Ridge. This flow and a mass of coarse, purple breccia on Granite Mountain have been mapped as distinct members of the formation. The upper latite is probably the oldest volcanic formation in the main range, but its age relation to the purple andesite to the south is not known (see fig. 2). Its average dip is about $30^{\circ} \mathrm{W}$., and its minimum calculated thickness is 1,200 feet on Granite Mountain and 1,200 to 1.400 feet on Stendel Ridge. The flow and the tuffs are not easily distinguished from each other on fresh surfaces, but in weathered outerops the tuffs and breccias show a distinct lamellar structure (pl. 7, A) in which individual layers are an inch or more thick, whereas the flows are massive.

Tuff and breccia.-On Stendel Ridge the basal 15 feet consists chiefly of angular and some rounded fragments of the underlying limestone, shale, quartzite, and grains of feldspar and quartz derived from preCambrian granite. These grains locally give this basal bed the appearance of rhyolite tuff. The matrix of this bed consists of tuff, which in places has been so much altered to epidote that it is yellowish green. Above this basal bed is a massive gray tuff, which is greenish on a weathered surface, has a uniform texture, and is so crowded with crystals that it appears more like a fine-grained crystalline rock. It probably represents a sorted material from which the finer ash particles were removed either by wind action during the eruption or by the more rapid descent of the heavier crystal fragments. The crystals consist chiefly of 
white plagioclase with an occasional pink orthoclase grain and scattered little specks of a black mineral.

Most of the tuffs of the upper latite are purplish gray, with a greenish tone on altered surfaces. At the 7,410-foot peak on Stendel Ridge they are bleached white. They resemble porphyry but their fragmental character can be recognized by the large number of chilled latite fragments, and their tuffaceous character is especially shown by their lamellar structure on a weathered surface and locally by beds or lenses of breccia. The crystal fragments are mostly less than 3 millimeters in diameter but may be as much as 7 millimeters. They consist of white plagioclase and pink orthoclase and a black ferromagnesian mineral.

The purple breccia member is well exposed on the south slope of Granite Mountain. This apparently thick zone can be traced to the north for only a short distance before it pinches out. Farther north just to the east of the peak are two horizons of purple breccia with a few scattered quartzite fragments, and similar rock is exposed on the northeast side of the mountain. These exposures are very probably local lenses, for none can be traced very far; yet locally they have a thickness of 25 feet and more, and because of their color are striking features. The breccia consists of fragments up to 2 inches in diameter, many of which are well-rounded, and simulates a conglomerate. The fragments consist of whitish felsitic fragments embedded in a purple to blue matrix.

One thin section of the lower tuff consists of about 70 percent of feldspar fragments, many of which have partial crystal outlines, and only a few fragments of latite. The feldspar fragments consist largely of oligoclase-andesine and a few grains of orthoclase and are considerably replaced by sericite and calcite. The original matrix, which consisted of extremely finegrained material, is now largely replaced by chlorite, sericite, and calcite. Most of the chlorite contains small magnetite grains, especially around the borders. A few small detrital grains of quartz, apatite, magnetite, and zircon are present, together with a little secondary quartz.

Thin sections show most of the tuffs to consist approximately of 30 to 40 percent of crystal fragments and 60 to 70 percent of matrix. The fragments are predominantly of plagioclase, but a few are of orthoclase, and some are "ghosts" of a ferromagnesian mineral. The plagioclase (oligoclase-andesine) forms rectangular to irregular grains and is somewhat replaced by sericite, calcite, and some epidote. The original ferromagnesian minerals, chiefly biotite but probably also hornblende, are now marked by local segregations of fine-grained iron oxide with chlorite and sericite. Quartz is partly in single grains about 1 millimeter in diameter, but most of it forms scattered fine-grained aggregates up to 0.3 millimeter in diam- eter, which show undulatory extinction and are probably secondary. Magnetite, apatite, and zircon are the minor accessory minerals. The matrix consists of a light-brownish microfelsitic material of low birefringence that seems to be chiefly orthoclase. Calcite associated with secondary quartz forms irregular patches 2 millimeters in diameter that are irregularly scattered through the matrix.

Flow.-The latite flow on Stendel Ridge is dark purplish where fresh, but more commonly it is altered to gray or greenish gray. It is porphyritic and resembles the rhyolite porphyry of the intrusive rocks, but quartz phenocrysts are absent. Feldspar, in crystals mostly less than 2 millimeters in diameter, is the predominant mineral; but a smaller amount of altered biotite is also present, some grains of which are dull, scaly, and of hexagonal outline. The groundmass is dense and flintlike.

Thin sections show the flow to be very porphyritic. The phenocrysts constitute from 30 to 40 percent of the rock, and of these the feldspars constitute about 75 percent and biotite, augite, and a little hornblende about 25 percent. The feldspar is chiefly oligoclaseandesine, with an occasional grain of orthoclase. The oligoclase-andesine forms rectangular to irregular grains, many of which are rounded and embayed owing to resorption. A few grains are zoned, and others have been in part replaced by a later feldspar of lower refringence, probably albite, which forms veinlets and irregular stringers in these plagioclase grains. In most sections the feldspar is slightly altered to sericite and calcite and has occasional epidote grains, but in a specimen collected from the small outcrop south of the Waldo tunnel the plagioclase has been almost completely replaced by sericite and calcite. One section had a few rounded and embayed orthoclase grains.

Biotite is the most common of the ferromagnesium minerals. It is partly or completely resorbed and is thus not readily recognized megascopically. The partly resorbed crystals contain fine-grained magnetite along their borders and cleavage planes, and those completely resorbed are represented chiefly by pseudomorphous areas of fine-grained magnetite with interspersed chlorite, quartz, and epidote, and in one section by muscovite. Augite, like the other phenocrysts, has undergone partial resorption. and replacement by calcite and quartz. Some grains are clouded with dustlike inclusions of iron oxide. Hornblende is absent in most sections, but a little brown hornblende is present in a specimen taken near the crest of the 7,562-foot hill on Stendel Ridge. Magnetite, apatite, and titanite are the minor accessory minerals. The groundmass is cryptocrystalline to microgranular, unlike that typical of andesite, and probably contains considerable orthoclase. On the basis of the texture the rock is classed as a latite. 


\section{PURPLE ANDESITE}

The purple andesite forms the basal volcanic formation south of Kelly. In most places it lies on the Abo sandstone, in others on the Madera limestone, and in still others it is separated from the sedimentary rocks by the latite porphyry sill that extends southward from Kelly. It is overlain by the banded rhyolite at the south end of the district, where its contact is well-exposed; but in the low hills between Patterson Canyon and Kelly it is in fault contact with some of the younger volcanic rocks. It consists chiefly of tuffs and breccias with some flow material near the top. The lower portion is a rather coarse breccia, locally containing many well-rounded fragments of the Madera and Abo formations as much as 5 inches in diameter and well-rounded fragments of andesite, some of which are a foot in diameter. The coarse layers are lenticular and are interbedded with layers of tuff. The formation has an estimated thickness of 1,200 feet.

The purple andesite presents some variations in appearance, but with few exceptions its purple color is characteristic. Locally its color may grade into a lavender or bluish tint, and at the contact with the Abo sandstone it is red. The flow material near the top of the formation is gray. Texturally the rock appears porphyritic with white tabular plagioclase crystals, most of which are less than 3 millimeters in diameter, and a less prominent black prismatic mineral embedded in a dense purple matrix.

Thin sections of the flow material are variable. The phenocrysts constitute as much as 30 percent of the rock and consist of plagioclase and an altered ferromagnesian mineral. The plagioclase ranges from sodic oligoclase to andesine. It is partly replaced by calcite in most sections and by albite in others. The ferromagnesian mineral has been completely altered to finegrained pseudomorphous iron oxide, which retains the original mineral outline and suggests hornblende (pl. $10, B)$. The cor'es of the pseudomorphs may consist of calcite and quartz impregnated with iron oxide. Augite has been observed in only one thin section and is partly replaced by calcite and quartz. The groundmass in some varieties is cryptocrystalline, showing microspherulites and a mesh of hematite needles (pl. 10, A), which probably represent resorbed and oxidized amphibole. This mesh does not penetrate the phenocrysts but is distinctly limited to the groundmass. In other varieties the groundmass is trachytic, and in still others it is microgranular and consists of short plagioclase laths bordered and in part replaced by albite. Secondary iron oxides disseminated through the groundmass somewhat obscure it. Aggregates of quartz (all probably secondary), varying amounts of calcite, epidote, and an occasional small flake of pale-green chlorite are also present. Apatite and zircon are the minor accessory minerals.
The tuffs, as seen in thin section, consist of andesite fragments and crystal fragments which are chiefly of oligoclase and an altered ferromagnesian mineral, with minor amounts of orthoclase, embedded in an extremely fine grained matrix. The character of the matrix is obscured somewhat by calcite and by iron oxide, which is especially common along the borders of the fragments. The oligoclase fragments are only slightly replaced by sericite and calcite, but the original ferromagnesian mineral whose outlines are like those of hornblende is now represented only by aggregates composed of a chloritic mineral, with or without sericite, calcite, and quartz with a border of hematite. Quartz is variable in amount, and most of it is probably secondary. It occurs in small grains 1 millimeter in diameter, but more commonly it forms mosaics with undulatory extinction or irregular chalcedonic patches. Apatite, magnetite, and zircon are the minor accessory minerals.

The andesite fragments are commonly unaltered and are in sharp contrast with the altered tuffaceous matrix. They consist of porphyritic andesite with a felty to trachytic groundmass. The phenocrysts are plagioclase crystals as much as 1.2 millimeters in length and ferromagnesian minerals now completely altered to muscovite with or without calcite and smaller amounts of quartz; but their original outlines, marked by iron oxide, resemble those of biotite, hornblende, and less clearly augite.

\section{BANDED RHYOLITE}

The banded rhyolite, the only prominent banded volcanic rock in the district, is the most widely distributed of the effusive rocks. It forms a discontinuous narrow band about 4 miles long and is the only formation that extends from the south end of the district into the central area and thus permits the determination of the relative age of the formations in the two parts of the district with respect to each other (fig. 2). A small exposure occurs at the north base of the range just east of Anchor Canyon and 2 miles northeast of the main mass, and extensive masses are found west of the Granite Mountain area and in the hills north of La Jenze Creek.

West of Granite Mountain it overlies the Tertiary (?) sandstone unconformably. In the central part of the district it is separated from underlying latite or andesite by the sill of rhyolite porphyry, and in the southern part it overlies the purple andesite. The strike of its banding in general conforms to the strike of the region. The angle of dip is approximately $30^{\circ}$ to $40^{\circ}$, but locally, as west of Kelly, it may be $50^{\circ}$. The thickness of the formation ranges between 250 and 400 feet in the southern part of the region and apparently between 675 and 875 feet west of Stendel Ridge, although the thickness may be exaggerated by concealed faults.

The banded rhyolite consists almost entirely of flow material characterized by alternating layers or thin lenses of hard dark-colored and soft light-colored finely 
porphyritic rhyolite. Its prevailing colors are shades of gray and pink, but at the south end of the district it is purplish red and becomes redder toward its contact with the overlying red andesite. The layers consist of dense flintlike groundmasses containing thinly scattered crystals of orthoclase, biotite, and a little quartz mostly less than 2 millimeters in diameter. The banding is intensified, especially in the southern area, by thin lenses of gray finely granular quartz up to 5 inches in length. In the gray facies in general, and in the upper portion of the red facies, these lenses are mostly less than a quarter of an inch long and give the weathered surface a "knotty" appearance.

In thin section the rock is variable. The red facies with a number of "knots" shows only a few phenocrysts of orthoclase, which have been partly replaced by mosaics of quartz. Quartz phenocrysts are rare and small, usually less than 0.1 millimeter in diameter. They are irregularly distributed and are embayed by partial resorption. Remains of probable biotite are marked by a few fine-grained aggregates of quartz surrounded by rims of iron oxide. The lenses and knots consist of very fine grained quartz, which is free from the iron oxide dust that clouds the matrix and accounts for its red color. Several lenses and stringers consist of radial growths of brownish cryptocrystalline material. These radial growths have an index of refraction less than that of Canada balsam and probably are intergrowths of potash feldspar and cristobalite. ${ }^{45}$ They usually contain crystallized quartz at the center and occasionally at the edge. It is evident that the lenses are secondary and probably fill vesicles of an original pumice. The groundmass is microfelsitic to glassy and is streaked by the unequal distribution of iron-oxide dust.

The gray facies north of Kelly consists of a slightly porphyritic rock containing a few phenocrysts of clouded orthoclase and partly resorbed biotite. Flow structure is well-developed in the cryptocrystalline to nicrogranular groundmass sprinkled with iron-oxide dust. Irregular streaks and aggregates of fine-grained quartz are common. Included in the rock are several finely sericitized rhyolite fragments that contain quartz and orthoclase phenocrysts. Apatite and zircon are minor accessory minerals.

The tuff at the base of the banded rhyolite is stratified and has the general appearance of a sedimentary rock. It is whitish to yellowish gray and in places is streaked and banded by limonite stains. It ranges in texture from fine-grained and chalky to distinctly fragmental. Quartz and orthoclase with chalcedony and opal are the only recognizable minerals. They are accompanied by fragments of a whitish-gray to green felsitic rock as much as half an inch in diameter.

Under the microscope the fine-grained tuff does not

${ }_{45}$ Ross, C. S., oral eommunication. appear very different from the gray flow rock except for the absence of banding and the presence of considerable sericite. From a rock composed chiefly of small glass fragments in a minutely granular matrix the tuff grades into one in which fragments of rhyolite and orthoclase constitute approximately 35 percent. Plagioclase was noted in only one thin section. Biotite is extremely scarce. Secondary minerals are most common in the more pseudoporphyritic and fragmental varieties. The principal secondary minerals are sericite and quartz, accompanied by considerable calcite in one thin section and by veinlets of quartz in others. Iimonite pseudomorphs after pyrite are disseminated through only one section, although limonite staining is present in others.

\section{RED ANDESITE}

The red andesite, which is restricted to the area south of Kelly, directly overlies the banded rhyolite near the southwest corner of the district. In the foothills south of Kelly it has been so faulted against older rocks or partly covered by alluvium that its lower contact is not exposed. It is in general overlain by the pink rlıyolite, the youngest of the effusive rocks in the southern part of the district, but in the foothills just north of South camp it is apparently conformably overlain by the red rhyolite. However, the contact is not extensive and is in general so obscured by debris that the relation is indefinite. South of South Camp the red andesite and the upper andesite form opposite banks of a gully, but their contact is concealed by debris. It is regarded, however, as an unconformity and is more fully discussed on page 29. The red andesite consists of interbedded. flows and tuffs, although the tuffs are found chieflly at its base. One of the basal beds 4 to 6 feet thick is whitish gray. The formation dips $30^{\circ}$ or less westward, and it ranges in thickness from about 500 to 800 feet.

The red andesite presents considerable variation in appearance. The type rock has the appearance of red hematite, and its texture is thoroughly dense or only slightly porphyritic. It grades into a reddish-gray or a purplish-gray facies, in which black altered phenocrysts are few and average about 1 millimeter in diameter. Some of the flows are dark gray and scoriaceous at the top, and where their smaller vesicles are filled with calcite or chalcedony they are distinctly amygdaloidal.

In thin section the typical red nonporphyritic andesite (pl. 10, $C$ ) consists mainly of small lath-shaped andesine crystals in a dark-red matrix thoroughly impregnated with iron oxide. It also contains many small round cavities, most of them less than 0.1 millimeter in diameter, that are filled with chalcedony, but some are filled mainly with calcite and others with quartz mosaics. The largest vesicles (pl. 11, B) are filled with calcite and lined with chalcedony from 
which a few prismatic quartz crystals have grown inward. Calcite may also form irregular streaks and patches. Phenocrysts of a ferromagnesian mineralaugite or hornblende-have been altered and are now represented by pseudomorphs of red iron oxide and chalcedony.

In the porphyritic facies the original phenocrysts whose outlines suggest hornblende are represented by shells of iron oxide filled with chalcedony. They are most common in the scoriaceous facies, but even there they constitute less than 5 percent of the rock. The groundmass is felty to trachytic and consists of plagioclase laths 0.2 millimeter and less in length. Minute grains of iron oxide are peppered through the groundmass. The trachytic variet $\bar{y}$ is much silicified with fine-grained quartz mosaics interstitial to the feldspar laths. In an andesite near the top of the formation secondary calcite is bordered by a green mineral, probably celadonite. This mineral, which is better developed in the upper andesite, is described on page 30.

\section{RED RHYOLITE}

An altered rock, tentatively determined as red rhyolite, is confined to three low hills north of South Camp. It somewhat resembles the red andesite but is paler and more purplish red and is more distinctly silicified. It contains thinly scattered phenocrysts of feldspar and biotite less than 1 millimeter in diameter but no phenocrysts of quartz, although small cavity fillings of quartz resemble phenocrysts. It is much fractured and recemented by quartz veinlets in places, and some of the quartz crystals that line cavities are topped by small, tabular barite crystals. Quartz veinlets lined with red iron oxide are also conspicuous.

In some thin sections phenocrysts of orthoclase and biotite are practically absent and in others they constitute as much as 20 percent of the rock. The orthoclase is unaltered in part, but some crystals are considerably replaced by a clay mineral of the montmorillonite-beidellite group. Some grains of similar outline but completely replaced by a clay mineral and quartz may represent plagioclase. Some biotite shreds are slightly resorbed and have the usual border of iron oxide. In some places ghosts of former crystals whose outlines suggest hornblende have been completely altered to a mixture of yellow or brown clay and chalcedony coated with iron oxide.

The groundmass ranges from glassy to granular and is usually clouded with "dust," the larger particles of which are recognizable as iron oxide. In the coarsergrained varieties orthoclase can be recognized. Quartz veinlets are common, and quartz also occurs in small aggregates and disseminated irregular grains, some of which appear to be secondary and some primary. The tentative recognition of primary quartz together with the dominance of orthoclase among the phenocrysts justifies the field designation of the rock as rhyolite, although identity is obscured by the amount of secondary quartz.

The red rhyolite evidently overlies the red andesite in essential conformity and is capped in one place by the pink rhyolite. Although its relations to the pink rhyolite are obscured to some extent by faulting, the red rhyolite was evidently beveled by erosion before the eruption of the pink rhyolite, which rests on red andesite a short distance east and north of the larger exposure of red rhyolite. No contact between the red rhyolite and the upper andesite is exposed, but the red rhyolite is believed to be the older, because of its conformable relation with the red andesite, which, as shown below, appears to be unconformably overlain by the upper andesite.

The thickness of the red rhyolite is not determinable, for nowhere in the district is its upper and lower contact exposed in the same outcrop; nor is its angle of dip known. But assuming an angle of dip of $30^{\circ}$, shown by the red andesite to the south, the red rhyolite has a minimum thickness of 400 feet.

\section{UPPER ANDESITE}

The upper andesite, which is exposed in the extreme southwest corner of the district, extends a considerable distance to the west and northwest and constitutes the lower parts of Magdalena Mountain and Elephant Butte (pl. 3, A), just beyond the west boundary of the district. It is also red but distinctly different from the red andesite previously described, as it contains abundant well-defined phenocrysts of plagioclase, biotite, and augite.

The upper andesite consists chiefly of flow material but includes some tuff. In the extreme southwest corner of the district the upper andesite has a platy or lamellar structure similar to that in the tuffs of the other formations in the district. Its minimum thickness is estimated at 300 feet, but its maximum thickness is probably much greater.

The structural relations of the upper andesite are in part obscure. The eastern boundary discordantly cuts off the adjacent banded rhyolite and red andesite along a gulch bottom and is so nearly straight as to suggest a fault, but at no place was the contact with these rocks actually seen. At the head of this gulch, however, the pink rhyolite conformably overlies the glassy top of the upper andesite and continues eastward over the red andesite without being displaced. If, therefore, a fault could have separated the upper andesite from the older rocks, it must have formed before the eruption of the pink rhyolite. It should have dropped the glassy top of the upper andesite to the west, and erosion should then have completely removed the upper andesite from the area east of the supposed fault without removing even the glassy top on the west. An alternative view 
is that the red andesite and banded rhyolite had been previously eroded to a steep slope, perhaps along a fault, and that the upper andesite later banked up against the slope. The pink rhyolite was erupted so soon afterwards that it flowed conformably over the glassy top of the upper andesite, overlapping eastward onto the erosion surface of the red andesite. This interpretation is illustrated in plate 4 (sec. G-G') .

The upper andesite varies somewhat in appearance. The type rock is light brick red, similar to the red andesite, but is distinguished by abundant phenocrysts of glassy to white plagioclase, 2 to 4 millimeters long, black biotite, and pyroxene crystals 1.5 millimeters in diameter. Furthermore, it is characterized by an abundance of chalcedony geodes from a fraction of an inch to 3 inches in diameter, fragments of which form a distinctive feature of the weathered surface. Although its megascopic appearance and its content of ferromagnesian minerals differ somewhat from place to place, the upper andesite is not readily divisible in the field into separate flows.

As seen in thin section the upper andesite ranges from a hypersthene andesite to a hypersthene-augite andesite, and in the glassy top of the formation biotite and brown hornblende are also present. Phenocrysts form as much as 25 percent of the rock, and of these the most common is plagioclase (labradorite), which nccurs in wellformed and tabular crystals conspicuously larger than the ferromagnesian phenocrysts (see pl. 11, A). The feldspar phenocrysts are zoned and comparatively clear, but many are in part replaced by calcite and by stringers of a pale-brown mineral of the montmorillonite-beidellite group, which lie along cleavage cracks and also form central blotches. This mineral will be discussed more fully below.

The most common of the ferromagnesian minerals has been completely replaced by fine-grained aggregates of celadonite with borders of hematite, but the outlines of the original crystals are well-defined and their square cross sections with truncated corners strongly suggest that the original mineral was hypersthene. Few of them are more than 5 millimeters long.

In the lower part of the formation the altered hypersthene was the only primary ferromagnesian mineral represented, but in the middle and upper part augite is also present. In contrast to the other pyroxene it is unaltered and forms crystals up to 1 millimeter in length. Still higher, in the glassy facies just below the pink rhyolite, deep-brown and reddish-brown biotite is present. In one thin section iron oxide associated with secondary quartz may represent resorbed biotite or hornblende. Bunches and streaks of fine-grained secondary quartz and geodes of chalcedony are common in some places. The minor accessory minerals are magnetite and apatite.

The groundmass is trachytic and consists of small feldspar laths in a brown glassy to cryptocrystalline matrix. Minute grains of red iron oxide are disseminated through the groundmass.

The eastern part of the upper andesite just below the pink rhyolite is a gray porphyritic glass of pitchstone, in places somewhat devitrified, with phenocrysts of glassy plagioclase (andesine), biotite, brown hornblende, and less commonly augite and altered hypersthene. Similar rock is abundantly exposed at the top of the andesite in Elephant Butte, just to the west of the district, and black andesite obsidian occupies the same position in Magdalena Mountain, just to the north of Elephant Butte. The glassy groundmass of the gray pitchstone shows perlitic cracks, and that of the black rock at Magdalena Mountain is full of radiating trichites. Irregular patches and microgeodes of zeolites with cores of opal and some chalcedony are common in the gray pitchstone (pl. 11, C).

Alteration products that are conspicuous microscopic features of the upper andesite and are present to a minor degree in the underlying volcanic rocks deserve special comment. The most abundant of these have the general properties of the montmorillonite-beidellite group of minerals. The mineral replacing the plagioclase is pale coffee brown and forms micaceous and exceedingly fine grained aggregates. The same or a similar mineral has also replaced some of the feldspar and hornblende (?) phenocrysts in the red rhyolite. In some thin sections hypersthene also has been replaced by a darkbrown, fibrous mineral of strong pleochroism, whose indices of refraction range from about 1.52 to 1.58 . Intergrown with the brown fibers is a very small amount of green fibers, suggesting the possibility that the aggregate consists of two minerals with birefringences less than those recorded.

Other thin sections show a mineral that is similar, but it is pale green and slightly pleochroic. The habit of the aggregates is that of serpentine, but the birefringence suggests clay minerals, probably rich in the nontronite molecule. ${ }^{46}$

The dark-green mineral with fibrous habit that replaces hypersthene a short distance below the top of the upper andesite has indices of refraction, moderately high birefringence, and pleochroism that agree with those of celadonite. Some hypersthene crystals are entirely replaced by this mineral, whereas in others hematite fills the original transverse cracks and the celadonite fibers or plates lie on both sides normal tc the hematite-filled crack. In still others the celadonitic material encloses a pale coffee-brown opal whose index of refraction is 1.420. Besides forming pseudomorphs after hypersthene, the celadonitic material also forms ringlets (pl. 12, $A$ ) and wormlike streaks in the groundmasses of both the upper and the red andesites. In the glassy top of the upper andesite it also surrounds small growths of zeolites and opal, and in the

${ }^{46}$ Ross, C. S., and Kerr, P. F., The clay minerals and their identity : Jour. Sed. Petrology, vol. 1, p. 60, 1931. 
crystalline groundmass it surrounds calcite and inclusions of groundmass in calcite.

These replacement minerals are the result of a selective process, for although hypersthene has been completely replaced and plagioclase partly replaced, augite and biotite remain unaltered. These minerals are usually regarded as the products of normal weathering, but, as the groundmass is fresh and the rock does not show the usual signs of weathering, they are believed to be a product of hot solutions.

The two partial chemical analyses presented in colums 1 and 2 below express the results of alteration. The high silica content, compared with that of the average andesite in column 3 , may be attributed to the development of quartz. The high content of ferric oxide and almost negligible amount of ferrous oxide express the development of hematite, and perhaps celadonite and nontronite, at the expense of hypersthene. The low content of magnesia also reflects the replacement of hypersthene. The percentages of lime - are not indicative, as the deposition of calcite tends to offset any removal of lime during alteration of plagioclase to montmorillonite or similar minerals.

Partial analyses of upper andesite and average andesite

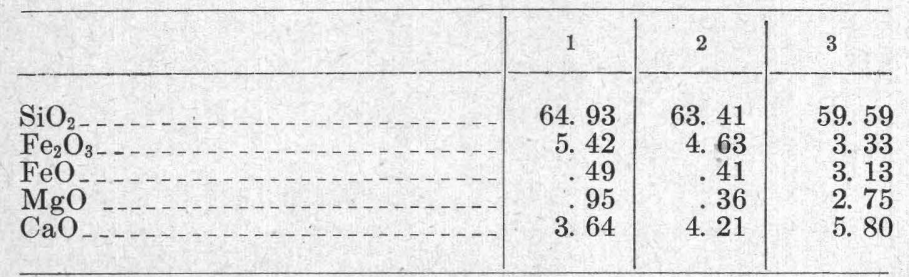

1. Upper andesite 2,000 feet due south of South Camp; A. R. Ferguson, analyst.

2. Upper andesite from extreme southwest corner of district; A. R. Ferguson, analyst.

3. Average of 87 samples of andesite; Daly, R. A., Igneous rocks and their origin, p. 26, New York, 1914.

\section{PINK RHYOLITE}

The pink rhyolite forms the crest of the high spur in the southwest corner of the district and caps some of the low hills south and west of Kelly. It also caps Elephant Butte and Magdalena Mountain, west of the area mapped. At Magdalena Mountain (pl. 3, A) the capping flow connects with a dike of northerly trend that forms the east cliff face of the mountain. For the most part the pink rhyolite lies directly on the red andesite, but at South Camp it caps the red rhyolite and in the extreme southwest corner it covers the upper andesite. These relations together with its relatively low angle of dip-about $10^{\circ} \mathrm{W}$.-indicate an unconformity at its base. Bleached tuffs at the base of the pink rhyolite on the low isolated hill west of Kelly have an abnormal dip of $65^{\circ} \mathrm{W}$. The thickness of the pink rhyolite within the district is about 400 feet, but its total thickness may be much greater. The pink rhyolite is the youngest of the effusive rocks with the possible exception of the white felsite tuffs in the northwest part of the district. It is cut, however, in the low hills southwest of Kelly by the rhyolite porphyry, which is among the oldest of the Tertiary (?) intrusive rocks.

The pink rhyolite comprises a lower member of tuff and a dominant upper member of one or more flows. Unquestioned tuff is found in the low isolated hill west-northwest of Kelly. Its lower portion is wellbedded and resembles cream-colored sandstone where not appreciably altered, but the greater part of it is bleached and peppered with rust spots. Where fresh the flows are massive, but where considerably weathered they have a pronounced platy structure; and in places they contain so many inclusions they are not readily distinguished from tuff. In the extreme south end of the district the rhyolite contains many elongated cavities up to 2 inches in length. The cavities have their long axes uniformly oriented, giving the rock a somewhat banded appearance, but marked flow structure is absent.

The type rock of the flows where fresh is mostly pink or purplish pink and locally red, but weathered surfaces are somewhat faded. It has a dense to finely porous groundmass with thinly scattered phenocrysts of orthoclase, quartz, and very little biotite that constitute 5 to 10 percent of the rock. The orthoclase phenocrysts are white to glassy and are as much as 2 millimeters in length. The quartz phenocrysts, which are thinly scattered colorless to smoky grains about 1 millimeter in diameter, distinguish the pink rock from the other effusive rocks, although minute aggregates of secondary quartz in the red rhyolite so resemble the quartz phenocrysts in the pink rhyolite as to be misleading.

In thin section the phenocrysts of orthoclase and quartz are shown to be commonly rounded and resorbed. The orthoclase is locally a little sericitized along cleavage cracks. A few shreds of unaltered biotite are present, but the biotite is mainly altered to pseudomorphic areas of fine-grained quartz and sericite.

The groundmass is cryptocrystalline to very finely crystalline and somewhat vesicular. In places it is partly impregnated with secondary quartz and chalcedony. Cryptocrystalline to fibrous chalcedony commonly fills or lines vesicles, and fine aggregates impregnate the groundmass.

The typical tuff consists of erystal fragments of quartz, orthoclase, a few plagioclase grains, and fragments of rhyolite embedded in a very fine grained matrix whose low birefringence corresponds to that of quartz and orthoclase. The crystal fragments average about 1 millimeter in diameter. The tuff is roughly stratified, fragments being more common in some layers than in others. The more lamellar beds are seen in thin section 
to consist of dark brown pumice fragments of rounded and cusplike outlines and a few crystal fragments in an extremely fine grained sericitized matrix.

\section{WHITE FELSITE TUFF}

Remnants of bleached sheeted tuff beds flank the north end of the lower andesite hills east of Granite Mountain. They are light greenish gray and weather to light gray or white. They contain thinly scattered fragments of feldspar up to 4 millimeters in diameter and conspicuous fragments of dull-green material.

In thin section the tuff is seen to consist mainly of altered glass fragments, many of which are crescentic and cuspate. Crystal fragments of albite-oligoclase, a few orthoclase grains, a few minute crystals of zircon, and altered rock fragments are also present. The crescentic and cuspate fragments are now replaced by minerals of the montmorillonite-beidellite group. The matrix appears microfelsitic and locally contains considerable chalcedony. Because of alteration and the large amount of original glass fragments the true character of the rock is unknown, and it is therefore given the noncommittal name felsite tuff.

The tuff dips at very low angles and is separated from the underlying effusive rocks by a considerable angular unconformity. It therefore corresponds in its structural relations to the bleached tuff at the base of the pink rhyolite; but it is too isolated and too different in composition to be correlated with it. Its color also suggests a close relation to the white rhyolite dikes, the youngest intrusive rock in the district, but it differs from them in containing a preponderance of plagioclase and no quartz fragments. Its distribution on an erosion surface of relatively low altitude suggests that it was extruded after the other volcanic rocks had been tilted and eroded to the extent that the relief of the Granite Mountain area was almost as moderate as it is at present. It may be, therefore, that the white felsite tuff is the youngest igneous rock in the district.

TERTIARY (?) INTRUSIVE IGNEOUS ROCKS GENERAL STATEMENT

The Tertiary (?) intrusive igneous rocks, insofar as relative ages can be determined within the district, are younger than all the effusive rocks, with the possible exception of the felsite tuff, and are divisible into three groups. The earliest group comprises sills and dikes of latite poryphyry and rhyolite porphyry, which were intruded before the main period of faulting and are therefore closely related in time to the effusive rocks. The second group includes stocks of monzonite and granite, which followed the main period of faulting, and may have been localized at the intersections of main fault systems. The small stocks of andesite on Granite Mountain and the sill-like mass on Stendel Ridge may also belong to this group. The third group includes dikes of lamprophyre and white rhyolite, which cut the stocks and older rocks and are the most closely related in time and structural relations to the ore deposits of the district. The rhyolite porphyry of the first group and the members of the third group extend throughout the length of the district, although they are most conspicuous north of Kelly and in the Granite Mountain area. The stocks are in the main range north of Kelly and at Granite Mountain. The stocks of monzonite and granite in the main range are in contact locally with metamorphosed limestone. Although no stocks are exposed south of Kelly, the presence of metamorphic minerals in limestone along a major fault zone in the Linchburg tunnel 2 miles south of Kelly suggests that there be another stock in that vicinity at no great depth. Monzonite is also exposed at the north base of Magdalena Mountain, but its extent has not been determined.

The relative ages of members of any one group cannot all be determined; for example, the latite porphyry and rhyolite porphyry of the first group have not been found in contact, nor has the main monzonite stock been found in contact with the granite stock, although a dike of granite cuts typical monzonite in a minor stock. The presence of late granitic facies in the monzonite also suggests that the granite stock may be relatively late. The andesite stock at Granite Mountain cuts the rhyolite porphyry of the first group, and the sill-like mass at Stendel Ridge is cut by monzonite; but the relations of either andesite body to the main period of faulting have not been determined, and it therefore is not definitely known whether these intrusive andesites are the youngest members of the first group or the oldest members of the second. In the third group the dikes of lamprophyre are cut by those of white rhyolite, which therefore is the youngest igneous rock in the district with the possible exception of the felsite tuff.

\section{LATITE PORPHYRY}

The latite porphyry occurs almost entirely as a much-faulted sill that extends southward from Kelly beyond the south limit of the district. It separates the Madera limestone from the Abo sandstone or from the purple andesite where the sandstone is locally absent. The small areas surrounded by sandstone near the Linchburg tunnel evidently represent the top of this sill, and the still smaller areas a little farther north incude a short dike that has branched from the top of the sill. Along Mistletoe Gulch west of the sandstone area a small dike has intruded the overlying purple andesite, and a little farther west another mass that is poorly exposed appears to represent a second sill intruded within or at the base of the red andesite. A small dike was also found in the southernmost workings of the South Juanita mine. 'The main sill varies in thickness. Just south of the Mistletoe mill it is only about 30 feet thick, although its broad 
exposures nearly parallel to its dip give the impression of a much greater thickness; a little farther west down Mistletoe Gulch its thickness exceeds 100 feet, and near the south end of the district it apparently exceeds 300 feet.

The latite porphyry is greenish gray with local darker-gray, purplish, and pinkish colors. Its more weathered outcrops are stained brown and are pitted from the weathering out of biotite phenocrysts. It has a dense groundmass with 10 to 20 percent of phenocrysts, chiefly of plagioclase and biotite. A few microphenocrysts of orthoclase and quartz, rather conspicuous apatite crystals associated with biotite and magnetite, and a few zircon crystals are identifiable in thin section. The plagioclase (albite-oligoclase) is so thoroughly replaced by sericite, calcite, and a probable clay mineral that its original composition can only rarely be determined. The biotite has been bleached and is partly replaced by calcite and chlorite impregnated with iron-oxide specks and rutile needles or, in some places, with calcite, sericite, and chlorite. The extremely fine grained groundmass probably consists of orthoclase, plagioclase, and quartz, but it is impregnated with ealcite, sericite, quartz, and brown specks of iron oxide.

\section{LATITE DIKES}

Besides the main sill and associated dikes of latite porphyry, a few dikes of similar but not identical composition have been noted. They have not been correlated with any of the larger intrusive masses. Only three have been mapped-one in argillite southwest of the Sleeper tunnel, one in argillite and gabbro southwest of the Germany mines, and one in the latite on Stendel Ridge. They are greenish gray, fine-grained, and porphyritic. Their phenocrysts, which are about 1 millimeter in length and constitute about 30 percent of the whole, include altered plagioclase and chloritized minerals. In thin section the plagioclase is considerably replaced by aggregates of sericite, epidote, calcite, and chlorite. The original ferromagnesian minerals, whose outlines imply hornblende and probably biotite, have been entirely changed to chlorite or aggregates of chlorite, epidote, calcite, and hematite. The groundmass consists of a felty to microgranular mass of feldspar prisms and irregular grains 0.1 millimeter long, small irregular elongate grains of chlorite, and interstitial quartz. Quartz also forms aggregates that are clearly secondary. Hematite, apatite, and zircon are the minor minerals.

\section{RHYOLITE PORPHYRY}

TYPICAL FACIES

The rhyolite porphyry, called granite porphyry by Gordon, ${ }^{47}$ is the most widely distributed of the Tertiary (?) formations in the district. It is present at inter-

${ }^{47}$ Lindgren, Waldemar, Graton, L. C., and Gordon, C. H., The ore deposits of New Mexico: U. S. Geol. Survey Prof. Paper 68, p. 248, 1910. vals along a broken belt of northerly trend on the west foothills of the main range and the upper slopes of Granite Mountain and continues at least 2 miles farther north. Most of its exposures are probably parts of one originally continuous sill-like mass, which lies between the upper latite and the banded rhyolite, but the smaller exposures south of Kelly include a dike and a sill-like mass in pink rhyolite. Identical rhyolite porphyry also occurs extensively in the Lemitar Mountains about 12 miles to the east. A magnetic variety caps three conical summits on Stendel Ridge, two at the southeast end and one at the northwest end. Because of their magnetic properties, which may interfere with surveying, and because of their alteration, which has obscured their identity, these three masses are separately indicated on the map and will be described separately after the description of the normal rhyolite.

The sill-like character of the main mass is best shown around North Camp and on Stendel Ridge. Near North Camp the top of the sill cuts across the flow structure of the overlying banded rhyolites at very small angles, although the sill has a gentle westerly dip similar to that of the flow. Its base is concealed by faults and alluvium at North Camp but is approximately indicated by the small outcrop of underlying latite in the first gulch south of North Camp. On Stendel Ridge the base cuts across the platy layers of the underlying latite tuff at small angles, although the contact is not clearly defined. On Granite Mountain, which has apparently derived its name erroneously from the rhyolite porphyry, the relations are very obscure. The rough banding there even suggests an eff usive origin, although the poorly defined sheeted structure accords with a silllike form. There is no sharp line of demarcation here between the rhyolite porphyry and the upper latite, as the occurrence of quartz in the upper part of the upper latite gives an apparent gradational effect. The structural position of the rhyolite porphyry, however, between the latite and the banded rhyolite that is just west of Granite Mountain is the same as it is farther south, and adequate exposures would probably prove its intrusive character.

The rhyolite porphyry sill has a minimum thickness of about 400 feet at the North Camp, 800 feet on Stendel Ridge, and about 1,400 feet on Granite Mountain, but at no place is the full thickness exposed.

The rhyolite porphyry is purplish red on the whole, but fresh varieties with a glassy to microcrystalline groundmass are deep purple to blue. Where it is hydrothermally altered its weathered surfaces are gray and pitted and irregularly stained by iron oxide. Its groundmass is dense or microgranular, and phenocrysts of plagioclase, orthoclase, quartz, and biotite constitute 30 or 40 percent of it. Abundant large phenocrysts of clear to smoky quartz as much as 3 millimeters in diameter distinguish this rock from all others of the dis- 
trict. Pink orthoclase, though variable in quantity, is the dominant feldspar, and with white to gray plagioclase it forms crystals up to 5 millimeters in length. Biotite, though subordinate, is conspicuous, especially just north of the railroad, where it occurs in abundant well-formed six-sided plates, which have weathered to a bronze color. The rhyolite porphyry contains many fragments of dark-purple, dense rock that are thought to represent an early, quickly chilled variety of the same intrusive mass.

In thin section the phenocrysts are all appreciably resorbed $(\mathrm{pl} \cdot 12, B)$. Thin shreds of biotite are largely replaced by dustlike aggregates of hematite, and the larger biotite grains are fringed with hematite which in the more altered grains is accompanied by chlorite, quartz, and rarely muscovite. The oligoclase-andesine is most commonly unaltered, but in places it is largely replaced by albite and sericite. The orthoclase, which is somewhat microperthitic, is little altered. The groundmass is microfelsitic to microgranular and in places has a faint flow structure. It consists essentially of untwinned feldspar, probably orthoclase, and quartz and in the altered facies may be considerably impregnated by calcite, which is scarce in the phenocrysts. Secondary quartz forms small aggregates in the groundmass of the more altered varieties. The minor accessories are magnetite, apatite, titanite, and zircon.

According to Gordon ${ }^{48}$ "a partial analysis of this rock was made in the laboratory of the Survey by George Steiger, with the following results: $\mathrm{SiO}_{2}, 69.32$; $\mathrm{CaO}, 0.53 ; \mathrm{Na}_{2} \mathrm{O}, 2.45 ; \mathrm{K}_{2} \mathrm{O}, 5.54$." The rock is rather typical of rhyolite, although the ratio of potash to soda is a little higher than in the average rhyolite.

\section{MAGNETIC FACIES}

The three masses of rhyolite porphyry that cap summits on Stendel Ridge largely resemble the neighboring rhyolite porphyry, but rock that more closely resembles monzonite is intimately associated with them. They differ from typical rhyolite porphyry or monzonite in their ability to deflect a compass needle. Compass readings made from these summits and checked by foresights and backsights were from $6^{\circ}$ to $10^{\circ}$ too far to the east. Fragments on the surfaces of the summits commonly have a polarity, one end attracting and the other repelling the compass needle. Notwithstanding this magnetic property, there is nothing in the mineral composition of the rock to account for it, and it may be attributable to some local abnormality in the earth's magnetic lines. Some fragments on these summits, however, are not magnetic but resemble the rhyolite poryhyry and feldspathic and porphyritic facies of monzonite so closely that near the northwest end of Stendel Ridge, where these rocks adjoin the magnetic rock, only arbitrary boundaries can be drawn. At sev-

\footnotetext{
${ }^{18}$ Lindgren, Waldemar, Graton, L. C., and Gordon, C. H., The ore deposits of New Mexico: U. S. Geol. Survey Prof. Paper 68, p. 248, 1910.
}

eral places typical monzonite and magnetic porphyry seem to grade texturally and mineralogically into each other, although their exact relations are obscured by debris.

The two masses of magnetic cap rock at the southeast end of Stendel Ridge have striking resemblances, and the westerly slope of their lower contacts prompts the suggestion that they are isolated remnants of the rhyolite porphyry sill that has been somewhat invaded by dikelets of feldspathic monzonite porphyry. The underlying monzonite has a fine-grained or chilled facies at its contact with the cap rock and is therefore regarded as the younger of the two. Both the monzonite and the cap rock contain dikelets and irregular "patches" of feldspathic monzonite or monzonite porphyry, but structural details are obscured by debris. If the magnetic cap rock is tentatively correlated with the rhyolite porphyry, the main mass of monzonite may be regarded as having been intruded along or parallel to the base of the sill; but the contact of the two magnetic masses with members of the upper latite is too steep to indicate a sill-like relation, and the mass is so far east of the main sill of rhyolite porphyry that such a correlation would require an offset of 800 to 1,000 feet along a fault that was later obliterated by the intruding monzonite. Such an interpretation, though obviously very speculative, is consistent with structural evidence as a whole, which indicates that a former major transverse fault zone crossed the area now occupied by the monzonite. Little or no faulting would be required to account for the rhyolitic facies of the magnetic rock at the north end of the ridge.

From what we know both of local evidence and of the processes involved in the intrusion of the mon zonitic stocks of the district, we interpret the origin of the magnetic cap rock as follows: The rhyolite porphyry was first cut by the monzonite stock. Late intrusions and emanations from the stock formed feldspathic dikelets and impregnated both rocks near their mutual contact with monzonitic material, so that the original contact in most places was obscured if not destroyed. Several facies without clear-cut relations were formed that range from the original normal rocks to such uncommon extremes as feldspathic quartz monzonite porphyry and a porphyritic granophyre containing plagioclase phenocrysts.

In appearance the magnetic rock is much like the rhyolite porphyry except that large quartz grains are less conspicuous. It ranges in color from a light gray, which is the more common, to a dark bluish gray. It is distinctly porphyritic, with a dense microgranular groundmass; but in places it is so crowded with crystals that it appears granular. This rather typical facies grades into a less porphyritic rock and, apparently at least, into nonporphyritic monzonite. White to gray plagio- 
clase, pink orthoclase, thinly scattered quartz, a few grains of bronze-colored mica, and specks of a black mineral can be recognized. Dense, dark-purple inclusions similar to those in the rhyolite porphyry are common in some places.

The magnetic rock varies considerably both in composition and texture, as seen under the microscope. In general it is distinctly porphyritic (pl. 12, $C^{\prime}$ ). Some thin sections show the phenocrysts to be so abundant that the groundmass is merely interstitial, whereas others show them to form less than 50 percent of the rock. The phenocrysts in general show considerable resorption. Those in specimens collected at the south end of Stendel Ridge consist of calcic andesine, orthoclase, augite, and biotite, with a little irregularly scattered quartz. Andesine in irregular and rectangular grains up to 2 millimeters long predominates over orthoclase, and in one thin section no orthoclase was noted. The plagioclase phenocrysts in the lower part of the formation are commonly zoned; in many thin sections the plagioclase is bordered by narrow rims of orthoclase (pl. 12, D) and in part irregularly replaced by orthoclase. Orthoclase forms irregular grains up to 3 millimeters in length. It is commonly clouded along its borders and cleavage cracks, but its cores are clear, suggesting that the clouding is a secondary feature. Quartz phenocrysts are rare.

The ferromagnesian minerals vary in amount and kind. They comprise augite, biotite, and locally a little hornblende. No hypersthene was found. Thin sections from the upper part of the formation have only a few scattered flakes of partly to completely resorbed biotite with very few or no augite phenocrysts. Fresh, pale-brown, fine-grained biotite is locally present in patches of micropegmatite and is believed to be later than the other ferromagnesian minerals. Lower in the formation augite is the dominant ferromagnesian mineral, and it occurs both as phenocrysts up to 0.7 millimeter in length and as microlites in the groundmass. Biotite, where partly resorbed, is marked by a border of segregated magnetite and augite microlites (pl. 13, C) or, where completely resorbed, by pseudomorphous areas of magnetite and fine-grained augite, with untwinned feldspar. The microlites, besides being especially bunched along the borders of partly resorbed biotite flakes where they are associated with fine-grained magnetite, are scattered throughout the groundmass. Whether or not all this granular augite in the groundmass is a result of the resorption of biotite, as is believed of the augite microlites in the groundmass of some andesites, ${ }^{49}$ is not certain; but there can be little question concerning that bordering and replacing biotite. Primary hornblende is scarce

${ }^{49}$ Washington, H. S., The magmatic alteration of hornblende and biotite: Jour. Geology, vol. 4, pp. 270-276, 1896. and is very pale brown. Magnetite, apatite, and zircon, which are the accessory minerals, occur in typical crystals. In one thin section from the southernmost exposure what appears to be a secondary green to orange pleochroic serpentine is sparingly scattered in small irregular grains and shreds and pseudomorphs through the rock, and some of it partly surrounds augite.

The groundmass is microgranular and consists chiefly of orthoclase with smaller amounts of quartz and the augite microlites already mentioned. In some thin sections quartz is very scarce and in others is present only in small amounts of micropegmatite.

The magnetic rhyolite porphyry from the north summit of Stendel Ridge is dominantly a feldspathic facies. It consists chiefly of cloudy microperthite phenocrysts with some oligoclase and an interstitial groundmass that is partly micrographic. Calcite and chlorite are relatively abundant in the interstitial material. Aggregates of finely granular magnetite with some chlorite suggests resorbed and altered biotite. The feldspar phenocrysts are slightly sericitized. This rock approaches the Tertiary (?) granite in mineralogical composition and texture.

\section{HORNBLENDE ANDESITE}

The hornblende andesite is found on Stendel Ridge, where it forms three small outcrops-one a small oval mass that is apparently intrusive into the rhyolite porphyry, another a sill intruded into latite tuff, and the third a small triangular block with obscure relations but evidently younger than the latite flow and older than the monzonite. The third exposure may be a part of the sill; if so, it was detached and lifted during the intrusion of the monzonite.

The hornblende andesite is dark purple with a dense to glassy groundmass in which small phenocrysts of white to colorless plagioclase and hornblende pseudomorphs are thickly distributed (pl. $13, B$ ). The plagioclase (andesine) crystals-in general less than 1 millimeter and rarely as much as 2 millimeters longare only slightly sericitized. The brown hornblende crystals, as much as 3 millimeters in length, have been largely replaced by aggregates of colorless amphibole, sericite, quartz, calcite, and chlorite, with rims of fine-grained iron oxide. Apatite, most of which is included in the replaced hornblende, and magnetite are the only minor accessory minerals. The groundmass, which shows distinct flow structure, consists of small plagioclase laths in a glassy base, veined and spotted with gray cryptocrystalline material. It is free from alteration, excepting some scattered calcite.

\section{AUGITE ANDESITE}

Augite andesite is present on the eastern slope of Stendel Ridge, the crest of Granite Mountain, and the 
low hills north of the district. The largest mass on Stendel Ridge has an irregular sill-like form and covers about 15 acres. A few small dikes are in line with its tapering south end. It cuts the upper latite tuff and is cut by a dike of fine-grained monzonite, but its relations to the adjacent magnetic rhyolite porphyry are obscure. The mass on Granite Mountain is small stock or plug with a surface area of about 30 acres. It is clearly intrusive into the rhyolite porphyry and upper latite. None of these masses are in contact with major faults. It is not known, therefore, whether they are more closely related in time to the effusive rocks that preceded the major period of faulting or to the monzonite and granite stocks that followed it.

The augite andesite is dark gray where least altered and greenish gray elsewhere and has a fine-grained to microgranular porphyritic texture. The phenocrysts, which are as much as 1 millimeter long, are white plagioclase and black augite and constitute from 10 to 20 percent of the rock.

In thin section (pl. 13, A) the phenocrysts are seen to consist of plagioclase (oligoclase-andesine to calcic andesine), augite, minor amounts of brown hornblende, and another ferromagnesian mineral now rẻpresented by chlorite. Those of plagioclase are partly replaced by epidote, calcite, and sericite. Those of augite predominate over plagioclase and are unaltered even where the plagioclase and hornblende are altered. Brown hornblende, sparingly present, is bordered by reaction rims of iron oxide, and many completely resorbed grains are represented by aggregates of iron oxide, calcite, and quartz that are pseudomorphous after hornblende. Chlorite (penninite ?) that represents another ferromagnesian mineral whose outlines suggest a pyroxene is present in appreciable amounts. Some of these grains are bordered by magnetite and a few by augite. Microphenocrysts of magnetite and apatite are thinly scattered through the groundmass.

The groundmass is trachytic and consists of twinned plagioclase laths intercrystallized with small amounts of obscure and irregular grains that are probably orthoclase and scattered magnetite grains. It contains a sprinkling of epidote, calcite, and sericite, but is much less altered than the plagioclase and hornblende phenocrysts.

\section{MONZONITE GROUP}

Four stocks of monzonitic and granitic rock are found within the boundaries of the district. The largest of these is a stock of granite that underlies an area of about 2 square miles on the north end of the Magdalena Range. As it is cut by Anchor Canyon, it will be called the Anchor Canyon stock. Next in size is the stock of typical monzonite north of the Nitt and Graphic-Waldo mines, here designated the Nitt stock. It underlies a known area of at least $1 \frac{1 / 2}{2}$ square miles but is partly covered by alluvium and may be continuous with a small stock northwest of Stendel Ridge as well as with monzonite exposed in the low hills south of the town of Magdalena. The stock northwest of Stendel Ridge, however, is conveniently described separately because of the diversity of its component rocks, which include monzonite and granophyre. The fourth stock is on the southwest side of Granite Mountain and includes monzonite and granite. There is a fifth stock of monzonite and allied rocks about a mile northwest of La Jenze Creek beyond the limits of the area.

The last three stocks and part of the Nitt stock have a northerly alinement over an area about 5 miles long, and half a mile wide. This relatively long and narrow group suggests intrusion from a common reservoir at favorable places along a structurally weak zone which, as will be shown on page 69 , is probably a major fault zone.

The Anchor Canyon stock is the exception to this zonal distribution of the stocks, but its position, which accords with the axis of a broad flexure along the valley that separates the Magdalena Range from Granite Mountain, implies intrusion along another weak zone.

The rectangular southeastern part of the Nitt stock with its steep and regular northern and southern contacts accords with an old transverse fault, which is expressed by the discordant relations of both sedimentary and volcanic rocks to the north and south of the monzonite; indeed this part of the stock has the outline of an unusually thick dike of east-northeast trend.

These stocks, with the exception of the Anchor Canyon stock, are clearly younger than the rhyolite porphyry and augite andesite and are probably the youngest of all the Tertiary (?) igneous rocks except the dikes of lamprophyre and white rhyolite, and presumably the felsite tuffs, which may be even younger than these dikes. The Anchor Canyon stock is intruded chiefly into pre-Cambrian and Paleozoic formations, and its only contact with the volcanic rocks, at the north base of the range, is too obscure to prove its intrusive relation. As the granite in this stock, however, is identical with that of the Granite Mountain stock, it is correlated with that stock and is therefore inferred to be of probable Tertiary age.

There is no direct evidence for the closer dating of the intrusions. As the Datil formation, which evidently includes at least the older of the local volcanic rocks, is tentatively regarded as Tertiary by Winchester, ${ }^{50}$ and as the major period of faulting intervened between the surface eruptions and the stock intrusions, the stocks could be late Tertiary; but such an interpretation cannot be reconciled with the large amount of erosion that has taken place subsequent to

${ }^{50}$ Winchester, D. E., Geology of Alamosa Creek Valley, Socorro County, N. Mex. : U. S. Geol. Survey Bull, 716-A, p. 9, 1920. 
the intrusion of the stocks. In the San Juan ${ }^{51}$ and Front Range ${ }^{52}$ regions of Colorado volcanic eruptions, closely followed by the intrusion of monzonitic stocks and related masses and deposition of ore, took place in both Eocene and Miocene time; and the monzonitic stocks at Magdalena could be tentatively assigned to either epoch, but until much more is known of the intervening region no attempt to assign a more definite age to the stocks is justified.

The depth of intrusion of the monzonitic stocks can be only roughly estimated until more definite information becomes available on the geology and physiographic history of the entire province. The volcanic rocks at one time undoubtedly covered the range within the district as shown on page 24. According to estimates already presented, the volcanic flows and sills had an aggregate thickness of 2,000 feet or more and furnished a cover sufficient to permit the monzonitic rocks to cool slowly and develop their granular texture.

\section{TYPICAL FACIES}

The monzonite has an unequal distribution in the different stocks. The Nitt stock is composed almost entirely of monzonite, but the small stock northwest of Stendel Ridge is largely granite and only its eastern part is equivalent texturally and mineralogically to the monzonite of the Nitt stock. The stock on the west side of Granite Mountain is also mostly granitic, with a southern margin of monzonite. From this stock and also from the northwestern part of the Nitt stock on Stendel Ridge apophyses extend from the main mass. The apophysis on Stendel Ridge, however, is gabbroic, and the transition into the monzonite of the main stock takes place within about 10 feet.

One characteristic feature of the monzonite is its magnetic property, which has permitted the tracing of its contact beneath a cover of alluvium by means of a dip needle. W. O. Hotchkiss, who spent 2 weeks in the field with Loughlin in 1916 testing the usefulness of the dip needle in the location of ore bodies and in geologic mapping, was able to trace the monzonite contact underneath the alluvium to the west edge of the district and beyond. ${ }^{53}$ (See pl. 2.) The tracing of an apparent apophysis to the south, however, led to a small exposure of lamprophyre, which was as magnetic as the monzonite, on the low rhyolite hill half a mile west of Kelly.

The typical color of the Nitt monzonite is medium gray, but it becomes darker as the texture becomes finer; the fine-grained marginal facies is considerably darker and in places has a purplish tint. On weathered surfaces

\footnotetext{
${ }^{51}$ Burbank, W. S., Revision of geologic structure and stratigraphy in the Ouray district of Colorado, and its bearing on ore deposition : Colorado Sci. Soc., vol. 12, No. 6, pp. 184-232, 1930.

62 Lovering, T. S., Geologic history of the Front Range, Colo. : Colorado Sci. Soc., $\nabla 01.12$, No. 6, pp. 92-109, 1929.

${ }^{53}$ Hotchkiss, W. O., Magnetic methods for exploration and geologic work: Am. Inst. Men. Met. Eng. Trans., vol. 69, p. 45, 1923.
}

the color is predominantly rusty brown. The rock is essentially fine-grained and nonporphyritic, the average grain being less than 1 millimeter in diameter. Lightgray glassy feldspar is its chief constituent, but glistening specks of biotite and augite are thickly disseminated. The chilled facies, such as is found in the apophysis near the north end of Stendel Ridge, is very fine grained and slightly porphyritic.

Thin sections of the typical monzonite (pl. 14, C) show an uneven granular texture. Some of the grains are rather well formed but most of them are very irregular, interlocking, and without sharply defined boundaries. The component minerals are feldspars about 75 percent, with plagioclase slightly in excess of orthoclase; quartz 2 percent; pyroxenes 14 percent, with augite somewhat in excess of hypersthene; biotite 7 percent; hornblende 1 percent, magnetite as much as 3 percent; and apatite and zircon in minute quantities. Graphic intergrowths of orthoclase and quartz with hornblende fibers are present in variable amounts, and a few grains of epidote were found in one thin section. The most common alteration product is a yellow to green material derived from hypersthene. Some of it appears to be merely a discoloration caused by oxidation, but some is fibrous and resembles serpentine. Incipient chloritization of biotite and sericitization of the feldspar were also noted in a few sections.

Plagioclase (andesine) is present in irregular and elongate zoned grains up to 1.5 millimeters in length. Most of the grains have been partly and irregularly replaced by more sodic plagioclase and thus have a spotted appearance and shadowy extinction. The transitional contacts with orthoclase largely account for the confusing appearance illustrated on plate 14, $C$. Orthoclase most commonly forms irregular grains up to 0.75 millimeter in diameter and is poikilitic but is, with quartz, in part interstitial to the other minerals. Augite forms irregular to rectangular grains 0.75 millimeter in diameter, a few of which are twinned. It is mostly fresh. Hypersthene likewise forms rectangular to irregular grains, which are in general somewhat smaller than those of augite. Schiller structure in fresh grains is common but not pronounced. The augite is essentially unaltered, but incipient alteration has begun along cleavage cracks in a few grains. The pyroxenes are commonly associated with biotite, hornblende, and magnetite, as well as with apatite and zir̂con, and form clusters with them. Some pyroxene grains are micrographically intergrown with magnetite. (PI. 14, A.)

The graphic intergrowths of orthoclase and quartz are believed to be secondary and comparable to the typical myrmekitic intergrowth of plagioclase and vermicular quartz as described by Sederholm. ${ }^{54}$ Many

${ }^{54}$ Sederholm, J J., On synantetic minerals and related phenomena: Com. Geol. Finlande Bull., No. 48, pp. 1-148, 1916. 
orthoclase grains are entirely free from vermicular quartz (pl. 14, B), whereas others have graphic cores, and still others have graphic zones without definite arrangement. Again, an irregular zone of the intergrowth may cross several adjoining orthoclase grains irrespective of boundaries. These relations as a whole clearly indicate that the intergrowths were developed later than the original crystals, and they are therefore believed to have resulted from a selective replacement of the orthoclase by vermicular quartz. Simple orthoclase grains adjoining graphic grains were probably not replaced because of unfavorable orientation. Associated with the graphic intergrowths and not found elsewhere are groups of delicate green amphibole crystals (pls. $15 A, B$ ), which are exceedingly numerous in some places and very scarce in others. They are most commonly oriented in one or two directions, but some grains lie at random. Their arrangement together with their association with the intergrowths of orthoclase and quartz show them also to be secondary.

\section{OTHER FACIES}

There are many variations of the monzonite, especially along the margins of the stocks. The fine-grained chilled rock in an apophysis near the northwest end of Stendel Ridge is finely porphyritic, with phenocrysts of sodic labradorite, augite, and hypersthene as much as 1 millimeter long in a microgranular groundmass. Its composition approaches that of norite rather than monzonite. The labradorite is strongly zoned and commonly bordered by a narrow fringe of orthoclase. The cores of some grains are full of augite granules. Hornblende is absent, and biotite, which forms an essential constituent in the typical monzonite, forms only narrow fringes around a few magnetite and pyroxene grains. It is relatively pale and may be secondary.

The groundmass of this apophysis consists of irregular granules of augite, plagioclase, and orthoclase. Those of pyroxene especially range in size from mere specks to well-defined grains and grade into the smaller phenocrysts (pl. 16, A). Quartz occurs in very small amounts interstitial to the feldspar, and magnetite and a few apatite grains form the minor accessory minerals.

About 1,000 feet north of the Graphic tunnel, a finegrained noritic rock forms a narrow border facies between the typical monzonite and a large inclusion of pre-Cambrian gabbro (pl.2). The contact is marked by a banded rock ( $\mathrm{pl} .15, C$ ) composed of thin layers and streaks of the relatively coarse grained preCambrian rock separated by lenses of the intrusive rock. The pre-Cambrian gabbro, whose grains are as much as 0.75 millimeter in diameter, consists essentially of labradorite and of pale-green hornblende whose borders have partly changed to augite, evi- dently owing to the heat of the invading rock. The norite, whose grains are irregular and in general less than 0.1 millimeter in diameter, consists essentially of labradorite, augite, and hypersthene (pl. 15, D), with a few grains of biotite, magnetite, and zircon. The augite and hypersthene are more abundant than in the norite apophysis on Stendel Ridge and may have been derived in part by reaction between the intrusive magma and the hornblende of the pre-Cambrian gabbro. Such a reaction, as suggested by Bowen, ${ }^{55}$ should cause deposition of the "heat equivalent of the member of the series with which the liquid is saturated."

Between the monzonite and granophyre in the stock just west of the banded rhyolite in the hills northwest of Stendel Ridge, there is a medium-grained rock richer in orthoclase than the monzonite. The orthoclase grains are as much as 2 millimeters in diameter and are poikilitic (pl. 16, C); enclosing andesine, pyroxenes, and accessory minerals. Hypersthene and augite here also are the dominant ferromagnesian minerals. Biotite, in part resorbed and in part of pale-brown color, forms only irregular small shreds and fringes around magnetite and the pyroxenes. Apatite is much more common than in the typical monzonite. Quartz in this facies occurs only in interstitial micrographic intergrowths with clouded orthoclase and some pale-yellow to orange biotite.

About 200 feet west of the outcrop just described the rock is more feldspathic and quartzose, but it is still medium-grained. Orthoclase and andesine form its bulk, but the orthoclase is not poikilitic. It is much clouded, except in the cores of some of the larger grains. Augite is the common ferromagnesian mineral, and hypersthene is rare. A very pale brown to yellow hornblende, which is green where altered, is present in minor amounts. Biotite, which is also present in minor amounts, is of two varieties. One consists of large yellow to deep reddish-brown flakes, which are largely resorbed and are now marked by a few remnants surrounded by fine-grained aggregates of magnetite, augite, and untwinned plagioclase. It is associated with apatite and altered pyroxene (probably hypersthene) and is evidently primary. The other variety, probably later, is orange to pale yellow, forms only small irregular shreds, and occurs with quartz in the interstitial micrographic intergrowths, which are believed to be secondary. A striking feature of this facies of monzonite is the relatively large content of graphically intergrown orthoclase and quartz (pl. 16, B).

Biotite-hornblende monzonite with poikilitic orthoclase is also exposed about a mile northeast of the Graphic tunnel along the Sleeper tunnel road. Biotite, in crystals as much as 2 millimeters in diameter, is

${ }_{55}$ Bowen, N. L., The evolution of igneous rocks, Princeton University Press, p. 221, 1928. 
conspicuous in specimens, but in thin section pale-green hornblende, slightly altered to chlorite, is the dominant ferromagnesian mineral. Augite is accessory only and with some andesine is enclosed in the orthoclase. Epidote, a few grains of titanite, and allanite are probably secondary minerals.

A more salic facies, and one very similar to the Tertiary (?) granite, is represented by an apophysis cutting argillite northeast of Oak Spring. It consists essentially of orthoclase, andesine, quartz, and biotite. Epidote, chlorite, and allanite are the secondary minerals. Dikelets that are still more feldspathic cut the monzonite near its contact north of Oak Spring and on the south end of Stendel Ridge. The plagioclase in these dikelets is albite-oligoclase. Grains of biotite, hornblende and augite are scarce; but chlorite and epidote are common. Epidote, with large irregular grains of titanite up to 1 millimeter long, is even more common in a salic facies exposed in a small prospect on the northern spur of the monzonite east of Hardscrabble Valley. In one thin section a late bluish-green fibrous hornblende was found replacing epidote (pl. 16, $D)$. The epidote is apparently a late product of crystallization and not an alteration product of feldspar, but the fibrous hornblende is probably hydrothermal in origin.

The more conspicuous development of orthoclase and biotite and especially of epidote and titanite near the contact and in dikelets in the monzonite is believed to imply concentration of salic and volatile constituents, a lowering of temperature in the monzonite mass, and a transition from strictly igneous to hydrothermal conditions.

\section{CHEMICAL COMPOSITION AND CLASSIFICATION}

The chemical analysis in column 1 of the following table represents the typical monzonite taken about 3,500 feet southeast of Hardscrabble Camp. A partial analysis of the same rock is given in column 2, and the average of 12 monzonites is given in column 3 .

A comparison of the typical monzonite of the district with the average monzonite shows a close agreement in most oxides excepting the alumina and to a smaller degree the lime, which are below the average, and reflect the more sodic character of the plagioclase and the relatively high pyroxene content. The total amounts of iron oxides in each rock are almost identical, but the local monzonite is richer in ferrous iron and lower in ferric than the average monzonite. The water, in view of the practical absence of secondary minerals, is probably largely present in biotite and hornblende; the titanium may be present chiefly in the magnetite, and to a small extent in biotite and pyroxenes; sulphur may be present in negligible quantities of finely dispersed sulphides; and barium is probably a constituent of the feldspar.
Analyses of monzonites

\begin{tabular}{|c|c|c|c|c|c|c|}
\hline \multirow[b]{3}{*}{$\begin{array}{l}\mathrm{SiO} \mathrm{O}_{2} \\
\mathrm{Al}_{2} \mathrm{O}_{3} \\
\mathrm{Fe}_{2} \mathrm{O}_{3} \\
\mathrm{FeO} \\
\mathrm{MgO} \mathrm{O} \\
\mathrm{CaO} \\
\mathrm{Na}_{2} \mathrm{O}_{2} \\
\mathrm{~K}_{2} \mathrm{O}_{2} \\
\mathrm{H}_{2} \mathrm{O}- \\
\mathrm{H}_{2} \mathrm{O}+ \\
\mathrm{TiO}_{2} \\
\mathrm{CO}_{2} \\
\mathrm{P}_{2} \mathrm{O}_{5} \\
\mathrm{~F} \\
\mathrm{~S} \\
\mathrm{~V}_{2} \mathrm{O}_{3} \\
\mathrm{MnO} \\
\mathrm{BaO} \\
\mathrm{SrO}\end{array}$} & \multirow{3}{*}{\begin{tabular}{|c|}
1 \\
57.06 \\
14.60 \\
2.46 \\
5.02 \\
4.21 \\
6.26 \\
3.45 \\
4.04 \\
Trace? \\
.53 \\
1.59 \\
Trace? \\
.60 \\
Trace? \\
.03 \\
.06 \\
None \\
.20 \\
Trace? \\
100.11 \\
\end{tabular}} & \multicolumn{2}{|l|}{ Analyses } & \multirow{2}{*}{\multicolumn{3}{|c|}{ Mode of No. 1}} \\
\hline & & 2 & 3 & & & \\
\hline & & $\begin{array}{r}57.67 \\
5.89 \\
3.47 \\
3.54\end{array}$ & $\begin{array}{r}55.25 \\
16.53 \\
3.03 \\
4.37 \\
4.20 \\
7.19 \\
3.48 \\
4.11 \\
.66 \\
.60 \\
.43 \\
\end{array}$ & 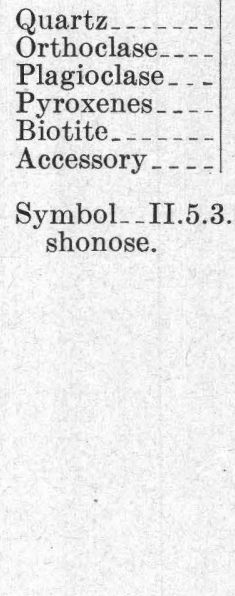 & $\left.\begin{array}{r}2.5 \\
33 \\
40 \\
14 \\
7 \\
3.5\end{array}\right\}$ & $\left\{\begin{array}{l}75.5 \\
24.5 \\
100.0 \\
\text { Sho- }\end{array}\right.$ \\
\hline
\end{tabular}

1. Monzonite, 3,500 feet southeast of Hardscrabble Camp, Magdalena district, New Mexico; J. G. Fairchild, analyst.

2. Partial analysis of monzonite, northeast of Graphic tunnel, Magdalena district, New Mexico; George Steiger, analyst: U. S. Geol. Survey Prof. Paper 68, pp. 39 and 247, 1910.

3. Average analysis of monzonite; Daly, R. A., Igneous rocks and their origin, p. 23, New York, 1914.

\section{TERTIARY (?) GRANITE}

Distribution and occurrence.-The Tertiary (?) granite is exposed in two stocks and covers a larger area than the monzonite. Similar rock, not indicated on plate 2 (see above), occurs just north and northeast of Oak Spring as a local differentiate of monzonite and in dikelets that cut the pre-Cambrian formations. On the north end of Stendel Ridge a dike of the granite cuts typical monzonite. The larger of the stocks forms the north end of the Magdalena Range east and west of Anchor Canyon. Its northern limit is concealed beneath alluvium, but the presence of such contactmetamorphic minerals as magnetite, garnet, and serpentine on two prospect dumps in the upper part of the Sandia formation north of the railroad suggests that granite or monzonite may extend nearly that far north. Granite also constitutes most of the stock on the west side of Granite Mountain. There it is bordered on the southeast and south by monzonite and on the northwest by hybrid rock that simulates granophyre.

The Tertiary (?) granite, as well as the monzonite and granophyre, weathers characteristically into subdued slopes covered by rounded boulders in marked contrast to the pre-Cambrian granite, which weathers into angular cliffs bordered by angular fragments. This contrast is shown on plate 17. In Anchor Canyon the Tertiary (?) granite has disintegrated into soil from 7 to 10 feet deep, whereas little or no residual soil covers the surrounding pre-Cambrian granite. The tendency of the Tertiary (?) granite in this vicinity 
to be eroded into valleys may at first give the impression that it represents a coarse-grained facies of the pre-Cambrian granite and grades upward into the finer-grained facies; but close examination reveals the Tertiary (?) granite in sharp contact with the pre-Cambrian granite.

Lithology.-The Tertiary (?) granite is light pinkish gray but some of its more weathered surfaces are brown. In general it is medium-grained and somewhat porphyritic (pl. 18, A), with the scattered phenocrysts of white to glassy plagioclase rarely more than 5 millimeters long in a groundmass of pink orthoclase, quartz, and biotite, whose average diameter of grain is between 1 and 2 millimeters. A somewhat finer-grained and practically nonporphyritic facies is found along the trail to the Hardscrabble mine, but its distribution relative to the coarser-grained facies is uncertain. Its average grain is about 1 millimeter in diameter.

The more distinet phenocrysts consist of plagioclase and amount to only 1 percent or less of the rock, but aggregates of opalescent white plagioclase with some orthoclase accentuate the porphyritic appearance, especially where weathered. Plagioclase is relatively resistant to weathering, for unaltered opalescent plagioclase is a characteristic constituent even in the thoroughly disintegrated rock. Quartz is not conspicuous but appears rather abundant under close inspection. Brown specks of titanite are common.

In thin section the thinly scattered plagioclase phenocrysts are embedded in a groundmass consisting largely of irregular feldspar grains and interstitial quartz (pl. $18, C)$. The minerals, in order of abundance, are microperthitic orthoclase 50 to 65 percent, plagioclase 15 to 20 percent, quartz 15 to 20 percent, biotite about 5 percent, with smaller amounts of hornblende. The ratio of orthoclase to plagioclase classifies the rock as granite rather than quartz monzonite, as it was called by Gordon. ${ }^{56}$ The minor accessory minerals are titanite, magnetite, apatite, and zircon. Secondary minerals are epidote, séricite, chlorite, and calcite.

The microperthitic orthoclase forms irregular grains some of which are 1.5 millimeters or more in length but most of which are less than 1 millimeter. Some, in micrographic intergrowth with quartz, is interstitial among the larger mineral grains. This orthoclase is characteristically clouded by minute dustlike inclusions which in some thin sections give it a brownish-gray appearance in transmitted light. In the larger grains the inclusions are found at the borders or next to cleavage cracks, leaving the core clear, but in the smaller grains they are evenly distributed throughout. Some of the inclusions have a higher index of refraction than the feldspar and may be sericite, and judging from the pink color of the feldspar some must be hematite;

${ }^{60}$ Lindgren, Waldemar, Graton, L. C., and Gordon, C. H., The ore deposits of New Mexico: U. S. Geol. Survey Prof. Paper 68, pp 36-39 and $247,1910$. others have a lower refractive index and are probably liquid- or gas-filled cavities.

The plagioclase is slightly sericitized oligoclase and forms both phenocrysts and irregular grains in the groundmass. Disseminated sericite in the plagioclase, though commonly scant, is more conspicuous than in the orthoclase, and in a few grains only is it sufficient to obscure the identity of the original plagioclase. The sericite is locally accompanied by a pale-brown mineral with low index of refraction and moderate birefringence, which is evidently of the montmorillonite-beidellite group.

Quartz forms irregular grains mostly less than 1 millimeter in diameter. It is almost entirely interstitial, forming continuous aggregates that closely interlock with irregular orthoclase grains and are in part graphically intergrown with them. Some grains appear to be earlier than at least a part of the orthoclase.

Biotite and hornblende tend to form clusters with the accessory minerals. Biotite is the more abundant, constituting 3 to 5 percent of the rock. It shows pale yellow to dark reddish-brown pleochroism, and some grains are altered to chlorite on the edges or next to cleavage cracks. Hornblende forms a few scattered grains up to 1.25 millimeters long, but it varies in amount and may locally exceed biotite. Its derivation from original augite is indicated by an occasional core of augite. Magnetite in irregular grains up to 0.5 millimeter in diameter is associated with the dark minerals. Titanite in wedge-shaped and irregular grains is relatively abundant. It is most commonly associated with biotite and hornblende and tends to form partial borders around magnetite grains. Apatite in its usual hexagonal crystals, and in shapeless grains, is also common. Zircon is relatively rare. Secondary minerals, other than sericite, montmorillonite-beidellite, and chlorite, are calcite and epidote. Calcite is rare, and the few irregular grains present are interstitial. Epidote is present in variable amounts. It is very abundant in some thin sections and rare in others, but in only one section is it entirely absent. Allanite was found in one thin section.

A thin section of the nonporphyritic facies of the granite shows that facies to consist mainly of orthoclase ( 70 to 75 percent) and quartz (20 to 25 percent). Plagioclase and ferromagnesian minerals are accessory, but in other respects this rock is similar to the typical porphyritic facies.

\section{APLITE DIKES}

Besides the small dikes and patches of granitic aplite in the Tertiary (?) granite west of Anchor Canyon, a few dikes have been noted in the monzonite, and one, 2,000 feet north of the Graphic tunnel, has been mapped. The dikes attain a maximum length of about 400 feet, but most of them are only about 20 to 


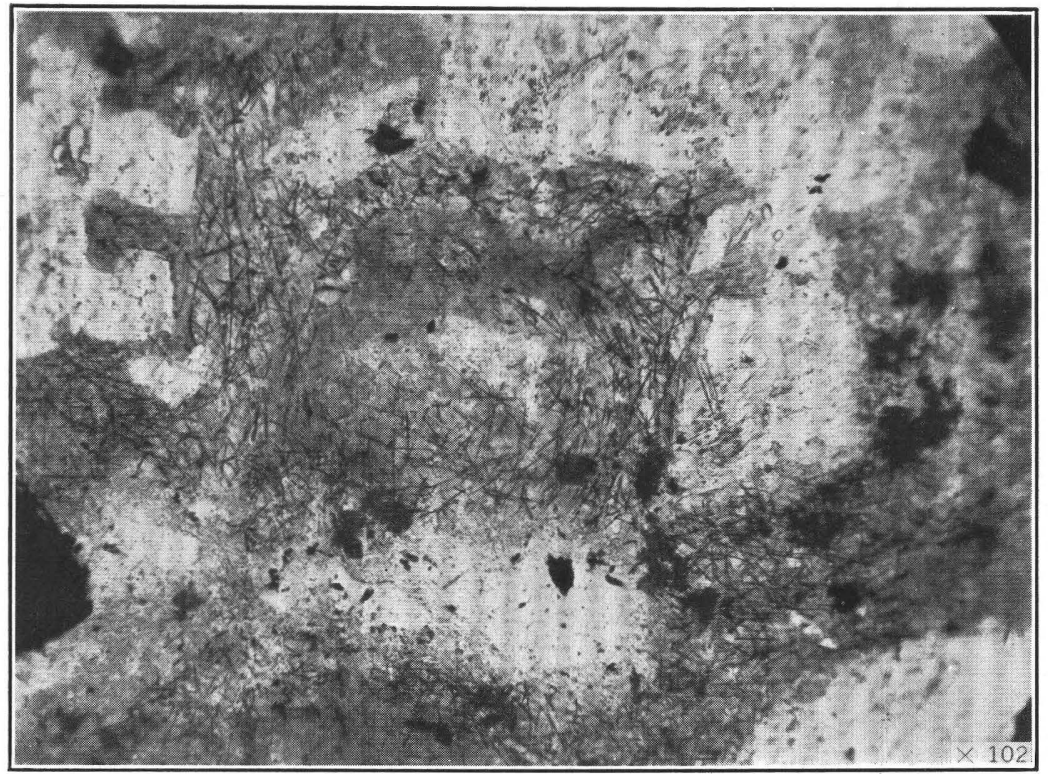

4. PHOTOMICROGRAPH OF PURPLE ANDESITE, SHOWING MESH OF HEMATITE, WHICH PROBABLy REPRESENTS RESORBED AND OXIDIZED AMPHIBOLE NEEDLES.

The mesh does not penetrate the phenocrysts. Plain light.

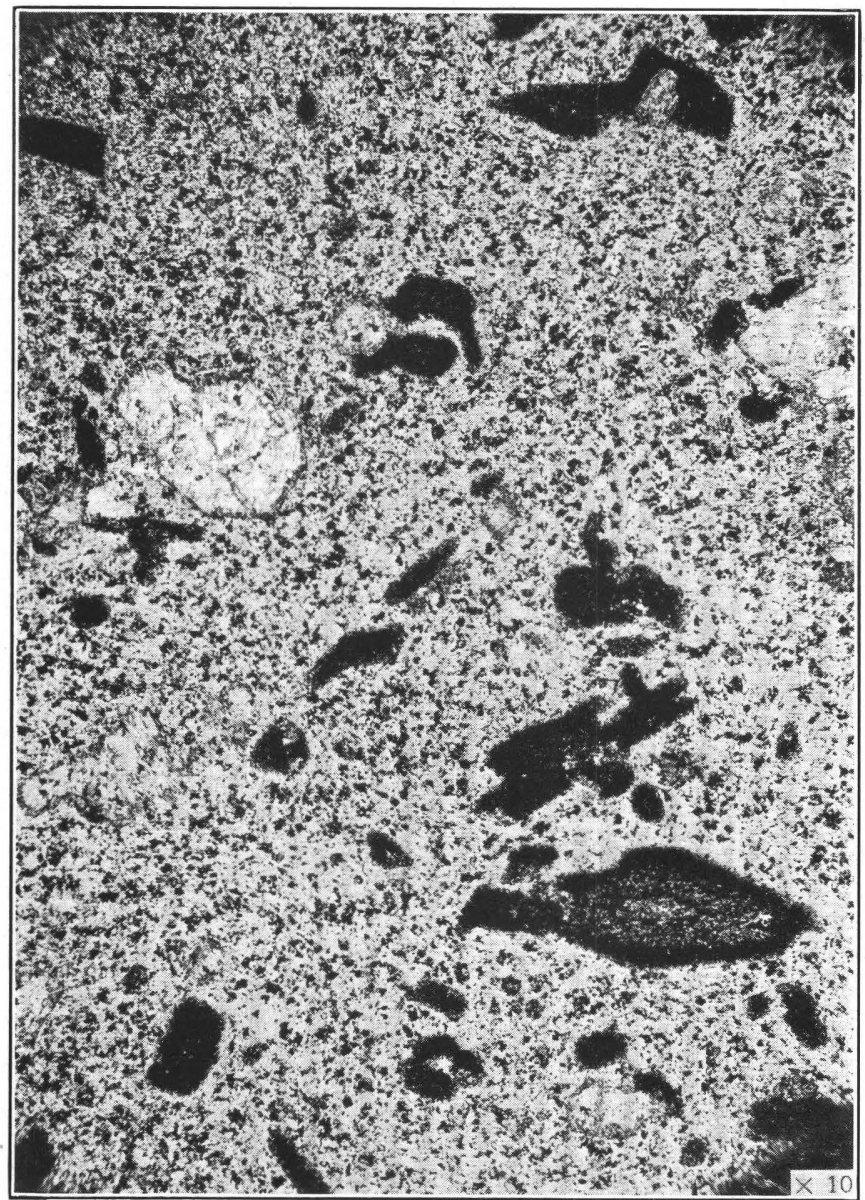

$B$. PHOTOMICROG RAPH OF PURPLE ANDESITE, SHOWING HEMATITE PSEUDOMORPHS AFTER AMPHIBOLE

A large amount of finely divided hematite is also present in the oroundmass. Plain light.

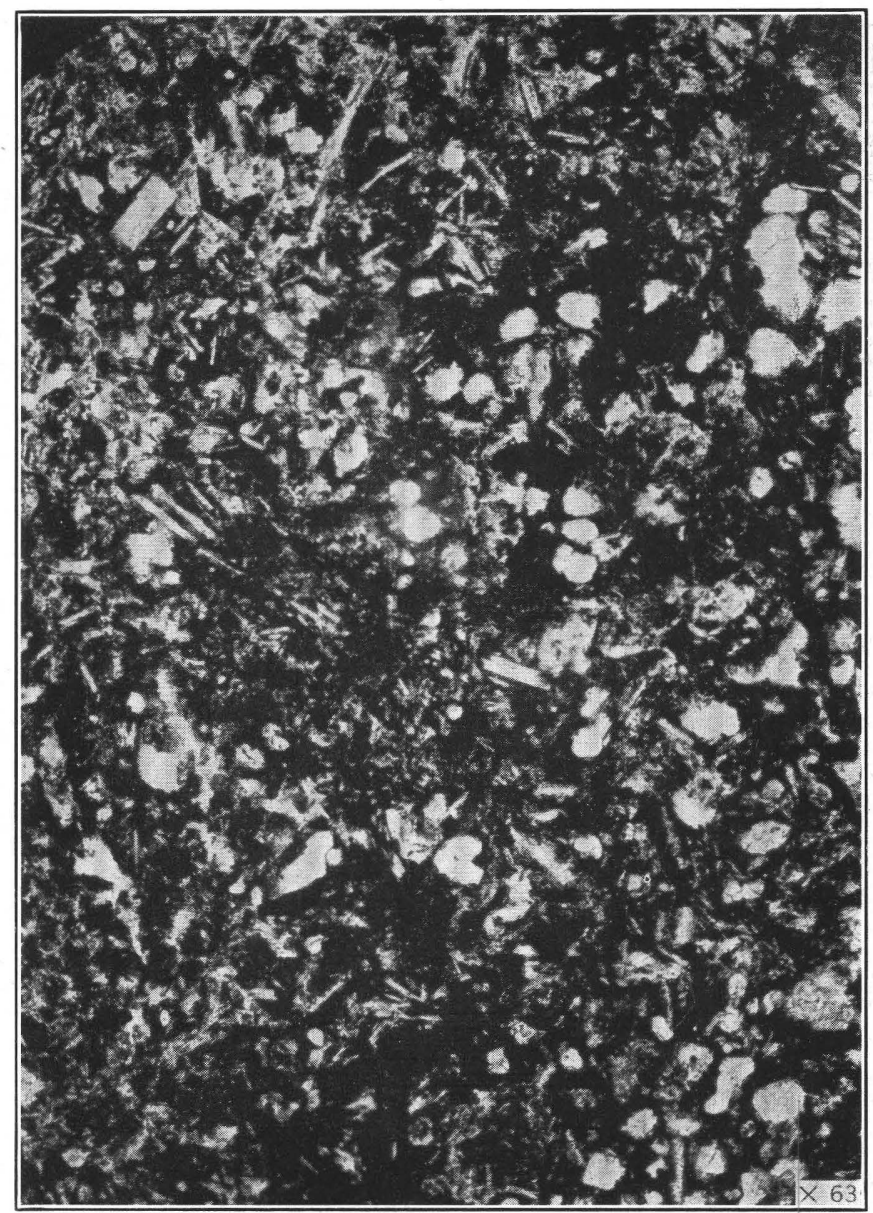

C. RED ANDESITE WITH GROUNDMASS THOROUGHLY OBSCURED BY RED IRON OXIDE.

White lath-shaped crystals are feldspar. The smaller round to irregular areas are vesicles filled with chalcedony; the larger ones contain calcite and mosaic quartz. 


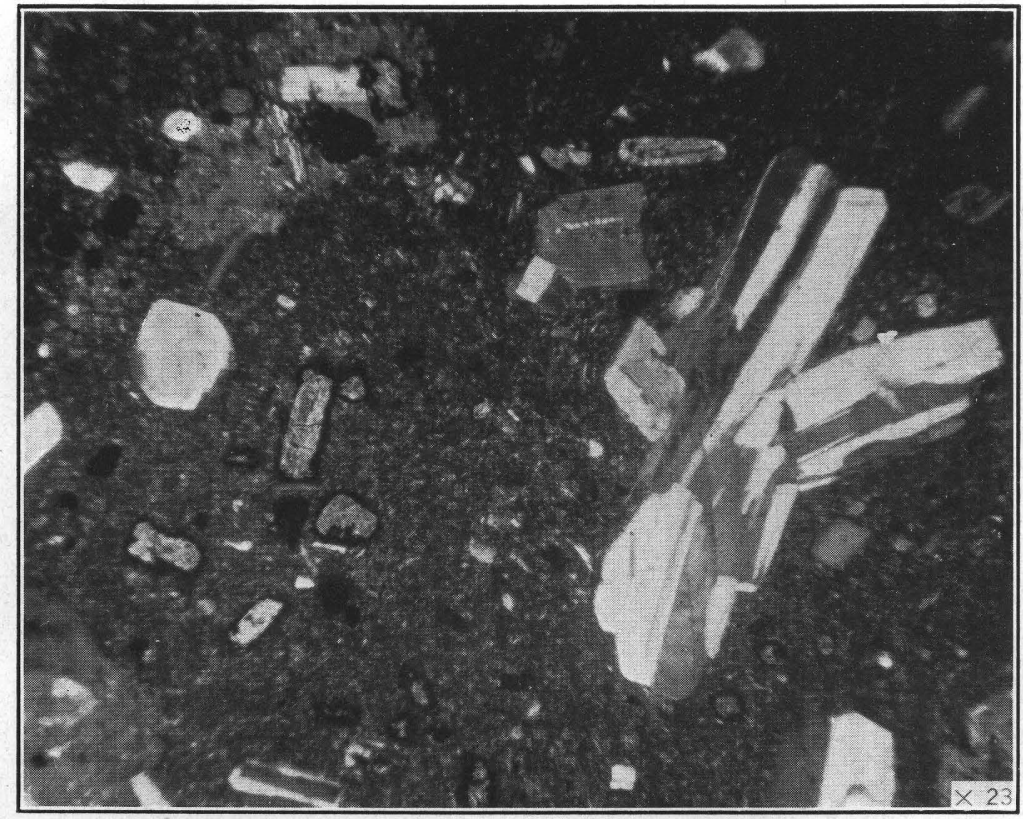

A. UPPER ANDESITE, SHOWING RELATIVELY LARGE PHENOCRYSTS OF PLAGIOCLASE AND SMALLER PHENOCRYSTS OF FORMER HYPERSTHENE BORDERED BY HEMATITE AND INTERNALLY REPLACED BY WHAT APPEARS TO BE A CLAY MINERAL. Crossed nicols.

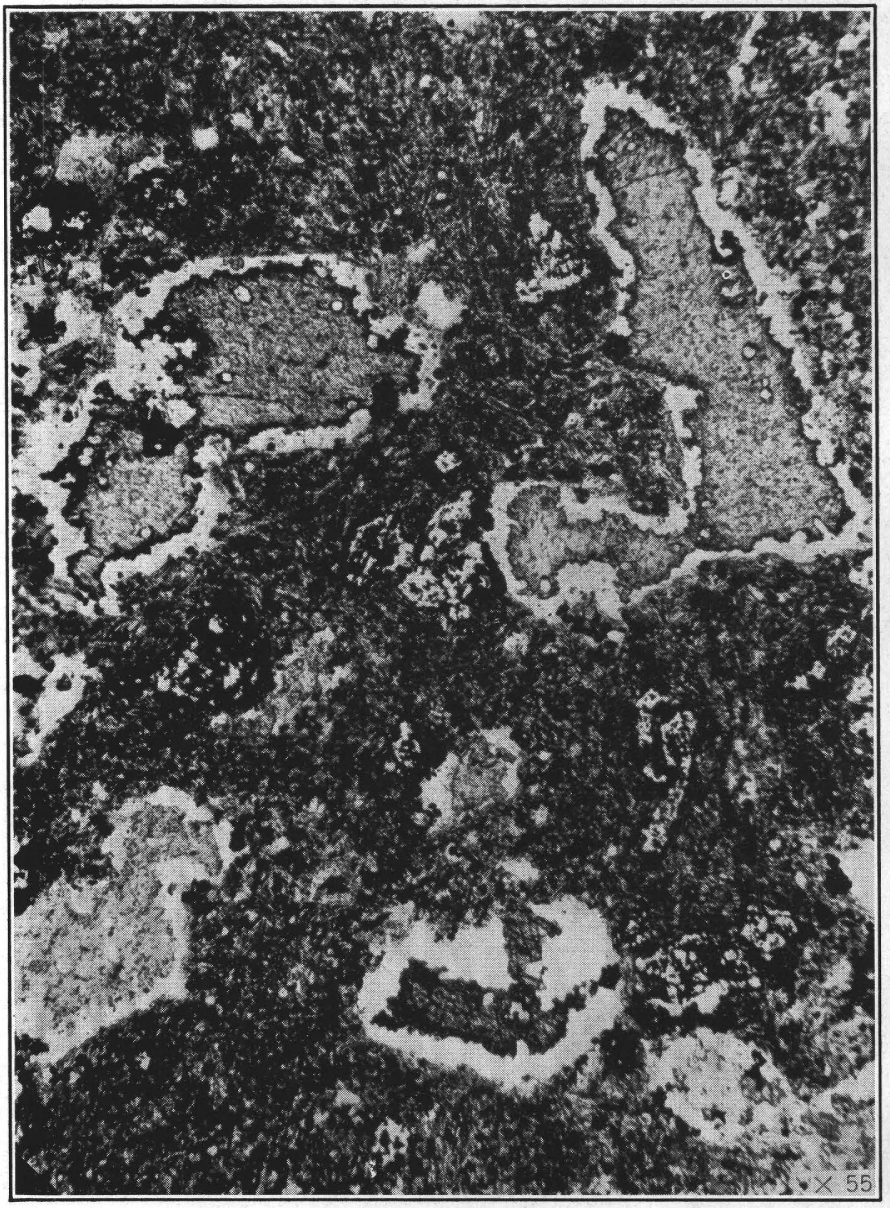

B. RED ANDESITE, SHOWING GROUNDMASS OBSCURED BY RED IRON OXIDE.

The large irregular areas are vesicles filled with calcite (gray) and lined with ehalcedony (clear). Small white hexagonal areas in the calcite are cross sections of quarty crystals projecting from the chalcedony borders. Plain light.

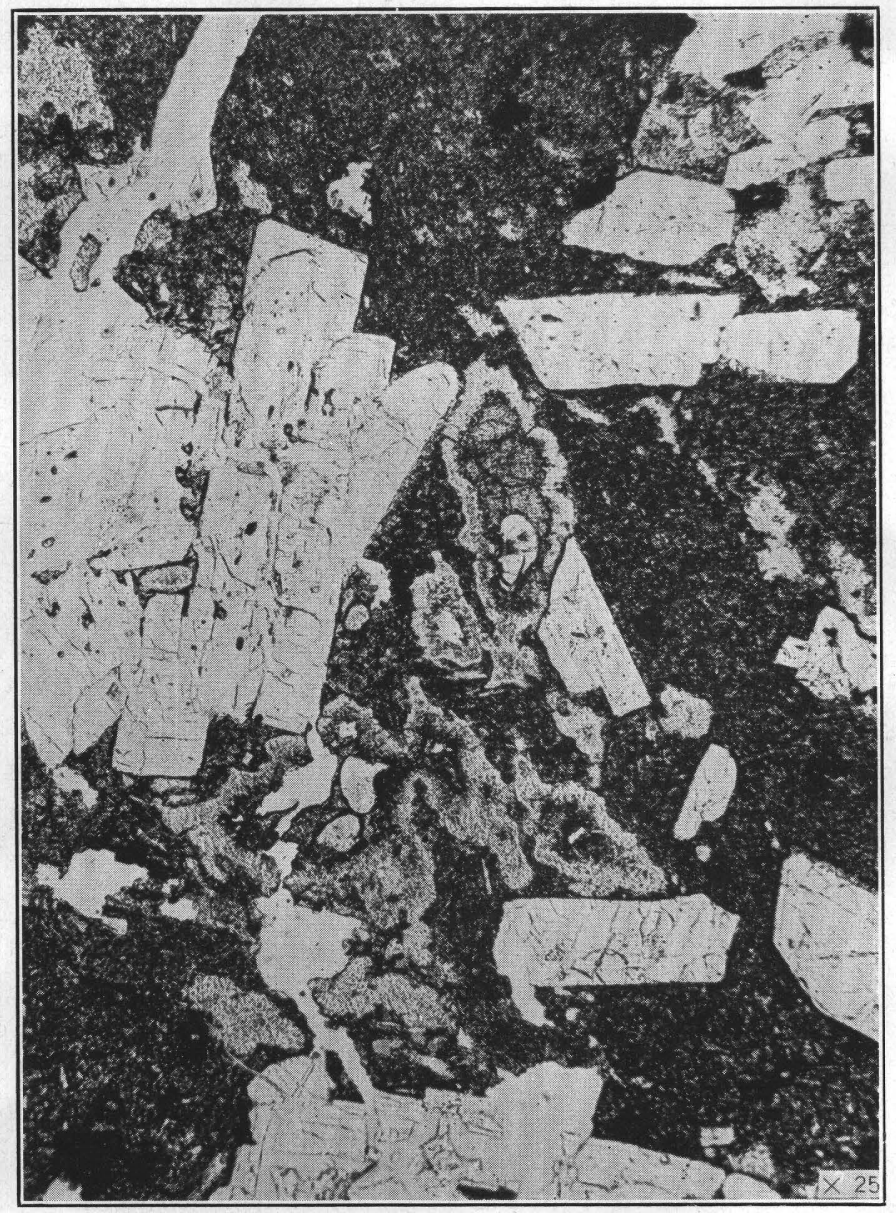

C PLAGIOCLASE PHENOCRYSTS AND MICROGEODES OF A ZEOLITE WITH OPAL OR CHALCEDONY CORE IN GLASSY PORTION OF UPPER ANDESITE.

Considerable red iron oxide obseures the groundmass. Plain light. 


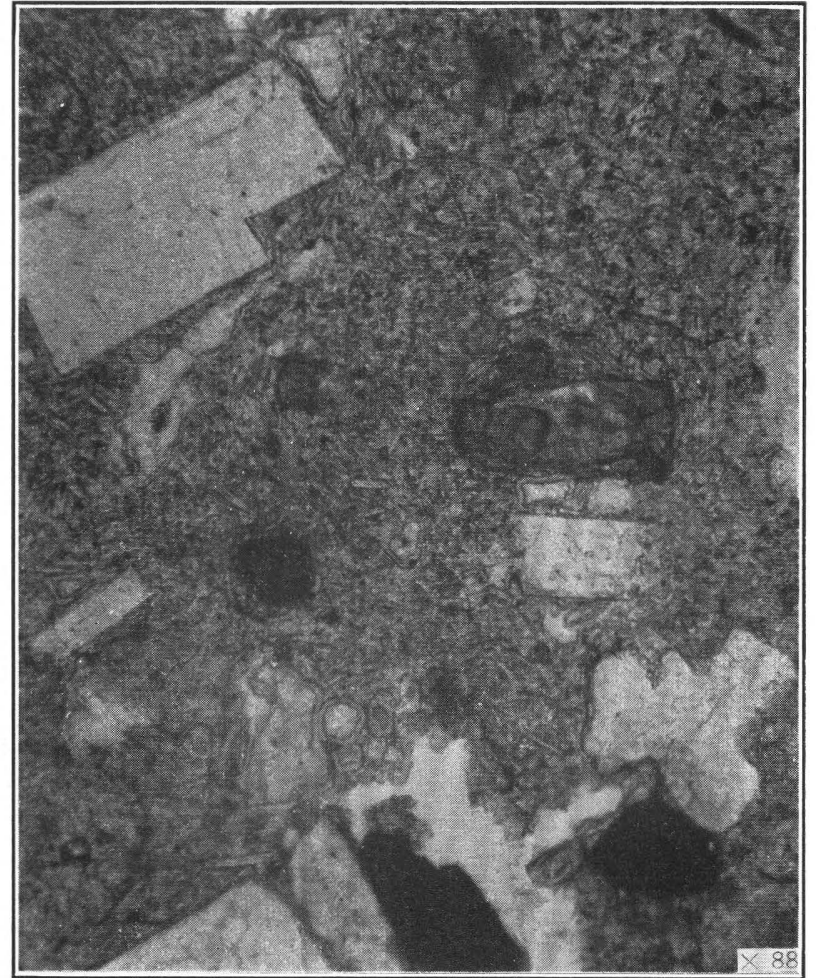

4. VITROPHYRE IN UPPER ANDESITE, SHOWING CELADONITE AS VERMICULATE TRACES AND RINGLETS AROUND ZEOLITE BLEBS.

Hypersthene also has been partly replaced by celadonite. Plain light.

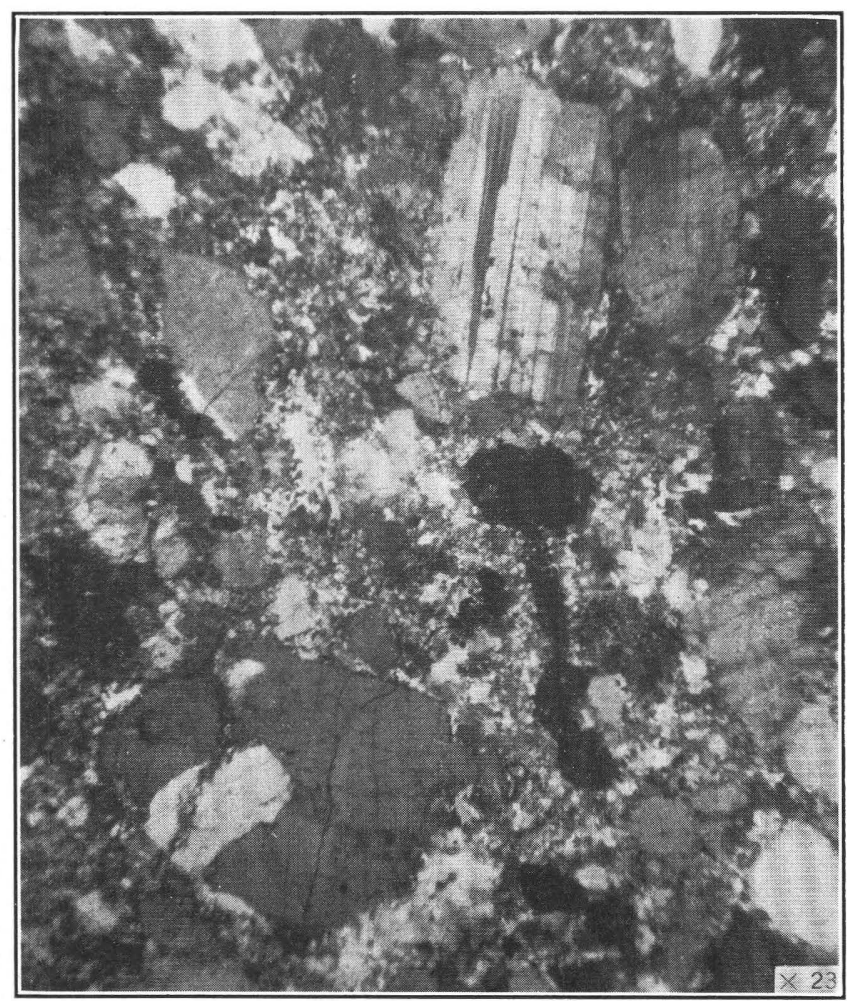

C. PHOTOMICROGRAPH OF TYPICAL MAGNETIC RHYOLITE PORPHYRY.

Phenocrysts consist of more or less rounded plagioclase and orthoclase grain with an occasional magnetite grain, embedded in a microgranular groundmass with some micropegmatite. Crossed nicols.

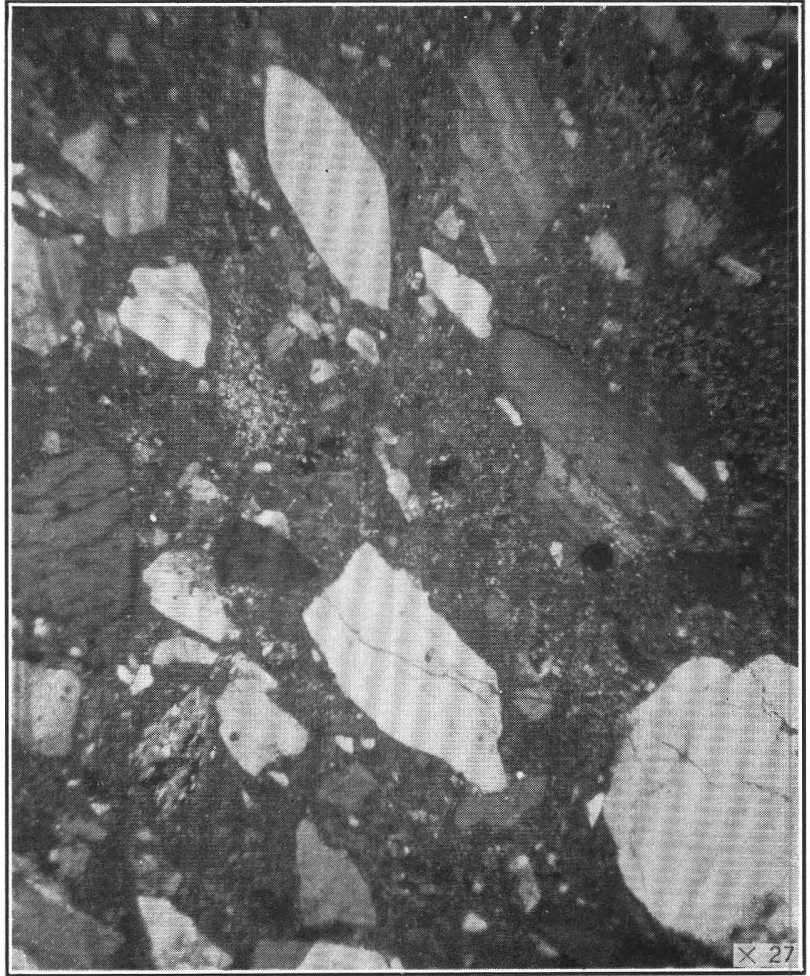

B. TYPICAL RHYOLITE PORPHYRY, SHOWING PARTLY RESORBED PHENOCRYSTS OF QUARTZ AND FELDSPAR.

The small amount of biotite present is also partly resorbed and is partly replaced by hematite. Crossed nicols.

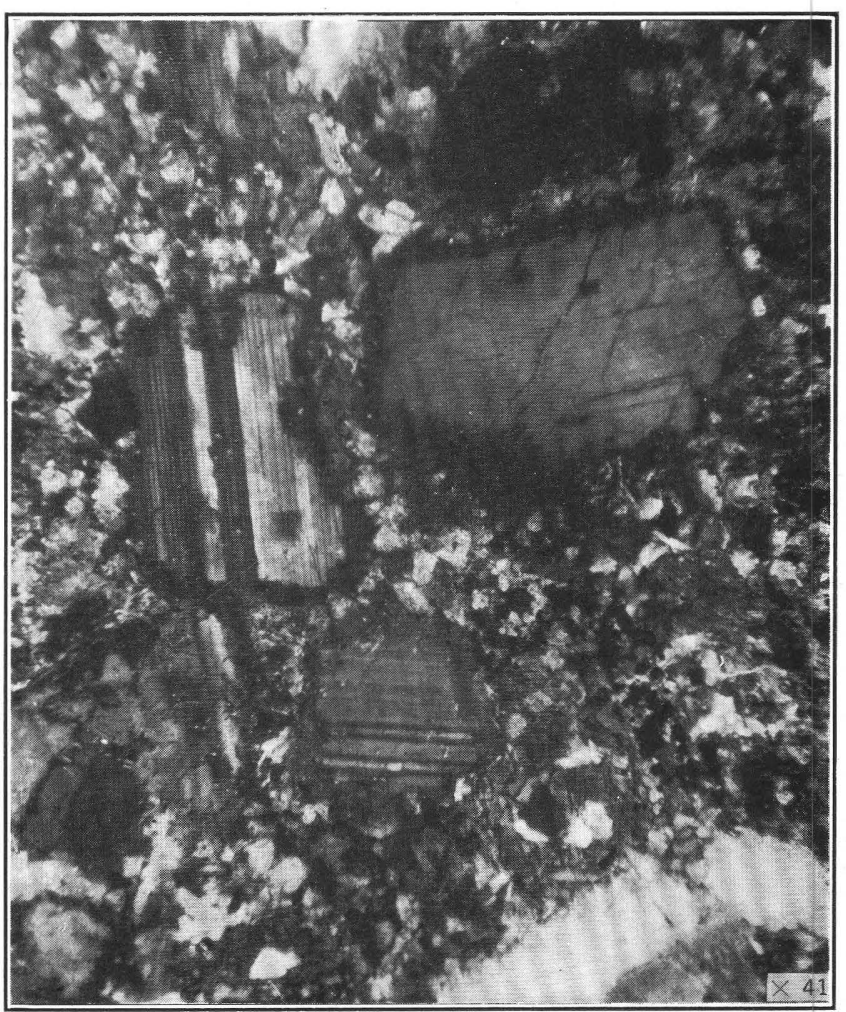

D. PHOTOMICROGRAPH OF MAGNETIC PORPHYRY, SHOWING CO RONAS OF ORTHOCLASE AROUND PLAGIOCLASE PHENOCRYSTS.

Groundmass is microgranular. Crossed nicols. 


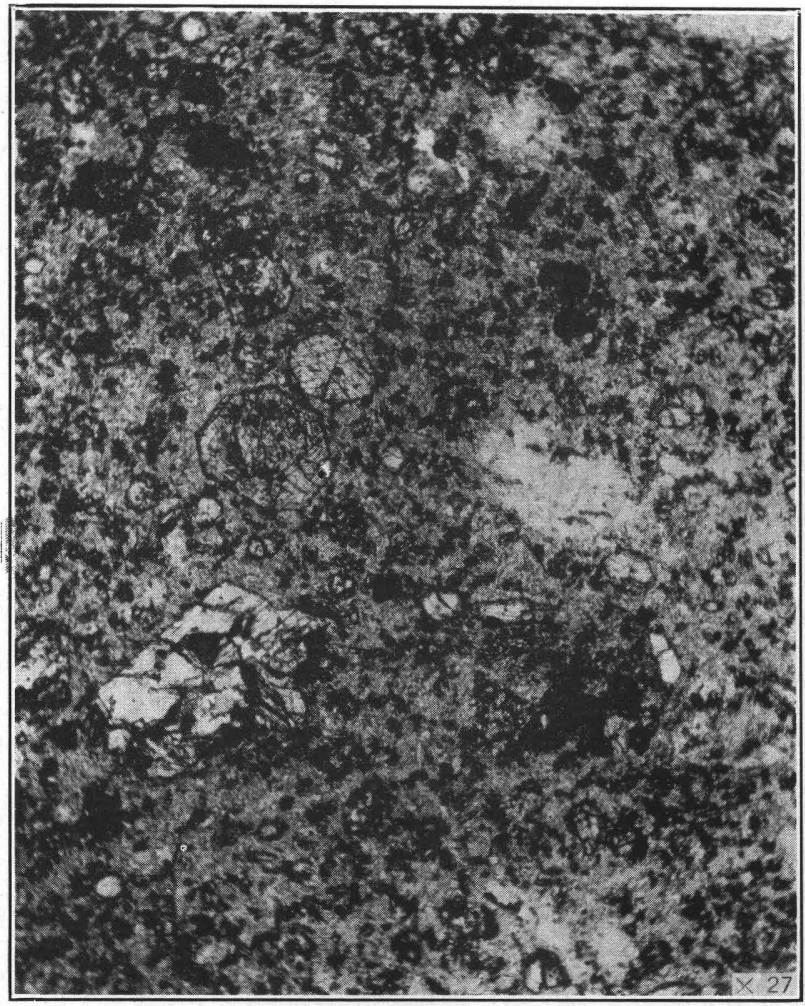

A. INTRUSIVE AUGITE ANDESITE WITH PHENOCRYSTS OF ALTERED PLAGIOCLASE AND AUGITE.

The groundmass contains considerable hematite. Plain light.

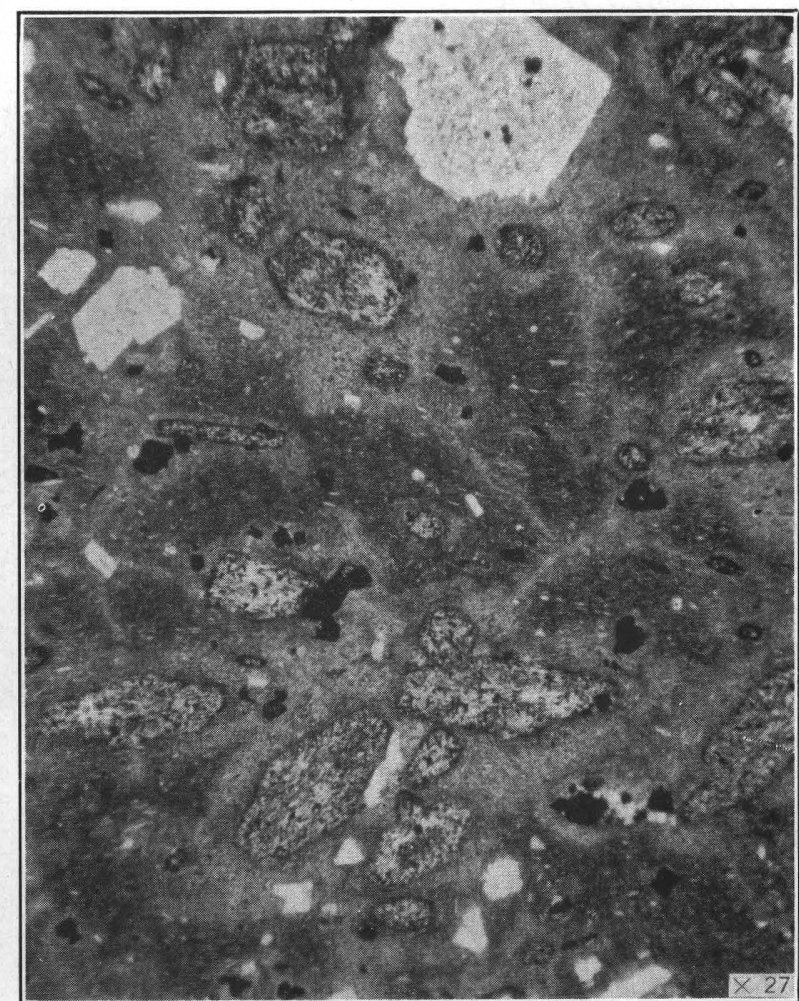

B. TYPICAL HORNBLENDE ANDESITE.

Hornblende phenocrysts are numerous but have been largely replaced by aggregates of colorless amphibole, sericite, quartz, calcite, and chlorite, and The groundmass is glassy to cryptocrystalline and contains dark glassy blotches veined and enclosed by gray cryptocrystalline material. Plainlight.

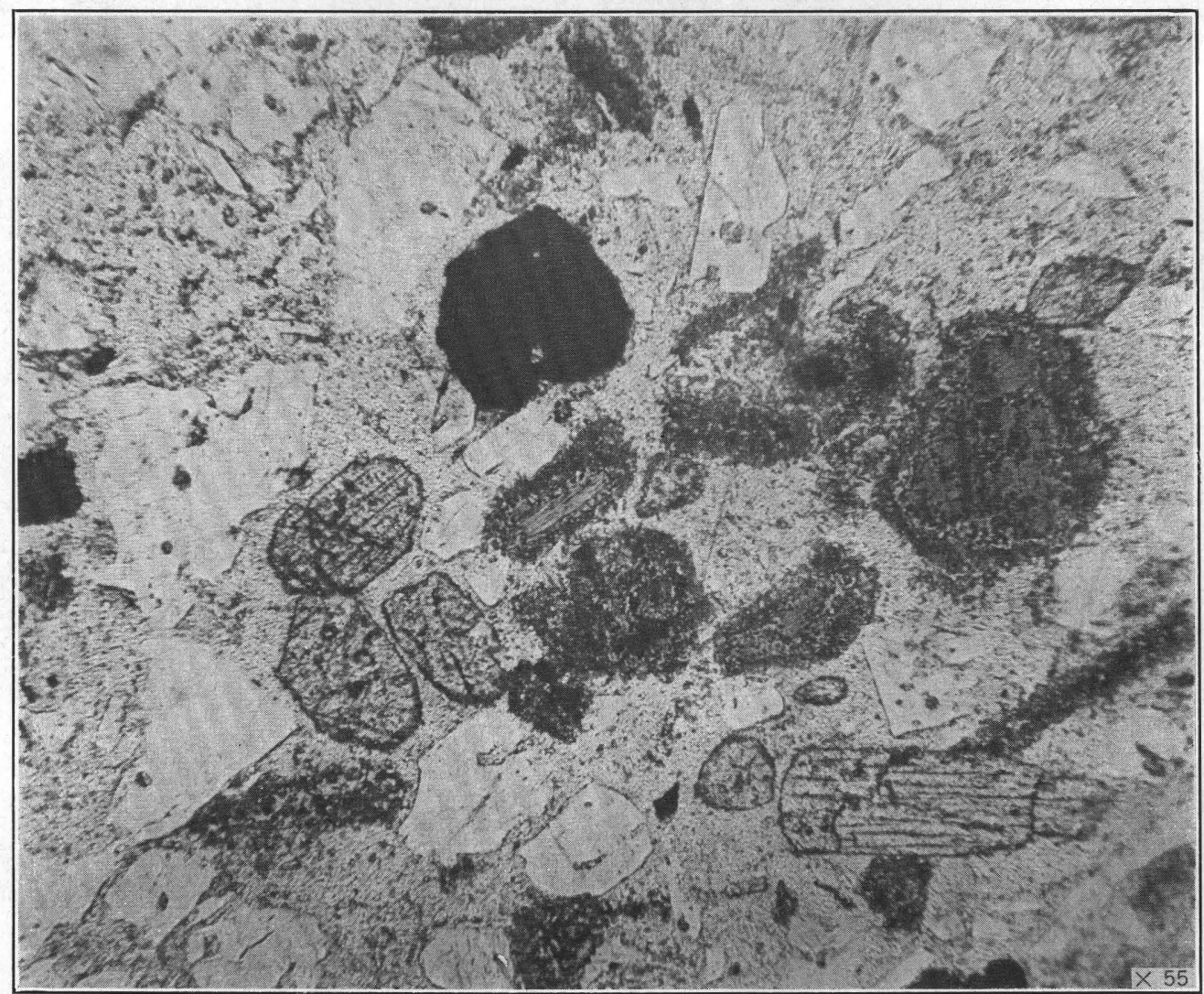

C. PHOTOMICROGRAPH OF MAGNETIC PORPHYRY FROM LOWER PART OF THE FORMATION, SHOWING PARTLY RESORBED BIOTITE PHENOCRYSTS WHICH ARE SURROUNDED BY AUGITE MICROLITES; THE AUGITE PHENOCRYSTS ARE UNAFFECTED. The feldspar phenocrysts have also been partly resorbed. Plain light. 


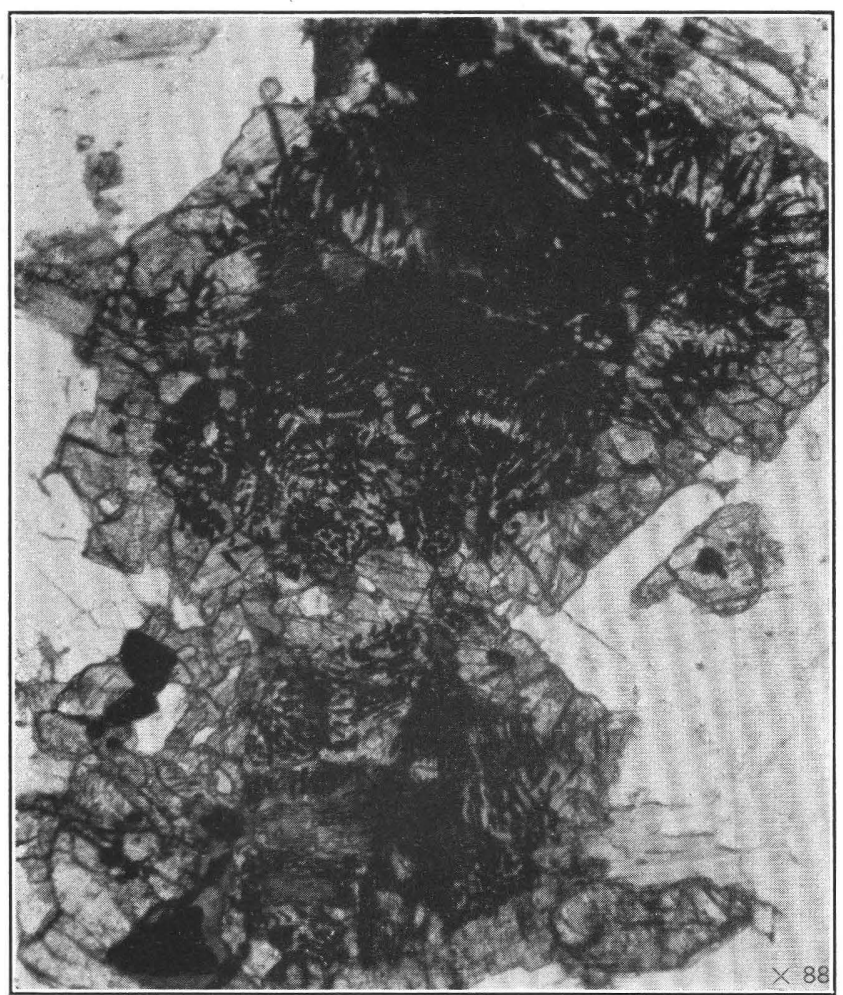

A. MICROGRAPHIC INTERGROWTH OF AUGITE AND MAGNETITE WITH A BORDER OF AUGITE AND A CORE OF MAGNETITE. In monzonite. Plain light.

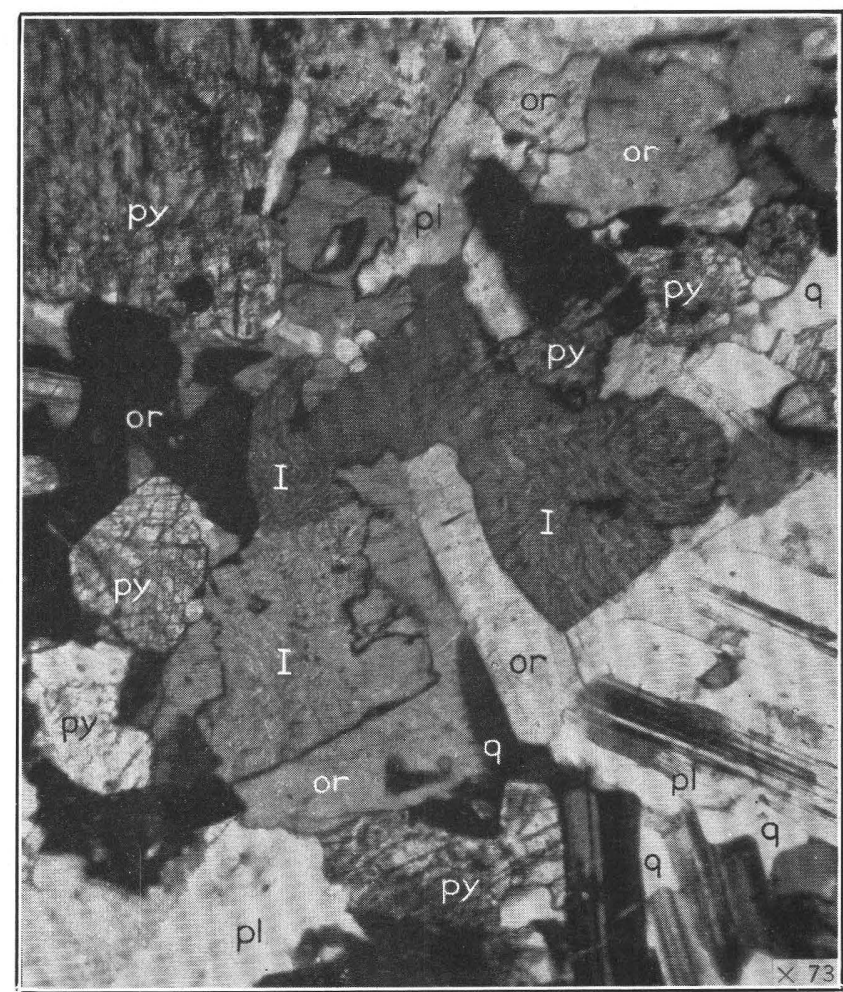

B. MONZONITE SHOWING GRAPHIC INTERGROWTH (I) OF ORTHOCLASE AND QUARTZ IN SHARP CONTACT WITH ORTHOCLASE (or). Crossed nicols.

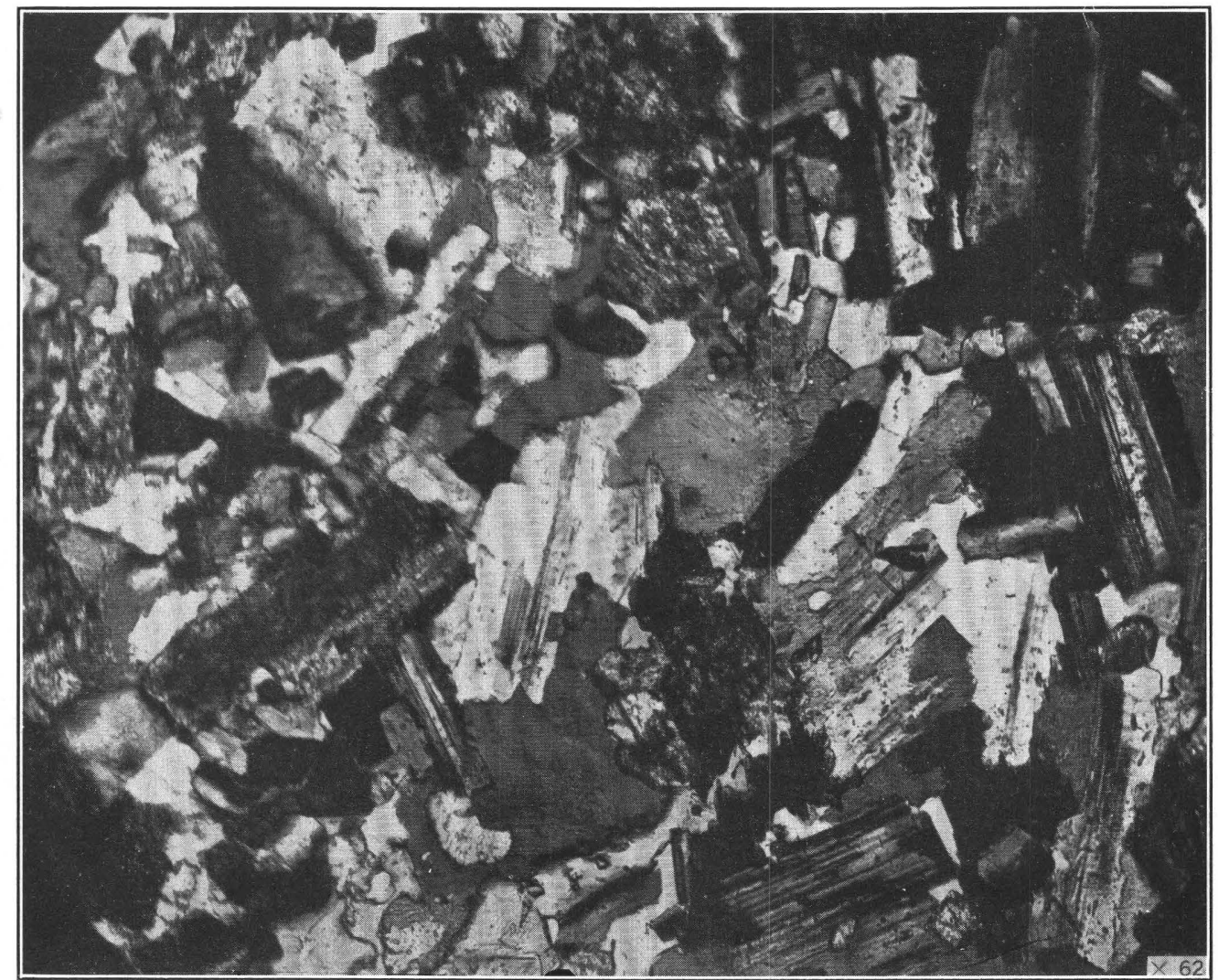

C. TYPICAL MONZONITE.

The essential constituents are plagioclase, orthoclase, and pyroxene; biotite and quartz are accessory. The rather confusing appearance is due to the irregular feldspar grains and the apparent transition of one feldspar grain into another. Crossed nicols. 

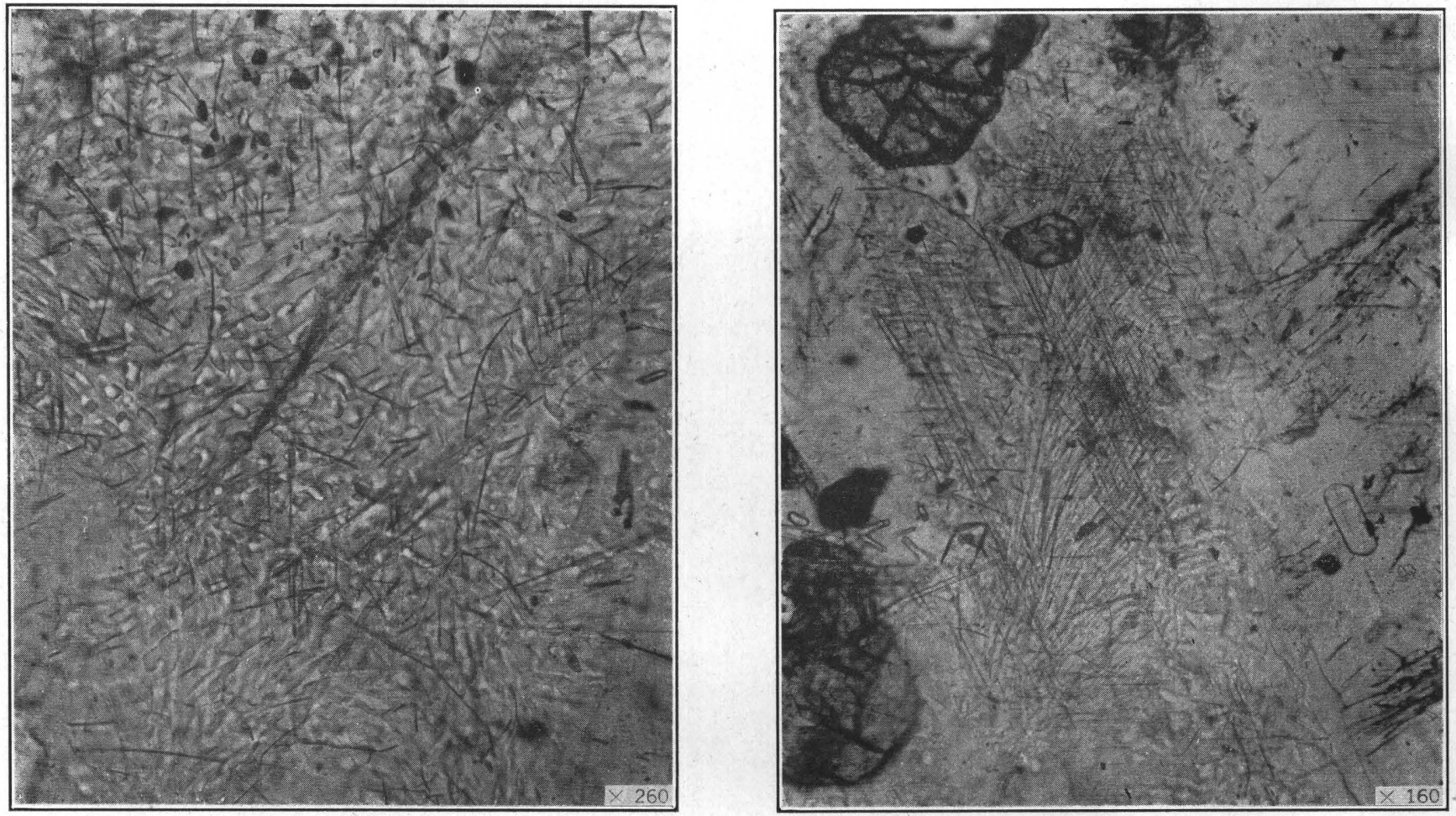

$A$, B. INTERGROWTHS OF ORTHOCLASE AND QUARTZ WITH NUMEROUS HORNBLENDE FIBERS WHICH MAY PENETRATE ADJOINING GRAINS BUT DO NOT EXTEND FAR BEYOND THE BOUNDARIES OF THE INTERGROWTHS.

Most of the fibers are paraliel but some have a random orientation. Plain light.

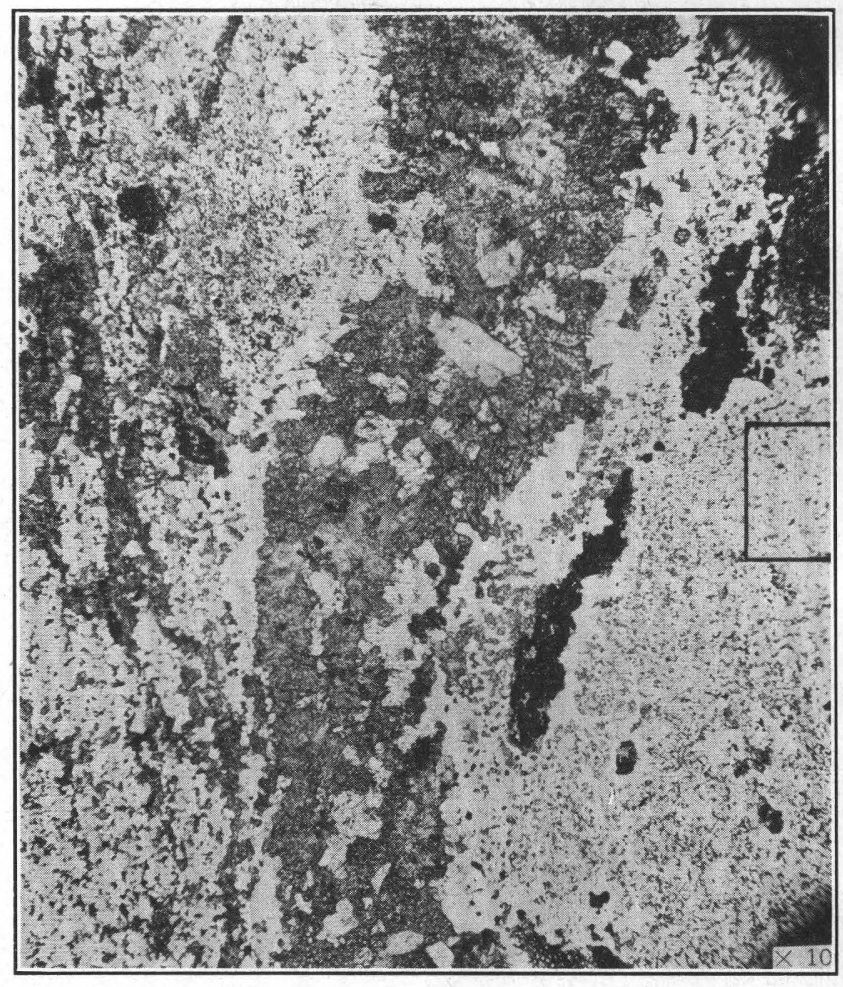

C. PHOTOMICROGRAPH OF MIXED ROCK FROM A CONTACT BETWEEN PRE-CAMBRIAN GABBRO AND MONZONITE.

The coarse-grained gray bands and lenses consist chiefly of green hornblende, augite, and labradorite, whereas the light-colored matrix is gabbroic, consisting chiefly of labradorite, augite, and hypersthene microlites. Plain light.

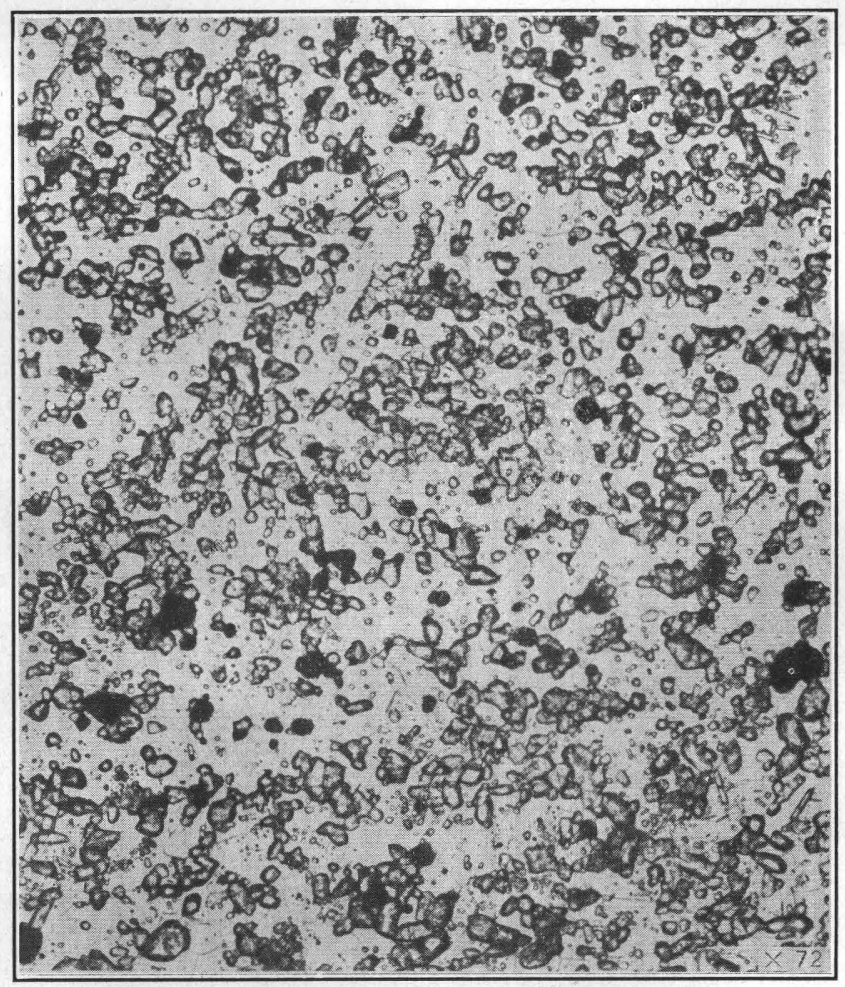

D. AN ENLARGEMENT OF THE FINE-GRAINED MATRIX IN $C$, APPROXIMATELY SHOWN IN RECTANGLE.

The light material consists of labradorite with disseminated augite and hypersthene microlites. Plain light. 


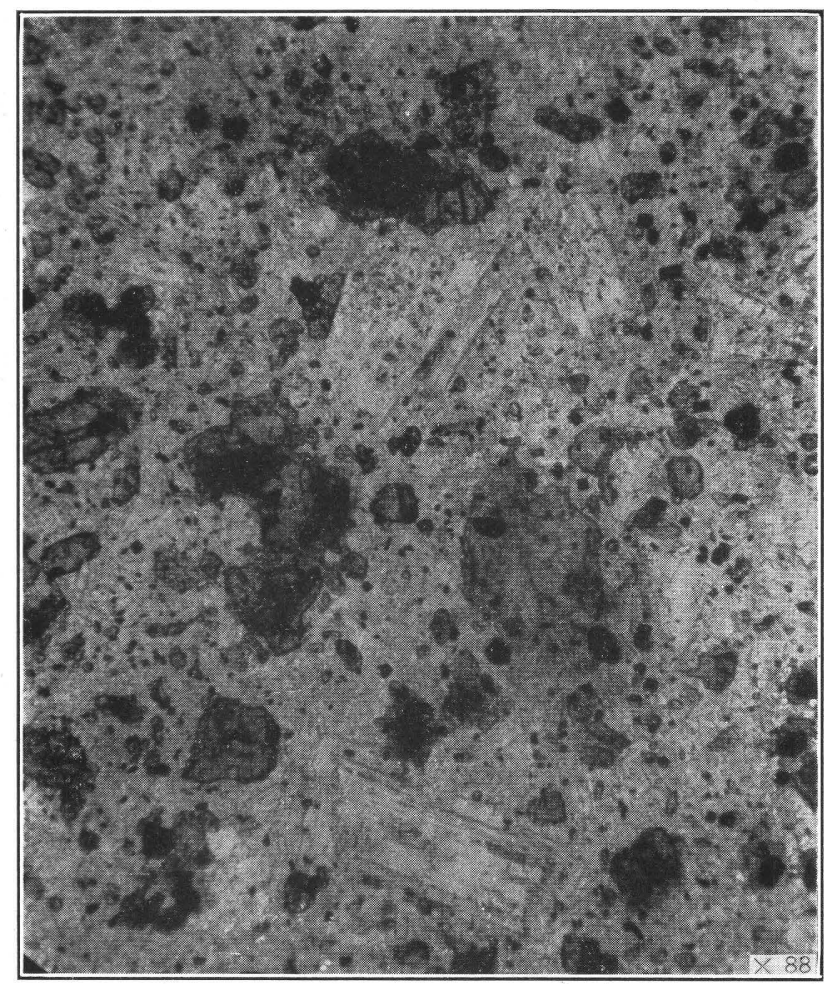

A. PHOTOMICROGRAPH OF NORITE FROM THE APOPHYSIS ON STENDEL RIDGE.

The rock consists essentially of plagioclase, augite, and hypersthene. The phenocrysts grade in size into the groundmass. Plain light.

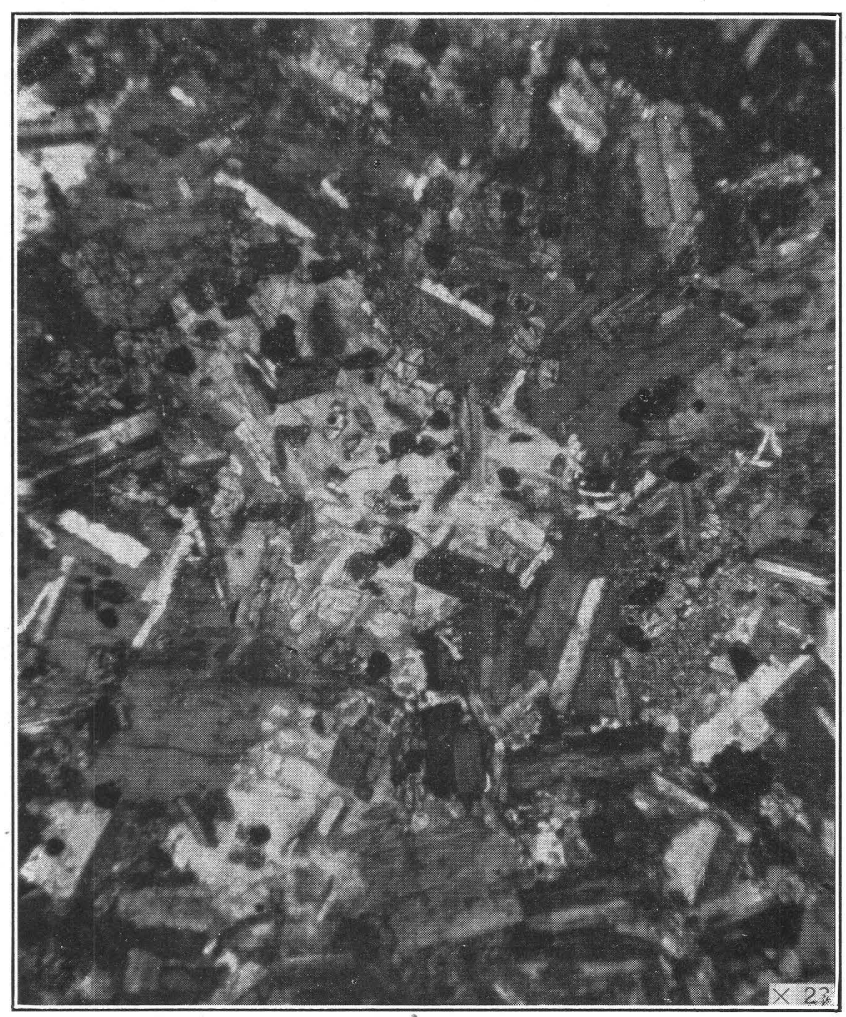

C. PHOTOMICROGRAPH OF FACIES OF TYPICAL MONZONITE FROM THE WEST SIDE OF THE MASS NORTHWEST OF STENDEL RIDGE, SHOWING LARGE POIKILITIC ORTHOCLASE WITH INCLUSIONS OF PYROXENE, PLAGIOCLASE, AND MAGNETITE.

Some orthoclase grains have peripheral inclusions only. Crossed nicols.

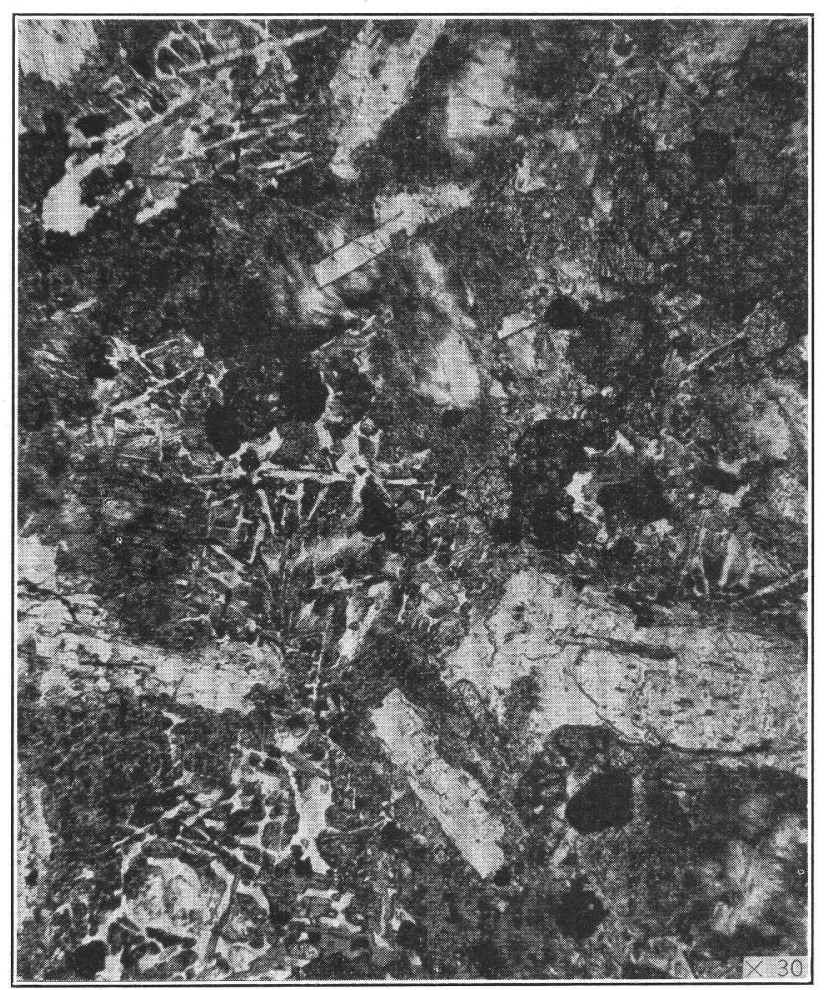

B. PHOTOMICROGRAPH OF MONZONITE FROM WEST SIDE OF MASS NORTHWEST OF STENDEL RIDGE, SHOWING INTERSTITIAL MICROGRAPHIC INTERGROWTHS OF QUARTZ AND "DUSTED" ORTHOCLASE.

Plain light.

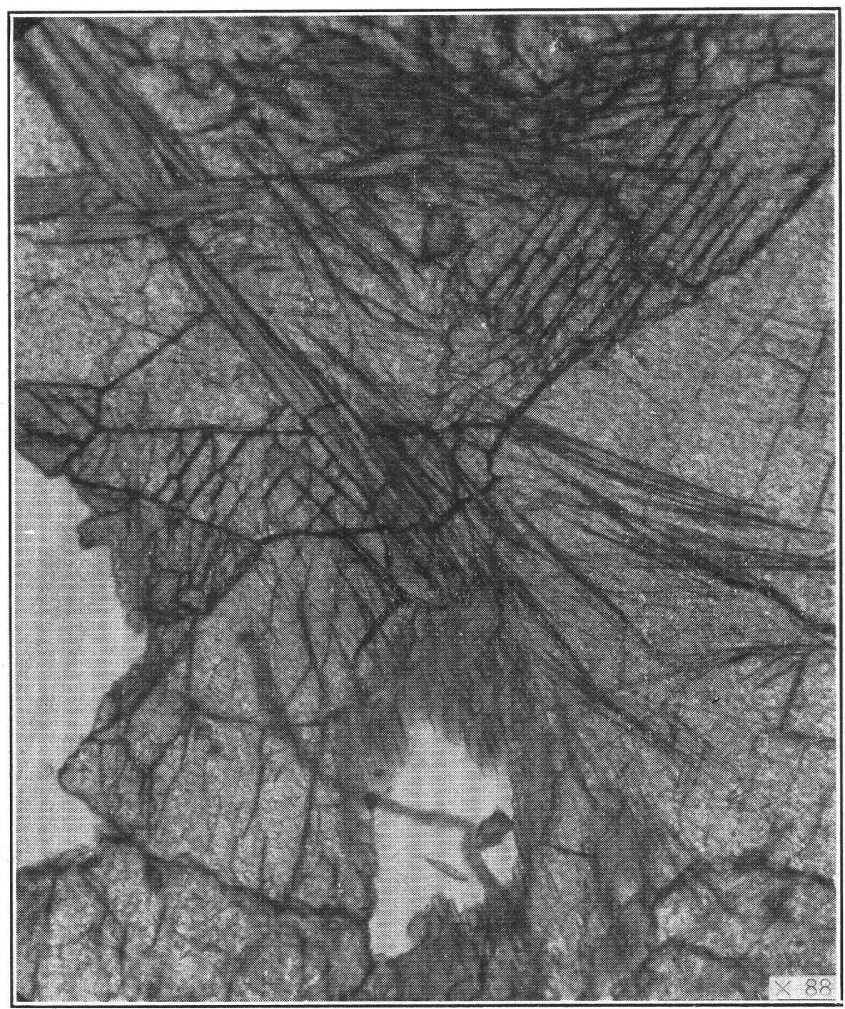

D. FIBROUS HORNBLENDE IMPREGNATING EPIDOTE IN EPIDOTIC MONZONITE FROM THE NORTH SLOPE OF THE MAIN MONZONITE HILL EAST OF HARDSCRABBLE VALLEY.

Plain light. 


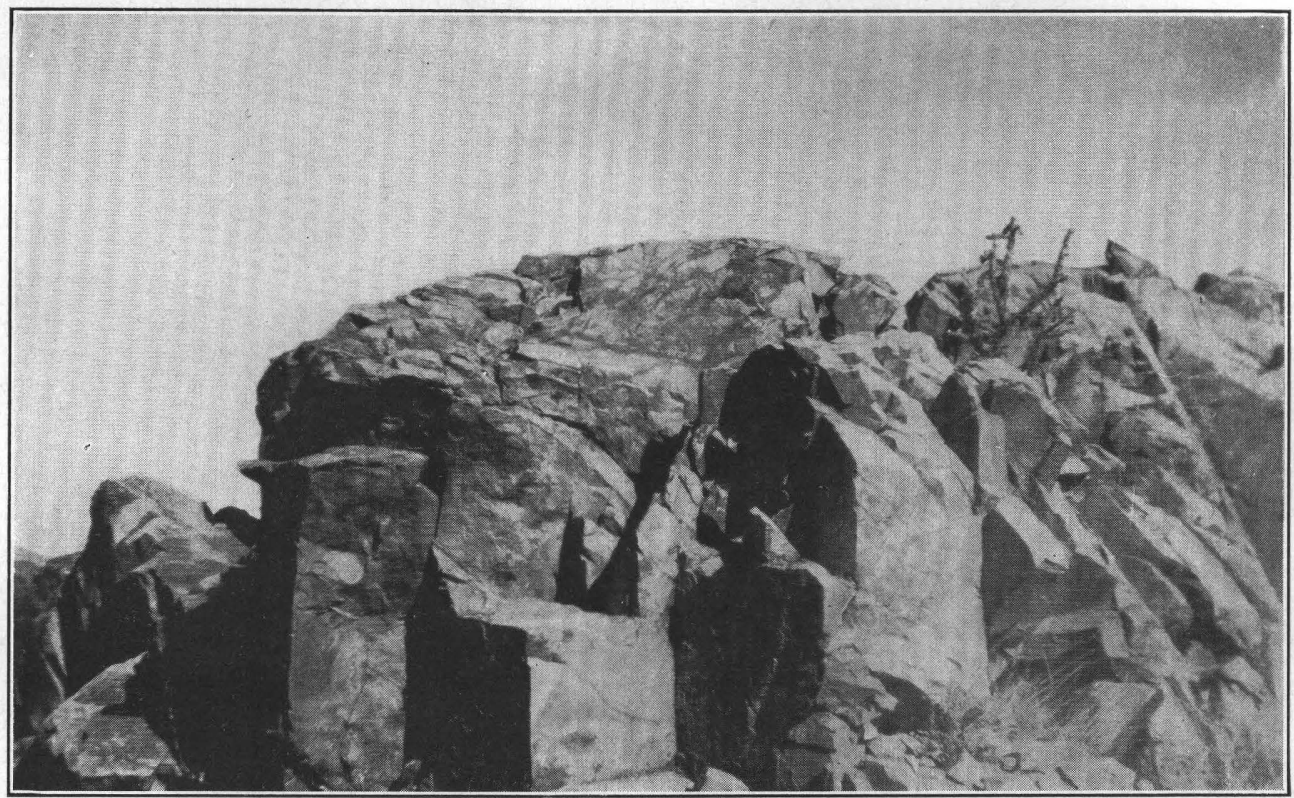

A. OUTCROP OF PRE-CAMBRIAN GRANTTE ON NORTH END OF MAGDALENA RANGE EAST OF ANCHOR CANYON, SHOWING ANGULAR OUTLINE AND BOLD CLIFFS.

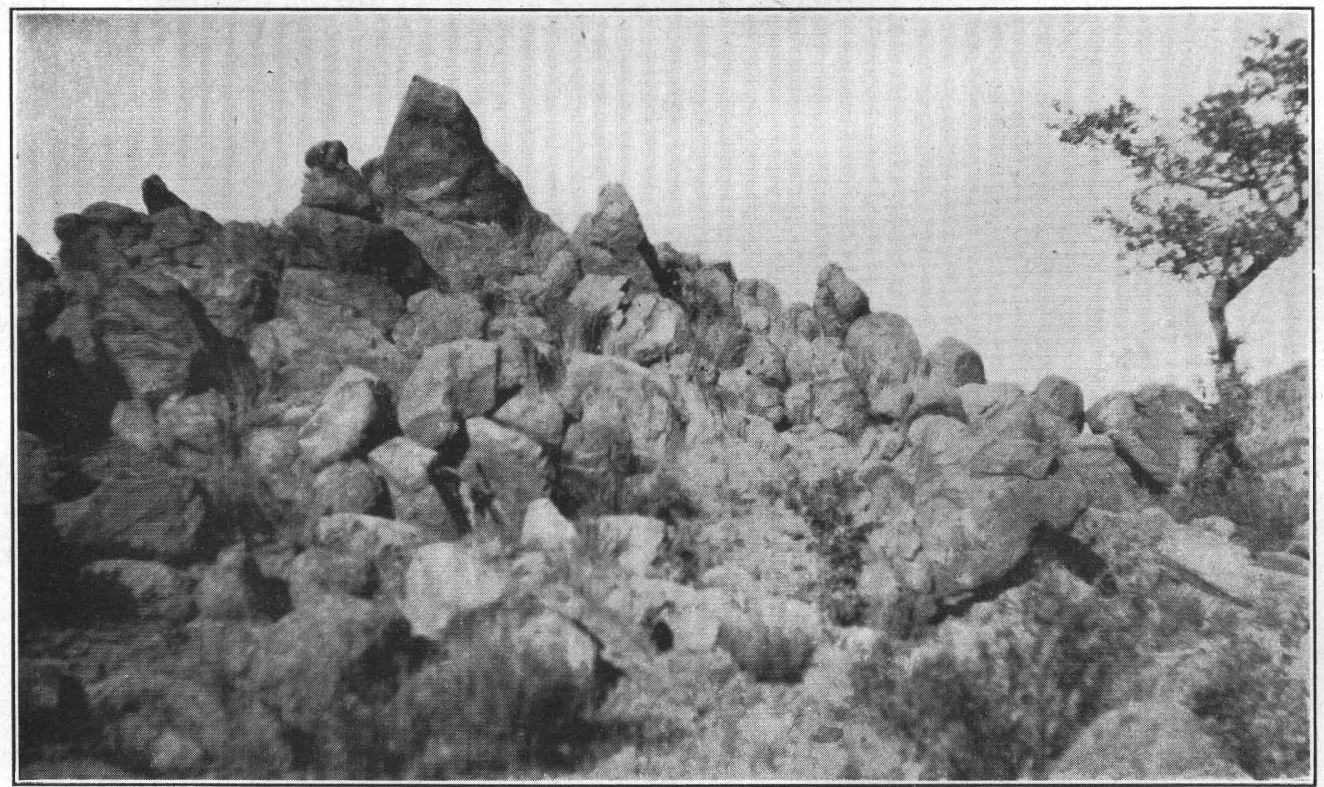

B. OUTCROP OF TERTIARY (?) GRANOPHYRE NORTHWEST OF STENDEL, RIDGE, SHOWING SPHEROIDAL WEATHERING AND SUBDUED SLOPES. 


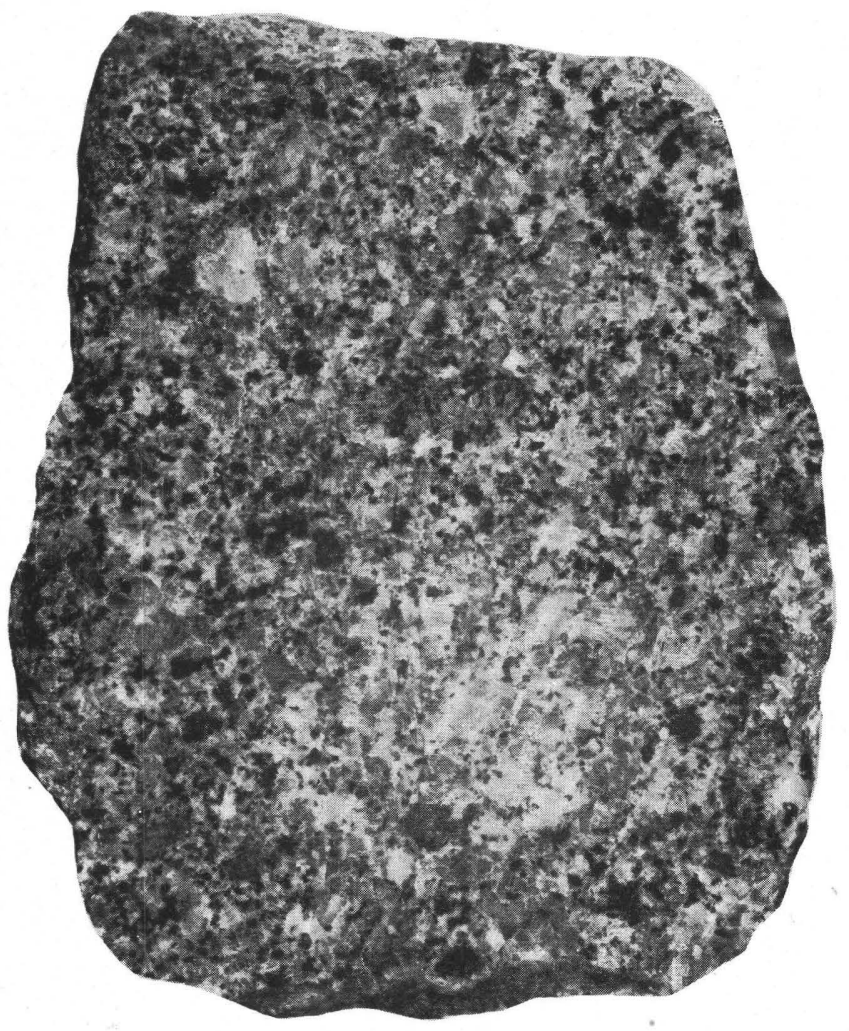

A. POLISHED SURFACE OF TERTIARY (?) GRANITE.

The chief constituents are orthoclase, quartz, and biotite, with subordinate oligoclase. Phenocrysts are rare, but local segregations of feldspars, as seen on the lower right, tend to produce a porphyritic appearance.

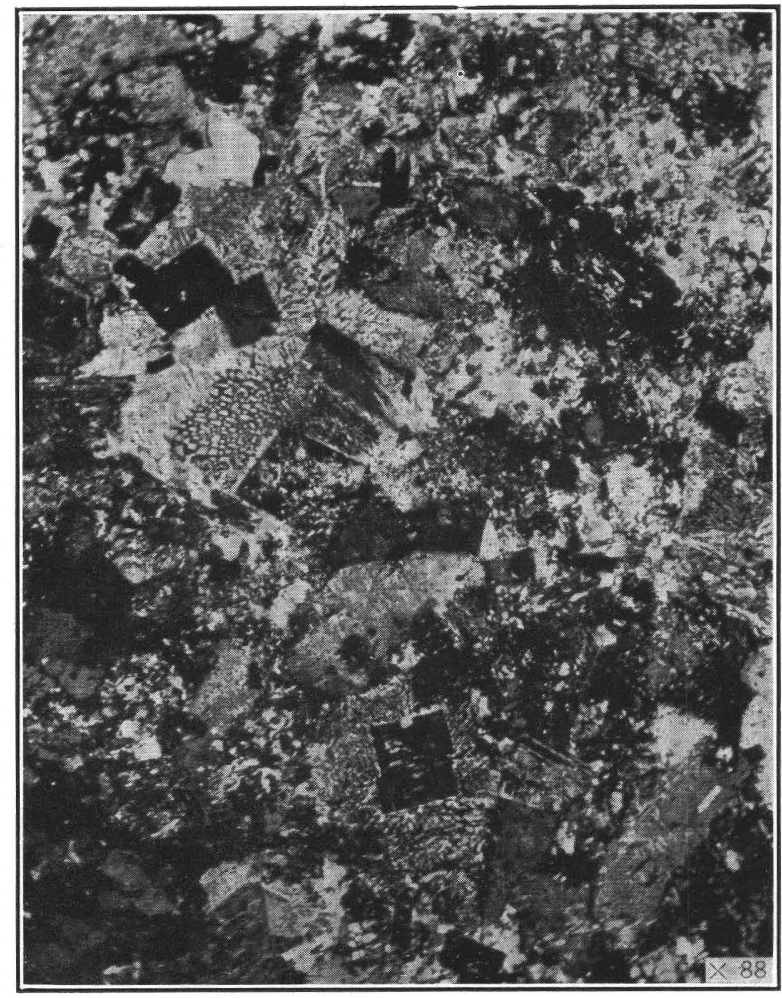

B. PHOTOMICROGRAPH OF "GRANOPHYRE" FROM MASS WEST OF GRANITE MOUNTAIN.

It shows an extreme development of micrographic intergrowth with cores of cloudy orthoclase. Mafic minerals are negligible. Crossed nicols.

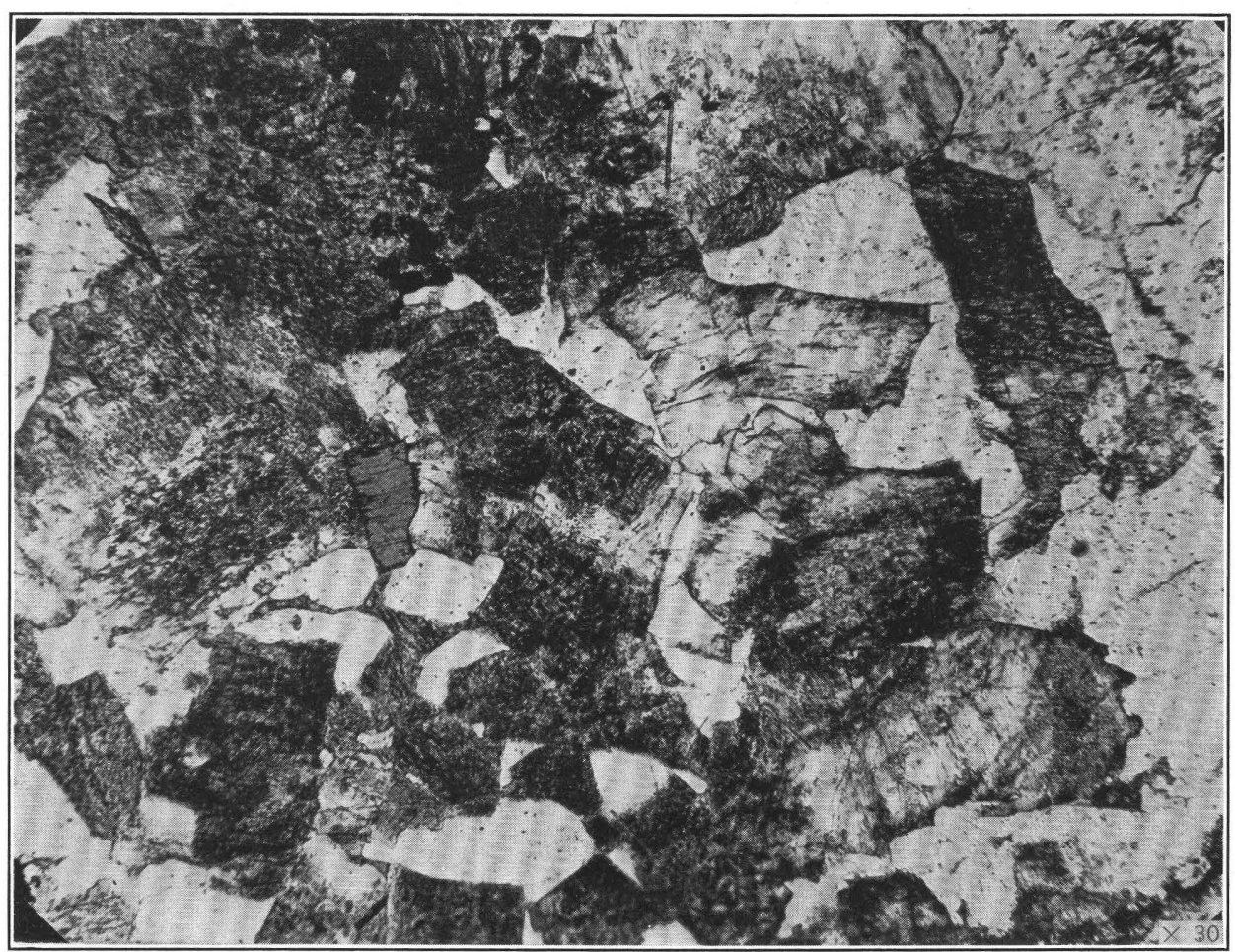

C. PHOTOMICROGRAPH OF TERTIARY (?) GRANITE, SHOWING CLOUDED ORTHOCLASE, BIOTITE, INTERSTITIAL QUARTZ, AND A LARGE CLEAR GRAIN OF OLIGOCLASE IN THE UPPER RIGHT CORNER. Many of the orthoclase grains are especially cloudy near their borders and cleavage cracks but have clear centers, 


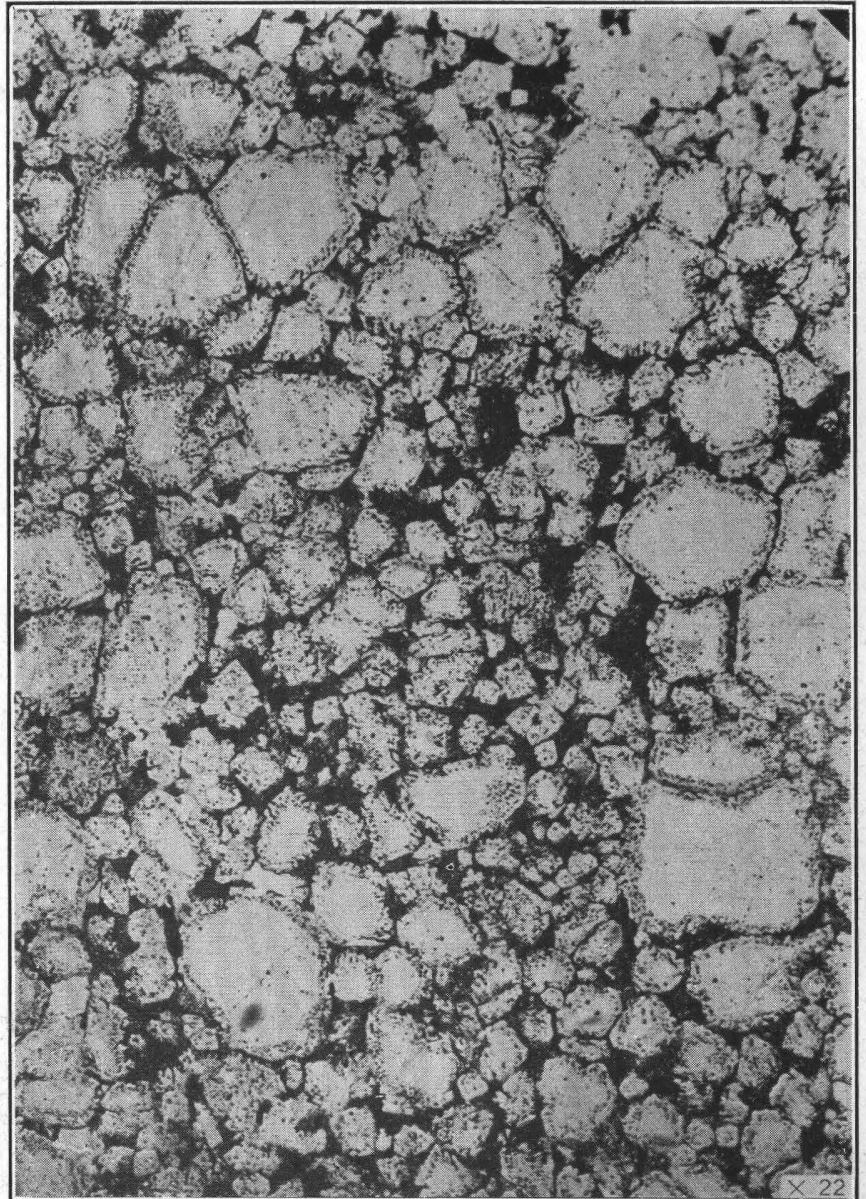

A. PHOTOMICROGRAPH OF METAMORPHOSED SANDSTONE FROM AN INCLUSION IN GRANITE WEST OF GRANITE MOUNTAIN.

The larger quartz grains have been replaced along their margins by concentric nows of specks consisting of sericite and liquid-filled cavities; the smallest grains have been more completely replaced. Detailed study shows the edges of the quartz grains to be irregular and scalloped. The interstitial material consists of sericite

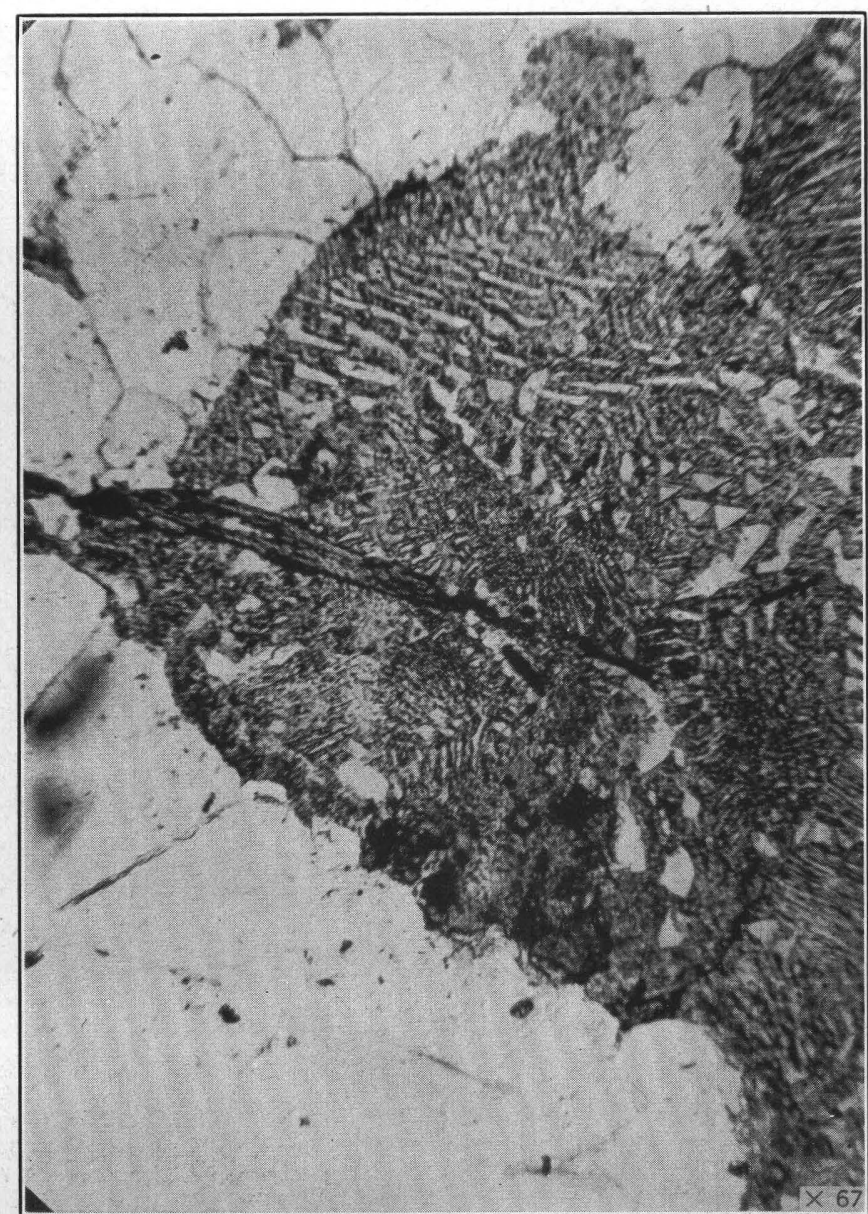

B. PHOTOMICROGRAPH OF TERTIARY (?) SANDSTONE WEST OF GRANITE MOUNTAIN PARTLY REPLACED BY A MICROGRAPHIC INTERGROWTH OF ORTHOCLASE AND QUARTZ.

The outlines of quartz grains are faintly shown. Note the scalloped edge between quartz and orthoclase along the lower contact. A biotite flake crosses the inter-
growth and is very prohably later. From the same thin section as $C$. Plain light.

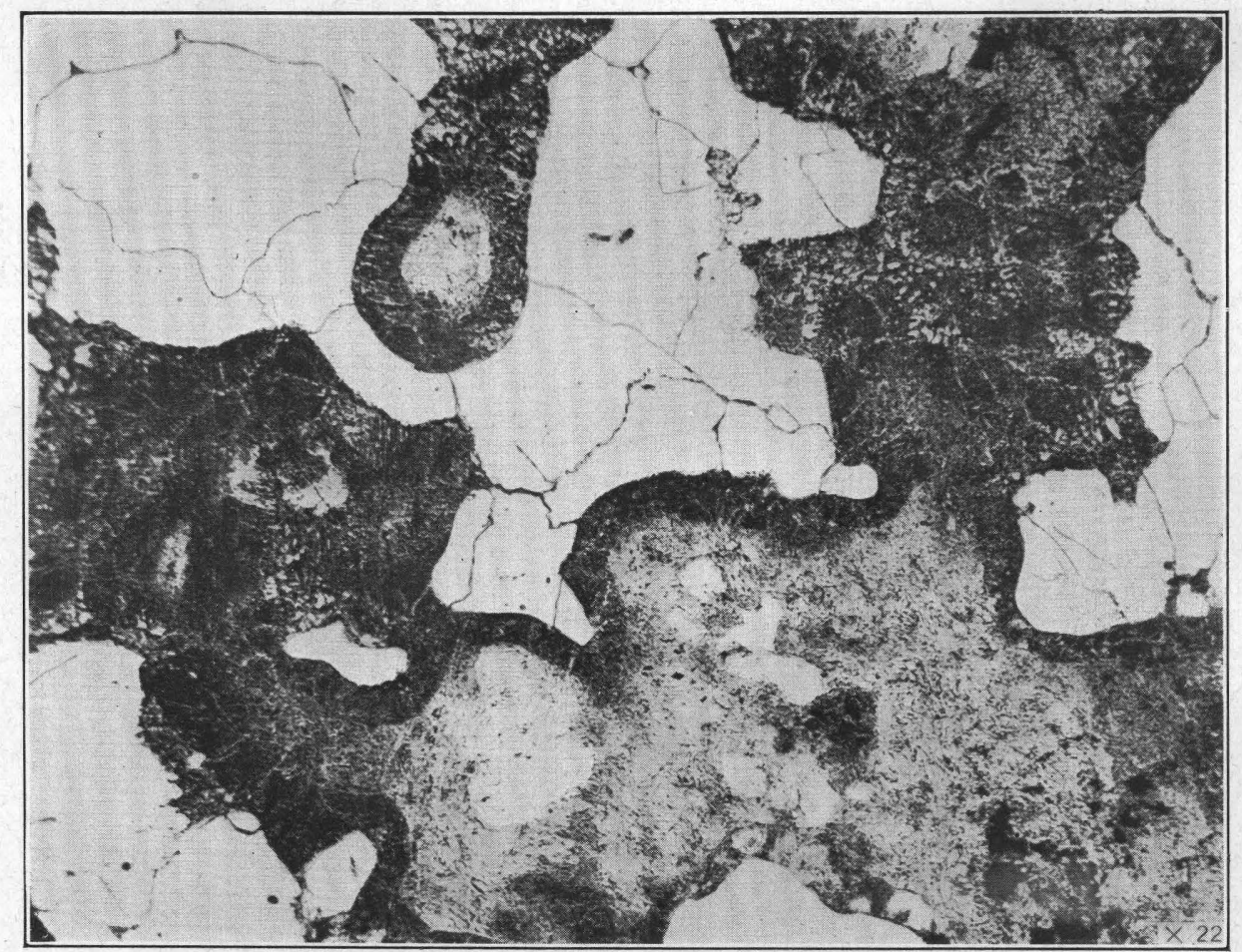

C. PHOTOMICROGRAPH OF TERTIARY (?) SANDSTONE FROM MASS WEST OF GRANITE MOUNTAIN PARTLY REPLACED BY ORTHOCLASE. The replacement has progressed irrespective of the boundaries of the quartz grain. The border of the advancing orthoclase is dark and eloudy, whereas the inner portion, which consists in part of oligoclase, is clear. The dark border may represent more thorough impregnation of the quartz than the marginal specks in $A$. It is prob-

able that replacement advanced by diffusion and that the dark border is an exceedingly fine intergrowth of quartz and or
scope. Much of the orthoclase shows micrographis intergrowth with quart\%. Plain light. 
60 feet long. The aplite is light pinkish gray and very fine even grained. Quartz and feldspar are recognizable as the chief constituents, and some dikes also contain small scales of pale biotite. Those without biotite resemble the fine-grained feldspathized quartzite (hybrid granophyre) on Granite Mountain.

In thin section the aplite dike in monzonite resembles closely the fine-grained Tertiary (?) granite in texture and composition. Its grains are irregular in shape and have an average size of 0.4 millimeter. It consists of 85 percent of cloudy microperthitic orthoclase, 10 percent of interstitial quartz, with sodic oligoclase, biotite, pale-green hornblende, magnetite, zircon, apatite, titanite, and allanite constituting the remaining 5 percent. The feldspars are slightly sericitized and epidotized, and a few grains of biotite have been partly or completely altered to chlorite. Rosettes of tourmaline 3 millimeters in diameter are present on fractured surfaces, but none are intergrown with the minerals of the rock. Tourmaline similarly occurs in monzonite, felsite, and argillite to the north, especially near the large quartz vein shown on plate 2.

The aplite in Tertiary (?) granite in thin section shows a distinctly granitic texture with an average grain diameter of about 0.6 millimeter. It consists of clouded microperthitic orthoclase, quartz, sodic oligoclase, and a few grains of magnetite and zircon. The feldspars are partly to completely sericitized. Orthoclase is in part distinctly interstitial to quartz, and many corroded grains of quartz included in orthoclase indicate partial replacement of quartz by orthoclase.

\section{Pegmatitic material}

Although no pegmatite dikes have been found in the Tertiary (?) intrusive rocks, the Tertiary (?) granite east of the Hardscrabble mine is pegmatitic in places along its contact. On the crest of the ridge east of Anchor Canyon, near the east boundary of the Tertiary (?) granite, the pre-Cambrian granite is cut by a short veinlet about an inch thick containing black tourmaline, feldspar, and quartz that may represent pegmatitic material from the Tertiary (?) granite.

\section{GRANOPHYRE}

Granophyre constitutes the greater part of the small stock just northwest of Stendel Ridge. It is bordered on the east by monzonite, into which it grades rather abruptly, but its other limits are concealed beneath alluvium. The hybrid rock west of the granite on Granite Mountain simulates granophyre, but from field and microscopic evidence presented below it is inferred to be a transformed sandstone. It should logically be described in the section on igneous metamorphism, but, because of its similarity to granophyre and the light that it sheds on the origin of some grano- phyre, its description follows that of the granophyre west of Stendel Ridge.

The granophyre is fine-grained and resembles aplite. It is most commonly pinkish gray, but some is dark gray. It consists of pink orthoclase and quartz with scattered biotite.

Its mineral composition, estimated in thin section, is orthoclase 70 to 90 percent, quartz 7 to 20 percent, sodic andesine as much as 7 percent, biotite with a little augite and hornblende 2 or 3 percent, magnetite, apatite, and zircon about 1 percent. The outstanding microscopic feature, which also characterizes the rock west of Granite Mountain, is the development of micrographic intergrowths of orthoclase and quartz around well-formed crystals of microperthitic orthoclase and rarely of irregular to well-formed grains of oligoclase and quartz. The orthoclase is much clouded with dustlike particles but is only slightly sericitized. A few of the quartz grains are embayed as if partly replaced by orthoclase. The biotite is similar to that in the adjacent monzonite and is accompanied in part by the other minor minerals. Magnetite, zircon, and apatite occur mostly in irregular grains. Titanite, which is a conspicuous minor mineral in the Tertiary (?) granite, is absent. The granophyre also differs from the granite in its finer texture, in the presence of micropegmatite, and in the somewhat more calcic plagioclase.

\section{HYBRID GRANOPHYKE}

A hybrid rock that simulates granophyre occurs west of Granite Mountain, where it is bordered by granite on the north and east and by Tertiary (?) sandstone on the west beyond the area mapped. A brief reconnaissance trip into the low hills west of Granite Mountain showed local patches of this hybrid rock in the sandstone. Many inclusions of the sandstone partly to completely replaced are present in the granite on Granite Mountain, but only the largest is shown on plate 2. There is a rather abrupt transition from the granite into the hybrid rock, so that the boundary line between them can be closely approximated. The hybrid rock is brown to buff, and in both it and the adjacent sandstone are abundant rusty stains and spots. Megascopically feldspar and quartz can be recognized.

Under the microscope the outstanding feature in this rock, as in the typical granophyre, is the development of micrographic intergrowth of orthoclase and quartz (pl. 18, B), which borders crystals of orthoclase. A few scattered grains of sodic oligoclase and muscovite are present. The feldspars are greatly altered to sericite, which is accompanied by minute flakes and sheaflike clusters of biotite. Much of the rock is rust-stained.

That this rock is a transformed sandstone and not of direct igneous origin is suggested by its similarity to the altered sandstone inclusions in the granite as well as by its field relations. 
The sandstone inclusions in granite range from sandy to aplitic in appearance. The aplitic variety consists of quartz grains in a micrographic matrix that has partly to completely replaced the original matrix and quartz grains of the sandstone. The earlier stage of the replacement process is shown by a specimen from the large sandstone inclusion a few feet from its contact with granophyre. Its general color is red but it contains white and gray spots about a quarter of an inch in diameter. Upon weathering the red material is first removed, leaving the gray and white areas in relief. In thin section ( $\mathrm{pl} .19, A$ ) it consists of a mosaic of angular to rounded quartz grains with interstitial sericite, orthoclase, and chlorite, and some iron oxide. Some quartz grains have scalloped outlines owing to replacement by sericite and orthoclase, but the most noteworthy feature is the impregnation of the grains along their borders and fractures by minute dark specks. These specks form rows that parallel the outlines of the larger grains, but they have no apparent arrangement in the smaller ones. In some of the larger grains also specks occur in a line crossing the grain. The larger specks comprise sericite and distinct liquid-filled cavities along whose walls films of iron oxide have been deposited.

A more aplitic specimen from a point near the same contact represents a more advanced stage of replacement of somewhat different type. It consists of interlocking grains of quartz (pl. 19, C) partly replaced by extremely fine-grained micrographic orthoclase and quartz, with minor amounts of oligoclase, iron oxide, sericite, green mica, and chlorite. The interlocking quartz grains presumably represent a quartzitic facies of the sandstone. This hybrid granophyre is invaded by darkly clouded orthoclase, which evidently penetrated along grain boundaries and fractures and replaced the quartz grains so completely that very few of them remain even as corroded inclusions. The replaced silica evidently recrystallized in part in the micrographic intergrowths but was largely removed. In places (pl. 19, B) the micrographic intergrowth is coarser-grained and more distinct. Very pale green mica and sericite partly replace the orthoclase and evidently represent a waning stage of replacement.

The essential identity of the replaced parts of sandstone inclusions and the hybrid granophyre, both in texture and mineral composition, leads to the inference that the granophyre on Granite Mountain is largely or wholly the result of replacement of sandstone by hydrothermal solutions rich in potash and alumina. The position of the granophyre, which caps a low spur bounded on three sides by granite, suggests that it is a replaced roof pendant and therefore accords with this inference, although it would also accord with the inference that the granophyre was simply a product of gravitative differentiation at the uppermost part of the granite.

The origin of granophyre in general has been a subject of considerable discussion. In many places it occurs along the upper contacts of diabase, gabbro, or norite sills in siliceous sedimentary rocks and has usually raised the question of whether the gabbroic magma has assimilated enough roof rock to promote the separation of a granophyric differentiate or whether the original magma differentiated thus without reaction with the sedimentary rock. ${ }^{57}$

The occurrence at Granite Mountain, described above, offers strong evidence that granophyre may be formed by the reaction of siliceous sedimentary rock, and perhaps of siliceous igneous rock as well, with solutions rich in potash and alumina that accompany or closely follow the intrusion of granitic and monzonitic magma.

There is no direct evidence from which to interpret the origin of the granophyre near Stendel Ridge. Its relations to adjacent rocks suggest that it may represent a similar replacement of either feldspathic monzonite or banded rhyolite or both. Its association with monzonite instead of granite favors such an origin rather than simple differentiation, which should have produced the same results at Stendel Ridge as at Granite Mountain, where monzonite passes into granite and granite into granophyre. On the other hand, although petrographic evidence shows that it differs from the granite in its finer texture, in the presence of micropegmatite, and in the somewhat more calcic plagioclase, it likewise differs from the granophyre on Granite Mountain in the more abundant and more calcic plagioclase, presence of brown biotite, and less micrographic orthoclase and quartz. The nature of the problem was not fully appreciated when the rocks were mapped. A careful review in the field, supplemented by more microscopic study, would doubtless throw more light on the problem.

\section{PITCHSTONE}

Two small dikes of pitchstone are exposed in prospect holes in the Madera limestone east of Granite Mountain. The rock is glassy and breaks with a conchoidal fracture. It is green on a weathered surface but brown where unaltered. It cannot be traced along the strike, and it has not been found in any other formation; therefore its age relation to the other igneous formations is unknown.

${ }^{57}$ Bowen, N. L., The evolution of the igneous rocks, Princeton University Press, pp. 90-91, 1928. Daly, R. A., Geology of the North American cordillera at the forty-ninth parallel : Canadian Geol. Survey Mem. 38, pp. 221-255, 1912 ; Igneous rocks and the depths of the earth, New York, MeGraw-Hill Book Co., pp. 428-436, 1933. Schofield, S. J., Origin of granite in the Purcell sills: Canadian Dept. Mines, Mus. Bull. 2, 1914. 


\section{LAMPROPHYRE DIKES}

The rocks mapped as lamprophyres include the basic dikes that were intruded after the emplacement of the Tertiary (?) stocks. These dikes are distributed throughout the district except in the extreme southern part but are most abundant within and near the monzonitic stocks in the central and northwestern parts. There they are associated with later white rhyolite dikes, some of which lie alongside or in direct contact with them. The lamprophyre dikes range in length from a few feet, too small to be mapped, up to 1,900 feet. Their widths are generally from 5 to 20 feet and probably do not exceed 30 feet. In Madera limestone southeast of North Camp a lamprophyre sill has been mapped. Other sills have been noted in the upper Sandia formation on the southwest slope of Tip Top Mountain and at the southeast end of the Granite Mountain area, but they are too small to be mapped.

In color and general appearance these dikes vary greatly. The least altered rocks are blackish gray and of basaltic appearance, but those that have been considerably chloritized are green. The texture, too, varies. Some varieties are porphyritic and others nonporphyritic with very fine grained groundmass; and still others are slightly porphyritic with a fine, unevengrained groundmass. The phenocrysts, which most commonly constitute less than 5 percent of the rock, consist chiefly of irregular white plagioclase grains as much as 5 millimeters in length. In the green facies, especially in the dikes west of Stendel Ridge, darkgreen specks of chlorite are conspicuous, and, together with the white plagioclase, give a speckled appearance. Grains and clusters of calcite can be recognized in some dikes.

The dikes also vary considerably in primary and secondary mineral composition. Some minerals are only slightly altered, but most of them are considerably altered to calcite, chlorite, epidote, quartz, and sericite, but in varying proportions in different dikes. These differences are illustrated by brief descriptions of six varieties of dikes.

1. The only unaltered lamprophyre was obtained from a dike in granophyre northwest of Stendel Ridge. In thin section it proved to be nonporphyritic and finegrained with a minor amount of microfelsitic material. The granular constituents are augite, hornblende, and andesine in about equal parts, with minor amounts of magnetite, biotite, and apatite. Hornblende is of the brown variety but of relatively low birefringence.

2. Another variety, which is only slightly altered, consists chiefly of an ophitic intergrowth of labradorite laths as much as 2 millimeters long and augite, with some chlorite and calcite, the whole peppered with iron oxide.

3. Some of the porphyritic dikes consist of calcite pseudomorphs after hornblende (?) in a groundmass composed largely of andesine laths 1 millimeter or less in length, accompanied in one specimen by interstitial chertlike quartz but more commonly by calcite, with some chlorite, sericite, and quartz. Iron oxide is relatively abundant. Scattered through the rock are small shreds of brown biotite, which was apparently the last mineral to form.

4. A fourth variety consists of andesine phenocrysts, somewhat replaced by calcite and sericite, and augite (?) phenocrysts completely replaced by chlorite, in a groundmass composed of andesine laths considerably replaced by calcite, sericite, chlorite, and scattered shreds of biotite. Iron oxide and apatite are the accessory minerals. .

5. A fifth variety consists of albite-oligoclase phenocrysts, in part replaced by sericite and calcite, a few scattered hornblende phenocrysts, in part altered to chlorite, and a much altered groundmass of plagioclase laths and interstitial quartz, largely replaced by chlorite, calcite, quartz, and some epidote. Iron oxide and apatite are common.

6. A sixth group may or may not contain phenocrysts of plagioclase and chloritized hornblende. The matrix consists of albite laths, uralitic hornblende, and some quartz. The albite is partly replaced by epidote and calcite. In one section of a porphyritic variety the plagioclase phenocrysts are considerably sericitized, and the hornblende is replaced by chlorite and epidote. Like the other varieties, this rock also has considerable iron oxide and some apatite.

To summarize, the dominant feature of the lamprophyres is the groundmass, which consists chiefly of a felty aggregate of plagioclase. The plagioclase ranges from labrodorite to albite, with characteristic and relatively abundant well-formed crystals of iron oxide. With few exceptions, the dikes also contain abundant secondary minerals, among which calcite, chlorite, epidote, or sericite predominates. Some of the dikes also contain abundant quartz, most of which is probably secondary. Brown biotite is one of the unusual secondary minerals, which was not found among the secondary minerals in the other rocks. Insofar as their primary mineral composition can be inferred, most of the dikes may be classified as spessartite, but those with an excess of hornblende are more appropriately called camptonite.

\section{WHITE RHYOLITE}

The white rhyolite dikes, the youngest of the igneous rocks, are found mainly in two zones of northerly trend. One, comparatively narrow, is in and near the granitic stock on the west slope of Granite Mountain and continues for at least 2 miles northward beyond the area mapped. The other, much broader, is in and near the Anchor Canyon granite stock. Other comparatively isolated dikes have been mapped 3,500 feet east-northeast of Tip Top Mountain and in the 
Grand Ledge tunnel in the southeastern part of the district. Those east of Tip Top Mountain are presumably end members of the broad zone, and a careful search for dikes to the north of them would probably prove them to be less isolated. The dike in the Grand Ledge tunnel lies along a mineralized fault zone that extends northward through the Linchburg workings, where the presence of garnetized Kelly limestone suggests metamorphism near a concealed monzonitic or granitic stock to which the dike also may be related.

Most of the dikes, which are conspicuous because of their white color, range in true width from 10 to 25 feet, and few exceed 50 feet; but, because of their banded or sheet structure parallel to the walls, they weather into thin slabby fragments that have crept down slopes for considerable distances from the outcrops. The lengths of single dikes followed continuously without a break range from a few tens of feet to 6,300 feet. Most of the dikes end rather abruptly, and one dike may be followed by another in steplike succession a few tens of feet away. Although these interruptions may appear at first like obscure faults, no faults offsetting the dikes have been found; on the other hand, some of the dikes have been intruded along faults. The maximum aggregate length of a steplike group of dikes is about 9,000 feet. The dikes dip in different directions, most of them very steeply or vertically, but some-notably those west of the Hardscrabble mine and west of Anchor Canyon-dip eastward at angles of only $35^{\circ}$ or $40^{\circ}$, and their outcrops across the steeper spurs therefore follow very undulating courses. The white rhyolite also forms sills in the effusive rocks, especially in the lower andesite, east of Granite Mountain.

Although the rhyolite is light pinkish gray on fresh fractures, its exposed surfaces are grayish white. It consists of quartz and dull, white feldspar phenocrysts up to 3 millimeters in diameter, in a dense appearing groundmass criss-crossed by hairlike veinlets of quartz. The dikes in and near the Anchor Canyon stock are impregnated with pyrite cubes largely altered to limonite. Most of them are less than 3 millimeters in diameter, but some are as much as 5 millimeters.

In thin section the rock appear's roughly banded because of alternating coarser- and finer-grained layers in the groundmass. The quartz and orthoclase phenocrysts are in about equal amounts and constitute less than 10 percent of the rock. Quartz forms irregular grains. It has been considerably resorbed and is bordered by reaction rims. Orthoclase, somewhat clouded, occurs in single well-formed crystals and in clusters of rectangular to irregular grains. It is usually unaltered, but it may contain local bunches of sericite. What probably were scattered biotite grains are now marked by pseudomorphous quartz and limonite, with or without a few shreds of muscovite. No other traces of ferromagnesian minerals are present. Apatite and zircon grains are very scarce.

The groundmass consists of microgranular untwinned feldspar and quartz in poorly defined grains as much as 0.2 millimeter in diameter. It is thoroughly impregnated with sericite and some secondary quartz, which obscure it and help to account for the dense appearance of the surface. The coarser bands are less sericitized than the finer.

The partial analysis given below is of a typical sample taken about 1,000 feet southwest of the Hardscrabble mine. The outstanding feature of this analysis is the relatively high content of silica and potash, which is in keeping with the prominence of quartz and orthoclase phenocrysts and the siliceous sericitized groundmass. The low lime and soda contents support the microscopic evidence of little or no plagioclase. The soda still present may be in the orthoclase.

Partial analysis of white rhyolite

[A. R. Ferguson, analyst]

$\begin{array}{lrll}\mathrm{SiO}_{2} & 75.42 & \mathrm{Na}_{2} \mathrm{O} & 0.73 \\ \mathrm{Al}_{2} \mathrm{O}_{3} & 14.17 & \mathrm{~K}_{2} \mathrm{O}_{2} & 6.29 \\ \mathrm{Fe}_{2} \mathrm{O}_{3}{ }^{1}- & .79 & & -97.90 \\ \mathrm{CaO} & .50 & & 97.9\end{array}$

${ }_{1}$ All iron determined as $\mathrm{Fe}_{2} \mathrm{O}_{3}$, although it is present mainly as pyrite.

\section{DIFFERENTIATION}

A comprehensive consideration of the origin and differentiation of the Tertiary (?) igneous rocks would be lengthy and on the whole inconclusive, especially for the volcanic rocks. Certain features of the monzonite and granite stocks, however, are worthy of brief attention, particularly those that emphasize the influence of liquid or gaseous solutions during and after the closing stages of intrusion.

The differences in sequence of the volcanic rocks in various parts of the district point to several centers of eruption, none of which have been found within the district; indeed, the interlayered rocks even in the same part of the district may have come from more than one center. Until these centers throughout the region can be recognized and the rocks erupted from each center within single periods can be studied, the volcanic rocks will contribute nothing definite to present speculative ideas about differentiation.

The intrusive masses of augite and hornblende andesites have little or no variation in composition and bear no significant relations to the monzonite group in mineral composition. The augite andesite, consisting essentially of andesine and augite, and the hornblende andesite, consisting chiefly of andesine and hornblende, are clearly not basic portions of the monzonite-granite magma, whose most basic facies is the gabbroic apophysis composed of labradorite, augite, hypersthene, and biotite on Stendel Ridge. The accessory minerals likewise point to a lack of relationship. Magnetite is rela- 
tively scarce in the andesites, although common in the gabbroic apophysis and monzonite, and apatite is common in the gabbro and monzonite but absent or scarce in the andesites. The intrusive andesites therefore cannot be regarded as products of the essentially continuous process of differentiation that gave rise to the monzonitic and granitic facies in the stocks.

The stocks of monzonite and granite are of more interest, as they have not only certain features in common but also considerable diversity in structure and composition; but even with them available data are insufficient to warrant more than tentative conclusions. Of the two usual concepts-that differentiation takes place either by gravitative changes within a molten mass after intrusion and during crystallization or by deeper-seated changes between successive stages of intrusion-the first finds little or no support in the district; the second is the more favored of the two but is obscured by the positive evidence of changes caused by liquid or gaseous solutions reacting with these rocks during and after the closing stages of consolidation. These changes also leave much for speculation, but they are of interest in their bearing on the derivation of ore-forming solutions, and the discussion that follows will, therefore, be focussed on them.

The evidence, presented on page 69 , that the Nitt stock has oblitered a transverse fault zone and the Anchor Canyon stock lies along the axis of a mild flexure implies that the magmas that formed these stocks and the volatile materials that accompanied or followed their intrusion rose rather directly from a deep source through ground weakened by disturbance. The fact that each of these two stocks in the main range is largely homogeneous in composition but is completely separated from the other at the surface leaves doubt as to their relative ages, and therefore, as to the major process of differentiation that gave rise to them. The distribution of facies in the smaller composite stocks as well as the presence of small feldspathic and granitic dikes in the Nitt stock implies that the granite was later than the monzonite; but whether this conclusion can be applied to the large granite stock whose composition is essentially uniform over an area of $21 / 2$ square miles and through a vertical range of 1,700 feet may be open to question.

There is no consistent evidence that the magmas forming the stocks were appreciably affected in composition by the rocks that they invaded. The large granite stock, where exposed, is in contact with either pre-Cambrian granite or argillite and contains a large inclusion of Kelly limestone, but no local variation in the granite was found to indicate contamination by either of these rocks. The Nitt stock is in contact with pre-Cambrian felsite and argillite, Paleozoic limestone, shale, and quartzite, and Tertiary (?) volcanic rocks, but none of its variations in composition show any con- sistent relations to these rocks. Hypersthene in granitic rocks is interpreted by some ${ }^{58}$ to indicate that the intruding magmas may have been contaminated by assimilation of aluminous sediments, and the presence of hypersthene in the monzonite at Magdalena may be regarded as the result of such contamination; but direct evidence in support of such contention was not found. The Nitt stock, as shown by its southern contact, invaded an unknown thickness of the pre-Cambrian argillite and the whole thickness of the Kelly and Sandia formations, but it is not known to what extent these rocks were assimilated by the magma. The Nitt stock shows minor variations along Stendel Ridge, and the typical monzonite north of the Graphic tunnel (see p. 38) has a narrow zone of norite or hypersthene gabbro adjacent to the inclusion of the pre-Cambrian gabbro, but in general the variations are unrelated to the host rock. Nor is the evidence afforded by the composite stocks northwest of Stendel Ridge and southwest of Granite Mountain indicative of contamination by exposed wall rocks, for on Granite Mountain both the monzonite and the granite are bounded by rhyolite porphyry and latite and northwest of Stendel Ridge the monzonite is bounded by the banded rhyolite. The replacement of the Tertiary (?) sandstone by granophyre is attributable to hydrothermal after-effects rather than to an attack by the original molten monzonite or granite.

Such changes in mineral composition as have been noted are in general agreement with the reaction series in consolidating magmas as proposed by Bowen. ${ }^{59}$ The noritic or gabbroic facies, which, according to this idea, crystallized at the highest relative temperature, is represented by the dike that branches eastward from the Nitt stock on the northern part of Stendel Ridge and by the narrow border of "norite around the altered gabbro inclusion north of the Graphic tunnel. The noritic border around the inclusion of altered preCambrian gabbro is clearly a local reaction between the monzonite magma and the hornblende and feldspar of the gabbro. Such a reaction as suggested by Bowen, ${ }^{60}$ should cause deposition of the "heat equivalent of the member of the series with which the liquid is saturated." The dike on Stendel Ridge, however, evidently marked the first stage of crystallization. It crystallized rather rapidly and was not penetrated later by liquid or volatile constituents of the magma. The same calcic plagioclase and hypersthene that constitute the dike may have crystallized throughout the greater part of the Nitt stock during this early stage, but, as the temperature of the magma declined and its fluid part became depleted in calcium, magnesium, and iron, these early minerals tended to react with the still molten

${ }^{68}$ Bowen, N. L., The evolution of the igneous rocks, Princeton University Press, pp. 207-214, 1928.

59 Idem, pp. 55-62.

${ }^{\infty 0}$ Idem, p. 221. 
material to form less calcic plagioclase and augite. The zonal character of the plagioclase and the lack of sharp boundaries between many mineral grains favor this interpretation.

Further decline in temperature eventually permitted the crystallization of sodic plagioclase, orthoclase, and quartz, the last two of which filled interstices among the earlier minerals. Concentration of water and other volatile materials during the later stages permitted the formation of biotite instead of the pyroxenes. Further concentration of alkalies, silica, and volatile matter, together with local fracturing, accounted for the small feldspathic and granitic dikes that are found in the upper part of the Nitt stock along Stendel Ridge and along its margin in the vicinity of Oak Spring.

Similar concentrations evidently took place deeper in the stocks after the upper part had become sufficiently crystallized to be subjected to fracturing, as is shown by the granite dike that branches from the Granite Mountain stock and contains rounded fragments of monzonite. The rounded rather than angular inclusions suggest either that the monzonite had not become well solidified before it was invaded by the granite or that the corners and edges of the fragments were resorbed by granite. Both conditions may have existed.

An extreme result of such concentrations is evidently represented on the west side of the Granite Mountain stock where hybrid granophyre is believed to have replaced Tertiary (?) sandstone (pp. 41-42) whose position implies that the replacement took place along the roof of the stock.

The fact that some stocks in the district are nearly homogeneous, whereas others are composite, discourages any idea of differentiation by crystal settling within the stock. On the basis of differentiation within a stock it is also difficult to explain just why one stock was arrested at the monzonite stage, whereas another was continued to the granite stage. The arrangement of the different facies on the present surface might suggest that the composite intrusive masses were of sill-like rather than stocklike form and were inclined westward and that the monzonite, the heaviest and the earliest of the facies, lay along the footwall, whereas the granophyre, the lightest facies, lay along the hanging wall; but the intrusive contacts as a whole do not suggest sill-like forms, although the hybrid granophyre west of Granite Mountain and the southernmost mass of magnetic rhyolite porphyry on Stendel Ridge are believed to be remnants of roof rock whose contacts with the intrusive rock conformed approximately to the general dip of the surrounding formations. It might be suggested also that the granite is an intermediate product of slow differentiation and that its presence at Granite Mountain indicates an arrested process, whereas its absence at the northwest base of Stendel Ridge indicates completion of the process. The comparatively large Nitt stock, however, whose rooflike contact at the south end of Stendel Ridge has already been noted, has little or no granite or granophyre in the upper part, where the only indication of differentiation is the presence of the small feldspathic dikes and segregations within the typical monzonite and in the local cap rock of magnetic rhyolite porphyry. If crystal settling played any conspicuous part in differentiation, therefore, the magmas that formed the stocks must have had different compositions before they were intruded. Such an inference would imply that the magmas were differentiated in a deep-seated reservoir and that monzonitic and granitic magmas were intruded at different times. If so, the granitic magma did not have access to all the channels followed by the monzonite and therefore left some monzonite masses intact, while it formed composite stocks with others and also formed independent stocks. If the granophyre northwest of Stendel Ridge were to be regarded as of direct igneous and not hydrothermal origin, it was presumably intruded last and was similarly selective, as it is in contact with monzonite at only one place. No sharp contacts between the different facies have been found, partly because the contacts are largely concealed beneath debris, and the idea of successive intrusions of the different facies therefore lacks proof. It is conceivable that a late facies intruding an earlier one that was not thoroughly solid could form a gradational contact, as maintained by Daly ${ }^{61}$ and Camsell. ${ }^{62}$ Such a concept may apply to the granite, but the clearly definite replacement of sandstone by granophyre west of Granite Mountain and the relatively inconspicuous evidence of replacement of monzonite by granitic material raise the question of how extensive replacement could have been throughout the stocks.

The local concentration of volatile materials during consolidation of the monzonite has already been considered. Small feldspathic or granitic dikes and segregations within the upper part of a monzonite mass may readily be attributed to such concentration, but the large granite masses, if attributed to a similar process, call for the concentration of an immense amount of volatile matter, which would be possible only in or below the deeper part of a monzonite mass. Localization, at least of the larger stocks, along intersections of fault zones or zones of structural weakness has been cited, and recurrences of movement after the consolidation of both monzonite and granite stocks (p. 70) have been recognized. It is therefore reasonable to infer that movements took place during the period of intrusion. Some movements would allow accumulated volatile material to rise and permeate the

al Daly, R. A., The Okanagan batholith of the Cascade Mountain system: Geol. Soc. America Bull., vol. 17, pp. 351 and $353,1905$.

${ }^{62}$ Camsell, C, Geology and ore deposits of the Hedley district, B. C. : Canadian Geol. Survey Mem. 2, p. 88, 1910. 
newly formed rock along and near reopened fault zones and to replace its original minerals with later minerals in the reaction series. Monzonite not subjected to permeation at this stage of the intrusion would escape granitization. Microscopic evidence of such replacement has been found throughout the monzonite, but although it can readily account for the incipient alteration that produced the graphic intergrowths or orthoclase and quartz with hornblende fibers and locally small patches of partly to completely granitized rock, considerable imagination is required to picture such thorough diffusion through a stock of monzonite as to convert it entirely into a granite mass of uniform composition. The fact that granophyre is the evident end product of this replacement process would make it the more remarkable that the process in general was arrested at the granite stage.

The granophyre at Granite Mountain represents the product of a solution that was active after the crystallization of the granite. Such a solution may have had only slight reacting power on the granite, whose composition is close to that of granophyre, but may have had appreciable influence on permeable rocks of different composition, such as sandstone and monzonite. It may also have been able to replace or at least recrystallize the glassy or microcrystalline groundmass of the banded rhyolite.

Regardless of the extent to which residual solutions were effective in the development of different rock facies, the part played by liquid or volatile constituents during and after the consolidation of the monzonite deserves recognition and is discussed in the following section. In addition to the small feldspathic and granitic facies already cited, the small veins composed of quartz, orthoclase, and epidote, near the monzonite contact at Oak Spring (p. 39) are of special interest, as they are intermediate between mineral aggregates characteristic of recognized igneous rocks and those of hydrothermal deposits. They may be regarded as representing temperatures below the stability range of the anorthite molecule of plagioclase, whose place has been taken by epidote, whether or not the calcium was derived from the monzonite or from limestone that had been invaded by the monzonite. They are closely associated with metamorphosed sedimentary rocks, the more siliceous of which contain considerable epidote, and thus support the idea that metamorphism was brought about by materials that in part escaped from the crystallizing stocks and in part rose through them soon after consolidation wherever fracturing or minor faulting permitted.

The role played by lamprophyres in differentiation has never been adequately explained, and as any ideas that we might add regarding it would be purely speculative we shall content ourselves here with emphasizing the position of the lamprophyres and the still later white rhyolite dikes in the general sequence of events and the consequent necessity of looking for their source not in the visible intrusive stocks but in a deep reservoir from which the stocks and the lamprophyre and rhyolite dikes as well as the ore deposits originated.

\section{ROCK ALTERATION AND ITS SIGNIFICANCE SUMMARY AND CONCLUSIONS}

The term "rock alteration" as here used includes the chemical, mineralogical, and textural changes that have affected the sedimentary rocks after their deposition and consolidation and the igneous rocks after their crystallization from a magma. The degree and kinds of alteration were not uniform over the entire district. The products of alteration, therefore, differ from place to place in the district, and in any one place they differ according to the original composition and permeability of the altered rock and according to proximity to intrusive contacts and to the main channels along which mineralizing solutions circulated. The evidence presented below shows a variety of processes that may have been active in some degree throughout the periods of volcanic eruption; but it is believed that the more conspicuous effects of alteration may be attributed to processes that were active in successive stages during and after the crystallization of the intrusive stocks.

Early alteration may have been produced to some extent by escaping liquids and gases, during and after each volcanic eruption, as is shown by phenocrysts with reaction rims, but its effects are relatively insignificant. Reaction rims around such minerals as hornblende or biotite are widespread and are recognizable even where the volcanic rocks are least altered, but the effects of more intense alteration that has replaced the cores of these minerals with chlorite or with epidote, sericite, calcite, or quartz, are prominent in certain areas and are clearly later than the reaction rims. Early alteration may also include the replacement of moderately calcic plagioclase by epidote, calcite, and less commonly albite. Secondary quartz in irregular grains and clusters is present in all the altered rocks, and some of it is unquestionably a byproduct of the early alteration of primary minerals; but its abundance in different areas and in different kinds of rocks, especially along and near faults, indicates that it has also been introduced by solutions that were distinctly later than the volcanic eruptions and the subsequent intrusions of stocks.

The alteration that accompanied or followed the intrusion of the stocks resulted in recrystallization of the argillite and rhyolite porphyry and the marbleization and silication of the adjacent limestone. The argillite and rhyolite porphyry are close to the monzonite contacts. Only one exposure of argillite was found that clearly indicated the infiltration of monzonitic material whereas most of the argillite nearby had been 
converted into hornfels. Marbleized and bleached limestones are found as much as 1,500 feet from the contact, but such relatively high temperature minerals as wollastonite, tremolite, diopside, and garnet (grossularite) in silicated limestone and andalusite in altered shale, with two exceptions, have not been found at a distance greater than about 200 feet. Garnet (andradite) and hedenbergite, associated with magnetite and sulphide minerals, occur at greater distances, notably along the main ore zones of the GraphicWaldo and Kelly mines and also in the Linchburg tunnel about 12,000 feet south of the monzonite contact. This exceptional occurrence in the Linchburg tunnel suggests the presence of a concealed stock, or at least a center of mineralization, at no great depth. Similarly, grossularite, magnetite, serpentine, chlorite, and bladed calcite, found on a prospect dump on the south edge of the sedimentary area east of Granite Mountain, suggest that the Tertiary (?) granite, concealed by alluvium, extends northward from the main range to this vicinity. The relations of this group of secondary minerals in limestone to the stocks clearly indicate that these minerals belong to a period of alteration that began contemporaneously with or even subsequent to the crystallization of the stocks and, as will be shown later, continued through the different stages of ore deposition.

In the shale, quartzite, and volcanic rock adjacent to limestone that contains these high-temperature minerals are conspicuous amounts of epidote, muscovite, chlorite, sepentine, calcite, and quartz. This mineral assemblage is also found much farther from intrusive contacts. It is distributed throughout the northern and central parts of the district and is present to different degrees in almost all the formations on Stendel Ridge and Granite Mountain. It is very conspicuous in the more permeable tuffs. The intensity of alteration in these areas is greatest near fissure zones or along the contacts between the sedimentary and volcanic rocks, for example on the southeast slope and northern foothills of Stendel Ridge. There the rocks, regardless of their original composition, are thoroughly bleached and have been converted into fine-grained aggregates of quartz and sericite with a little pyrite. Farther away they are less thoroughly replaced, have greenish colors, and contain much disseminated epidote, chlorite, and calcite, as well as sericite and quartz.

The relative abundance of these minerals also depends on the composition of the host rock. In general the less pure limestone and calcareous shales and the igneous rocks that contain relatively large amounts of original calcic minerals have developed larger amounts of epidote and calcite, whereas those with more magnesian minerals have developed corresponding amounts of chlorite.

The distribution of these secondary minerals points to their derivation from the hot solutions that permeated the district soon after the intrusion of the stocks and became cooler and weaker the farther they moved from the stocks; but the presence of some of these minerals also in lamprophyre and white rhyolite dikes, which cut the stocks and extend throughout the district, indicates that they were formed at least in part distinctly later than the consolidation of the stocks. The evidence as a whole, as will be shown, indicates that stocks, dikes, and mineralizing solutions were all introduced along zones of structural weakness and were derived from the same general source.

The chief process of alteration in the sedimentary rocks of the southern part of the district was the replacement of the Kelly limestone and locally the preCambrian argillite along the upper part of the range by immense amounts of jasperoid. Large masses of jasperoid are also present east of Granite Mountain. Fractures and other openings in the jasperoid are filled or lined with vuggy quartz. Locally barite accompanies quartz in the vugs, and both minerals are coated in places by black mangenese oxides and green copper carbonate. Barite is also present in metalliferous veins that cut the jasperoid and indicate that silicification preceded ore deposition. The thorough silicification of the argillite along the Grand Ledge fault east of Patterson Canyon implies that there was a local source of silica supply nearby, either the same source that supplied the high-temperature minerals in the Linchburg tunnel or one still farther south. The fact that this extensive silicification took place before ore deposition correlates it with the formation of silicates farther north. It is thought, therefore, that both processes took place at the same general time but that the solutions in the southern area traveled so far before reaching limestone that they had been cooled below the temperatures at which silicates could be formed.

The chief processes of alteration in the volcanic rocks in the southern area were hematitization and silicification. Only the purple andesite and latite porphyry, which were subject to permeation by solutions that spread along the Kelly-Graphic and Waldo fault zones, have been appreciably altered to sericite, epidote, chlorite, and calcite.

Hematitization has imparted red and pink colors to the rocks and where these colors are most intense they have formed at the expense of the groundmass. Silicification in the volcanic rocks is most pronounced in the upper andesite, which contains many geodes or small spherical and irregular masses of chalcedony, the larger of which have replaced the red groundmass, and in the adjacent red rhyolite, which is crisscrossed by many quartz veinlets. Small lenses, veinlets, and grains of secondary quartz and chalcedony are also found in the banded rhyolite. The interiors of some of the larger geodes have been filled with calcite. 
Where the reddish rocks are cut by quartz-baritecalcite-sulphide veins they have been bleached to light gray, showing that the hematitization originated before the veins. The relations between these veins and the silicification in the volcanic rocks just cited is not clear. The presence of calcite in the central parts of geodes could suggest that they were formed by the same solutions that deposited the veins, but the uniform distribution of geodes and the restricted distribution of the veins does not support the suggestion.

Clay minerals and celadonite occur as minor alteration products in the upper andesite and to a smaller extent in the red andesite and red rhyolite. These minerals, together with the calcite that fills the chalcedonic geodes, were very probably formed during a late stage, when the temperature was comparatively low and the solutions had been practically depleted of acid constituents but could still produce hydration.

An outstanding feature of alteration throughout the district is the wide areal extent of the altered rocks in contrast to the localization of the ore deposits, which are confined to the immediate vicinity of fault zones. The alteration, therefore, evidently took place under a pressure sufficient to force solutions through the heated rocks for these relatively great distances. Ore deposition is believed to have taken place at a later time after the renewal of fissuring or minor faulting had given opportunity for new supplies of liquid and volatile material to rise from great depth, in part through the igneous stocks themselves but mostly along fault zones in the surrounding rocks.

In the following detailed descriptions the secondary minerals found at and near intrusive contacts and commonly called contact-metamorphic will be grouped, and those not definitely found at or near contacts will be described by areas. The alteration of the preCambrian rocks prior to the intrusion of the Tertiary (?) stocks has already been discussed, and only the alteration attributed to Tertiary processes will be included here. The alteration of the rhyolite porphyry on Stendel Ridge and that of the Tertiary (?) sandstone west of Granite Mountain into hybrid granophyre also have already been fully described ( $p p$. 34 and 41 ) because of their bearing on the origin of certain facies of igneous rocks. These processes may have been equivalent in time to those that produced anhydrous silicates in limestone, as both preceded any processes that produced similar results in both igneous rocks and limestones, as well as in shale and quartzite.

\section{ALTERATION NEAR INTRUSIVE CONTACTS ALTERATION OF PRE-CAMBRIAN ROCKS}

Alteration of the pre-Cambrian rocks induced by the Tertiary (?) intrusions is slight and in most places absent. Thus the contact between the pre-Cambrian granite and the Tertiary (?) granite is well exposed at several places and for varying distances in Anchor Canyon, yet no evidence of alteration was found, except small seams of epidote, chlorite, specularite, and quartz, which may have been formed either in preCambrian time or subsequent to the intrusion of the Tertiary (?) granite. The usually dark pre-Cambrian felsite locally may be bleached nearly white; but the bleached rock is adjacent to veins, for example north of Ambrosia Peak, and the bleaching has undoubtedly been produced by solutions spreading from vein fissures and not by the intruding granite. The intrusion of the Tertiary (?) granite into argillite produced no noteworthy alteration, but the intrusion of the Nitt monzonite stock converted argillite into hybrid rock and hornfels near the Graphic tunnel. Tufts of tourmaline are found on fracture surfaces in the argillite and felsite, but they do not penetrate either rock. They also coat fracture surfaces in the monzonite and are present in aplite dikes south of Hardscrabble Camp. They are therefore clearly related to the Tertiary (?) intrusions.

Hybrid rock between monzonite and argillite is found on the spur north of the Graphic tunnel and just east of the road leading to the Sleeper tunnel. It was unquestionably produced by the monzonite intrusion. This zone of mixed rock is about 20 to 30 feet wide and grades into the unaltered argillite. It is a rather light colored, banded rock and appears as though the argillite had become plastic and was then squeezed into bands. A thin section of this mixed rock shows much the same mineral composition as the argillite, but the constituents have recrystallized to a coarser grain. Quartz, muscovite, chlorite, and biotite are the principal minerals, and orthoclase, magnetite, and zircon are subordinate. The micas are pseudoporphyritic, and each tends to form relatively pure bands of uniformly oriented grains. Much of the colorless mica still is sericite, but most of it forms large flakes of muscovite up to 0.4 millimeter in diameter. Chlorite is of two varieties. The more common variety is green and contains rosettes and fine rods of a dark mineral with rather high birefringence, probably rutile. The other variety, regarded by Ross ${ }^{63}$ as an unusual species of chlorite, is yellow and its birefringence is as great as that seen in some of the green chlorite. It is biaxial, but its optical character could not definitely be determined although it seems to be negative. A few crystals have good cleavage and parallel extinction, but the prevailing absence of any observable cleavage is unusual for either mica or chlorite. It usually forms poikilitic grains up to 0.75 millimeter long with many quartz inclusions. It is practically all bordered by a very narrow margin of sericite, into which it appears to grade.

Some of the gabbro and diabase dikes, which were

${ }^{63}$ Ross, C. S., oral communication. 
altered in pre-Cambrian time, show a late development of epidote and clinozoisite superimposed on the earlier alteration products, particularly uralite. The outstanding example is the wide dike northwest of the Sleeper tunnel. This dike is in an area of hornfels and marbleized limestone near the monzonite contact. Its late alteration products, which are similar to those in shale and impure limestone described below, are attributed to emanations that accompanied or followed the latest stages of monzonite intrusion.

\section{ALTERATION OF SHALE}

An impure sandy shale, now metamorphosed into a dark-green hornfels, is found on the west side of the Kelly limestone at the Hardscrabble mine and is believed to represent the base of the Sandia formation. In thin section it is seen to consist essentially of subangular quartz grains with interstitial sericite, which has replaced part of the quartz. Scattered through the rock are large optically continuous areas of chlorite that enclose quartz grains. Andalusite forms a few scattered grains associated with the sericite and chlorite. This rock probably represents the most intense alteration of shale in the district.

Northeast of Oak Spring an impure shaly bed of the lower quartzite about 75 feet east of the contact between monzonite and the quartzite of the Sandia formation is altered to a dark-green mass. A thin section shows this to consist largely of epidote, both as minute grains and as large optically continuous areas enclosing calcite, quartz, and chlorite. Some of the calcite appears fibrous and is probably the hightemperature variety.

A shaly bed at the base of the lower quartzite just southeast of Oak Spring has been altered into a banded shale with green layers typical of this bed near the monzonite. A thin section shows this rock to consist of alternating layers of undeterminable claylike material with an occasional quartz and chlorite grain and irregular blotches of apatite alternating with layers composed of numerous quartz grains embedded in dark bluish-green chlorite with relatively high birefringence. Occasional epidote grains are present. Alteration seems to have been confined to the quartzose layers, which were probably more permeable. The quartz grains themselves may be slightly corroded but in general have not been affected.

\section{ALTERATION OF LIMESTONE}

Marbleization.-White marbleized limestone is mostly confined to a zone within 300 feet of the monzonite contact, but isolated local areas may be found 1,500 feet from the contact. The Kelly limestone, which is predominantly a gray medium- to coarse-grained crystalline limestone throughout the area, has been bleached and thoroughly recrystallized to a marble in a few places next to the contact. Its most intense recrystallization, accompanied by a minor development of silicates, took place in the inclusion in Tertiary (?) granite at the Hardscrabble mine and along the east margin of the monzonite near Oak Spring. Both limestone and shale members of the Sandia formation have been so recrystallized and bleached in the area between Oak Spring and the Sleeper tunnel that the structure and stratigraphy are much obscured. The Madera limestone is marbleized in the vicinity of the Nitt mine and near Hardscrabble Camp.

Sitication.-High-temperature silicate minerals are present at or near the contacts of the marbleized limestones with the Tertiary (?) intrusive stocks. They include wollastonite, diopside, garnet, hedenbergite, tremolite, muscovite, sanidine, titanite, epidote, chlorite, and serpentine. They are mostly found within 500 feet of the exposed contacts, and wollastonite and diopside are probably within 200 feet of them; but striking exceptions are the occurrence of garnet in the Linchburg tunnel and in the Granite Mountain area. In the Linchburg tunnel, about 12,000 feet south of the nearest exposed monzonite contact, garnet (andradite) and hedenbergite are present in association with specularite, magnetite, and sulphides along the main mineralized fault zone. They suggest the presence of a concealed stock of monzonite, or at least a center of mineralization similar to those closely associated with monzonite, at no great depth. The grossularite in the altered limestone east of the Granite Mountain area suggests that the concealed north boundary of the Tertiary. (?) granite stock is nearby.

The Kelly limestone contains more wollastonite, diopside, garnet, and hedenbergite than the other limestones, which for the most part are colored green by epidote and chlorite; but the Madera limestone and the limestone members of the Sandia formation are bleached and partly replaced by silicates east of Oak Spring, near the Nitt mine, and east of Granite Mountain. The more intensive alteration of the Kelly limestone is attributed to its permeability and the scarcity of shaly beds to prevent circulation within it; furthermore, as it was the lowest of the limestones, it was the first to be reached by rising solutions, which were deflected into it by the overlying impervious shales.

The best development and greatest number of silicate minerals in the Kelly limestone has been found near Oak Spring. The thoroughly silicated limestone is white and consists of a very fine grained matrix with specks and streaks of a greenish prismatic mineral cut by thin veinlets of calcite. Its contact with the monzonite is very sharp.

Microscopically the rock consists of an indeterminate dark-gray slightly pleochroic porcelain-like matrix, which encloses specks and areas of wollastonite and greenish diopside. Some garnet (grossularite) and 
occasional flakes of muscovite are also present. A thin section of a specimen taken from the dump near Oak Spring shows tremolite, sanidine, and titanite in addition to those already mentioned. Tremolite is less common than wollastonite and is found in small blades within wollastonite and very probably replacing it. The prevailing purity of the original Kelly limestone implies that the constituents of these silicates, with the exception of calcium, were introduced during metamorphism; but the magnesia and any alumina in them may have been derived from the "silver pipe" beds.

The lower limestone member of the Sandia formation, east and northeast of Oak Spring, also contains areas that are colored green by epidote or fine-grained pyroxene, both of which evidently represent recrystallization of the original rock with little or no addition of material except water.

The Kelly limestone enclosed in Tertiary (?) granite at the Hardscrabble mine contains masses of pure wollastonite. The big caved stope east of the north glory hole is filled with blocks composed of alternating layers of white coarse- and fine-grained sugary wollastonite. The coaser-grained material consists of larger tablets of wollastonite in a calcite matrix.

Near the north end of the Hardscrabble workings, where the marbleized Kelly limestone is in contact with hornfels, a calcareous layer in the hornfels is composed of quartz, garnet (grossularite), and pyrite, with minor quantities of epidote, secondary calcite, and chloritic material. Aggregates of these minerals are interstitial to the quartz grains, which have very irregular interlocking contacts and may represent either introduced silica or original quartz thoroughly recrystallized.

Blocks of silicated limestone enclosed in monzonite close to its contact are exposed on the Nitt 300-foot level. Their positions imply that they belong to the upper part of the Sandia formation or the lower part of the Madera limestone. One of these blocks is now a medium-grained rock composed entirely of granular diopside in a subordinate matrix of recrystallized calcite. Here also the constituents of the silicates, except the magnesia of the diopside, can have been derived from the original rock, although here and elsewhere local transfer of material must be inferred to account for nearly pure masses of such silicates as diopside or epidote.

In the Granite Mountain area rock fragments on two dumps along limestone layers within the upper quartzite member of the Sandia formation contain silicates, which suggest that the concealed north contact of the Tertiary (?) granite stock is nearby. One of these prospects is about 550 feet west and 300 feet north of the southeast corner of sec. 12, T. 2 S., R. 4 $\mathrm{W}$.; the other is about 450 feet farther southwest. The fragments consist of pale-green dense serpentine- chlorite rock banded with black layers of magnetite as much as one-eighth of an inch thick. The serpentine predominates and is intimately intergrown with chlorite. Magnetite is present in large grains and as minute specks in the chlorite and serpentine. Associated with the minute magnetite grains are minute microlites of a transparent highly birefringent mineral resembling diopside. Neither the serpentine nor the chlorite show any evidence of derivation from some other silicate such as diopside.

Fragments of silicate rock either from the lower limestone member of the Sandia formation or from a limestone layer in the shale member are found on a small dump 1,150 feet east of the southwest corner of sec. 7, T. 2 S., R. 3 W. These fragments at first glance resemble a coarse-grained granitic rock, but they consist of intergrown calcite, chlorite, quartz, epidote, garnet (grossularite), and diopside, listed in the order of their abundance. The calcite is bladed and is the high-temperature variety. Chlorite is for the most part interstitial to the bladed calcite, but in places lobes of it penetrate the blades. The lobate structure of the chlorite implies direct deposition from hydrothermal solutions and not derivation from some other silicate. Epidote is mostly associated with the quartz and chlorite, very little being present in the calcite. The few small scattered grains of garnet, which contain small remnants of partly replaced diopside, are most common in the calcite. These relations indicate the deposition first of diopside and then of garnet. Whether the bladed calcite was deposited with or after either of these silicates is not clear. It was followed by the deposition of chlorite, which was presumably formed at the same time as epidote and quartz.

An inclusion of limestone in monzonite about 800 feet northeast of the Graphic mine consists chiefly of calcite and diopside, with some sericitic aggregates and a little garnet. The garnet forms narrow borders surrounding both calcite and diopside grains and partly replacing both.

\section{ALTERATION FAR FROM INTRUSIVE CONTACTS} ALTERATION IN THE NORTHERN AREA

The rock alteration centering around Stendel Ridge and that around Granite Mountain are similar, but they differ from that in the southern part of the district south of Kelly. In the northern area the secondary minerals are epidote, chlorite, and sericite, accompanied by quartz and calcite. Though any one or more of these minerals may predominate locally, none predominates over the entire region. In the southern part of the district these secondary minerals are present in appreciable amounts only in the purple andesite and latite porphyry, and if they once existed in the upper volcanic rocks they were later destroyed 
by the solutions that silicified and hematitized these rocks.

Chlorite is common in the igneous rocks in the northern area and locally in altered shale and impure limestone. It is also a gangue mineral in the pyritic deposits of the Graphic-Waldo mine. In the effusive rocks it is an alteration product of hornblende, biotite, and less commonly augite, and it is enclosed in pseudomorphous rims of hematite. However, some chlorite entirely free from hematite is so irregularly distributed through the ground masses of these rocks that it is evidently a direct precipitate from solution and not a direct alteration product of ferromagnesium minerals. The chlorite is commonly accompanied by epidote, calcite, sericite, and quartz.

Epidote is probably the most abundant of the secondary silicates. It is an alteration product of ferromagnesian minerals and plagioclase of the igneous rocks. It is also widely distributed as veinlets and disseminated grains in the sedimentary rocks. In addition to these obviously secondary modes of occurrence, epidote is a prominent and evidently primary constituent of feldspathic dikes and apophyses related to the Nitt monzonite stock; and it may be inferred that the magmatic solutions that formed these apophyses aided in the formation of epidote in both the igneous and sedimentary rocks nearby.

Epidote is especially abundant in the basal tuff and in the shale member of the Sandia formation on Stendel Ridge, in the thinly bedded sedimentary rocks in the gulch south of the Vindicator shaft, and in the lower latite, lower andesite, and adjacent sedimentary rocks in the Granite Mountain area. It is also abundant in the lamprophyre dikes, some of which owe their greenish color to it. It is only sparingly present as a gangue mineral in ore bodies.

Limestone interbedded with the shales at the east base of Stendel Ridge is in places green with epidote. In the coarse breccia at the base of the overlying latite the fragments of shale, limestone, and quartzite are impregnated and the tuffaceous matrix is largely replaced by epidote. Thin limestone beds alternating with the shale and quartzite beds of the Madera limestone in the gulch just to the south of the Vindicator shaft are partly replaced by epidote, and the green color in some of the shale beds may be due to the presence of epidote and chlorite. Impure limestone at the head of the draw east of the Waldo shaft contains streaks and layers colored green with epidote.

The limestone and calcareous shale beds in the southeastern part of the Granite Mountain area are now so epidotized that the rock is green and is extremely vuggy and "knotty," owing to areas of epidote that stand in relief on weathered surfaces. A thin section of this vuggy rock reveals an intimate intergrowth of epidote and quartz with smaller amounts of calcite and chlorite.
Occasional tufts of sericite have replaced some quartz, and a little magnetite is also present.

The occurrences of epidote in the Stendel Ridge area are so related to the Nitt monzonite stock and its late feldspathic dikes and apophyses that they are most reasonably attributed to solutions that emanated from the stock and moved along the more permeable parts of both sedimentary and volcanic rocks. The relations of epidotized rock to the monzonitic stock of Granite Mountain are not so clear, but a similar interpretation of them is reasonable. The closing stage of stock intrusion, therefore, is regarded as the time when most of the epidote was formed, but minor quantities may have been formed by emanations that accompanied or closely followed any or all of the volcanic eruptions, and the epidote in the lamprophyre dikes, which cut the different varieties of monzonite, was formed at a later time, probably by water concentrated in the lamprophyre magma during its crystallization.

Sericite is most abundantly developed in the white rhyolite dikes and along the late quartz veins, but even in the slightly altered rocks tufts of sericite impregnate the feldspar. Sericite is common in the magnetic rhyolite porphyry on the north end of Stendel Ridge, and locally it is common in the latite tuffs and the tuffs of the banded rhyolite west of Stendel Ridge. The extreme development of sericite in some of the quartz veinlets in the Tertiary (?) granite indicates that the main period of sericitization followed that of stock intrusion. Some quartz veinlets are now represented by a porous mass of quartz with films of sericite. One thin section shows quartz intercrystallized with fluorite and a few zircon grains. Both the quartz and the fluorite are extensively replaced by sericite, which therefore is a comparatively late vein mineral.

Secondary quartz is most conspicuous in veins and in one mass of jasperoid. It also forms irregular grains and clusters in altered igneous rocks throughout the district, but it is far less common in the northern and central parts than in the southern part (p. 53). Much of it is unquestionably a byproduct of the alteration of the primary minerals, but some may also have been introduced by permeating solutions. A thin section of a quartz vein in the Tertiary (?) granite contains abundant fluorite and pyrite, several zircon grains, and a few small allanite grains, all apparently contemporaneous, and sericite, which is interstitial to the quartz and apparently has replaced quartz and fluorite. Quartz forms the walls of the Anchor vein, and barite and fluorite form the middle. In the veins in monzonite and in the ore bodies nearby much of the quartz was deposited with specularite and magnetite and also with the later pyrite, whereas small amounts accompanied and followed the later sulphides. Thus, the evidence as a whole indicates that vein quartz was 
deposited over a long period but mainly before the deposition of ore minerals.

The jasperoid mass, which replaced the basal part of the Kelly limestone 11/2 miles east of Granite Mountain, was also formed before the ore minerals. Its features are similar to those of the extensive jasperoid masses in the southern area, which are described on this page.

Calcite in variable amounts is present in all the formations, though very little has been found in the rhyolites. It is very common in the epidotized rocks, but it is also moderately common in rocks that have no epidote. Some of the much-altered lamprophyre dikes contain veinlets and pseudophenocrysts of calcite, and some of the latite and andesite tuffs also contain rather large quantities. Its general absence from the rhyolites implies that the calcite in general has been derived from such minerals as plagioclase, augite, and hornblende, which characterize the andesites, latites, monzonites, and lamprophyres, and that it belongs to the same stages of alteration as chlorite, epidote, and sericite. The bladed calcite in silicated limestone (p. 102) was deposited during the high-temperature stage of alteration, and the scalenohedral calcite ( $p$. 103) marked the closing stage of ore deposition. In short, the deposition of calcite in one form or another took place throughout the general period of rock alteration and ore deposition.

\section{ALTERATION IN THE SOUTHERN AREA}

The most common processes of alteration in the southern part of the district were silicification of the Kelly limestone and hematitization of the volcanic rocks. Less commonly the hornblende, pyroxene, and biotite in the volcanic rocks were altered to minerals of the montmorillonite-beidellite group and celadonite. Only the purple andesite and latite porphyry were appreciably altered to epidote, chlorite, and sericite. The purple andesite was also extensively altered to calcite, which partly replaced both phenocrysts and groundmass. The sedimentary rocks, other than the Kelly limestone, were not conspicuously altered, but the red Abo sandstone, as well as the red volcanic rocks, has been bleached to light gray along the margins of veins that contain small amounts of sulphides.

Silicification.-Silicification was the most widespread process of alteration in the southern area. It profoundly affected the Kelly limestone and locally the argillite, and its effects are represented to some degree in all the volcanic rocks by irregular areas of chalcedony, bunches of mosaic quartz, and quartz veinlets.

However, the largest amount of quartz in the entire district occurs as light-gray, yellowish, and brownish jasperoid, which has replaced a large part of the Kelly limestone from Tip Top Mountain to the south end of the district ( $\mathrm{pl} .2$ ) and has even replaced the pre-
Cambrian argillite just southeast of the Grand Ledge tunnel. The jasperoid commonly contains lenticular and irregular vugs as much as 5 feet long. The presence of limestone remnants in the jasperoid suggests that at least the largest vugs represent similar remnants that have been removed by the solvent action of ground water or by surface weathering. Some of the smaller vugs, however, are clearly a result of brecciation of the jasperoid. The vugs are mostly parallel to the bedding and are lined with quartz crystals as much as half an inch long-and a quarter of an inch thick. In places the uppermost, platy layers of Kelly limestone have been replaced by thin bands of jasperoid separated by crystal-lined openings that represent original bedding planes (see pl. 28, A).

Silicification evidently took place in two stages, which were separated by a period of shattering. These are indicated in places by the brecciated jasperoid ( $\mathrm{pl}$. $28, B$ ) and its recementation by clean, white, vuggy quartz aggregates, which are in marked contrast with the gray, yellowish, or brownish jasperoid. Some small veins and vugs in the jasperoid, especially along or near mineralized faults, contain quartz and barite with small amounts of sulphides or their oxidation products. These veins, which fill distinct fractures in the jasperoid, are identical in mineral composition and structural relations with ore bodies that have been worked in the vicinity and prove that the extensive replacement by jasperoid preceded that stage of ore deposition.

The boundaries between the limestone and jasperoid are sharp, like those in the Black Hills, South Dakota, ${ }^{64}$ and the Tintic, ${ }^{65}$ Stockton, and Fairfield districts, ${ }^{66}$ Utah, and field evidence therefore suggests the same explanation - that silification advanced as a wave from fissures of access, replacing all the rock as it progressed and maintaining an abrupt contact until the impulse was exhausted; but thin sections show that, in some places at least, well-formed quartz crystals grew in advance of the main mass of jasperoid (see p. 101).

In a few places, particularly along minor faults, both the lower and upper parts of the Kelly limestone have been thoroughly replaced, whereas the intervening "silver-pipe" bed has been only slightly affected; but only the uppermost thin platy beds have been replaced throughout the jasperoid area. As the relatively impervious limestones of Sandia and Madera formations, however, have escaped appreciable silicification, even along faults, it is concluded that the solutions depositing the jasperoid rose along premineral fissures until

${ }^{6}$ Irving, J. D., Replacement ore bodies; their characteristics and the criteria by means of which they may be recognized: Econ. Geology, vol. 6 , pp. $556-558,1911$.

${ }^{65}$ Lindgren, Waldemar, and Loughlin, G. F., The geology and ore deposits of the Tintic mining district, Utah: U. S. Geol. Survey Prof. Paper 107, pp. 154-158, 1919.

68 Gilluly, James, Geology and ore deposits of the Stockton and Fairfield quadrangles, Utah: U. S. Geol. Survey Prof. Paper 173, p. 98, 1932. 
they reached the shale at the base of the Sandia formation; they were then deflected along bedding planes and other openings in the Kelly limestone, particularly its uppermost beds, and replaced it with jasperoid.

The maximum degree of silicification, in argillite as well as limestone, is along the Grand Ledge fault zone. It is therefore concluded that this fault zone was the main conduit along which the silicifying solutions rose, and that bedding planes and transverse and longitudinal faults nearby served as branch conduits that permitted permeation of the limestone throughout the southern area. As the same fault zones later served as conduits for the solutions that deposited sulphides, the silicifying solutions were closely related in time with those that formed the silicates hedenbergite and andradite along the main conduits; furthermore, as the silicified rocks are far from any recognized centers of high-temperature mineralization, it may be inferred that the solutions that formed them had traveled so far through underlying siliceous rocks that, by the time they reached the limestone, they had cooled below the temperature at which the silicates could form. In short, the silicified limestone is the equivalent of silicated limestone, but farther from the sources of mineralization.

Although silicification in the volcanic rocks is much less intensive than in the Kelly limestone, it is rather widespread. It is most conspicuous in the red andesite and upper andesite. The scoriaceous parts of the red andesite contain vugs lined with chalcedony and centrally filled with calcite. The upper andesite contains many geodes of chalcedony, and its weathered surface also is strewn with many residual fragments of the geodes. The largest geodes have replaced the reddish groundmass. The red rhyolite has a rather glassy luster, caused by the silicification of its groundmass, and is crisscrossed by many white quartz veinlets. The more porous layers in the banded and the pink rhyolites contain small openings partly or completely filled with quartz. The other volcanic rocks of the area, as shown by thin sections, have been only slightly silicified.

The process of silicification is most conveniently considered with that of hematitization, which follows.

Hematitization.-The most striking product of alteration in the volcanic rocks of the southern area is hematite, which has given red, pink, and purple colors to all varieties except the relatively impermeable vitrophyre at the top of the upper andesite.

The hematite in the redder rocks is of two varieties. When examined under the binocular microscope in reflected light, hematite in the resorbed phenoerysts is bluish-black and appears granular to micaceous. This variety is evidently specular hematite and is probably a high-temperature product of resorption. The other variety, which is exceedingly fine grained and is scat- tered through the groundmass, is red in reflected light and accounts for the reddish color of the rocks.

The finely divided hematite in the reddish rocks for the most part represents complete oxidation and in part redistribution of the original iron content, although some of it may represent iron that was introduced. Most of the red andesites probably had sufficient iron originally to account for their present content of hematite, but at least part of the hematite in the banded rhyolite was evidently introduced from another source. In the central area and west of Granite Mountain, for example, the banded rhyolite is pale gray and thin sections of it show insufficient iron oxide or ferromagnesian material to account for all the hematite that the same rock contains in the southern area. The excess may have been derived from the andesites.

Although some hematitization may have been effected by gases and liquids that escaped from each flow as it solidified, as is believed to have happened in the upper part of flows in the Michigan copper country ${ }^{67}$ and in some flows in south-central Oregon, ${ }^{68}$ hematitization at Magdalena has taken place throughout entire flows and in such great degree that any hematite formed during the different eruptions has evidently been supplemented by deposition from solutions that permeated all the flows subsequent to eruption.

The coextensiveness of both red hematite and chalcedony strongly indicates that both were formed by solutions from the same general source. The fact that the red groundmass of the upper andesite has been replaced by chalcedony geodes shows that concentration of silica into geodes took place after hematitization, although silicification and hematitization of the groundmass as a whole, as in the red rhyolite, may have been parts of one general process. Gruner's experiments ${ }^{69}$ show that magnetite and presumably ferrous silicates can be oxidized by steam at a temperature as low as $200^{\circ} \mathrm{C}$. and that oxidation is accelerated by the addition of a small amount of hydrochloric acid.

Similar results can be produced by the presence of small amounts of sulphuric acid, as shown by Day and Allen, ${ }^{70}$ and by Burbank, ${ }^{71}$ who has applied the findings of Day and Allen to the altered rocks of the Bonanza district, Colorado. The degree of this kind

or Butler, B. S., and Burbank, W. S., The copper deposits of Michigan : U. S. Geol. Survey Prof. Paper 144, pp. 34-45, 1929.

68 Fuller, R. E., The mode or origin of the color of certain varicolored obsidians: Jour. Geology, vol. 35, pp. 570-573, 1927.

${ }^{69}$ Gruner, J. W., Hydrothermal oxidation and leaching experiments ; their bearing on the origin of Lake Superior hematite-limonite ores: Econ. Geology, vol. 25, pp. 697-717 and 837-867, 1930.

${ }^{70}$ Day, A. L., and Allen, E. T., The volcanic activity and hot springs of Lassen Peak: Carnegie Inst. Washington Pub. 360, pp. 113, 140-145, 1925. Allen, E. T., and Day, A. L., Steam wells and other thermal activity at "The Geysers," California : Carnegie Inst. Washington Pub. 378 , pp. $45-50,1927$.

Burbank, W. S., Geology and ore deposits of the Bonanza mining district, Colorado: U. S. Geol. Survey Prof. Paper 169, pp. 80-85, 1932. 
of alteration at Magdalena is less than at Bonanza, where the reddened rocks were much silicified and the greatest amount of alteration was more clearly associated with mineralized fissures.

It may be inferred, however, that volcanic exhalations, which commonly consist mainly of steam with some hydrochloric acid, hydrogen sulphide, or sulphuric acid and carbon dioxide, produced both silicification and hematitization in the southern part of the district; furthermore, that during the process the silica tended to move into cracks and other openings, forming veins and geodes and replacing small amounts of the adjacent rock. It is also conceivable that small quantities of silica were introduced after hematitization. As the reddened volcanic rocks have been bleached along the margins of quartz-sulphide veins, hematitization must have preceded ore deposition and therefore may have taken place at the same general time as silicification in the limestone. If both processes are attributed to the same solution, the solution must have been largely depleted of silica before it permeated the volcanic rocks.

Alteration to clay minerals and celadonite.-The origin of two more alteration products in the upper and red andesites and the red rhyolite deserve attention. These are the fibrous mineral of the montmorillonite-beidellite series and celadonite.

The montmorillonite-beidellite partly to completely replaces hypersthene and is also found in plagioclase phenocrysts as blotches not related to cleavage cracks. Its most common variety is pale green. But another variety, which is coffee brown though like the green variety in its other properties, in places grades into the green variety, suggesting that both are of the same group and suggesting also that the green variety may have a higher content of the nontronite molecule. ${ }^{72}$

Hypersthene in the upper vitrophyric part of the upper andesite is partly replaced by a mineral that has a distinct bright-green to yellowish-green pleochroism and appears to be optically identical with celadonite. ${ }^{73}$ Augite and biotite in the same rock are unaltered. The smaller hypersthene phenocrysts are completely replaced by the celadonite, but the larger ones are replaced by it only along transverse cleavage cracks whereas their remainders now consist of a brownish isotropic substance or a brown fibrous material of very low birefringence. The celadonite also forms narrow borders around chalcedony and calcite grains and forms wormlike traces in the red and upper andesites (pl. 12, A). These relations show it to be of late origin and apparently contemporaneous with

\footnotetext{
72 Ross, C. S., and Kerr, P. F., The clay minerals and their identity Jour. Sed. Petrology, vol. 1, No. 1, p. 58, 1931

${ }^{73}$ Von Gümbel, C. W., Ueber die Grünerde vom Monte Baldo : K. bayer. Akad. Wiss. Sitzungsber., vol. 26, p. 548, 1896. Clarke, F. W., The data of geochemistry : U. S. Geol. Survey Bull. 770, pp. 520-521, 1924. Ross, C. S., The optical properties and chemical composition of glauconite : U. S. Nat Mus. Proc., vol. 69, Art, 2, p. 15, 1926.
}

the silicification and calcitization or even later.

Neither the origin of the montmorillonite-beidellite minerals nor that of the celadonite is clear. Both minerals are usually regarded as products of normal surface alteration, but, as the groundmass of the host rock shows none of the usual signs of general alteration or weathering, they are believed to have been deposited by hot solutions. Although it has been impossible to separate these alteration products cleanly for chemical analysis the recorded compositions of montmorillonite, beidellite, and celadonite suggest that the less stable minerals of the andesite were attacked by water containing potash, which could react with hypersthene and form celadonite and the potash-magnesia-bearing type of montmorillonite and could convert plagioclase also into montmorillonite. That these products were formed instead of sericite and chlorite implies that alteration took place close to the surface at moderately low temperature.

\section{STRUCTURE}

\section{SUMIMARY OF DEFORMATION}

The outstanding structural features of the district are the faulted homoclinal masses that constitute the mapped part of the Magdalena Range and the Granite Mountain area. Their development, as shown by local evidence, has been rather complex, and as the forces involved must have been active throughout a large region, interpretation of them should be based on detailed studies at several places; but such detailed studies outside of the Magdalena district have been few, and in much of the region structural features are so thoroughly concealed that any interpretation must be partly conjectural. Structural features will be considered in chronologic order, and conclusions regarding processes of deformation and their practical significance will be drawn with full realization that they have still to be subjected to regional correlation.

A general summary of the major events of deformation will first be given. Descriptions of local structural features will then be given, and they will be followed by an interpretation of the Laramide and later deformation that produced the principal structural features of the district. Plates 2, 4, and 20 will be found useful in following the discussion.

Pre-Cambrian deformation included the tilting or isoclinal folding of the argillite and successive intrusions of gabbro, felsite, granite, and diabase dikes. Many minor fractures in the pre-Cambrian rocks do not continue into the overlying Kelly limestone, thus suggesting that they are of pre-Cambrian age; but the only pre-Cambrian fractures that can be recognized with any assurance are those that contain pre-Cambrian dikes and veins. Insofar as fractures in the pre-Cambrian coincide with those in younger formations they may be younger than the pre-Cambrian, or the pre- 
Cambrian structure may have influenced fracturing of the younger rocks.

Structural features formed in Paleozoic time are not conspicuous. They include only local minor folds and minor erosional unconformities within the Sandia formation and between the Madera limestone and $\mathrm{Abo}$ sandstone. Their influence on present structure, if any, is slight. As no Mesozoic formations are present within the district, no record of deformation during this era is available.

During the Laramide revolution, when folding and overthrusting were taking place in the surrounding region, the sedimentary and underlying pre-Cambrian rocks were subjected to easterly compression, which produced a gentle flexure and some minor reverse and bedding faults, initiated major longitudinal and transverse faults, and elevated and tilted the whole district represented by the main Magdalena Range and Granite Mountain. After this compressive movement subsided, the uplifted mass was subjected to the first stage of gravitative adjustment, during which the first major movement occurred along the east-dipping faults. The sliding of blocks along these faults involved additional westerly tilting. Where movement along them was rapid, subsidiary faults with nearly vertical dips were formed; and the blocks between them and the related east-dipping faults sank below the surrounding blocks. The adjustment also involved movements along major transverse faults. During and after this early period of deformation the country was subjected to erosion, the tilted formations were beveled, and the surface was reduced to one of low relief.

The first period of volcanic eruptions, represented by the latites, lower andesites, banded rhyolite, and red andesite, followed; and lavas and tuffs unconformably covered the sedimentary rocks.

The major stage of tilting followed, and the Magdalena Range was evidently uplifted and tilted westward, presumably along a profound longitudinal fault east of the area mapped. Tilting was presumably accompanied or closely followed by collapse along east-dipping faults. Great slabs settled eastward and became still more steeply tilted along the east-dipping faults within the range. The rocks of the second volcanic period, represented mainly by the upper andesite and pink rhyolite, were deposited unconformably on the older voleanic rocks. The second volcanic period ended with the intrusion of rhyolite porphyry.

The principal stage of vertical faulting followed the second volcanic period and probably intensified some of the earlier movements. Tilting, however, was slight during this stage of deformation. It was accompanied by production or further depression of local downfaulted blocks. Downfaulting also took place between favorably situated transverse faults. By far the greatest amount of downfaulting involved the western part of the present Magdalena Range and the valley west of it.

The intrusion of the monzonite and granite stocks that followed took advantage of fault intersections, particularly along the margins of the great downfaulted area. Subsequent movement was small. Soon after emplacement of the stocks, settling of the major fault blocks locally reopened the faults along their margins and opened fissures or minor faults within them, which permitted the intrusion of lamprophyre dikes. Somewhat later, further adjustment was accompanied by movement along bedding planes, which locally offset the lamprophyre dikes. The white rhyolite dikes were intruded after those of lamprophyre, but their relations to these bedding faults have not been determined. Still further adjustments, particularly along the vertical fault zones that border the greatest depressed areas and along subsidiary oblique and transverse faults, gave access to ore-forming solutions.

Faulting again took place after ore deposition. This latest stage of faulting, expressed by at least one fault scarp along the northeast base of the range, involved only trivial movements and caused the fracturing and slickensiding of ore deposits within the district. The dominant geologic process since ore deposition has been erosion, which will be considered on pages $73-75$.

\section{PRE-CAMBRIAN STRUCTURE}

The deformation in pre-Cambrian time was conveniently considered in the descriptions of the preCambrian formations. It involved the tilting or close folding of the argillite, the intrusion of gabbro and felsite, the subsequent intrusion of granite whose upper surface was about normal to the dip of the argillite, the fissuring of the granite and older rocks, the intrusion of diabase dikes, and the erosion to a surface of low relief. The pre-Cambrian rocks are much fractured, but the only fractures that can be assigned to pre-Cambrian deformation with any assurance are those filled by pre-Cambrian dikes and by veinlets of minerals attributed to deposition at the close of preCambrian igneous activity. To what extent pre-Cambrian structure may have influenced later deformation is not clear.

\section{PALEOZOIC AND MESOZOIC STRUCTURE}

Structural features formed in Paleozoic and Mesozoic time are not conspicuous and have been conveniently considered in the description of sedimentary rocks. They include minor unconformities in the Sandia formation, which are largely results of sedimentation, although a little deformation may also have been involved. The unconformity between the Madera limestone and the Abo sandstone more clearly indicates some deformation, which is also suggested 
by the fact that local minor folds or undulations shown in the Madera limestone south of Chihuahua Gulch are not represented in the Abo sandstone close by. These folds, however, are too local to be satisfactorily interpreted, as any development of them prior to deposition of the Abo sandstone may have been modified. by subsequent warping and faulting. The lower Sandia beds in the long, slightly downthrown block near the southeast corner of the district suggest a minor anticline with a southerly pitch, but whether this deformation was earlier or later than the deposition of the Abo sandstone is not known.

As no Mesozoic formations have been found within the district, there is no record of deformation since the deposition of the Abo sandstone and before the great Laramide upheaval that marked the transition from Mesozoic to Cenozoic time. Any minor movements, like those cited in the preceding paragraph, may have contributed slightly to the present structure, but their effects have been completely masked by later tilting, faulting, and local crumpling.

\section{LARAMIDE AND TERTIARY STRUCTURE}

The principal structural features of the district are referred to Laramide and Tertiary time, during which deformation took place on a large scale throughout the West; but inability to determine precisely the age of any of the post-Permian formations prevents the assignment of local deformation to any definite period. The most conspicuous structural features are the homoclinal fault blocks that compose the Magdalena Range, shown by the discordant relations of the formations; but the distribution and trends of the sedimentary rocks and the unconformities that separate them from the volcanic rocks indicate that some doming or folding preceded the principal stages of faulting.

\section{FOLDS}

No clearly defined folds are present within the district, and minor undulations that have been noted may have been formed in Paleozaic rather than Laramide time (p. 56); but the entire district may represent part of a major fold.

Volcanic rocks rest upon Abo sandstone south of Kelly, but farther north along the east base of Stendel Ridge they rest upon the Sandia formation. The base of the volcanic rocks in the intervening area has been concealed by faulting, but, as the Madera limestone is present there, it is evident that the volcanic rocks overlapped northward on a beveled erosion surface and that more prevolcanic erosion had taken place at Stendel Ridge than farther south. In the Granite Mountain area the basal volcanic rocks overlap southward from Madera limestone onto the Sandia formation, and prevolcanic erosion must have been greater in the southern part than in the northern part of that area.
These differences in the amount of erosion, together with the general strike of the sedimentary rocks, which changes from about $\mathrm{N} .15^{\circ} \mathrm{W}$. in the main range to N. $30^{\circ}$ E. in the Granite Mountain area, indicate that the rocks had been arched or bowed and that the central part of the bow had been beveled by erosion in prevolcanic time.

This arch has been obscured by faulting, by erosion of the sedimentary rocks from the eastern part of the district, and by a cover of volcanic formations and alluvial deposits, which have concealed the sedimentary rocks in much of the western and northern parts of the district.

Farther northeast two of the three small outcrops in the arroyo just south of La Jenze Creek, near the northeast corner of the district, strike eastward and dip northward. This strike and dip show a marked increase in the curvature of the formations and suggest that the northern end of the Granite Mountain area is the northward plunging nose of an anticline; but the relations of these outcrops to one another and to those in the main Granite Mountain area, evidently because of faulting, are too discordant to be used as a reliable basis for the interpretation of structure. In fact, the prevolcanic structure here is even more obscure than in the district as a whole. In spite of this obscurity, however, the available local evidence, together with our knowledge of the surrounding region, is in keeping with the suggestion that the prevolcanic rocks were arched into an elongated dome or anticline of northerly trend, only the westerly, bow-shaped limb of which is within the area mapped. Similar anticlines are present in many parts of the State and are typified by the Sandia Mountains. ${ }^{74}$ The positions and attitudes of certain local faults, to be described later, suggest that these faults were produced by the same forces that produced the folds, although later recurrent movements have taken place along some of them.

\section{FAULTS}

Faults of moderate to vertical dip that crosscut sedimentary and adjacent igneous rocks are shown on plates 2 and 20. Most of these are normal faults, but some are reverse. There are also many faults along the bedding and at least a few reverse faults with moderate dips that are difficult to recognize except in mine workings. The crosscutting faults form two main groups-longitudial faults with northerly trends and transverse faults with northeasterly to easterly and exceptionally southeasterly trends. Each group is divisible into two subgroups, which dip in different directions. There are doubtless many representatives of each subgroup within the more extensive igneous formations, especially the volcanic rocks, but only those actually recognized are shown on plate 2 . The few

\footnotetext{
${ }_{74}$ Darton, N. H., Tectonics of Arizona and New Mexico [abstract] :
} Geol. Soc. America Bull., vol. 39, p. 182, 1928. 
reverse faults that are definitely known have dip slips of only 50 or 60 feet and may be related to certain bedding faults whose attitudes suggest a reverse movement. The bedding faults, where recognized, however, afford little or no opportunity to appreciate the amount of displacement along them, except in those mine workings where they have offset dikes, and there the movement has been normal. In some places, however, they have exerted an appreciable control over ore deposition. The relations of the different groups are such that it is best to base descriptions primarily on areas and secondarily on groups of faults. Certain major and minor faults and fault blocks are conveniently referred to by appropriate names.

\section{FAULTS SOUTH OF THE NITT STOCK}

The longitudinal faults south of the Nitt stock comprise two sets, one dipping eastward at moderate angles and the other dipping vertically or very steeply to the west or east. As a whole they lie mainly in a broad zone that appears to diverge northward from an area south of the district; the apparent divergence in trend is partly caused by the angles at which faults with moderate dips meet the sloping surface and partly by the widening belt of sedimentary formations, in which faults are more easily recognized than in the volcanic formations.

The transverse faults also comprise two sets, one dipping southward and the other northward. The largest of them lie west of the diverging zone of longitudinal faults, but a conspicuous group has been mapped on the southwest slope of Tip Top Mountain within the most divergent part of the longitudinal zone. Others of small to considerable extent lie east of the longitudinal zone and within it.

Some of the minor transverse faults end against longitudinal faults and are so related to curves in the longitudinal faults as to be attributed to local strains induced by movement along them. ${ }^{75}$ Some longitudinal faults, however, regardless of their dips, terminate against transverse faults or are interrupted by them. A study of the faults as a whole forces the conclusion that they were formed chiefly in three well-defined stages before the intrusion of the stocks. East-dipping longitudinal faults dominated in certain places, steeply dipping or vertical faults in others, and transverse faults in still others. At a few places, particularly near the southern contact of the Nitt stock, longitudinal faults appear to be offset by transverse faults. This suggests a later, relatively local disturbance during which movement along the transverse faults dominated. As the movement in general involved adjustments of the different major and minor blocks, the amount of slip along any major fault commonly

${ }^{75}$ Lasky, S. G., Transverse fractures as coordinate structures : Am. Jour. Sci., 5th ser., vol. 19, pp. 451-462, 1930. changed at intersection with other major or minor faults. The movements were dominantly down the dips of the faults, but movement down moderately dipping faults involved an appreciable amount of movement along the strike of relatively transverse faults.

EAST-DIPPING LONGITUDINAL FAULTS

The east-dipping longitudinal faults or fault zones form a group with an imperfect steplike or en echelon arrangement, which is obscured by terminations against major transverse faults. The three members of thic group that are most clearly defined on plates 2 and 20 are the Germany, Stonewall, and Crest fault zones. West of the Germany fault zone are other east-dipping faults, identified only in mine workings, whose positions accord with the steplike arrangement insofar as they are exposed, but they may have been formed wholly or in part during later disturbances than those that formed the well-defined zones. North of the Nitt stock the Stendel fault, which has been partly obliterated by the monzonite intrusion and is partly concealed beneath alluvium, evidently dips eastward also and may conform to this steplike arrangement.

Germany fault zone.-The Germany fault zone includes the Germany fault and its branches and a group of faults that is approximately in line with it as far north as Oak Spring. These faults collectively form a zone whose members are connected by transverse faults and show a marked downthrow to the east. The connection, however, is locally obscured by vertical longitudinal faults with downthrow to the west.

The Germany fault itself, which is cut by the lower Germany tunnel, is the most conspicuous of the major faults that dip eastward at moderate angles. It forms the east boundary of the relatively uplifted block of pre-Cambrian rocks east of Kelly, and the easterly dip along most of its course is clearly expressed by its outcrop on the sloping surface. The dip in the lower Germany tunnel is $40^{\circ} \mathrm{E}$. Its maximum amount of displacement is along its southernmost part just north of Chihuahua Gulch, where the Madera limestone lies opposite pre-Cambrian argillite. The fault, however, ends abruptly against a concealed transverse fault at Chihuahua Gulch. Only a minor fault with downthrow on the west lies along the southward projected course of the Germany fault.

North of Chihuahua Gulch the amount of displacement along the Germany fault decreases progressively at intersections with minor transverse faults. At the Germany mine, where a local minimum of displacement is shown, the strike of the fault changes from north to north-northwest, but the amount of change is exaggerated by the topography. At Kelly Gulch the fault branches into a diverging group of step faults, but near the Grand Tower mine, between the main fault 
and its nearest branch, local dropiping of a block within a network of minor faults has brought Madera limestone opposite Kelly limestone. A little farther north the downthrow is small, and beyond the junction with a short cross fault, at the Tip Top road, the true Germany fault cannot be recognized. The fault directly in line with it, and therefore likely to be regarded at first as a part of it, is one of the vertical or steeply dipping set. It forms the east boundary of a downfaulted block in which the actual continuation of the Germany fault may be concealed.

About 800 feet to the northwest, however, the Madera limestone forms the east wall of a fault that separates Madera from the lower part of the Sandia formation. This fault, where cut by the Mitchell tunnel, dips $32^{\circ}$ E. and records a marked drop to the east corresponding to that along the Germany fault. It ends abruptly, both to the south and the north, against major transverse faults, but an equivalent fault to the northeast, interrupted by transverse faults; separates Sandia and Madera beds from argillite. Minor branches of it extend northward into the argillite, but the outcrop of the main fault curves rather sharply down the slope to the Sleeper tunnel, near which it shifts to the east along another transverse fault and continues to a point northeast of Oak Spring. From there northward it rapidly diminishes and becomes lost in the large area of felsite.

A major branch of the Germany fault, named the Sampson fault, extends northward through the Grand Tower and Sampson claims. Opposite the intersection of the Germany fault with the Tip Top road, where the throw along the Germany fault is negligible, the throw along the Sampson fault increases markedly at its junction with a transverse fault. North of the Sampson claim the Sampson fault curves westward and is concealed beneath a considerable area of debris. It may follow the lower quartzite member of the Sandia formation down the slope, or it may trend northward and merge into a transverse northward-dipping fault that is obscured by the debris-covered surface but that extends northwestward down the slope for 1,000 feet and joins the northerly continuation of the Germany fault. Both suggestions are indicated on plate 2.

Stonewall fault zone.-The Stonewall fault zone includes the Stonewall and South Stonewall faults and associated transverse faults, two of which connect the zone with the Germany fault zone. It roughly parallels the main Germany fault but is obscured where it changes from a northeasterly to a northwesterly course. Displacement along it is much less than along the Germany fault. The South Stonewall fault dies out southward near the Mistletoe mine and half a mile southeast of the south end of the Germany fault. From its south end it trends north-northeastward nearly to the crest of the range, and its dip slip gradually attains a maximum of 150 feet or more where the lower quartzite of the Sandia formation is faulted against pre-Cambrian granite. This displacement is abruptly increased between two rather closely spaced transverse faults that cross the crest of the range and enclose a small downfaulted block. Beyond this small block the fault has been obscured by the removal of the sedimentary rocks, but it may coincide in part with the steep upper east slope of the Magdalena Range, and it may also have been shifted eastward along one of the transverse faults, as shown on plates 2 and 20. The Stonewall fault begins about 800 feet farther north, at another cross fault. A little farther on it is joined without deflection by a south-dipping cross fault that trends southwestward down the west slope and either joins another east-dipping longitudinal fault or curves into a longitudinal position. This longitudinal fault ends against one of the transverse members of the Germany zone and forms a connecting link between the Germany and Stonewall zones.

The Stonewall fault zone, which decreases abruptly in dip slip beyond its junctions with the transverse faults on its east side, curves to a northerly course, as shown by its exposure in the Stonewall workings. There its dip is $45^{\circ} \mathrm{E}$. and its dip slip is no more than 100 feet, but the only accessible place in the district where enriched gold ore has been mined is in a winze along a minor member of this fault zone. Beyond the next transverse fault the dip slip increases to about 350 feet, and a little farther north the Stonewall fault becomes lost in the transverse fault zone of Tip Top Mountain. This transverse zone has a north downthrow and may extend westward to the junction of the Sampson fault with the northern part of the Germany fault zone, but it has not been traced throughout this distance because of vegetation, debris covering, and the absence of distinctive beds in the Madera limestone.

Crest fault.- The Crest fault extends along the crest of the range for nearly 4,000 feet, east of the Black Cloud and Mistletoe mines, and its northern continuation has been traced along the east slope for nearly a mile, to a point where it passes beyond the east boundary of the area mapped. The Crest fault, like the South Stonewall fault, dies out southward, but at a place about 1,500 feet farther southeast. The south ends of these two faults and the Germany fault lie almost in a straight line that trends N. $45^{\circ} \mathrm{W}$.

The dip of the Crest fault, as shown by the peculiar abrupt bend in its course east of the Mistletoe mine, is about $25^{\circ} \mathrm{E}$., and the footwall of the fault coincides with the present east-sloping granite surface. The dip slip, which is very small to the south of the bend, is abruptly increased to 450 feet or more at the transverse fault just to the north. It diminishes considerably at the second transverse fault, increases again to about 
650 feet at the fourth, and increases about 150 feet more at the fifth fault. Between the last two of these faults the crest of the range turns slightly westward, and the gently dipping Crest fault extends northeastward down the east slope. Displaced diabase dikes along its northernmost part indicate dip slips of 150 feet or more. The Crest fault is flanked on the east by several short east-dipping faults that end against the transverse faults.

Other east-dipping faults.-Besides the three major fault zones described above, there are many other eastdipping faults of small to moderate size that have escaped detection on the surface but are shown by different mine crosscuts. Level 10 of the Kelly mine (fig. 15) shows four between the Traylor shaft and the Waldo fault within a distance of 1,100 feet; and higher workings between the Traylor shaft and the KellyGraphic fault show four more. These faults, all within the Kelly fault block, have downthrows to the east and evidently end northward against the Kelly-Graphic cross fault, whose throw, accordingly, diminishes westward and becomes small or negligible before the Waldo fault is reached. The larger of these east-dipping faults may have originated at the same time as the major east-dipping faults, but some of them at least appear to be local and to have been formed by adjustment of the Kelly fault block along the major faults that bound it. Similar east-dipping faults are exposed in the Graphic-Waldo mine (pls. 31 and 32) and others in the Mistletoe and Linchburg tunnels (fig. 18). They are normal faults, with few exceptions to be considered presently, and although they are of premineral origin, very little ore has been found along them; however, the main ore body of the Grapic-Waldo mine lies along one of them, called the "roll" fault, which was evidently formed by adjustments within the Graphic block. These adjustments will be considered later.

The distribution of the three major zones of eastdipping faults in the main range justifies the opinion that there may be other faults of similar size, but less readily recognized or traced, farther east in the granite area. Interpretation of the structure must, therefore, be based on very incomplete evidence. Bryan ${ }^{76}$ reports a fault scarp along the east base of the Magdalena Range, presumably with easterly dip, where rather recent uplift has taken place; but no noteworthy movement since ore deposition has been noted along any of the eastward-dipping faults within the Magdalena district.

VERTICAL OR STEEPLY DIPPING LONGITUDINAL FAULTS

Kelly-Graphic fault.-The Kelly-Graphic fault, which forms the approximate east limit of explored ground in the Kelly and Graphic-Waldo mines, is the

\footnotetext{
76 Bryan, Kirk, oral information, 1933.
}

most familiar of any of the faults in the district. It belongs to a steplike and branching group of faults in a zone that extends southward beyond the south end of the district and coincides with the main ore zone. Mineralized faults throughout this zone have been referred to by some as the Kelly-Graphic fault, but structural relations are such that it is more consistent to restrict that name to the fault that forms the east wall of the Kelly and Juanita ore bodies and to apply local names to the other faults of the zone. The zone as a whole, however, is conveniently designated the Kelly-Graphic fault zone, after the two largest mines along it. It coincides with the main ore zone of the district.

The Kelly-Graphic fault has an average strike of N. $20^{\circ} \mathrm{W}$., and its dip where exposed ranges from vertical to $80^{\circ} \mathrm{E}$. Its northernmost part curves to a northerly course and even branches to the northnortheast, but because of the scarcity of mine workings here its relations to other faults are obscure. At the Tip Top road it joins a short transverse fault that forms the south boundary of a downfaulted block and connects with the Germany fault. This transverse fault evidently marks an abrupt easterly deflection of movement, which resumed its northward course along the fault with west downthrow that is in line with the Germany fault and is exposed underground near the breast of the Mitchell tunnel. If the Kelly-Graphic fault continues northward without deflection beyond the transverse fault it is lost in the shale member of the Sandia formation. Beyond the shale and in line with the Kelly-Graphic fault there is a fault that separates Madera limestone from the lower limestone member of the Sandia formation, but it has a much greater throw than the Kelly-Graphic fault and ends to both the north and the south against transverse faults.

In the Kelly mine the Kelly-Graphic fault is flanked on the west by two nearly parallel faults that dip steeply west. The longer of these, called the Brown fault, and the Kelly-Graphic fault converge southward; but the Brown fault practically-ends against a transverse fault that is concealed by alluvium. It also curves to a northerly course, along which mine development has been discouraging, and becomes lost in shale. Movement along it may have been absorbed by the flexible shale; if not, the Brown fault ends against the major transverse fault known as the Kelly-Graphic cross fault. Beyond this the east-dipping fault cut by the Mitchell tunnel and regarded as a part of the Germany fault zone is approximately in line with the Brown fault.

- The Kelly-Graphic and Brown faults as seen underground are connected by a few minor transverse faults or fissures that have aided in the thorough replacement of limestone by the ore in the Kelly mine. These do 
not appear in plates 2 or 20 but are shown on the map of the Kelly mine (pl. 36). Another minor fault, almost in line with the Brown fault, is exposed to the south in the Juanita tunnel but has escaped notice on the surface, where both of its walls are quartzite. It also is connected with the main Kelley-Graphic fault by mineralized cross faults, one of which has brought the Kelly limestone to the surface along its south wall. Farther south two other transverse faults, but with downthrow to the south, extend westward from the Kelly-Graphic fault, whose throw is accordingly increased.

South of these faults-well-shown in the South Juanita mine but not so well-shown on the surfacethe Kelly-Graphic fault curves to a more southeasterly course and evidently abuts against the Germany fault.

Mistletoe fault.-South of Chihuahua Gulch the principal fault of the Kelly-Graphic or main ore zone is cut near the face of the Mistletoe tunnel and is therefore called the Mistletoe fault. The westerly dip of this fault is shown by its curving course down the slopes of Chihuahua Gulch. North of the gulch it is somewhat obscured because both of its walls are in the quartzite members of the Sandia formation, and beyond its junction with a cross fault of northeast trend it is entirely within the lower quartzite member. The principal amount of downthrow shifts to the cross fault that extends westward from the Mistletoe fault to the Germany fault. In short, the downthrown ground just north of Chihuahua Gulch forms a reentrant angle bounded by the Germany fault, the cross fault of northeast trend, and the Mistletoe fault.

A little south of Chihuahua Gulch the downthrow along the Mistletoe fault is lessened as much as 150 feet by uplift along the south side of a short cross fault if the quartzite exposed at the junction of the two faults marks the top of the Sadia formation; but the exact stratigraphic position of the quartzite has not been proved. Farther south the fault splits into three parts along which the western downthrow is about equally distributed. The western fork, which most nearly maintains the course of the fault, is flanked on the west by southward converging faults that recall the Brown fault in the Kelly mine. It is apparently offset by a transverse fault, south of which its downthrow is so increased that purple andesite lies against Madera limestone. Farther south, just east of the Linchburg tunnel, the principal displacement is shifted eastward along two short cross faults to a spur of the middle fork, but the southerly continuation of the west fork is in part represented by a fault in steplike relation that extends beyond the south boundary of the district. The continuation is somewhat obscured because the northern part of this fault consists of two members that enclose an uplifted wedge-shaped block.

The middle fork of the fault is partly concealed by landslide material, beneath which it may be deflected by concealed cross faults; but it also has a markedly curved course. South of the junction of its spur with the two short cross faults mentioned above it is concealed by more landslide material, beneath which it either curves sharply eastward or is deflected by a concealed cross fault. It reappears for a short distance south of the landslide, where it separates andesite from latite porphyry and is followed by a low-grade vein. It evidently ends southward against a cross fault along which the displacement is in part deflected eastward to the Grand Ledge fault; but displacement was in part deflected westward also and continued southward along a fault between Mrdera limestone and latite porphyry.

Young America fault.-The east fork of the Mistletoe fault is conveniently called the Young America fault, from the mine whose workings lie along and east of it. It is also cut by the Linchburg tunnel, which exposes the base of the Kelly limestone just west of it and therefore shows that the downthrow on the west is about 480 feet. The fault is largely covered with landslide debris, but its course where exposed is about S. $20^{\circ}$ E. South of the Young America mine it curves southeastward and joins the Grand Ledge fault.

Grand Ledge fault.-The movements that were dispersed southward along the Mistletoe and Young America faults became largely concentrated again along the Grand Ledge fault, whose northern end is concealed beneath landslide material northeast of the Young America mine. North of its junction with the Young America fault its throw is about 150 feet, but south of the junction it is 400 or 500 feet. A little farther south, where the Grand Ledge fault curves southwestward and is probably joined by a concealed cross fault that connects with the middle fork of the Mistletoe fault, its throw is 550 feet or more, which brings the base of the Madera limestone opposite the top of the Kelly limestone. At the Grand Ledge tunnel it resumes a southerly course, and beyond the next west cross fault its throw has increased to about 900 feet. South of the Connelly tunnel it curves to a southsoutheast course, and the principal displacement shifts first eastward along a short cross fault and then southsoutheastward again along a reverse fault that dips $60^{\circ}$ east-northeast where exposed in the West Virginia tunnel. This distinctly reverse attitude of the fault zone is exceptional and is thought to be a local irregularity.

East Slope fault.-The East Slope fault crosses the crest of the range near the southeast corner of the district. It converges southward with the Grand Ledge fault and the two may join beyond the south boundary of the district. If so the East Slope fault may be regarded as a branch from the Kelly-Graphic fault zone. It extends northward along the upper east slope for a long distance and has a west downthrow. 
which increases or decreases somewhat at its intersections with minor cross faults. Its relation to the southern part of the east-dipping Crest fault is like that of the Mistletoe fault to the southern part of the Germany fault, the two pairs of faults bounding broken, downthrown blocks; furthermore, the two faults with west downthrow extend much farther south than those with east downthrow.

Waldo foult.-The Waldo fault, cut by the Waldo tunnel, is the principal representative of a zone here called the Waldo fault zone that lies west of the Kelly-Graphic or main fault zone and coincides with the little developed mineralized zone that extends along the base of the range as far as South Camp. This west fault zone and the Kelly-Graphic zone converge slightly to the north and are evidently connected by cross faults, the most clearly defined of which is the Kelly-Graphic cross fault.

As the Waldo fault separates intrusive rhyolite porphyry from the Madera limestone, it was formerly regarded as an intrusive contact along which a rather wide zone of shattering had developed. The fact that dikes of monzonite and late white rhyolite had been intruded along it helped to obscure its dimensions. The driving of the west crosscut on level 10 of the Kelly mine in 1916, however, disclosed purple andesite cut by white rhyolite along the west side of the fault; and core drilling farther north by the Ozark Mining \& Milling Co. in 1928 showed that the rhyolite porphyry was underlain by latite, which verified the identity of the small outcrop of latite in the gulch 1,200 feet southeast of North Camp. The rhyolite porphyry along the Waldo fault, therefore, is not an essentially vertical or dikelike mass, as had been supposed by some, but a west-dipping sill intruded between a roof of banded rhyolite and a floor of latite and andesite. Its upper contact is well-exposed on the low hills around North Camp and its lower contact along the west slope of Stendel Ridge. If the entire thickness of the underlying volcanic rocks on Stendel Ridge is also present beneath the rhyolite porphyry along the fault, the throw along the Waldo fault may exceed 1,200 feet but, owing to the unconformity at the base of the volcanic rocks, as well as changes in thickness of the volcanic members, this figure expresses only a rough estimate.

The Waldo fault zone is easily traced from the Nitt stock, against which it ends abruptly, to the low saddle southeast of North Camp; but its relations to the westernmost part of the Kelly-Graphic cross fault are concealed. As stated on page 60, however, the displacement along this part of the cross fault may be small or negligible. In the next gulch to the south the fault is clearly exposed, between rhyolite porphyry and steeply dipping Madera limestone, but farther south where banded rhyolite is in contact with the limestone the surface is so covered with debris and soil that the presence of the fault was not suspected at first. Its dip where exposed, either at the surface or underground, ranges from vertical to $85^{\circ} \mathrm{E}$.

The fault may be cut beneath the alluvium of Kelly Gulch by workings from the Contact shaft, which has been inaccessible to us, and it evidently ends against a concealed cross fault along which downthrow on the south is shown by the discordant relations of the rocks on opposite sides of lower Kelly Gulch. Another fault must separate the isolated hill just west of Kelly from the rhyolites west of the Waldo fault, but it is uncertain whether it is a cross fault with downthrow to the northeast, opposite to that of the fault beneath lower Kelly Gulch, or a longitudinal fault with downthrow to the east, as shown tentatively on plates 2 and 20. If it is longitudinal it may be one of the eastdipping faults and may form the west boundary of a downfaulted block that is bounded on the east by the Waldo fault.

Faults between Kelly and South Camp.-The principal fault south of Kelly and due south of the Waldo fault separates purple andesite from younger volcanic rocks and has a downthrow of 500 to 1,000 feet on the west. It is joined and interrupted by concealed cross faults, whose influence on differences in throw is not clear. It is also paralleled by at least two poorly exposed longitudinal faults with downthrow to the east and presumably with east dip. Only one, a minor transverse fault, has been identified south of South Camp, although others undoubtedly are present; but the irregularities in formation boundaries there apparently represent unconformable contacts.

The low rhyolite hill a quarter of a mile west of Kelly is evidently separated from the rhyolite area northeast of it by a vertical or steeply dipping fault. This hill may also be separated from the next hill to the west by a similar fault, but the thicknesses and succession of the local volcanic rocks are too little known to afford estimates of the amount of faulting. There must, however, be a major fault between the most westerly of these hills and Magdalena Mountain, which is $13 / 5$ miles beyond the west boundary of the district, as each hill is capped with the pink rhyolite and the vertical difference between their altitudes, as determined by aneroid, is about 900 feet. Allowance for the westerly dip of the rhyolite on the low hill would imply an actual displacement of as much as 4,000 feet, although the displacement may be distributed and compensated to some extent along several faults concealed beneath alluvium, as suggested in figure 5.

\section{TRANSVERSE FAULTS}

Transverse or cross faults have already received so much consideration in the descriptions of the longitudinal faults that further reference to them may seem 
superflous. Attention, however, is called to the distribution and throw of the larger ones. The fault zone along the west slope of Tip Top Mountain, with a cumulative downthrow of about 500 feet to the north, forms the south boundary of a large depressed block, conveniently called the Tip Top block. In contrast the fault almost in line with it, which curves northwestward by the Graphic tunnel, has a downthrow of unknown but probably small amount on its southern side and forms the south boundary of a block whose relative uplift is the highest in the district. To the south the KellyGraphic cross fault and unnamed faults bound blocks that are successively downfaulted as far as South Camp, beyond which the volcanic rocks are upfaulted. They form a series of steps intermediate in altitude between the blocks east of the Kelly-Graphic zone and those west of the Waldo zone, which are in the large downfaulted area that extends westward to Magdalena Mountain. The blocks separated by the transverse faults, therefore, may be regarded as the easternmost parts of the large downfaulted area.

\section{BEDDING FAULTS}

Bedding faults have been noted at several horizons in mine workings and are doubtless present at several others. The most conspicuous is along the "silver pipe" bed of the Kelly limestone, which is followed by more mine workings than any other horizon. Others have been noted along the shale bed at the base of the Sandia formation and at several places within the large shale member of the formation. Some, so far as exposed, lie along a single bedding plane and might have been overlooked if they had not offset dikes that lie about normal to the bedding. Such faulted dikes, seen in the Kelly and Graphic-Waldo mines, are offset as much as 40 feet along the dip of the bedding (figs. 6 and 7), the upper, or hanging-wall, part of the dike moving down dip. Other faults in the same mines locally swerve from the lower to the upper contact of the "silver pipe" bed and give the-impression of overthrusts, as if the hanging wall had moved upward, although their direction of movement cannot be proved. In the southern part of the Graphic-Waldo mine, on level 9, a bedding fault (fig. 3) has swerved from the base of the Sandia formation down to the top of the "silver pipe" bed, thus locally eliminating the entire upper Kelly limestone. In the Tip Top-Key mine (p. 153) a small reverse offset along the "silver pipe" bed is clearly exposed. Bedding faults within the shale member of the Sandia formation are well-exposed in the Waldo tunnel (fig. 3) and the Ida Hill tunnel. Their influence on local differences in thickness of the formations is obvious. They also suggest movement analogous to local overthrusting. The contrast between apparent overthrusting and proved normal movement along bedding faults suggests different directions of
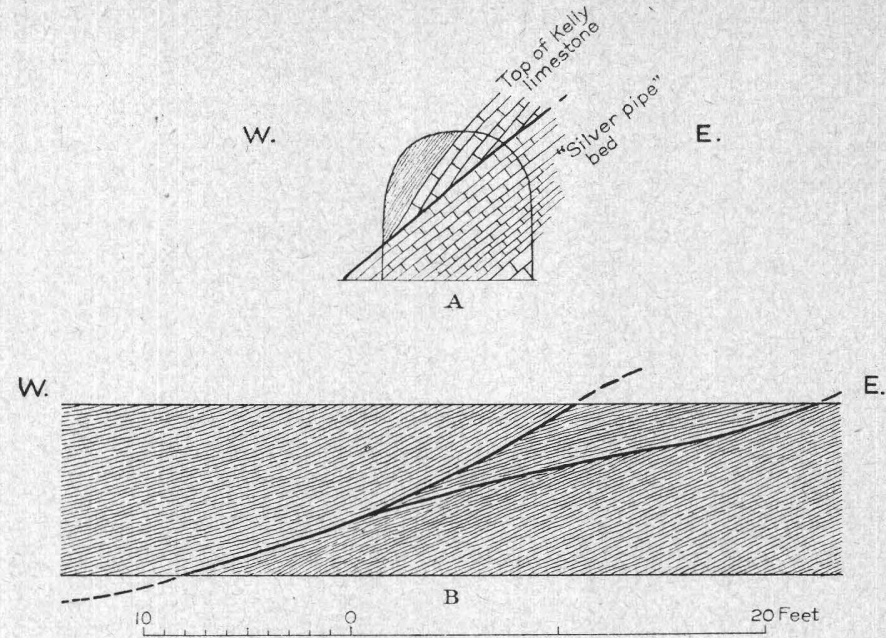

FrgURe 3.-Bedding faults in Graphic-Waldo mine. $\boldsymbol{A}$, Bedding fault at top of "silver pipe" bed, south end of level 9. Direction of movement not clear. $B$, Sketch of branching fault approximately along bedding in shale member of Sandia formation. North wall of Waldo tunnel, 350 feet east of Waldo shaft.

movement at different times. This will be discussed under the heading "Interpretation of Laramide and Tertiary structure" (pp. 66-72).

The distinct reverse faults that crosscut the bedding at small to moderate angles are too few and scattered to be very significant. Some dip west from $55^{\circ}$ to $70^{\circ}$, as shown on level 10 of the Kelly mine, and others may dip at lower angles. Their dip slips range only from about 50 to 70 feet, and it is not known whether they represent overthrusting and are to be correlated with the inferred overthrusting along bedding planes or with the margins of blocks to which strike slip along the faults has given a reverse aspect. In the Nitt mine, where a group of minor northeast-dipping faults is normal as a whole, one fault within the group is reverse and is attributed to such a strike slip. The reverse faults that dip $50^{\circ}$ or less to the west, however, seem more reasonably regarded as minor results of overthrusting; and it may be that if followed they would be found to grade upward into bedding faults.

\section{FAULTS NORTH OF THE NITT STOCK}

Very few faults have been recognized north of the Nitt stock, mainly because the contacts between formations are largely concealed and because formations of uniform character, in which faults are not readily recognized, cover relatively large areas; furthermore, the Tertiary (?) granite and Nitt monzonite stocks are thought to have been intruded in places weakened by intersecting fault zones and to have obliterated several major and minor faults. If so, the faults that cut the Tertiary (?) granite (pl. 2) and doubtless the monzonite also, represent moderately late disturbances equivalent to mild renewals of movement along the faults and to the development of the "roll" and other minor faults south of the Nitt stock. Some of 
these movements followed the intrusion of lamprophyre dikes; some preceded and others followed the intrusion of white rhyolite dikes, and some renewal of movement followed the deposition of ore.

Faults within Tertiary (?) granite.-The white rhyolite dike that has been traced southward through Tertiary (?) granite and monzonite to Oak Spring dips east at a moderate angle and is in line with the Germany fault zone. Whether it fills a fault or only a fissure along which no appreciable movement has taken place is not known, but its alinement with the Germany fault zone implies at least a slight renewal of the disturbance that produced the east-dipping faults. The Hardscrabble fault with northeast trend and southeast dip is obliquely trensverse to the white rhyolite dike and may have the same relation to the dike fissure that the transverse faults elsewhere have to the east-dipping faults against which they end.

Another white rhyolite dike east of Anchor Canyon is broken by a pair of cross faults, between which the west-dipping dike has been relatively depressed. The trend of the dike parallels that of the Anchor vein, which however, fills an east-dipping fault or fissure. Farther north a northwest-trending fault, whose dip and amount of displacement have not been determined, cuts off an aplite dike.

Older faults obliterated by the intrusion of Tertiary (?) granite are suggested by the small exposures of banded rhyolite northeast of Anchor Canyon. One of these faults, of northerly trend, evidently separated the rhyolite from the pre-Cambrian argillite and granite east of it; others of easterly trend separated the rhyolite from the pre-Cambrian and Carboniferous formations across the valley to the north.

Vindicator fault.-The Vindicator fault separates Tertiary (?) granite on the east from Madera limestone on the west. It is followed by a white rhyolite dike and a sulphide vein, has a vertical or steep easterly dip, and is similar in structural relations to faults in the Kelly-Graphic and Waldo zones. Its southward continuation is represented by a pyritized fissure zone in monzonite along upper Hardscrabble Valley. It forms the east boundary of a narrow relatively downthrown block that is largely concealed by alluvium. Displacement along the fault cannot be determined because no sedimentary rocks are present along its east wall. If the pre-Cambrian argillite and felsite a short distance to the southeast approximately represent the floor upon which the Kelly limestone was deposited, the Madera limestone west of the Vindicator fault has dropped 500 feet or more; but this amount of displacement may have taken place along a transverse fault that has been destroyed by the granite intrusion. The only movements along the Vindicator fault for which there is direct evidence obviously took place after the intrusion of the Tertiary (?) granite stock and before ore deposition and are comparable in time to minor recurrences of movement along the KellyGraphic and Waldo faults; however, as both of these faults were mainly developed before the intrusion of the Nitt monzonite stock, similarity in attitude and trend suggests that the Vindicator fault also may have originated before the intrusion of the stocks and may therefore acount, in part at least, for the subsidence in preintrusion time of the block between it and the Stendel fault. If so, the western edge of the intruding granite stock must have followed the original fault very closely, as no granite has been found on the west side of the present fault, either at the surface or underground.

Stendel fault.-The Stendel fault is completely concealed by the alluvium of Hardscrabble Valley, but its presence, is indicated by the discordance between the west-dipping altered shale member of the Sandia formation along the east base of Stendel Ridge and the Madera limestone near the Vindicator mine. There may be a zone of two or more parallel faults instead of a single fault. The easterly downthrow suggests that this fault or fault zone is one of the east-dipping group and forms, with the Vindicator fault, a troughlike structure broken by transverse faults similar to that between the Germany and Mistletoe faults. The degree of dip, however, and the depth at which the Stendel and Vindicator faults meet can be determined only by drilling or underground exploration and must be considered in the planning of any deep development work in this part of the district. The steep dips $\left(55^{\circ}-70^{\circ} \mathrm{W}\right.$.) in the lower Madera strata just west of the Vindicator fault and the presence of shale beds of the Sandia formation west of the Stendel fault would imply an aggregate dip slip of 1,000 to 1,500 feet along the Stendel zone; but dips along the Vindicator fault may be partly due to drag, which would decrease the displacement correspondingly.

The thick covering of volcanic rocks that now con. stitutes much of Stendel Ridge must have extended far to the east and covered the block that is now downfaulted. There may be a remnant of it, concealed by alluvium, in the west part of the downfaulted block, as suggested on plate 4 (sec. C- $\mathrm{C}^{\prime}$ ) and figure $4, C$. It is possible that some tilting and movement along the Stendel fault began before the volcanic eruptions took place and that the fault was covered with volcanic rock, as shown in figure $4, A$. If so, the erosion interval between early faulting and volcanic eruption was sufficient to remove the Madera limestone from the relatively uplifted area west of the Stendel fault. An alternative interpretation proposes that the volcanic rocks were spread over an erosion surface, from the western part of which the Madera limestone had been removed before any faulting had taken place, and that the Stendel fault was formed later near the west limit of the 


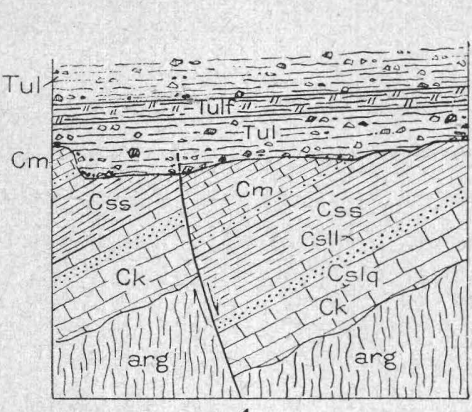

A

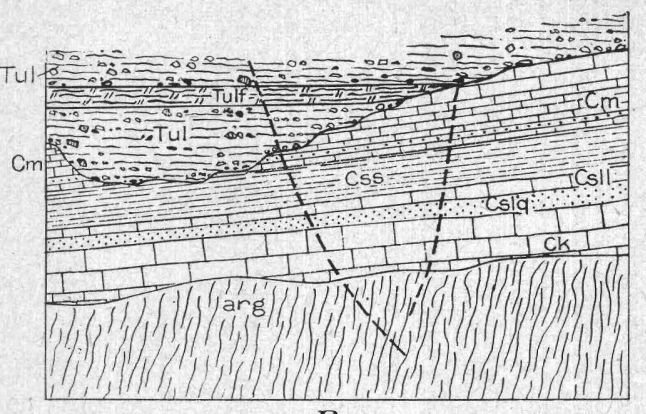

$B$

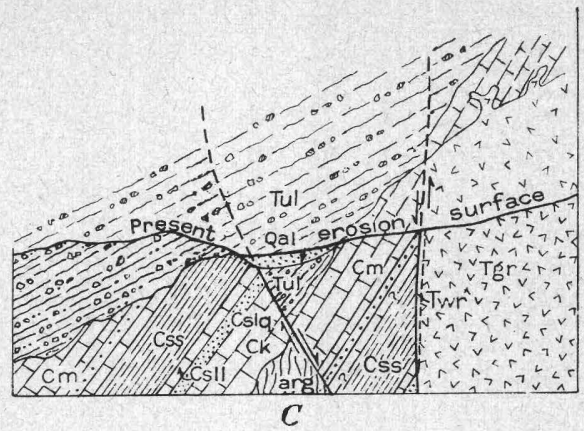

Frgune 4.-Diagrammatic interpretations of structural development in the vicinity of the Stendel and Vindicator faults. Arg, Pre-Cambrian argillite; Ck, Kelly limestone; Cslq, lower quartzite, Csll, lower limestone, Css, shale, members of the Sandia formation; Cm, Madera limestone; Tul, upper latite tuff with Tulf, latite flow; Tgr, Tertiary (?) granite; Twr, white rhyolite dike; Qal, alluvium.

A. Supposed prevoleanic faulting followed by erosion and later by deposition of volcanic tuffs over the erosion surface, covering a fault between the Sandia and Madera formations.

$B$. Volcanic tuffs overlapping an unfaulted erosion surface of the Sandia and Madera formations.

$C$. Tilting and downfaulting of either $A$ or $B$ followed by the intrusion of Tertiary (?) granite and white rhyolite and by erosion to the present surface. Compare plate 4 , sec. C-C'.

Madera limestone, as suggested in figure $4, B$. The second interpretation would avoid the necessity of inferring a prevolcanic period of faulting but would depend on the coincidence that faulting happened to take place close to the boundary of an eroded formation. There is no reason for objecting to a prevolcanic period of faulting, although no stronger suggestion of it has been found in the main Magdalena Range. Other suggestions of prevolcanic faulting, however, are present in the Granite Mountain area.

\section{FAULTS IN THE GRANITE MOUNTAIN AREA}

Faults in the low hills east of Granite Mountain are clearly exposed for only very short distances. Strike faults have been noted at many of the prospect holes, but they are traceable for only a few feet and are therefore not shown on plate 2. It is not known whether they dip along or across the bedding. One of them is within the Kelly limestone near a group of old shafts and prospect holes. Another between the Kelly limestone and the lower limestone member of the Sandia formation is suggested by the absence of the lower quartzite member, which intervenes elsewhere, but the quartzite member may have thinned ont between this area and its northernmost exposure, which is at Oak Spring, nearly 3 miles to the south. Many faults are exposed in the shale member of the Sandia formation, but none of them can be traced more than a few feet. They suggest that the extraordinary thickness of the shale may have been caused in part by duplication of its beds along either bedding faults or crosscutting strike faults; however, the relatively great but true thicknesses of the upper limestone and quartzite members of the formation suggest that the thickness of the shale also may be mainly the result of original deposition.

At least two major transverse faults of west-northwest trend and northerly downthrow, though concealed by alluvium, are implied by the discordant positions of the Madera limestone and the upper members of the Sandia formation to the southeast of Granite Mountain. The fact that neither the lower latite, which unconformably overlies both formations, nor the volcanic rocks adjacent to it show any corresponding offsets indicates that these transverse faults were formed before the beginning of volcanic eruptions, as was suggested for the Stendel fault. Three other concealed faults-two transverse with northeasterly strike and one longitudinal with north-northwest strike-are implied by the discordant relations between the lower andesite and the upper latite at the north end of Granite Mountain. These faults are not reflected in the rhyolite porphyry on the west and appear therefore to be older than the rhyolite porphyry and to belong to the stage of deformation that occurred between the first and second volcanic periods. A younger transverse fault of east-northeast trend has offset the contact between rhyolite porphyry and upper latite tuff on the north slope of Granite Mountain, but no longitudinal faults in the volcanic and intrusive rocks of the area have been noted.

\section{INTERPRETATION OF THE LARAMIDE AND TERTIARY STRUCTURE}

The wide distribution of the major faults and their different relations to rock formations leaves no room to doubt that they were produced by recurrent regional disturbances; on the other hand the relations of certain of the minor faults point to local origin during late stages of structural development of the district. The difficulty of interpretation is increased by the facts that faults formed at different times have similar trends and dips and that movements along a single fault recurred at different times and perhaps in different directions. A general interpretation of faulting therefore can be most consistently presented by reviewing the different stages of regional and local deformation in the order of development; but conclusions regarding regional movements must necessarily be tentative until a much larger area has been investigated. 
Such a review can also point out the conditions that favored or hindered the circulation of ore-forming solutions along the different sets of faults. The principal stages of deformation to be reviewed involve (1) folding or doming accompanied by faulting and followed by partial collapse before volcanic eruptions began, (2) major tilting, and presumably faulting also, between the first and second stages of volcanic activity, (3) major vertical faulting after the second stage of volcanic activity, (4) local faulting during the intrusion of igneous stocks, (5) minor adjustments after intrusion but before ore deposition, and (6) minor adjustments after ore deposition.

\section{DEFORMATION BEFORE VOLCANIC ERUPTIONS}

It is generally agreed that the different significant stages of tilting and faulting in New Mexico and adjacent parts of Texas, Colorado, and Arizona took place-during and immediately after the Laramide revolution, which marked the transition from Cretaceous to Tertiary time. ${ }^{77}$ Only 20 miles northwest of the district Winchester ${ }^{78}$ found that Cretaceous rocks were moderately folded and faulted, whereas the Tertiary Datil formation which unconformably overlies the Cretaceous, is practically horizontal ${ }^{79}$ though faulted.

The different kinds and degrees of deformation in neighboring parts of New Mexico are illustrated by Darton. ${ }^{80}$ Gentle and sharp folds, overthrusts, transverse or tear faults, and longitudinal normal faults were produced. The absence of well-defined folds and overthrusts in the Magdalena district is an obstacle to thorough correlation, but as they were produced in surrounding areas it may be inferred that the compressive forces that produced them were active to some degree during the earliest stages of deformation in the Magdalena district.

Mild folding in the district during prevolcanic time is suggested by the northwesterly strike of the sedimentary formations in the main range and their northeasterly strike in the Granite Mountain area and by the beveled erosion surface on which the oldest volcanic rocks lie.

The westerly tilting of the sedimentary rocks presumably began during the early stage of compression, and the minor west-dipping reverse faults, as well as

\footnotetext{
7 Lindgren, Waldemar, Graton, L, C., and Gordon, C. H., op. cit, pp. 32-33, 1910. Ross, C. P., Aravaipa and Stanley mining districts, Ariz.: U. S. Geol. Survey Bull. 763 , pp. $40-41,51,1925$. Lovering, T. S., Geologic history of the Colorado Front Range: Colorado Sci. Soc. Proc., vol. 12, pp. 93-94, 1929. Burbank, W. S., Revision of geologic structure and stratigraphy in the Ouray district of Colorado and its bearing on ore deposition: Colorado Sci. Soc. Proc., vol. 12, p. 209, 1930. Burbank, W. S., and Goddard, E. N., Problems of structure and stratigraphy in the Sangre de Cristo Range, Colo. [abstract] : Geol. Soc. America Bull., vol. 43, p. 168, 1932. King, P. B., oral information regarding Marathon Basin, Tex., 1933. Richardson, G. B., U. S. Geol. Survey Atlas, El Paso folio (No. 166), p. 9, 1909.

${ }^{78}$ Winchester, D. E., Geology of Alamosa Creek Valley, Socorro County, N. Mex. : U. S. Geol. Survey Bull. 716, pp. 4-5, 9, 1920.

79 Idem, p. 9.

so Darton, N. H., "Red beds" and associated formations in New Mexico: U. S. Geol. Survey Bull. 794, 356 pp., 1928.
}

some bedding faults and transverse faults, could have developed at the same time. If so, the rocks within the district formed only a small part of an anticlinal structure that extended beyond the limits of the present mountain range. At the end of the period of compression a general collapse of the anticline took place and the east-dipping normal faults were initiated. The movement along them involved westward tilting, as shown in figure 5. Some faults died out in one or both directions, whereas others stopped at one or both ends against older transverse faults.

It may be argued that the influence of early compression is not necessary to explain the faulting and that the tilting of strata and the formation of transverse faults and longitudinal east-dipping faults may be attributed entirely to local uplift accompanied or closely followed by collapse and adjustments within the major blocks. We have no serious objection to the interpretation, although the minor west-dipping reverse faults are not so readily explained. According to either interpretation, the collapse involved the relative dropping of a large mass east of the district, and probably east of the range, and the eastward slumping of the range itself along the east-dipping faults, as shown in figure 5. Owing to the moderate to low angles of dip along these faults, gravity must have pressed their hanging walls tightly against their footwalls.

If this interpretation is extended to include faults as far west as Magdalena Mountain it may imply that the mass comprising the present main Magdalena Range and the valley west of it were tilted in one direction and that the tilting was accompanied or closely followed by faulting.

That some transverse and perhaps longitudinal faulting took place before volcanic eruptions began is strongly suggested by the transverse faults concealed by alluvium southeast of Granite Mountain, where large displacements of sedimentary rocks are not reflected in the adjoining oldest members of the volcanic group. Prevolcanic faulting in the main range is suggested less strongly by the Stendel fault. The greater dips of sedimentary rocks than of adjacent volcanic rocks and the general unconformity at the base of the volcanic group throughout the district also point to some tilting, as well as faulting, before volcanic eruptions began. More must be known about the area north of the main range and east of Granite Mountain before any further inferences regarding prevolcanic folding, tilting, faulting, and erosion are justified.

\section{DEFORMATION BETWEEN THE FIRST AND SECOND STAGES OF VOLCANIC ACTIVITY}

The major amount of tilting occurred between the first and the second stages of volcanic activity. It was doubtless accompanied by faulting, as faults that offset the older but not the younger volcanic rocks are indicated north of Granite Mountain; but no such faults 
have been recognized within the main range. The volcanic rocks of the first stage, represented by the latites, lower andesites, and banded rhyolite in general, dip at angles ranging from $30^{\circ}$ to $40^{\circ}$, whereas the rocks of the second stage, represented mainly by the upper andesite and pink rhyolite, are nearly horizontal. The dips of the sedimentary rocks commonly range from $30^{\circ}$ to $55^{\circ}$, though local dips may be smaller or greater, indicating that the amount of tilting at the beginning of volcanic activity was probably small, locally not more than $10^{\circ}$ to $20^{\circ}$ (pl. 4 , sec. C- $\mathrm{C}^{\prime}$ ).

Just what structural features resulted from this intravolcanic deformation-whether asymmetric folds or uplift along major faults east of the area-is not known. The greater part of the east slope of the Magdalena Range falls outside of the area mapped, and relatively little is known of this part of the range; but, because of its importance relative to the structure and origin of the range, the information at hand will be discussed here. The east slope of the range east of the area mapped is composed almost entirely of pre-Cambrian rocks, chiefly granite, except where Carboniferous formations are present in local downfault blocks. The Carboniferous formations found on the east side of the crest have the normal regional westerly dip and give no indication that the east slope may be the east limb of an anticline. This westerly dip continues for at least 3 miles beyond the southeast corner of the district. There, in the Water Canyon district, as shown by Lasky, ${ }^{81}$ the Mississippian and Pennsylvanian strata and the overlying volcanic rocks rather well down the east slope of the range also dip westward. Lasky made no reference to folds and attributed the tilted blocks to faulting. Wells ${ }^{82}$ reported that although the formations in the vicinity of Water Canyon are tilted to the west, those in the southern part of the range are tilted to the east. This statement suggests that folding like that in the Sandia Range ${ }^{83}$ may have taken place, but no information is available regarding the extent or structural details of the eastward-tilted rocks. The meager data available on the northern part of the range give no indication of eastward-dipping sedimentary rocks. If, therefore, the structure of the range is that of an anticline or elongate dome, the sedimentary rocks have been thoroughly removed from the east side.

The general absence of the Carboniferous formations on the east slope, except in local west-dipping

\footnotetext{
${ }^{81}$ Lasky, S. G., The ore deposits of Socorro County, N. Mex.; New Mexico School of Mines, State Bur. Mines and Mineral Resources, Bull. 8, pp. 46-47, 1932.

82 Wells, E. H., Manganese in New Mexico : New Mexico State School of Mines Bull. 2, p. 71, 1918.

${ }^{83}$ Darton, N. H., Tectonics of Arizona and New Mexico [abstract] Geol. Soc. America Bull., vol. 39, p. 182, 1928.
}

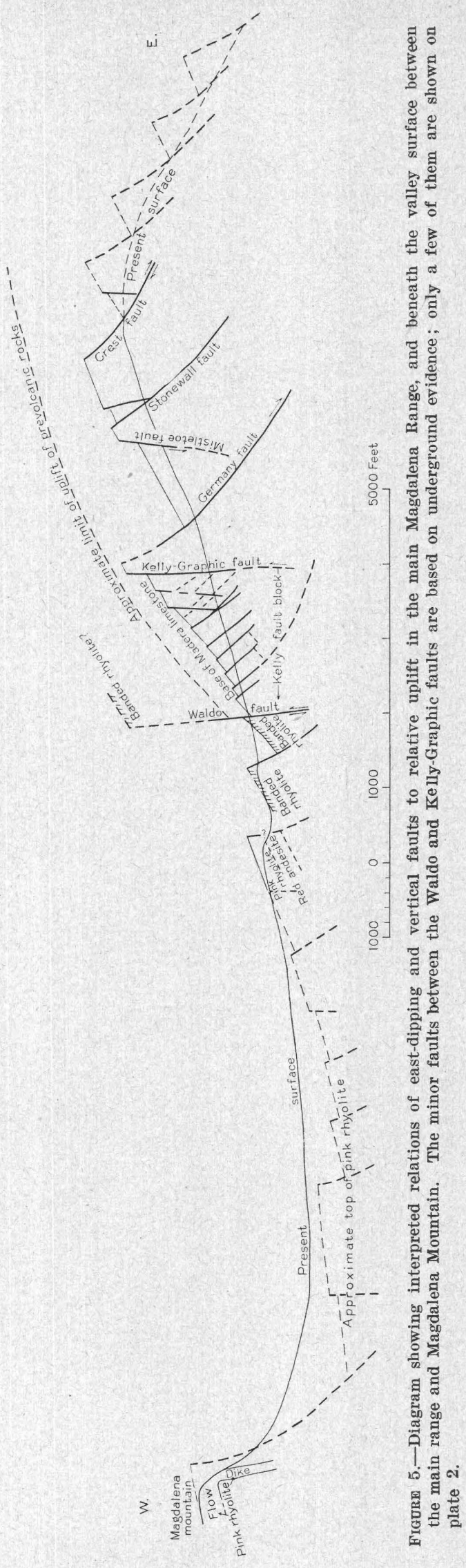


fault blocks, implies that the range is bounded on the east by a major east-dipping or vertical fault. Recently Bryan ${ }^{84}$ has reported a young fault scarp along the northeast base of the Magdalena Range and thus partly supports the thesis of a fault or fault zone along the east front. The difference in altitude between the plain to the east and the top of the peaks covered with sedimentary rocks on the crest is about 4,000 feet, but the amount of faulting along the east front would appear much greater if the dip of the Carboniferous rocks were to be projected eastward to their intersection with an upward projection of the fault. It is not clear from available information whether the east slope, as a whole, has resulted from movement along a single major fault or a set of distributive or step faults, as is suggested near the crest of the range east of Kelly.

As the uplift and tilting of the Magdalena Range involved east-west arching or elongate doming of the region as a whole and removal of support to the east, large blocks or slabs would tend to settle eastward along the east-dipping faults that compensated for the uplift.

Some north-south stretching and local collapse also took place, which produced the depressed or steppeddown blocks between major transverse faults that dip towards each other, as is illustrated by the Tip Top block. Although southward tilting of the bedded rocks is not pronounced, these downfaulted blocks, or groups of blocks, within the district were most depressed near their southern ends.

Minor vertical faults, subsidiary to the east-dipping faults, are probably contemporaneous with them and related in origin. Where the movement was most pronounced and the east-dipping faults had rather low angle dips, the overhanging parts of the slabs became unsupported, broke along vertical longitudinal faults, and settled as faulting progressed, forming local downfaulted blocks. This subsidiary movement is most clearly represented by the minor fault that parallels the southern part of the South Stonewall fault (pl. 20). Similar faults subsidiary to the major transverse faults are present at several places within the district. This mode of origin, together with their vertical to steep easterly dip, would tend to keep these faults more open than those with moderate to lowangle easterly dips. It is significant that most of the ore bodies in the district are closely associated with vertical faults.

DEFORMATION AFTER THE SECOND STAGE OF VOLCANIC ACTIVITY

A large amount of faulting also took place after the second stage of volcanic activity but before the stage of stock intrusion that followed. The intrusive rhyo-

\footnotetext{
${ }^{84}$ Bryan, Kirk, written communication, December 1931.
}

lite porphyry, the youngest member of the second volcanic group, is cut by faults that have been partly obliterated by the stocks. Most of the movement in this stage took place along the vertical and transverse faults west of the zone of pre-Cambrian outcrops along the west slope of the range. Faults in and west of the vertical Waldo fault zone offset the rhyolite porphyry, and faults of the Kelly-Graphic or main ore zone, as well as adjoining transverse faults, cut the older volcanic rocks (pl. 4 and fig. 5). Possibly movement was renewed also along some of the earlier faults. The faults with east downthrow between Magdalena Mountain and the Waldo fault are of this age, but no information on their dip is available.

The origin of the major vertical faults cannot be finally determined without thorough study of a much larger area. Whether their origin was the same as that of the minor vertical faults east of the horsts is questionable, for they are probably much younger than the east-dipping faults. The north extension of the KellyGraphic fault, for example, is younger than the eastdipping fault west of it. The south end of the KellyGraphic fault, which dips very steeply eastward and curves into the Germany fault, suggests that it is subsidiary to east-dipping faults, but no major east-dipping fault has been found near it on the west that would strongly support the suggestion. The larger of the east-dipping faults within the Kelly fault block (fig. 5) may be older than the Kelly-Graphic fault, but they cannot be distinguished from parallel faults that developed later and are subsidiary to the Kelly-Graphic fault. Movement along the northern part of the Mistletoe fault evidently corresponds to a renewal of movement along the southern part of the Germany fault, but the Mistletoe fault as a whole and the broad zone of vertical faults in general alinement with it farther south are not related to any neighboring major east-dipping fault. Similarly, the depressed blocks between the Crest fault and the vertical fault east of it fit this explanation, but the vertical fault continues much farther south than the Crest fault and appears to converge with the broad zone of vertical faults.

No major east-dipping faults intervene between the vertical Kelly-Graphic fault zone and the Waldo fault zone, which is also vertical and has a large west downthrow northwest of Kelly, whereas the Kelly-Graphic zone has a larger downthrow southeast of Kelly. The principal downthrow is shifted from one to the other along cross faults, particularly the fault concealed beneath Chihuahua Gulch. The two vertical fault zones, therefore, may be regarded as members of a composite zone. West of this composite zone the only known fault or fault zone that has a large east downthrow is the one that underlies the broad valley between Magdalena Mountain and the low hill capped with pink rhyolite half a mile west of Kelly, but its direction and 
amount of dip are not known. This fault zone (fig. 5) apparently marks the west boundary of the composite tilted block that forms at least the northern part of the main range, but, even if a rather low angle easterly dip is assumed, it is too far from the Waldo and KellyGraphic fault zones for them to be regarded as directly subsidiary to it.

An alternative suggestion and the one preferred by us is that these major vertical faults were formed during subsidence of the western part of the range and the adjoining valley area subsequent to the extrusion of the late group of volcanic rocks but prior to the intrusion of stocks; in other words, that the vertical faults are major faults separating depressed areas from relatively elevated areas. If so, a considerable amount of subsidence took place in the valley area west of South Camp, and the most depressed block is concealed beneath alluvium. The neighboring fault blocks that are bounded on the east and west by the Waldo and KellyGraphic fault zones and descend in steplike succession from the Nitt stock to South Camp form intermediate benches between the depressed valley block and the main part of the range. The southerly increase in displacement along the Kelly-Graphic zone at the south end of the district suggests that there may be another center of principal subsidence farther south. As this general subsidence took place after the period of volcanic eruptions, it could be regarded as a compensation for the large amount of volcanic material removed from below and piled upon the undermined surface; but, as the principal volcanic vents or conduits have not definitely been located, their relations to areas of sunken blocks remain to be determined.

Burbank, ${ }^{85}$ in the Bonanza district, found that tension faults dip towards the centers of maximum collapse, and workers in the Tertiary igneous areas of Scotland have shown, as summarized by Richey, ${ }^{86}$ that ring dikes, which occupy faults, are steeply inclined outward from the centers of reservoirs. Kingsley, ${ }^{87}$ however, states that the dike occupying the boundary fault that outlines the Ossipee Mountain cauldron in New Hampshire is vertical. It is probably that, even though the Waldo and Kelly-Graphic faults are vertical or dip steeply eastward, they were formed along the east boundary of an area of subsidence over an area of volcanic reservoirs and, as shown in the following paragraphs, they extended so deeply that they exerted considerable influence on the intrusion of stocks.

The horsts or relatively uplifted blocks of pre-Cambrian rocks, which form a diagonal zone of southeast trend on the west slope of the main Magdalena Range, have apparent major structural significance. In gen-

\footnotetext{
${ }^{85}$ Burbank, W. S., Geology and ore deposits of the Bonanza district, Colorado : U. S. Geol. Survey Prof. Paper 169, p. 55, 1932.

86 Richey, J. E., Tertiary ring structures in Britain: Geol. Soc. Glas gow Trans., vol. 19, pp. 42-140, 1932.

${ }_{87}$ Kingsley, Louise, Cauldron subsidence of the Ossipee Mountains : Am. Jour. Sci., 5th ser., vol. 22, pp. 145-146, 1931.
}

eral, the recognized major faults east of this zone dip eastward at moderate angles and those west of this zone are nearly vertical (fig. 5). The general uniformity in direction of dip on either side of the horsts could suggest that they mark an axis of early uplift, that the faults originally dipped away from the horsts at high angles, and that subsequent uplift and westward tilting of the range as a whole decreased the angle of dip of the faults east of the horsts but increased the angle of those to the west. The fault pattern, however, is more complex than this suggestion would imply and, as already pointed out, not all of the faults on either side of the horsts are of the same age. If the horsts marked the core of an early flexure which subsequently collapsed, it would be expected that the faults on either side of the axis should be symmetrically arranged around them, but they are not. Furthermore, faults on the same side of a zone of horsts dip in opposite directions and complicate the structural picture.

In the zone of vertical and west-dipping faults, only local and minor east-dipping faults occur, which, like the vertical faults in the east zone (p. 68), evidently have resulted from the settling of overhanging or unsupported parts of blocks bounded by major vertical faults.

The foregoing discussion clearly indicates that the horsts were not the controlling factor in the complex structure pattern of the main range but rather the product. They mark the boundary between the eastdipping normal faults of the second stage of deformation and the vertical or steep faults of the third or postvolcanic stage of deformation.

\section{LOCAL FAULTING DURING THE INTRUSION OF STOCKS}

The intrusion of stocks, which followed the principal stage of faulting, was evidently guided by the most open fault zones and zones of weakness. The relation of intrusive stocks to faults is most strongly suggested by the Nitt stock. One of these faults was in the transverse fault zone that separated the Stendel Ridge block from the Graphic block and extended westward into or along the north boundary of the large downfaulted blocks in the valley area. Its intersection with longitudinal faults is suggested by the sharp bends in the outline of the Nitt stock along the west slope of Stendel Ridge and beneath the alluvium of the valley, where the monzonite boundary was determined by a dip-needle survey; also by the dike of monzonite porphyry exposed underground along the Waldo fault, and by the details of the monzonite contact in the vicinity of Oak Spring.

The possible relations of the other stocks to faults are obscure. The Tertiary (?) granite stock is partly concealed by alluvium and elsewhere is bounded by preCambrian rocks in which faults, even though proved to exist, are not readily traceable. The position of the banded rhyolite east of the mouth of Anchor Canyon, 
however, suggests the former presence of longitudinal and transverse faults that have been obliterated by the intrusion. Probably of equal or greater importance in the emplacement of the Anchor Canyon stock is its position along the axis of the mild flexure affecting both the main range and Granite Mountain (pp. 36, 57). The small stocks in the Granite Mountain area and farther north are also so inadequately exposed that mapping around them has been insufficient to indicate their possible relations to faults. The general alinement of the stocks, however, in a north-northwest direction, essentially coincident with the trend of the KellyGraphic and Waldo fault zones suggests that the intrusions took place along an extensive fault zone of northnorthwest trend, especially at points favored by junctions with cross fault zones.

Whether the process of intrusion was mainly passive or produced movements in adjacent fault blocks is uncertain. If only strictly local evidence were being considered, the fact that the Graphic block and the block northeast of it, both of which lie along the southeast boundary of the Nitt stock, are relatively higher than any others would suggest uplift by intruding monzonite; but to what extent this apparent uplift is the result of the intrusion and to what extent the result of earlier regional movement cannot be determined. The same uncertainty applies to the smaller blocks just east of the monzonite. As the faults bounding these blocks are all normal or essentially vertical, any appreciable uplift of the Graphic and adjacent blocks by intruding monzonite must have been sufficient to thrust the surrounding blocks aside, as is suggested by the offsets of the east-dipping longitudinal faults by certain of the transverse faults along the east margins of the blocks.

The Graphic block, however, is cut by one or more dikes of monzonite that follow fractures of northwest trend and northeast dip. These fractures may be regarded as the result of local tension produced after upthrust by the intruding monzonite had subsided but before the main part of the stock had become solid. The dike along the Waldo fault could also have followed such an uplift.

Although the monzonite stock has a dominant southwesterly trend, this evidence of uplift is confined to its southeast side. Some uplift of the Stendel block on the opposite side of the fault could be imagined, but to a much less degree, as the position of the rhyolite porphyry sill there is essentially accordant with that to the south on the downthrown side of the Waldo fault. To explain the extremely localized uplift, therefore, some unsupported assumptions would be necessary; for example, that the obliterated transverse fault along which the intrusion may have taken place dipped southward and the uplifting force was concentrated on its hanging wall; also that the regional movement was still in progress and produced sufficient tension along the Germany fault zone to render uplift of the Graphic and adjacent blocks easy. It would then, however, be difficult to account for the absence of dikes along the major transverse faults. It is less awkward to conclude that the present arrangement of major fault blocks was essentially the same before intrusion as it is now and that uplifting by the intruding monzonite was very subordinate.

The relatively uplifted blocks 'along the KellyGraphic fault zone but away from the Nitt stock must also be considered. The largest of these uplifted blocks lie along the east side of the Kelly-Graphic fault zone, which is the main ore zone of the district, and are separated or broken by depressed blocks. The fact that ore bodies that were formed at relatively high temperatures lie along the west side of these blocks in the Kelly mine and even in the Linchburg tunnel, which is 12,000 feet away from the nearest exposed intrusive stock, prompts the suggestion that these ore bodies may be underlain by other stocks at rather shallow depth along the zone and that the force of their intrusion was sufficient to uplift the blocks. This suggestion accords with the idea that intrusion took place along fault zones or their intersections and implies that the faults had already been formed and that the force of intrusion only produced later modifications in the amount and perhaps the direction of faulting. The assumed thrusting action that would have forced wedgelike blocks upward would also have extended compressive action along both the east-dipping and the vertical faults, but there is no evidence of upward drag, which should be especially evident along the hanging walls of the east-dipping faults. If any such upthrust took place, therefore, it must have been too little to counteract the evidence of settling that took place prior to the stock intrusions or to persist during any minor settling subsequent to the intrusions.

On the whole, therefore, it appears that the intruding Nitt stock was not a primary cause of uplift but that it worked its way upward along the margin of the great sunken block west of the range. This relation recalls the distribution of stocks along the margins of the great sunken block in the Silverton district of Colorado, as shown by Burbank, ${ }^{88}$ who also shows that the metalliferous veins of that district are systematically arranged along and around the same sunken block. Whether the Nitt and other stocks in and near the Magdalena district maintain a similar structural setting can be determined only by a much more extensive areal study. The north-northwest alinement of the stocks suggests such a structural control, as does the arrange-

${ }^{88}$ Burbank, W. S., Vein systems of the Arrastre Basin and regional geologic structure in the Silverton and Telluride quadrangles, Colorado: Colorado Sci. Soc. Proc., vol. 13, pp. 174-181, 1933. 
ment of the major ore bodies along the fault zones that border the sunken valley block; but the complete dimensions of the sunken block are far from being known. A thorough test of this relation would involve detailed studies to the south, west, and north of the Magdalena district.

MINOR ADJUSTMENTS AFTER STOCK INTRUSION BUT BEFORE ORE DEPOSITION

One of the few monzonite dikes that have been found follows a principal vertical fault, but the others follow subordinate oblique faults and fissures that reflect the settling and expansion rather than compression of major fault blocks. It could be assumed that some relaxation followed the upthrust after the form of the stock had been essentially established but before the monzonite had completely contracted through crystallization. The numerous lamprophyre dikes, which were intruded subsequent to the stocks and dikes of monzonite, also follow major faults in a few places, but in the GraphicWaldo and Kelly mines most of them follow minor transverse and oblique faults and fissures that reflect continued settling of the major fault blocks.

The dikes of white rhyolite, which were intruded later than those of lamprophyre, are scarce in mine workings and therefore show no definite relation to these minor faults; but their presence along some of the major vertical faults, notably the Vindicator, Waldo, and Grand Ledge faults, indicate the reopening of these faults without any noteworthy renewal of displacement. The east-dipping dike that cuts Tertiary (?) granite, approximately in line with the Germany fault zone, suggests similar reopening of east-dipping faults. This confinement to major fault zones also suggests that the intrusion of the dikes accompanied rather than followed the reopening, and thereby counteracted subsidiary movements along the minor faults within the major blocks. Subsequent to the intrusion of these dikes, however, minor adjustments were resumed along both major and minor faults, and some new minor faults were formed. These adjustments involved further reopening of the vertical longitudinal faults and the settling of rock towards them along favorably situated minor faults and bedding. In the Kelly fault block, for example, the movement, though small, was similar to that which took place during the major prevolcanic faulting. The block, freed on its east and west sides, tended to settle along the Kelly-Graphic cross fault, as shown in figure 6 . Its northeast corner, where this fault converged with the Kelly-Graphic longitudinal fault, was pressed tightly against the fault walls; but a little farther south, where the longitudinal fault curved slightly eastward, an appreciable open space began to develop. A similar open space began to develop along the Brown fault, a parallel subsidiary of the main longitudinal fault. The wedge-shaped blocks between these faults and the eastward-dipping faults of northerly to northwesterly strikes were left unsupported and settled toward the vertical faults, tending to press tightly against the east-dipping faults and the KellyGraphic cross fault but less tightly against the vertical longitudinal faults. The movement also tended to open minor transverse fractures or faults, particularly in the slab between the two vertical faults, owing to drag along the main cross fault. Longitudinal tension cracks dipping toward either vertical fault also prevailed in the same slab. In short, this slab was rendered especially permeable to ore-forming solutions, and the open bedding planes in the Kelly limestone increased permeability near the cracks and faults. Tension cracks could allow some westward spreading of solutions into the wedge-shaped blocks, which had settled so tightly against the east-dipping faults as to reduce permeability on the whole.

Structure in the Graphic block was more complex than that in the Kelly block. The Graphic block is bounded on the south by the Kelly-Graphic cross fault, on the west by the Waldo fault, on the northeast by the cross fault of northwesterly trend whose western part has been obliterated by the intrusion of the Nitt stock, and on the east by an east-dipping fault with a hanging wall of Madera limestone. Simultaneous movements down the northeast boundary fault and along the west and east boundary faults shifted the block downward and southward and tended to open fissures or minor faults of northerly or northwesterly trend within the block. Those with easterly and northeasterly dips were most subject to opening. Transverse fractures between these minor faults also tended to open, and local movements of minor blocks between pairs of northeast-dipping faults opened tension fractures of northerly and northeasterly trends and steep to vertical dips. Settling along the hanging walls of these faults and fractures counteracted their opening to some degree and produced the Roll fault (fig. 7) and similar rolls along other faults; but openings available for circulation developed along fault intersections, and the west-dipping bedding planes were opened by tension movements along these faults beneath the rolls. As a result, the principal channels for circulation of rising ore-forming solutions were along the Roll fault and other faults of northeast and east dip and also along the intervening cross faults and vertical tension fractures of northerly trend.

The east boundary fault of the Graphic block is compound and of low easterly dip with a tight hanging wall composed at the surface principally of Madera limestone and shale. Shearing along this fault tended to open minor steeply dipping or vertical faults to the west of it, as shown in the Mitchell tunnel (fig. 13), but these minor faults evidently died downward, as tension decreased away from the main fault. These 


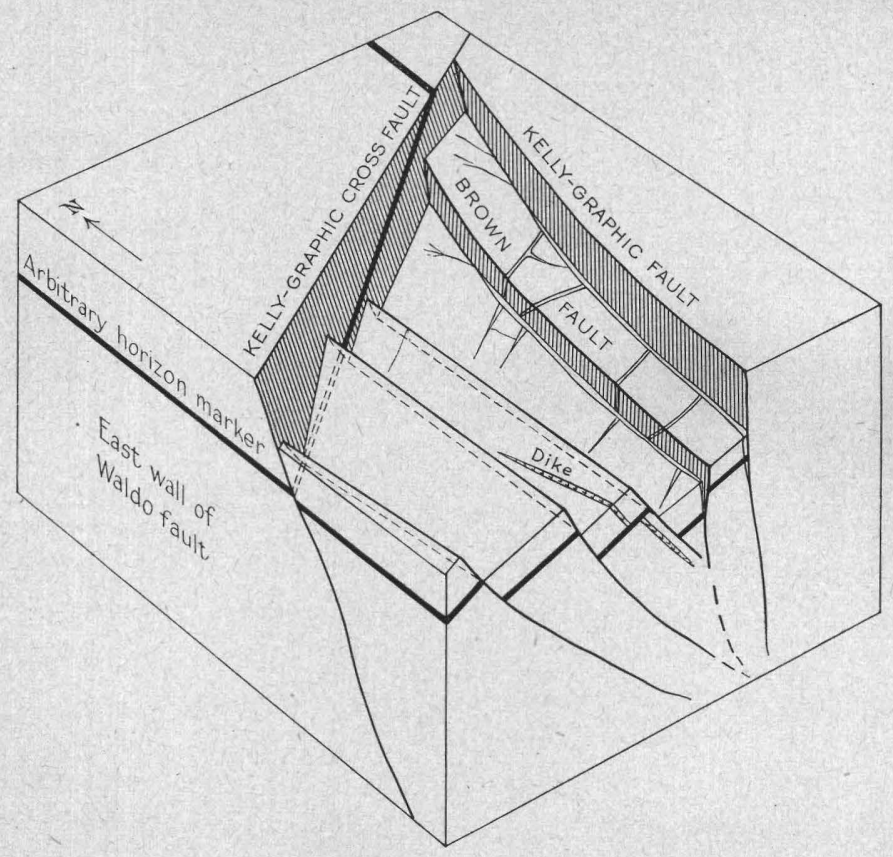

FIGURE 6.-Diagram of Kelly fault block, showing decrease in throw along Kelly-Graphic cross fault at its junctions with minor eastdipping faults, the relatively open parts of longitudinal vertical faults and the transverse faults between them, and a dike offset along a bedding fault.

faults, as well as the east-dipping fault, have been weakly mineralized, not from below but by solutions that escaped eastward along transverse fractures from the principal channels in the Graphic block.

East of the east-dipping boundary fault there is a north-trending fault zone with prevailing steep westerly dip and a net downthrow to the west. This zone may be the northward continuation of the Kelly-Graphic fault zone. It connects with the eastward continuation of the northwest-trending fault that forms the northeastern limit of the ore zone in the Graphic block, but it also shows only weak effects of mineralization, and it appears as if the squeezed shale in the downfaulted wedge between it and the east-dipping fault prevented ore-forming solutions from reaching it in any considerable quantity. Some may have regarded this fault zone instead of the east-dipping fault as the east boundary of the Graphic block, and insofar as minor movements before ore deposition are concerned, it may be; but the east-dipping fault has the greater throw and more nearly defines the east limit of productive ground.

The opening of the Waldo fault, which forms the west boundary of the Kelly and Graphic blocks, must have induced settling towards it, especially down the dip of bedding planes. Irregularities along the major cross fault that bounds the Graphic block on the northeast and along the Kelly-Graphic cross fault also favored supplementary faulting along bedding planes but mainly in the direction of strike; and a combination of the two movements doubtless resulted in an oblique movement. The positions of the east-dipping minor faults and the west-dipping beds (fig. 7) also favored simultaneous movements along faults and bedding planes owing to the downward pressure of overlying rock. The outstanding examples of these simultaneous movements are the "roll" fault in the Graphic mine and the associated bedding faults along the top and "silver pipe" beds of the Kelly limestone.

The Roll fault strikes northwest and dips about $45^{\circ}$ NE. Its dip slip is clearly expressed in the Kelly limestone, but for the most part the fault passes upward into a small monocline or roll in the basal shale bed of the Sandia formation. Where the dip slip in the limestone is greatest-as much as 30 feet-the shale in the

\footnotetext{
Figure 7.-Diagram showing the Roll fault and an associated bedding fault along the "silver pipe" bed in the GraphicWaldo mine. The Roll fault dips $45^{\circ} \mathrm{NE}$. and passes upward into a roll in shale.
}

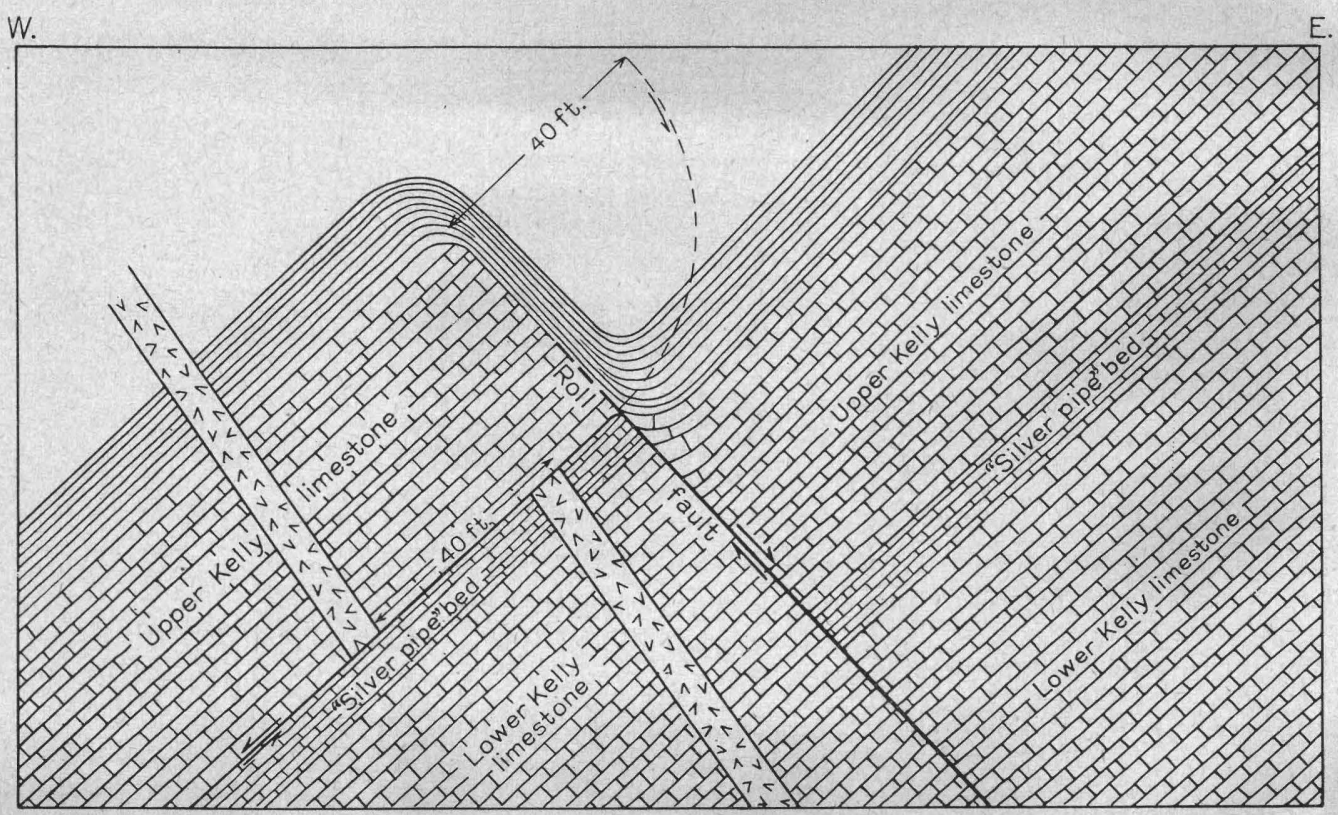

50
0 50 Feet 


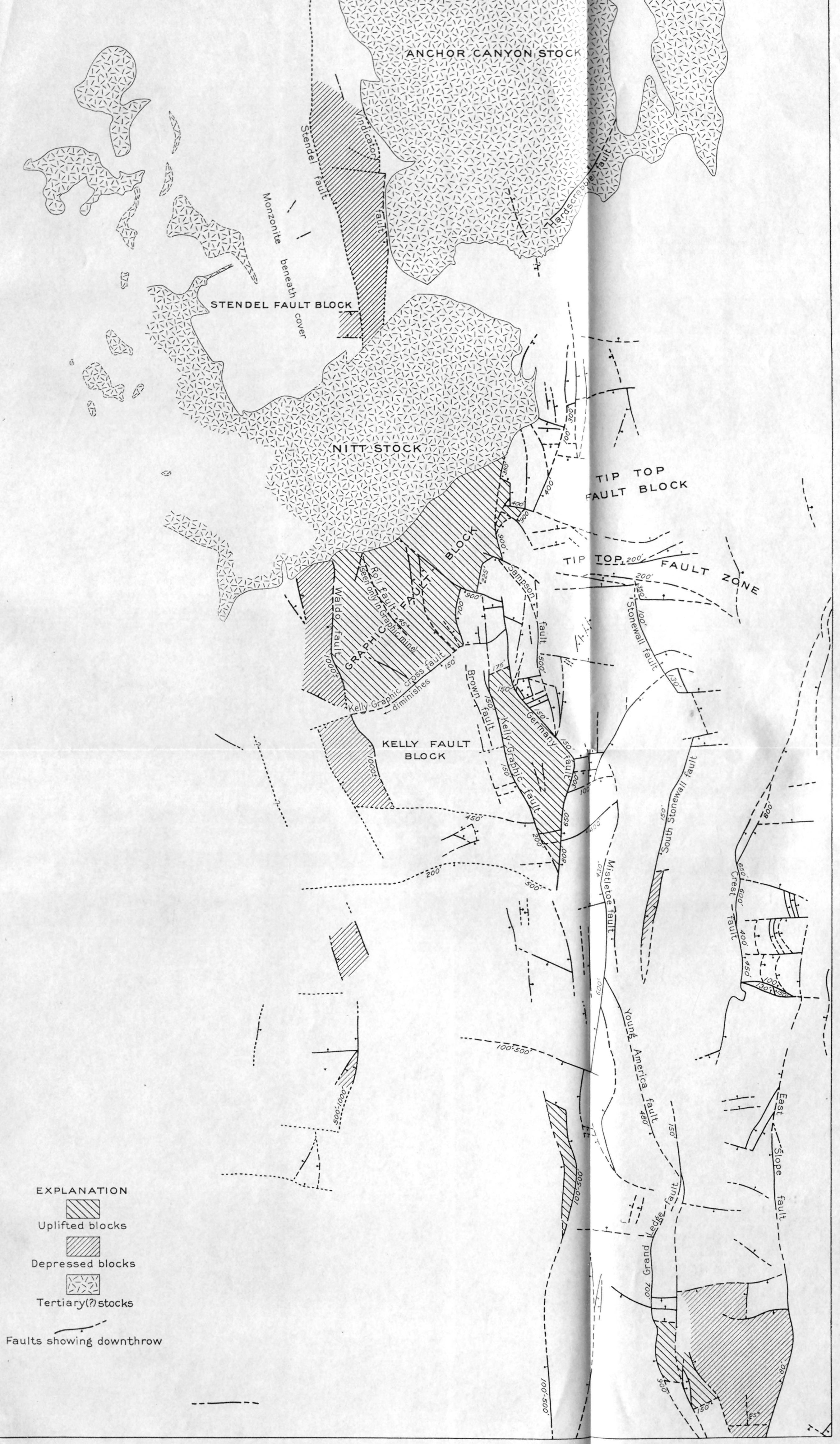




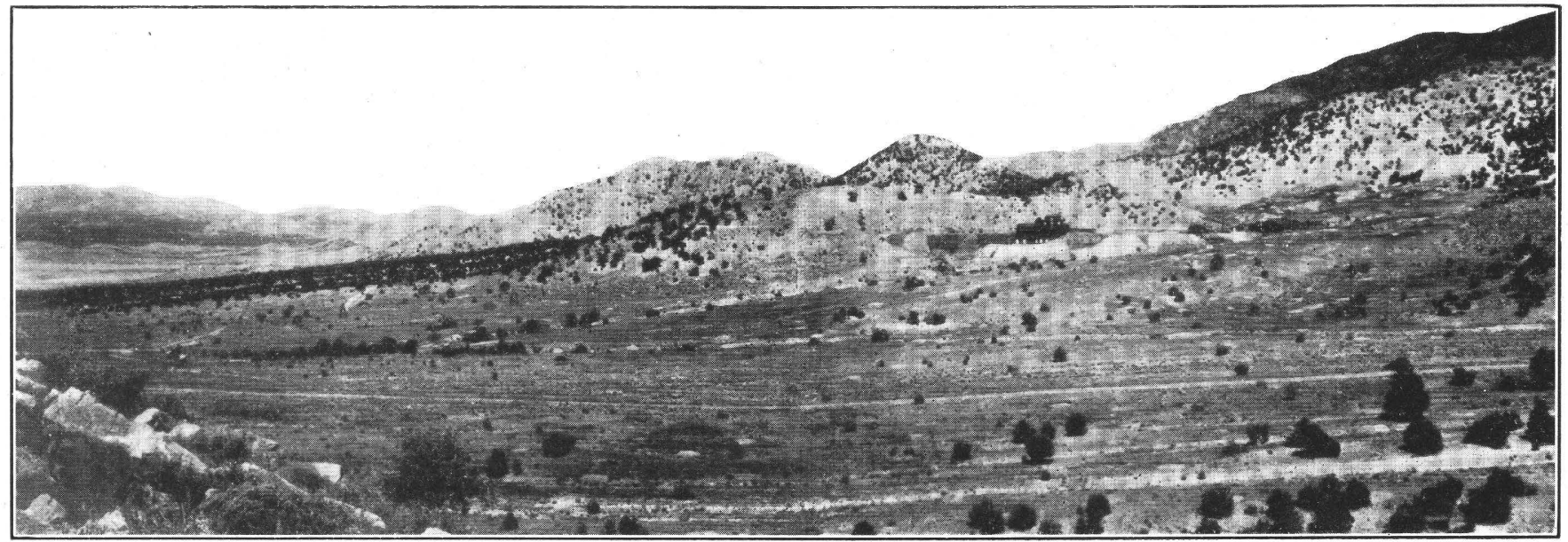

A. FOOTHILls OF MAgDALENA RANGE, LOOKING NORTH FROM LOW RHYOLITE HILL THREE-QUARTERS OF A MiLE WEST OF KELLY.

Waldo tunnel and dump in right middle ground and Waldo shaft and dump at extreme right. The wooded alluvial slope in the left middle ground is cut by shallow gullies that expose theibedrock of pediment B. The low spur behind the dump of the Waldo tunnel is correlated with pediment D. Stendel Ridge in the middle background is correlated with pediment $\mathbf{F}$.

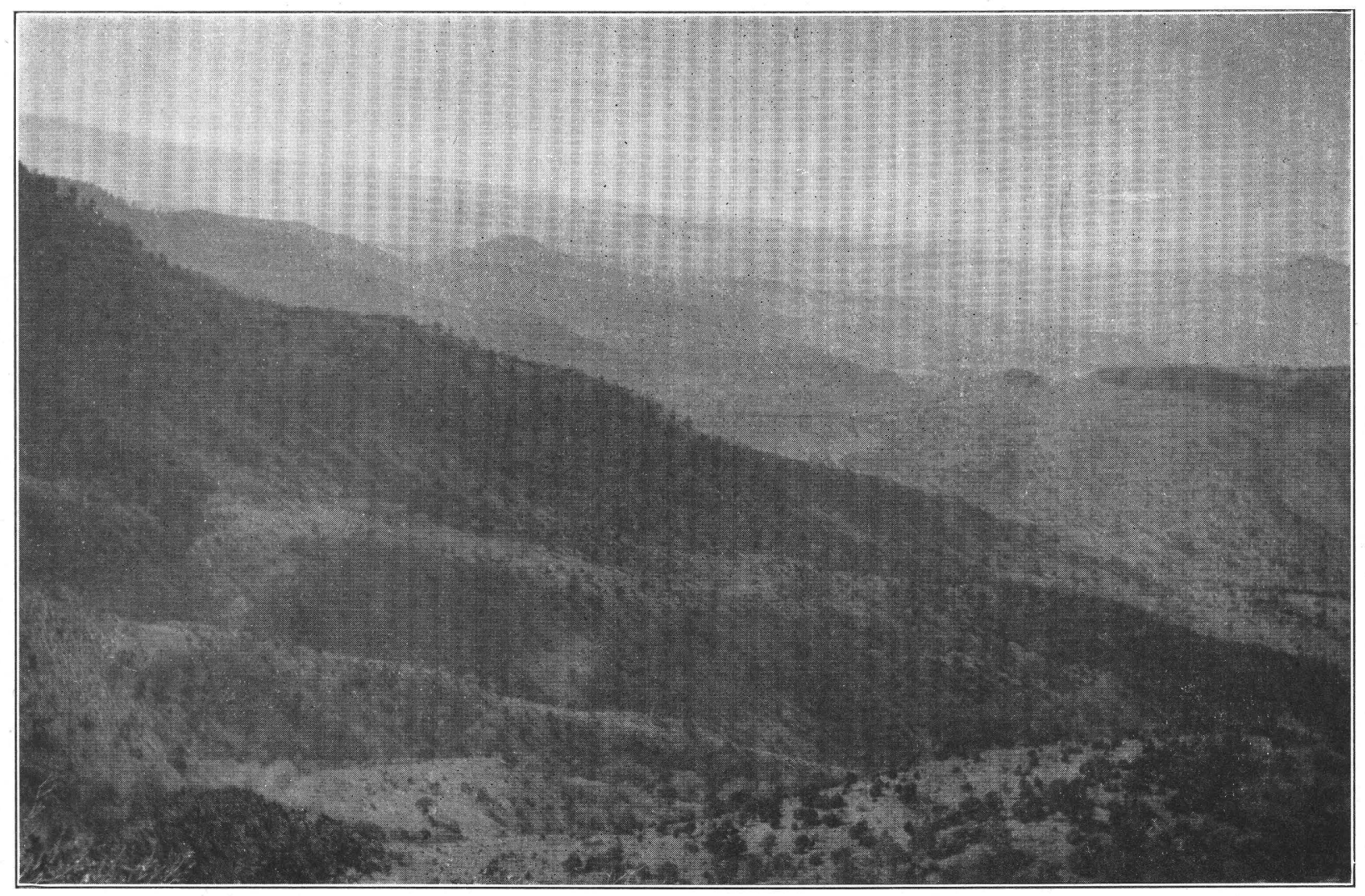

B. UPPER PATTERSON CANYON, LOOKING WEST.

The light-colored bench between the upper and lower shaded slopes in the foreground is covered with alluvium and represents pediment $\mathrm{D}$. 
th 
roll has also been displaced for 15 feet down the dip of the fault. Movement along the "silver pipe" bedding fault is indicated by the offset of a monzonite dike for about 40 feet, the part above the bedding fault moving down the dip. At one place, on level 10 of the GraphicWaldo mine, the bedding fault was seen to curve sharply into the Roll fault, showing that there must have been a rather large component of movement along the junction, which pitched north-northwest at a rather small angle. As the trend of the dike is oblique to the strike of the bedding, southward movement of the upper part of the dike could produce an effect, as seen in cross section, similar to a movement directly down the dip. The relative amounts of strike slip and dip slip have not been determined. To make room for the roll in the shale the Kelly limestone beds above the "silver pipe" bed must have been pushed directly or obliquely down the dip of the bedding fault a corresponding distance. At the same time the bedding planes in the limestone on both sides of the Roll fault were in position to be opened as tension cracks by shearing along that fault, and their permeability to ore-forming solutions was thereby increased. Minor transverse faults and fissures connected the Roll fault with the longitudinal faults along the Graphic tunnel and aided in promoting circulation along both faults.

This relation of late bedding faults to eastward- or northeastward-dipping faults is doubtless common throughout the district. Lamprophyre dikes offset in the same general direction and by the same amount as the monzonite dike just cited have been mapped in the extreme southeastern part of the Graphic-Waldo mine and in the Kelly mine, and one part of another dike beneath a bedding fault was found in the Juanita mine. Where no dikes are exposed along bedding faults, however, it has not been possible to distinguish between early reverse movements that accompanied regional folding and tilting and the later normal movements that accompanied the different stages of faulting since the eruption of the volcanic rocks.

The movements that took place in the intrusive stocks between the periods of dike intrusion and ore deposition are not clearly shown, as the rocks at the surface are largely reduced to residual boulders and very few mine workings penetrate stocks. In the Nitt mine a few dikes branching from the monzonite stock are exposed and are much shattered, but no definite trends of major fractures are shown. The mineralized fractures to the north along Hardscrabble Valley, however, indicate fissuring in a northerly direction. They suggest that a major zone of fissuring in monzonite underlies the upper part of the valley and is in line with the Vindicator fault, along which some movement took place after the intrusion of the Tertiary(?) granite stock and also after that of the white rhyolite dike that occupies the fault. The Hardscrabble workings also show that some shearing has taken place in Tertiary(?) granite along a transverse fault of southwest trend and that where this fault meets a fault or fissure zone of northeasterly trend, the granite is thoroughly shattered. No measurable amount of displacement along either fault could be determined. This evidence, though too small and scattered to be very significant, is in keeping with the idea of minor adjustments along faults throughout the region.

\section{MINOR ADJUSTMENTS AFTER ORE DEPOSITION}

Faulting subsequent to ore deposition is negligible within the district. A little evidence of shattering was noted in a veinlet along the Kelly-Graphic cross fault, and some slickensides were seen in ore along fractures in the Kelly-Graphic fault zone; but no measurable amount of offset was found. Bryan, ${ }^{89}$ however, has called attention to a recent fault scarp along the northeastern base of the Magdalena Range and has suggested that the relative uplift that it signifies has influenced the subsequent topographic development of the range. The part of the range within the district, however, including the valley between the main range and Magdalena Mountain, has acted essentially as a structural unit, although trivial adjustments have doubtless taken place throughout it.

\section{PHYSIOGRAPHIC DEVELOPMENT}

The present topographic features have resulted from several stages of erosion, all of which are later than the main stage of faulting and the intrusion of the monzonite and granite stocks. From the correspondence in altitude of the tops of some of the spurs with remnants of alluvium well above the general alluvial slopes it is concluded that the spurs mark the positions of older bedrock floors, here called rock pediments. The altitudes of other spurs are so related as to indicate still higher pediments. The recognition of these pediments (pl. 21 and fig. 8) throws considerable light on the erosion history of the district, which we have discussed at some length elsewhere ${ }^{90}$ and shall only briefly review here. As the stages of erosion have been traced from the most recent to the earliest that can be recognized, the youngest, represented by the present arroyos, is designated $\mathrm{A}$, and the successively older are $\mathrm{B}$ to $\mathbf{H}$, $\mathrm{H}$ being the oldest that is at all definable.

The most recent pediments, designated B on plate 21 , are well represented on the slope just west of the Nitt mine, in the floor of Anchor Canyon, and at several places in lower Hardscrabble Valley and around Granite Mountain, where bedrock beneath veneers of alluvium is exposed in gulleys and shallow prospect pits. The pediment west of the Nitt mine (pl. $22, A)$ slopes

89 Bryan, Kirk, written communication, 1933.

${ }_{90}$ Koschmann, A. H., and Loughlin, G. F., Dissected pediments in the Magdalena district, New Mexico: Geol. Soc. America Bull., vol, 45, pp. $463-478,1934$. 
about 600 feet to the mile, whereas the alluvial veneer above it slopes 500 feet to the mile. Both pediment and alluvial veneer slope away from the mountain front and in the main directions of drainage. Pediment C, which antedates pediment $\mathrm{B}$, is well represented in the vicinity of South Camp by low spurs and hills of pink rhyolite and silicified andesite. North of Kelly and in Granite Mountain area, where erosion has been greater, pediment $\mathrm{C}$ is not so well represented.

The most clearly defined of the older, dissected pediments is $\mathrm{D}$, which is represented by a sloping alluviumcovered bench (pl. 22, B) along the southwest side of Patterson Canyon between altitudes of 7,725 and 7,875 feet. The north end of the bench is a landslide remnant that has been planed off to conform to the pediment slope. The gentle westerly slope just south of Chihuahua Gulch is also covered, but less conspicuously, with remnants of alluvium between the same altitudes and is evidently another representative of pediment D, although the $\mathrm{D}$ stage of erosion there cannot be sharply distinguished from the $\mathrm{E}$ and $\mathrm{C}$ stages. The intervening spurs and hills that conform to pediment $\mathrm{D}$ are shown on plate 21 .

The saddle that connects Stendel Ridge with the main Magdalena Range has an alluvial cover distinctly higher than the adjacent part of pediment $\mathrm{B}$, though not isolated from it by exposures of bedrock. The saddle conforms in altitude with pediment $\mathrm{D}$ but consists of distintegrated monzonite that is so readily and uniformely eroded that it does not maintain steep slopes but has allowed the alluvium of pediment D to slump down onto that of pediment B. Its slope shows that its alluvial cover was formed by drainage from the east, but the present drainage from the east is diverted northward down Hardscrabble Valley. This valley is so much more directly connected with the trunk drainage channel of the district than is the slope west of the saddle that erosion was correspondingly more rapid and extended the valley headward until it tapped the westward-sloping gulches and diverted their drainage from the adjacent part of pediment $\mathrm{D}$.

Hills and spurs on the north slope of Stendel Ridge that correspond to pediment $\mathrm{D}$ are between altitudes of 6,800 and 7,000 feet. Those with altitudes near 6,500 feet in the Granite Mountain area are also tentatively assigned to pediment $\mathrm{D}$ because of their comparable size and their heights above pediment B. They are about 100 feet above the present valley bottom.

Pediment D corresponds closely in altitude to the bottom of the thoroughly oxidized ore in the Kelly and Graphic-Waldo mines. It appears that erosion of the thick shale member of the Sandia formation from the main fault zone and the lowering of the ground-water level during this stage of erosion favored rapid circulation and oxidation. Erosion during later, comparatively short stages has not been sufficient to lower the water level in the different fault blocks below that of stage $\mathrm{D}$.

No remnants of alluvium above pediment D are preserved, but spurs are so grouped at certain altitudes that, with proper allowance for westerly and northerly slopes, they indicate at least four pediments, which are designated $\mathrm{E}, \mathrm{F}, \mathrm{G}$, and $\mathrm{H}$ on plate 21 . The most distinct of these is pediment $\mathrm{F}$, along which two beveled masses of landslide material remain. It was evidently
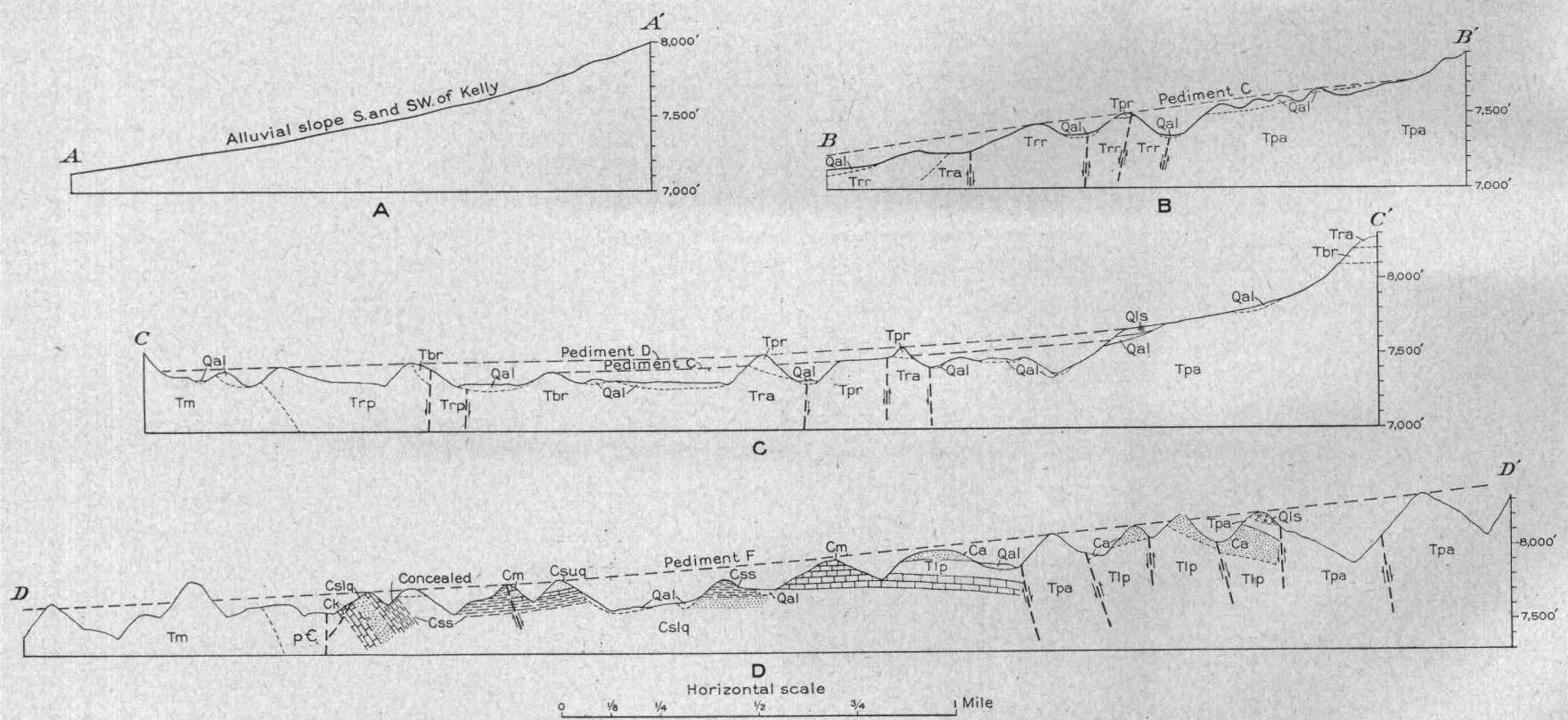

Figure 8.-Profiles showing concordant altitudes of spurs and foothills interpreted as dissected pediments. Lines of profiles are shown on plate 21.

Quaternary: Qal, alluvium; Qls, landslide. Tertiary: Tm, mozouite; Trp. rhyolite porphyry; Tip, latite porphyry; Tpr. pink rhyolite; Trr. red rhyolite; Tua, upper andesite; Tra, red andesite; Tbr, banded rhyolite; Tpa purple andesite, Carboniferous; Ca, Abo sandstone; Cm, Madera limestone; Csuq (upper quartzite), Css (shale), and Cslq (lower limestone), members of Sandia formation; Ck, Kelly limestone. Pre-Cambrian, pC (chiefly argillite, felsite, and granite). 
during the early part of stage $\mathrm{F}$ that rapid erosion of shale along the west side of the Young America and adjoining faults of the Kelly-Graphic zone (pl. 2) developed an oversteepened scarp. This scarp, together with the west dip of the sedimentary rocks and the west-dipping fractures in the underlying granite, led to the formation of the landslides, whose scars are still distinct east of the fault zone from the vicinity of the Young America mine southward.

In tracing the spurs that accord with pediment $\mathrm{F}$, it is found that the present summits on Stendel Ridge also accord with it approximately. These summits imply that the valley floor west and north of the ridge sloped gradually away from them during stage $F$. The valley north of the ridge had an inferred altitude of about 7,000 feet, so the summit of Granite Mountain, therefore, must have been barely exposed above the general slope of pediment $\mathrm{F}$. The volcanic rocks that once covered the northern part of the main range extended beneath this old pediment and were continuous with those of the Granite Mountain area, although broken by fault zones. During still earlier stages of erosion, when the pediments and valley floors were still higher, the main range must have sloped gradually northward to the Granite Mountain area and beyond.

When the erosion cycle began, the northern part of the main range had a volcanic cover 2,000 feet thick (pp. 23, 37). Nothing is known of the corresponding cover over Magdalena Mountain, as the formations that once overlay its present cap of pink rhyolite all lie west of the area studied. There must have been some topographic relief as a result of the faulting, and the earliest stages of postvolcanic erosion must have been guide by it.

The downfaulting of the area between the main range and Magdalena Mountain may have formed a closed basin; but if so, it was doubtless filled at an early stage, and then, owing to the high barrier that the main range formed at the time, the drainage may have been westward.

The principal drainage of the surrounding region, however, was along the Rio Grande. As its western tributaries had relatively short, steep courses mainly through volcanic rocks, the country east of the Magdalena Range was lowered more rapidly than the western slope. The relative downfaulting of the Granite Mountain area, whose more resistant rocks were mainly below the earlier pediment levels, permitted erosion to develop much more rapidly than in the main range. As the more resistant rocks became exposed during and after stage $\mathrm{F}$, erosion became confined to the great transverse fault zones and the adjoining easily eroded stock of Tertiary (?) granite. The courses of La Jenze Creek and its southern tributary became established, Granite Mountain became separated from the main range, and Stendel Ridge began to develop as a spur of the main range.
As the transverse valley between Granite Mountain and Stendel Ridge deepened, drainage from the valley west of the main range became diverted through it, and the topography of the district became much as it is today, except for the subsequent gradual deepening of the valley and the corresponding deepening of the adjoining gulches.

So great an amount of erosion implies a large amount of relative uplift of the range since the main period of faulting that is recorded within the district; furthermore, the more distinct pediments, $\mathrm{F}$ and $\mathrm{D}$, imply halts in the uplift sufficiently long for the valleys in and adjoining the district to broaden and establish temporary base levels. During this intermittent uplift the mass that includes the main range, Granite Mountain, and Magdalena Mountain acted as a unit. Too little is known of physiographic development in the surrounding region to correlate these principal pediments with any definite stages of regional erosion, but the pediments are believed to be related to the varying rates at which Rio Salado and its tributary La Jenze Creek cut their channels downward through the volcanic flows and tuffs that lie east and northeast of the Magdalena Range. The present continuation of this process is apparent along the road between Socorro and Magdalena, where alluvial slopes belonging to one of the more recent stages of erosion are protected by hard rock in some places and are largely removed in others. Bryan, ${ }^{91}$ on the basis of his physiographic studies in the Socorro region, states that pediment $\mathrm{B}$ of the Magdalena Range is in perfect adjustment to Snake Ranch Flats (pl. 1), whose surface corresponds to the older of two distinct erosion surfaces on the east side of the Socorro Mountains; ${ }^{92}$ also that the slight dissection of pediment B may be attributed to climatic causes or to the recent uplift of the Magdalena Range that corresponds to the fault scarps along the northeast base of the range.

\section{ORE DEPOSITS}

\section{HISTORICAL SKETCH}

The historical sketch presented below has been compiled mainly from statistical reports by Raymond, ${ }^{93}$ Mint reports by Burchard, ${ }^{94}$ annual "Mineral Resources" reports by Henderson,,$^{95}$ and short papers by several authors cited in the bibliography (pp. 4-5).

\footnotetext{
01 Bryan, Kirk, written communication, January 1934.

92 Bryan, Kirk, Pediments developed in basins with through drainage as illustrated by the Socorro area, New Mexico [abstract]: Geol. Soc. America Bull., vol. 43, pp. 128-129, 1932.

${ }^{93}$ Raymond, R. W. Statistics of mines and mining in the States and Territories west of the Rocky Mountains (1869, p. 413; and 1872, p. $313)$ : U. S. Treas. Dept., 1870 and 1873.

-4 Burchard, H. C., Report of the Director of the Mint upon the production of precious metals in the United States (in 1881, pp, 327, 340 341 ; in 1882, pp. 340, 376-379) : U. S. Treas. Dept., 1882 and 1883.

95 Henderson, C. W., Annual chapters on New Mexico in Mineral Resources U. S., U. S. Geol. Survey, 1908-24; U. S. Bur. Mines, 1925-31; Minerals Yearbook, U. S. Bur. Mines, 1932-35.
} 
According to Raymond ${ }^{96}$ a California miner found a very rich piece of silver ore in the Magdalena Range in 1866, "and subsequent prospecting expeditions resulted in the discovery of many lodes, most of them small but rich in copper and silver." They were found on the summit and western slope of the range, mainly in its northern part. Raymond gave brief notes on the "Washington lode" and the "Chavez," its south extension, located near the north end of the summit, dipping $35^{\circ} \mathrm{W}$., and containing copper, lead, silver, and gold. He also described the Santa Juliana lode, at the base of the western slope, as a large vein from 10 to 20 feet wide, traceable for a long distance and containing lead carbonate with some copper, silver, and gold. These three names are not mentioned in any other reports, but the Washington lode and the Chavez may correspond to claims between the Ambrosia and Stonewall, and the Santa Juliana to the Juanita, Graphic, or some intervening claim in the main ore zone.

According to Brinsmade, ${ }^{97}$ Gordon, ${ }^{98}$ and others, Col. J. Hutchison (or Hutchason?) discovered lead ore at Kelly and located the Juanita and Graphic claims in the spring of 1866 while looking for rich silver ore said to have been found in that part of New Mexico a short time before. According to records of the General Land Office, however, the Juanita claim was not located until 1875 and the Graphic claim until 1879. Hutchison and his partner, Pete Kinsinger, smelted the ore in adobe furnaces and shipped the bullion to St. Louis as return freight for the bull teams then hauling out supplies for the region over the Santa Fe Trail. Pig lead was then $121 / 2$ cents a pound at St. Louis, but its continued fall in price finally made shipments unprofitable, and mining languished for several years.

Raymond ${ }^{99}$ in 1872 mentioned the Grand Tower, Poor Man's, Little Fanny, Pony, Alpine, Washoe, Sucker, Wolverine, and Sterling as the most prominent carbonate lodes, but of these only the Grand Tower was recorded on Herrick's claim map, compiled in 1910.

The Grand Tower claim, according to Burchard, ${ }^{1}$ was worked about 1872

by a party of adventurous miners and the ore smelted in rude adobe furnaces, and after being taken to St. Louis via the old Santa Fe Trail, was sold simply as lead, no returns being made for the 10 to 30 ounces of silver per ton it carries.

It may be that this shipment is the same as that credited above to Hutchison and Kinsinger, although the claims mentioned are different. The Grand Tower claim, according to the records of the General Land Office, Washington, D. C., was not located until September 20, 1879, and was patented January 25, 1887.

\footnotetext{
9 Raymond, R. W., op. cit. for 1869 , p. $413,1870$.

${ }^{\text {or }}$ Brinsmade, R, B. Kelly, N. Mex - A rinc camp whose ores have been made available by modern metallurgical methods: Mines and Min erals, vol. 27 , p. $49,1906$.

${ }^{98}$ Lindgren, Waldemar, Graton, L. C., and Gordon, C. H., Ore deposits of New Mexico: U. S. Geol. Survey Prof. Paper 68, p. 241, 1910.

${ }^{99}$ Raymond, R. W., op. cit. for 1872 , p. 313,1873 .

${ }^{i}$ Burchard, H. C., op. cit. for 1882 , p. 377,1883 .
}

The Poor Man's and Little Fanny deposits were described as from 30 to 60 feet wide and rich in lead but with "little over $\$ 30$ per ton in silver." Raymond also referred to "a few experiments" that had been made to reduce the ore, which was "carbonate of lead, bearing silver at the rate of $\$ 30$ to $\$ 600$ per ton, and sulphuret of copper also rich in silver." George Way \& Co. had tried to reduce ore from the Little Fannie in a small reverberatory furnace, and had produced " $1,8391 / 2$ pounds of lead containing 66.7 ounces of silver, but much of the lead was lost in the slag." J. D. Baker and brother, after unsuccessful attempts with a reverberatory furnace, built a small cupola furnace and supplied the blast by hand bellows. It was more successful than the reverberatory furnace but was too small to be operated to advantage.

Brinsmade ${ }^{2}$ states that in 1876 , when prices had somewhat recovered after the panic of 1873 , "Col. E. W. Eaton acquired the Juanita claim and smelted its ore for 4 years in an adobe furnace at Kelly or Middle Camp." About 1880 he bought the adobe smelter of Shaw and Ales at South Camp and, changing it to a water-jacketed blast furnace, kept it in blast for several years on lead ore from the Imperial and adjoining claims. This may be the same smelter with a capacity of 40 tons but "out of blast for some time," mentioned by Burchard in his report for $1881^{3}$ as connected with the Iron Mask mine, which was then full of water.

The large ore bodies in the Kelly and Graphic claims were discovered, according to Philip B. Argall, in 1878-79, "when it might be said the district took its first boom." The Graphic claim was purchased for $\$ 30,000$ by Hanson and Dawsey, and the Kelly for $\$ 45,000$ by Gustav Billings. According to the General Land Office records many of the claims in the district were located in 1879-81, including the Alhambra, Ambrosia, Anchor, Cimarron, Graphic, Grand Tower, Hardscrabble, Iron Mask, Juanita Extension, Kelly, Legal Tender, Little Loella, Review, Sampson, Stonewall, and Waldo.

Billings built the Rio Grande smelter at Socorro in 1881. This smelter was operated steadily for several years, using the lead carbonate ores of the Kelly mine, which were low in silver, to flux the siliceous ores from the Socorro and other districts tributary to the Atchison, Topeka \& Santa Fe Railway system. This period was essentially one of silver mining, as shown by the production for the years 1881-87 in the accompanying table of metal output in Socorro County; there was little demand for base metals. The district was said by Burchard in $1881^{4}$ to be "next to Socorro in point of importance." He also said that the ore was principally galena, which occurred in large quantities; it was accompanied in some of the mines by considerable cop-

\footnotetext{
2 Brinsmade, R. B., op, cit., p. 49.

3 Burchard, H. C., op. cit. for 1881 , p. 340,1882

4 Idem, pp. 340-341.
} 
per and in others by zinc, which rendered the ore refractory. Evidently some essentially unaltered sulphide ore had already been found. Burchard continues:

The North and Middle Camps of the district contain the leads most extensively worked in the past, and the ruins of old smelters are still to be seen. It was believed that this galena carried large or at least paying quantities of silver, and shipments to the St. Louis Smelting Works, some years since, aggregating $20,000,000$ pounds, yielded something over $\$ 20,000$ worth of silver. It would seem, with present railroad facilities for the transportation, that mines producing ores of this value could be made to pay, but for some cause work is suspended, and the machinery left to decay.

He referred specifically to the Iron Mask mine and smelter, which were then owned by a company in Toledo, Ohio. The Iron Mask and the adjoining Lungren claims contained "exceedingly high grade ore." The Juniata (Juanita?) was the best-developed and most productive mine, and the Imperial, whose ore unfortunately contained zinc blende, was next in importance. The Graphic mine then had three shafts, each in ore "composed principallly of lead in different forms, iron, and a small amount of silver." The ores mined were reported to be sold to the Cerrillos Smelting Co., for fluxing purposes, the company paying for 12 ounces of silver to the ton. He also referred to the Mammoth claim as on an undeveloped bold outcrop of white quartz over 2,000 feet long and containing "many small veins of rich silver ore." This description could apply either to the vein in felsite east of Hardscrabble Camp or to the long ledges of silicified Kelly limestone along the summit of the range east and southeast of Kelly. The district was then connected with Socorro "by an excellent natural road," and the railroad that was then planned to "intersect the richest part of the Magdalenas" was expected to make a "vast quantity of low- and medium-grade ores of the district * * * valuable." Billings was later instrumental in having a branch of the Atchison, Topeka \& Santa Fe Railway, which was surveyed and constructed in central and southern New Mexico in the period 1879-82, extended from Socorro to Magdalena.

Burchard in $1882^{5}$ said that the Juanita, with much less development than the Kelly in 1882, was reported to show a large body of lead carbonates. The lode was then said to be located and opened up at points for a distance of about 3 miles, "invariably rewarding development by showing a good vein of ore near surface." In other words the main ore zone as defined in this present report had been prospected throughout the extent of the main range shown on plate 2 .

The veins along the upper slope and top of the range had also been well prospected, and, though the silver content of the ores was not high, it was sufficient to make them desirable as flux for smelters treating

\footnotetext{
5 Burchard, H. С., op. cit. for 1882, p. $376,1883$.
}

richer but more refractory ores; for example, ore containing galena and valued at $\$ 40$ a ton was mined in the North and South Imperial claims, which ezidently included the present Young America. A small body of copper ore was mined at the bottom of a 120-foot shaft in the Young America claim.

The Hardscrabble and the adjoining Belcher claims were being steadily worked in 1882. Twenty-five tons of the Hardscrabble ore, shipped to the Cerrillos smelter, gave a return of 25 percent of lead and 33 cunces of silver to the ton.

The Victor and Great Western claims, owned by the Magdalena Mining Co., which also owned the Iron Mask, were both being worked for lead carbonate ores, whose respective assays showed 50 percent of lead and 16 ounces of silver to the ton and 62 percent of lead and 17 ounces of silver. These claims evidently included the unpatented Victor claim, which, according to W. H. Herrick's claim map, compiled in 1910 , adjoins the Oak Forest claim just beyond the southeast corner of the district. On the Josephine claim, leased to the same company, a 5-foot ledge of quartz assaying 50 ounces of silver to the ton was being developed, and the Raven claim, recently purchased for its fluxing ore, also proved to be of value as a silver-lead property. The iron ore included magnetite and also hematite, which contained 23 ounces of silver to the ton. The Raven claim may have been, on the present Medley Ranch, west of Magdalena Mountain, from which magnetic iron ore was said to have been shipped to the South Camp smelter in 1882 (see p. 163).

The Kelly was proving to be a valuable mine. It was developed by a tunnel then more than 200 feet long, presumably one of those along the Kelly-Graphic fault, and by connected drifts, crosscuts, and inclines. The ore was "low-grade sand carbonate" containing some galena, averaging between 50 and 60 percent of lead, about 10 ounces of silver to the ton, and showing a little copper. The ore was being mined at a rate of 35 tons a day, at an average cost of about $\$ 1$ a ton, and was "bought directly on the dump of the mine by the [ore purchaser of the] American Mining Co.'s smelter." This was evidently the name of the Billings company. According to Kirchoff ${ }^{6}$ the ore from the Kelly mine together with custom ore [including lead ore from other counties] treated in Billings' smelter at Socorro accounted for the bulk of the lead produced in New Mexico during the next few years. He estimated the total lead produced in New Mexico at 2,400 tons in 1883, 6,000 tons in 1884, and less than 5,000 tons in 1885, when the Billings smelter produced 4,651 tons of base bullion cortaining 909,652 ounces of silver and 3,926 ounces of gold. Production did not increase in 1886, although in addition to lead produced by the Billings smelter,

${ }^{6}$ Kirchoff, C., Jr., Lead : Mineral Resources U. S. 1882, p. 313 ; 1883-4, p. $425 ; 1885$, p. 258 . 
which continued to be the principal smelter in the T'erritory, the Graphic smelting works produced lead from Magdalena ores. The two smelters produced 7,325 tons of lead in 1887, in spite of the fact that the Kelly mine was at one time thought to be exhausted. Its lower levels had entered sulphide ore, but the discovery of a new ore body by a lessee restored the mine to its old rank for a short time. In 1888 the Graphic mine was closed for a considerable period "because the affairs of the property were much involved," and the output of the Kelly mine decreased in that year and the following year, partly because "dead work" in the spring of 1889 stopped the work of lessees. A small concentrator to treat low-grade ores was operated" "in a very desultory manner." The lead produced from ore mined in Socorro County, practically all from the Magdalena district, amounted to 1,187 short tons in $1889,{ }^{7}$ but the agent for the Director of the Mint gives 1,708 tons. Other mines that were reported to be productive prior to 1890 were the Juanita, Hardscrabble, Cavern, and Grand Ledge.

No reference to the district or to Socorro County was made by Kirchoff in the "Mineral Resources" volumes for 1891-1904, but Brinsmade ${ }^{8}$ and Argall $^{9}$ state that the Rio Grande [Billings] smelter was operated steadily until 1893 , and thereby imply that the Kelly mine and doubtless others were active during that period. The Rio Grande smelter, according to Tuttle, ${ }^{10}$ was handicapped in 1890 , when the Windom bill went into effect, increasing duties on certain grades of leadsilver ores coming from Mexico. Then followed the establishment of larger smelting plants in Mexico and at El Paso, which together with high freight rates, the depression of 1893 , and the apparent exhaustion of lead carbonate ore in the Kelly and Graphic mines, forced the Rio Grande smelter to close permanently. The plant had been employing from 500 to 1,000 men, and when it closed in 1893 Socorro became nearly deserted. In 1901 it was purchased and dismantled by the American Smelting \& Refining Co., which also purchased the El Paso smelter and enlarged it to permit the handling of copper ores. Since then lead and copper ores from the Magdalena district have been shipped to El Paso. Slag from the smelter dump at Socorro, because of its metal content and fluxing value, has also been shipped to El Paso.

Between 1894 and 1902 the mines were worked in desultory fashion, while the lead carbonate ores, the only ores of shipping grade, were approaching exhaustion. In $1896^{11}$ the Graphic smelter, of 100 tons daily capacity, was erected $1 \frac{1}{2}$ miles west of Kelly. It is

\footnotetext{
${ }^{\tau}$ Kirchoff, C., Jr., op. cit. for 1886 , p. $146 ; 1887$, p. $110 ; 1888$, p. 89 ; $1889-90$, p. 80 .

8 Brinsmade, R, B, op cit, p, 49 .

- Argall, Philip B., op. cit., p. 366.

10 Tuttle, E. G., The Magdalena mining district, New Mexico: Mines and Minerals, vol. 33, p. 275, 1912.

${ }^{11}$ Brinsmade, R. B., op. cit., p. 49. Argall, Philip B., op. cit., p. 366.
}

not to be confused with the smelter casually mentioned by Kirchoff in 1886 and $1887 .^{7}$. It was operated intermittently until 1902 , when the lead carbonate ore of the Graphic mine was largely exhausted. It was handicapped by the shortage of local siliceous ore and by high freight rates on ore, fuel, and supplies from elsewhere. In 1902 a 50-ton water-jacketed stack was erected half a mile south of the Graphic smelter by B. A. Statz, of Albuquerque, who was connected with the Cavern and Grand Ledge mines, but it was never blown in. The closing of the Graphic smelter marked the end of the lead carbonate period of the district, when mining practically came to a standstill.

Production of zinc in the western states had been negligible until 1898 , partly because the oxidized lead ores, which had greatly predominated, had been essentionally free from zinc and partly because metallurgists had not been successful in separating zinc from lead in sulphide ores; but the large bodies of zinc-lead sulphide ore found below the oxidized zone in the principal lead-mining districts induced successful efforts at separation. The earliest production of zinc from sulphide ores in the Magdalena district, however, was overshadowed by the discovery of high-grade zinc carbonate ore in the Graphic mine.

In this mine the oxidized lead shoots that extended from the northern part of the third or main tunnel level down to level 5 had been practically worked out by 1892 , and the mine was believed exhausted; but it was sold for $\$ 90,000$ to A. Bement, of Terre Haute, Ind., for whom it was managed by J. B. Fitch. Fitch found a 20,000-ton shoot of oxidized lead ore at the south end of level 3 but had mined it all by 1902 , when he and C. T. Brown took a bond and lease on the mine. They discovered zinc carbonate beneath this shoot in 1903 and completed the purchase. ${ }^{12}$

They took a sample to southwest Missouri, where it so impressed the operators of the Joplin smelter that a large shipment was ordered and the district's zinc period began. Other shipments were made to Wisconsin, where zinc carbonate ores were also in high favor with zinc-pigment manufacturers. Heretofore large quantities of zinc carbonate, whether recognized or not, had been removed as waste and thrown over the dumps; but now large bodies of these ores began to be worked in the Kelly and Graphic mines, and smaller bodies, doubtless, in several other mines. Zinc operators generally became interested. In 1904 the Sherwin Williams Paint Co. purchased the Graphic mine from Fitch and Brown for $\$ 150,000$ and organized the Graphic Lead \& Zinc Mining Co. to operate it. The name was changed a year or two later to the Ozark Smelting \& Mining Co., which is the present owner. Later in 1904 the Tri-Bullion Smelting \&

\footnotetext{
12 Brown, C. T., oral information, 1915.
} 
Development Co., of Chicago, bought the Kelly mine from Mrs. Gustav Billings of Cincinnati for a price reported to be $\$ 200,000$, and the Empire Zinc Co. bought the Lillie group, which lay west of the Kelly mine. ${ }^{13}$ Large shipments were made, in part from dumps, but mainly from underground bodies that already were largely blocked out and could be mined and shipped with a minimum of time and labor. ${ }^{14}$ Zinc recovered from ore shipped amounted to 1,856,297 pounds in 1903 and $17,991,780$ pounds in 1904. The district became the leading zinc producer of New Mexico and retained its rank until 1920. New Mexico became one of the five leading western states in zinc production. According to Haddon,,$^{15}$ the zinc carbonate ore from Kelly averaged more than 40 percent of zinc and brought $\$ 15$ a ton at the mine on a 35-percent basis with $\$ 1$ per unit variation.

Haddon also calls attention to minor shipments of high-grade copper ore, carload lots from the Young America "having averaged as high as 13.5 percent." Rich ore containing cuprite and native copper was opened in the Graphic mine in 1905 in a structural trough at the bottom of the oxidized zone, and " 40 or 50 cars of this ore" in unsorted lots "netted the company an average of $\$ 1,500$ per car."

The zinc carbonate, which for the most part underlay the lead carbonate ore shoots, passed downward in part into mixed sulphide ore. Rather large shipments of sulphide ore were made from the Kelly mine in 1906, and the Ozark Smelting \& Mining Co. was said to have developed about 100,000 tons of ore too low in grade to be shipped as zinc ore without milling. The Key mine in the same year had opened a stope along the "silver pipe" bed.

The sulphide ore shipped in 1904-6 contained about 21 to 26 percent of zinc, 12 percent of lead, 15 percent of iron, 1 to 3 percent of copper, 1 to 5 ounces of silver to the ton, a trace of gold, and 10 percent of silica. Oxidized lead ore shipped contained 20 percent or more of lead and 2 to 5 ounces of silver to the ton. The oxidized zinc ore contained 25 percent or more of zinc and as much as 3 ounces of silver to the ton, which was not recovered. Some siliceous ore, containing 15 to 30 ounces of silver to the ton, evidently from the uppermost part of the Kelly limestone, was shipped from the Juanita mine, and one car of ore from the Young America mine assayed 1 ounce of gold to the ton, although gold rarely exceeded 0.05 ounce to the ton in the ores shipped from the district.

The Waldo tunnel, driven for about 1,700 feet to connect with the silver pipe bed on level 9 of the Graphic-Waldo mine, was completed in June 1906.

\footnotetext{
13 Statz, B. A., Geology of the Magdalena district, New Mexico: Min. Sci., vol. 66 , p. $407,1912$.

14 Brinsmade, R. B., op. cit., p. 49.

15 Haddon, R. W., Zine mining in New Mexico: Eng. and Min. Jour., vol. 81, p. 845,1906 .
}

Ore from this mine was then being dumped below the Waldo adit and run to the railroad terminal at the Graphic smelter on a 36-inch tram, and the empty cars were hauled back by horses. Ore from other mines was hauled in 4-horse, 5 -ton wagons to the same terminal. Brinsmade in 1906 also mentioned the 50-ton Cavern mill, "the only wet concentrator in the camp" as having been built a few years earlier "at a cost of about $\$ 25,000$ to clean low-grade lead carbonate ore. Water for power and washing was supplied from a spring on the Cavern claims." The mill was connected with the mine by an inclined tramroad. He also mentions the Hardscrabble tramroad and "the unused Woodland aerial ropeway."

In $1906,11,700$ tons of zinc-lead sulphide ore was shipped, along with 23,000 tons of zinc carbonate, 500 tons of lead carbonate, and 300 tons of copper and siliceous ores. The output of the Kelly mine was greatly increased, as was that of the Juanita, whose shipments included a small amount of high-grade siliceous silver ore, whereas that of the Graphic-Waldo mine decreased. The Mistletoe mine (formerly the Enterprise) was being developed by the Ark Mining \& Smelting Co., and the Cavern mine had blocked out a considerable tonnage of ore containing lead, copper, and a little gold. The Wheel of Fortune mine, in the adjoining Hop Canyon district to the south, was being developed.

The years 1907 and 1908 were marked by a general industrial depression, but the great decrease in zinc production in the district in 1907 was attributed to the large amount of development work and surface improvement by the larger companies. At the Kelly mine the Tri-Bullion Smelting \& Development Co. erected a new surface plant and did 2,783 feet of development work. The Traylor shaft of the Kelly mine by that time had released a large flow of water that would supply its mill. The same company was sinking the Nitt shaft, and the Graphic mine was being developed from the Waldo tunnel. The Germany Mining Co. was developing the Germany and Alhambra properties and was reported to have exposed considerable low-grade ore. The Mine Development Co., which had been developing the Tip Top mine since 1900 , had connected the Tip Top with the Key'workings, and had exposed three stopes. It had also completed the road from Kelly to the mine, built its ore bins, and begun shipping ore. ${ }^{16}$ The Magdalena Tunnel Co., evidently affiliated with the Mistletoe Mining Co., had purchased the Utica Nos. 1, 2, and 3 claims in the vicinity of Mistletoe Gulch. These companies, under management of $\mathrm{Wm}$. F. Gordon, formerly manager of the Ozark Zinc Oxide Co., spent the entire year in development work, drove their main or Gordon

${ }^{16}$ Late news from mining camps: The Mining World, vol. 27, pp. 38 and $576,1907$. 
MAGDALENA MINING DISTRICT, NEW MEXICO

tunnel practically to completion, and reported the finding of a new ore shoot.

Mineral production in 1908 was far below the average for $1904-6$, but the output of zinc represented 93 percent of New Mexico's total. The new work done by the Ozark Smelting \& Mining Co. in the Graphic mine and in the Ida Hill group, which it had also acquired, now amounted to 6,837 feet of tunnels, drifts, crosscuts, and raises. The old workings of these mines totaled about 7 miles. The zinc and zinc-lead ores were sent to the company's zinc oxide plant at Coffeyville, Kans. The Tri-Bullion Smelting \& Development Co. operated the Kelly mine for about 6 months of the year and shipped a large tonnage of zinc ore and concentrates to smelters. The company's concentrating plant had a capacity of 100 tons a day. Zinc carbonate ore was shipped from the Juanita mine. The Mine Development Co. on the Key group shipped a few cars of oxidized lead-silver ore and reported a considerable tonnage as blocked out and awaiting better prices, evidently an over-optimistic report. The Mistletoe \& Magdalena Tunnel Co., evidently a consolidation of the two companies active in 1907, had completed a pneumatic concentrator which operated for a while. In 1909 the Tri-Bullion Smelting \& Development Co. began operating its wet concentration plant with roasters and magnetic separators. The Ozark mill was closed in that year, while experiments were being made with the then new flotation process.

In 1909 and 1910 the production of zinc approached its record for 1904-6 and that of lead exceeded the records for those years. Seven mines produced in 1909 , including the Hardscrabble, Key, Old Soldier (in the Hop Canyon district), and the Germany, which was a new producer.

The annual report of the Tri-Bullion Smelting \& Development'Co. for the fiscal year ending October 31, 1910, stated that ores mined and milled from the Tri-Bullion (Kelly) group aggregated about 20,000 tons, of which the shipments aggregated 14,645 tons of crude ore, zinc and lead concentrates, and iron middlings. C. T. Brown, then lessee on the upper levels of the Kelly mine, shipped an additional 15,074 tons, and the company's net income from all ore shipped was $\$ 270,285.36$. The milling of sulphide ores by this company began in January 1910, and the last crude sulphide shipped was billed January 14 . The company's wet mill was reported successful in the separation of lead from zinc and its magnetic mill in the separation of zinc blende from pyrite. The mills were equipped with eight Traylor tables, two Deister slime tables for separating lead from zinc, and four Dean magnetic separators. The combined capacity of the mills was about 1,800 tons per month. The Ozark Smelting \& Mining Co., besides shipping zinc sulphide ore to its oxide plant at Coffeyville, Kans., continued experiments with the flotation process. The Mistletoe \& Magdalena Tunnel Co., besides its mine development, experimentally treated lead-zinc carbonate ore in a 50 -ton concentrator, equipped with Sutton and Steele dry tables.

Production was much less in 1911 and 1912. The Tri-Bullion Smelting \& Development Co. continued to be the chief producer, operating in conjunction with lessees. Its mill in 1911 produced 7,710 tons of zinc concentrates, 1,404 tons of lead concentrates, 4,525 tons of iron middlings, and 232 tons of zinc carbonate. Its net income from company operation and royalties was $\$ 271,739$. Lessees on the upper levels of the Kelly mine stopped operations in September 1911.

The Ozark Smelting \& Mining Co. shipped lead and zinc carbonates to smelters, but its production of sulphide ore was evidently curtailed, pending completion of a new mill that was being built in 1912. The Mistletoe mill was idle. A considerable tonnage was reported to have been developed in the Germany mine, and several shipments of zinc and lead carbonate ores were made in 1912. The Juanita mine, which submitted no reports of activity to the U. S. Geological Survey in 1909 and 1910, made large shipments of zinc and lead carbonate ores in 1912 .

The years 1913-16 were marked by a great advance in the production of zinc, which reached a maximum in 1916. Production of lead and copper fluctuated but increased markedly on the whole and reached maximums in 1917. The increase is attributed in part to the Ozark mill, completed in February 1913, and to the demand for metals, created by the World War, which followed the minor depression of 1914. The Ozark Smelting \& Mining Co., which became the leading proaucer in 1913, made a big increase in output in 1915. Its 150 -ton concentration mill was operated continuously and attained a daily output of 125 tons. Its zinc concentrates were shipped to smelters and zinc oxide plants. The company also shipped crude copper sulphide, lead sulphide, zinc sulphide, zinc-lead carbonate, and zinc carbonate ores.

The Tri-Bullion Smelting \& Development Co. operated the Kelly mine and its combination mill for only 6 months in 1913, shipping lead, iron, and zinc concentrates, crude zinc carbonate, lead carbonate, and copper sulphide ores. Shipments, according to the company's annual report for 1913 , included 2,572 tons of zinc concentrates, 1,467 tons of lead concentrates, 2,096 tons of iron middlings, 1,505 tons of copper ore, 417 tons of zinc carbonate ore, 137 tons of zinc sulphide ore, and 45 tons of lead carbonate ore. The smelter returns on these shipments amounted to $\$ 153,861$, but after deduction of operating costs the net loss amounted to $\$ 21,678$. The cost of development work at Kelly amounted to an additional $\$ 28,208$. Late in 1913 the Kelly mine and the mill were purchased for $\$ 87,500$ by the Empire Zinc Co., which made several changes 
in the mill. The Tri-Bullion Smelting \& Development Co., however, retained ownership of the Nitt and adjoining claims, which adjoined the Ozark Smelting \& Mining Co.'s ground on the north.

In 1914 the Ozark Co.'s production came not only from the Graphic but also from the Waldo workings, which included the downward and northward continuation of the southern shoots in the Graphic mine, as well as a smaller shoot along the Waldo fault farther west. A 500-foot vertical shaft was started near the fault. The Nitt group, which contained the northern ends of both ore zones, was leased to the Ozark Co. by the Tri-Bullion Co. in 1914 or 1915. The Ozark mill was destroyed by fire on August 10, 1916, and its reconstruction was begun soon afterwards.

Zinc carbonate was shipped from the Kelly mine in 1914, but its mill underwent remodeling and did not resume operation until 1915. The mill was then equipped with several units for the magnetic separation of magnetite-specularite and ferruginous zinc blende and gravity separation of pyrite and galena; but the magnetic process was successful only in separating the highly magnetic magnetite-specularite, as there was sufficient iron in gangue material to prevent its electromagnetic separation from the zine blende. The main shoot of sulphide ore in the Kelly mine was approaching exhaustion toward the end of 1916, and development work had failed to disclose more than small bunches of ore elsewhere. The Juanita, Germany, and Ambrosia mines were minor producers during the period 1913-16. The Hardscrabble mine, which had been idle since 1909, resumed production in 1916; and the Black Cloud mine, adjoining the Mistletoe, also began operation in that year, after building a 40-ton concentration mill, but it was active for only a short time.

The decline in 1917 and 1918 of the war demand for zinc was followed by the depressions of 1919 and 1921 . In 1921 zinc production throughout the West was almost entirely suspended. The Ozark Smelting \& Mining Co. was active throughout the period, shipping its usual variety of ores. Its mill resumed operations in March 1917, being equipped with a Blake crusher, rolls, Chilean mill, tube mill, Janney flotation machines, Ovoca classifiers, and Oliver filters, and continued until late in 1918. During 1919 and 1920 it was operated only for short periods, largely for testing purposes. The concentrates accumulated in 1918 and 1919 were shipped in 1920.

The Kelly mine and mill were operated in 1917, but the magnetic mill was not operated thereafter, and the output of zinc carbonate ore declined. In 1920 several cars of zinc carbonate but only two cars of lead-silver ore was shipped, and the mine was idle throughout 1921. Other mines from which shipments were reported during the period 1917-20 were the
Juanita, South Juanita (in 1919 only), Hardscrabble. Germany, and Ambrosia (1916 and 1918). The Graphic-Waldo, operated by the Ozark Smelting \& Mining Co., was the only mine active in 1921.

As the largest developed ore shoots in the GraphicWaldo, as well as in the Kelly mine, had been exhausted at about the time of the 1921 depression, the district's output never closely approached the tonnage of the war period, even though the period 1922-29 was prosperous in the western mining states as a whole. The Graphic-Waldo mine was operated only by lessees from 1922 to 1925 , and its mill remained idle. The Kelly mine remained idle in 1922 , its mill was dismantled, and the magnetic machinery was moved to the Empire Zine Co.'s plant at Canyon City, Colo. During the rest of the period it was worked by lessees. The Juanita mine was operated during every year of this period by lessees, who shipped lead and zinc-lead sulphides, as well as the usual oxidized ores. The South Juanita was productive in 1927-29 and the Black Cloud in 1923-28. A few shipments were made from the Germany and the Vindicator in 1929. Slag with a sufficient lead-silver content to be used as flux was shipped from the old Graphic smelter dump at Magdalena in 1925 and from the old dump at South Camp in 1926.

The Nitt mine, which had been leased to the Ozark Smelting \& Mining Co. from 1914 to 1922, was leased to J. A. Macdonald of Kelly in 1923. It continued production for several years, although the lack of mill facilities restricted its operations to the selective mining of ore that could be shipped crude to smelters.

The years 1926 and 1927 were marked by brief renewed milling operations. The Ozark mill, idle since 1921, was set in operation on February 15, 1926, and was operated at the rate of about 125 tons daily on low-grade zinc ore from the Graphic-Waldo mine. The concentrate, with a ratio to crude ore of 4.7 to 1 and a content of 48 percent of zine, was exported to Belgium. The mill was remodeled in 1927 and operated from January to August. The Chilean mill was replaced with a ball mill, and the Janney flotation miachines were replaced with mineral separation machines, which together with finer grinding raised the grade of zinc concentrates from 48 to 52 percent. The ore was ground to pass completely through a 65 -mesh and 80 percent through a 200 -mesh screen. The crude zinc sulphide ore contained 1 to 3 percent of lead, which was separated from the zinc-lead flotation product by tabling. The mill has been idle since 1927 .

The Black Cloud mill, which was operated in 1927 and 1928, produced several hundred tons of 45 -percent lead concentrate from lead carbonate ore. The ore, which also contained some galena, anglesite, quartz, and iron oxide, was sulphidized in a 5 -foot agitator, tabled, and floated. At the Kelly mine (Hughes lease) 
lead carbonate ore was tabled during the first quarter of 1927 and made a 43-percent concentrate. Shipments were made by R. R. Foster from the Black Cloud tailings pile, the Juanita mine dump, and the slag dumps of the old Kelly (Graphic?) and Socorro smelters.

The output of the district was less in 1928 than in any previous year for which records are available, except the depression years of 1907 and 1921. Lead ore dominated in 1928 and 1929, and the output of gold was more than usual in 1928. The Waldo workings below the tunnel level, which had been allowed to fill with water in 1928, were unwatered in 1929 but, owing to the outlook of the zinc market, were allowed to fill again. The mine then remained idle until April 1937, although some dump ore was shipped by lessees. The Nitt and Juanita mines continued to be operated by lessees in 1928-30, and occasional shipments were made by the South Juanita in 1927-28 and by the Germany and Vindicator in 1929.

The district had thus become essentially dormant before the beginning of the great depression in the fall of 1929. Only one carload of ore was reported from the district in 1931, and the 804 tons reported in 1932 probably consisted largely of gold ore, with probably small amounts of silver, lead, and lead-zinc ore.

Some recovery was made in 1933 and 1934, and annual shipments from then until 1939 fluctuated between 1,110 and 5,525 tons. The Kelly mine was worked intermittently under the Hughes lease from 1928 until 1939. Its output was mainly zinc-lead sulphide ore, which was shipped to Coffeyville, Kans., whereas its silver-lead-copper ore was shipped to El Paso. The Graphic-Waldo mine was reopened in April 1937 and was active until February 1938, and again during the last quarter of 1939. Zinc and zinc-lead ores mined by the company and lessees were shipped to Coffeyville, Kans. Other mines active during the interval 1934-39 were the Morning Star, which made small shipments, chiefly of gold ore, to the El Paso smelter in 1934-36, and the Mistletoe mine, which was active during part of 1938 and produced most of the gold-silver-lead ore shipped from the district in that year. In 1939 the Oro Alto Mining Co. shipped goldsilver-lead-copper ore from a property south of Kelly, and small shipments of smelting ore were reported from other properties. Several lots of silver-lead ore were shipped from dumps during the period 1934-39.

In the Water Canyon district the Open Cut mine was active during 1935, 1937, and 1939, and experimental concentrations of its gold-silver ore were undertaken. Small shipments of silver-lead and high-grade gold ore were made from the Queen property in 1935, 1936, and 1937, and a 4-ton shipment of lead ore was made from the Balakohna No. 1 claim in 1937.

It thus appears that the Magdalena district and the adjacent areas will continue to be small producers until the demand for zinc justifies the resumption of milling and of developments in relatively little explored parts of the district. As shown elsewhere, there is reason to expect substantial reserves of zinc-lead sulphide ore in at least three mines-the Graphic-Waldo, Linchburg, and Grand Ledge-Cavern-but production from them must await times that will justify the necessary reclamation of flooded and caved workings and the exploration of promising undeveloped ground.

\section{PRODUCTION}

Events eited in the foregoing pages are summarized in the accompanying table (pp. 84-85) which shows the output of Socorro County from 1881 to 1940 and that of the Magdalena district from 1903 to 1940. Figures for the years 1881-1902 in the table were compiled by F. B. Blockson, under the direction of C. W. Henderson, of the United States Bureau of Mines, from records of the United States Mint at Denver, Colo. Collecting of detailed records of ore and metal output was begun by the Division of Mineral Resources, United States Geological Survey, in 1903 and continued until 1924, when that division was transferred to the United States $\mathrm{Bu}$ reau of Mines, which has continued the work. The records for New Mexico have been compiled for both bureaus since 1907 by C. W. Henderson, who has kindly supplied all the data tabulated in this report.

Socorro County was organized about 1881, and any 
metal produced before that year may have been credited to Grant County. ${ }^{17}$ Socorro County at first included also the present Sierra and Catron Counties, ${ }^{18}$ but in the accompanying table the output of those counties has been deducted by Henderson, so the figures represent only production within the present area of Socorro County.

Steady production in the Magdalena district probably began in 1881, when Gustav Billings began to operate the Kelly mine. The lead output in Socorro County from 1881 and the zinc output from 1900 to the present time have been entirely from the Magdalena district, with the exception of a few trivial amounts of lead noted in the table. Comparison of the ratios of gold and silver to lead in the earlier years with those in the years when separate figures were tabulated for the Magdalena district shows that the output of gold and silver in the county came largely from other districts until 1900. No estimate of the Magdalena output of gold and silver for the early years is worth attempting, however, as some of the oxidized lead ore mined then was evidently rather rich in silver and a few small shipments of siliceous and copper ores were unusually rich in gold. The other districts continued to contribute to the gold and silver output of the county until 1914 and made minor contributions to the copper output until 1917, but the total metal output of the county since 1902 is only little greater than that of the Magdalena district.

The total value of the Magdalena output to 1904 was estimated by Jones ${ }^{19}$ to be $\$ 8,700,000$, of which $\$ 5,800,000$ was credited to the Kelly and Graphic mines.

\footnotetext{
${ }^{17}$ Burchard, H. C., op. cit. for 1881 , pp. 339-340, 1882

18 Burchard, H. C., op. cit. for 1883 , p. $601,1884$.

19 Jones, F. A., New Mexico mines and minerals, p. 119, Santa Fe, N. Mex., 1904.
}

Brinsmade ${ }^{20}$ estimated the total value to be $\$ 6,600,000$, to which the Kelly and Graphic mines contributed 90 percent. The accompanying table, which makes no allowance for any small shipments between 1866 and 1880 , shows a total value of $\$ 6,548,068$ for the output of the encire county from 1881 to 1903 inclusive and therefore agrees closely with Brinsmade's estimate. The small extent of the workings, other than those of the Kelly and Graphic mines, and the little success experienced in early efforts to treat the ore implies that the quantity of unaccounted ore could not have been very great, and the rounded figure of $\$ 6,600,000$, therefore, appears to be essentially accurate.

The bulk of the output of all the metals recorded has come from the Kelly and Graphic-Waldo-Nitt ore bodies. From 1903 to 1939 , inclusive, these mines accounted for 87 percent of the ore mined, 22 percent of the gold, 76 percent of the silver, 98 percent of the copper, 98 percent of the lead, and 99 percent of the zinc recorded. The Juanita mine contributed 2.7 percent of the ore mined and the remainder comprised small shipments from the other mines listed in the table on page 86. Shipments made in 1904 and later years are tabulated or quoted in the mine descriptions on pages $124-158$.

The figures for the Magdalena district, which are quoted from Henderson's annual chapters in Mineral Resources of the United States and the Minerals Yearbook, include small shipments from the adjoining Water Canyon and Hop Canyon districts and from other claims in the vicinity whose locations have not been definitely given. All of these shipments that have been reported from 1905 to 1939 are recorded in the table on page 86 . For the most part they appear to

\footnotetext{
${ }^{20}$ Brinsmade, R. B., op. cit., p. 49, 1906.
} 
Production of metals in Socorro County and Magdalena mining [Compiled under direction of C. W. Henderson, Geological Survey

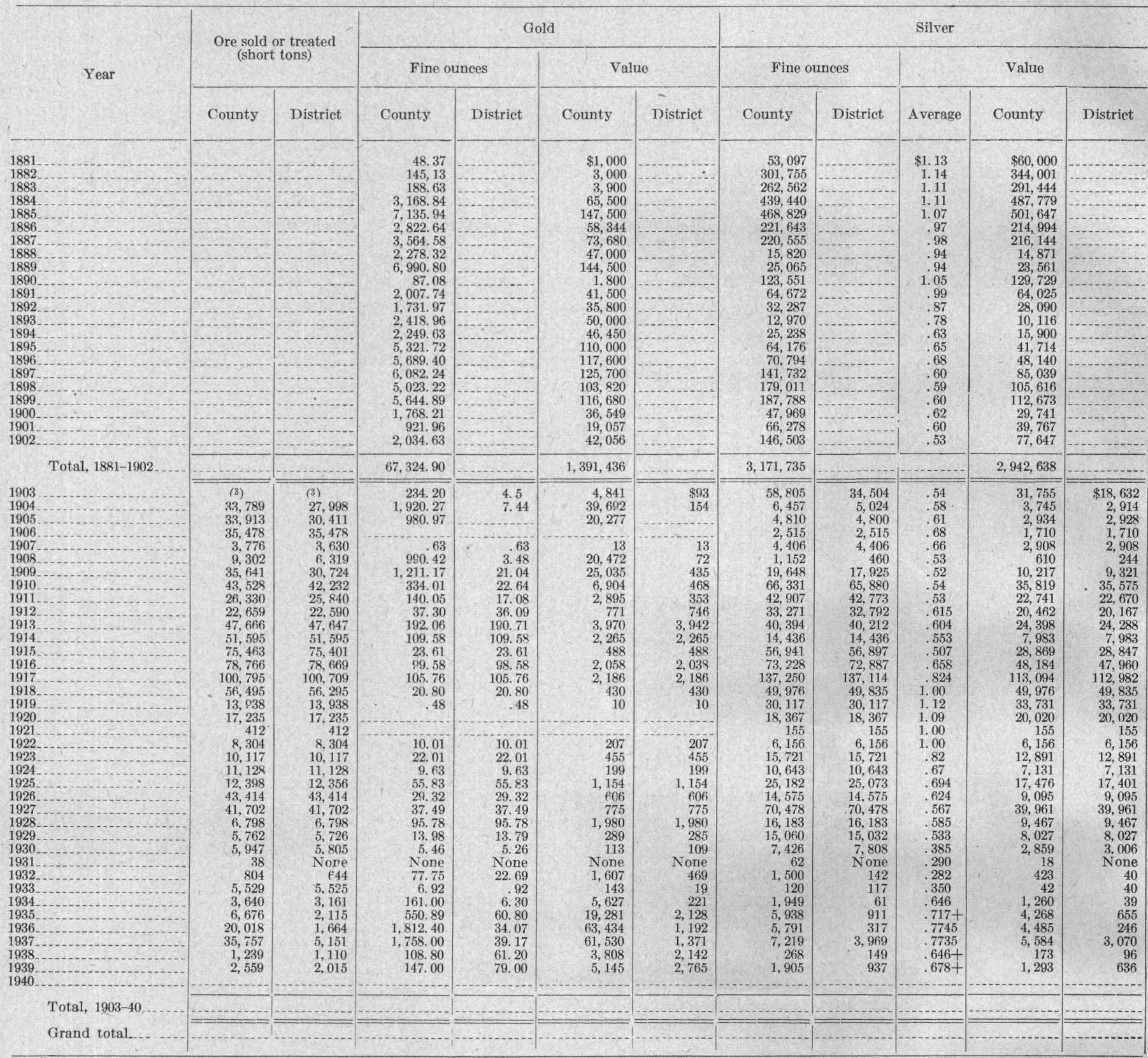

1 Practically no zine.

${ }_{3}^{2}$ Small shipments of zinc.

41,136 pounds valued at $\$ 50$ came from outside Magdalena district.
$\$ 44,563$ pounds valued at $\$ 3,164$ came from outside Magdalena district. 610,000 pounds valued at $\$ 870$ mined outside Magdalena district.
723,700 pounds valued at $\$ 1,185$ mined outside Magdalena district. 
district, New Mexico, 1881-1940, in terms of recovered metals

and Bureau of Mines, U. S. Department of the Interior, Denver, Colo.]

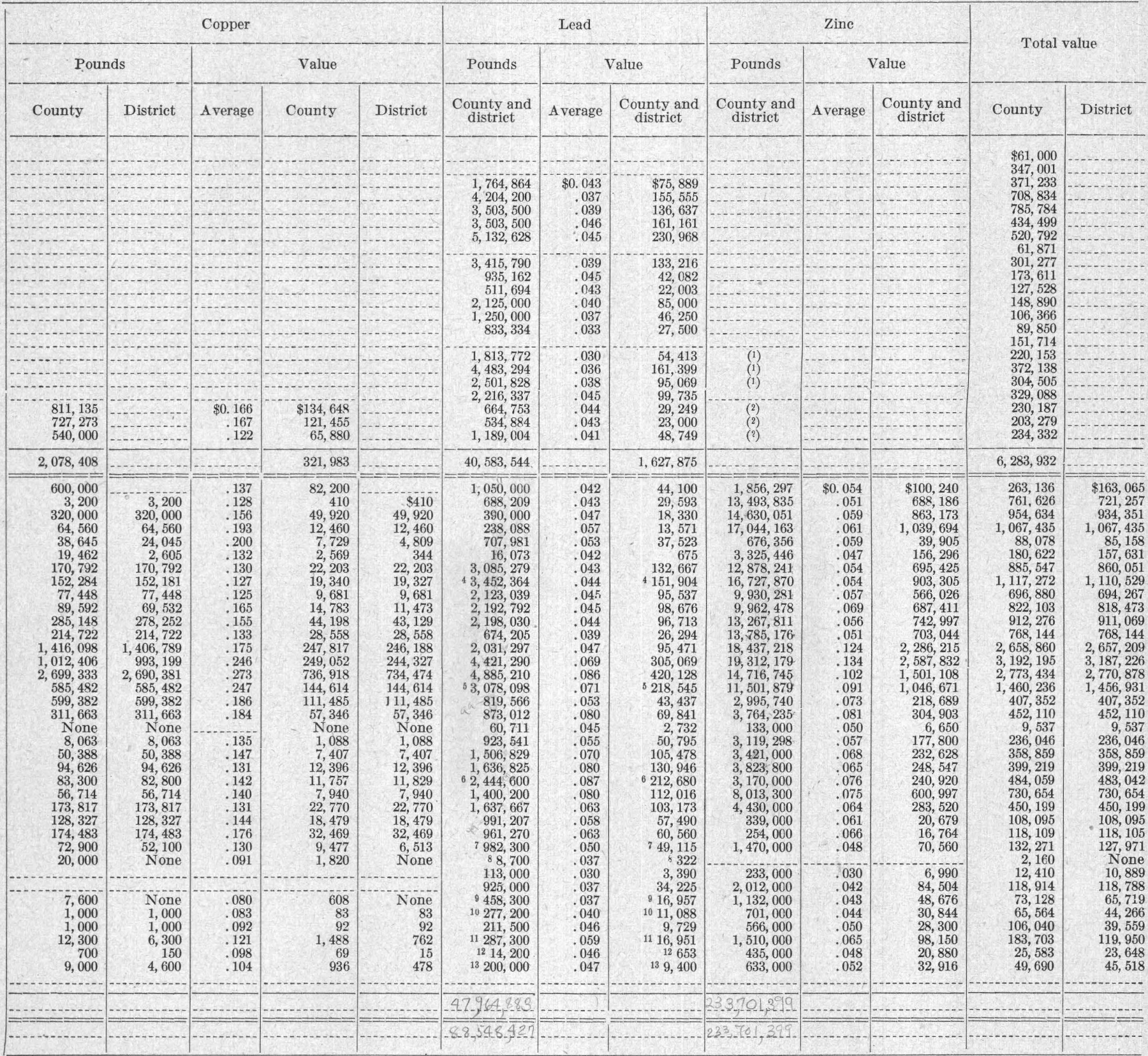

88,700 pounds valued at $\$ 322$ mined outside Magdalena district. 4,700 pounds valued at $\$ 174$ mined outside Magdalena district.
10 14,300 pounds valued at $\$ 572$ mined outside Magdalena district.
11 6,000 pounds valued at $\$ 354$ mined outside Magdalena district. 123,000 pounds valued at $\$ 138$ mined outside Magdalena district.
1314,400 pounds valued at $\$ 677$ mined outside Magdalena district. 
Ore shipped from small properties, mostly in outlying districts, 1905-39,1 and gross metal content [Data collected by C. W. Henderson, Geological Survey and Bureau of Mines, U. S. Department of the Interior, Denver, Colo.]

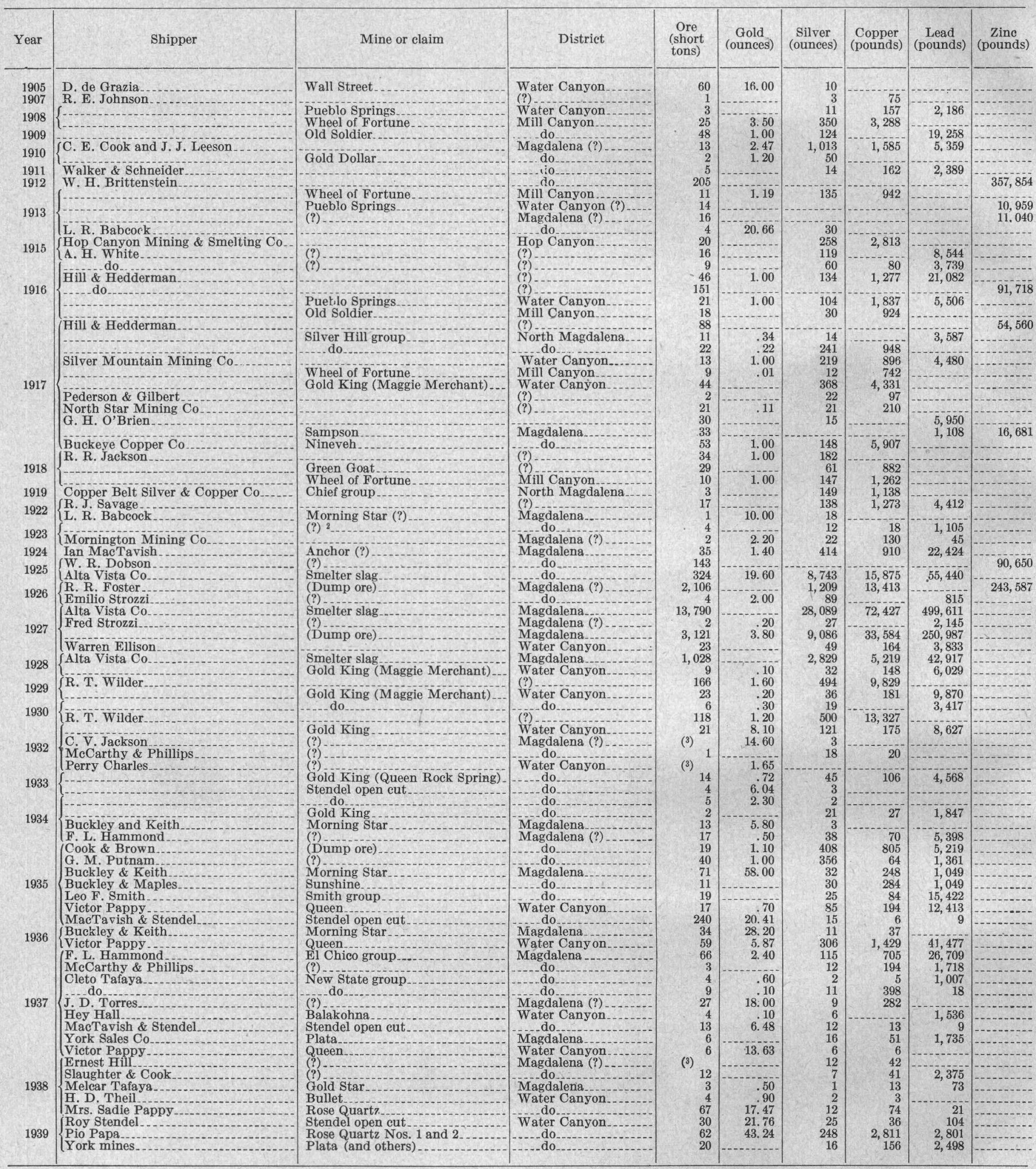


Minerals of the ore deposits

\begin{tabular}{|c|c|c|c|c|c|c|c|c|c|c|c|c|}
\hline & \multirow[b]{2}{*}{ Zone } & \multicolumn{7}{|c|}{ Ore minerals } & \multicolumn{3}{|c|}{ Gangue minerals } & \multirow[b]{2}{*}{$\begin{array}{c}\text { Carbonates, sulphates, } \\
\text { and fluorides }\end{array}$} \\
\hline & & Iron & Manganese & Zine & Lead & Copper & Silver & Gold & $\begin{array}{l}\text { Silicates of lime, mag- } \\
\text { nesia, iron, and } \\
\text { manganese }\end{array}$ & Silica & Aluminum silicates & \\
\hline \multirow[t]{2}{*}{ 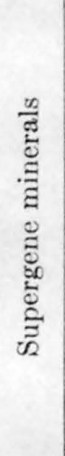 } & Oxidized. & $\begin{array}{l}\text { Limonite (goe- } \\
\text { thite). } \\
\text { Hematite. } \\
\text { Jarosite. } \\
\text { Melanterite. }\end{array}$ & $\begin{array}{l}\text { Pyrolusite. } \\
\text { Psilomelane. } \\
\text { Wad. } \\
\text { Chalcophanite. }\end{array}$ & $\begin{array}{l}\text { Smithsonite (co on - } \\
\text { taining cadmium } \\
\text { carbonate and the } \\
\text { cadmium sulphide, } \\
\text { greenockite). } \\
\text { Hydrozincite. } \\
\text { Aurichalcite. } \\
\text { Hemimorphite (cala- } \\
\text { mine). } \\
\text { Chalcophanite. } \\
\text { "Tallow clay." } \\
\text { Goslarite. } \\
\text { Willemite. }\end{array}$ & $\begin{array}{l}\text { Cerussite. } \\
\text { Anglesite. } \\
\text { Plumbojarosite. } \\
\text { Wulfenite. } \\
\text { Vanadinite. }\end{array}$ & $\begin{array}{l}\text { Malachite. } \\
\text { Azurite. } \\
\text { Aurichalcite. } \\
\text { Chrysocolla. } \\
\text { Chalcanthite. } \\
\text { Antlerite. } \\
\text { Cyanotrichite. } \\
\text { Spangolite. } \\
\text { Cuprite. } \\
\text { Native copper. } \\
\text { Tenorite. }\end{array}$ & Cerargyrite (?). & Native gold. & & $\begin{array}{l}\text { Opal(?) } \\
\text { Chalcedony (?). } \\
\text { Quartz. }\end{array}$ & $\begin{array}{l}\text { Clay minerals: } \\
\text { Allophane. } \\
\text { Halloysite. } \\
\text { Beidellite. } \\
\text { Kaolinite. }\end{array}$ & $\begin{array}{l}\text { Calcite. } \\
\text { Aragonite. } \\
\text { Thaumasite. }\end{array}$ \\
\hline & Sulphide enrichment. & & & & & $\begin{array}{l}\text { Chalcocite. } \\
\text { Covellite. }\end{array}$ & $\begin{array}{l}\text { Native silver. } \\
\text { Argentite (?). }\end{array}$ & Native gold. & & & & \\
\hline \multirow{4}{*}{ 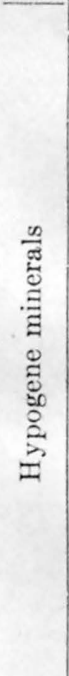 } & $\begin{array}{l}\text { Low temperature (ep- } \\
\text { ithermal). }{ }^{\circ} \\
50^{\circ}-150^{\circ} \mathrm{C} \text {. }\end{array}$ & & & & & & & & $\begin{array}{l}\text { Montmorillonite (?). } \\
\text { Celadonite. }\end{array}$ & Chalcedony. & & Caleite. \\
\hline & $\begin{array}{l}\text { Mild temperature } \\
\text { (leptothermal) } .^{2} \\
100^{\circ}-200^{\circ} \mathrm{C} .\end{array}$ & Pyrite. & & $\begin{array}{l}\text { Sphalerite (zinc } \\
\text { blende low in iron). }\end{array}$ & Galena. & Chaleopyrite. & $\begin{array}{l}\text { In argentiferous } \\
\text { galena. } \\
\text { In siliceous ore. }\end{array}$ & Native gold (?). & & $\begin{array}{l}\text { Quartz. } \\
\text { Jasperoid. }\end{array}$ & Sericite. & $\begin{array}{l}\text { Barite. } \\
\text { Fluorite. } \\
\text { Calcite. } \\
\text { Dolomite. } \\
\text { Siderite. } \\
\end{array}$ \\
\hline & $\begin{array}{l}\text { Moderate tempera- } \\
\text { ture (mesotherm- } \\
\text { al) } 1^{\prime} \\
150^{\circ}-300^{\circ} \mathrm{C} .\end{array}$ & $\begin{array}{l}\text { Pyrite. } \\
\text { Pyrrhotite(?). }\end{array}$ & & $\begin{array}{l}\text { Sphalerite (zinc } \\
\text { blende high in } \\
\text { iron). }\end{array}$ & Galena. & $\begin{array}{l}\text { Chalcopyrite. } \\
\text { Bornite (?). }\end{array}$ & & & $\begin{array}{l}\text { Serpentine. } \\
\text { Chlorite. } \\
\text { Epidote. }\end{array}$ & $\begin{array}{l}\text { Quartz. } \\
\text { Jasperoid. }\end{array}$ & $\begin{array}{l}\text { Sericite. } \\
\text { Chlorite. } \\
\text { Epidote. }\end{array}$ & Sideritic carbonate. \\
\hline & $\begin{array}{l}\text { High temperature } \\
\text { (hypothermal and } \\
\text { pyrometasomatic) } .^{1} \\
300^{\circ}-800^{\circ} \mathrm{C} \text {. }\end{array}$ & $\begin{array}{l}\text { Specularite. } \\
\text { Magnetite. }\end{array}$ & & & & & & & $\begin{array}{l}\text { Epidote. } \\
\text { Garnet (andradite, } \\
\text { grossularite). } \\
\text { Hedenbergite. } \\
\text { Actinolite (?). } \\
\text { Tremolite (?). } \\
\text { Diopside. } \\
\text { Wollastonite. }\end{array}$ & Quartz. & $\begin{array}{l}\text { Tourmaline. } \\
\text { Andalusite. } \\
\text { Garnet (grossularite). }\end{array}$ & $\begin{array}{c}\text { Calcite (platy crys- } \\
\text { tals). }\end{array}$ \\
\hline
\end{tabular}


represent ore mined during prospecting and development. Most of the properties represented were reported active for only a few years, but some at least received assessment work throughout most of the period. It is noteworthy that little or no output has been reported from several claims that were active in the early ' 80 's, and perhaps in the '90's as well. Some of these claims, for example, the Young America and Sampson, which later were taken over by the large companies, are known to have been worked on a small scale by lessees during the world-war period, but their outputs were evidently included in those of the controlling companies.

During the lead period, 1882-1903, the price of lead ranged from 3 to 4.6 cents a pound, but fluctuations in price do not appear to have had much effect on the quantity of lead produced, which was evidently governed mainly by the availability of ore. The steady decline in the price of silver from 1891 to 1894 is not reflected in the quantity of lead produced, as the ore was prevailingly low in silver.

The complete records of output, from 1904 to the present, began just as the oxidized zinc ores of the district were attaining full development. The output of these oxidized zinc ores attained its maximum just before the Nation-wide depression of 1907-8, during which the development and treatment of complex sulphide ores in the two principal mines became welladvanced. The prices of lead and zinc were fairly steady from 1904 to 1913, that of lead averaging about 4.6 cents a pound and that of zinc about 5.7 cents. Fluctuations in output during that period coincided with difficulties in milling, which, so far as can be inferred from the annual chapters in Mineral Resources of the United States, rendered the production rather unprofitable; but thereafter the annual output of ore, stimulated by World War prices, increased to a maximum in 1917 (although the maximum value had been reached in 1916), and operations were profitable. By 1918 , however, an oversupply of zinc had accumulated in the United States, and a decrease in output followed, especially during the dull post-war year of 1919 and again in 1921, when very little zinc was produced throughout the country. The decrease in the Magdalena district is also accounted for by the practical exhaustion of the principal sulphide ore bodies in both the Kelly and Graphic-Waldo mines. Between 1921 and the depression that began in 1929 the prices of zinc and lead averaged higher than in the pre-war period, and the Ozark mill was put in operation in 1926 and 1927. The Graphic-Waldo mine was partly unwatered in 1928, but its discontinuance, together with the fact that any mill ore above water-level was not worked or developed in either the Graphic-Waldo or Linchburg mines suggests that current prices were not sufficiently encouraging to warrant activity. Since 1927 the entire output of the district has been made by lessees. No ore was shipped from the district in 1931, but substantial outputs were made in 1933, 1934, and 1937, principally from the Kelly mine. As many ores in the undeveloped areas referred to later as deserving attention are likely to be similar in grade and composition to those already produced and to involve similar problems of treatment, the foregoing review and the tabulated data may serve as a basis for judging market conditions that would favor a renewal of activity.

\section{MINERALS OF THE MAGDALENA DISTRICT}

By S. G. LASKy and G. F. LoughLIN

As an appreciation of the significance of minerals that constitute the ore deposits of the district is essential to a consideration of the character, distribution, and origin of the ores, descriptions of these minerals are presented in considerable detail. Most of the minerals described were studied in the field and collected by Loughlin in 1916 and were studied in the laboratory by Lasky in 1929 and 1930. We are indebted to W. T. Schaller, of the Geological Survey, for the critical reading of these descriptions, for the investigation of the cadmium content of smithsonite, and for the descriptions of a few unusual minerals; also to Herman Wuestner, of Cincinnati, Ohio, who had made an extensive collection of minerals in the Magdalena district and supplied some of the unusual specimens studied by Schaller. 
An alphabetical list of the ore and gangue minerals occurring in the district is given below. Original rockforming minerals and their alteration products are not included, even though they constitute gangue in some ores, as they are of no fundamental importance in the interpretation of ore-forming processes.

The minerals in this list include those formed by ascending ore-forming solutions (hypogene minerals) and other minerals derived from them by the action of descending waters (supergene minerals). All minerals of the list are arranged in the accompanying table according to the principal metals they contain, and those of the hypogene group are subdivided according to the relative temperatures at which they were deposited. A few minerals, either because they were deposited through a great range of temperature or

Alphabetical list of minerals in the Magdalena district

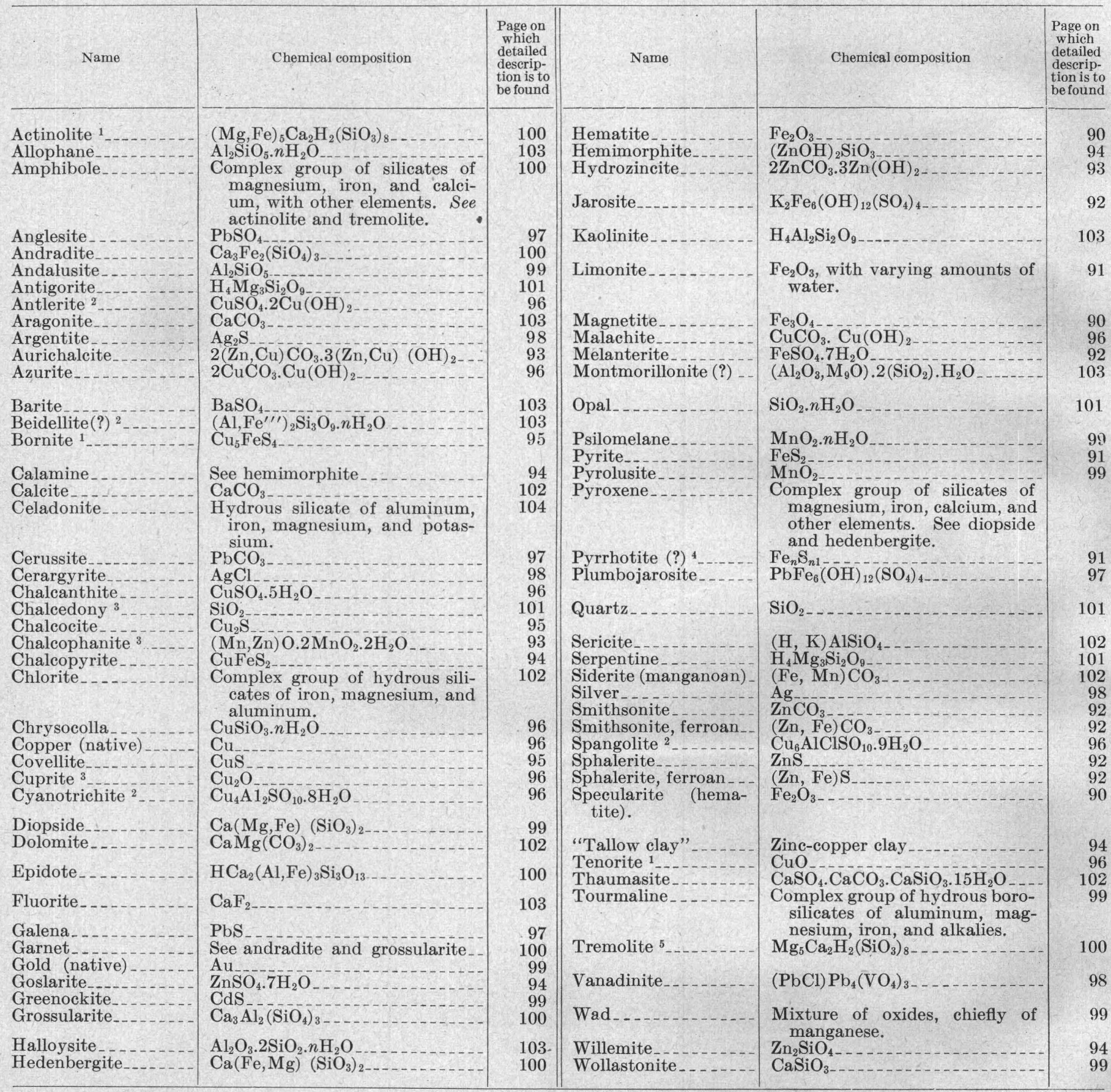

1 Reported in Wuestner, Herman, A check list of minerals from Kelly, N. Mex. Rocks and Minerals, vol. 5, pp. 127-130, 1930.

2 Determined by W. T. Schaller, U. S. Geological Survey, 1937.

3 Reported by C. H. Gordon in U. S. Geol. Survey Prof. Paper 68, p. 253, 1910, and by Wuestner, Herman, op. cit., pp. $127-130$.

${ }_{4}^{4}$ Reported by Philip Argall, Min. and Sei. Press, vol. 112, pp. 129-130, 1916. 
because they contain more than one metal, are represented in more than one place.

The subdivisions are based on relative temperatures. they follow Lindgren's classification, which was first proposed in $1907^{21}$ and was supplemented by Graton in $1933 .{ }^{22}$ Neither this nor any other arrangement is perfectly consistent, as some minerals, notably pyrite, quartz, calcite, sericite, and epidote, may form throughout a great range of temperature and may depend on the compositions of reacting solutions and rocks rather than on temperature; but the arrangement adopted emphasizes the characteristic positions of the minerals in the deposits of the district and therefore their significance in the interpretation of the deposits and in the practical problem of ore hunting. Very few definite experimental data are available regarding the temperatures at which the different minerals can form under anything like natural conditions, and the grouping of the minerals is therefore largely relative. Of the minerals formed by replacement of limestone, wollastonite can be formed in the laboratory between temperatures of $400^{\circ}{ }^{23}$ and $1,500^{\circ},{ }^{24}$ and its occurrence at Magdalena is such as to suggest that it formed near the lower end of this range. The magnetic specularite may indicate a temperature between $300^{\circ}$ and $500^{\circ} \mathrm{C}$. (See p. 90.) Data on the other silicate minerals listed in the high-temperature group are not so definite, but field relations show that most or all of them were formed at lower temperatures than wollastonite, though still during the earliest stage of mineral deposition. Specularite and magnetite are closely associated with these silicates but were deposited later and evidently at still lower temperatures.

The sulphide minerals, particularly pyrite, are also closely associated with silicate minerals and especially with the iron oxides specularite and magnetite, but in view of experimental and microsccpic evidence it is most likely that pyrite began to form as the iron oxides ceased to form. This change may conveniently be regarded as marking the boundary between the high-temperature and moderate-temperature minerals in the Magdalena deposits formed by the replacement of limestone, though the boundary is not sharply defined. (See p. 91.) Under different conditions pyrite may form at higher temperatures. Sphalerite with a high content of iron followed the main deposition of

\footnotetext{
21 Lindgren, Waldemar, The relations of ore deposition to physical conditions: Econ. Geology, vol. 2, pp. 105-127, 1907; A suggestion for the terminology of certain mineral deposits: op. cit., vol. 17, pp. 292 294,1922 .

22 Graton, L. C., The depth zones in ore deposition: Econ. Geology vol. 28 , pp. 513-555, 1933; The hydrothermal depth zones : Ore deposits of the Western States (Lindgren volume), pp. 181-197, Am. Inst. Min. Met. Eng., 1933.

2:3 Allen, E. T., and White, W. P., On wollastonite and pseudo-rollastonite-polymorphic forms of calcium metasilicate: Am. Jour. Sci., 4th ser., vol. 21 , p. $89,1906$.

${ }^{24}$ Bowen, N. L., Schairer, J. F., and Posnjak, Eugene, The system, $\mathrm{CaO}-\mathrm{FeO}-\mathrm{SiO}_{2}$ : Am. Jour. Sci., 5th ser., vol, 26, p. $207,1933$.
}

pyrite, and galena and chalcopyrite followed the main deposition of sphalerite. As all these minerals were formed for the most part by the replacement of limestone, any unreplaced remnants of limestone beside or within masses of the high-temperature minerals were subject to replacement later by moderate-temperature minerals, resulting in a confusing association of minerals at some places.

On the basis of mineral association and proximity to exposed igneous stocks, there might be some justification for classifying the sulphides as high-temperature minerals. On the whole, however, the sulphide minerals, which crystallized distinctiy later than the silicates and the iron oxides, extend farther from the stocks and farther from the main fissures along which mineralizing solutions were introduced. They are therefore consistently assigned to the moderate-temperature class.

Barite and fluorite are abundant only in places well removed from the centers of mineralization, and are therefore the most characteristic minerals of the outlying deposits, which were necessarily formed at relatively mild temperatures. The sphalerite associated with conspicuous amounts of barite is commonly lower in iron than that near the high-temperature centers, but no comparative analyses bearing on this difference have been made.

Calcite represents a wide range in temperature. Its long pointed crystals or scalenohedrons represent a stage later than the barite and fluorite, but other forms represent hotter or earlier stages. A conspicuous feature of some of the mixed oxide-sulphide ores is the presence of radiating aggregates of platy calcite crystals that may be mistaken underground for tremolite or some similar silicate. These crystals have in part replaced silicates and in turn have been replaced by specularite and sulphides, or they may represent limestone that recrystallized during impregnation by specularite; but either suggestion implies formation at a temperature above that at which the iron-rich sphalerite formed.

Quartz also represents a wide range in temperature, as it is associated with characteristic minerals of most of the different groups; however, it is most abundant in the outlying parts of the district, especially the southern part, where it forms the immense masses of fine-grained to dense jasperoid that have replaced limestone. These masses in turn are cut by veins containing barite, quartz, and sulphides and evidently represent an outlying, milder temperature facies of the early stage of mineral deposition. In other words, the early siliceous solutions from a deep source in the southern part of the district became cooled below the silicate-forming range while rising through the sili- 
ceous pre-Cambrian rocks and on reaching the overlying Kelly limestone were only able to replace it with silica.

Of the minerals that have replaced siliceous rocks, the only mineral commonly regarded as indicative only of high temperature is tourmaline, which is confined to pegmatite stringers in Tertiary (?) granite and to minor cracks in aplite, monzonite, felsite, and argillite near the Tertiary (?) granite stock east of Hardscrabble Camp (see pp. 41, 49). Its relation to other ore or gangue minerals is too obscure to warrant further comment here. The most characteristic gangue minerals in the siliceous rocks are quartz, sericite, epidote, chlorite, and calcite. The epidote with quartz, feldspar, and calcite is present in a few veinlets in monzonite near contacts with high-temperature silicate deposits in limestone and evidently indicates deposition at a relatively high temperature; but sericite, quartz, epidote, and chlorite are closely associated with sulphides in partly replaced monzonite, granite, and volcanic rock and evidently represent deposition at a moderate temperature for the most part.

\section{IRON MINERALS}

\section{SULPHIDE ZONE}

SPECULARITE AND MAGNETITE

Of the two high-temperature iron oxides, specularite and magnetite, specularite is by far the more widely distributed. It forms bladelike crystals in radiating sheaves and interlacing mats. Single blades average about 1 millimeter in length, and few exceed 2 millimeters. Practically all the specularite seems to be magnetic. Most of it contains admixed magnetite, but some that appears free from magnetite even at a magnification of 385 diameters is also magnetic.

This magnetism may be due to submicroscopic particles of magnetite, or it may be a property of the specularite itself; for recent experiments ${ }^{25}$ show that $\mathrm{Fe}_{2} \mathrm{O}_{3}$ oxidized from $\mathrm{Fe}_{3} \mathrm{O}_{4}$ is magnetic between temperatures of $300^{\circ}$ and $500^{\circ} \mathrm{C}$. If such magnetic $\mathrm{Fe}_{2} \mathrm{O}_{3}$ (magnetic specularite) is formed in nature ${ }^{26}$ and if the magnetism is retained as the mineral cools down through geologic time, magnetic specularite would constitute a good geologic thermometer.

Magnetite commonly forms irregular grains and aggregates interstitial to the specularite blades or coating them. (See pl. 23, A.) It also forms minute grains within specularite (see pl. $23, B$ ) that locally are predominant and even form complete pseudomorphs after specularite. (See pl. 23, C.) In some places the magnetite forms octahedra as much as 0.5 millimeter in diameter, and in a few places it is cut by veinlets of crystalline though nonbladed hematite. These different relations imply slight oscillations in the physical conditions that controlled the deposition of the two minerals.

The specularite-magnetite aggregates form masses several feet in diameter along the main ore zone in the northern part of the Graphic-Waldo mine rather near the Nitt monzonite stock, but small masses or layers in sulphide and partly oxidized ores have been seen in the southern part of that mine and in the Kelly mine as far south as the Big Twenty stope, 3,300 feet from the stock. A typical occurrence in sulphide ore is shown in figure 9. Specularite and magnetite in nearly equal proportions are also present in the ore of the Hardscrabble mine 2,200 feet north of the Nitt monzonite but close by the Tertiary (?) granite stock. The magnetite there forms distinct octahedra as much as 0.5 millimeter in diameter.

25 Gotoh, Yuuichi, On the reduction of ferric oxide by hydrogen and oxidation of metallic iron reduced from ferric oxide: Inouye commemoration volume, Ryojun College Eng. Mem., pp. 393-413, 1934.

28 Winchell, A. N., Maghemite or oxymagnite : Am. Mineralogist, vol. 16, pp. $270-271,1931$.

W.

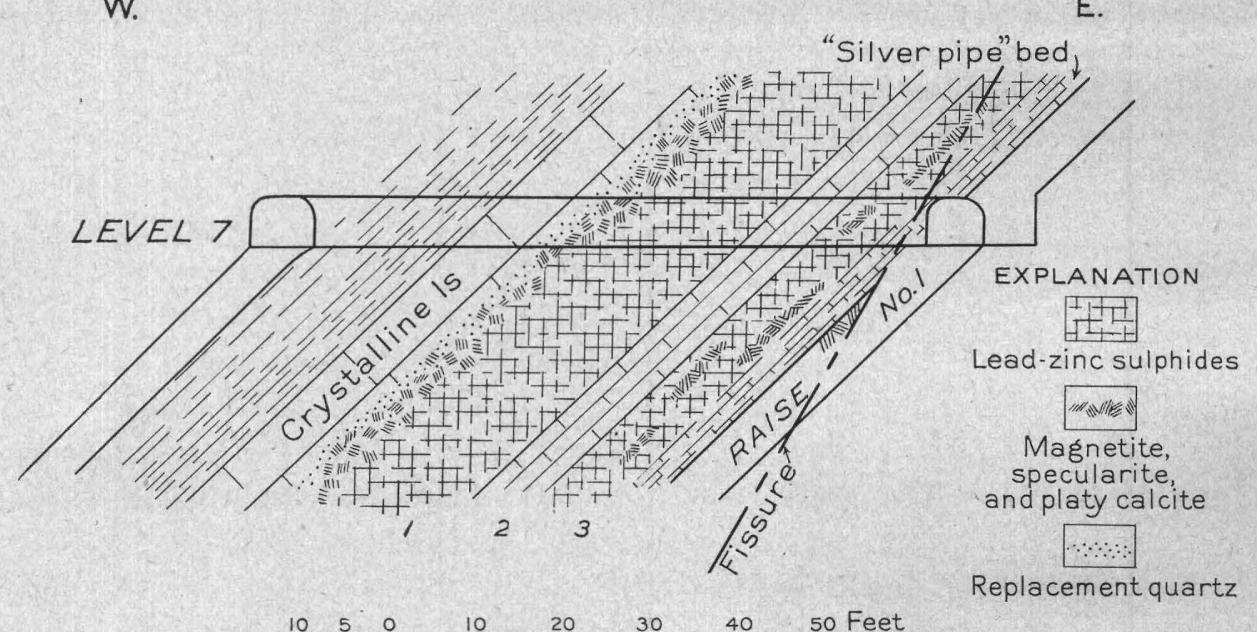

FigURE 9.-Generalized section through top of raise No. 1, level 7, GraphicWaldo mine, 1,100 feet south of Nitt monzonite stock, showing relation of specularite-magnetite aggregates to sulphide ore and gangue. Looking south. (1) 7 feet of lead-zinc sulphides accompanied by magnetite and specularite. The iron oxides tend to form layers in the zinc sulphide. (2) 7 feet of limestone, partly bleached and recrystallized to siderite (?). (3) 21 feet of zinc lead sulphide ore, which passes into platy calcite, specularite, and magnetite on the hanging-wall side. This aggregate is followed successively by a thin layer of replacement quartz and crystalline limestone. 
Magnetite and probably specularite were found associated with serpentine and chlorite on the dumps of pits southeast of Granite Mountain. No intrusive contacts are exposed nearby, but the Tertiary (?) granite stock is probably present underneath the alluvium a short distance to the south.

The specularite-magnetite aggregates are everywhere accompanied by pyrite and in most places by ferroan sphalerite (marmatite). The sulphides commonly contain inclusions of the oxides, which they have corroded or replaced to some degree. (See pl. $23, D$.) Some small crystals of specularite (pl. $24, A$ ) appear to have been completely replaced by pseudomorphs of pyrite. In some partly leached ore galena is the only sulphide now associated with the two oxides, but the large amount of limonite also present implies the former presence of pyrite and doubtless sphalerite.

\section{PYRITE}

Pyrite occurs in sulphide deposits throughout the district and for the most part is the earliest of the sulphides, as shown by inclusions of pyrite in the other sulphides; but small amounts of fine-grained pyrite with quartz or calcite form veinlets that cut the other sulphides in places. Pyrite is also commonly present in altered country rock. It forms large coarsely crystalline masses that have replaced Kelly limestone in the Nitt mine, and it is the dominant sulphide in the "copper shoot" along the eastern part of the main ore zone in the Nitt and Graphic-Waldo mines, where it is accompanied by interstitial chalcopyrite. It also forms lenses and layers in specularite-magnetite masses. It tends to form well-shaped crystals up to three-quarters of an inch in diameter, both in pyritic and mixed sulphide masses. The common crystal forms are combinations of the cube and pyritohedron. Some grains are microscopic intergrowths of isotropic and weakly anisotropic pyrite.

The relations of pyrite to specularite and magnetite show that on the whole the pyrite was formed later, although there was evidently a little oscillation of conditions during the change from the early oxide to the later sulphide stage. Plate $24, C$, shows pyrite interfingering with blades of specularite and partly replacing them. Such interfingering pyrite locally passes into pyrite crystals that are partly surrounded with gangue and so have been able to grow in part without interference from the older specularite. Pyrite, with well-defined crystal boundaries where in contact with gangue but with irregular boundaries where in contact with specularite, is shown on plate 24, D. Much of the pyrite contains inclusions of slightly corroded iron oxides, and minute pyrite rods, apparently pseudomorphs after specularite (pl. 24, B), have been noted that merge into pyrite crystals with inclusions of specularite.

Although the foregoing relations show that pyrite on the whole was deposited later than the iron oxides, there are minor exceptions. Coarse-grained cubic crystals of pyrite from level 10 of the Graphic-Waldo mine contain minute inclusions of specularite in zonal arrangement, as shown on plate $25, A$, which hardly seems attributable to the simple engulfment illustrated above. Such an arrangement implies either a brief interruption to the growth of pyrite and an intervening growth of specularite or, less likely, an impregnation of pyrite by specularite along one or more especially susceptible zones. Either suggestion implies a slight reversal of the general change in conditions of normal mineral deposition and practically no appreciable interval of time between the specularitemagnetite and the pyrite stages.

The most conspicuous pyritic impregnation of country rock is in the altered monzonite along the upper part of Hardscrabble Valley, where the rock, though in too small quantity to be of commercial interest, has the general character of disseminated pyritic copper ore. Disseminated pyrite grains or limonite pseudomorphs after them are conspicuous in some white rhyolite dikes in the Tertiary (?) granite.

\section{PYRRHOTITE}

Pyrrhotite was incidentally mentioned by Philip Argall as a constituent of the ores of the GraphicWaldo mine. ${ }^{27}$ None was found by us.

\section{OXIDIZED ZONE}

\section{LIMONITE}

Limonite, here used as a field name for fine-grained aggregates of ferric oxide that contain varying amounts of water, ${ }^{28}$ forms a large part of the oxidized ores. It has resulted chiefly from the oxidation of pyrite and ferroan sphalerite. Small quantities may have been derived from siderite, manganosiderite, manganiferous calcite, and jarosite, all but the last of which are described under gangue minerals. It is commonly yellow brown or reddish and earthy. In some places it is mixed with manganese oxides and grades into wad. The shiny, brown-black, fibrous variety is found in a few places, and boxwork varieties that represent incomplete replacement of sulphide ore or limestone have been found in several mines. Pseudomorphs of limonite after pyrite are conspicuous in some of the white rhyolite dikes.

\footnotetext{
${ }^{27}$ Rickard, T. A., Philip Argall and metallurgical progress : Min. and Sci. Press., vol. 112, pp. 129-130, 1916.

${ }^{28}$ Posnjak, Eugen, and Merwin, H. E., The hydrated ferric oxides : Am. Jour. Sci., 4th ser., vol. 47, pp. 311-348, 1919.
} 
JAROSITE OR NATROJAROSITE

Jarosite, a hydrous sulphate of ferric iron and potash, or its soda equivalent, natrojarosite, has been noted at several places throughout the district in the upper part of the oxidized zone. It is conspicuous in the outcrop at the south side of the main glory hole of the Hardscrabble mine, in the Tabaschi tunnel of the Graphic-Waldo mine, and in the outcrop of the Black Cloud ore body. It is also conspicuous at the Papa prospect (Queen group) in the Water Canyon district just south of the Magdalena district. ${ }^{29}$ At the Hardscrabble mine and the Papa prospect it was found associated with plumbojarosite. It is soft, earthy, and ocherous yellow to yellowish brown, and in its darker shades resembles light-colored limonite. Only at the Papa prospect was jarosite visibly crystalline. No analyses of the mineral from any of these places have been made, and it is therefore not known whether the mineral is jarosite or natrojarosite. Perhaps both are present.

\section{MEIANTERITE}

Wuestner ${ }^{30}$ reports that melanterite occurs locally with goslarite and chalcanthite incrustations on the walls of mine workings, apparently where the rate of evaporation of sulphate waters has exceeded the rate of oxidation of the contained iron.

\section{ZINC MINERALS}

SULPHIDE ZONE

SPHALERITE (ZINC BLENDE)

Sphalerite, or zinc blende, is the most abundant sulphide in the Magdalena ores with the possible exception of pyrite. It forms irregular grains in the dominant mixed sulphide ores and also occurs as massive aggregates of high-grade zinc ore in which only small amounts of pyrite and galena are present. Some of these high-grade masses are near the contact of the Nitt monzonite stock, where specularite-magnetite and pyritic masses dominate, and others are considerable distances from it. Although most of the sulphide ores have been of sufficiently coarse grain to permit separation into zinc and other concentrates, some, for example on level 6 of the Graphic-Waldo mine, have been such fine-grained mixtures of sphalerite and galena that they have been utilized only by oxide plants for the manufacture of zinc-lead pigments. In the Germany mine some sphalerite forms botryoidal crusts, and some polished specimens of ore from the same mine show sphalerite crystals surrounded with galena.

Nearly all the sphalerite mined has been dark brown to black and has contained considerable iron, though no chemical analyses of it are available; but in mar-

\footnotetext{
${ }^{20}$ Lasky, S. G., The ore deposits of Socorro County, N. Mex.: New Mexico State Bur. Mines Bull. 8, p. 54, 1932.

${ }^{30}$ Wuestner, Herman, op. cit., p. 130.
}

ginal parts of the main ore shoot in the Kelly mine a lighter-brown or resinous variety has been found, and in the outer parts of the district some of it is clear yellow and comparatively low in iron. The sphalerite examined microscopically contains minute inclusions of chalcopyriate (see p. 95).

\section{OXIDIZED ZONE}

\section{SMITHSONITE}

Smithsonite, the principal constituent of the oxidized zinc ores, occurs in a variety of forms and colors. The most common variety is gray to buff and finegrained to dense (pl. 25, C) and has replaced the "silver pipe" and other limestone beds. It is so easily mistaken for limestone that much of it was thrown over the dump during the early or lead carbonate stage of the district's history. This variety contains considerable iron, sufficient for the smithsonite, in part at least, to be classed as the monheimite variety. It turns brown on oxidation, and may be partly coated with black dendritic stains of manganese oxide. Another common variety (pl. $25, B$ ) is the cellular to layered smithsonite or "dry bone." Some is intermediate in texture between the compact and cellular varieties and is pink to reddish brown. The larger round to irregular cavities in cellular smithsonite doubtless represent dissolved remnants of unreplaced limestone, but the parallel openings in layered smithsonite, which so far as seen has replaced limestone along the walls of fissures and bedding planes, are original features and are believed to result from rhythmic replacement and to represent the large amount of shrinkage due to a simple reaction between zinc sulphate solution and the calcium carbonate of limestone.

A more striking variety than the others $(\mathrm{pl} .26, A)$ is the stalactitic, botryoidal, or crustified smithsonite whose color is commonly bluish green and less commonly brown, purple, yellow, and white. One or more of these colors may be present in a single specimen. The chemical analysis of the green smithsonite quoted below ${ }^{31}$ shows the presence of considerable copper.

Chemical analysis of green smithsonite from Magdalena, N. Mex.

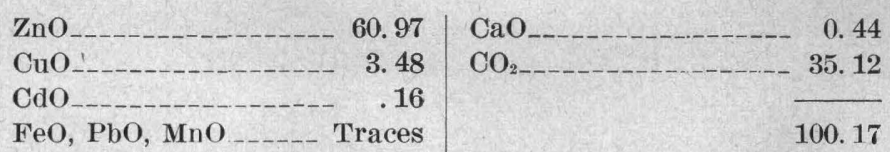

Two specimens of yellow smithsonite, designated A and $\mathrm{B}$, from the Kelly mine were analyzed by W. T. Schaller, J. G. Fairchild, and George Steiger, of the U. S. Geological Survey, to determine the quantity and distribution of any cadmium present, and Schaller has contributed the remaining paragraphs on smithsonite.

${ }^{31}$ Argall, Philip B., The ore deposits of Magdalena, N. Mex. : Eng. and Min. Jour., vol. 86, p. $369,1908$. 
A polished surface, specimen B (pl. 26, B) shows that the variously colored smithsonite forms regular concentric layers, each from 2 to 5 millimeters wide, surrounding a central cellular mixture composed mainly of brown iron oxide with green malachite and white smithsonite. From the center outward the layers are brownish amesthystine (analysis 5), milky white (analysis 4), yellow (analysis 3 ), and finally white with several thin brown bands of iron oxide.

Parts of both specimens A and B were crushed and the fragments hand-sorted, those of specimen A into (1) yellow and (2) milky white fractions and those of specimen B into (3) yellow, (4) milky white, and (5) brownish amethystine. Amethystine smithsonite is also present in specimen A, but it was not separated. The fractions were partially analyzed with the following results:

Partial chemical analyses of hand-sorted fractions of smithsonite from banded specimens, Kelly mine, Magdalena mining district, Socorro County, N. Mex.

\begin{tabular}{|c|c|c|c|c|c|}
\hline & \multicolumn{2}{|c|}{ A } & \multicolumn{3}{|c|}{ B } \\
\hline & $\begin{array}{c}1 \\
\text { Yellow }\end{array}$ & $\begin{array}{c}2 \\
\text { Milky } \\
\text { white }\end{array}$ & $\begin{array}{c}3 \\
\text { Yellow }\end{array}$ & $\begin{array}{c}4 \\
\text { Milky } \\
\text { white }\end{array}$ & $\begin{array}{c}5 \\
\quad \text { Brownish } \\
\begin{array}{c}\text { amethys- } \\
\text { tine }\end{array}\end{array}$ \\
\hline $\begin{array}{l}\text { Cadmium (Cd)1 } \\
\text { Manganese oxide }(\mathrm{MnO})^{2} \\
\text { Ferrous oxide }(\mathrm{FeO})^{3} \\
\text { Lead oxide (PbO) } \\
\text { Insoluble in hydrochloric acid }\end{array}$ & $\begin{array}{r}0.57 \\
.34 \\
1.56 \\
\text { Trace } \\
.02\end{array}$ & $\begin{array}{l}0.39 \\
{ }^{(4)} .58 \\
(4) \\
(4) \\
.01\end{array}$ & $\begin{array}{r}0.56 \\
.34 \\
1.31 \\
\text { Trace } \\
.01\end{array}$ & $\begin{array}{l}0.43 \\
.56 \\
1.03 \\
.33 \\
.01\end{array}$ & $\begin{array}{r}0.40 \\
.57 \\
1.46 \\
\left.{ }^{4}\right) \\
\quad .04\end{array}$ \\
\hline
\end{tabular}

1 No. 1, average of 0.56 (Fairchild) and 0.58 (Schaller); No. 2, determined by W. T. Schaller; No. 3, average of 0.58 (Fairchild) and 0.58 and 0.51 (Schaller); No. 4 , a verage
of 0.45 (Fairchild) and 0.45 and 0.39 (Schaller); No. 5 , determined by W. T. Schaller. 2 Determined by George Steiger.

Determined by W. T. Schaller.

Present but not determined.

Determined by J. G. Fairchild

Qualitative tests for sulphide, as $\mathrm{H}_{2} \mathrm{~S}$, evolved by treatment with hydrochloric acid and testing with moist lead acetate paper, which turns black if $\mathrm{H}_{2} \mathrm{~S}$ is present, indicated sulphide as follows: (1) Yellow, strong; (2) Milky white, weak; (3) Yellow, strong; (4) Milky white, trace; (5) Brownish amethystine, trace.

As 1 and 3 are yellow smithsonite and give a strong test for $\mathrm{H}_{2} \mathrm{~S}$, it seems that cadmium is present as sulphide. But as samples 2, 4, and 5, which are not yellow and which give only a faint to weak test for $\mathrm{H}_{2} \mathrm{~S}$, nevertheless contain, on an average, 72 percent of the total cadmium content of the yellow smithsonite, it would seem that most of the cadmium in these differently colored varieties of smithsonite is present as cadmium carbonate and that only a minor quantity is present in the yellow smithsonite as sulphide.

That cadmium is present in two forms in yellow smithsonite is also suggested by the analysis of a bright yellow variety from Marion County, Ark., for H. N. Stokes reports ${ }^{32}$ in his analysis 0.63 percent of $\mathrm{CdO}$ and 0.25 percent of CdS, confirming the conclusion, reached as a result of the determinations on the smithsonites from the Kelly mine, that most of the cadmium in yellow smithsonite is present as the carbonate. It also follows that the lack of a yellow color in any smithsonite is no indication of the absence of cadmium. The yellow layer contains a maximum of cadmium and a minimum of manganese and lead, whereas the white smithsonite contains less cadmium but more manganese and lead. The content of iron shows no regular variation.

The quantities of cadmium in the milky white and brownish amethystine varieties are unexpectedly high and are evidently present in the form of white carbonate. They suggest that

\footnotetext{
${ }^{3}$ Dana, E. S., System of mineralogy, 6th ed., p. $279,1892$.
}

cadmium may be more generally present in smithsonite than has commonly been realized. Apparently only a few tenths of a percent of yellow cadmium sulphide is sufficient to color smithsonite yellow.

Spectrographic tests for Ag, As, Be, Bi, Ga, Ge, Zn, Re, Sb, $\mathrm{Sn}$, and Tl, made by George Steiger, gave no evidence of their presence in any of the five samples tested.

\section{HYDROZINCITE}

Hydrozincite, a basic zinc carbonate, typically occurs as thin white chalky or earthy layers between thicker layers of fibrous botryoidal or crustiform smithsonite (pl. 26, A) and is probably present in some of the whiter varieties of massive smithsonite. Some hydrozincite is very pale green as if impregnated with small amounts of green copper carbonate or with aurichalcite. The association of the hydrozincite with botryoidal smithsonite implies alternating changes in the composition of descending waters.

\section{AURICHALCITE}

Aurichalcite, a basic zinc-copper carbonate, corresponds chemically to hydrozincite with part of the zinc replaced by copper. The pure mineral, according to Penfield, ${ }^{33}$ contains from 53 to 54.4 percent of zinc and 20 to 21.2 percent of copper, but different chemical analyses show from 50 to 59 percent of zinc and from 15 to 22 percent of copper. ${ }^{34}$ The zinccopper ratio ranges from $2: 1$ to $1: 2$, according to Biehl. ${ }^{35}$

It occurs in minor quantities throughout the district but is nowhere of economic importance. It is pale green to blue green and is silky and fibrous or scaly. It forms layers in crustiform and botryoidal smithsonite (pl. 26, A), coats drusy cavities, and forms little spherulitic tufts on smithsonite and associated minerals. Keyes ${ }^{36}$ describes an occurrence from the old Graphic workings in which the aurichalcite is enveloped in crystals of calcite, which are thus colored a beautiful green.

\section{CHALCOPHANITE}

Chalcophanite, like aurichalcite, is widespread in very small quantities. ${ }^{37}$ It occurs in steel-blue aggregates ${ }^{38}$ and crusts of radiate structure ${ }^{39}$ on smithsonite. One brown-black botryoidal crust on

3s Penfield, S. L. On the chemical composition of aurichalcite: Am. Jour. Sci., 3d ser., vol. 41, pp. 106, 108, 1891.

${ }^{34}$ Emmons, S. F., Irving, J. D., and Loughlin, G. F., Geology and ore deposits of the Leadville mining district, Colo. : U. S. Geol. Survey Prof. Paper, 148, p. 157, 1927.

${ }^{35}$ Biehl, F. K., Mineral abstracts 1, p. 203, 1921. Cited by Winchell, N. H., and Winchell, A. N., Elements of optical mineralogy, pt. 2 (deseription of minerals), p. 85, John Wiley \& Sons, Inc., 1927.

36 Keyes, C $\mathrm{R}$, Remarkable occurrence of aurichalcite: Iowa Acad. Sci. Proc., vol. 11, p. 253, 1904.

${ }^{37}$ Brinsmade, R. B., Kelly, N. Mex., a zinc camp whose ores have been made available by modern metallurgical methods: Mines and Minerals, vol. 27, pp. 51-53, 1906.

${ }^{38}$ Lindgren, Waldemar, Graton, L. C., and Gordon, C. H. Ore deposits of New" Mexico: U. S. Geol. Survey Prof. Paper 68, p. 253, 1910.

39 Wuestner, Herman, op cit., p. 128. 
smithsonite resembled chalcophanite but was found to contain not only zinc but also considerable copper.

HEMIMORPHITE (CALAMINE)

Hemimorphite $\left(\mathrm{H}_{2} \mathrm{Zn}_{2} \mathrm{SiO}_{5}\right)$, the hydrous zinc silicate, occurs typically as aggregates of elongated crystals, hardly more than 2 or 3 millimeters long, in drusy cavities in smithsonite and locally with associated limonite and clayey material. It is in places coated with colorless flat calcite rhombs, notably in the Ida Hill tunnel, where it occurs in pockets in the ore in considerable quantities.

\section{WILLEMITE}

Willemite, the rare anhydrous silicate of zinc, has been found at only one place in the Magdalena districtin the Stonewall mine, along the incline on the Stonewall fault. The ore in this incline consists essentially of specks of native gold with cerussite and willemite in a gangue of silicified limestone and a little microscopic barite. The willemite occurs in abundant, small to microscopic rosettes or spherulites of stubby prismatic crystals (see pl. $26, C^{\prime}$ ).

\section{GOSLARITE}

Goslarite, the water-soluble hydrated zinc sulphate, is, like melanterite (p. 92), found only as coatings on the walls of mine workings where water that has leached zinc from sulphide ore has evaporated. Goslarite forms white fibrous masses and silky tufts as much as 4 inches long, but they are so delicate that good specimens cannot be obtained.

\section{ZINC-BEARING CLAY OR "TALLOW CLAY"}

The "tallow clay" of the Magdalena district resembles the "tallow clay" of the Mississippi Valley leadzinc deposits, which when moist has much the appearance of chocolate-brown tallow. It is regarded by the miners in the Magdalena district as a good guide to zinc carbonate ore. The most distinct occurrence noted is in the Black Cloud mine, where the clay has replaced limestone along a nearly vertical fissure (see fig. 10). An analysis of this material by J. G. Fairchild shows it to contain only 0.5 percent of zine and an estimated 0.5 percent of copper. The "tallow clay" of Arkansas ranges from 10.6 to 30.2 percent of zinc, which is believed by Branner ${ }^{40}$ to be present as the silicate hemimorphite (calamine). Similar clay at Leadville contains from 18 to 35 percent of zinc, the percentage of zinc varying inversely as that of alumina. ${ }^{41}$

${ }^{40}$ Branner, J. C., Zinc and lead region of North Arkansas : Arkansas Geol. Survey Ann. Rept. for 1892, vol. 5, pp. 198, 266.

${ }^{41}$ Loughlin, G. F., The oxidized zinc ores of Leadville, Colo. U. S. Geol. Survey Bull. 681, pp. 24-28, 1918. Emmons, S. F., Irving, J. D. and Loughlin, G. F., Geology and ore deposits of the Leadville mining district, Colo, : U. S. Geol. Survey Prof. Paper 148, pp. 160-162, 1927.

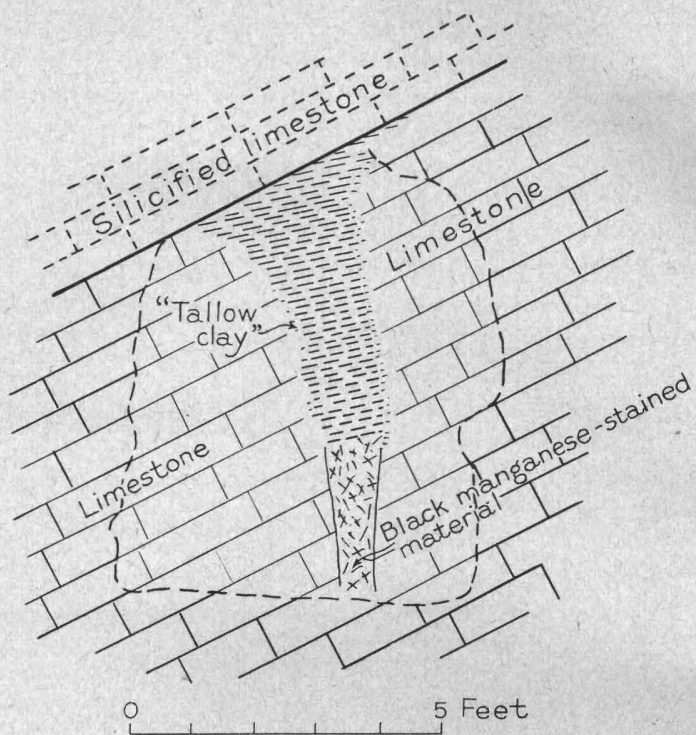

Figure 10.- "Tallow clay" replacing limestone along a fissure beneath a cap of silicified limestone and passing downward into black manganese-stained material. It shows fine horizontal banding. The transition zone between it and limestone is only an inch thick. Black Cloud mine, tunnel level.

The "tallow clay" of the Magdalena district is attributed mainly to the replacement of limestone along fractures by alumina, silica, and small quantities of zinc, carried by descending water in colloidal solution and probably in fine suspension also. The process is comparable to the treatment of slimes by lime in oredressing operations. The flocculating action of lime on colloids is well known, and the flocculated material may even replace the precipitating agent.

\section{COPPER MINERALS}

\section{SULPHIDE ZONE (HYPOGENE)}

CHALCOPYRITE

Chalcopyrite, the common sulphide of copper and iron, is the only original copper mineral that we found in the district. It occurs in two forms: (1) Visible irregular bright yellow to tarnished grains, commonly very small, but in places as much as an inch in diameter; (2) minute to microscopic specks, blebs, and linear forms enclosed in sphalerite. The first variety forms inconspicuous interstitial grains in the pyritic copper ore in the basal part of the Kelly limestone, especially in the Graphic-Waldo and Nitt mines. It is present in the pyritized monzonite north of the Nitt mine, and also forms large irregular grains or lumps, commonly associated with sphalerite and galena, in remnants of sulphide ore in outlying parts of the district. The largest lump noted-an inch in diameter-was in galena ore from the Black Cloud mine, but some of the cavities lined or filled with limonite in partly leached ore may represent still larger lumps. It is not known that any copper sulphide ore composed mainly of these lumps has been shipped, but they have undoubtedly been the source of some small bodies of 
rich oxidized ore, notably in the Young America mine. Under the microscope the boundaries between this variety of chalcopyrite and sphalerite commonly appear straight and smooth without clear evidence of relative age, but close examination usually shows that they connect with veinlets of chalcopyrite in sphalerite and therefore appear to be at least in part the younger. Veinlets of chalcopyrite cut pyrite, and chalcopyrite is also interstitial to specularite (see pl. 27, A). Chalcopyrite is cut by veinlets of galena, but in one specimen, found in the office of the Graphic-Waldo mine, chalcopyrite is interstitial to galena:

The microscopic specks and other forms in the sphalerite are illustrated on plate $27, B, C$, and $D$. They have been regarded by some as products of unmixing from a solid solution and by others as products of replacement effected by infiltrating solutions. Our microscopic investigations and a few experiments, though inconclusive, lead us to favor the replacement theory and to infer that the iron in the chalcopyrite may have been derived from that in the replaced sphalerite.

The chalcopyrite specks, except those in the smallest sphalerite grains, are commonly arranged in rows or zones parallel to the edges of the enclosing grains and near to them. The border of clear sphalerite is characteristic. Where large grains of chalcopyrite are in contact with sphalerite the inclusions tend to concentrate along this contact in preference to others, but inclusions are likewise clustered along contacts with other ore and gangue minerals and along incipient veinlets (see pl. $27, D$ ). Rarely a few minute inclusions of galena and pyrite are found associated with those of chalcopyrite, and galena and chalcopyrite may both be present in a single inclusion.

A thorough discussion of the subject is too long for presentation here but it may be pointed out that the restriction of the chalcopyrite specks to zones within the outer parts of sphalerite grains hardly conforms to what would be expected if the specks had formed by the unmixing of a solid solution, unless it is assumed that the solid solution evolved only during a late but not the latest stage in the growth of the sphalerite. It could also be suggested that the zonally arranged chalcopyrite specks, like the minute blades of specularite in pyrite, represent slight oscillations in chemical equilibrium during transition from the sphalerite to the chalcopyrite stage of deposition; but the alinement of chalcopyrite specks along veinlets in sphalerite ( $\mathrm{pl}$. $27, D$ ) implies deposition subsequent to the crystallizing and later fracturing of the sphalerite. A copper solution seeping along fractures and grain boundaries could penetrate sphalerite along cleavage planes, react with minute quantities of its iron and sulphur, and, when saturated, could deposit the specks of chalcopyrite. The parallel rows suggest a rhythmic process analogous to the formation of diffusion rings in gels.
BORNITE

We found no bornite in the district, but Wuestner ${ }^{42}$ states that it is sparingly present.

\section{SULPHIDE ZONE (SUPERGENE)}

CHALCOCITE

Chalcocite, or copper glance, the richest of the copper sulphides, is not abundant at Magdalena. This scarcity is probably due to the ease with which the oxidation products of chalcopyrite react promptly with the limestone wall rocks to form copper carbonates. Where the ore is encased in silicified limestone or in other siliceous rocks, however, and the liberated copper can be carried in solution into the sulphide zone, chalcocite has had more opportunity to form. This condition applies especially to the copper sulphide ore shoot in the Graphic-Waldo mine, which is floored with argillite and walled with siliceous and metamorphosed beds of the lower Kelly limestone. There sooty, black chalcocite fills cracks and small cavities, especially in chalcopyrite and pyrite, and coats them with black films. It has replaced chalcopyrite along minute veinlets, the middles of which are filled with carbonates. The deepest point at which chalcocite has been found in the Graphic-Waldo mine is on level 10, about 290 feet below the bottom of the thoroughly oxidized zone. There it is associated with coarse-grained pyrite in a chloritic gangue.

Crystalline chalcocite is present in the Stonewall and doubtless other mines on the upper slope of the range, where the ore bodies are overlain with silicified limestone; and very small quantities of chalcocite have been noted in the pyritized monzonite north of the Nitt mine. At the Iron Mask mine in South Camp massive crystalline chalcocite intergrown with argentite (?) is present in a vein that cuts highly oxidized silicified red rhyolite. Rounded fragments of pyrite are the only representatives of original ore minerals in the-vein. Alteration of the chalcocite through covellite to malachite is well advanced.

\section{COVELLITE}

Covellite, a dark-blue copper sulphide, is about as generally distributed as chalcocite and, like chalcocite, occur's as minute to microscpic grains in close association with chalcopyrite, galena, and chalcocite. It has replace chalcopyrite to a considerable degree, notably in the copper shoot of the Graphic-Waldo mine (pl. 27, $A$ ); but it has replaced galena along grain boundaries and cracks to a greater degree. Covellite and anglesite, clearly visible to the unaided eye, occur together where galena is associated with much chalcopyrite, suggesting that cupric sulphate, derived by the oxidation of chalcopyrite, has reacted

${ }_{42}$ Wuestner, Herman, op. cit., p. 128. 
with the adjacent galena to produce cupric sulphide (covellite) and lead sulphate (anglesite).

At the Iron Mask mine covellite is the first product of the oxidation of chalcocite. As seen under the microscope, it penetrates the chalcocite and is bordered or penetrated in turn by the products of further oxidation-native copper, cuprite, and copper carbonates.

\section{OXIDIZED ZONE}

\section{MALACHITE}

Malachite, the green basic copper carbonate, is a common minor constituent of oxidized ore throughout the district and corresponds in quantity and distribution to chalcopyrite in the sulphide ores. It forms films, crusts, and crystalline aggregates and is present along the edges of worked-out stopes. Wuestner says that it has replaced azurite and has formed pseudomorphs after crinoid stems and after small octahedra of cuprite, some of which have been changed to an unidentified white mineral. ${ }^{43} \mathrm{He}$ also says that it has altered to aurichalcite.

AZURITE

Azurite, the blue basic copper carbonate, is more prominent than malachite, though not necessarily more abundant. A common mode of its occurrence is as balls and knobs composed of innumerable flat plates. It is found in cavities in cellular smithsonite and on crusts of clayey material, malachite, aurichalcite, hydrozincite, allophane, and oxides of manganese and iron. On a specimen of secondary minerals from the Juanita mine, azurite has altered in varying degrees to an undetermined white mineral of a radiate fibrous structure resembling that of the hydrous copper silicate bisbeeite; but the mineral, according to spectrographic tests by George Steiger, is a silicate of aluminum and magnesium.

\section{CHRYSOCOLLA}

The hydrous copper silicate chrysocolla is rare in the limestone areas of the Magdalena district, but it is common in veins in andesite in the area adjoining the main district to the west and northwest. ${ }^{44}$ The blue allophane that is common in the oxidized ores contains copper that is supposed to be present as chrysocolla.

NATIVE COPPER

Native copper is common, according to Brinsmade, ${ }^{45}$ as "thin leaves or as niggerheads." It also occurs in arborescent forms, embedded in cuprite, ${ }^{46}$ and as crusty scales and veinlets in limestone that has been partly replaced by zinc carbonate. An ore body said to contain "lumps of native copper too big for two men to

43 Wuestner, Herman, op. cit., p. 128.

${ }^{44}$ Lasky, S. G., op. cit., p. 38.

${ }^{45}$ Brinsmade, R. B., op. cit., p. 50

${ }^{46}$ Wuestner, Herman, op. cit., p. 130. lift" ${ }^{47}$ was stoped in the southern part of the GraphicWaldo mine between levels 5 and 6 .

\section{CUPRITE}

Cuprite, the red oxide of copper, occurs ${ }^{48}$ in masses that here and there contain native copper and as beautifully crystallized, highly modified cubes and dodecahedrons that fill cavities in the massive material. Very small octahedrons, altered to malachite or rarely to azurite, are also present.

\section{TENORITE}

Thin scales of tenorite, the black cupric oxide, fill cavities in native copper. ${ }^{49}$

\section{CHALCANTHITE}

Chalcanthite, a hydrous copper sulphate, commonly known as "blue vitriol," occurs sparingly in old workings and open fissures where it has been formed by evaporation of copper sulphate solutions.

ANTLERITE

Very small quantities of antlerite, $\mathrm{CuSO}_{4} \cdot 2 \mathrm{Cu}(\mathrm{OH})_{2}$, associated with spangolite and azurite, are present on a specimen of cuprite kindly furnished by Wuestner. The optical properties were determined by W. T. Schaller as follows: Orthorhombic, biaxial, positive. Obtuse bisectrix normal to cleavage, $2 \mathrm{~V}$ (acute) medium large, dispersion $r<v$. Refractive indices: $\alpha$ (yellowish green) $=$ $1.725 \pm 0.003, \beta=1.735 \pm 0.003, \gamma($ green $)=1.785 \pm 0.005$.

SPANGOLITE

The same cuprite specimen that contains antlerite contains larger quantities of a green mineral with a bluish tinge, which was identified by W. T. Schaller as spangolite, $\mathrm{Cu}_{6} \mathrm{AlClSO}_{10} .9 \mathrm{H}_{2} \mathrm{O}$. This is the mineral provisionally referred to as gerhardtite by Wuestner. The presence of chloride, sulphate, aluminum, and abundant copper was verified by qualitative chemical tests. The mineral has a perfect basal cleavage on which are produced readily the triangular etch figures ${ }^{50}$ with dilute sulphuric acid $(1: 50)$, so characteristic of spangolite.

The optical properties of the spangolite from the Magdalena district are: Uniaxial, negative. $\epsilon$ (nearly colorless in very thin pieces $)=1.630, \omega$ (green, with a bluish tinge) $=1.678$. These indices of refraction are slightly lower than those previously determined on spangolite from Arizona, namely, $\epsilon=1.641$, $\omega=1.694$.

\section{CYANOTRICHITE}

Deep-blue compact masses of radiating fibers, about a millimeter thick, are sparsely present in a second small

${ }^{47}$ Brown, C. T., oral information, 1915.

${ }_{48}$ Wuestner, Herman, op. cit., p. 130.

49 Idem, p. 128

50 Dana, J. D. and E. S., System of mineralogy, 6th ed., p. 920 , figs. 4 and $5 \mathrm{a}, 1909$ 


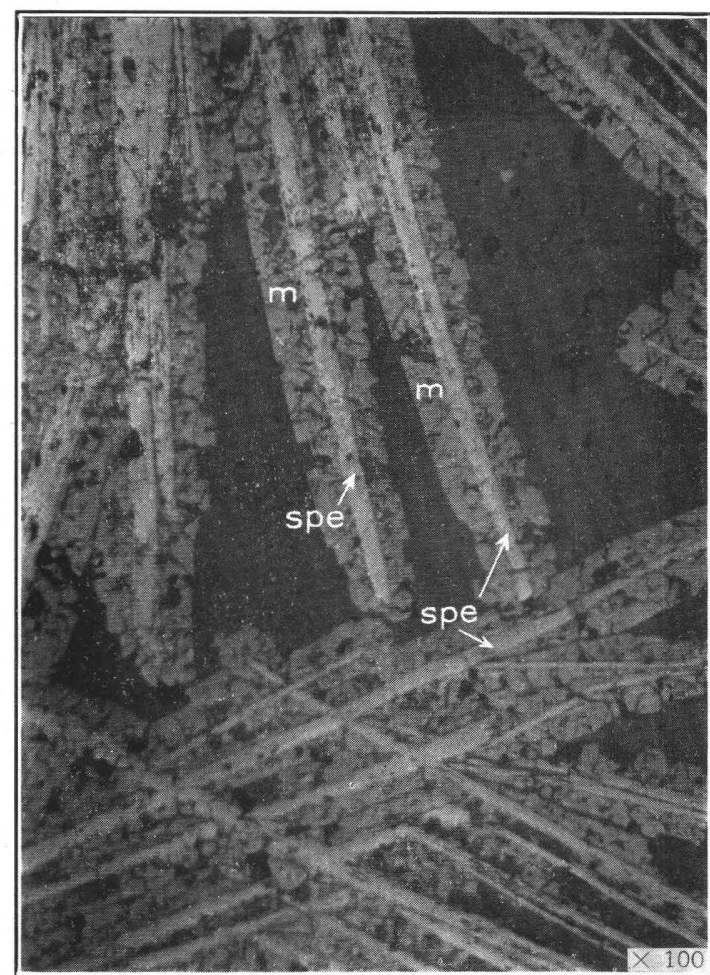

4. MAGNETITE (m) ENCASING SPECULARITE (spe).

Edges and especially ends of specularite blades are ragged, as if partiy

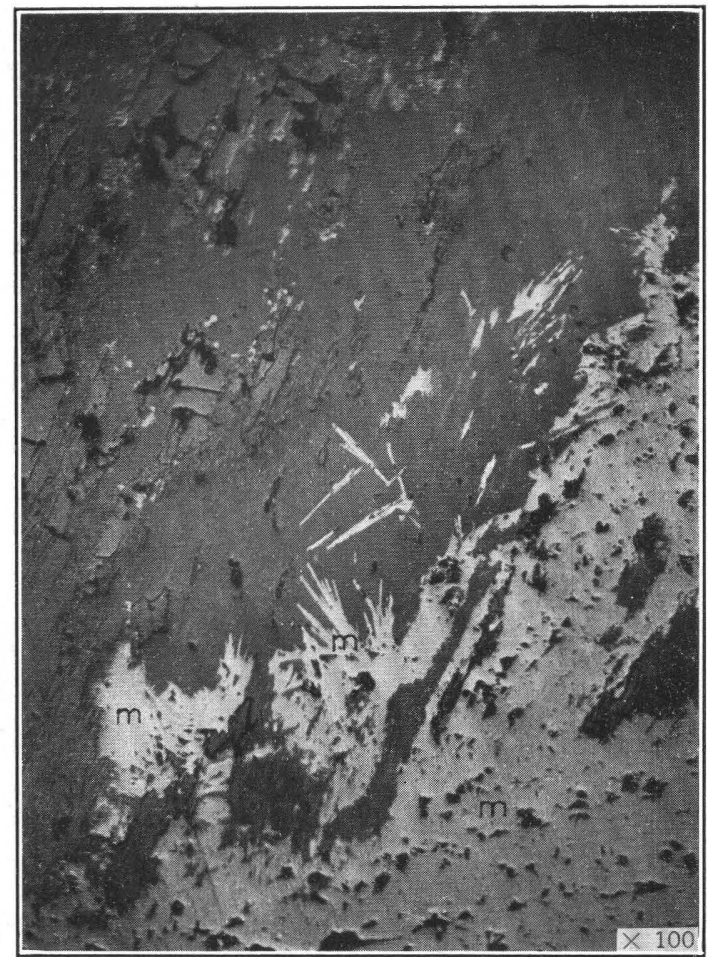

C. MAGNETITE PSEUDOMORPHS (m) AFTER SPECULARITE.

Dark area includes quartz and hedenbergite. From same specimen as plate $29, A$. Graphic-W aldo mine.

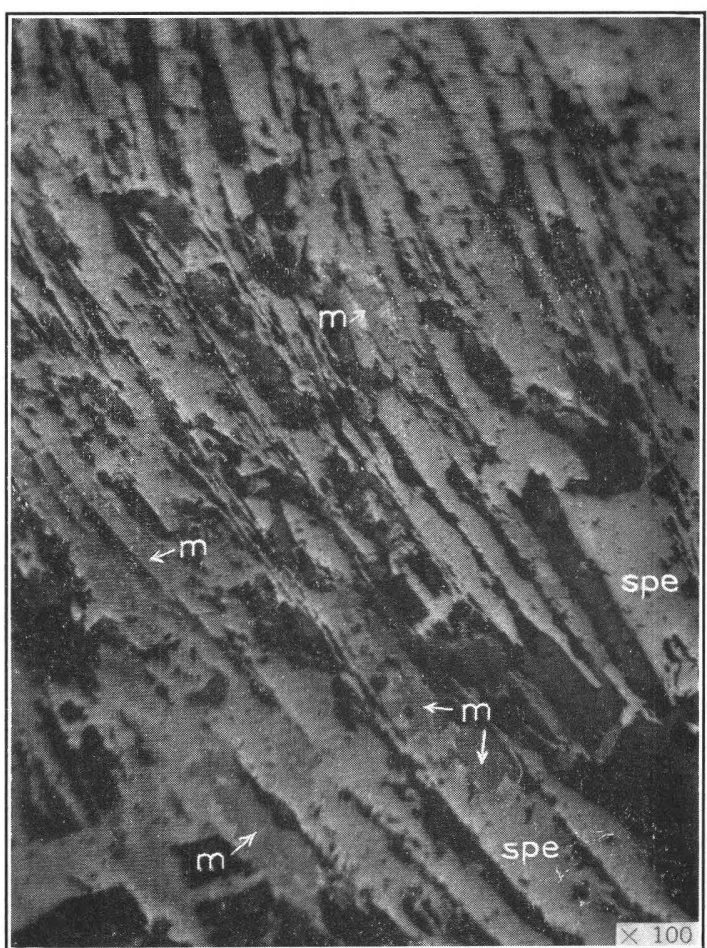

$B$. SPECULARITE-MAGNETITE AGGREGATE, SHOWING PARTIAL REPLACEMENT OF SPECULARITE (spe) BY MAGNETITE (m).

Black comprises quartz and calcite. Nitt mine.

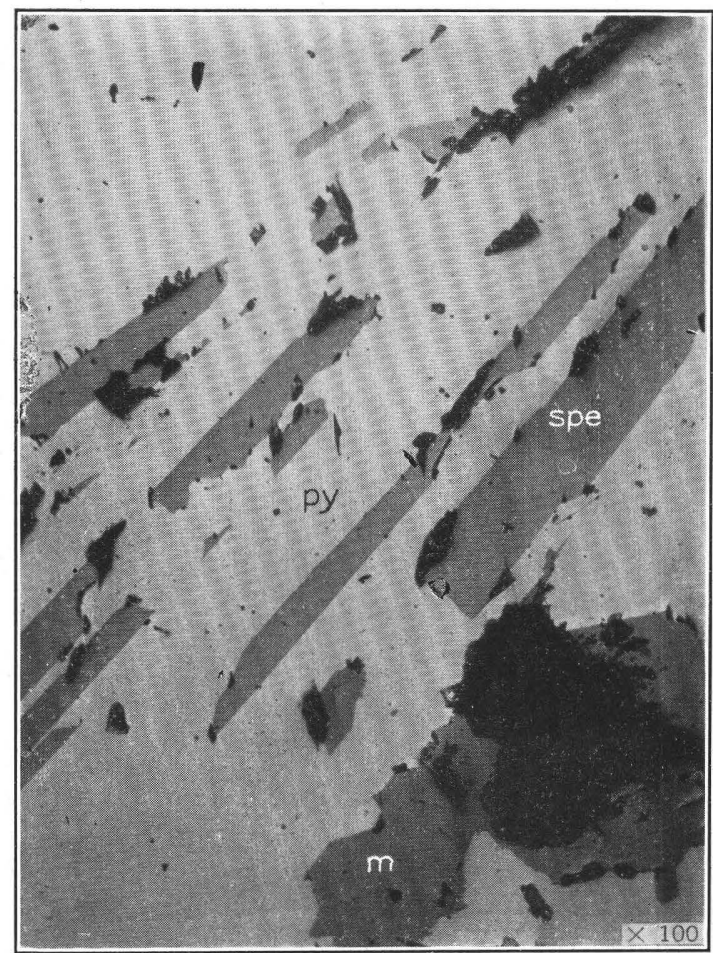

D. MAGNETITE (m) AND PARTLY REPLACED SHEAF OF SPECULARITE BLADES (spe) IN A POLISHED CRYSTAL FACE OF PYRITE.

Black areas are cavities, Graphic-Waldo mine. 


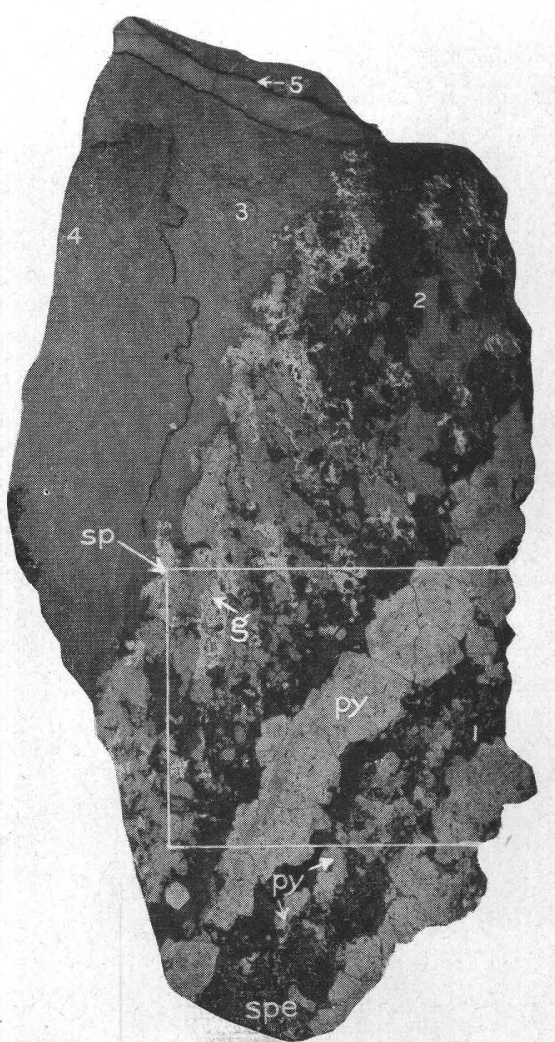

A. BANDED MIXED-SULPHIDE ORE FROM KELLY MINE.

(1) Specularite (spe) and pyrite (py) in a calcite-quartz-chlorite matrix; (2) sphalerite (sp) and galena (g) replacing calcite, quartz, and chlorite; (3) calcite and quartz, continuous with band 2
grading into band $4 ;(4)$ limestone; (5) late calcite-pyrite vein.

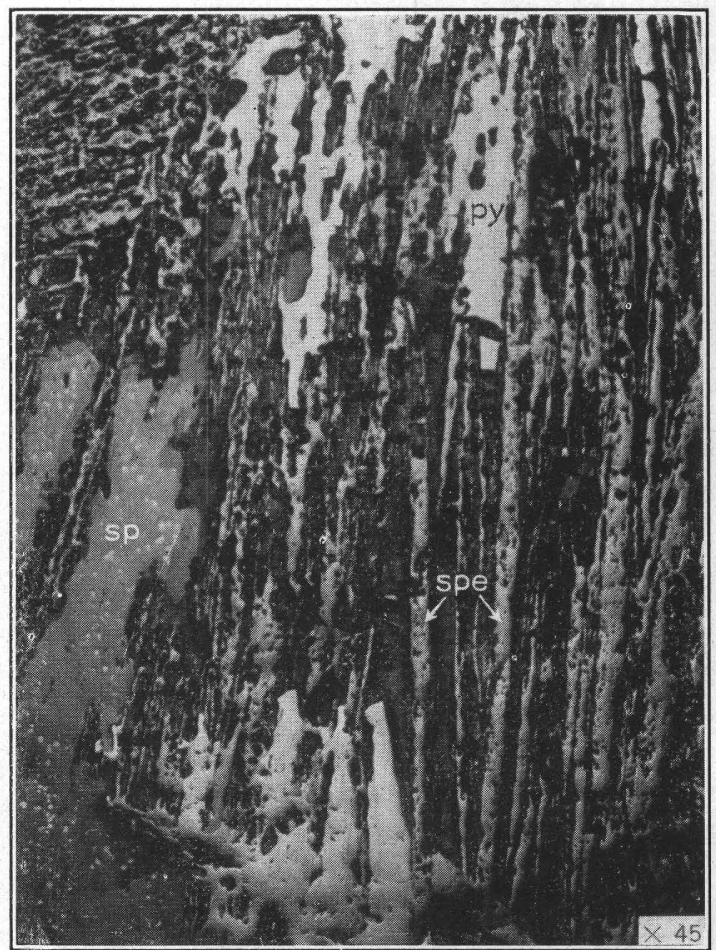

C. INTERFINGERING PYRITE (py) AND SPECULARITE (spe) WITH SPHALERITE (sp) IN A CARBONATE GANGUE. White dots in sphalerite are inclusions of chalcopyri $r$. Nitt mine.

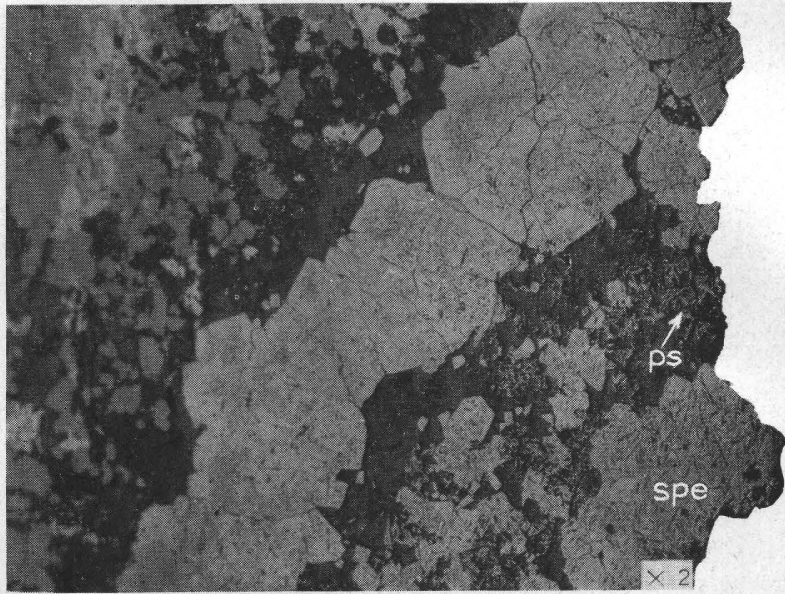

B. ENLARGEMENT OF PART OF $A$.

Shows small pyrite pseudomorphs (ps) after specularite and inclusions f

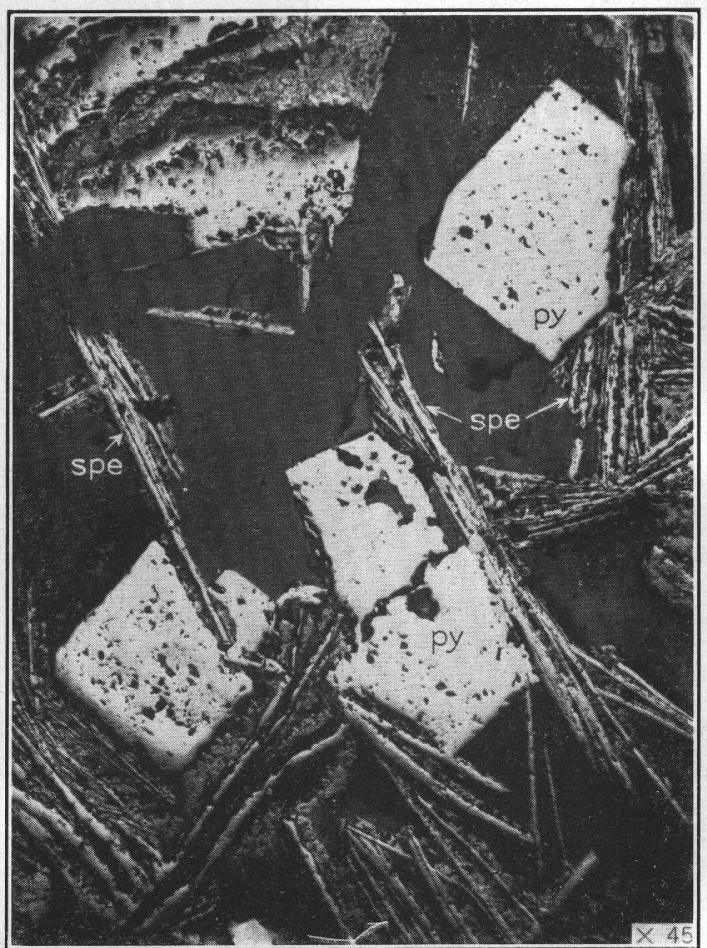

D. PYRITE CRYSTALS (py) AND SPECULARITE-MAGNETITE BLADES (spe) IN QUARTZ GANGUE.

Pyrite shows crystal boundaries against the gangue but irregular boundaries caused by growth against the earlier specularitegrown around one of these blades. Black areas are pits. Kelly mine. 


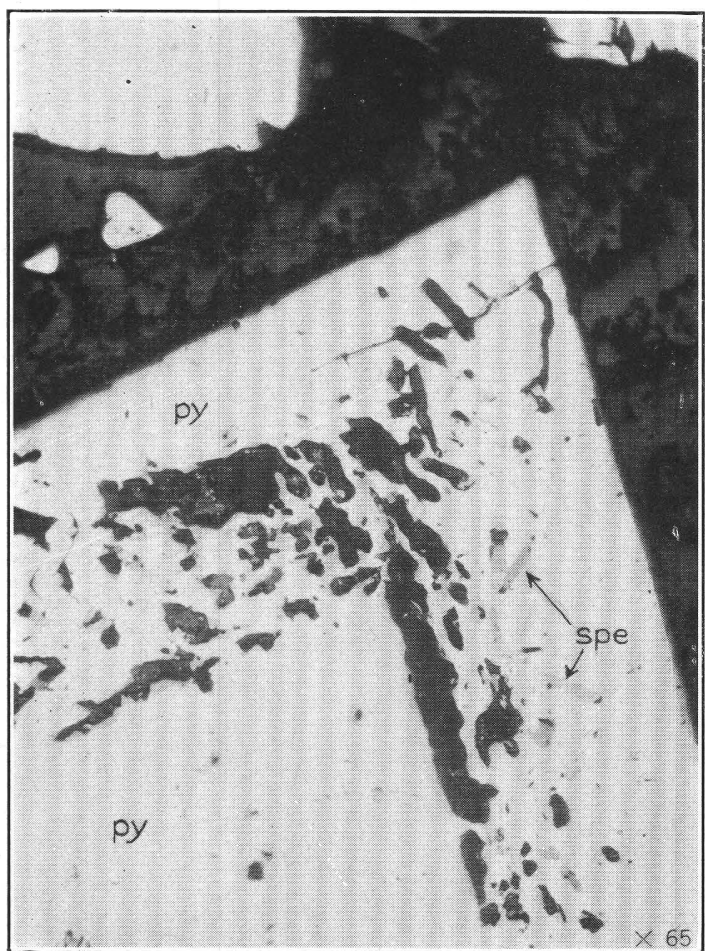

A. PYRITE CRYSTAL (py) WITH A ZONE OF SMALL SPECU. LARITE BLADES (spe).

Black areas are pits from which specularite has been removed during polishing. Gangue is chlorite. Graphic-Waldo mine.

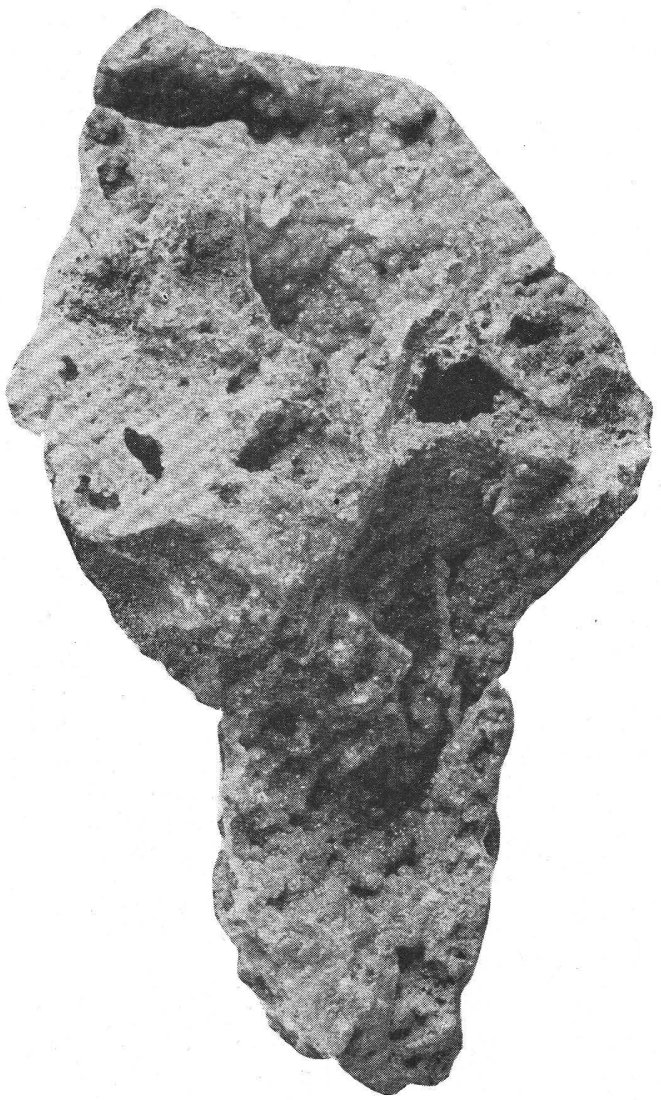

B. CELlULAR SMITHSONITE ("DRY BONE ORE").

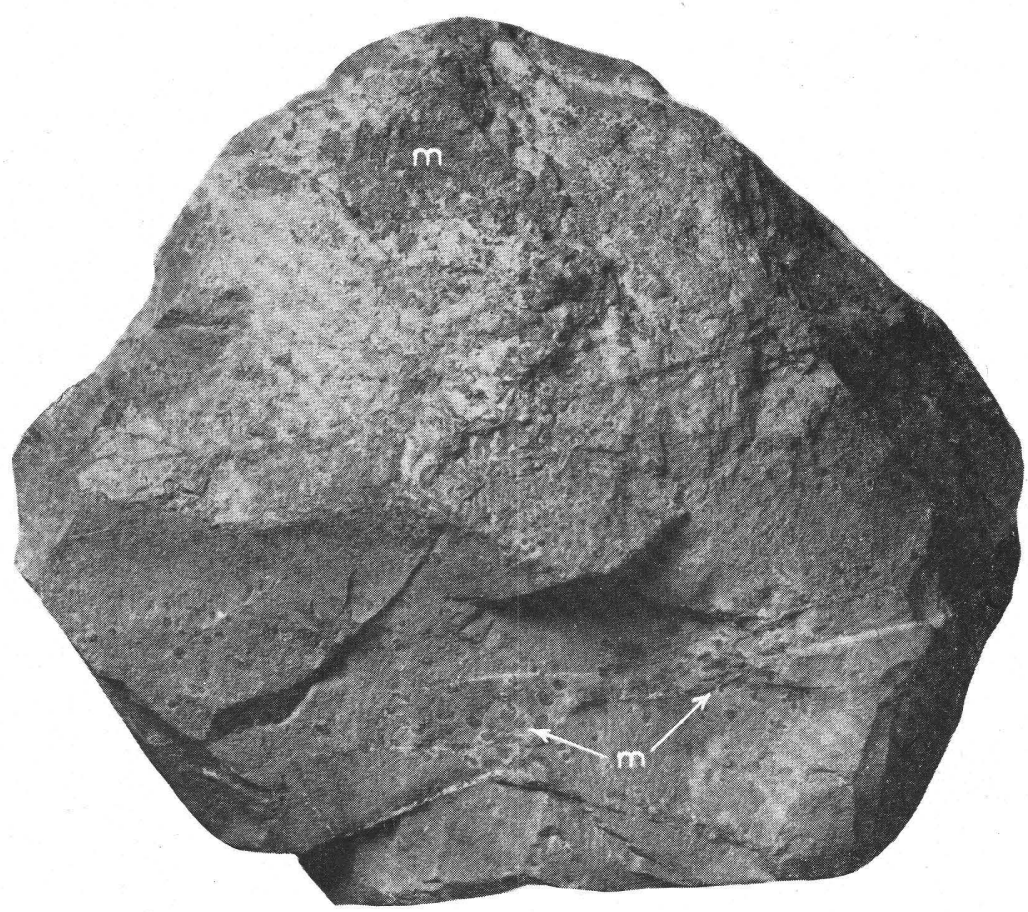

C. MASSIVE ZINC CARBONATE THAT HAS REPLACED THE "SILVER PIPE" BED OF THE KELLY LIMESTONE, m, Manganese oxides. Kelly mine. 


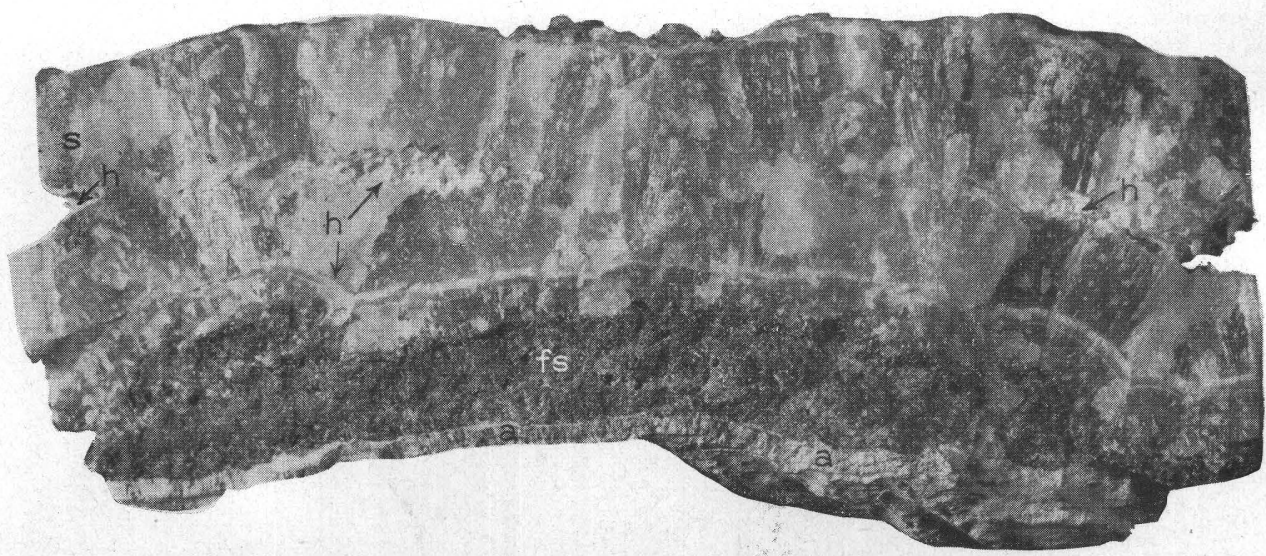

A. CRUSTIFORM FIBROLS SMITHSONITE.

(s) Bluish-green translucent smithsonite, (h) hydrozincite, (fs) ferroan smithsonite, (a) aurichaleite.

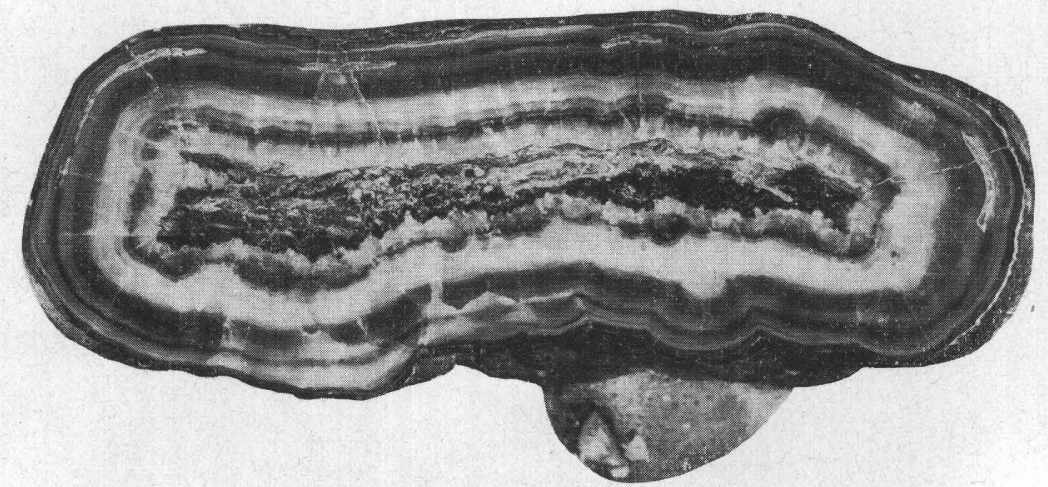

B. CONCENTRIC AMETHYSTINE, WHITE, AND YELLOW LAYERS OF SMITHSONITE SURROUNDING A CELLULAR MIXTURE COMPOSED MAINLY OF BROWN IRON OXIDE, GREEN MALACHITE, AND WHITE SMITHSONITE.

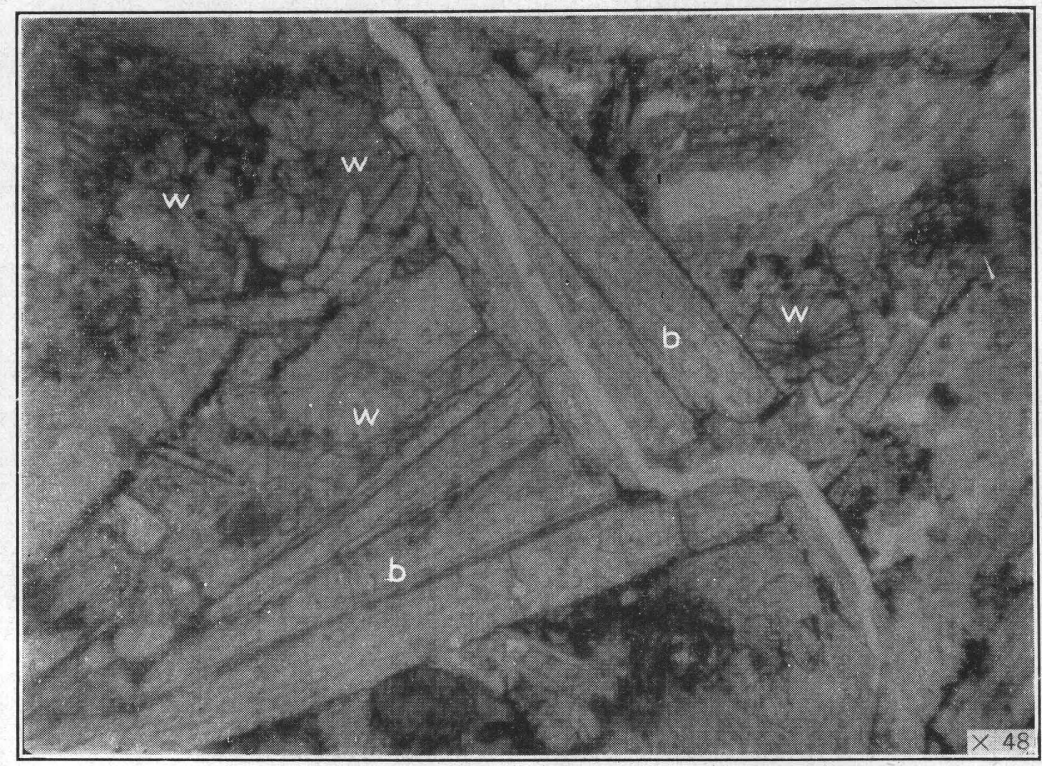

C. PHOTOMICROGRAPH OF ORE FROM STONEW ALL MINE, SHOWING LATH-SHAPED CR YSTALS OF BARITE (b) AND ROSETTES OF WILLEMITE ( ) IN A MATRIX OF CERUSSITE AND CALCITE. 


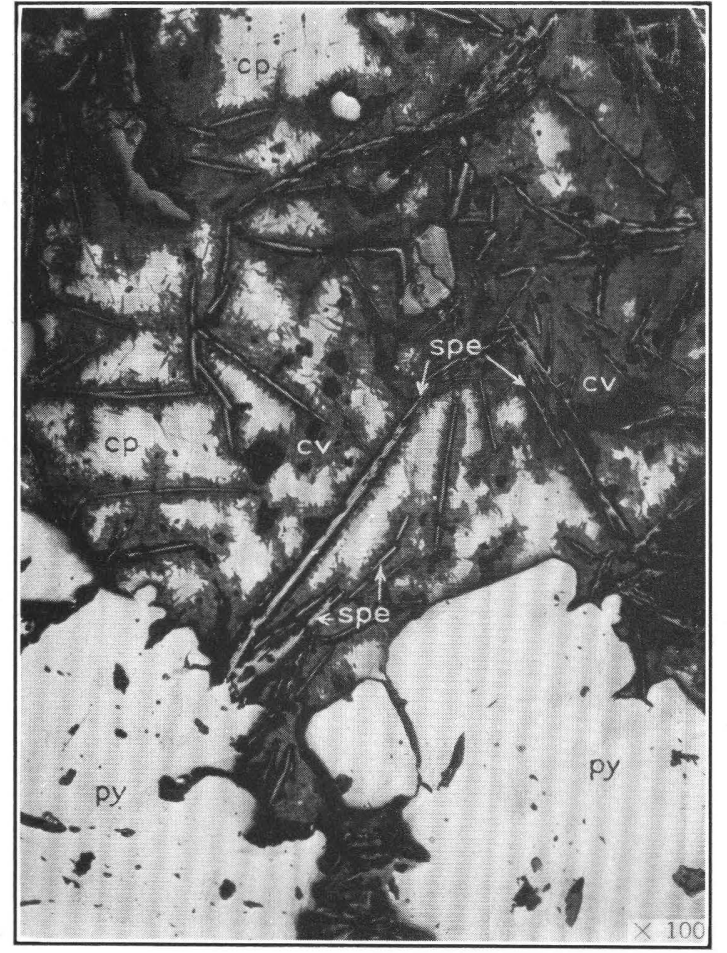

$A$. CHALCOPYRITE (cp) INTERSTITIAL TO LIGHT-GRAY BLADES OF SPECULARITE (spe) AND PARTLY REPLACED BY DARK-GRAY COVELLITE (cv). Large white crystals in lower part of illustration are pyrite (py).
Stope below level 5, Graphic-Waldo mine.

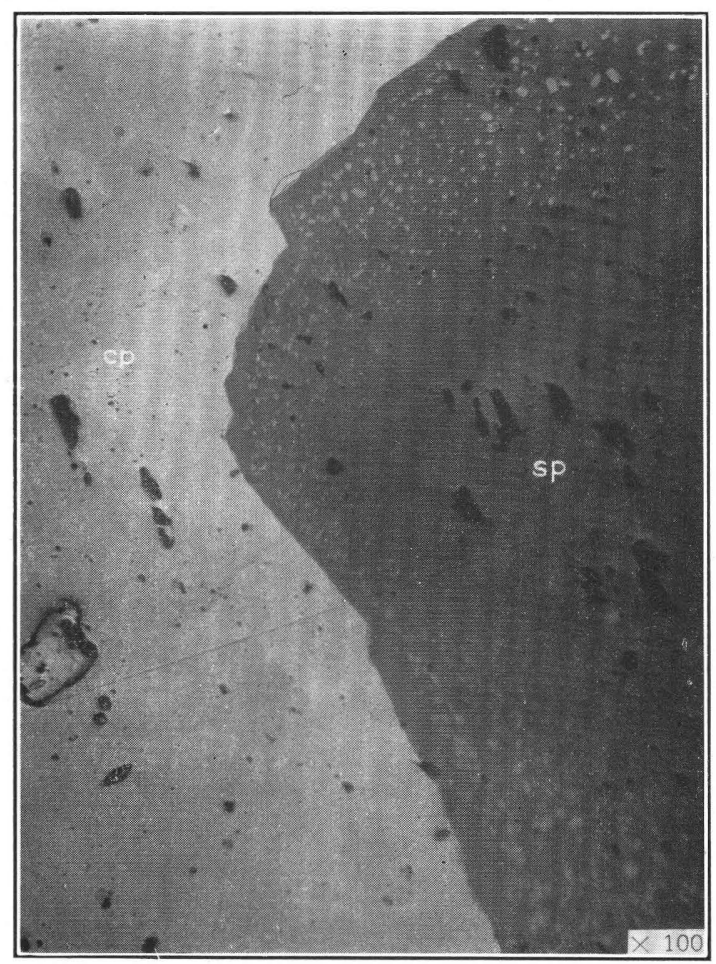

C. INCLUSIONS OF CHALCOPYRITE IN SPHALERITE (sp) SEGREGATED NEAR AND PARALLEL TO CONTACT WITH A CONTINUOUS AREA OF CHALCOPYRITE (cp).

Note narrow, clear border of the sphalerite and the tendency to linear arrangement of the chalcopyr:te inclusions. Grand Tower mine.

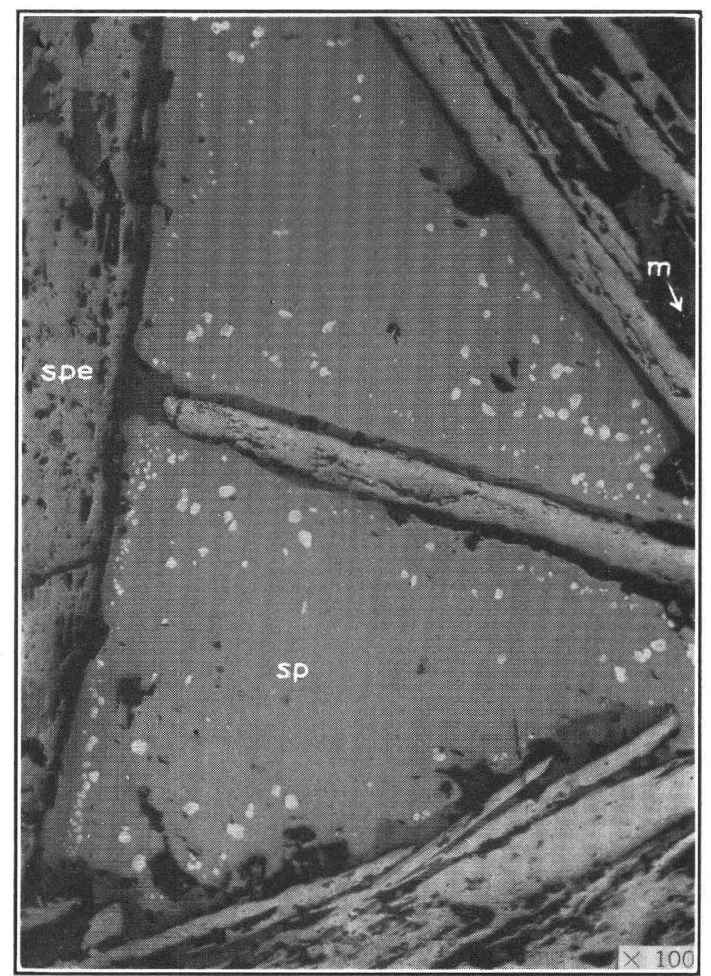

$B$. INCLUSIONS OF CHALCOPYRITE (WHITE DOTS) IN SPHALERITE (sp) SEGREGATED NEAR CONTACTS WITH SPECULARITE (spe).

Dark borders along the specularite blades seem to be either smithlarge specularite crystal at right edge. Nitt mine.

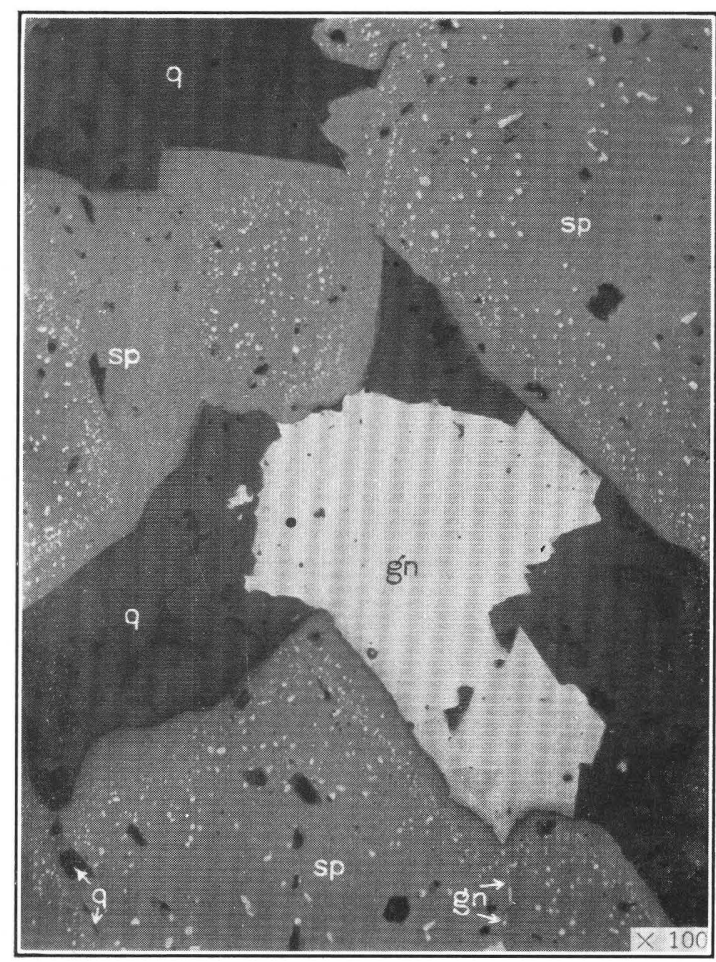

D. INCLUSIONS OF CHALCOPYRITE IN SPHALERITE (sp) PARALLEL TO ITS CONTACTS WITH GALENA (gn) AND QUARTZ (q).

The deviation of the chalcopyrite from visible boundaries in left central part is inferred to conform to invisible grain boundaries within a sphalerite aggregate; likewise the roughly circular cluster of inclusions in the upper grain of this aggregate is thought to represent a surface near the original surface of the grain and about 
piece of cuprite (Wuestner No. 4417) collected at the Kelly mine between 1900 and 1905 by Mr. Wuestner. Although at first thought to be one of the blue copper silicates, the blue fibers are probably cyanotrichite.

On optical examination W. T. Schaller found that the minute fibers extinguish parallel, are strongly pleochroic, and agree with cyanotrichite in their indices of refraction, which are as follows: $\alpha$ (normal to fibers, nearly colorless $)=1.59 ; \beta=1.62 ; \gamma$ (parallel to fibers, deep blue) = about 1.65 .

Qualitative tests showed the presence of aluminum and sulphate but no chloride.

Half a centimeter away from the cyanotrichite is a little spangolite, both minerals being hydrous sulphates of copper and aluminum, spangolite containing chlorine in addition. Their formulas are: Cyanotrichite, $\mathrm{Cu}_{4} \mathrm{Al}_{2} \mathrm{SO}_{10} .8 \mathrm{H}_{2} \mathrm{O}$; spangolite, $\mathrm{Cu}_{6} \mathrm{AlClSO}_{10} .9 \mathrm{H}_{2} \mathrm{O}$.

\section{LEAD MINERALS}

SULPHIDE ZONE

GALENA

Galena, lead sulphide, is present in most of the ores in the Magdalena district, the proportion of galena to the other sulphides increasing with distance from the monzonite contact. According to the superintendent at the Nitt mine, a little galena was found in one stope, and a few microscopic specks were noted in sphalerite in one specimen from that mine; but it first appeared in appreciable quantities in the Graphic-Waldo mine about 300 feet south of the contact.

In most places it is a subordinate constituent of mixed sulphide ore and is very fine grained, but in the outer parts of the district it is very much coarser grained and in places is by far the predominating ore mineral. There temperature and pressure during mineral deposition were relatively low and less subject to rapid changes, and the ore-forming solutions, after deposition of considerable quantities of pyrite and zinc blende, were relatively dilute but relatively rich in lead. All the ores seen in the outlying parts of the district, however, have been partly leached, and their original content of zinc blende was doubtless much higher than it is now. Microscopic study shows that although the boundaries between the grains of galena and sphalerite or chalcopyrite are commonly irregular, galena is clearly interstitial to some sphalerite and forms veinlets in both minerals. One specimen with chalcopyrite interstitial to galena has already been noted. In general the deposition of galena appears to have followed that of chalcopyrite, which had already followed that of sphalerite, but available evidence is somewhat conflicting.

Remnants of galena are present in the oxidized ores as kernels surrounded by anglesite and cerussite and are locally associated with plumbojarosite.

The etching of polished specimens of galena discloses microscopic inclusions of some other mineral or minerals, a very common feature of silver-bearing galena. Some of these inclusions are crystals or irregular spots and others are thin threads along cleavage planes or grain boundaries. These inclusions are further discussed on page 98.

\section{OXIDIZED ZONE}

ANGLESITE

Anglesite, lead sulphate, is common as the first product of oxidation of galena, and its occurrence as thinbanded gray to white crusts surrounding nodules of galena in the oxidized zone is so generally characteristic that no special description is necessary. It shows all stages of alteration to cerussite.

CERUSSITE

Cerussite, lead carbonate, is present in the oxidized ore of all the mines, and in some of the ore shoots it is commercially the most important mineral. In the early days of the district effort was confined largely to the mining of slightly consolidated cerussite or "sand carbonate" ores near the surface. Silliman ${ }^{51}$ described a body of lead carbonate ore in the "Juaniata" (Juanita?) mine that was 40 to 60 feet wide.

Cerussite generally occurs as glassy masses or aggregates of prismatic to bladelike crystals. The cerussite is typically derived from anglesite as the second step in the oxidation of galena, and in places it preserves the anglesite banding. The color of pure cerussite is gray to white, but much of the cerussite mined is stained reddish-brown or yellow by iron oxides and perhaps in part by plumbojarosite.

Although most of the cerussite was formed practically in place, some of it was transported for short distances, as is shown by veinlets and small clusters of cerussite crystals that occupy fractures in otherwise unmineralized rock near ore bodies. Some movement and concentration of lead as carbonate within an ore shoot is illustrated by a highly cellular spongy specimen from the Graphic-Waldo mine. This specimen is composed of cerussite crystals in random orientation, cemented and coated wtih iron and manganese oxides. The prismatic cerussite crystals range in length from 1 millimeter to 12 millimeters and project into the openings in the mass and bridge them. The small crystals, many of which are white and unstained, have grown at random in large part upon the surfaces of the larger crystals.

\section{PLUMBOJAROSITH}

Plumbojarosite, a basic sulphate of lead and iron, is chemically the same as jarosite except for the replacement of potassium by lead. It is prominent in the outcrop at the large glory hole of the Hardscrabble

si Silliman, Benjamin, Jr., Mineral regions of southern New Mexico; Am. Inst. Min. Eng. Trans,, vol. 10, pp. 424-444, 1882. 
mine, and Lasky ${ }^{52}$ reported its presence at the Papa prospect of the Water Canyon district, which adjoins the Magdalena district ou the southeast. It occurs in minute crystalline flakes that are very similar in appearance to those of jarosite, from which they can be reliably distinguished only by optical or chemical tests.

\section{VANADINITE}

Vanadinite, a lead chlorovanadate, has not been recognized within the area mapped, but Lasky ${ }^{53}$ reports some from prospects about $11 / 2$ to $21 / 2$ miles north of Magdalena on the Jack Frost, Night Hawk, and Pleasant View groups of claims. It forms an incrustation on quartz.

\section{SILVER MINERALS.}

\section{SULPHIDE ZONE (HYPOGENE)}

All the sulphide ores contain a little silver whose exact mode of occurrence is not known. No undoubted primary silver minerals have been found. The galena of the ore contains microscopic inclusions of various forms that become visible upon polished surfaces etched with hydrochloric or nitric acid. Concavo-cubic outlines are common. Other forms include dots of indistinct outline, stubby and elongate rods, and very thin threads that follow grain boundaries or cleavage planes in the galena.

Such inclusions, common in the galena of silverbearing ores, have been described by different authors ${ }^{54}$ as inclusions of argentite, proustite, pyrargyrite, or tetrahedrite. The inclusions are much too small to extract for analysis, and their nature may ony be inferred, although Nissen and Hoyt have shown that argentite can separate from a solid solution with galena and that when it does so it forms inclusions similar to those found in natural galena. Some of the inclusions in the galena at Magdalena may be of a silver mineral, but it is doubtful if they all can be as the silver content of the ore is so low.

In addition to its probable presence in some of the minute inclusions in galena, silver is also present in some unknown form in the comparatively galena-free ores. An average assay of the zinc-copper ore mined close by the monzonite contact in the Nitt mine during 1925-32 shows only 0.5 percent of lead but 2 ounces of silver to the ton. Brinsmade ${ }^{55}$ states that the average sulphide ore mined in the district in 1906 contained 12 percent of lead and from 1 to 5 ounces of silver to the

\footnotetext{
${ }^{52}$ Lasky, S. G., The ore deposits of Socorro County, N. Mex. : New Mexico State Bureau of Mines Bull. 8, pp. $53-54,1932$.

53 Idem, pp. 42-43.

${ }_{54}$ Nissen, A. E., and Hoyt, S. L., On the occurrence of silver in argentiferous galena ores: Econ. Geology, vol. 10, pp. 172-179, 1915. Lindgren, Waldemar, Mineral deposits, 3d ed., p. 970, 1928. Schneiderhöhn, H., Anleitung zur mikroskopischen Bestimmung von Erzen, pp. 100, 104, 105, 133, 208, 209, Berlin, 1922. Van der Veen, R. W., Minerography and ore deposition, vol. 1, pp. 47-48, The Hague, 1925.

${ }_{55}$ Brinsmade, R. B., op. cit., p. 51.
}

ton. Galena ore from the Black Cloud mine assayed 13.5 percent of lead and 2 ounces of silver to the ton.

Apparently the silver is not confined to the galena but is also present in some unrecognizable form in or with some of the other minerals, as has been emphasized for the Leadville district, Colorado. ${ }^{56}$ Where the silver content of the ore is higher than ordinary, this lack of definite relations may be attributable to submicroscopic supergene silver minerals in sulphide ore a short distance below the oxidized zone, as interpreted for the ore of the Ground Hog mine in the Central mining district, New Mexico. ${ }^{57}$

\section{SULPHIDE ZONE (SUPERGENE)}

\section{ARGENTITE (?)}

A mineral not positively identified but like the silver sulphide argentite in most of its properties is intergrown with chalcocite in the high-grade silver ore of the Iron Mask vein. As it seems to be contemporaneous with chalcocite, it is thought to be supergene.

NATIVE SILVER

Wire silver is found at the Anchor mine in seams and crevices in the sulphides, chiefly galena, and in the gangue. The richest ore begins about 50 feet below the surface and is confined to a vertical zone about 75 feet deep. The vein below this zone contains scant sphalerite and very little silver; in other words, the silver is limited to a certain vertical zone with an abrupt change from good ore to almost worthless veinmatter. This change is very suggestive of supergene processes in or just below the oxidized zone. No native silver was noted in the two polished specimens of this ore examined, but the late E. H. Wells, ${ }^{58}$ then president of the New Mexico School of Mines, stated that native silver was distinctly visible in polished specimens examined at that institution some time ago. The specimens were lost in the fire that destroyed the museum in 1928.

Specks of native silver accompanied by pyrite occur at the Black Cloud mine in replacement quartz, which also contained minor quantities of galena, sphalerite, and secondary chalcocite and covellite.

\section{OXIDIZED ZONE}

\section{CERARGYRITE}

All the oxidized ores, both lead and zinc, contain a few ounces of silver to the ton. Brinsmade ${ }^{59}$ states that the oxidized lead ores contained from 2 to 5 ounces of silver to the ton and the oxidized zinc ores somewhat less. The large body of lead carbonate

${ }^{56}$ Emmons, S. F., Irving, J. D., and Loughlin, G. F., Geology and ore deposits of the Leadville mining district, Colorado: U. S. Geol. Survey Prof. Paper 148, pp. 198-199, 1927.

${ }^{57}$ Lasky, S. G., Distribution of silver in base-metal ores : Am. Inst. Min. Met. Eng. Trans., vol. 115 (Mining Geology), pp. 69-80, 1935.

${ }_{58}$ Personal communication.

${ }^{59}$ Brinsmade, R. B., op. cit., p. 51. 
mined in the Juanita mine in the early days contained from 8 to 10 ounces of silver to the ton, ${ }^{60}$ and some of the references to ore mined in the earliest days of the district imply a much greater content. The exact nature of the silver in the oxidized ore has not been determined, but in the richer oxidized ores at least it was presumably in horn silver, or cerargyrite, which is common in the oxidized silver ores throughout the West.

\section{NATIVE GOLD}

Most of the sulphide and oxidized ores have contained very little gold, as is shown in the table of production, but native gold was visible in oxidized ore of the Stonewall mine. This gold occurred as grains and wires accompanied by cerussite and willemite in partly silicified limestone. Galena was found on the lower side of one pocket of gold ore, and it was reported that wire gold occurred with the galena. Ore with an average gold content of 1 ounce to the ton was shipped from the Young America mine, probably before 1900 , but there is no information regarding the mode of occurrence of the gold.

\section{MANGANESE MINERALS} SULPHIDE ZONE

Although manganese is present in all the oxidized ores, the primary mineral or minerals from which it was derived are not clearly evident and may only be inferred. The siderite found at the Germany, mine may contain manganese and very probably some calcite contains manganese. The altered mineral described under "Hedenbergite" and the calcite that has replaced undoubted hedenbergite also contain manganese.

\section{OXIDIZED ZONE}

PYROLUSITE, PSILOMELANE, AND WAD

The manganese oxides pyrolusite and psilomelane and wad, the earthy impure variety of psilomelane, ${ }^{61}$ may be individually recognizable in isolated occurrences, but they are generally so mixed with one another and with iron oxides that exact mineral species cannot be identified. These mixtures, accompanied by clay minerals, are prominent along the borders of zinc and lead carbonate ore bodies, particularly on their undersides. The massive, buff-colored variety of zinc carbonate is impregnated with dendritic manganese stains, and manganese and iron oxides along cleavage planes of calcite are common.

\section{CADMIUM MINERAL GREENOCKITE}

Greenockite, cadmium sulphide, occurs as a very thin orange-yellow coating upon smithsonite and as a yellow stain within it. Partial analyses of the yellow smithsonite are given on page 93.

\footnotetext{
${ }^{60}$ Silliman, Benjamin, Jr., op. cit., p. 426.

61 Orcel, J., and Pavlovitch, S., Les caractères microscopiques des oxydes de manganese et des manganites naturels : Soc. franç. minéralogie Bull., vol. 54, pp. 108-179, 1931.
}

GANGUE MINERALS

The gangue minerals are treated for convenience in the following order: silicates formed at relatively high temperature and characteristic of the "contact-metamorphic" zone; silicates, quartz, barite, and fluorspar formed at moderate to relatively low temperatures; and clay minerals formed only in and just below the oxidized zone by descending waters.

\section{TOURMALINE}

Tourmaline, a complex borosilicate of aluminum with magnesium, iron, or the alkali metals, occurs in a small pegmatite dike about an inch thick in pre-Cambrian granite east of Anchor Canyon but is probably of the same general age as the ore deposits (p. 49). Tufts of tourmaline occur on fracture surfaces in the argillite and felsite near the Tertiary (?) granite and also in the aplite dikes in monzonite south of Hardscrabble Camp. Its occurrence in the aplite correlates it with the final stage of monzonitic intrusion, during or soon after which the early high-temperature silicate minerals in the sedimentary rocks were formed.

\section{WOLLASTONITE}

Wollastonite, a calcium silicate, is a light gray to white mineral that occurs both in fine-grained to dense masses and in coarse-grained aggregates of elongate or flbrous crystals. It is characteristic of contactmetamorphic limestone and has been found in masses of Kelly limestone enclosed in monzonite just north of Oak Spring and in Tertiary (?) granite at the Hardscrabble mine. That at Oak Spring closely resembles fine-grained marble except for its higher specific gravity. That at the Hardscrabble mine, in the caved roof of the stope east of the north glory hole, includes both the finegrained sugary variety and a relatively coarse-grained variety in sharp contact with each other. Under the microscope the fine-grained variety proves to be essentially pure wollastonite, whereas the coarse-grained variety is a mixture of wollastonite and calcite.

\section{ANDALUSITE}

Andalusite, an aluminum silicate, has been found only in hornfels that evidently marks the basal Sandia beds along the west edge of the Kelly limestone at the Hardscrabble mine. There it forms a few scattered grains associated with sericite and chlorite. This basal bed is in contact with the granite that encloses the limestone.

\section{DIOPSIDE}

Diopside, a calcium-magnesium silicate of the pyroxene group, is a common constituent of contact-metamorphic limestone, mostly in association with wollastonite and garnet. At Oak Spring it is associated with wollastonite in Kelly limestone, where the two minerals have been converted in part to a dense or fine-grained aggregate. 
On level 3 of the Nitt mine a block of limestone enclosed in monzonite but close by a sulphide ore body has been changed into a medium-grained rock composed of diopside crystals in a matrix of calcite. The diopside occurs as prismatic grains that are slightly altered to serpentine (antigorite). Its indices of refraction $(\alpha=1.68 ; \beta=1.69 ; \gamma=1.71)$ indicate that it contains about 25 percent of the hedenbergite molecule.

East of Granite Mountain a limestone layer in the upper quartzite member of the Sandia formation is impregnated with microscopic transparent specks whose birefringence suggests diopside. They are associated with minute magnetite grains, serpentine, and chlorite.

\section{HEDENBERGITE}

Hedenbergite has a formula analogous to that of diopside, but it contains iron instead of magnesium. It is found farther from igneous contacts than diopside, and its association with other minerals implies that it was formed at a lower temperature and during a later stage of mineralization than diopside. Chemical tests show that the hedenbergite from Magdalena contains considerable manganese. It was present in the mixed sulphide ore collected by Gordon in the Graphic mine in $1905^{62}$ and in similar ore collected by Loughlin in the Linchburg tunnel in 1916. It forms fine-grained masses and also rosettes about half an inch in diameter and columnar sheaves as much as 2 inches long. The indices of refraction of the hedenbergite from the Linchburg tunnel are $\alpha=1.722 ; \beta=1.733, \gamma=1.748$. The fresh mineral is clear greenish black, but the altered mineral is dull green to brown. It is associated with garnet (andradite), specularite, magnetite, quartz, and calcite. Under the microscope it is seen to be considerably replaced by quartz and calcite and only poorly defined skeletal crystals remain that resemble groups of parallel slender needles. (See pl. 29, A). Similar material described by Wuestner ${ }^{63}$ as altered hedenbergite, and submitted by him to Lasky, resembles hedenbergite in structure and apparently contains manganese; but it is intimately mixed with iron oxides and silicate minerals and cannot be positively identified.

\section{TREMOLITE AND ACTINOLITE}

A thin section of the metamorphosed limestone taken from a dump near Oak Spring shows tremolite associated with wollastonite, grossularite, diopside, muscovite, rare sanidine, and titanite. Gordon reported ${ }^{64}$ that the ores studied in 1905 contained tremolite, the magnesium-calcium amphibole, intergrown with pyroxene and associated with specularite and sphalerite; and Wuestner reported the presence of actinolite, the

\footnotetext{
${ }^{62}$ Lindgren. Waldemar, Graton, L. C., and Gordon, C. H., op. cit, pl. $18, B$.

63 Wuestner, Herman, op. cit., p. 129.

Lindgren, Waldemar, Graton, L. C., and Gordon, C. H., op. cit., ก. 253 .
}

ferroan variety of tremolite, but, with the exception of the specimen from the dump near Oak Spring, no tremolite or actinolite was found during the later survey; however, pseudomorphs of antigorite found on level 2 of the Nitt mine may represent former tremolite or actinolite.

Radiating aggregates of specularite, pyrite, and zinc blende and a white material that resembled tremolite were found at several places in the Graphic-Waldo mine, but the white material proved to be calcite accompanied by a little quartz and chlorite.

\section{GARNET}

Garnet, though prominent in a few places, is a minor member of the high-temperature group. Two varieties-grossularite and andradite-are present, the first associated with wollastonite and diopside and the second with hedenbergite.

Grossularite, the calcium-aluminum garnet, is conspicuous in metamorphosed Kelly limestone at the Hardscrabble mine and at Oak Spring; at the east base of Stendel Ridge and in the low hill east of Granite Mountain it is present in limestone beds of the Sandia formation. It forms brown and green granular aggregates. Garnets of both colors are present at the Hardscrabble mine and Oak Spring. The index of refraction for the brown variety is about 1.76 , and that of the green variety 1.74 , both of which correspond to grossularite. Both varieties are colorless and indistinguishable in thin section, and both contain concentric zones, some of which are anisotropic.

Yellowish-brown andradite, the calcium-iron garnet, has been found in the Linchburg tunnel associated with hedenbergite, quartz, calcite, specularite, magnetite, and sulphides, which have replaced the "Pinto" bed of the lower Kelly limestone. It appears to have formed later than the hedenbergite but earlier than the other minerals. Its index of refraction is 1.885 . Its crystals, as seen in thin section, have six-sided and four-sided outlines and consist of "pyramids" whose apices meet in the center and whose bases correspond to crystal faces. This structure, according to Winchell, ${ }^{65}$ is characteristic of the uvarovite-grossularite-andradite group. The "pyramids" contain concentric anisotropic zones. The garnet in the adjacent argillite is colorless and isotropic in thin section. Its index of refraction has not been determined. Garnet has also been reported from the edge of the zinc sulphide stope below level 9 of the Graphic-Waldo mine.

\section{EPIDOTE}

Epidote, a hydrous silicate of calcium, aluminum, and iron, forms distinct dark-green bladelike to columnar crystals, which are sparingly present in the ores. It also forms dense green to yellowish-green veins and

\footnotetext{
${ }^{65}$ Winchell, A. N., op. cit., pp. 257-265.
} 
patches, especially in altered igneous and siliceous sedimentary rocks. Minute to microscopic grains are commonly associated with quartz, sericite, and chlorite and add to the green color of altered rocks. Some of the limestone beds of the Sandia formation enclosed in monzonite on level 2 of the Nitt mine have been converted to rather coarsely granular epidote that somewhat resembles the granular green garnet at Oak Spring. Limestone interbedded with the shales at the east base of Stendel Ridge is also green with epidote in places, as is the coarse breccia at the base of the overlying volcanic rocks. The breccia is composed of epidotized shale, limestone, and quartzite fragments in epidotized volcanic tuff. Another noteworthy occurrence of epidote is in small coarse-grained or pegmatitic veins of quartz, feldspar, epidote, and calcite that cut the monzonite near its contact with metamorphic limestone at Oak Spring.

\section{SERPENTINE (ANTIGORITE)}

Antigorite, a variety of serpentine, occurs as an alteration product of one or more of the magnesiumbearing silicates, particularly diopside, in contactmetamorphic zones, and also as a direct replacement product of limestone. On level 2 of the Nitt mine, pseudomorphs of antigorite after some elongate crystals whose form resembles that of actinolite or tremolite were found. The antigorite is pale brown to fleshcolored and is soft and highly cleavable.

Serpentine is also present in fragments on two small dumps a little west and southwest of the southeast corner of sec. 12 , T. 2 S., R. 4 W. It is intimately intergrown with chlorite. The serpentine-chlorite rock is banded with black layers of magnetite as much as an eighth of an inch thick.

\section{QUARTZ}

Quartz is the most widespread product of mineralization in the district. It forms massive veins of milky to gray quartz with or without conspicuous amounts of other minerals and fine-grained to dense masses of jasperoid that have replaced limestone. Both of these massive varieties contain vugs and fractures lined with well-formed white to brownish quartz crystals. In the southernmost part of the district, chalcedonic quartz forms small geodelike growths, especially in the upper andesite.

Quartz is least conspicuous in the silicate zones near intrusive stocks and in the large bodies of specularitemagnetite and sulphide ores of the Graphic-Waldo and Kelly mines. The average silica content of the sulphide ores mined in 1906 was about 10 percent. ${ }^{66}$ Most of the ore bodies, however, are connected with fissures that contain milky quartz, with or without other vein minerals. They also have small to conspicuous casings of

Brinsmade, R. B.; op. cit., p. 50. fine-grained quartz or jaspcroid. Quartz veins, most of which are comparatively small, are more conspicuous in the outer parts of the district, where they cut both the Tertiary (?) volcanic and the pre-Cambrian rocks. The large prominent replacement veins of milky quartz in felsite southeast of Hardscrabble Camp and in monzonite and rhyolite porphyry south of Granite Mountain are striking exceptions to the veins as a whole.

By far the greatest development of quartz is in the large masses of jasperoid that have replaced the Kelly limestone throughout the southeast part of the district (pl. 28). Southeast of Grand Ledge tunnel and north of the Socorro highway the pre-Cambrian argillite is also replaced by jasperoid. The masses that have replaced limestone contain many openings, some of which may express shrinkage during replacement but most of which represent incomplete replacement; many may even contain remnants of unreplaced limestone that have not been entirely removed by subsequent weathering processes. These openings are lined with small to large crystals of quartz, some of which under the microscope show several stages of growth, as shown in figure 11. Some fractures in the jasperoid contain small veins of milky quartz, barite, and sulphides identical with the quartz veins elsewhere in the district.

Under the microscope some specimens of jasperoid suggest the progress of replacement by the growth of small well-formed crystals in advance of the main mass. As the process continues and these crystals form a net-

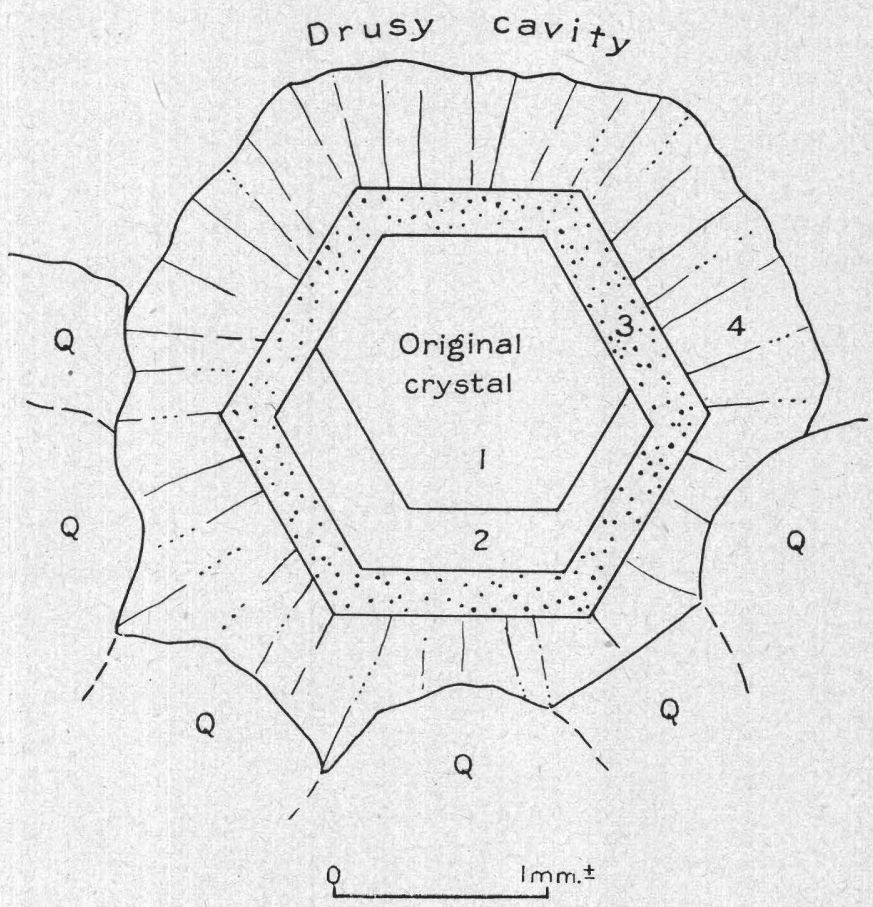

Figure 11.-Microdrawing showing four distinct stages of growth of a quartz crystal in a drusy cavity in jasperoid: 1 , Original crystal of clear quartz; 2 , accretion, also of clear quartz; 3 , zone containing considerable "dust"; 4 , clear quartz with radial structure. All four zones are in optical continuity. Q, Adjacent quartz grains in jas perold. 
work, the spaces between them become filled with anhedral grains, some of which are in optical continuity with the well-formed crystals. Similar wellformed crystals enclosed in sulphides indicate that silicification on a relatively small scale has been overtaken by sulphide deposition that completed the replacement of limestone. Field observations, however, suggest that jasperization in the main occurred along a wavelike front that yielded a sharp contact between jasperoid and limestone.

\section{SERICITE}

Sericite, a fine-grained silky variety of muscovite, is an abundant constituent of argillite and altered igneous rocks and a minor constituent of quartz veins. In the altered rocks it commonly impregnates or replaces feldspar grains, and where alteration has been very pronounced it has replaced other minerals, even including quartz. Parts of the pyritized monzonite in upper Hardscrabble Valley, for example, have been changed to aggregates of sericite, pyrite, and chlorite in nearly equal amounts. The sericite is in part intergrown with chlorite and in part forms radial sheaflike growths. Where silicification has been extreme, any sericite formerly present has been replaced by quartz, but for the most part sericite and fine-grained quartz have been deposited simultaneously and represent a less extreme degree of alteration.

\section{CHLORITE}

Chlorite, a dark green micaceous mineral, is commonly fine-grained and closely associated with sericite. For the most part it impregnates or replaces the dark silicate minerals of the igneous rocks, but it is also a constituent of altered sedimentary rocks and of mineral deposits. It is abundant in the pre-Cambrian argillite, gabbro, and diabase, accounting largely for their darkgreen or greenish-gray colors. It is also common in the Tertiary (?) igneous rocks, especially the monzonite and lamprophyre, and in altered shale, impure limestone, and quartzite. It is a prominent gangue mineral in some of the pyritic lenses of the Graphic-Waldo mine.

\section{THAUMASITE}

A white fibrous crystalline mineral with properties corresponding to those of thaumasite, a hydrous silicate-carbonate-sulphate of calcium, occurs as a felted crust of silky fibers on some of the metamorphic limestone northeast of Oak Spring. The optical properties are as follows : $\epsilon=1.47 \pm ; \omega=1.51 \pm$; the mineral is optically negative. It effervesces in hydrochloric acid, leaving a flaky residue of silica.

\section{SIDERITE}

Siderite is associated with galena, zinc blende, replacement quartz, and comparatively abundant pink barite on level 3 of the Kelly mine. Siderite crystals are also conspicuous in a vein near the south end of the Germany mine. The erystals occur as pearly palebrown to white interlocking rhombs, as much as 2 millimeters in diameter. They coat vugs in the vein and adjoining silicified limestone and are also perched on botryoidal growths of sphalerite.

All the siderite examined has an $\omega$ index of refraction not much above 1.82 , which implies the presence of some other element, as the index $\omega$ of pure siderite is 1.873 .

A massive granular carbonate resembling the manganosiderite of the Leadville district, of Colorado, was found on levels 6 and 7 of the Graphic-Waldo mine and was the principal constituent of a bleached and apparently recrystallized 7 -foot bed of limestone that lay between two ore shoots (see fig. 9). The associated ore and gangue minerals were specularite, magnetite, sulphides, quartz, and radiating blades of calcite. If similar carbonate with high contents of iron and manganese was originally present in the ore bodies that have been thoroughly oxidized, the prominence of brown iron oxides, and especially the manganese oxides, could be more readily explained. The contrast in association between this granular carbonate and the siderite noted above recalls a similar contrast at Leadville, where small crystals of siderite coat sulphide ore in the Tucson mine and large masses of manganosiderite in the same mine are replaced by sulphide ore. ${ }^{67}$

\section{DOLOMITE}

The only dolomite seen-in a specimen collected by Philip Argall-lined the opening in the middle of a layered veinlet that cut a typical mass of specularite and interstitial quartz. The outermost layer of the veinlet was quartz followed by one of specularite, another of quartz, and next the layer of dolomite. The dolomite was pale pink and formed typical rhombs.

\section{CALCITE}

Calcite, besides being the principal constituent of the limestones, occurs in three forms that are of considerable significance in the interpretation of ore-forming processes. These forms are platy crystals in radial aggregates, long pointed crystals or scalenohedrons, and flat or disklike rhombohedral crystals.

The platy crystals have been found in the sulphide ores of the Graphic-Waldo and Kelly mines and in metamorphic limestone on the dumps east of Granite Mountain. They give a distinctive appearance to the ore and the contact rock. They are white to light gray and are as much as 12 millimeters in length and 2 millimeters in width. In the ore they are accompanied by scales of specularite arranged along their radiating boundaries and by sphalerite and small amounts of

67 Emmons, S. F., Irving, J, D, and Loughlin, G. F , Geology and ore deposits of the Leadville mining district, Colorado: U, S. Geol. Survey Prof. Paper 148, pp. 152, 291, 1927. 
other sulphides and quartz that have impregnated them but preserved much of their radial arrangement. As the thinner plates appear fibrous in cross section (pl. 29, $A$ ), aggregates of radiating and interlocking crystals may be mistaken at first for such fibrous silicates as tremolite and hedenbergite (see p. 100). Some of the platy to fibrous calcite is so closely associated with these silicates as to indicate their pseudomorphous replacement by calcite, but this relation has been obscured by the replacement of hedenbergite, and perhaps of calcite also, by quartz (pl. 29, $A$ ).

East of Granite Mountain platy calcite is intergrown with fine-grained interstitial aggregates of chlorite, serpentine, epidote, quartz, and garnet (pl. 29, $B$ ). In places lobes of chlorite and serpentine replace the edges of calcite crystals. Only a few small, scattered grains of garnet occur, and they are most commonly enclosed in the platy calcite.

Platy calcite is a relatively high temperature form, and aggregates of it are among the earliest products of crystallization in quartz-calcite-gold veins characteristic of the shallow or epithermal zone of ore deposition. The platy calcite of Magdalena, therefore, may have resulted from recrystallization of limestone during or soon after the development of the high-temperature silicates, and its tendency to radial arrangement may have been favored by the radial habits of the silicates. The specularite flakes may also have grown with the calcite or may have impregnated it along crystal boundaries. Regardless of its exact mode of origin, this calcite is regarded as evidence of mineral deposition at relatively high temperature and before the main sulphide stage. Qualitative tests on unstained calcite showed the presence of some iron, and the calcite associated with hedenbergite was found to contain considerable manganese.

The scalenohedral calcite occurs mainly along fissures outside the margins or ends of ore shoots, and to a minor extent as vug and fracture linings within ore shoots. This mode of occurrence is typical of several districts ${ }^{68}$ and evidently represents deposition by weak ascending or hypogene solutions that had become largely depleted of their metal content. Where the crystals have completely filled fissures they form veins with transverse columnar structure.

The disklike or "nail-head" crystals are colorless and as much as half an inch in diameter. They are characteristic of the oxidized zones and are very common as cavity linings in bodies of iron and manganese oxide. They are also present in oxidized lead and zinc ores, and in the adjoining rocks. They are found coating hemimorphite, the latest oxidized zinc mineral, and mark the very latest stage of deposition in the oxidized zone.

\footnotetext{
${ }^{68}$ Lindgren, Waldemar, and Loughlin, G. F., Geology and ore deposits of the Tintic mining district, Utah: U. S. Geol. Survey Prof. Paper 107, p. 159,1919 . Loughlin, G. F., and Behre, C. H., Jr., Zoning of ore deposits, Leadville district, Colorado: Econ. Geology, vol. 29, p. 230, 1934.
}

\section{ARAGONITE}

Aragonite, the orthorhombic form of calcium carbonate, has been reported by Wuestner ${ }^{69}$ in a number of forms-delicate fibres coating other minerals, clusters of pseudohexagonal crystals in part changed to smithsonite, and botryoidal or mushroomlike, fibrous, and massive forms.

\section{BARITE}

Barite, barium sulphate, occurs in white to pale-pink platy crystals as much as 4 inches in diameter. They form radiating and interlocking groups with interstitial quartz and fluorspar and are characteristic constituents of the gangue in the outlying deposits of the district, where the temperature of mineralizing solutions was comparatively low. The northernmost occurrence of it in the main ore zone south of the Nitt stock is on level 3 in the southeast part of the Graphic-Waldo mine. It is present in the Kelly mine but only in spots along the margins of the ore shoots and in veinlets that cut the massive sulphide ore and are preserved in the oxidized ore. Some of the veinlets are nearly free from quartz and fluorspar. Barite is more conspicuous in the Juanita mine and is a characteristic gangue mineral from there southward. The barite in these outlying deposits was deposited before the sphalerite and galena that accompany it and before part of the quartz. The largest crystals seen, however, are in small prospects of little promise on the upper east slope of the range. Narrow veins of barite, quartz, and sulphides fill fractures in the extensive masses of jasperoid or silicified limestone in the southeast part of the district. Barite with fluorspar and quartz is a principal gangue mineral in the Anchor vein, near the east edge of the larger stock of Tertiary (?) granite, and in several of the prospects in the Granite Mountain area.

\section{FLUORSPAR}

Fluorspar, calcium fluoride, forms colorless to green crystals of cubic to irregular outline as much as an inch in diameter. It is associated with barite, as noted above, but is more restricted to the outlying deposits and is most conspicuous in prospects of little promise.

\section{CLAY MINERALS}

Allophane, halloysite, beidellite, montmorillonite, kaolinite.

Masses, veins, and patches of clay or "talc", in part colored by red, brown, and yellow iron oxides and black manganese oxides, are common associates of the oxidized ores. They represent in part the original impurities in leached limestone beds, particularly the "silver pipe", but the largest masses, derived largely through the leaching of overlying shaly rock, have replaced Kelly limestone along major faults and around oxidized ore bodies. Specimens from a most

${ }^{6}$ Wuestner, Herman, op. cit., p. 129. 
conspicuous exposure at the outcrop of the Kelly ore body along the Kelly-Graphic fault on the north side of Kelly Gulch consist mainly of the amorphous mineral allophane, which is pale bluish or greenish and translucent on freshly broken surfaces but becomes chalky white after prolonged exposure. The bluish or greenish color is caused by a small amount of chrysocolla, and some allophane is accompanied by the blue copper carbonate azurite. Some of the chalky white crusts have finely botryoidal surfaces and radiating structures, and those examined microscopically consist of other clay minerals derived from allophane; for example, material from a veinlet in the Juanita mine has been tentatively determined by C. S. Ross, of the U. S. Geological Survey, as halloysite that has crystallized from the allophane. Other material that forms white, platy rosettes on allophane more closely resembles beidellite. One pale blue specimen, from a vein cutting zinc carbonate in the Kelly mine proved to be a mixture of halloysite and kaolinite. Kaolinlike material is the essential impurity in the "silver pipe" bed, but the claylike residues of zinc carbonate ores that have replaced the "silver pipe" bed resemble sericite microscopically. Some of the clay associated with zinc-carbonate ores may contain appreciable amounts of zinc, but the few samples tested showed only negligible quantities. (See p. 94.)

The clay minerals beidellite-montmorillonite and the celadonite that occur in some of the volcanic rocks have already been deseribed (p. 55).

\section{CELADONITE}

No celadonite has been found in close association with ore bodies, but the celadonite and associated clay mineral in altered volcanic rocks, described on page 30 and considered in connection with processes of alteration (p. 55) may be cited here as indicative of deposition under relatively low temperature conditions.

\section{DISTRIBUTION AND CLASSIFICATION OF MINERAL} DEPOSITS

The distribution, sizes, and general forms of most of the ore bodies that have been mined in the Magdalena district are shown on plate 30 , which represents the area south of the Nitt monzonite stock, and in the illustrations that accompany mine descriptions (pp. 123 to 162). The largest deposits, which lie in the main ore zone between the Nitt stock and the town of Kelly, have replaced beds in the Kelly limestone both below and above the "silver pipe" along fissures of northerly and north-northwesterly trend. The main ore bodies in the Graphic-Waldo and Kelly mines pitch north-northwestward along the intersections of the fissures with the west-dipping limestone beds. Their southern or upper parts, above the general level of pediment D (p. 74), are oxidized and include separate shoots of lead carbonate and zinc carbonate ore. At the bottom of the oxidized zone some rich copper ore has been found, particularly in the Graphic-Waldo mine. Ore bodies in the Kelly mine are bounded on the east in places by small veinlike bodies that lie along the Kelly-Graphic fault.

South of Kelly the main ore zone is represented by replacement bodies in the Juanita and South Juanita mines. Farther south the Kelly limestone has been downfaulted along the main ore zone and is exposed only underground at the east end of the Linchburg tunnel, where some low-grade sulphide ore has been developed. At shallower levels, from Chihuahua Gulch to the south boundary of the district, the main ore zone is represented by veins that lie in or near the faults that separate pre-Cambrian from the Sandia and Madera formations. Most of these veins are in the oxidized zone and have been worked for lead-silver ore, although a little high-grade copper-gold ore is said to have been shipped from the Young America mine. Some mixed sulphide ore has been mined below the oxidized zone.

East of the main zone, in the southeast part of the district, much of the Kelly limestone has been replaced by fine-grained massive quartz or jasperoid, and the ore shoots are small replacement masses or bunches that lie beneath or between masses of jasperoid and also just below the "silver-pipe" bed. They consist of partly or completely oxidized lead ore accompanied in part by small bodies of oxidized zinc ore. West of the main ore zone only small veins in Abo sandstone and volcanic rock have been found. Very little ore has been produced from them.

North of the Nitt monzonite stock the continuation of the main ore zone extends along Hardscrabble Valley and is represented by small prospects in pyritic monzonite and by the Vindicator vein (pl. 38), which occupies a fault between Madera limestone and Tertiary (?) granite. To the east elongate replacement deposits of oxidized lead-silver ore in Kelly limestone have been mined in the Hardscrabble mine (pl. 38), and farther east, across the summit of the range, a vein cutting Tertiary (?) granite has been worked in the Anchor mine (fig. 27).

No underground information is available on any of the small deposits in the Granite Mountain area and the area west of it; in fact, almost no records at all have been available to us regarding prospects in this area. To the south of the Magdalena district the small Water Canyon and Hop Canyon districts, briefly described by Lasky, ${ }^{70}$ may be considered continuations of the Magdalena district. Further consideration of distribution is most conveniently presented in the descriptions of the different classes of ore, particularly on pages $105-110$.

\footnotetext{
${ }^{70}$ Lasky, S. G., The ore deposits of Socorro County, N. Mex. ; New Mexico School of Mines, State Bur. Mines and Mineral Resources, Bull. 8 , pp. $43-44$ and $46-54,1932$.
} 


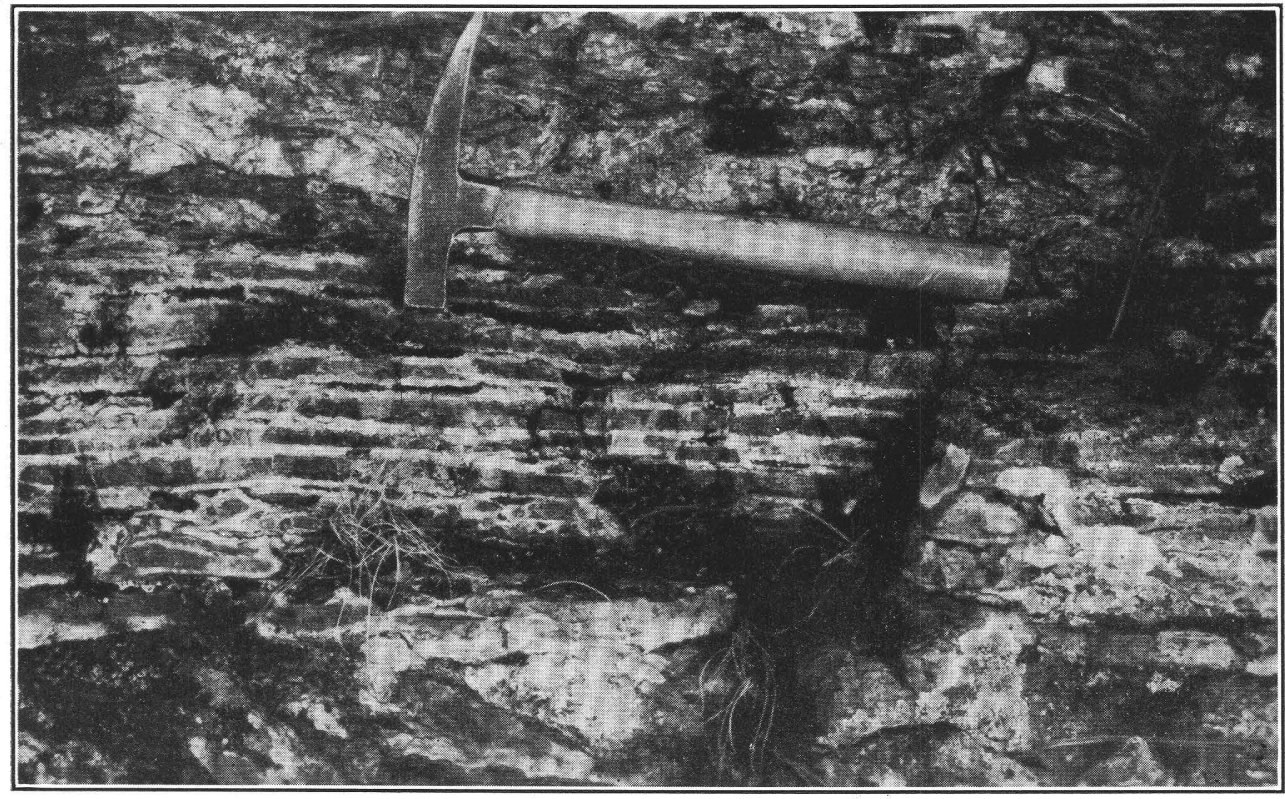

A. PARALlel BANDED SILICIFIED KELLY LIMESTONE.

Looking down on surface of large boulder. Parallel cavities are lined with quartz crystals. Near crest of main range in southeastern part of district.

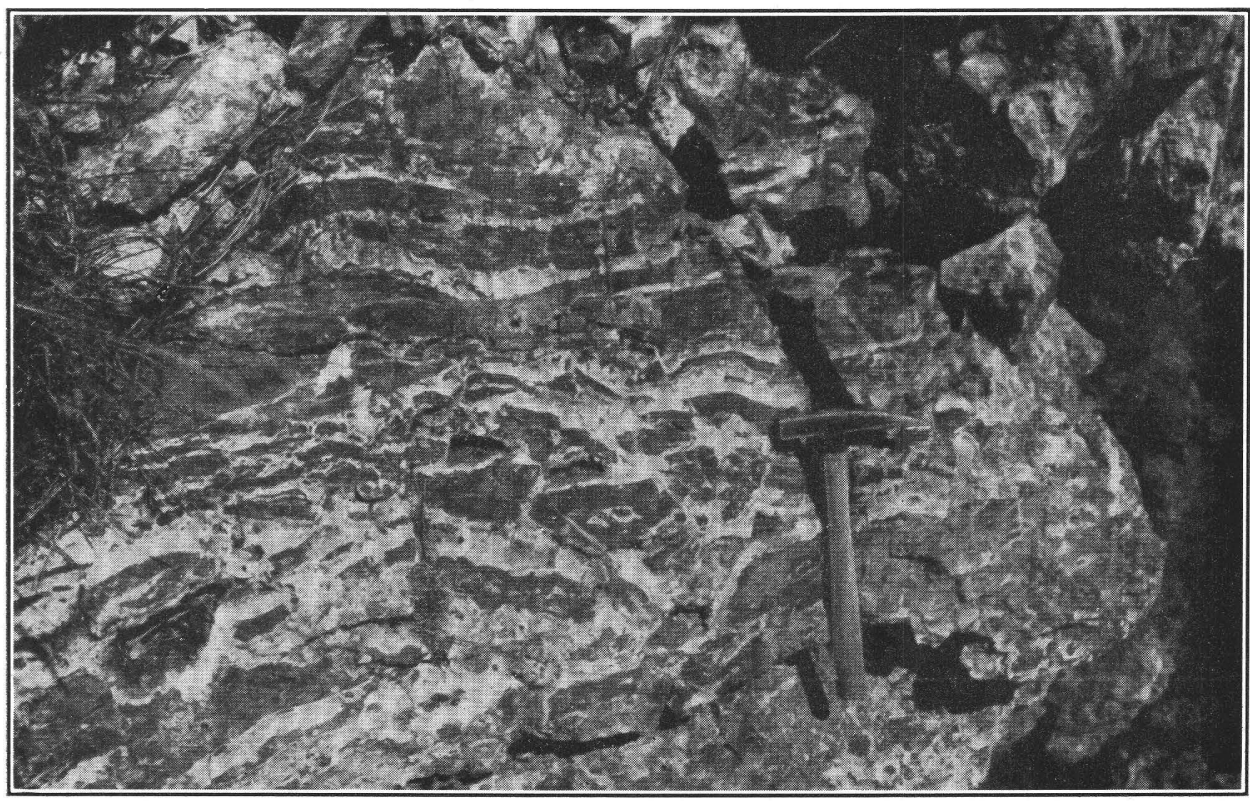

B. BRECGIATED SILICIFIED KELLY LIMESTONE RECEMENTED BY LATER MILKY QUARTZ. Near crest of main range in southeastern part of district. 


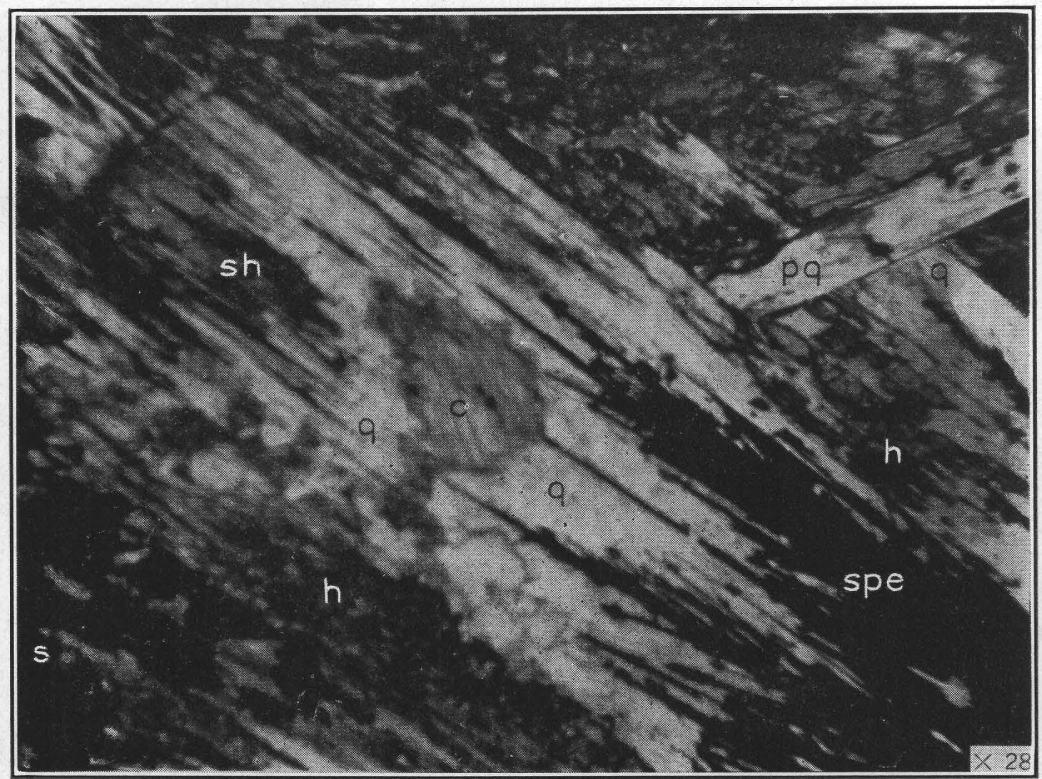

A. PHOTOMICROGRAPH OF ORE FROM GRAPHIC-WALDO MINE.

Shows specularite (spe), hedenbergite (h), quartz (q), calcite (c), and sulphides (s). Skeletal crystals of hedenbergite (sh) are largely replaced by quartz, and the relation of the pseudomorphous quartz (pq) to the specularite suggests that the specularite represents an earlier partial replacement of hedenbergite. Plain light.

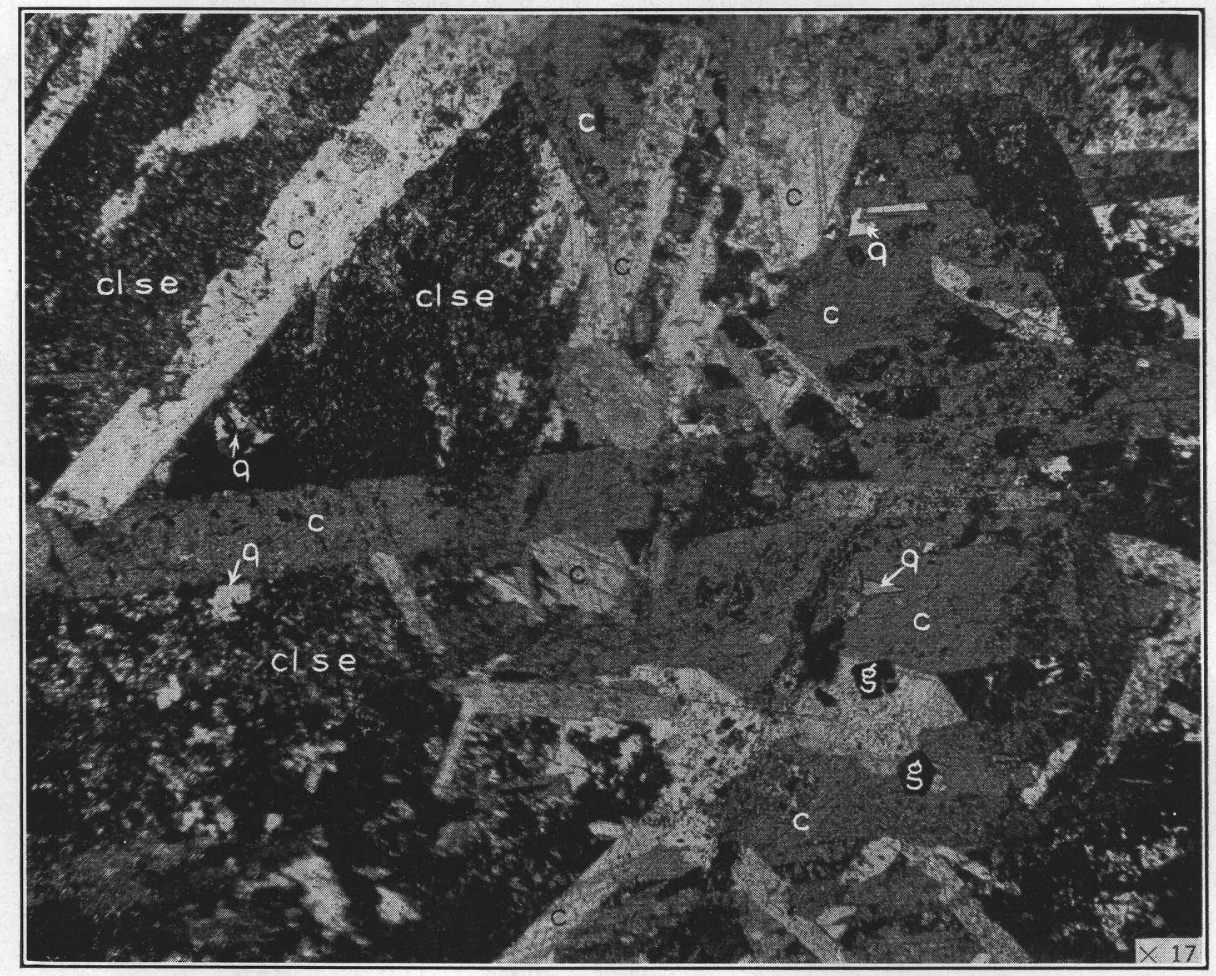

B. PHOTOMICROGRAPH OF METAMORPHIC LIMESTONE FROM A BED IN THE SHALE MEMBER OF THE SANDIA FORMATION EAST OF GRANITE MOUNTAIN. The rock consists of interlocking platy calcite crystals (c) and a fine interstitial intergrowth of chlorite, serpentine, and epidote (cl s e) with some quartz (q) and a few garnets (g). 
The ore bodies of the district are classified in this report mainly according to origin-primary, or hypogene, and secondary, or supergene. The primary ores are further classified according to the relative temperatures at which they were formed-high temperature or hypothermal and moderate temperature or mesothermal. The moderate-temperature class evidently has a great temperature range. It is conveniently subdivided into a "hotter" and a "cooler" group, which are distinguishable by their mineral compositions and have differed markedly in their relative commercial importance. The "cooler" group has recently been recognized by Graton as a distinct class and was designated by the term "leptothermal" (formed at mild temperature). ${ }^{71}$ No low-temperature or epithermal ore deposits have been recognized within the district, but certain minerals are believed to have been deposited at relatively low temperature by solutions that had already deposited ore at moderate temperature. The minerals formed at these different temperatures are shown in the table on page 88 .

The ore bodies thus classified may be further classified according to form, but this further classification is of interest mainly in connection with the moderatetemperature class, which includes disseminated sulphide deposits in monzonite, in veins mainly within or along the margins of igneous rock and argillite, and in replacement deposits, mostly in limestone. Nearly all the output of the district has come from replacement deposits in limestone. A few productive veins have been mined along or close by major faults that separate limestone from Tertiary (?) granite or pre-Cambrian argillite. The disseminated sulphide deposits are of little or no prospective value.

The ores of the primary deposits may be classified according to their dominant metal contents, but such a subdivision is worth while only for the "moderatetemperature" ores. The secondary ores are divided first into oxidized and sulphide ores and subdivided according to dominant metal content.

\section{DEPOSITS FORMED AT HIGH TEMPERATURES}

Ores formed exclusively at high temperature in the Magdalena district are of no economic interest except insofar as they are associated with ores formed at moderate temperatures and thereby complicate mining and milling. The highest-temperature deposits, as may be surmised, are mostly limited to the immediate vicinity of the centers of igneous intrusion-the stocks of monzonite and Tertiary (?) granite; a few that have been found remote from the exposed stocks suggest the presence of concealed stocks below the present surface. The character of the high-temperature deposits differs considerably from place to place. They are mainly ex-

${ }^{71}$ Graton, L. C., The depth-zones in ore deposition: Econ. Geology, vol. 28 , pp. $513-555,1933$.

$200889-42-8$ pressed at the surface by the conversion of the original blue, gray, or black limestones into white crystalline limestone or into white, green, or brown aggregates of silicate minerals, principally wollastonite, diopside, garnet, and hedenbergite and the conversion of green argillite and black shale into dense green to gray hornfels; but these altered rocks afford no definite clue to the positions of ore bodies. Hedenbergite and the andradite variety of garnet are more closely associated with ore zones than the other silicate minerals. The significance of the silicate minerals in connection with rock alteration and origin of ores is considered on pages 50 and 51 .

A later stage of deposition at high temperature is expressed by the specularite-magnetite masses, none of which are sufficiently large to form commercial bodies of iron ore under present local conditions. These minerals have been found in the mines just south of the Nitt monzonite stock, at the Hardscrabble mine, the Linchburg tunnel, two prospect dumps in the Granite Mountain area, and in surface debris on the Medley Ranch to the northwest of Magdalena Mountain, where iron ore is said to have been obtained as flux for the old smelter at South Camp about 1882. The occurrences south of the Nitt stock, however, are intimately associated with sulphides in the largest ore bodies of the district. The specularite-magnetite masses were evidently formed by solutions that followed fissures and spread along adjacent bedding planes, impregnating and replacing limestone, some of which had already been partly replaced by silicates. Some of the specularite-magnetite masses are several feet in diameter, but most of them consist of layers only a foot or two thick with considerable interlayered limestone that has recrystallized into platy calcite (pp. 102-103). These thin layers were formed along the main ore zone and its principal branches throughout the Nitt, most of the Graphic-Waldo, and at least the northern half of the Kelly mine, and reduced the amount of limestone that was later available for replacement by sulphide ores. The distribution of specularite-magnetite masses and associated sulphide ores indicates that the ores of these mines were supplied from two local sources, one near the south contact of the Nitt stock and one at the intersection of the Kelly-Graphic fault and Kelly-Graphic cross fault. These sources will be considered in connection with structural discussions.

The occurrence of specularite and magnetite in the Linchburg tunnel, in the southern part of the district, is of particular interest, as they are associated with hedenbergite and garnet and indicate a high-temperature group of minerals. The occurrence therefore implies another center of mineral deposition along a major fault zone but remote from any exposed stock of monzonite or Tertiary (?) granite. Its discovery justifies the expectation of much more undeveloped 
ore in the southern part of the district than would otherwise have seemed possible.

\section{DEPOSITS FORMED AT MODERATE TEMPERATURES}

All the commercial deposits of the district and most of the minor deposits consist mainly or wholly of minerals that are characteristically formed at moderate temperatures, but they are divisible into two groups that represent the hotter and cooler parts of this range, or mesothermal and leptothermal as defined by Graton (see table, p. 88). The first group includes the more productive ore bodies, a few large quartz veins, and the immense jasperoid deposits that have replaced limestone; the second group includes relatively small ore bodies in the outlying parts of the district. Each group could be further divided according to mineral composition, form, and wall rock, but to do so would give undue prominence to features of little practical significance. It will suffice here to give first a brief separate description of a few large barren quartz veins in igneous rock that attract attention because of their size and then to consider the outstanding features of the productive ore bodies.

\section{LARGE BARREN QUARTZ VEINS IN IGNEOUS ROCK}

Large quartz veins in igneous rock have been found at two places in the district: in pre-Cambrian felsite south of the Hardscrabble mine on the west slope of the Magdalena Range and in the Tertiary (?) monzonite and rhyolite porphyry on the low hill a mile south of Granite Mountain. They cannot be definitely correlated with other mineral deposits in the district, but it seems most consistent to regard them as deposits formed during an early stage of the period of ore deposition but at a moderate temperature.

The large white vein in the Magdalena Range is a distinct topographic feature, which parallels the contact between felsite and argillite for 2,300 feet. A short thick vein lies 250 feet northwest of the southwest end of the large vein in steplike arrangement. No proof that it is a faulted part of the large vein could be found. The large vein is 25 feet thick at the crest of the range. It strikes $\mathrm{N} .70^{\circ} \mathrm{E}$. and dips steeply southsoutheast. It ranges in character from a white solid granular mass, completely replacing felsite and crisscrossed and bordered by a network of milky quartz veinlets, to vuggy masses lined with quartz crystals an inch or more long. Incomplete replacement of the felsite is represented by a porous mass of quartz crystals coated with films of sericite and accompanied by oxidized pyrite and green and black stains of copper and manganese minerals.

The large vein is cut by the same sets of minor fractures that cut the felsite, and midway down the west slope of the range it is slightly offset by a short fault of north-northwest trend that also offsets the contact between felsite and argillite but does not cross the contact between argillite and Tertiary (?) granite. This evidence suggests that the vein is older than the granite and could even be of pre-Cambrian age; but no similar veins have been found in the pre-Cambrian rocks of the district, and the trend of the vein is similar to that of some of the transverse faults that cut the Carboniferous rocks. Both the Tertiary (?) granite and the vein are cut by a white rhyolite dike, one of a linear group, and it may be that the minor fault that cuts the vein is a local member of a relatively new or reopened fissure zone along which the dikes were intruded.

Prospects along the vein are located at places where the vein has been disturbed. At the crest of the range it is crossed by a small barite-quartz-sulphide vein of northerly trend and in this respect is similar to the immense mass of jasperoid that has replaced Kelly limestone and pre-Cambrian argillite in the southern part of the district. Near its southwest end the large vein is crosscut by a shear zone of northwesterly trend that has been followed by an incline. A prospect dump at the short vein nearby shows rusty honeycombed quartz but no evidence of ore minerals, and it could not be determined whether this quartz was a part of the original vein or of a minor vein that cuts the original vein. Structural evidence, therefore, regarding the age of the two veins in felsite is inconclusive. There is no proof that they are not pre-Cambrian, but they may be of the same age as the jasperoid that was formed after the main period of vertical faulting in Tertiary (?) time (p. 53).

The large barren vein on the hill south of Granite Mountain is similar in general character to the veins in felsite just described. This vein, however, cuts rhyolite porphyry and monzonite and is apparently cut by a lamprophyre dike, although its intersection with the dike is concealed by debris. No contact between the vein and any white rhyolite dike is exposed. The age of this vein is, therefore, determined as younger than that of monzonite and probably older than that of lamprophyre. In this respect, it is similar to the granophyre that has replaced Tertiary (?) sandstone (p. 41). The granophyre may be regarded as a product of replacement at high temperature and the quartz vein one of replacement at a temperature too low to permit the formation of granophyre.

This interpretation is paralleled by that of the origin of jasperoid in the southern part of the district (p. 53). The jasperoid was deposited at the same general time as the high-temperature silicates that replaced limestone but at a temperature too low to permit the formation of those silicates.

\section{SULPHIDE DEPOSITS}

Sulphide deposits that represent the higher part of the moderate-temperature range include the large re- 
placement deposits of zinc-lead and copper ores in the Kelly limestone that have accounted for the greater part of the output of the district, small deposits of similar ore in adjacent parts of the Sandia and Madera formations, and noncommercial pyritic copper deposits in monzonite.

With few exceptions, these deposits lie along the main ore zone of the district, which extends southsoutheast through the Nitt, Graphic-Waldo, and Kelly mines (pl. 30) and continues beyond the south end of the district. The ores are represented along the main ore zone in the three mines named and in the Linchburg tunnel. Even material consisting mainly of specularite and magnetite is commonly so much impregnated with sulphide as to be classed as commercial sulphide ore of mill grade. The main zone may also be regarded as continuing northward under Hardscrabble Valley through the mineralized part of the Nitt monzonite stock. The exceptions include the deposits in the west ore zone along the Waldo fault and ore shoots of the Hardscrabble mine which lie along a relatively short fissure zone in Tertiary (?) granite northeast of the Nitt stock.

Ores that represent the cooler or leptothermal part of the moderate-temperature range are found throughout the rest of the district. They include all of the known deposits in the main zone south of the Kelly mine except that in the Linchburg tunnel and perhaps that in a poorly exposed vein near the breast of the Mistletoe or Gordon tunnel, and they may be grouped as follows: all the known deposits along the Germany, AmbrosiaTip Top, and Black Cloud zones, which may be regarded as eastern branches of the main zone; the minor zones in volcanic rock, most or all of which are western branches of the main zone; the Anchor vein, which may well be connected with the Hardscrabble deposit of hotter mesothermal ore; and the deposits in the Granite Mountain area and those north of Magdalena Mountain, which are too scattered and inadequately exposed to be correlated with any distinct zones.

The large replacement bodies lie mainly along minor faults and fissures, which as a group may be regarded as auxiliary members of the main fault zone. Some of the minor vertical to steeply west-dipping fissures in the Kelly mine are clearly branches or spurs that diverge north-northwestward from the KellyGraphic fault, which forms the east wall of the ore shoot. The Brown fault, along which the Kelly ore shoot attains its greatest length, has a similar divergent position but is terminated or interrupted by minor cross faults near the Kelly tunnel and does not actually join the Kelly-Graphic fault. The main ore shoot in the Graphic-Waldo and Nitt mines lies along minor faults and fissures of northwest strike and northeast dip, but the intersections of these faults with the west-dipping Kelly limestone have north-northwest trends and pitches. The principal of these minor faults pass upward into small "rolls" or monoclinal folds in the basal shale bed of the Sandia formation. The movement along these faults, as shown on page 71, caused auxiliary movement along bedding faults, especially at the top, middle, and probably the base of the Kelly limestone, which thus became especially permeable to ore-forming solutions.

Transverse faults, mostly of northeast strike and southeast dip, but in part of northwest strike and northeast dip, have also exerted some control over the form and distribution of the ore shoots. In the Graphic-Waldo mine they have permitted a widening of the larger ore shoots at or near their intersections with the longitudinal faults, and these intersections have also allowed solutions to rise into the Sandia formation and form small shoots that have been mined in its lower quartzite and lower limestone members. The transverse faults, though formed mainly before ore deposition, have also caused a few apparent offsets in the ore shoots that had replaced the previously offset parts of limestone beds. They appear to have been especially influential in the southern part of the Graphic-Waldo mine and to have served as connecting links between the main and eastern ore shoots; but most of the stopes there are so old and filled that data for a complete picture of them were not obtainable. Minor transverse faults in the Kelly mine have played similar parts.

The largest of the transverse faults associated with these ores is the Kelly-Graphic cross fault (see pl. 20). It forms an abrupt north end to the Kelly ore body, which was being mined in 1916 and from which a veinlet extends along the fault on level 6. This veinlet is somewhat shattered, indicating a small amount of postmineral movement along the fault; but the main ore body showed little effect of such movement; furthermore, the ore shoots found on the north side of the fault are small and irregular and are clearly not offset continuations of the main Kelly ore body. Practically all the movement along this fault, therefore, took place before ore deposition. Besides the difference in form, the presence of barite in the small ore shoots north of the fault suggests a gradation into the cooler mesothermal or leptothermal ores, whereas the large Kelly ore body, with its associated silicates, specularite, and magnetite, suggests that the broken ground near the intersection of the longitudinal Kelly-Graphic fault and the Kelly-Graphic cross fault was a local center of ore deposition distinct from that near the boundary between the Nitt and Graphic-Waldo mines. The small incompletely mapped ore shoots of the Juanita mine bear the same relations to the Kelly center as do those in the southern part of the Graphic-Waldo mine to the Nitt-Graphic center.

The west ore zone, along the Waldo fault, has been seen only where it is crossed by the Waldo tunnel. 
There it has the general structure of a vein in shattered ground along the fault that is bounded on the east by steeply dipping shale and limestone. South of the tunnel a nearly vertical pipe of sulphide ore was found at the intersection of a member of this fault zone and a fault or fissure of northwest trend. The west zone has also been explored in the Kelly mine, but we have very little information about it.

As the ore in the Linchburg tunnel has been mainly developed since our visit, the only specific remark that we can make about it is that it is walled on the east by the Young America fault, which corresponds to the Kelly-Graphic fault in the Kelly mine, although the argillite or "greenstone" in the east wall of the fault is impregnated with ore minerals to a minor degree.

In the Hardscrabble mine, which is in an elongate block of Kelly limestone enclosed in Tertiary (?) granite, the largest ore shoots are controlled by a set of fissures intersecting the bedding nearly at right angles. The ore extends from the limestone even into the underlying granite, which it has replaced along a network of fissures.

The Kelly limestone as a whole is the principal ore stratum in the district, but it is divisible into three or four minor units (fig. 1), which locally coalesce. The lowest is the "pinto" bed, which lies along or just above the impure basal beds and is overlain by fine-grained to dense beds, locally including the "marbleized lime" of the Kelly mine and the "lower silver pipe". Above the "lower silver pipe" the next unit is the coarsegrained or "lower crystalline" limestone, which underlies the main "silver pipe" bed. Similar coarse-grained limestone just above the main "silver pipe" forms a third unit in places, but it is less extensively mineralized than the coarse-grained limestone that lies near the top of the formation and is capped either by a thin "upper silver pipe" bed or by the shale at the base of the Sandia formation. In the Nitt and northern part of the Graphic-Waldo mine these beds are thoroughly connected, especially along the local faults that have shattered the "silver pipe" bed and even brought the beds below and above it into contact with each other. The "silver pipe" bed a very short distance from the faults, however, has resisted replacement almost entirely. In the Kelly mine the beds below the main "silver pipe" bed have probably been more productive than those above it, but a considerable part of their output has been oxidized zinc ore, which replaced limestone that had not been reached by the original sulphide ores; furthermore the upper beds have been eroded from the southern part of the Kelly mine.

Strata that have been productive above the Kelly limestone include the following: a quartzite bed just above the base of the Sandia formation in the old part of the Graphic-Waldo mine, where movement along intersecting faults had made it unusually pèrmeable; the lower limestone member of the Sandia formation in which ore deposition was also favored by intersecting faults above and between the principal ore shoots of the Graphic-Waldo mine; a limestone bed in the shale member of the Sandia formation, opened by the Cimarron tunnel near the intersection of the KellyGraphic cross fault and a probable branch of the 'longitudinal Kelly-Graphic fault; massive Madera limestone in the Vindicator mine made accessible by the longitudinal Vindicator fault and cross faults south of the shaft. These and other beds may contain ore shoots elsewhere, where structural conditions and proximity to ore zones are favorable; but in the light of past experience their contribution to the output of the district. will be small, and whether or not they are workable at a profit is questionable.

\section{HOTTER MESOTHERMAL ORES}

The character of the original sulphide ores will be considered here because of its bearing on the origin of the ores and on future exploration and development. The oxidized and enriched sulphide ores are more conveniently treated after the origin of the original sulphide ores has been considered.

The original ores of the hotter mesothermal group are mixtures of pyrite, sphalerite, galena, and chalcopyrite, with some or all of the following minerals in small to considerable amounts: specularite, magnetite, silicates, quartz, calcite, and manganiferous siderite. They are divisible according to their principal mineral or metal content into the following groups: (1) Pyritic or iron ores, (2) chalcopyrite-pyrite or copper ores, (3) sphalerite or zinc ores, (4) galena or lead ores, (5) mixed sulphide ores. The first two and last three of these groups are conveniently considered together.

$$
\text { IRON AND COPPER (PYRITIC) ORES }
$$

Massive, coarse-grained pyrite has replaced a considerable part of the Kelly limestone in the Nitt mine and the northernmost part of the main ore shoot in the Graphic-Waldo mine. It is accompanied by minor amounts of quartz and chlorite, but much of it appears at first glance to be essentially pure pyrite. The massive pyrite contains only negligible quantities of silver or gold. It could be regarded as a small reserve for the manufacture of sulphuric acid, but as much larger deposits in other districts are nearer markets, it must be regarded as of not even potential value under ordinary conditions.

The pyritic ore continues southward along the basal part of the Kelly limestone throughout the sulphide zone of the Graphic-Waldo mine, where it contains sufficient interstitial chalcopyrite to become a copper ore. Its copper content, however, has been appreciably increased in places by chalcocite, covellite, and mala- 
chite. Available records of shipments show its copper content to range from 1.7 to 9.4 percent and its silver content from 2.0 to 5.6 ounces to the ton. It contains considerable quartz, chlorite, and iron oxides, which are locally so abundant as to be left as pillars in the stopes. It also grades into mixed sulphide and sphalerite ores.

The limitation of this pyritic copper ore to the basal part of the Kelly limestone is remarkable and not satisfactorily explained. The distribution of oxidized copper ore implies that this pyritic ore was originally continuous in the same bed through much of the Graphic-Waldo mine and was present in parts of the Kelly mine also. A simple explanation would be that the solutions depositing this ore rose during an early stage and permeated the lowest replaceable bed; but it is noteworthy that the still earlier solutions of the silicate and specularite-magnetite stages, as well as the later solutions of the sulphide stages, replaced the upper part of the Kelly limestone. If temporary obstructions along the feeding fissures deflected the pyritic copper solutions into the lowest limestone beds, it is remarkable that they were effective at the same horizon and at the same time throughout the GraphicWaldo and at least part of the Kelly ground. The close association of the pyritic copper ore with the siliceous basal beds of the limestone and the siliceous argillite that forms the footwall of the pyritic copper shoot suggests that these siliceous rocks exerted some influence on the deposition of this particular ore, but there is no apparent reason why siliceous rocks should have any greater influence than those of pure limestone.

It is commonly recognized in many districts that pyrite-chalcopyrite ore represents an earlier stage of deposition than sphalerite and galena ores. The chalcopyrite, however, is interstitial to pyrite, and, in the Magdalena ores at least, no evidence has been found to show whether it was deposited by the same solution that deposited the pyrite or by a distinctly later solution that permeated not only the pyritic ore but sphalerite and galena ore as well. According to the second suggestion, the greater though unevenly distributed quantity of chalcopyrite in the pyritic ore could be attributed to the precipitating power of pyrite, whose iron and sulphur would react with copper in solution and produce chalcopyrite. If this were accepted, all the chalcopyrite in the deposits could be attributed to one stage which followed that of sphalerite and perhaps that of galena, but there is no reason why chalcopyrite could not have been formed at more than one stage.

The relative concentration of chalcocite and other copper minerals as coatings on chalcopyrite and pyrite and as linings of cavities and fractures will be considered on page 122 .
ZINO BLENDE, GALENA, AND MIXED SULPHIDE ORES

Zinc blende ores-those that contain sufficient zinc to be shipped to smelters or that yield only zinc concentrates in appreciable quantity through millinghave been the most abundant in the district, and their highest grades have been mined throughout the sulphide zones of the larger mines. They have not been mapped separately from zinc-lead sulphide ores, into which they grade, and the stopes shown on mine maps include both kinds, as well as small amounts of galena ores. They have been found at all horizons of the Kelly limestone, and their quantity at any one place, as well as their mineral composition, has depended on the degree of fracturing and permeability and on the extent to which the limestone had already been replaced by silicates, quartz, iron oxides, and pyrite. Surprisingly large irregular masses have been mined in the Hardscrabble and Nitt mines and in the northern part of the Graphic-Waldo mine, although iron oxides and pyrite are the most abundant minerals in all three places. Small shoots are present here and there in the pyritic copper ores. Elsewhere they are the dominant ores. Their composition varies greatly. Zine ores shipped crude have contained from 19.7 to 37.7 percent of zinc. They consist of ferroan zinc blende with small amounts of pyrite, galena, chalcopyrite, quartz, and calcite or other carbonate. Milling ores have contained from 10.1 to 15.3 percent of zine with correspondingly larger amounts of the other sulphides and especially of specularite, magnetite, and gangue minerals.

Ores in the hotter mesothermal zone that contain sufficient galena to be shipped directly as lead sulphide ores are scarce and have been seen in commercial quantity only at the transition between the sulphide and oxidized zones, where large quantities of zinc blende and smaller quantities of chalcopyrite and pyrite have been removed. Shipments of lead ore have contained from 15 to 20 percent of lead and from 3.4 to 5.3 ounces of silver to the ton. In the original sulphide deposits galena ore is confined to small lenticular bodies and streaks in which other minerals are comparatively scarce. These small bodies for the most part represent limestone that had escaped appreciable replacement during the zinc blende and earlier stages of deposition but some represent deposition along bedding planes or other openings. Galena for the most part is disseminated in single grains and small aggregates or streaks through zinc blende and mixed sulphide ores. In some of these ores it can be largely separated by milling, but in others zinc blende and galena are so fine grained and intimately mixed that separation has been impractical and the ore has been shipped crude for the direct manufacture of zinc-lead oxide pigment. Shipments 
of crude zinc-lead sulphide ore have contained from 14 to 30 percent of zinc and 5 to 15 percent of lead.

Chalcopyrite has formed distinct streaks to a smaller extent than galena and is a smaller visible constituent of the mixed sulphide ores; but, as shown on pages 94-95, minute to microscopic grains of it are present in the zinc blende, and are attributed by us to reaction between copper in solution and iron and sulphur in zinc blende, similar to that between solution and pyrite that produced pyritic copper ores.

The contents of silver and gold in these sulphide ores are too small to warrant suggestions as to exact modes of occurrence. In this respect the mixed sulphide ores of Magdalena are similar to those in other districts, where the silver and gold have been thought to be partly in solid solution in galena and partly in submicroscopic grains of native gold and silver or of argentite or some other silver sulphide. Practically no assays of the zinc and zinc-lead ores of Magdalena show more than 0.02 ounce of gold and 4 ounces of silver to the ton.

\section{COOLER MESOTHERMAL (LEPTOTHERMAL) ORES}

The cooler mesothermal or leptothermal ores include not only replacement deposits in limestone similar in structural relations to replacement deposits already described, but also vein deposits in other kinds of rock. They contain the same sulphides as the hotter mesothermal ores, but pyrite is subordinate, and the zinc blende is resinous and of a lighter-brown or even yellow color and evidently lower in iron. The principal gangue minerals are quartz with conspicuous amounts of barite and small commonly inconspicuous quantities of fluorite. Calcite in minor quantity lines fractures or cavities in the form of long pointed crystals or scalenohedrons (dog-tooth spar). Replacement quartz is more prevalent than in the hotter mesothermal ores. It had replaced so much of the limestone before the arrival of sulphide solutions that the sulphide ore shoots are correspondingly restricted and commonly lie beneath a roof or between walls of replacement quartz. Some small shoots, which have replaced remnants of limestone that had escaped earlier replacement, are entirely surrounded by quartz. The quartz-barite aggregates, which were later than the early replacement quartz but earlier than the sulphides, were deposited as open-textured masses. Into these the sulphides were introduced, forming comparatively low grade ore. Because of these features, as well as the undesirability of barite in smelting, these ores and their oxidized equivalents have been less profitable to work; and, notwithstanding their wide distribution, they have contributed only a minor part of the output of the district.

These ores may originally have nearly or quite all been mixed sulphides, their prevailing ratio of galena to zinc blende may have been relatively high, and their copper content may have been high enough in a few places to give them commercial value as lead-copper ores; but, owing to their shallow positions, they have been for the most part so thoroughly oxidized that galena is the only sulphide left in sufficient quantity to constitute sulphide ore. Some of this galena, for example in the Young America and Enterprise claims, is so massive and free from cavities that it no doubt formed small shoots of high-grade lead sulphide even in the original ore.

Shipments of crude lead sulphide ore of this class have ordinarily ranged from 0.02 to 0.04 ounce of gold and 2.3 to 4.5 ounces of silver to the ton, 0.2 to 0.8 percent of copper, and 12 to 33 percent of lead. One lot of 7 tons contained 47 percent of lead and 8 ounces of silver to the ton; and one of 427 tons credited to the Germany mine averaged 0.28 ounce of gold and 28.7 ounces of silver to the ton, about 2 percent of copper, and about 10 percent of lead. The only definitely recorded shipments of crude copper sulphide ore-13 tons from the Black Cloud mine-contained 11.7 ounces of silver to the ton, about 7 percent of copper, and 1.5 percent of lead.

The veins in volcanic and other siliceous rocks are prevailingly small and of such low grade that few prospects have attained any considerable depth. So far as known only one-the Iron Mask at South Camp-was ever developed into a mine. It was worked about 1880 but has contributed only negligible quantities of ore since then. The ore, as shown on pages 95 and 98 had undergone some sulphide enrichment and therefore contained considerable chalcocite and argentite (?) along with oxidation products. The original composition of the ore was not definitely determinable. Small shipments from the Morning Star claim, just north of the Iron Mask, were made in 1934-36.

\section{DEPOSITS FORMED AT LOW TEMPERATURES}

As shown in the table on page 88 , no ore minerals are thought to have been formed at low temperatures; at least, they cannot be distinguished from those formed at moderate temperatures. The long pointed crystals or scalenohedrons of calcite, which were deposited later than the ore minerals, may have been formed in part at low temperature, especially where they are not closely associated with ore minerals. The only other minerals in the district that can be consistently classed as low-temperature minerals are the chalcedony, celadonite, and montmorillonite (?), small amounts of which are present in altered andesite in the southern part of the district (see p. 55). These minerals are rather far from any zone of intense mineralization, and they may be attributed either to cooled, spent, ore-forming solutions or to emanations that permeated the andesite immediately after its eruption. 
GENESIS OF ORIGINAL (HYPOGENE) ORES

Tentative opinions regarding the source of the original ore-forming solutions, previously expressed by Gordon ${ }^{72}$ and Ringlund ${ }^{73}$ after reconnaissance work, have been that the ores were most clearly related to the rhyolite porphyry, formerly called "granite porphyry," along the west base of the range. Our work, however, has shown that the major period of faulting, as well as the intrusions of the monzonite and Tertiary (?) granite stocks and the lamprophyre and white rhyolite dikes, all took place after the intrusion of the rhyolite porphyry and before ore deposition. Some of those interested in the district in 1915 and 1916 thought that the ores were derived from the "faulting dikes" of lamprophyre with which they are so closely associated in the Kelly mine; but the fissures through which the ores were introduced only coincide in part with the dikes, whereas some fissures cross or slightly offset the dikes and others are far away from them. The fact that these dikes were intruded after the monzonite stocks also precludes any suggestion that the ore-forming solutions were emanations expelled from the crystallizing main monozonitic stocks, and the only tenable idea that remains is that the oreforming solutions were derived from a deep sourcepresumably the same as that from which the Tertiary (?) intrusive rocks had already been derivedand rose along the most persistent fault zones, from which they spread wherever there was opportunity.

That mineral deposition took place during several stages, mainly within the ranges of high and moderate temperatures, has already been implied. Minerals formed by rock alteration during these stages have already been considered at some length (pp. 47-55), and their correlation with different stages is only summarized here. The earlier stages, especially, are believed to be represented by minerals indicative of high temperatures near the sources of supply and moderatetemperature farther from the sources; but no productive deposits were formed during these stages. The ore-forming stages are believed to have taken place at moderate temperatures throughout the district, but they, also are represented by relatively high temperature or mesothermal deposits near sources of supply and lower-temperature or leptothermal deposits elsewhere. Low-temperature deposits, which are represented within the district by only a few gangue minerals, are present over a large area, mostly far from centers of mineralization and are only considered incidentally. As the different stages of deposition have been most clearly defined by processes that took place in limestone, these processes will be considered first.

\footnotetext{
72 Gordon, C: H., in Lindgren, Waldemar, Graton, L. C., and Gordon, C. H., Ore deposits of New Mexico: U. S. Geol. Survey Prof. Paper 68, p. 254,1910 .

${ }_{73}$ Ringlund, Soren, Geology and ore deposits of the Magdalena district, unpublished thesis, New Mexico School of Mines, 1913.
}

\section{PROCESSES IN LIMESTONE}

EARLY SILICATE-FORMING STAGES

The earliest stage of mineral deposition, as shown on pages 49,50 , evidently accompanied the later stages of crystallization of the intrusive stocks. It is represented by such minerals as tourmaline, wollastonite, diopside, and garnet (grossularite), particularly within 300 feet of the monzonite contact at Oak Spring. These minerals are found mainly in the Kelly limestone, but they are not restricted to the main ore zones; in fact, they are extremely scarce or absent there. They were evidently formed by solutions that escaped through fractures in the newly crystallized marginal parts of the stocks and permeated the adjoining limestone along fractures and bedding planes. Beyond the limits of their deposition, the limestones of the Kelly, Sandia, and Madera formations were bleached and recrystallized for as much as 1,000 feet from the contact.

The second stage, represented by hedenbergite, garnet (andradite), and platy calcite, took place after the consolidation and profound fracturing of the stocks. It is most conspicuously represented along the main ore zones of the Graphic-Waldo and Kelly mines and the Linchburg tunnel, and its solutions rose along reopened faults for moderate to long distances from sources that cannot be correlated with any exposed parts of intrusive stocks, although the stocks and solutions doubtless had the same general deep source. As neither hedenbergite nor andradite nor platy ealcite have been recognized within monzonite, the effects of this second stage on monzonite has not been determined, although the Nitt monzonite stock was fractured by the recurrent movements along the fault zone in which these minerals were formed in the GraphicWaldo mine.

The solutions of the first two stages reached permeable limestone at temperatures sufficiently high for silicates to form. However, where the same solutions traveled so far before reaching permeable limestone that they had cooled below the stability ranges of those silicates, they replaced the limestone with fine-grained quartz or jasperoid, which is very extensive in the southern part of the district and also near Granite Mountain. The large quartz veins in felsite, rhyolite, porphyry, and monzonite are more consistently assigned to one of these early stages than to any other.

\section{SPECULARITE-MAGNETITE STAGE}

Specularite, magnetite, and quartz are also regarded as high-temperature minerals and, like hedenbergite, formed for the most part along the most productive ore zones. Small veins of magnetite and quartz also formed within the monzonite. - The solutions of this stage reached the Kelly limestone, even near intrusive con- 
tacts, at temperatures too low for the formation of calcium-iron silicates but too high for iron to combine with sulphur to form pyrite. The quartz was deposited partly in close association with the specularite and magnetite and partly in fine-grained replacement masses that are not distinguishable from jasperoid of the earlier stages unless in their closer association with ore bodies. Deposits belonging to this stage have not been recognized away from the centers of mineralization.

Any or all of these stages may be represented by epidote and perhaps chlorite, particularly in the less pure limestones, shales, quartzites, and igneous rocks; but epidote is so widely distributed, both near and far from intrusive contacts and ore zones, that it is of little or no value in the recognition of different stages of mineral deposition. It was doubtless formed during stages of moderate as well as high temperatúre.

The restricted distribution of specularite and magnetite throws more light on centers of mineralization than the silicates. The abundance of these iron oxides in the lower, northern part of the Graphic-Waldo mine implies that solutions rose along the Roll fault (p. 127) near its junction with the Nitt monzonite stock and spread upward to the south and east throughout much of the Graphic-Waldo ground before their temperature fell below the stability range of the iron oxides. Little or no magnetite was deposited in the extreme southern part of the Graphic-Waldo ground so far as known, but evidence there is obscured by thorough oxidation and the inaccessibility of most of the workings.

The prominence of specularite and magnetite in the northern half of the Kelly mine, together with local structural conditions, imply that solutions rose through fractured ground at the intersection of the KellyGraphic fault and the Kelly-Graphic cross fault. The south limit of specularite and magnetite in this mine also is obscured by oxidation and the inaccessibility of old stopes, but no trace of these minerals has been found in the southernmost part of the mine or in the Juanita mine, farther south.

The specularite in the Linchburg tunnel implies a third center of mineralization in the vicinity, but too little is known of the extent of the specularite to indicate the approximate position of the center or to correlate it with junctions of longitudinal and cross faults. It does show, however, that the distribution and zonal relations of ores are not to be correlated with exposed intrusive stocks but with places along major fault zones where circulation from great depth was most favored. As the pre-Cambrian argillite, gabbro, and granite had little reacting power with the rising solutions during this stage, deposition did not take place in appreciable quantity until the solutions reached the Kelly limestone.
Occurrences of specularite and magnetite in the Hardscrabble mine and in the areas east of Granite Mountain and northwest of Magdalena Mountain imply other centers of mineralization. That in the Hardscrabble mine is along a fault, but available information from a study of the debris-covered surfaces elsewhere is insufficient to delimit the extent of other occurrences or their relation to faults. Still other centers of mineralization may be present-for example near the north boundary of the Nitt stock in Hardscrabble Valley; but they are not represented by high-temperature minerals and must be inferred from evidence presented elsewhere (p. 164).

\section{ORE-FORMING STAGES}

The ore-forming stages are represented by the sulphides pyrite, sphalerite, galena, and chalcopyrite. Minor local disturbances may have fractured the hightemperature minerals before the deposition of any appreciable quantities of sulphides, which characterize the ore-forming stage, but no evidence of pronounced fracturing or faulting between the specularite-magnetite and sulphide stages has been observed; on the other hand, the relation of pyrite to specularite indicates a gradational change. Deposition of sulphides may be conveniently regarded as having taken place in four general stages represented respectively by pyrite, zinc blende, galena, and chalcopyrite.

The pyrite stage is clearly represented only around the Nitt-Graphic and Kelly centers of mineralization, as shown in the description of pyritic iron and copper ores on pages 108-109. The pyrite-forming solutions followed the same general courses as those that had formed hedenbergite, specularite, and magnetite. They replaced the adjacent limestone, the recrystallized interstitial calcite in silicate masses, and to a slight extent the silicates. The pyrite, however, was less extensively deposited than the earlier minerals, especially in the upper parts of the Kelly limestone and along the minor fissures.

The sphalerite stage, which followed, was the most extensive of any in the ore-forming group. Sphalerite was deposited along the same courses as the earlier minerals, replacing them to a slight degree and thoroughly replacing interstitial calcite and limestone that had previously escaped replacement. It enveloped the layers and bunches of specularite and earlier minerals that had not been previously enveloped by pyrite. The areal extent of replacement by sphalerite along and at right angles to the main feeding fissures is shown on plate 30 and in more detail on the maps that accompany mine descriptions. Sphalerite partly enveloped quartz and in places formed beneath a thin cap of quartz, 
especially along the top of the Kelly limestone. It also evidently replaced some quartz and drove it along in solution so that it was redeposited as a rim or casing around the margins of the zinc-blende shoots. The sphalerite that was deposited relatively near the centers of mineralization, where the solutions were more concentrated, had a comparatively high content of iron, a feature characteristic of several mining districts. It was deposited while barite, fluorite, and dolomite remained in solution. These minerals near the centers of mineralization are present only in very small quantity and in fractures and small cavities in the zinc blende.

Farther from the centers of mineralization either through cooling or dilution of the solutions, barite and fluorite were precipitated in advance of the sphalerite that had remained in solution. This later-formed variety of sphalerite had a relatively low content of iron, and a little of it, which was pale yellow or nearly colorless, contained almost none. The solutions that deposited these outlying ores were evidently under less pressure than those near the centers of mineralization and had correspondingly less penetrating and replacing power. The Kelly limestone in the outlying areas, furthermore, had already been extensively replaced by masses of dense quartz or jasperoid, and the zinc solutions were in part dispersed through these masses, impregnating or replacing any remnants of limestone that they happened to reach. They also formed deposits beneath the large masses of jasperoid. Even the largest of these deposits was smaller and contained more gangue than those nearer the centers of mineralization.

Solutions rising from the southern or Linchburg center and escaping above the Kelly limestone along the west wall of the Young America fault rose through the Sandia formation and formed the veinlike ore shoot of the Cavern and Grand Ledge mines, which lie between lower Madera limestone on the west and preCambrian argillite on the east. The solutions doubtless were deflected along the Kelly limestone and minor faults east of the Young America fault and formed the shallow deposits in the Young America and adjacent claims.

Solutions similarly escaping from the Nitt-Graphic and Kelly centers also formed outlying deposits, many of which have doubtless been eroded. The solutions that rose mainly through these centers were evidently deflected in part along transverse faults below the present mine workings and into the faulted ground east of the Germany fault, where only deposits characteristic of the outlying areas have been found.

The relative order of the galena and chalcopyrite stages is not clear. In some places the chalcopyrite appears to have filled interstices among crystals of galena, and in others the opposite relation seems to hold. The solutions during both stages, however, followed the usual courses, filling openings and replacing limestone or calcite among the minerals already formed. The galena, introduced in greater quantity than chalcopyrite, was deposited wherever there was opportunity in relatively small quantity near the centers of mineralization and more abundantly beyond the range of the high-temperature minerals and the large deposits of pyrite.

The chalcopyrite that clearly belongs to this late stage cannot be sharply distinguished from the interstitial chalcopyrite in the pyritic copper shoot (pp. 108109) and the minute specks of chalcopyrite in zinc blende (pp. 94-95). If the suggestion is accepted that the chalcopyrite specks grew by replacement of sphalerite, the chalcopyrite throughout the district was formed later than the other sulphides with the possible exception of galena. It is therefore conceivable that all the chalcopyrite was deposited during one stage, that pyrite and sphalerite both favored its deposition through reaction with solutions, and that much of the copper, even though it was introduced late, was therefore deposited within shoots of pyrite and sphalerite near the centers of mineralization. Copper that was not deposited through these reactions was carried into the outlying parts of the ore zones but was nowhere deposited in sufficient quantity to form an original sulphide ore body. This suggestion-that all the chalcopyrite in the district was introduced at one stage-is consistent with the facts regarding its occurrence in this district and assumes a simple succession of depositional stages, each characterized by one metal; but natural processes are not necessarily simple, and evidence in other districts that have similar ores may clearly indicate that copper. was introduced during more than one stage.

The precious metals, which are scarce in the original sulphide ores, were presumably deposited either in solid solution in the sulphide ore or as free gold and argentite. They impregnated the minerals already formed wherever they could but in quantities too minute to be detected with a microscope.

Solutions nearly or quite depleted of their metal contents and containing mainly calcium carbonate-derived from limestone that had been replaced by ore and other gangue minerals-eventually deposited calcite in its relatively low temperature or scalenohedral form, both near centers of mineralization and in the outlying areas. This calcite may be accompanied by a little zinc blende and galena and also fine-grained pyrite and quartz. Any or all of these minerals may represent material that had been removed from deposits near centers of mineralization and redeposited.

\section{PROCESSES IN IGNEOUS ROCKS}

Although the igneous rocks of the district were subjected to attack by the same solutions that formed ores 
in limestone and were extensively altered to different degrees, they were much less subject to replacement by ore and the different stages of ore deposition in them are not so clearly defined. In previous discussions (pp. 39, 47, 49), it was inferred that the feldspathic dikes and veins in monzonite and the tourmaline that lines fractures in monzonite and argillite could represent the same early stage of alteration as the wollastonite and other silicates in limestone and at least some of the secondary silicates in volcanic rocks close to the monzonite contact. No direct evidence for distinguishing a second stage, equivalent to the hedenbergite stage in limestone, was recognized; but the large quartz veins in monzonite south of Granite Mountain may have been formed during this stage by solutions that had cooled below the stability range of such silicates as hedenbergite. (See p. 106.) Veinlets of magnetite and quartz in monzonite suggests deposition on a small scale by the same solutions that replaced limestone with specularite and magnetite, and the main ore body of the Hardscrabble mine shows that these solutions also attacked the Tertiary (?) granite. This ore body consists of mixed sulphides associated with specularite and magnetite, which form a casing around the sulphides. It is similar in general composition to the hotter mesothermal ore bodies of the Graphic-Waldo and Kelly mines. It is mostly in the large block of Kelly limestone but extends downward into the granite, which it has replaced along a network of closely spaced fractures in a fault zone. The specularite and magnetite are confined to the ore body, whereas the adjoining granite is largely altered to sericite, chlorite, and pyrite along fractures. It therefore appears that the mineralizing solution was hot enough to deposit the iron oxides only within the fault zone and that those portions of it that spread into the walls were cooled to a temperature at which the sulphide pyrite was stable.

The hotter mesothermal stages are represented by the Hardscrabble ore body just mentioned, by pyritic veinlets that cut the Nitt monzonite stock close by the massive body of pyrite that replaces the adjoining Kelly limestone along the main ore zone in the Nitt mine, and by veinlets and disseminated grains of pyrite and chalcopyrite in the monzonite along the north extension of the main ore zone in the upper part of Hardscrabble Valley. The monzonite adjoining the Nitt ore body is thoroughly fractured for at least 300 feet west of the main ore zone, as far as it is exposed by the crosscut from the Nitt shaft. The fractures throughout this distance are filled with veinlets of pyrite and quartz, and the monzonite is chloritized and impregnated with pyrite. The marked contrast between this wide scattering of the pyrite in the monzonite and its concentration into a massive replacement body in the Kelly limestone evidently reflects corresponding differences in fracturing and replaceability. The limestone was readily and thoroughly replaceable and the pyrite was therefore deposited close to the channel along which it was introduced, whereas in the monzonite only the minerals containing iron were very subject to replacement and the solution permeated far from its main channel of access before it lost its ability to form pyrite. Although the larger pyritic veinlets in monzonite suggest that the pyrite was introduced from the main channel, the conversion of the iron-bearing minerals to pyrite indicates that the solution introduced sulphur but little or no iron into the monzonite for any appreciable distance from the fractures along which it circulated.

The monzonite along the north extension of the main ore zone is also crisscrossed by pyritic veinlets and is thoroughly impregnated by pyrite. The pyrite is accompanied by chalcopyrite, which is mainly confined to the veinlets and gives the rock a close resemblance to the well-known disseminated or "porphyry" copper ores; but the amount of disseminated chalcopyrite is so small and in an area of such little topographic relief that it is of no commercial interest. The restriction of the chalcopyrite to fractures in the ore zone is in marked contrast to the much wider distribution of pyrite. The chalcopyrite is also interstitial to pyrite. These relations indicate either that the chalcopyrite was the last sulphide to crystallize during the pyrite stage, the view commonly held, or that it was introduced at a distinctly later stage and was deposited through reaction between the solution and pyrite as suggested on page 109. According to either view the solution was not able to impregnate the monzonite itself with chalcopyrite to any appreciable degree.

The monzonite is also considerably altered to sericite and quartz along the more pronounced veinlets. The concentration of sericite, here and at the Hardscrabble mine, in rock near these veinlets, implies that the formation of sericite was for the most part closely associated with the pyrite stage of deposition if not with sulphide deposition as a whole. The sericitized rock grades into chloritized-epidotized rock, which suggests that either chlorite and epidote had been formed at an earlier stage and were replaced by sericite and quartz or all were formed during the same stage. If all were formed during the same stage the introduced potash and silica seem to have been promptly used up, whereas the original ferromagnesian minerals were hydrated and converted into chlorite and epidote for greater distances:

As stated on page 52, epidote may have formed during several stages within the ranges of high and moderate temperatures, and the same statement may apply to chlorite and sericite, although the concentra- 
tion of sericite near the main zones of circulation of sulphide solutions has the significance emphasized above and is of distinct value in the recognition of possible ore deposits in or beneath exposed bodies of igneous rock. The bleached, sericitized pyritic tuff on the southeast slope of Stendel Ridge, for example, suggests that sulphide ore may be concealed in underlying limestones along the Stendel fault; however, the advisability of searching for such ore depends on several factors that are discussed elsewhere.

The only sphalerite-galena ore in igneous rock that is referable to the hotter mesothermal stage is that of the Hardscrabble mine, already cited. This ore has replaced a small amount of highly sericitized granite, which was distinctly more permeable and replaceable than the original rock. The fact that no similar ore has been found elsewhere in igneous rock, even along recognized ore zones, implies either that the solutions of sphalerite and galena, unlike those of chalcopyrite, had little reacting power with pyrite or igneous rocks or that in some places they had deposited their sulphides in limestone before they rose into overlying volcanic rocks.

The cooler mesothermal or leptothermal stage is represented by the Anchor vein in Tertiary (?) granite and by several small veins in volcanic rock in the southern part of the district. These veins consist typically of quartz and barite with small to moderate amounts of sphalerite, galena, pyrite, and smaller amounts of chalcopyrite. Those in the southern area also contain calcite. The granite walls of the Anchor vein are not appreciably altered, and vein-forming solutions therefore did little besides fill the vein fissure with quartz, barite, and sulphides. Veins in the southern area are commonly bordered by bleached wall rock from an inch to a foot or more thick. The sulphide solutions that formed the veins were evidently able to permeate the walls slightly and to reduce and remove the hematite in the reddish volcanic rocks and the Abo sandstone. Their relatively large content of calcite may represent material that had been removed from underlying limestone or from the more calcareous volcanic rocks during the upward passage of the solutions. The fact that very little ore has been found in any of these veins implies either that only small amounts of solutions during the sphalerite, galena, and copper stages reached the present surface or that they had already deposited most of their metal contents in underlying formations.

No effects of mineralization at low temperatures along ore zones in igneous rocks have been recognized, but the presence of calcite scalenohedrons in altered impure limestone near monzonite not far from the Nitt shaft implies that the monzonite also was invaded by solutions at comparatively low temperatures.

\section{OXIDIZED ORES}

Oxidized ores constituted almost the entire output of the district until 1905, and, though the large bodies were practically exhausted many years ago, small quantities have been intermittently produced until the present time, mainly by lessees working small deposits or recovering small amounts that had been left in and around old stopes. The oxidized ores show a wider variation in mineralogic character than the sulphide ores, as is true in other districts of mixed sulphide ores; furthermore, the processes of oxidation have separated them to a greater degree, especially the lead from the zinc ores.

The different classes of ore and their derivation are: (1) Oxidized iron and iron-manganese ores in small quantities, derived from pyritic ores in limestone and perhaps also from disseminated pyrite in altered shale and igneous rock; (2) lead carbonate ore, derived from massive galena and mixed sulphide ores; (3) zinc carbonate ore, derived from massive zinc blende and mixed sulphide ores; (4) oxidized copper ores, derived from pyritic copper ores; (5) oxidized gold ore, derived locally from siliceous mixed sulphide ore; (6) oxidized silver ore, derived locally from siliceous mixed sulphide ore.

\section{OXIDIZED IRON AND IRON-MANGANESE ORES}

Oxidized iron ores derived from pyritic ores low in silica are of interest because of their association with other ores. They are mainly confined to the lower Kelly limestone in the southern parts of the GraphicWaldo and Kelly mines, where the oxidized copper ores had been mined before our work in the district began. This type of material consists essentially of brown hydrated iron oxide with irregularly distributed siliceous material, and lies within the original pyritic ore bodies and just down the dip from them.

Similar iron ore accompanied by manganese oxide and clay is found below the original positions of mixed sulphide bodies, now represented by lead carbonate ore, and along beds and fissures in limestones that underlie thoroughly oxidized masses of pyritic shale or igneous rock. Those beneath oxidized shale are little more than iron-stained clays.

The largest deposit of brown iron oxide not definitely related to sulphide ore bodies is that in the Vindicator mine. This body, as shown in figure 28, has replaced Madera limestone through a vertical range of at least 200 feet and an area 80 by 175 feet. On the east it adjoins the Vindicator vein, which consists of mixed sulphides in a quartz-barite gangue; on the west it grades into unmineralized limestone. The only chemical analysis available is that given on the following page, together with a partial calculation of the mineral composition. It represents a sample from the 
main shaft on the 100 -foot level of the mine that was submitted by V. C. Grubnau.

Partial chemical analysis of brown oxidized material ${ }^{1}$ from the Vindicator mine

[R. E. Stevens, analyst]

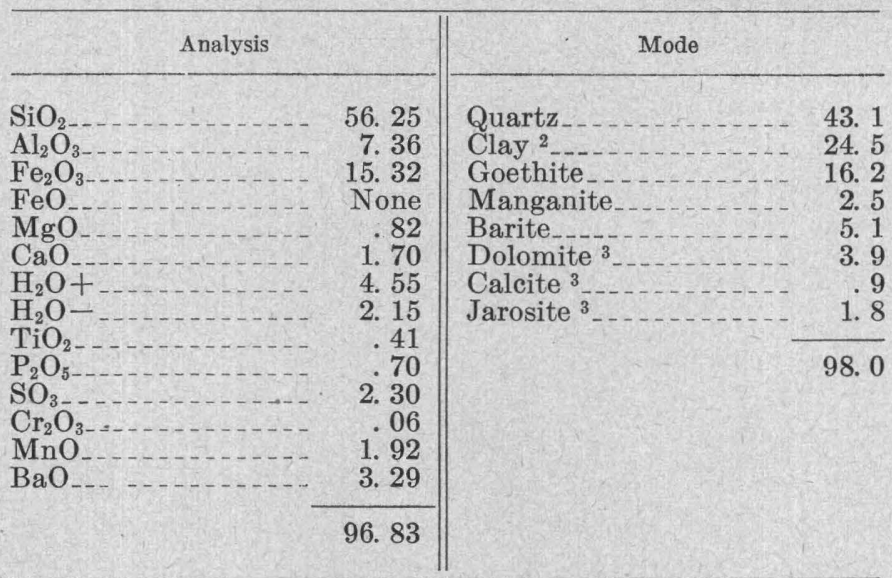

1 Insoluble in hydrochloric acid, 70.38 percent.

2 A clay mineral with most of the properties of beidellite has been identified, but

3 Dolomite and calcite imply the presence of 2.3 percent of carbon dioxide, and jaro-
other clay minerals may also be present. site the presence of 0.2 percent of potash. These constituents would raise the total
of the chemical analysis to 99.3 percent.

The difference between the total and 100 is mainly accounted for by carbon dioxide, which is present with $\mathrm{CaO}$ and $\mathrm{MgO}$ in the form of carbonate. The conspicuous amounts of $\mathrm{TiO}_{2}, \mathrm{P}_{2} \mathrm{O}_{5}$, and $\mathrm{Cr}_{2} \mathrm{O}_{3}$ have not been correlated with any recognized mineral. Assays of other samples collected at different times showed some lead, zinc, silver, and gold. (See p. 161.) Inspection of the sample shows that it contains considerable quartz and barite coated with brown earthy limonite and that it evidently represents a remnant of a quartz-barite vein concealed within the large body of iron oxide. There may be several minor veins concealed within the deposit, but the body as a whole appears to contain much more limonite and to have resulted directly from the replacement of limestone. The cellular texture and fine box-work patterns in parts of it have prompted the suggestion that it was formed by partial replacement of sphalerite, which has since been completely removed. The only direct evidence of replacement seen by us, however, is that of unmineralized limestone by limonite. The source of so large a quantity of brown iron oxide is not directly evident, but, as suggested on pages 120, 162163 , a considerable thickness of volcanic rock that formerly overlay the limestone may have been impregnated with pyrite along the main fault zone in the vicinity, and downward circulation of water through this zone after leaching iron from the oxidizing volcanic rock could cause extensive replacement of the limestone by the brown iron oxide.

The black manganese oxides, which are conspicuous in parts of the iron and other oxidized ores, have evidently been derived mainly from manganiferous cal- cite, siderite, and hedenbergite, and to a minor degree from the minute quantities of manganese present in any of the rocks along the ore zones. No appreciable bodies of commercial grade have been reported.

\section{IEAD CARBONATE ORES}

The lead carbonate bodies occupy the same positions as the original sulphide bodies from which other minerals have been wholly or partly leached. They have been mined throughout the upper levels of the larger mines and have been the principal product of most of the outlying mines.

Lead carbonate ores, as the name implies, consist mainly of cerussite with minor to negligible quantities of the sulphate anglesite and the yellow lead-iron sulphate, plumbojarosite. Other lead minerals, such as vanadinite and wulfenite, may have been found in places; but none were noted by us in the mines of the main Magdalena Range, although mine dumps in the area northwest of the town of Magdalena contain conspicuous amounts. Impurities include mainly iron and manganese oxides and silica, and some of the outlying ores have doubtless contained barite and a little fluorite. The highest-grade ore, called "sand carbonates," consists of loose or only slightly cemented crystals of cerussite, some of which has run like sand when the ore body was opened from below. The most noteworthy occurrence of this ore was in the Big Twenty stope of the Kelly mine, where according to the late C. T. Brown, who was a lessee of the mine for several years, many tons flowed down to the underlying drift and was shoveled into mine cars. Some of the high-grade cerussite is firmly cemented into "hard carbonate" ore, but other varieties of "hard carbonates" contain considerable silica and represent original ore in which galena was disseminated in grains or streaks through partly silicified limestone, especially in the outlying parts of the district.

The lead content of the lead carbonate ores shipped since 1904 has ranged from 8 to 38 percent. The silver content, however, has been prevailingly low, ranging from 1.2 to 10.5 ounces to the ton, although in some assayed samples and some of the early shipments (pp. 75-78) it has been considerably higher. Some ore from the Germany mine, though relatively low in lead, has contained as much as 45 ounces of silver and 1.09 ounces of gold to the ton.

\section{ZINC CARBONATE ORES}

The zinc carbonate ores have mainly been found either vertically below the lead carbonate ores or down the dip from them. A few bodies have been found in the hanging walls of the lower or down-dip parts of lead carbonate bodies. The largest bodies have been formed by replacement of limestone beds and some smaller bodies by replacement of the limestone walls of fissures by reaction with descending water that had 
leached zinc from the original sulphide ore. The larger bodies may be separated from the lead carbonate bodies by a few feet of mixed clay and iron oxide or may also be separated from them by one or more beds of dense or relatively unfractured and therefore impermeable limestone. The "silver pipe" bed, which commonly resisted replacement by sulphide ore, has formed the floor of zinc carbonate bodies and, where rendered permeable, has been replaced by zinc carbonate to a considerable degree. A few small bunches of zinc carbonate have been found at considerable distances from known lead carbonate or iron oxide bodies of considerable size, and it therefore appears that in some places water with zinc in solution traveled a long way before finding an opportunity to react with limestone.

Some of the zinc carbonate ore, especially that in the "silver pipe" bed, is gray to brown and of massive granular texture and so closely resembles the replaced limestone as to escape recognition; but most of it is of brown to reddish color and of a more open texture, with cavities as much as 2 inches in diameter. Close examination of the finely porous ore indicates that the original grains in limestone had been replaced from their boundaries inward, and that where replacement was not complete the unreplaced parts of grains were later dissolved. Some of the most open textured ore has a boxwork pattern, as if the zinc carbonate had replaced limestone along intersecting small fractures and the intervening remnants of unreplaced limestone had later been dissolved. Another conspicuous variety is the ore consisting of parallel layers separated by essentially empty spaces. This layered ore replaces limestone in part along bedding planes and in part along crosscutting fractures, and, as stated on page 92 , is attributed to rhythmic molecular reaction with water containing zinc sulphate.

The most striking variety is the green, blue, and yellowish smithsonite in botryoidal and related forms described on page 92 , but its quantity has been small and localized. It has perhaps been of more interest and value as museum material and semiprecious stone than as zinc ore. Practically all of it had been removed before our study of the district began, but, from what could be seen of it underground and in available specimens, it had formed as linings of fractures and cavities in and near the massive and cellular zinc carbonate ore. Although the deeper-blue variety contains a few percent of copper and the yellow variety contains cadmium, these metals have not contributed to the value of the ore.

Other zinc minerals occur in small to negligible quantity in and near the oxidized ores. Calamine, the most abundant of them, forms druses in the cellular and layered ore and in the adjacent brown iron oxide and clay. It may even account for all of the zinc in some of the low-grade material. Willemite, so far as known (p. 94). is only locally present but has not been found in commercial quantity, either by itself or in association with other zinc minerals. Chalcophanite occurs only in local small, thin drusy coatings in the carbonate ore. Most of the shipments of zinc carbonate ores have contained from 26 to 38 percent of zinc, but a few small shipments from mines outside of the main ore zone have contained as little as 20 percent.

\section{OXIDIZED COPPER ORES}

The oxidized copper ores, though found in relatively small quantity, have a more diversified mineral composition than the other oxidized ores. Small bodies of them, some of very high grade, have been found at widely scattered localities, particularly in the GraphicWaldo, Kelly, and Young America mines and probably the Hardscrabble mine. Shipments of copper ore from these mines have ranged from 3.6 to 42 percent of copper and 1 to 23 ounces of silver to the ton.

The ores in shallow thoroughly oxidized ground consist mainly of the green and blue carbonates in drusy bunches and fracture linings throughout masses of brown iron oxide or iron-stained silica and to some extent in oxidized zinc ore. Their colors in these materials are so prominent that their quantity may readily be overestimated. In deeper ground considerable quantities of the black oxide may be present, and, where local structural conditions permitted concentration of descending water near the bottom of the oxidized zone, cuprite and native copper, somewhat coated with the black oxide and the carbonates, are the dominant minerals. The trough in the older workings of the Graphic-Waldo mine, formed by the intersection of the west-dipping argillite at the base of the Kelly limestone and an east-dipping lamprophyre dike, was most effective in permitting copper-bearing waters to converge and concentrate attack on the wedge of limestone within the trough. No definite information has been obtained regarding the local structural conditions where ore containing 13 percent of copper was found in the Young America mine.

Even below the oxidized zone the oxidized copper minerals have been deposited along fissures and adjacent bedding planes where circulation from above was favored, thus enriching the original sulphide ore to some degree. Such enrichment is especially marked along the copper zone in the lower part of the GraphicWaldo mine.

\section{OXIDIZED GOLD ORE}

The only noteworthy deposit of oxidized gold ore that we have seen is in the Martin lease of 1915 and 1916 in the Stonewall mine. There the gold, in flakes and wires, was closely associated with galena in leached siliceous sulphide ore, where the intersection of the west-dipping Kelly limestone and an east-dipping fault had pro- 
duced a troughlike structure that favored the concentration of descending water. The derivation of the gold is not clear, but it was presumably leached from very thinly disseminated gold in the silicified upper Kelly limestone or in mineralized parts of the overlying shale and quartzite. It may well have been precipitated at the former base of the oxidized zone, not only by galena but especially by chalcocite-coated zinc blende and chalcopyrite, which were subsequently leached, leaving the gold in residual forms. Shipments of oxidized dry and lead ores, credited to the Germany mine but probably from the Stonewall claim, which was owned by the same company, have contained as much as 1.09 ounces of gold to the ton.

\section{OXIDIZED SILVER ORE}

Although no oxidized silver ore has been studied by us in place, small shipments of siliceous silver ore have been reported from time to time. They evidently came from places in the silicified Kelly limestone where the small content of silver in original siliceous sulphide ore could be concentrated, presumably in the form of chloride. The highest silver contents in shipped ore, up to 45.1 ounces to the ton, are credited to oxidized dry and lead ores from the Germany mine. The enriched and partly oxidized silver-copper sulphide ore in the Iron Mask mine has been described on page 95 and the enriched and partly oxidized silver-lead-zine sulphide ore in the Anchor mine on pages 159-161.

\section{ZONES OF ALTERATION}

The alteration of ores, as shown incidentally on preceding pages, has been effected through processes of oxidation and sulphide enrichment. Ores of the oxidized zone were formed in part above the groundwater level and in part at or below it. Some sulphide ore remained above it, but enrichment by addition of new sulphide minerals took place below it. The change from the zone of thoroughly oxidized to leached sulphide ore is rather abrupt in the largest ore bodies, although the transition to the zone of original unleached sulphides is gradual and is marked by ore from which all sulphides except galena have been nearly or entirely removed. Partial oxidation, moreover, has taken place along faults and certain open bedding planes considerably deeper than elsewhere and overlaps the zone of sulphide enrichment. This zone is not clearly defined, as enrichment has taken place to some degree even to the bottom of the deepest ore body studied. No information is at hand regarding its downward extent in the west ore zone along the Waldo fault.

The depth of the oxidized zone differs in different parts of the district because of its relations to erosion surfaces, different kinds of rock, and geologic structure. The bottom of the oxidized zone has an approximate altitude of 7,450 feet in the Graphic-Waldo mine and 7,550 feet in the Kelly mine. These mines are comparable, as they lie west of the Kelly-Graphic fault and beneath the erosion bench called pediment F. (See p. 74). The bottom of the oxidized zone where clearly defined in these mines is slightly above the general slope of pediment D. Oxidation therefore appears to have taken place mainly during the development of pediment $\mathrm{D}$, which marked a temporary base level, and to a minor extent since then. The impounding of water by faults, however, as will be shown later, appears to account for the lower limit of thorough oxidation, as the impounding formed local reservoirs that have not been reached by drainage courses active subsequent to the development of pediment D. The bottom of the Juanita mine, at an altitude of 7,587 feet, is about on a level with the projected position of pediment $\mathrm{D}$ and contains partly oxidized ore. The bottom of the South Juanita mine, at an altitude of 7,728 feet, or at least 100 feet above the nearest part of pediment $\mathrm{D}$, is in oxidized ore.

Farther south, in the Mistletoe and Linchburg tunnels, which cut the Mistletoe and Young America faults, sulphides are present, although the altitudes of the tunnels-approximately 7,960 and 8,050 feet-are well above and east of the nearest part of pediment D, whose altitude here is about 7,750 feet. These ore bodies, however, are well to the east of the pediment at depths of 300 and 400 feet below the present surface and are separated from the pediment by faults that doubtless dammed the groundwater to the east of them.

Sulphides are present in the lower Germany tunnel, east of the Germany fault, at an altitude of about 7,860 feet, and in the Grand Tower mine, which is east of the same fault at an altitude of about 8,000 feet. The shallower mines on the upper slope of the range are all in oxidized or partly oxidized ground, although residual galena ore has been shipped from some of them, and some ore containing considerable sphalerite, which had escaped oxidation, was reported in the early days of mining. (See p. 76.)

In the northern part of the Magdalena Range the Hardscrabble mine contains mixed sulphide ore at an altitude of 7,750 feet, which is about the altitude of pediment $\mathrm{F}$, whereas the bottom of the Vindicator mine in Hardscrabble Valley contains oxidized iron ore at an altitude of only 6,800 feet, although its main vein contains mixed sulphide ore at an altitude of about 6,850 feet.

These differences in altitude in part conform to the general slope of the range but are governed largely by structure and the different kinds of rock. The Kelly limestone with its open bedding planes and high degree of solubility had allowed water from the surface to develop channels down to ground-water level, which, if dependent solely on this limestone, would be at the base of the range. The shaly Sandia formation, in contrast, has tended to divert water along 
its bedding planes and to maintain a shallow water level which is expressed by springs. Where the Kelly limestone crops out and dips below the Sandia formation oxidation has taken place along water courses, even though they are covered by the unoxidized Sandia formation, provided they are above the general groundwater level of any restricted area. The Madera limestone is intermediate between the other two formations in its influence on ground water. Its upper more massive beds tend to develop water courses and a relatively deep. water level, whereas intervening shaly beds and the lower thin-bedded member tend to develop local perched water tables. The igneous rocks as a whole tend to develop shallow water levels, except where faults in the higher and steeper parts of the range have drained them. Shafts partly filled with water even along the crest as well as near the base of the range illustrate their capacity for holding water in their less opèn or permeable fractures.

The two faults that most clearly affect the groundwater table are the Germany and Waldo faults. Little information is available regarding the others, as workings along them are too shallow. The Germany fault and the mass of argillite and gabbro west of it formed a barrier to circulation down the west-dipping Sandia strata and established a local ground-water reservoir that must have drained through springs into upper Kelly Gulch until disturbed by the Alhambra and Germany tunnels. Drainage through the Germany tunnel has supplied the town of Kelly with water, and where drainage is blocked by fallen rock the tunnel is flooded. The original water level marked the approximate lower limit of oxidation, and only sulphide ore with little or no evidence of oxidation was seen in accessible parts of the Germany mine.

The Waldo fault along the base of the Magdalena Range is walled on the west by rhyolite and forms a similar barrier to circulation in the Sandia and lower Madera beds. Before the local ground-water reservoir was disturbed by deep mining its outlet was through a spring along the fault that furnished water for North Camp. Minor, east-dipping faults in the western part of the Kelly mine made minor barriers that had maintained a rather high water level and restricted the depth of oxidation along the ore zone. The original level of the water is not known, but, as a large amount of water was pumped through the Traylor shaft in 1907 , when the sulphide ore was being newly developed, the original water level could not have been much if any below level 5, at an altitude of 7,541 feet. Even as late as 1915 development of a prospect on level 7 was being postponed until it could be drained through a lower drift. Some natural drainage may have taken place into Kelly Gulch near the 7,500 foot contour line.

Although the Traylor shaft extends about 200 feet below the spring near North Camp, the spring was not affected until the west crosscut on level 10 from the bottom of the shaft cut the Waldo fault in 1916. Then the spring ceased flowing. The fault zone itself was obviously full of water that had been supplied from circulation along the Sandia and lower Madera beds. Pumping through the Traylor shaft continued during the sinking of a winze in the volcanic rock west of the fault to the level of the Kelly limestone in the east wall. This deep work was abandoned about 1918, and pumping through the Traylor shaft ceased about 1921. The mine has been filling ever since, and, according to the late Professor Weir, ${ }^{74}$ of the New Mexico School of Mines, the water surface early in 1935 was about 300 feet below the collar of the shaft, or at an approximate altitude of 7,280 feet, and about 70 feet below the dried spring along the Waldo fault.

No record of the original water level in the GraphicWaldo mine has been found. It was presumably near the bottom of the oxidized zone, whose altitude is about 7,450 feet, although direct connection with the Waldo fault could have lowered it somewhat. It was lowered by the Waldo tunnel in 1906 to an altitude of about 7,300 feet and by pumping through the Waldo shaft in 1916 to an altitude of about 6,800 feet. Water pumped from the mine served as a temporary water supply for the town of Magdalena during the dry spell in 1928, when the regular supply from Hop Canyon, south of the district, failed. Pumping through this shaft was abandoned in September 1928, and the mine has since then filled to a level 115 feet below the Waldo tunnel. Rainfall since 1928 may have been below the average, but, even so, the slow rate of inflow and the consequent limitations of mine water as means of irrigation are noteworthy. The fact that the lowering of the water below the Waldo tunnel level had no appreciable effect on the spring near North Camp implies that southerly drainage was impeded by cross faults.

Water level along the west side of the main fault zone south of Kelly was somewhere above the Mistletoe and Linchburg tunnels, whose respective altitudes are about 7,950 and 8,050 feet. Still farther south it is represented by the spring in Patterson Canyon, which lies close to a west member of the fault zone at an altitude of about 8,100 feet. This spring is along a fault that forms the east boundary of igneous rock of a considerable thickness in which the ground-water level is doubtless very shallow.

North of the Nitt mine the differences in water level in monzonite and Madera limestone are striking. Shallow shafts along the pyritic monzonite zone in upper Hardscrabble Valley are partly filled with water, which stands at an altitude of about 7,100 feet, whereas no water has been found in the Madera limestone at the bottom of the Vindicator mine at an approximate

\footnotetext{
${ }^{74}$ Weir, J. A., written communication, April 13, 1935.
} 
altitude of 6,750 feet. If the Madera limestone continues very far beyond its northernmost outcrop in lower Hardscrabble Valley, the altitude of the groundwater surface may be as low as 6,500 feet and may slope northward with an extremely low gradient towards the valley bottom along the railroad. If the northerly pitch of the strata is appreciable, the slope of the water surface is likely to be determined by shale below the massive beds of the Madera limestone. This position will be of interest if further development is undertaken along the Hardscrabble Valley, as water in and near the pyritic monzonite and in the volcanic and underlying shaly rocks of Stendel Ridge can be drained northward at a depth that will permit considerable work without pumping. If exploration should be undertaken in the Kelly limestone, whose altitude beneath the Vindicator workings may be as low as 6,100 feet, water would have to be lifted only 400 to 500 feet; and work in Kelly limestone beneath the shale on the west side of the Stendel fault may require no pumping.

Information on ground water in the Granite Mountain area is limited to the low eastern part, where a few shallow shafts are partly filled with water. As some of the shafts, in particular the Cambria shaft, are rapidly filled with water after heavy rains, they are apparently connected with surface fissures that probably intersect the creek to the south. The Cambria shaft, which is about 75 feet deep, is also rapidly drained..$^{75}$ The depth to ground-water level is unknown but may be 100 feet or more. The rather steep dips, however, together with the strike of the beds and faults directly toward the valleys, suggest that the ground-water surface is more regular than it is in the main Magdalena Range.

\section{PROCESSES OF ALTERATION}

As the sulphide and oxidized ores in the Magdalena district are similar to those in the Leadville district, Colo., and as the processes of alteration, which are therefore similar, have been thoroughly discussed in the Leadville report, ${ }^{76}$ only a comparatively brief review of the processes will be given below.

When the period of dominant erosion and of alteration by descending water began, the present surface of the Magdalena district was covered by some additional thickness of sedimentary rocks and by a considerable thickness of volcanic rock. (See fig. 2.) It was not until the stage of erosion represented by pediment $\mathrm{F}$ (p. 74) had been completed that the principal ore bodies of the district west of the Kelly-Graphic fault zone were subjected to chemical attack by descending water. By that time the volcanic rocks had been about

\footnotetext{
75 Moore, Paul, oral communication.

70 Emmons, S. F., Irving, J. D., and Loughlin, G. F., Geology and ore deposits of the Leadville mining district, Colorado: U. S. Geol. Survey Prof. Paper 148, pp. 248-272, 1927.
}

as completely removed from the upper slopes of the range as they are today, but Patterson Canyon and Hardscrabble Valley, which were not developed until later, were represented by smooth pediments composed of volcanic rocks. The volcanic rocks in the mineralized fault zone in the position of the present Hardscrabble Valley are believed to have been pyritic, as suggested below. The impure quartzite and shale beds of the Sandia formation, the pre-Cambrian argillite, and the lamprophyre and white rhyolite dikes were also pyritic to some degree, especially along mineralized fault zones.

\section{ALTERATION OF COUNTRY ROCKS}

The leaching of these pyritic rocks produced sulphuric acid and ferric sulphate, which in turn leached alkalies and alkaline earths, silica, and carbon dioxide from the different rock-forming minerals in igneous and shaly rocks and replaced them with ferric oxide and clay minerals. Where water with these dissolved constituents entered shale it was largely deflected down the dip; and thick shale beds, even near the larger faults, may have prevented the water from reaching some ore bodies until the shale was almost entirely eroded. The amount of descending water that reached and attacked the sulphide ores, therefore, was much less in some parts of the district than in others.

Where the descending water passed from pyritic rock into limestone, any free acid in it was promptly neutralized and the ferric sulphate reacted with the limestone, replacing it with ferric hydrate, which later became partly dehydrated to limonite. Such a reaction has been suggested to account for the large body of brown iron ore in Madera limestone in the Vindicator mine. Similar deposits may be present in limestone beds of the Sandia formation, though none have been noted, and in the uppermost part of the Kelly limestone, where they may be mistaken for the oxidized tops of sulphide bodies.

Similar reaction between aluminum sulphate and limestone formed allophane or other clay minerals, which replaced the limestone, usually just below those parts that had been replaced by brown iron ore. As the process continued and the iron and clay deposits grew, the iron oxide tended to migrate downward, replacing the clay and driving it along as an advance guard. The descending water became increasingly charged with calcium sulphate and carbon dioxide, the carbon dioxide tending to dissolve the limestone and to form open channels or water courses. Silica from the descending water also replaced limestone to some degree, but its relatively small quantity is not readily distinguished from the large quantity that preceded and accompanied the deposition of sulphide ore and later became stained with iron and manganese oxides.

Where the concentration of alkalies as well as iron 
was high, presumably where water from igneous rocks, after its free acid and oxygen had been exhausted, became concentrated on reaching limestone, jarosite was formed. The clay minerals and jarosite, where subjected to further attack by water containing oxygen, became veined with brown iron and black manganese oxides. The combination of iron oxides and clay minerals with or without jarosite and amorphous or chalcedonic silica constitutes the oxidized "vein" material that lies along the principal courses followed by the descending water; its origin is obviously independent of ore bodies in the limestone that it has replaced, although it may be closely associated with some of them.

\section{ALTERATION OF SULPHIDE ORES}

\section{SOLUTION OF PRIMARY SULPHIDES}

Where descending water charged with material derived from siliceous rocks reached permeable sulphide bodies, the sphalerite was dissolved and removed before any other sulphides were greatly attacked. Water with free sulphuric acid was neutralized by reaction with sphalerite and carbonate gangue. Where the sulphuric acid had been exhausted, either before or after reaching the ore, ferrie sulphate reacted with sphalerite replacing it with brown or red iron oxide. The zinc was removed in solution together with sulphate and carbonate radicals. Chalcopyrite was removed by similar processes.

Pyrite in pyritic and mixed sulphide ore reacted in the same way as that disseminated in the siliceous rocks and increased or renewed the quantity of sulphuric acid and ferric sulphate available for attacking ore, gangue, and country rock. Part of its iron was converted to limonite and remained essentially in place, forming comparatively pure masses and staining other materials. The remainder was carried downward as ferric and ferrous sulphates.

Galena, though beginning to oxidize promptly, became quickly coated with a protecting film of lead sulphate which in turn became converted into the even more insoluble lead carbonate. The galena, therefore, remained almost intact until the other sulphides had been practically all removed. Honeycombed masses of high-grade galena have been mined in otherwise thoroughly oxidized ground. These masses also mark the transition from the oxidized to the sulphide zone, as is well shown in the Graphic-Waldo mine. (See pl. 33.)

The transfer of gold in the oxidized zone was presumably dependent on the liberation of chlorine. The chlorides, possibly derived from the air and from small amounts in siliceous rocks by descending water, may have reacted with any manganese dioxides that had already been formed by oxidation, thus liberating chlorine, which was able to extract minute quantities of gold from any of the ores. This reaction evidently took place after the general process of oxidation was well-advanced. In the absence of this reaction gold would remain in leached ore in its original position, but no noteworthy amount of strictly residual gold has been recognized in the Magdalena district. Its ultimate source, therefore, is indefinite. Presumably it was finely disseminated throughout veins and replacement bodies of ore and along pyritic fissures and seams in the siliceous rocks.

The general absence of high silver content, either in oxidized ore or in the underlying parts of the larger sulphide ore bodies, forces the inference that most of the silver remained without appreciable transfer or concentration throughout the entire period of oxidation. A little silver, however, was presumably dissolved and carried downward and redeposited nearby, usually in close association with lead carbonate. The failure to detect visible grains of chloride or other compounds leaves the occurrence of silver in the scattered bodies of relatively high-grade oxidized ore to conjecture.

\section{REDEPOSITION AS PRODUCTS OF OXIDATION}

The metals dissolved by descending water were redeposited, as partly implied already, by the following processes: hydration and oxidation, which accounted for the relatively insoluble brown iron ore and lead sulphate and carbonate; evaporation, which accounted for incrustations of minerals along cavities, fractures, and the walls of mine workings; reaction between different solutions and between solutions and sulphide ore or wall rock, which accounted for the large bodies of zinc carbonate and smaller bodies of oxidized copper and gold ore, as well as enriched copper and silver sulphide ores. As oxidation took place in stages, redeposition is most conveniently considered in corresponding stages.

Zino carbonate stage.-Where water that had passed through a sulphide body into limestone contained free sulphuric acid and ferric sulphate, the acid was promptly neutralized and the uppermost part of the limestone was replaced by ferric oxide, manganese oxide, and clay. Such deposits are found today as layers separating lead carbonate and even some galena ores from underlying deposits of zine carbonate, which were formed after the iron, manganese, and clay had been removed from solutions. Where water had been depleted of the acid and ferric, manganic, and aluminum sulphates before reaching the limestone, no such layer was formed, and zinc carbonate replaced limestone immediately below the original ore body or its siliceous casing.

The replacement of limestone by the normal zinc carbonate, smithsonite, began along grain boundaries and worked toward the centers of the grains. Where replacement was complete the zinc carbonate preserved the structure and texture of the limestone. As replace- 
ment was in part the result of reaction between calcium carbonate and zinc sulphate, which involves considerable shrinkage, it is concluded that some of the zinc was in solution as bicarbonate and, while replacement was in progress, was deposited as additional carbonate in sufficient quantity to preserve the original structure and texture. Where this additional supply of zinc was insufficient, a corresponding amount of shrinkage resulted and is represented by the layered ore. Openings in the cellular ore may be in part the result of shrinkage, but they appear mostly to represent unreplaced remnants of limestone that have been subsequently removed. Minute openings in the massive ore may be attributable to one or both causes.

Complete replacement took place ${ }^{77}$ close to the ground-water level if not below it, where the limestone could be permeated by slowly moving or stagnant solutions. The ferrous and manganous carbonates in the gray zinc carbonate ore supports this statement, as they show that the reaction took place in the absence of oxygen, the presence of which would have prevented the formation of ferrous and manganous carbonates. Where the gray ore was later exposed to oxygen it turned brown, owing to the oxidation of its iron.

Iron-manganese oxide stage.-After the removal of zinc blende from the original ore bodies, oxidation of pyrite and chalcopyrite generated new supplies of sulphuric acid and ferric sulphate, most of the sulphate being promptly converted into brown iron oxide and left as a porous residue. Any that escaped oxidation, together with the acid, was carried downward into the zinc carbonate zone, where it reacted as in the first stage. Casings of quartz or jasperoid or any layers of siliceous rock became stained with brown or red iron oxide. Zinc carbonate was replaced by the same oxides, which supplemented the layer previously formed between the zinc and lead carbonate bodies, and the dissolved zine was redeposited farther down, either by replacement or as linings of openings. As the water during this stage had little or no excess of carbon dioxide, this redeposited zinc was more likely to form the layered and cellular varieties than the massive variety of zinc carbonate ore.

As chalcopyrite, though more readily soluble than pyrite, was, for the most part, considerably protected by its interstitial position in pyritic ore, the transfer and redeposition of copper accompanied rather than preceded the iron-manganese oxide stage. The minute inclusions in sphalerite were doubtless dissolved during the zinc carbonate stage, but the quantity of copper involved was too small to account for any conspicuous amount of copper carbonate, separate from that transferred later. The copper was carried downward as sulphate and replaced either limestone or zinc carbon-

\footnotetext{
${ }^{77}$ Lindgren, Waldemar, The nature of replacement: Econ. Geology, vol. 7, p. $531,1912$.
}

ate with the copper carbonate. Whether the green carbonate, malachite, or the blue carbonate, azurite, was formed evidently depended upon differences in concentration of copper, carbon dioxide, and water. Replacement of zinc carbonate by copper carbonate evidently did not exhaust quite all the copper in solution; the remainder of it was deposited as a minor constituent of the blue and green crustiform and botryoidal smithsonite and as a major constituent of aurichalcite, whose deposition followed or alternated with that of the crustiform smithsonite.

The copper that descended along the pyritic zone without coming in contact with limestone or other carbonates was in part deposited, temporarily at least, as the green and blue carbonates, but toward the bottom of the oxidized zone, where carbon dioxide was deficient and where ferrous sulphate was present in solution, it was deposited as the black and red oxides and, where oxygen also was deficient, as native copper. Where structural conditions permitted the descending waters to converge and stagnate at the bottom of the oxidized zone, as in the trough between the tilted argillite floor and crosscutting lamprophyre dike in the Graphic-Waldo mine, these minerals accumulated in unusual quantity. Where the water could descend below the oxidized zone, the copper sulphate in solution was reduced by contact with chalcopyrite and pyrite and deposited as coatings of chalcocite. Similar reaction with galena and sphalerite produced coatings of covellite.

Lead carbonate stage.-Oxidation of galena mostly followed that of pyrite. The descending waters during this stage were bringing in very little sulphuric acid; and the proportion of carbon dioxide, especially in water that had passed through limestone before reaching the ore, was relatively high. Thus most of the lead sulphate derived through oxidation of galena was quickly changed to the carbonate without appreciable transfer; and the lead carbonate ores therefore remained in the general positions of the original sulphide bodies, either in nearly pure masses or mixed with iron oxide, quartz, and barite, according to the composition of the original ore. The change from lead sulphate to carbonate released the sulphate radical, which helped the water to retain some lead and iron sulphate in solution; and where these constituents became sufficiently concentrated and the acid neutralized, the yellow basic lead-iron sulphate, plumbojarosite, was formed as a replacement of either limestone or iron oxide. Too little of this mineral has been found in the district to justify further discussion of the origin.

Final base-metal stages.-After processes involving sulphuric acid and ferric sulphate had come to an end, processes involving oxygen, carbon dioxide, and silica caused minor changes and additions to the oxidized 
ores. Oxygen attacked iron and manganese in zinc carbonate ore, forming brown iron and black manganese oxides and the manganese-zinc oxide chalcophanite. Zinc carbonate was dissolved to some extent and redeposited as coatings, in part over those of iron and manganese oxides. The exhaustion of excess carbon dioxide caused the deposition of the basic carbonates hydrozincite and aurichalcite, usually upon crusts of smithsonite or alternating with layers of smithsonite, as if there had been small renewals of solution that still retained some excess of carbon dioxide. After practically all the carbon dioxide had been used in this way, silica became the most active acid radical and formed calamine, the latest of the definite zinc minerals. It formed mainly along cracks and openings in and near the zinc carbonate as a result of supersaturation, although it replaced the carbonate to a small extent. Its deposition was accompanied by that of small amounts of "tallow clay," which was formed either by the direct deposition of a hydrous aluminum-zine silicate or by the partial replacement of aluminum in clay by zinc. The source of the small amount of silica represented was evidently in the siliceous gangue of the original ore and in the silicate minerals of the overlying rocks. Small amounts of opal or chalcedony may have followed calamine.

During the final stages the secondary sulphides and oxides of copper tended to change into the more stable carbonates. The process is well illustrated in the Iron Mask mine, where progressive changes from chalcocite through covellite and cuprite to malachite are represented. Copper that had not been removed from the oxidized residue of pyritic ore was deposited as crusts and veinlets of malachite or azurite in brown iron ore.

The last product of deposition was colorless calcite in the flat, disklike or "nailhead" variety of rhombohedrons. These crystals line cracks and vugs in all varieties of oxidized ore-especially the porous brown iron ore-and in the adjoining wall rock. No consideration has been given to aragonite, wulfenite, vanadinite, and certain other minerals that have been merely reported from the district but have not been seen by us.

Precious metal stage.-The amounts of silver and gold in the original ores were so small that they were affected only after alteration of the common sulphides exposed them to attack. Although some silver may have been retained in the oxidized zone as chloride, some was carried down in solution and deposited either as minute quantities of native silver or argentite in or below the lower part of the oxidized zone by reaction with ferrous and copper sulphates, by complex reaction between these sulphates and zinc blende, or by direct reaction with chalcocite. The only visible silver mineral, which could not be separated in sufficient quantity to permit identification, is associated with chalcocite in the ore of the Iron Mask mine.

Gold, carried in solution as chloride, could be precipitated by ferrous sulphate at or below the bottom of the oxidized zone; also by chalcocite, chalcopyrite or galena, and less readily by pyrite or sphalerite. The close association with sphalerite or with cavities left by the leaching of sphalerite may be explained by a complex reaction involving gold chloride, ferrous sulphate, and sphalerite, or by reaction between the chloride and films of chalcocite that once coated the sphalerite. Whatever the reactions were, the original amounts of gold were so small and thinly scattered that the effect of downward transfer was negligible except where small structural troughs, illustrated in the Stonewall mine, permitted the convergence of water from a wide area into a place where the reacting minerals were available.

\section{MINES}

The mine descriptions are arranged in the following order: Those extending southward from the Nitt stock along the main ore zone; those east or west of the main zone and south or east of the Nitt stock; those north of the Nitt stock and in the main Magdalena Range. Very little information is available on properties north and west of the main range, as most of the work in those places was done so long ago that few records, even including heresay evidence, have been found; but the few brief descriptions presented should give a fair impression of conditions there.

\section{MINES IN THE MAIN ORE ZONE}

\section{NITT MINE}

The Nitt mine is owned by the Tri-Bullion Corporation, incorporated in 1927 as a successor to the TriBullion Smelting \& Development Co. It comprises about 115 acres, including the Silver Bell claim (pl. 2) and an adjoining group of six unpatented claims that were acquired by the older company in $1912 .{ }^{78}$ These claims are mostly within the area of the Nitt stock, but they include an adjoining strip of sedimentary rock about 210 feet wide that is crossed by the northernmost part of the main ore zone. This ground was leased to the Ozark Smelting \& Mining Co. from 1914 until 1923, and its output for those years was included with that of the Graphic-Waldo mine. From 1923 until 1930 it was leased to J. A. Macdonald, of Kelly, who, because of the closing of the Ozark Co.'s mill in 1921, mined only ore of shipping grade. The output in these years is shown in the tables on page 124 . This ore, according to Mr. Macdonald, has averaged about 20 percent of zinc, 2 percent of copper, 0.5 percent of lead, and 2 ounces of silver to the ton.

\footnotetext{
78 Mines handbook, vol, 14, p. 1260, 1920.
} 
Ore shipped from Nitt mine, $1923-30{ }^{1}$ and its gross metal content

[Data collected by C. W. Henderson, Geological Survey and Bureau of Mines, U. S. Department of the Interior, Denver, Colo.]

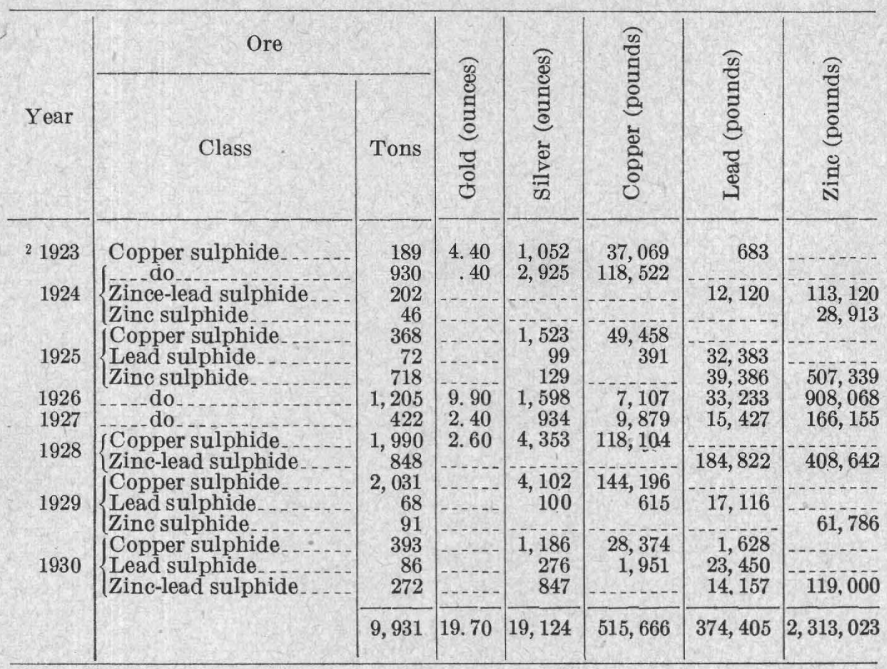

1 Mine idle 1931-39.

${ }^{2}$ Output for 1914-22 was included in output of Graphic-Waldo mine, operated by Ozark Smelting \& Mining Co., to which the Nitt mine was leased.

Sulphide ores snipped from Nitt mine, 1923-30, and average gross metal content (based on assays)

[Data collected and classified by C. W. Henderson, Geological Survey and Bureau of Mines, U. S. Department of the Interior, Denver, Colo.

\begin{tabular}{|c|c|c|c|c|c|c|c|c|c|c|c|}
\hline \multirow[b]{2}{*}{ Year } & \multicolumn{3}{|c|}{ Copper } & \multicolumn{3}{|c|}{ Lead } & \multicolumn{3}{|c|}{ Zinc-lead } & \multicolumn{2}{|c|}{ Zine } \\
\hline & $\begin{array}{c}\text { Ore } \\
\text { (tons) }\end{array}$ & $\begin{array}{c}\text { Silver } \\
\text { (oz. } \\
\text { per } \\
\text { ton) }\end{array}$ & $\begin{array}{l}\text { Cop- } \\
\text { per } \\
\text { (per- } \\
\text { cent) }\end{array}$ & $\begin{array}{c}\text { Ore } \\
\text { (tons) }\end{array}$ & $\begin{array}{l}\text { Silver } \\
\text { (oz. } \\
\text { per } \\
\text { ton) }\end{array}$ & $\begin{array}{l}\text { Lead } \\
\text { (per- } \\
\text { cent) }\end{array}$ & $\begin{array}{c}\text { Ore } \\
\text { (tons) }\end{array}$ & $\begin{array}{l}\text { Zinc } \\
\text { (per- } \\
\text { cent) }\end{array}$ & $\begin{array}{l}\text { Lead } \\
\text { (per- } \\
\text { cent) }\end{array}$ & $\begin{array}{c}\text { Ore } \\
\text { (tons) }\end{array}$ & $\begin{array}{l}\text { Zine } \\
\text { (per- } \\
\text { cent) }\end{array}$ \\
\hline \multirow{7}{*}{$\begin{array}{l}1923 \ldots \\
1924 \\
1925 \\
1926 \\
1927 \\
1928 \\
1929 \\
1930\end{array}$} & 189 & 5.6 & 9.8 & & & & & & & & \\
\hline & 930 & 3.1 & 6.4 & & & & 202 & 28.0 & 3.0 & \multirow{3}{*}{$\begin{array}{r}46 \\
718 \\
1,205 \\
422\end{array}$} & \multirow{3}{*}{$\begin{array}{l}31.4 \\
35.3 \\
37.7 \\
19.7\end{array}$} \\
\hline & 368 & 4.1 & 6.7 & 72 & 1.4 & 22.5 & & & & & \\
\hline & & & & & & & & & & & \\
\hline & 1,990 & 2.2 & 3. 0 & & & & 848 & 24.1 & 10.9 & \multirow[b]{2}{*}{91} & \multirow[b]{2}{*}{33.9} \\
\hline & $\begin{array}{r}2,031 \\
393\end{array}$ & $\begin{array}{l}2.0 \\
3.0\end{array}$ & $\begin{array}{l}3.5 \\
3.6\end{array}$ & $\begin{array}{l}68 \\
86\end{array}$ & $\begin{array}{l}1.5 \\
3.2\end{array}$ & $\begin{array}{l}12.6 \\
13.6\end{array}$ & 272 & 21.9 & 2.6 & & \\
\hline & 5,901 & & & 226 & & & 1,322 & & & 2,482 & \\
\hline
\end{tabular}

NOTE.-The copper ores shipped in 1923-25 were evidently enriched somewhat in copper and silver, whereas those shipped in 1928-30 more nearly express the origina metal content. The lead and zinc-lead ores were comparatively low in lead and correspondingly low in silver. Assays of the zinc ores shipped in 1926 and 1927, which are presumably representative of the zinc ores as a whole, showed an ave
ounces of silver to the ton, 0.5 percent of copper, and 1.5 percent of lead.

The mine is opened by a shaft 300 feet deep, whose collar has an altitude of 7,446 feet. Two levels have been driven from it at depths of 200 and 300 feet. Sublevels connected with these levels by winzes have been driven in the ore zone at depths of 230,275 , and 350 feet, the last two connecting with levels 10 and 11 of the Graphic-Waldo mine. About 4,000 feet of drifts and crosscuts have been driven, including some short irregular drifts in ore that have been destroyed by stoping. The mine was studied by Loughlin in 1916 and by Lasky in 1929. As its ore body is the northern part of the main ore body of the Graphic-Waldo mine, the two are described as one on the following pages.

\section{GRAPHIC-WALDO OR OZARK MINE}

The Graphic-Waldo mine, owned by the Ozark Smelting \& Mining Co., a subsidiary of the Sherwin Williams Paint Co., comprises a continuous area of 227 acres about three-fifths of a mile north of Kelly. The developed ground is bounded on the west by the Waldo and Contact claims and on the east by the Miriam and 1896 claims. The company also owns the Ozark mill, $11 / 2$ miles west-northwest of Kelly, and its total holdings cover 800 acres. $^{79}$

There is some confusion in the naming of the mine. The Graphic and Waldo claims, which are among the oldest in the district, are about 1,000 feet apart, are on different ore zones, and were originally under different ownership. The original Waldo workings were along the Waldo fault, but after the Waldo tunnel was driven, in 1906, the deeper ores of the main ore zone in the Graphic ground were mined through it, and the Graphic property also became known as the Waldo mine. The levels throughout the entire workings are numbered consecutively, and it has become the informal practice to refer to levels above level 6 as the Graphic and to all levels below that as the Waldo. In this report the mine as a whole is called the Graphic-Waldo mine. The workings have also been called the Ozark mine, after the present owners.

The Ozark mill, erected in 1913, was operated until the depression of 1921, as shown on pages $80-81$, except during the last half of 1916 , when it was destroyed by fire and had to be rebuilt. Production of the mine and mill during the period 1918-20, inclusive, declined markedly, according to the company's report to the State Tax Commission, and operations were conducted at an aggregate loss of $\$ 403,619.06 .^{80}$ The report also stated that ore reserves amount to 50,000 tons averaging 12 percent of zinc.

The mine and mill, because of market conditions, remained closed between 1921 and 1926, except for a little work by lessees in 1924. Company operations were then resumed, and both ore and concentrates were shipped until the end of 1926. Some or all of these concentrates were exported. The mill was again closed in 1927, and mining operations were restricted to pumping and diamond-drilling and a little leasing until late in 1929. The mine was closed from 1929 to 1937 , when mining was resumed on a restricted scale.

The output from 1905 to 1939 , inclusive, is shown in the accompanying tables. Operations were confined mainly to the mining of oxidized ores from the older workings and the selective mining of high-grade zinc sulphide ore until 1913, when milling began. Thereafter the lower-grade zinc ores were mined and along

\footnotetext{
(9 Mines handbook; vol 18, p. 1685, 1931.

${ }^{80}$ Finlay, J. R., Report on appraisal of mines in New Mexico: New Mexico State Tax Commission, 1921-22, p. 53, 1922
} 
with them the zinc-lead ores, which were shipped to zinc-oxide plants, and the pyritic copper ores, which underlay the bulk of the other sulphide ores and were not developed until about 1913. The percentages of copper in copper sulphide ores imply local enrichment, but any enrichment in silver has been negligible. The quantity of lead sulphide ore shipped is surprisingly small, considering the quantity seen in the transition zone between the oxidized and sulphide zones in 1915; it may be that the lead sulphide has been included with oxidized lead ores in the annual statistical reports.

The output of oxidized ore, largely the work of lesses, represents the extension of lead stopes in the older part of the mine and the mining of zinc carbonate ore in the adjoining ground. The relatively large output of oxidized lead ore of less than average grade in 1916-18 accords with the high, wartime price of lead. The low content of silver and its rather uniform ratio to lead in the oxidized lead ore is noteworthy, as is the prevailingly high grade of the oxidized zinc ore regardless of the average value of zinc.
Ore produced at Graphic-Waldo mine, 1905-39 ${ }^{1}$ and gross metal content

[Data collected by C. W. Henderson, Geological Survey and Bureau of Mines, U. S. Department of the Interior, Denver, Colo.]

\begin{tabular}{|c|c|c|c|c|c|c|}
\hline Year & $\begin{array}{c}\text { Ore } \\
\text { shipped } \\
\text { (tons) }\end{array}$ & $\begin{array}{c}\text { Gold 2 } \\
\text { (ounces) }\end{array}$ & $\begin{array}{c}\text { Silver } \\
\text { (ounces) }\end{array}$ & $\begin{array}{l}\text { Copper } \\
\text { (pounds) }\end{array}$ & $\begin{array}{l}\text { Lead } \\
\text { (pounds) }\end{array}$ & $\begin{array}{c}\text { Zinc } \\
\text { (pounds) }\end{array}$ \\
\hline $\begin{array}{l}1905 . \\
1906\end{array}$ & $\begin{array}{r}25,150 \\
6,907\end{array}$ & & 2,000 & $\begin{array}{r}365,100 \\
64,560\end{array}$ & $\begin{array}{r}94,500 \\
948,680\end{array}$ & $\begin{array}{r}15,421,875 \\
3,341,300\end{array}$ \\
\hline $\begin{array}{l}1907- \\
1908\end{array}$ & $\begin{array}{l}6,907 \\
2,250 \\
1,766\end{array}$ & & 2,300 & & $\begin{array}{r}1,248,680 \\
375,000\end{array}$ & $\begin{array}{r}3,341,300 \\
825,000\end{array}$ \\
\hline 19 & $\begin{array}{l}1,00 \\
1,263\end{array}$ & & 1,126 & 12,871 & 164,543 & $\begin{array}{l}1,240,200 \\
661,500\end{array}$ \\
\hline & 6,280 & 1.55 & & & & $4,234,300$ \\
\hline & 2,894 & 3.0 & 1,834 & 23,869 & 159,578 & $1,739,033$ \\
\hline 12 & 1,085 & .60 & 522 & 2,012 & 72,827 & 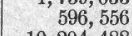 \\
\hline 1913. & 33,382 & 5. 22 & 6,008 & 167,198 & 822,382 & \\
\hline 1914 & 49,681 & 5. 51 & & 54 & & $15,449,692$ \\
\hline $\begin{array}{l}19 \\
19\end{array}$ & $\begin{array}{l}63,939 \\
47,116\end{array}$ & 18.30 & & $\begin{array}{r}1,394,165 \\
913,944\end{array}$ & $\begin{array}{r}990,249 \\
2,116,034\end{array}$ & $\begin{array}{l}17,022,410 \\
11,672,000\end{array}$ \\
\hline & 68,599 & 26.99 & 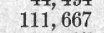 & $2,632,068$ & & $9,555,600$ \\
\hline 19 & 49,943 & .80 & 50,037 & 505,762 & $3,285,033$ & $12,474,200$ \\
\hline 191 & 12,014 & & 24,144 & 611,089 & 783,579 & $3,130,080$ \\
\hline & 16,295 & & 31,486 & 302,918 & $1,151,484$ & $4,427,765$ \\
\hline 921. & $\begin{array}{r}412 \\
8045\end{array}$ & & $\begin{array}{l}155 \\
2484\end{array}$ & & & $\begin{array}{r}163,178 \\
3.869123\end{array}$ \\
\hline $\begin{array}{l}199 \\
19\end{array}$ & $\begin{array}{l}8,045 \\
8,379\end{array}$ & & 2,484 & $\begin{array}{l}7,358 \\
5,166\end{array}$ & $\begin{array}{l}1,615,170 \\
1.880 .574\end{array}$ & $\begin{array}{l}3,861,894 \\
4,161,894\end{array}$ \\
\hline 1924 & $\begin{array}{l}8,393 \\
8,393\end{array}$ & $\ldots$ & 1,475 & & $\begin{array}{l}1,544 \\
1,54\end{array}$ & $4,637,800$ \\
\hline 1925 & 8,310 & & 6,424 & 16,067 & 1,71 & $3,319,840$ \\
\hline 1926 & 38,087 & 2.74 & 8,230 & 43,342 & $1,007,950$ & $\begin{array}{l}8,366,606 \\
5\end{array}$ \\
\hline $\begin{array}{l}1927 . \\
1928 .\end{array}$ & $\begin{array}{l}21,900 \\
67\end{array}$ & 5.70 & $\begin{array}{r}29,320 \\
2,152\end{array}$ & $\begin{array}{r}124,296 \\
896\end{array}$ & $\begin{array}{r}654,254 \\
44,499\end{array}$ & $\begin{array}{r}5,168,11 \\
25.9\end{array}$ \\
\hline \multirow{2}{*}{$\begin{array}{l}1929- \\
1937 . \\
1938-\end{array}$} & $\begin{array}{r}248 \\
3878\end{array}$ & 1. 50 & 706 & 8,531 & & \\
\hline & 3,878 & & & & 114,788 & $1,750,510$ \\
\hline \multirow[t]{2}{*}{$\begin{array}{l}1938- \\
1939\end{array}$} & $\begin{array}{l}983 \\
989\end{array}$ & & & & $\begin{array}{l}24,291 \\
24\end{array}$ & 566,783 \\
\hline & 488,255 & 71. 91 & 374,909 & $7,441,642$ & $23,706,002$ & $144,572,338$ \\
\hline
\end{tabular}

1 Mine idle $1930-36$.

2 No gold recorded until 1910

Classes and average gross metal content of ore shipped from Graphic-Waldo mine, ${ }^{1} 1905-39$

[Data collected and classified by C. W. Henderson, Geological Survey and Bureau of Mines, U. S. Department of the Interior, Denver, Colo.]

\begin{tabular}{|c|c|c|c|c|c|c|c|c|c|c|c|c|c|c|c|c|c|c|c|c|c|c|}
\hline \multirow[b]{3}{*}{ Year } & \multicolumn{11}{|c|}{ Sulphide ore } & \multicolumn{11}{|c|}{ Oxidized ore } \\
\hline & \multicolumn{3}{|c|}{ Copper ore } & \multicolumn{3}{|c|}{ Lead ore } & \multicolumn{3}{|c|}{ Zinc-lead ore } & \multicolumn{2}{|c|}{ Zinc ore } & \multicolumn{3}{|c|}{ Copper ore } & \multicolumn{3}{|c|}{ Lead ore ${ }^{2}$} & \multicolumn{3}{|c|}{ Zinc-lead ore } & \multicolumn{2}{|c|}{ Zine ore } \\
\hline & 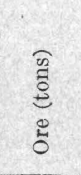 & 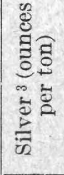 & 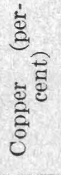 & $\frac{\widehat{a}}{0}$ & 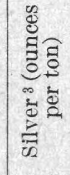 & 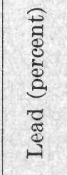 & 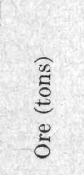 & 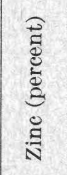 & 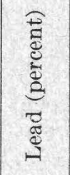 & 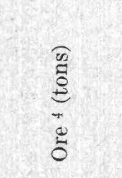 & 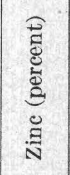 & 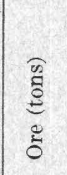 & 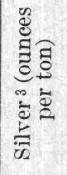 & 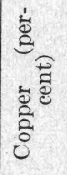 & 竎 & 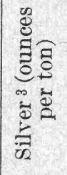 & 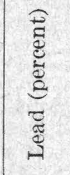 & $\frac{\text { के }}{\underbrace{2}_{\tilde{E}}}$ & 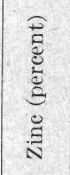 & 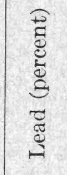 & 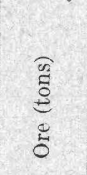 & 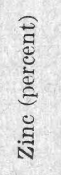 \\
\hline $\begin{array}{l}05- \\
06-\end{array}$ & & & & & & & 6,103 & 25 & 10 & $900 \mathrm{~S}$ & 33.3 & $\begin{array}{r}1,500 \\
269 \\
200\end{array}$ & $\begin{array}{c}1.2 \\
2.4\end{array}$ & $\begin{array}{r}12.2 \\
12 \\
6\end{array}$ & $\begin{array}{r}150 \\
52 \\
750 \\
\end{array}$ & $\begin{array}{r}1.2 \\
-2.4 \\
-2.1\end{array}$ & $\begin{array}{l}31.5 \\
27 \\
25 \\
-25\end{array}$ & & & & $\begin{array}{r}23,500 \\
483 \\
400 \\
1,766\end{array}$ & $\begin{array}{l}32.8 \\
30.0 \\
28.1 \\
35.1\end{array}$ \\
\hline 1909. & & 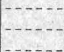 & & 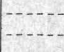 & & $\cdots$ & & -. & & $\begin{array}{r}945 \mathrm{~S} \\
6,019 \mathrm{~S}\end{array}$ & 35.0 & & & & $\begin{array}{l}318 \\
231\end{array}$ & $\begin{array}{l}\begin{array}{l}3.54 \\
2.75\end{array} \\
\end{array}$ & $\begin{array}{l}25.9 \\
15.4\end{array}$ & & & & & \\
\hline 1912 & & & & $\cdots$ & & 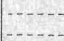 & & a. & & $659 \mathrm{~S}$ & 35.0 & & & & $\begin{array}{l}448 \\
163\end{array}$ & $\begin{array}{l}4.1 \\
3.2\end{array}$ & $\begin{array}{l}17.8 \\
22.3\end{array}$ & & & & 1,787 & 36 \\
\hline 1913. & 448 & . & 8.5 & 26 & & 36.8 & & & & $\begin{array}{l}452 \mathrm{~S} \\
000 \mathrm{M}\end{array}$ & $\begin{array}{l}38.7 \\
13.1\end{array}$ & 320 & & 14.2 & 1,348 & 4.4 & 26.7 & 413 & 21.0 & 10.0 & 4,375 & $\begin{array}{l}32.4 \\
33\end{array}$ \\
\hline 914 & 2,600 & 2.8 & 4.0 & 29 & & 23.5 & 1, 503 & 24,8 & 12.0 & $M$ & $\begin{array}{l}30.0 \\
13.6\end{array}$ & & & & 551 & 2.7 & 23.5 & 634 & 18.0 & 15.0 & 6,114 & 33 \\
\hline $\begin{array}{l}1915 \\
1916\end{array}$ & $\begin{array}{l}12,627 \\
10,128\end{array}$ & $\begin{array}{l}2.7 \\
2.7\end{array}$ & $\begin{array}{l}5.4 \\
4.2\end{array}$ & & & $1-$ & 5,500 & 18.0 & & 42 & 14.9 & 82 & 5 & 9.1 & 648 & 3.7 & 23.6 & 2,281 & 18 & 15 & 6,000 & 30 \\
\hline & $\begin{array}{l}36,303 \\
7344\end{array}$ & $\begin{array}{l}2.5 \\
2.4\end{array}$ & 3.5 & & .... & $\cdots$ & 3,450 & 18.0 & 10.0 & $\begin{array}{l}24,1 \\
18,2\end{array}$ & $\begin{array}{l}14.6 \\
15.3\end{array}$ & 76 & 5.2 & 7.8 & $\begin{array}{l}2,912 \\
6,356\end{array}$ & $\begin{array}{l}5.7 \\
3.2\end{array}$ & $\begin{array}{l}17.4 \\
16.8\end{array}$ & & & & $\begin{array}{l}4,400 \\
4,290\end{array}$ & $\begin{array}{l}30 \\
32\end{array}$ \\
\hline $\begin{array}{l}1918 \\
1919\end{array}$ & $\begin{array}{l}7,344 \\
4,224\end{array}$ & $\begin{array}{l}2.4 \\
5.1\end{array}$ & $\begin{array}{l}3.0 \\
7.1\end{array}$ & $\ldots$ & & $\ldots$ & 13,250 & 20 & 8 & 21,27 & 11.1 & & & & 3,593 & 3. 5 & 14.3 & & & & 4,485 & 27.4 \\
\hline & 2,875 & 3.8 & 5.0 & & & & $\begin{array}{l}1,340 \\
2,849\end{array}$ & ${ }_{21.2}^{22}$ & $\begin{array}{l}11.9 \\
12.5\end{array}$ & $\begin{array}{l}2,850 \mathrm{M} \\
8,061 \mathrm{M}\end{array}$ & $\begin{array}{l}13.4 \\
14.2\end{array}$ & & & & $\begin{array}{l}771 \\
964\end{array}$ & $\begin{array}{l}3.53 \\
4.6\end{array}$ & \begin{tabular}{|l|}
16.8 \\
20.7
\end{tabular} & 1,550 & 31.5 & 6 & $\begin{array}{l}1,279 \\
1,546\end{array}$ & $\begin{array}{l}31.1 \\
30\end{array}$ \\
\hline 1922 & 32 & 4. 6 & 2.4 & $\ldots$ & $\ldots$ & $\cdots$ & $\begin{array}{r}351 \\
6,160\end{array}$ & $\begin{array}{l}19.9 \\
25.0\end{array}$ & $\begin{array}{r}9.8 \\
10.0\end{array}$ & & & & & & 26 & 6.0 & & & & & & $\begin{array}{l}30 \\
33.1\end{array}$ \\
\hline & & & & & & & 7,685 & $\begin{array}{l}26.0 \\
2.0\end{array}$ & 11. 0 & & & & & & $\begin{array}{l}483 \\
468\end{array}$ & $\begin{array}{l}4.8 \\
5.0\end{array}$ & $\begin{array}{l}24.3 \\
20.3\end{array}$ & 640 & 23.5 & 11.5 & $\begin{array}{l}730 \\
226\end{array}$ & $\begin{array}{l}33.4 \\
36.7\end{array}$ \\
\hline 1924 & & & & 1,914 & 3.4 & 17.3 & & $\begin{array}{l}30.0 \\
26.2\end{array}$ & $\begin{array}{l}8.0 \\
8.0\end{array}$ & & $\ldots$ & & & & 422 & 3.5 & 19.9 & 724 & 0 & & & \\
\hline 1926. & 319 & 3.4 & 4.8 & & & & $\begin{array}{l}3,425 \\
3,40\end{array}$ & $\begin{array}{l}25.2 \\
25.2\end{array}$ & $\begin{array}{l}8.0 \\
7.4\end{array}$ & & & & & & & & & 400 & 23.0 & 11.0 & & \\
\hline & & & & 567 & 32.0 & 33.2 & 456 & 17.0 & 5.0 & 20,722 & 12.0 & & & & 722 & 3.0 & 18. 9 & & & & & \\
\hline & ${ }^{6} 248$ & 2.8 & 1.7 & & & . & & & & & & & & & & & & & & & & \\
\hline & & & & & & & & & & $\begin{array}{l}{ }^{8} 3,878 \mathrm{~S} \\
8983 \mathrm{~S}\end{array}$ & $\begin{array}{l}22.6 \\
27.6\end{array}$ & & & & & & & & & & & $\cdots$ \\
\hline 1939 & & $\cdots$ & $\cdots$ & $\ldots$ & . & & 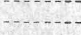 & $\ldots$ & -... & $\begin{array}{l}8989 \mathrm{~S} \\
\end{array}$ & 28.1 & & & & & & & ..... & 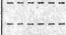 & 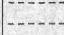 & 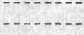 & 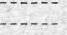 \\
\hline & 77,148 & -4 & $\ldots$ & 2,036 & & 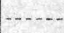 & 65,315 & & & 403 & & 2,447 & & & 22,926 & & & 6,642 & & & 62,338 & \\
\hline
\end{tabular}

1 Includes shipments from Nitt mine from 1914 to 1922, when that mine was under lease and was worked as a part of Graphic-Waldo mine.

. to the mine in 1926 came from this ore.

Average silver content expressed in ounces to the ton, is commonly too low to b paid for and frequently has not been recorded. Average gold content is less than ores than in lead ores.
${ }_{4} \mathrm{~S}$, Ore shipped crude; $\mathrm{M}$, mill ore.

5 Mine and mill idle. 67 tons of lead concentrates were separated from zinc concentrates by tabling and were shipped. It contained 0.083 ounce of gold and 32 ounces of silver to the ton, 0.7 percent of copper, and 33.2 percent of lead; also, 19.4 percent zine, which was lost.

Dry ore from dump of Waldo shaft. Averaged 0.006 ounce of gold to the ton

8. Mine and mill idle 1930-36. 1939. 
The mine was studied by Loughlin in 1916, but the workings opened since then were inaccessible when field work was resumed in 1928 and 1929. We are iridebted to the late Philip B. Argall, general manager, and Superintendents Pressler (1915) and P. H. Argall (1916-29) for helpful information during the study and to Professor J. A. Weir, of the New Mexico School of Mines, for information regarding depths of more recent workings and the depth of ground water in 1935.

The mine includes 14 levels, 10 of which are shown on plate 31 . These levels are opened by several tunnels and one shaft. The Mitchell tunnel, whose altitude is 7,840 feet, is equivalent to level 1 and crosscuts the southeastern part of the property. Five short tunnels at similar and higher altitudes explore the long faulted outcrop of Kelly limestone in the northeastern part. The lower, western part of this outcrop is opened by the Graphic tunnels 1, 2, and 3, which correspond to levels 1,2 , and 3 . The No. 1 tunnel is also called the Gibbany tunnel.

\section{MAIN WORKINGS}

The No. 3, or main Graphic tunnel, extends southward along the Kelly limestone. It connects about 1,200 feet south of its portal with the crosscutting Greyhound tunnel, which extends east-northeastward from the central part of the property. Farther south level 3 connects through a stope-raise 30 feet high with level 4 of the Kelly mine.

Level 4 of the Graphic mine was opened through the Ida Hill tunnel, which follows a zigzag northeasterly course, explores mineralized fissures in the Sandia formation, and connects eastward with level 3 through stoped inclines in the Kelly limestone. Levels 5 and 6 , and also level 4 , were opened through a southsloping incline from level 3 , but levels 7 to 11 were opened through the Waldo tunnel whose portal is at North Camp at an altitude of 7,284 feet. This tunnel, completed in 1906, extendéd eastward for about 1,700 feet through rhyolite porphyry and the Madera, Sandia, and Kelly formations and is equivalent to level 9. Levels 6,7 , and 8 are reached from it by inclined raises along the dip of the "silver pipe" bed of the Kelly limestone, and levels 10 and 11 by an inclined winze of north-northwesterly trend also along the "silver pipe" bed and nearly parallel to the pitch of the main ore zone. Levels 10 and 11 have been extended into the Nitt.mine, where they are called the 275- and 350-foot levels. Since 1916 an inclined winze down the dip of the "silver pipe" bed from level 11 has served to open the northern parts of levels 12 , 13 , and 14.

The western ore zone along the Waldo fault has been opened through the Waldo shaft. This shaft, the altitude of whose collar is 7,436 feet, is just north of the Waldo tunnel and about 450 feet from the portal. Four levels, equivalent to levels 9, 10, 11, and 14 , have been driven from it, but only the workings open on the tunnel level in 1916 have been accessible to us.

The general method of development on each level has been to drift along the "silver pipe" bed and to drive crosscuts from it through the upper and lower parts of the Kelly limestone; but in some places, notably on levels 3 and 5, drifts have been driven for considerable distances along or near the top of the Kelly limestone.

The Graphic-Waldo and Nitt mines lie in the large relatively uplifted Graphic fault block, which is bordered by rhyolite porphyry on the west and monzonite on the north. The formations present include the preCambrian argillite, Kelly limestone, Sandia formation, Madera limestone, the Nitt monzonite stock, and dikes of monzonite and lamprophyre; but the ore mined has come almost entirely from the Kelly limestone supplemented to a small extent by ore from the lower members of the Sandia formation. The general distribution of the different formations and their exploration by mine workings are shown on plates 31 and 32 . The sedimentary rocks above the argillite dip $45^{\circ}-50^{\circ}$ WSW. They have all been metamorphosed to some degree near the monzonite contact, and their identity is therefore obscured in Nitt workings west of the main ore zone; but elsewhere they are typically represented, and the only uncertainty in identification is where faulting has brought shale beds of different members of the Sandia formation together.

The Graphic fault block is broken by at least six sets of minor faults, nearly all of which are normal. Each set appears to have played some part in the control of ore deposition. These different sets have the following trends: (1) northwest strike and northeast dip; (2) north-northwest to north-northeast strike and vertical to easterly dip; (3) east-northeast to northeast strike and southeast dip; (4) east to east-northeast strike and south dip; (5) east-southeast strike and northeast dip; and (6) bedding faults. Some of these sets could be divided into two minor sets on the basis of relative age; for example, early faults or fissures of northwest trend that contain dikes have been offset along normal bedding faults that were formed at the same time as later faults of northwest trend. Some bedding faults, in contrast to those just cited, may be reverse and may have been formed during the earliest stages of deformation. Faults of north-northwest to north-northeast trend are grouped together because their influence on ore deposition has been uniform, although, if details of deformation could be more thoroughly recognized, more than one north-trending set might be recognized.

The set that has had the greatest influence on ore 
deposition strikes northwest and dips $45^{\circ}$ or less northeast. The lines of intersection of these faults with the west-dipping beds pitch north-northwest at rather small angles. The set is well-developed in the Kelly limestone, where its dip slips are as much as 30 feet. It passes upward into small monoclines or rolls in the basal shale bed of the Sandia formation. These rolls have in part absorbed the entire movement, but in some places the shale is offset as much as 15 feet along the dip of the fault. The rolls have not been explored upward, so their continuity and relations to minor faults or fissures in quartzite and limestone beds of the Sandia formation can only be inferred. The most prominent member of this set, called the Roll fault, is shown on plates 32 and 33 . It extends south-southeastward along the main ore zone from stopes in the Nitt mine to a point on level 8 of the Graphic-Waldo mine about opposite the Waldo tunnel, where it probably ends against a cross fault of east-northeast trend. Its northern part especially is closely paralleled by smaller faults that constitute a zone as much as 175 feet wide that is normal to the dip. (See fig. 12.) A steplike continuation of the Roll fault extends southsoutheast along the main ore zone on levels 6 and 7 , but it has not been identified along the old stopes in oxidized ore on level 5 .

A dike of monzonite, older than the ore, is exposed at intervals on levels $5,6,8$, and 9 . It occupies a fissure of northwest trend and moderate northeast dip, but it is offset by one or more bedding faults that are related to the Roll fault, indicating that faults of northwest trend and northeast dip were formed at different times.

A similar though smaller fault, which is here called the East Roll fault, is exposed along the west drift on level 5 and lies along the east ore zone of the mine. Its trend is more northerly than that of the main Roll fault and it is correlated with the north-northwesttrending set of faults, although in all other respects it is similar to the main Roll fault. It ends against a fault of east-northeast trend a little south of the Greyhound tunnel, and no steplike continuation of it has been recognized. Other faults of north-northwest to north trend and moderate to steep easterly dips are exposed on levels 3 and 4 and lie within the east ore zone.

Only minor faults of north to north-northeast trend have been exposed and none have been followed any considerable distance, although some form boundaries to small stopes in the upper levels near the incline from the Graphic tunnel and in the Ida Hill workings.

The faults of northeast to east-northeast trend dip $35^{\circ}$ to $40^{\circ} \mathrm{SE}$. and are nearly parallel to the Kelly-Graphic cross fault, which forms the south or southeast boundary of the major fault block. Some of them are followed by lamprophyre dikes and others, which are mineralized, apparently form connecting links between the east and main ore zones, although ore has not been mined along them for any considerable distance except near junctions with faults or fissures of the other sets.

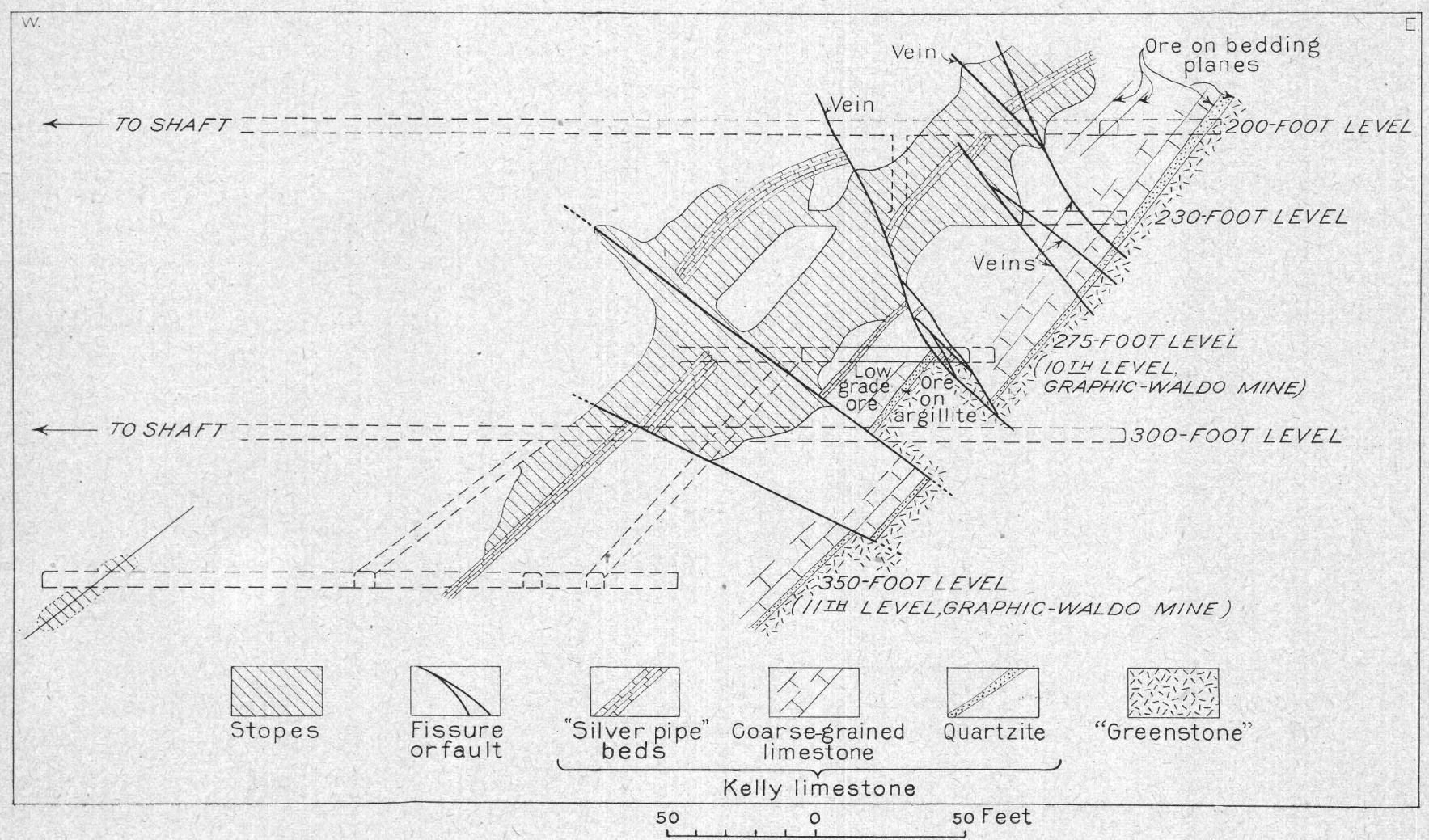

FIGURE 12.-Generalized cross section through Nitt mine, looking north. By S. G. Lasky. 
The northernmost fault of northeast to east-northeast trend is exposed at the top of the incline on level 3, and the incline descends obliquely along it. Its presence on level 2 is expressed by discordant positions of old stopes in Kelly limestone to the northwest and southeast of it. It is also exposed just north of the old shaft that connects level 4 with the Ida Hill workings, and its southwesterly projection through the main ore zone extends approximately along the interval between the stope on level 6 and that on level 8. (See pl. 31.)

A fault of east to east-northeast strike is exposed in the Ida Hill workings, but the exposures are insufficient to serve as a basis for positive interpretation of its structural relations. Together with associated faults of northerly trend, however, it appears to bring the shale member of the Sandia formation on the south down to the same level as the lower quartzite member on the north, as shown on plates 31 and 32 . It was not recognized on the debris-covered surface; whether it extends upward into the Madera limestone or merges into bedding faults in the Sandia formation, as is suggested on plate 32 , is not known. This fault, if projected eastward, would join the fault just described, but it may end against some concealed fault of more northerly trend. Other faults with northeast strike and southeast dip are exposed on levels 3 and 5 in the southern part of the old Graphic workings. With one exception the hanging walls of all except the southernmost of these faults have moved downward and northeastward. The southernmost fault was not seen because of the caved and filled ground among the old stopes in oxidized ground, but its approximate position is suggested by the discordant positions of the Kelly limestone, which indicates that the hanging wall has moved southwestward.

The only noteworthy fault of east-southeast trend and northeast dip is exposed in the southern parts of levels 6 and 9 ; its southeasterly projection would nearly coincide with the stope at the south end of level 3. Its upward projection would closely parallel the lamprophyre dike shown on plate 2, about 1,200 feet southeast of the Waldo tunnel portal.

Bedding faults have been noted along the "silver pipe" bed in the Kelly limestone and at several places along shale beds in the different members of the Sandia formation. Only the fault along the "silver pipe" bed near its junction with the Roll fault is clearly associated with the distribution of ore, but it may be similarly associated near the East Roll fault, and bedding slips along the shale bed at the top of the Kelly limestone may have similar significance. Where the monzonite dike has been offset along the "silver pipe" bed on levels 8 and 9, near the east end of the Waldo tunnel, its upper part with the enclosing upper Kelly beds has moved downdip to the west as if to make room for the roll in the shale along the Roll fault, as shown in figure 7 and plate 33. Along the southern part of level 9, however, particularly where the fault of east-southeast trend is exposed, all the upper Kelly beds are locally eliminated and the overlying shale is in contact with the "silver pipe" bed (fig. 3). At the south end of level 9 the same fault, or one closely parallel to it, is exposed within the "silver pipe" bed. These last two exposures seem most reasonably explained by either a reverse movement of the hanging wall upward to the east, opposite to the normal movement induced by the Roll fault, or by movement in the general direction of strike but at a small angle with the dip of the beds. The suggested reverse movement could have accompanied the original tilting of the major fault block or the folding that preceded faulting, but it could hardly have accompanied the subsequent minor faulting. Movement in the direction of strike could have accompanied that along the Roll fault.

Although some of the bedding faults in shale may also be supplementary to faults of the roll type, those at considerable distance from crosscutting faults seem more likely to be related to the reverse movement. This relation seems especially true of a fault in the shale member of the Sandia formation exposed in the Waldo tunnel about 350 feet east of the Waldo shaft (see fig. 3).

As shown in the general section on structure (pp. 65-73) faulting took place at different times and the direction of movement along any one fault changed at different times. The most significant movement that affected ore deposition in the Graphic-Waldo mine, however, was a settling of the major Graphic fault block soon after the intrusion of the Nitt monzonite stock. During this settling, which tended to open the major faults along its boundaries, the block as a whole tended to expand by the slipping of minor blocks within it along the minor faults. The faults with north or northwest strikes and northeast dips were the most favorably situated to serve as slipping planes in the eastern half of the block, and movement along them tended to produce tension fractures as well as normal bedding faults along the adjacent west-dipping bedding planes that were ideally situated in this respect. These open bedding planes and the more open parts of the northeastward-dipping faults, therefore, became the most favored courses to be followed by oreforming solutions. The faults of northeast strike and southeast dip were favorably situated for slipping in the southeastern part of the block, but the attitude of the bedding did not give so good an opportunity for associated tension cracks to form adjacent to them. These faults, therefore, served mainly to aid in the development of open ground near their junctions with faults of north-northwest to northwest trend, especially on the west sides of the junctions; but small openings along them may have permitted a minor 
Sandia formation ; Kelly limestone i $\downarrow$

Madera limestone

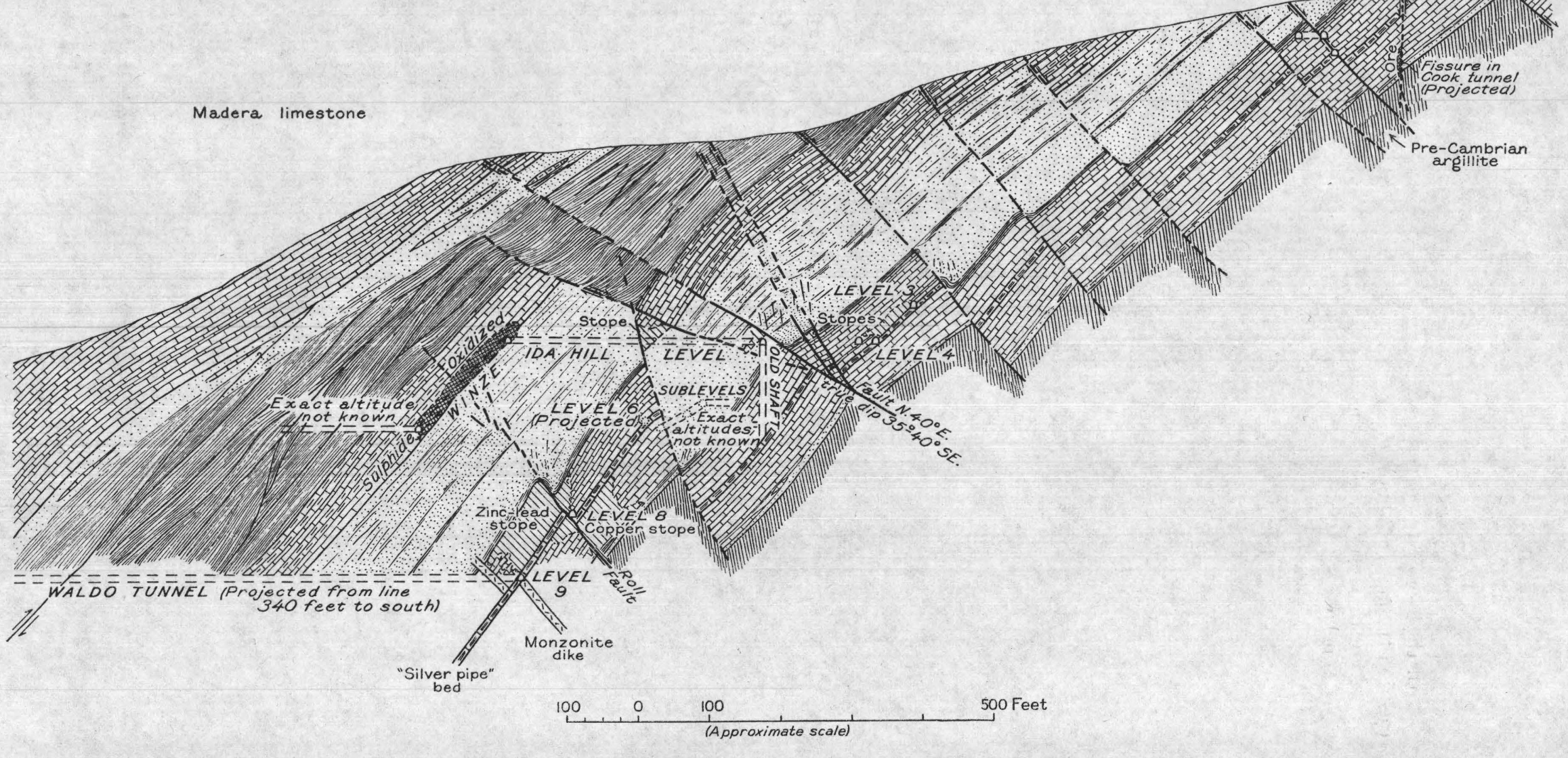

CROSS SECTION OF THE IDA HILL, WALDO, AND GRAPHIC WORKINGS, LOOKING N. $77^{\circ} \mathrm{E}$ Shows relations of stopes to faults and stratigraphic horizons. 



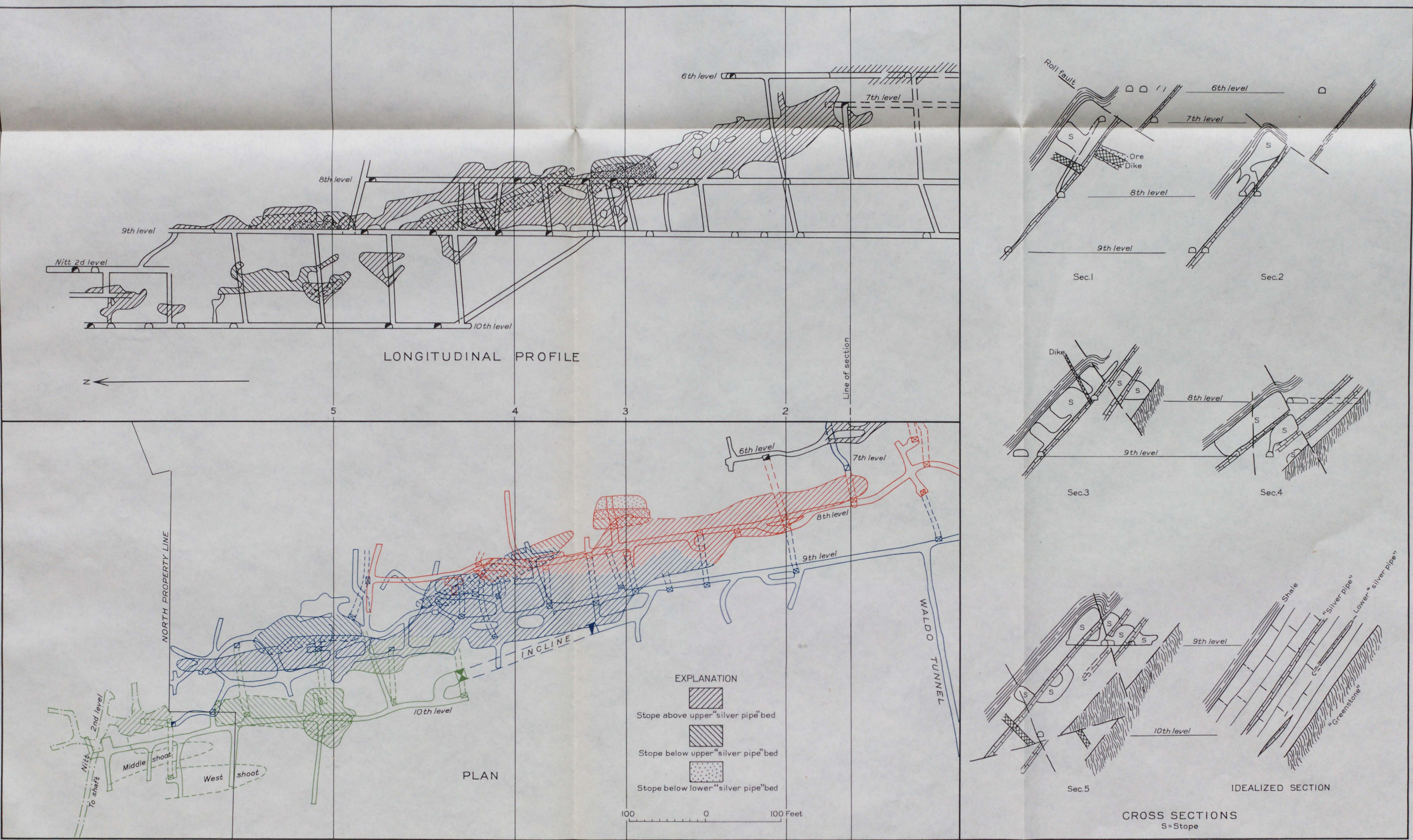

PLAN, LONGITUDINAL PROFILE, AND CROSS SECTIONS OF MAIN ORE SHOOT NORTH OF WALDO TUNNEL, GRAPHIC-WALDO MIN 


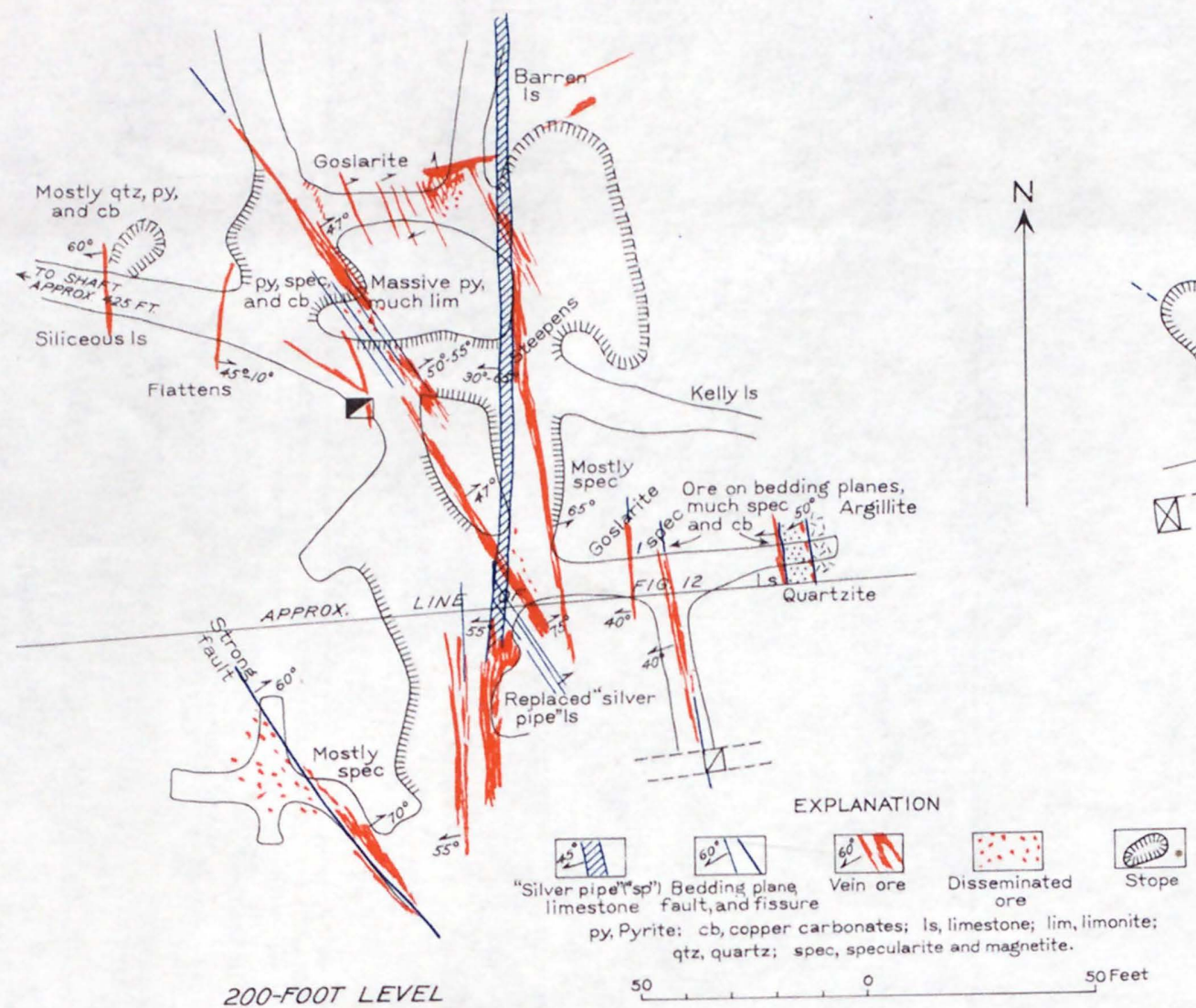

GEOLOGIC SKETCH OF 200-AND 275-FOOT LEVELS OF THE NITT MINE

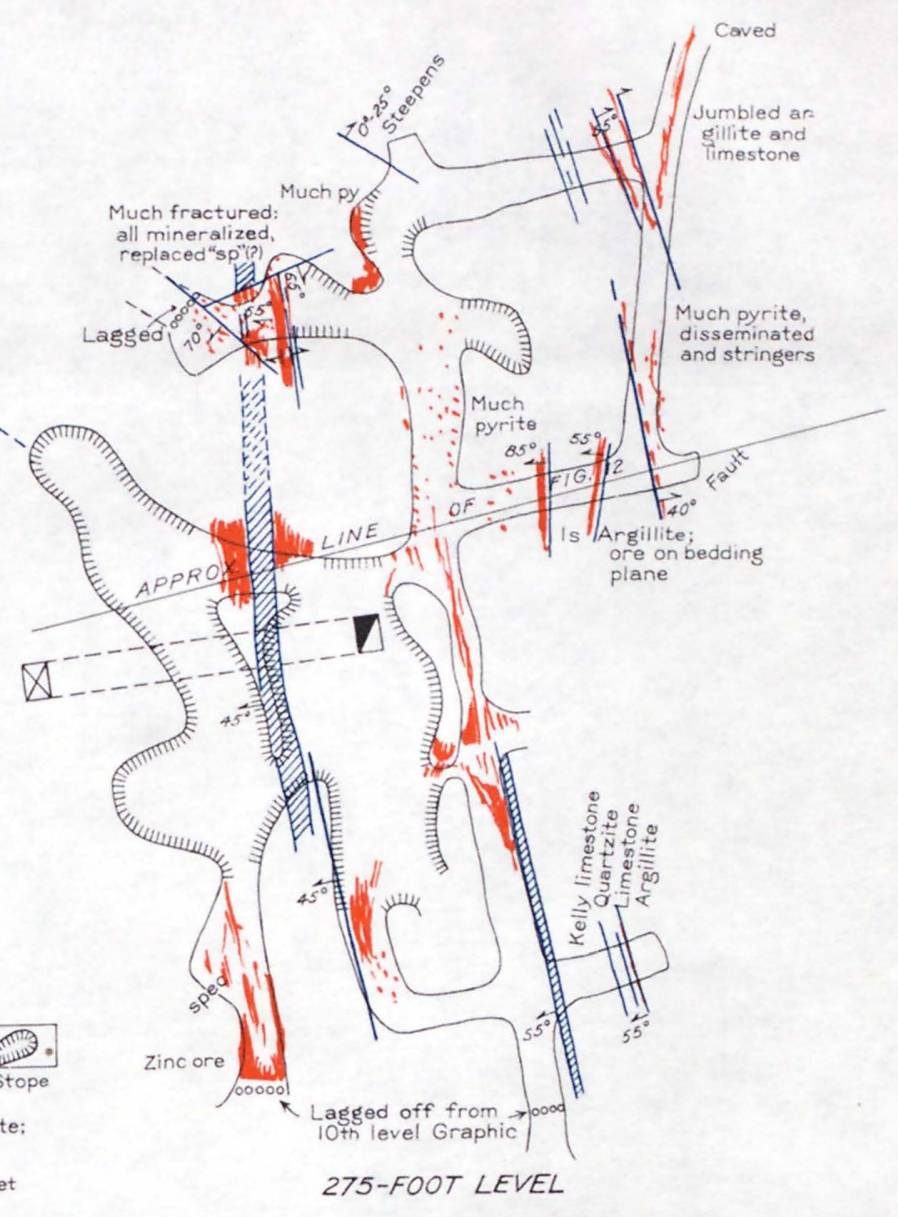

By S.G.Laskey, Dec.1,1929 
amount of circulation between parallel groups of northwestward-trending faults.

The faults of east-southeast strike and northeast dip, noted only in the southern part of the mine, were too unfavorably situated to become slip planes during this stage of settling, although they aided in the formation of open ground at their junctions with other faults. The bedding faults, besides being subjected to opening along faults of east and northeast dip in the eastern half of the block, as stated above, were in position to serve as slip planes near the western side. They corresponded in this respect to the northeast-dipping faults in the eastern half of the block. Complementary tension fractures across the bedding could have formed between bedding faults, but as bedding faults are numerous and close together on the whole, the tension cracks would have been very short and confined to the more brittle beds of limestone and quartzite. They would not have provided trunk channels for circulation, although those close to the west boundary of the block could have served as local branch channels for solutions that rose along the more open parts of the Waldo fault.

The ore bodies of the Graphic-Waldo and Nitt mines lie in three zones-the eastern or Graphic zone, the middle or main zone, and the western or Waldo zone. The eastern zone has been developed through the three Graphic tunnels but mainly on levels 3 and 5. Its ore shoots are entirely in Kelly limestone, except in the west part of level 4 , where one small shoot has been stoped along a quartzite bed near the base of the Sandia formation and near the intersection of northand northeast-trending faults. The ore mined has been mostly lead carbonate, and zinc carbonate, but some rather high grade, partly oxidized copper ore has been mined on and below the southern part of level 5 . Oxidation has obscured the structural relations to some extent, but the dependence of the ore shoots on the intersection of minor faults with the upper and lower members of the Kelly limestone is generally clear. The principal original minerals left along stope walls are streaks and thin replacement masses of specularitemagnetite with some pyrite and here and there a little zinc blende and radiating, platy calcite.

Many of the stopes are caved or filled with waste, but in those available for study the character and distribution of the ore are typical. The lead carbonate had been largely mined out by 1905, and in 1915 and 1916 zinc carbonate was being taken from the floors or walls of the old stopes. The copper ore on level 5 lay along a bed 18 inches thick in upper Kelly limestone. This bed had been replaced by magnetite-specularite aggregates and pyrite, with a little original chalcopyrite and a small amount of green copper carbonate. Near the south end of level 5, this same bed was replaced by a shoot from which some shipments in 1915 were said to assay as much as 5 percent of copper. Material seen from this shoot consisted of typical magnetite-specularite aggregates with minor amounts of pyrite and copper minerals. About 1905 an enriched shoot was followed from level 5 nearly to level 6 in a trough between the argillite floor and the northeast-dipping monzonite dike. It was said to contain lumps of native copper "too big for two men to lift."

The main Graphic tunnel, or level 3, follows a steplike group of east-dipping fissures southward in upper Kelly limestone for about 600 feet to their intersection with the northernmost fault of northeast strike and southeast dip. Along this fault several small stopes have been mined at intersections with north-trending fissures in both upper and lower Kelly limestone. The westernmost of these stopes connects with a narrow, crescent-shaped stope in the overlying quartzite. Farther south for 330 feet level 3 follows along some old stopes that extend down to level 4 both above and below the "silver pipe" bed. The level then crosscuts eastward and follows the "silver pipe" bed southward to a point about 100 feet beyond the Greyhound tunnel. The main drift south of the tunnel follows the upper Kelly limestone for 400 feet to the first of a group of east-northeast-trending faults that shift the Kelly limestone first eastward and then westward, as shown on plate 31 . The drift follows a sinuous course along old stopes in the cross-faulted ground, then follows the "silver pipe" bed to the south boundary of the mine, near which it is connected through an inclined stope with level 4 of the Kelly mine, 30 feet above the Graphic level 3.

The Graphic No. 2 tunnel, which corresponds to level 2, and No. 1 tunnel, which is about 50 feet above No. 2, open some old stopes associated with the northern cross fault. Level 2 is also developed through a raise in a stope near the Greyhound tunnel. It contains a few small stopes as far south as its intersection with a reverse fault of northwest trend and northeast dip. Beyond this fault no ore was noted.

The middle or main ore zone extends south-southeastward from the monzonite contact in the Nitt mine for more than 1,400 feet and practically unites with the east zone in the cross-faulted ground in the south part of the mine. The monzonite and metamorphic Sandia strata near the north end of the main ore zone are impregnated with pyrite and are thoroughly cut by a network of slickensided fractures, many of which contain pyrite and quartz and a few of which contain pockets lined with calcite scalenohedrons. The pyrite evidently represents little besides the conversion of original iron minerals in the rock, and the calcite evidently represents redeposition of material that had been replaced and removed from the ore zone.

The ore extending from the Nitt ground as far south as level 6 consists of specularite-magnetite aggregates, 
sulphides, and minor amounts of quartz. On and above level 6 it is thoroughly oxidized. The specularite-magnetite aggregates form replacement masses along beds throughout the Kelly limestone, particularly beneath such impervious beds as the lower and upper "silver pipes" and the basal shale of the Sandia formation. Pyrite replaced limestone that was not reached or was only partly replaced by the specularitemagnetite aggregates, and zinc blende and galena replaced limestone that escaped attack by pyrite. The specularite-magnetite aggregates and pyrite are most abundant in the northern part of the shoot, but they are conspicuous throughout the sulphide zone. Pyrite forms large apparently pure masses throughout the thickness of the Kelly limestone near the south boundary of the Nitt mine; but farther south it is concentrated mainly beneath the "silver pipe" bed, where it constitutes the eastern or copper shoot of the zone that had been mined out on levels 8, 9, and 10 in 1916 . It had not been explored on higher levels, but the position of the enriched copper shoot below level 5 , about where the east and main zones unite, suggests that the copper shoot of the middle zone may continue southward above level 8. The copper ore consists largely of pyrite, specularite, magnetite, and a little chalcopyrite, somewhat enriched by chalcocite and malachite. The base of the Kelly limestone has provided a good course for downward circulation, and thus acounts largely for the enrichment, but it has been supplemented by some of the minor faults of north-northwest trend along which oxidation has taken place lower than elsewhere.

A small proportion of zinc ore has been found in the copper shoot, but zinc and zinc-lead sulphide ores are the principal products of the middle and western shoots. The western shoot, opened on level 10, is in the upper Kelly limestone west of a fault that evidently dies out southward or ends against a cross fault in the northern part of the Graphic-Waldo mine. The middle shoot is the most continuously developed. It has been mined continuously from the Nitt ground to a point above level 8 opposite the Waldo tunnel. The zinc blende in the middle and western shoots forms irregular bodies in the pyritic ore near the monzonite contact. The stopes shown on plate 34 and figure 12 are largely walled by massive pyrite.

The steplike continuation of the middle zone was being developed on level 7 in 1916. Its outline on that level had not been proved, but its outline on level 6, where it extends upward into the oxidized zone, is shown on plate 31 . Its position on level 5, north of its obscure junction with the east zone, is shown by a few small stopes in lead-carbonate ore, around which some zinc carbonate ore has doubtless been mined. The combined east and middle zones appear to weaken beyond the south boundary of the mine, which is about 200 feet north of the Kelly-Graphic cross fault. The main zone also includes a few small shoots in the lower limestone member of the Sandia formation that have been mined through the Ida Hill tunnel. The eastern of these shoots have replaced beds along faults of north and north-northwest trends near their junctions with one of east-northeast trend and southsoutheast dip that has apparently brought the shale member of the Sandia formation on the south down to the level of the lower quartzite member on the north. No fault of such magnitude was recognized or suspected when the surface in the vicinity was mapped, and the interpretation is therefore subject to doubt. It accords with evidence on levels 8 and 9 directly below the Ida Hill workings, as shown on plate 32, and with that in the Ida Hill crosscut and level 4 to the east; but more accessible workings and better exposures in critical places would doubtless result in some revision. The western Ida Hill shoot, as shown on plate 32 , is along the up-dip projection of the main Roll fault. Doubtless the fault, or even the roll in the basal shale bed, is not continuous across the lower quartzite; but the presence of some equivalent effects of disturbance may have afforded a somewhat tortuous course along which ore-forming solutions could reach the lower limestone member. The western ore shoot, from which oxidized lead and zinc ores were mined, was followed by an incline down the dip of the formation for about 100 feet where it is said to have passed into sulphide ore containing copper.

The western ore zone lies near the Waldo fault. It is crossed by the Waldo tunnel and has been explored through the Waldo shaft, from which three levels have been driven below tunnel level at altitudes of 7,158 , 6,982 , and 6,780 feet. Only the workings on the tunnel level have been accessible to us. The Waldo fault in the tunnel is about 150 feet west of the shaft. Its position is obscured by chloritic alteration along slickensided fractures that range in strike from S. $20^{\circ}$ E. to SE. Some of them dip west or southwest, whereas others dip east or northeast. Although the principal rock west of the fault is rhyolite porphyry, the rock at the contact with Madera limestone, which lies east of the fault, is a monzonitic porphyry with a chilled contact. It is evidently a dike intruded along the fault. The limestone adjoining the porphyry is finely brecciated and somewhat silicified. The brecciated rock passes into recrystallized limestone impregnated with magnetite, specularite, and pyrite.

Drifts have been driven northward and southward from the tunnel along a shear zone about 30 feet east of the contact. The short north drift was timbered and only collapsed, slickensided, chloritic rock could be seen along it. The south drift is in softened or leached, white, crystalline limestone and hard dark- 
green chloritic rock, both of which are pyritic and thoroughly cut by a network of wet, slickensided fractures. The drift ends at a fissure zone about 5 feet wide that strikes N. $65^{\circ} \mathrm{W}$. and dips $65^{\circ} \mathrm{NNE}$.; along this zone a small, pipelike shoot of pyritic lead-zinc sulphide ore has been stoped above and below the level. The shoot appears to pitch steeply westward.

The character of the ore is similar to that of the main zone. The structural conditions also are similar to those that control the small oxidized shoot near the south end of level 6 . The fact that ore has been deposited in this western zone in the Madera limestone, which was presumably rather inaccessible to rising solutions because of the shale beneath it, should encourage deeper exploration in the limestone members of the Sandia formation and in the Kelly limestone. Owing to the abnormally steep dip near the Waldo fault, however, the depth that these limestones reach in the fault zones and the amount of water that must be handled render mining relatively expensive. Although considerable exploration has been undertaken below the tunnel level, the results have not been disclosed.

The depth to promising limestone horizons west of the fault can only be roughly estimated. Some drilling has been done there, but we have not learned the results. The rhyolite porphyry and underlying volcanic rocks there may have a thickness of 1,500 or 2,000 feet, and the top of the Kelly limestone may be 1,200 or 1,500 feet deeper-too deep to encourage development under ordinary market conditions.

SMALI TUNNELS EAST OF GRAPHIC TUNNEL

The No. 2 Graphic tunnel, or level 2, which is 150 feet southeast of the No. 3 or main Graphic tunnel, extends 450 feet southward in an irregular course; and crosscuts extend from its southern end for 150 feet westward and 200 feet eastward. The tunnel is for the most part in pre-Cambrian argillite, but the southern part and the crosscuts penetrate the Kelly limestone. The fault of northeast trend that crosses the head of the Graphic incline on level 3 evidently crosses the southern part of level 2 also and accounts for the easterly offset of the Kelly limestone. The limestone is also cut by faults of more northerly trend, but the workings are so thoroughly filled or caved that no detailed study of them was possible.

The No. 1, or first-level, Graphic tunnel, also called the Gibbany tunnel (pl. 31), is about 50 feet above and 260 feet east-southeast of the No. 2 tunnel. Some low-grade lead ore was being mined from beds just below the "silver pipe" bed in 1916.

The Gibbany tunnel, follows an irregular southerly course for about 200 feet. Its portal is at the top of the Kelly limestone, but the tunnel curves southeastward until it reaches the "silver pipe" bed. It then follows the "silver pipe" bed for 100 feet to its inter- section with a fault of westward trend and steep northward dip, which offisets the "silver pipe" 50 feet to the west. The tunnel turns west along the fault and south again along the "silver pipe", which it follows for 35 feet. North of the west-trending fault the tunnel cuts a shoot of partly oxidized pyritic copper ore that replaces a bed just below the "silver pipe." The shoot has been stoped southeastward obliquely up the dip and at the south end of the stope was 3 feet thick. Thirty-five feet east of the tunnel the replaced bed is slightly offset by a fault that dips east at a very low angle. The ore as a whole is said to have contained 4 percent of copper and 10 percent of lead, but no lead minerals were recognized in the ore exposed in 1916.

The Augustine tunnel, 270 feet east-southeast of the Gibbany tunnel, follows a sinuous southerly course for about 130 feet and cuts a vertical fault of northeast trend in the top of the Kelly limestone. A small streak of oxidized lead ore was being worked along the shale roof on the northwest side of the fault.

The Tabacchi tunnel, 130 feet east-southeast of the Augustine tunnel, is 70 feet long and follows the lower Kelly limestone. It has served to take ore through a chute from the Martin tunnel stope above it.

The Martin tunnel, about 100 feet long, is in upper Kelly limestone and follows a fissure that strikes $\mathrm{N}$. $20^{\circ} \mathrm{E}$. and $\operatorname{dips} 45^{\circ} \mathrm{E}$. Thirty feet from the portal a winze has been sunk for 25 feet along the fissure and a drift from it extends about 80 feet along the intersection of the fissure with the "silver pipe" bed. A little ore has apparently been stoped along the fissure from the "silver pipe" bed to a point on the surface about 25 feet above the tunnel, but the ore was interrupted in places by rusty gougy material.

Cook tunnel, 120 feet east of the Tabacchi tunnel, is 80 feet long and is entirely in pre-Cambrian argillite. The shallow shaft above it has been sunk along a vertical fault that strikes $\mathrm{N}$. $35^{\circ}$ E. and separates Kelly limestone on the northwest from argillite on the southeast. A small stope has been mined along the fault.

The Mitchell tunnel, whose portal is 2,300 feet east of North Camp at an approximate altitude of 7,830 feet, has explored the ground east of the southern Graphic workings. It is about 930 feet long, trends a little north of east, and crosscuts complexly faulted ground, as shown on plate 31 and figure 13. Its first 550 feet is mainly in the lower quartzite-shale member of the Sandia formation, but the Kelly limestone appears at three places, in two of which it is separated from the quartzite-shale member by vertical or steeply dipping faults. At the north end of the north drift (pl. 31) it is also separated by a fault that nearly parallels the bedding and partly removes the upper Kelly limestone. For the next 200 feet along the main 


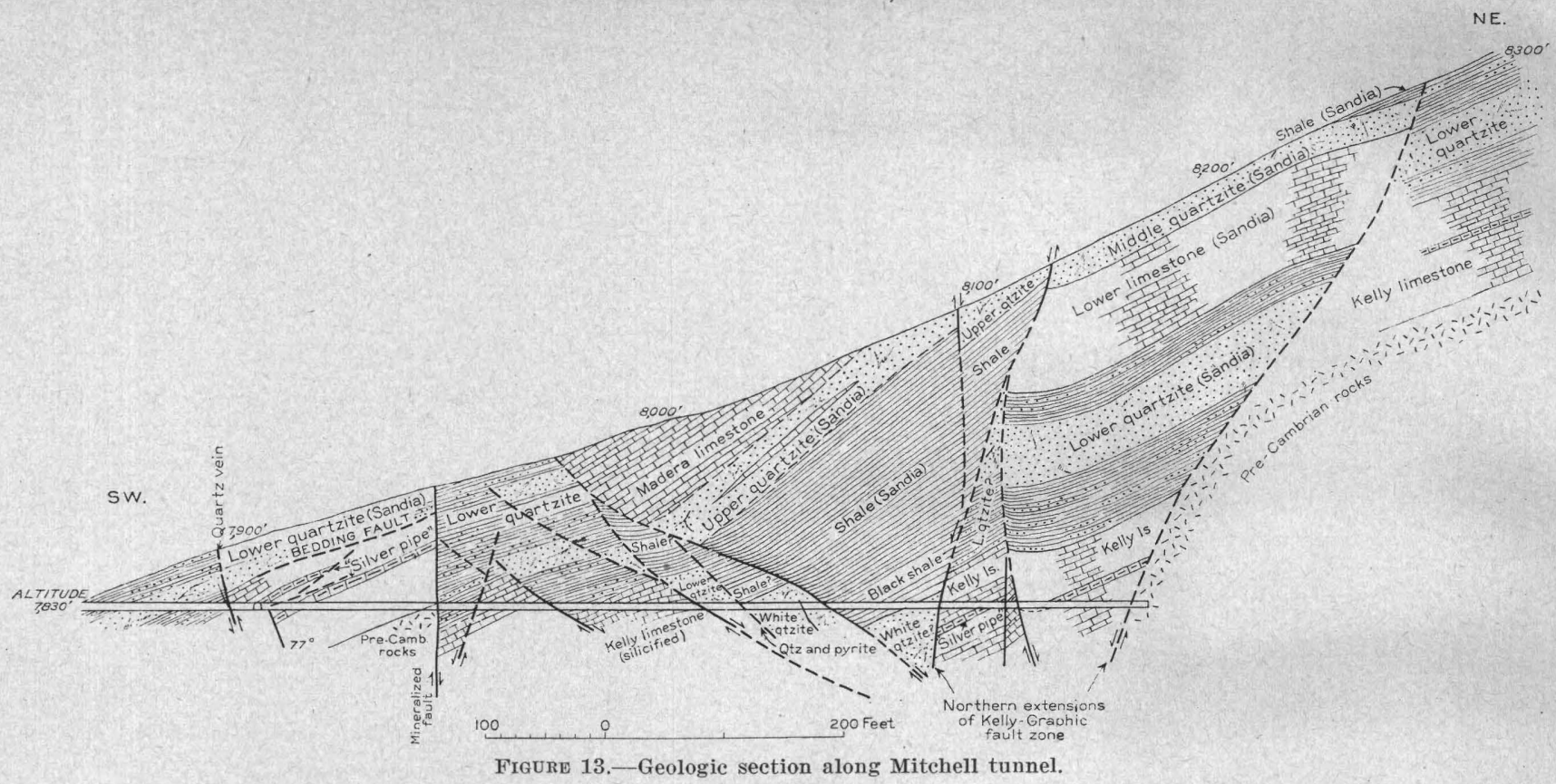

tunnel the shale member of the Sandia formation appears and is stepped down along the east side of a fault that dips $32^{\circ} \mathrm{E}$. The shale is bounded on the east by the westernmost of a group of faults that may be regarded as north continuations of the Kelly-Graphic fault zone. The Kelly limestone forms the east wall of the westernmost fault and persists as far as the easternmost fault near the end of the tunnel, where it is faulted against pre-Cambrian diabase and argillite. Pre-Cambrian diabase also appears beneath the Kelly limestone at a vertical fault 300 feet from the portal.

The faults west of the Kelly-Graphic fault zone belong to the prevailing sets, some dipping east at angles of $30^{\circ}$ to $35^{\circ}$ and others dipping vertically or steeply to east or west. Both sets are mineralized but contain only quartz and a little pyrite and are flanked by silicified limestone and pyritized shale, quartzite, or diabase. Solutions during the earlier stages of mineralization were apparently under sufficient pressure to penetrate along some of these comparatively tight faults, but the later ore-forming solutions were not.

The steep reverse fault 125 feet from the portal is an exception, as it contains the quartz-barite aggregate that is characteristic of the later or weaker stage of ore deposition. A little ore may have been stoped along its eastern or hanging side. This fault evidently marks the east limit reached by the solutions that deposited ore in the southern part of the GraphicWaldo mine.

\section{KELLY MINE}

The Kelly mine, including the Paschal, Traylor, and old Billings shafts and the Kelly tunnel (pl. 35), owned by the Empire Zinc Co., is just northeast of the town of Kelly. The company at first owned only the Lillie group of claims west of the Kelly mine but in
1913 purchased the mine and mill from the TriBullion Smelting \& Development Co. The property now consists of 40 claims, covering 578 acres. ${ }^{81}$ Intensive development was begun in 1913, and improvements were made in the combination wet concentration, roasting, and magnetic concentration mill; but the milling process was not altogether successful, partly because the gangue contained sufficient iron to prevent its electromagnetic separation from the zinc blende. The company reported ${ }^{82}$ that during the years $1915-17$ zinc ores were produced at some profit above operating expenses, not including amortization of capital invested. At the end of that period the main sulphide ore body of the mine, which bottomed near level 6 , was practically exhausted. Meanwhile developments on lower levels had disclosed very little ore; so company operations ceased, though some leasing continued. The mine was idle in 1921 and 1922, and the company's report, cited above, stated that all known pay ore had been removed; it also stated that there was "a possibility of zinc ore on property not prospected but the prospects have been deemed so unfavorable that nearly all equipment has been removed from the property and the plant buildings scrapped." Since 1922 lessees have made small outputs, mainly of lead, but in 1930 , 1933 , and 1934 they produced from $1,000,000$ to $2,000,000$ pounds of zine, as well as from 447,000 to 915,000 pounds of lead, annually.

The output of the mine from 1905 to 1939 , inclusive, is shown in the accompanying tables. The second table contrasts with the corresponding table for the GraphicWaldo mine in the smaller relative quantity of copper ores and in the dominance of zinc-lead sulphide instead

81 Finlay, J. R., Report of appraisal of mines in New Mexico: New Mexico State Tax Commission, 1921-22, p. 53, 1922.

82 Idem, p. 53. 
of zinc sulphide ore. The bulk of the copper and gold credited to the mine in the first table came from lead ores and lead concentrates. The low silver content of the lead ores and the prevailingly high grade of the oxidized zinc ores are common to both mines.

Ore shipped from Kelly mine, 1905-39 ${ }^{1}$ and its gross metal content

[Data collected by C. W. Henderson, Geological Survey and Bureau of Mines, U. S. Department of the Interior, Denver, Colo ]

\begin{tabular}{|c|c|c|c|c|c|c|}
\hline Year & $\begin{array}{c}\text { Ore } \\
\text { (tons) }\end{array}$ & $\begin{array}{c}\text { Gold } \\
\text { (ounces) }\end{array}$ & $\begin{array}{c}\text { Silver } \\
\text { (ounces) }\end{array}$ & $\begin{array}{l}\text { Copper } \\
\text { (pounds) }\end{array}$ & $\begin{array}{c}\text { Lead } \\
\text { (pounds) }\end{array}$ & $\begin{array}{c}\text { Zine } \\
\text { (pounds) }\end{array}$ \\
\hline & & & & & & 060 \\
\hline & & & & & (2) & $18,775,500$ \\
\hline & & & 15,684 & & $3,429,126$ & $14,911,185$ \\
\hline & & 12 & & 101 & 3,769 & $16,663,665$ \\
\hline & 22,3 & & $x_{2}$ & 258 & 2,1 & 9,1 \\
\hline & 16,7 & & & & & \\
\hline 1913- & $\begin{array}{l}10,540 \\
68\end{array}$ & 2 & 14 & 151,742 & $1,281,568$ & $\begin{array}{r}3,652,297 \\
55,109\end{array}$ \\
\hline & 9,449 & & & & 709 & $\begin{array}{r}3,756,257 \\
\end{array}$ \\
\hline & 8.4 & & & & $3,016,524$ & \\
\hline
\end{tabular}

Classes and average gross metal content of ore shipped from Kelly mine, 1905-39

[Data collected and classified by C. W. Henderson, Geological Survey and Bureau of Mines, U. S. Department of the Interior, Denver, Colo.]

\begin{tabular}{|c|c|c|c|c|c|c|c|c|c|c|c|c|c|c|c|c|c|c|c|c|c|c|}
\hline \multirow[b]{3}{*}{ Year } & \multicolumn{14}{|c|}{ Sulphide ore } & \multicolumn{8}{|c|}{ Oxidized ore } \\
\hline & \multicolumn{3}{|c|}{ Copper ore } & \multicolumn{3}{|c|}{ Lead ore ${ }^{2}$} & \multicolumn{8}{|c|}{ Zinc-lead ore } & \multicolumn{3}{|c|}{ Copper ore } & \multicolumn{3}{|c|}{ Lead ore 2} & \multicolumn{2}{|c|}{ Zine ore } \\
\hline & $\check{5}^{\overparen{g}}$ & कृ & 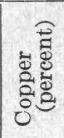 & કั & s0 & 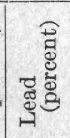 & 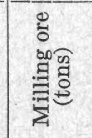 & 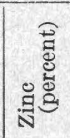 & 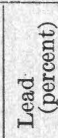 & 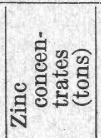 & 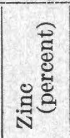 & 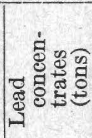 & ๘ँ & 莺 & 它氮 & 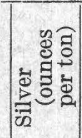 & 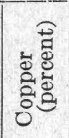 & કั & 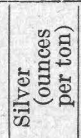 & 总 & ธूँ & 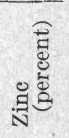 \\
\hline & & & & & & & 35,575 & & & & & & & & & & & & & & 4,496 & 31.2 \\
\hline 008 & & $\cdots$ & & & & & $\begin{array}{r}0,010 \\
-\quad 375 \\
\end{array}$ & 11.7 & & 4125 & 35.0 & & & & & & & & & & $\begin{array}{l}21, \sqrt{25} \\
44,000\end{array}$ & $\begin{array}{l}34.4 \\
35.0\end{array}$ \\
\hline & & $-\cdots$ & -. & 5 & & & 3,444 & 12.6 & 4.4 & 1,148 & 37.7 & & & & & & & & & & 25,449 & 27.6 \\
\hline 10 & & $\cdots$ & & & $\cdots$ & & $\begin{array}{l}519,605 \\
716,333\end{array}$ & 21. 6 & $\begin{array}{l}7.0 \\
5\end{array}$ & 11,062 & 38.4 & 4,622 & 10. 9 & 29. 9 & & & & 63,000 & $\begin{array}{l}3.9 \\
4.4\end{array}$ & 20 & $\begin{array}{r}612,788 \\
4,883\end{array}$ & $\begin{array}{l}39.0 \\
31.8\end{array}$ \\
\hline & & & & & & & 15,040 & $\begin{array}{l}10.0 \\
21.7\end{array}$ & 6.5 & 8,664 & \begin{tabular}{|l|}
00.0 \\
37.6
\end{tabular} & $\begin{array}{l}3,030 \\
3,369\end{array}$ & 8.7 & $\begin{array}{l}\text { to. } 0 \\
29.2\end{array}$ & 36 & & 4.5 & 259 & $\begin{array}{r}10.2 \\
10.2\end{array}$ & 17.1 & $\begin{array}{l}4,880 \\
1,401\end{array}$ & $\begin{array}{l}31.8 \\
32.4\end{array}$ \\
\hline 13 & & & - & & & & 8,200 & 18.5 & 7.7 & 4,086 & 37.1 & 2,479 & 4.7 & 25.5 & 1,503 & 2.2 & 4.5 & & & & 837 & 37.0 \\
\hline 915 & & & & & & & & & & & & & & & & & & 3,100 & 4.3 & 23.1 & 6,349 & \\
\hline 1916 & & & & 82,525 & 3.8 & 22.0 & $\begin{array}{r}8,183 \\
10 \\
5 \\
5\end{array}$ & $\begin{array}{l}12.8 \\
21.8\end{array}$ & $\begin{array}{r}4.8 \\
11.0\end{array}$ & 94,750 & 22.1 & & & $\ldots$ & 29 & 8 & 6.7 & 1,185 & 4.8 & 28.5 & 10,913 & 25.9 \\
\hline $\begin{array}{l}1917 . \\
1918\end{array}$ & 29 & $\begin{array}{l}2.0 \\
3.3\end{array}$ & 7.5 & 121.95 & 53 & 228 & 17,904 & 16.1 & 6.5 & 11 14,057 & 20.5 & 30 & 15.7 & 44.1 & 67 & 2.1 & 12.5 & 2,115 & 4.1 & 16.5 & 4,491 & 29.0 \\
\hline 119 & & & & 1,990 & 0.5 & 22.8 & & & & & & & & & & & & & 6.7 & 25.2 & & $\begin{array}{l}33.4 \\
34.3\end{array}$ \\
\hline & & & $\cdots$ & & & & $\cdots$ & & & & & & & & & -5 & & 81 & 6.3 & 19.6 & 365 & 21.1 \\
\hline 24 & & & & & & & & & & & & & & & & & & 259 & $\begin{array}{r}6.3 \\
3\end{array}$ & 24.4 & & \\
\hline 25 & & & & & & & ${ }^{14} 28$ & 57.0 & 50 & & & & & & & 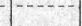 & & 682 & & & & \\
\hline 06 & & & & & & & & & & & & & & & & & & 15471 & $\begin{array}{l}5.9 \\
4.3\end{array}$ & 22.0 & & $\cdots$ \\
\hline & & & $\ldots$ & & & & $\ldots$ & & 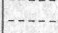 & & & & & $\ldots$ & & ... & & ${ }_{16}^{16} 1,186$ & $\begin{array}{l}.0 \\
1.2\end{array}$ & 5.4 & & \\
\hline & & & & & & & & & & & & & & & & & & ${ }^{17} 598$ & 2.8 & 16.3 & & \\
\hline & & & & & $\ldots$ & & $\begin{array}{r}14497 \\
143423\end{array}$ & 24.0 & 14. 9 & & & & & & & $\cdots$ & & 1,869 & 4.4 & 18 & & \\
\hline & & & & & $\cdots$ & & 14622 & $\begin{array}{l}25.1 \\
23.4\end{array}$ & $\begin{array}{l}11.9 \\
12.5\end{array}$ & & & & -4 & $\cdots$ & & . & $\cdots$ & 1,110 & 4.4 & 13.4 & & \\
\hline & & & & & & & 145,501 & 22.9 & & & & & & & & & & - & & & & \\
\hline & & & & & & & & & 10 & & & & & & & & & & & & & \\
\hline & & & & & & $\cdots$ & 14, & & & & & & & & & & & & & & & \\
\hline & & & & 18 & 4. & 11.4 & 13, 1,58 & 21,7 & 7.9 & & 1 & & & $\cdots$ & & 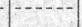 & -- & 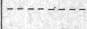 & $\cdots$ & - & 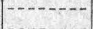 & $\cdots$ \\
\hline 1939 & 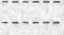 & . & 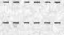 & 19144 & 3.4 & 23.1 & 569 & 20.0 & 11.1 & & 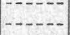 & & ...- & $-\cdots$ & ...... & $\cdots$ & $\ldots$ & $\cdots$ & 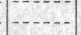 & - & $\ldots$ & $\ldots$ \\
\hline Total. & 433 & & & 5,344 & & & 117,819 & & 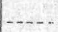 & & 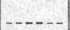 & & & ..... & 1,635 & & & 18,450 & & & 100,368 & \\
\hline
\end{tabular}

1 Mine was idle during 1907,1931 , and 1938; no ore was shipped during 1921 and 1922.
2 to 2.0 percent of copper and as much as 0.04 ounce of gold to the ton

3 Zinc-lead ore in 1906 contained 32 percent of lead and zine and was evidently shipped to zinc-oxide plants. About 16 of the total recovered zine for 1906 was used as pigment.

4 Shipments of zinc concentrates and crude oxidized zinc ore averaged 35 percent of zinc.

of Original metal content of crude ore calculated from metal recovered from concentrates.

${ }^{6}$ Tonnages approximate, based on pounds of recovered metal from a total of 15,788 tons of lead and zinc ores shipped separately. Lead ore shipped by C. T. Brown, lessee, contained 2.9 ounces of silver to the ton, 9.2 percent of copper, 22.3 percent of his crude ore.
Ore shipped from Kelly mine, 1905-39 ${ }^{1}$ and its gross metal content-Continued

\begin{tabular}{|c|c|c|c|c|c|c|}
\hline Year & $\begin{array}{c}\text { Ore } \\
\text { (tons) }\end{array}$ & $\begin{array}{c}\text { Gold } \\
\text { (ounces) }\end{array}$ & $\begin{array}{c}\text { Silver } \\
\text { (ounces) }\end{array}$ & $\begin{array}{c}\text { Copper } \\
\text { (pounds) }\end{array}$ & $\begin{array}{c}\text { Lead } \\
\text { (pounds) }\end{array}$ & $\begin{array}{c}\text { Zinc } \\
\text { (pounds) }\end{array}$ \\
\hline 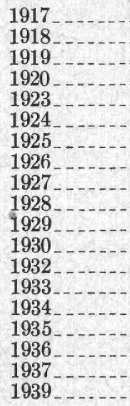 & $\begin{array}{r}24,606 \\
4,528 \\
1,179 \\
446 \\
318 \\
682 \\
748 \\
471 \\
1,186 \\
3598 \\
2,366 \\
4,533 \\
622 \\
5,501 \\
3,129 \\
1,957 \\
1,571 \\
962 \\
713\end{array}$ & $\begin{array}{r}15.26 \\
1.00 \\
.48 \\
5.40 \\
32.10 \\
4.08 \\
3.70 \\
7.10 \\
3.00 \\
\end{array}$ & $\begin{array}{r}9,309 \\
11,899 \\
4,557 \\
511 \\
1,624 \\
2,515 \\
4,232 \\
2,015 \\
1,365 \\
1,702 \\
8,169 \\
4,908 \\
\end{array}$ & $\begin{array}{r}113,529 \\
98,130 \\
11,319 \\
3,228 \\
6,497 \\
4,584 \\
6,649 \\
3,389 \\
2,300 \\
5,674 \\
19,418 \\
10,667 \\
\end{array}$ & $\begin{array}{r}3,019,591 \\
943,061 \\
343,340 \\
31,799 \\
126,141 \\
249,974 \\
319,934 \\
149,814 \\
127,439 \\
194,767 \\
823,067 \\
1,111,518 \\
155,800 \\
1,307,660 \\
639,028 \\
350,280 \\
248,012 \\
172,985 \\
126,217\end{array}$ & $\begin{array}{r}8,365,424 \\
1,401,340 \\
342,314 \\
234,330 \\
41,012 \\
31,950 \\
238,368 \\
1,718,534 \\
290,720 \\
2,515,540 \\
1,363,801 \\
844,560 \\
682,097 \\
63,734 \\
227,138\end{array}$ \\
\hline & 244,133 & 196.59 & 251,097 & $1,335,253$ & $27,585,911$ & $109,390,001$ \\
\hline
\end{tabular}

1 Mine idle 1907, 1921-22, 1931, and 1938.

2 Contained undetermined amount of lead.

${ }^{3}$ All from dump. 


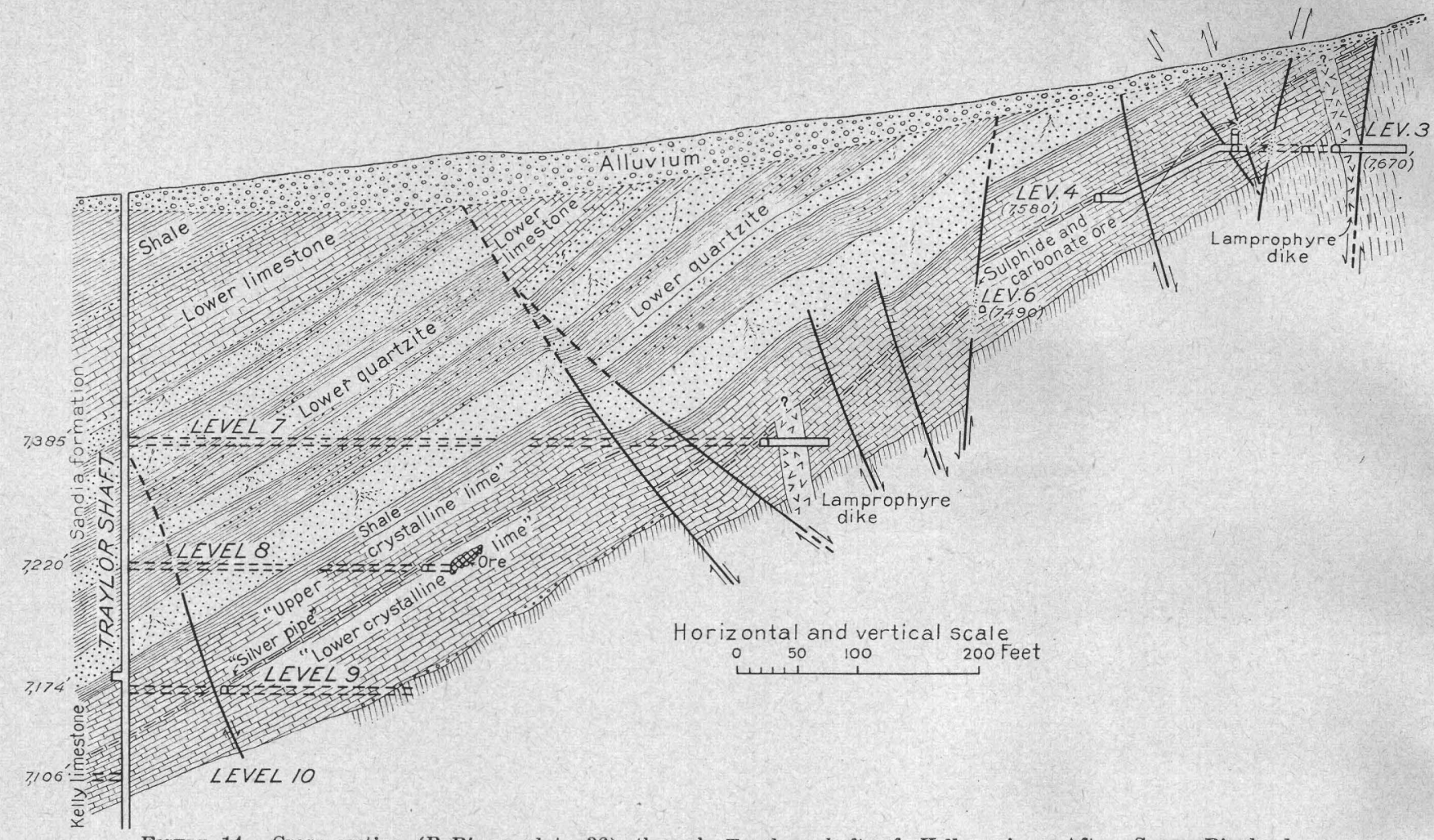

FiguRe 14.-Cross section (B-B' on plate 36) through Traylor shaft of Kelly mine. After Soren Ringlund.

W.

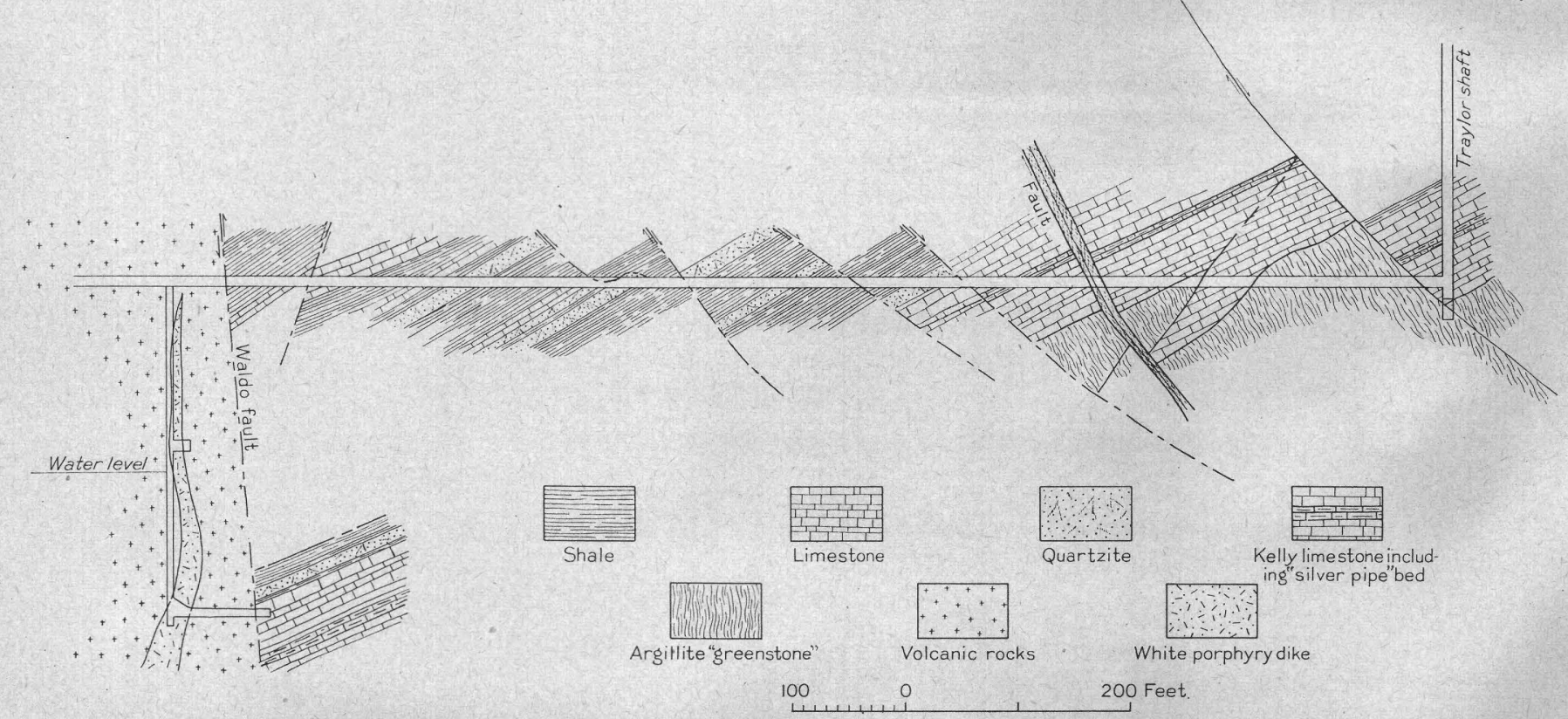

Figure 15.-Cross section along level 10 of Kelly mine, west of Traylor shaft. After C. M. Glasgow and R. G. Garnett. 


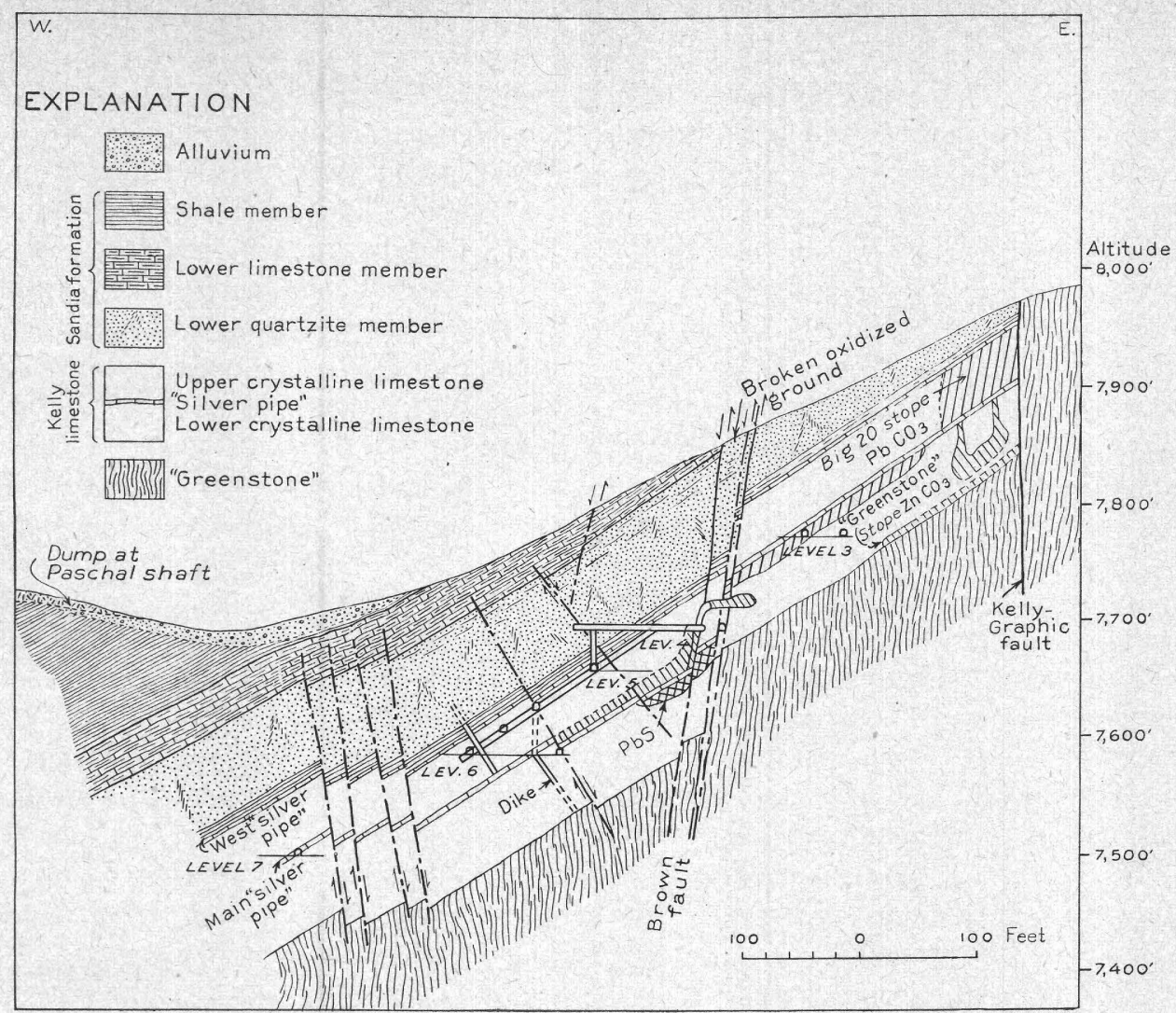

Figure 16.-Cross section (A-A' on plate 36 ) through middle part of Kelly mine. Shows relations of lead-carbonate and zinc-carbonate ore shoots. After Soren Ringlund.

The mine (pl. 36 and figs. 14-16) is opened by the Kelly tunnel, which corresponds to level 3, and by three shafts, two of which-the old Billings and the Paschal-had been abandoned before 1915. The old Billings shaft, 200 feet east of the portal of the Kelly tunnel, extends only to level 4 ; the Paschal shaft, 750 feet to the northwest, extends to level 7; the Traylor shaft, 700 feet southwest of the Kelly tunnel, is connected with levels 7 to 10 . All the levels except level 10 are developed mainly in the Kelly limestone, and most of the main drifts are along the "silver pipe" bed. Level 10 (fig. 15) consists of a long crosscut that extends westward for about 1,150 feet, partly through argillite and Kelly limestone but mostly through the Sandia formation, and into the volcanic rocks beyond the Waldo fault. A winze from level 10 has been sunk about 380 feet in the volcanic rocks, and an east crosscut from it crosses the fault and enters the upper Kelly limestone.

The Kelly limestone in the mine has been subdivided for local purposes into the following members, beginning with the lowest: (1) a 6-inch layer of pebbly arkose in a calcite matrix, (2) a few feet containing much quartz and epidote (the "pinto lime"), (3) coarse-grained "lower crystalline" limestone 70 to 80 feet thick, which includes a bed of fine-grained, white ("marbleized") limestone 1 to 4 feet thick, (4) the dense, argillaceous "silver pipe" bed, 1 to 6 feet thick about 20 feet above the "marbleized lime", (5) the "upper crystalline lime" 45 feet thick, which is divided near the middle by a "west" or "upper silver pipe" bed about 2 feet thick. In places, however, especially in the west-central part of the workings, the "upper silver pipe" is immediately below the basal shale of the Sandia formation, perhaps as a result of faulting along the bedding. The principal ore-bearing strata are below the "marbleized lime" and below the main "silver pipe" bed. The "upper crystalline lime," very productive in the Graphic-Waldo mine, has been less productive than the "lower crystalline lime" in the Kelly mine, partly because it has been eroded from the southern part of the mine.

The productive ground is in the eastern part of the Kelly fault block (p. 71), which is bounded on the east by the Kelly-Graphic fault, on the north by the KellyGraphic cross fault, on the west by the Waldo fault, and on the south by a cross fault, mostly concealed, that joins the Kelly-Graphic fault a little south of the Juanita tunnel. This block has dropped in relation to the block east of it and also to the block north of it, but the blocks south and west of it have dropped much more. The Kelly block is cut by sets of minor faults, of which four are normal, one is reverse, and one follows the bedding. The set having the most marked 
influence on ore deposition is the normal set of northnorthwest trend and vertical to steep westerly dip. It is slightly convergent southward with the east boundary, or Kelly-Graphic fault, and includes the Brown fault, which is 120 to 130 feet west of the KellyGraphic fault and is the axis of the ore zone. A second normal set is of east-northeast trend and southerly dip, generally parallel to the north boundary or Kelly-Graphic cross fault. The members of this set between the Kelly-Graphic and Brown faults have served as minor channels for the circulation of oreforming solutions. A third set, of west-northwest to west trend and northerly dip, is similarly related to ore deposition. A fourth normal set, of northwesterly trend and northeasterly dip, is conspicuous west of the ore zone but is only slightly mineralized. Only two reverse faults have been noted, both in the west crosscut on level 10, where their relations to other faults have not been determined. The outstanding bedding fault is along the "silver pipe" bed. It has offset a lamprophyre dike west of the ore zone, the hanging wall showing an apparent movement of 38 feet down the dip (fig. 16); but the actual movement here, as in the Graphic-Waldo mine, was probably for the most part along the strike of the bedding. Some of the normal faults are followed approximately by lamprophyre dikes. (See pl. 36.) Small movements along the normal faults have recurred since the intrusion of the dikes and both before and since ore deposition.

The movement that provided openings for ore-forming solutions was principally down the dip of the Kelly-Graphic cross fault. It involved some southerly movement along the longitudinal Kelly-Graphic and Brown faults, whose curvature, as shown in figure 6 and plate 36, caused all but their northernmost parts to open. The cross faults between them also opened. Some settling toward the Kelly-Graphic and Brown faults must have taken place along the northeast-dipping faults whose relatively low angles of dip evidently kept them tight. In this respect they are in marked contrast to the Roll fault in the Graphic-Waldo mine.

The ore-forming solutions evidently rose from a deep source into the northeast corner of the Kelly block and moved through the open ground along the KellyGraphic and Brown faults. There is no evidence that they came southward from the Graphic block, as the ores in the southern part of that block contain barite and were deposited farther from their source than were the northernmost Kelly ores which contain considerable specularite, magnetite, and some silicate gangue. Specularite and magnetite have been found as far south as crosscut 3 on the Kelly tunnel level, and they may have extended somewhat farther in ground that is now thoroughly oxidized; but ore in the southernmost part of the mine and in the Juanita workings beyond contains considerable barite.
Ore bodies in the Kelly mine are essentially confined to one zone along the eastern part of the Kelly block. Development in the middle part of the block has disclosed only small occurrences of ore, and that along the Waldo fault at the west edge of the block has also had discouraging results. The ore zone crops out at the Kelly-Graphic fault on the north slope of Kelly Gulch. On the lower slope the upper part of the Kelly limestone has been eroded, exposing lead carbonate, allophane, and zinc carbonate, which have replaced the lower part. The outcrops of both the upper and lower parts were developed first by shallow tunnels along or near the fault, and their down-dip continuations were later reached through the Kelly tunnel (level 3) and the Billings shaft, which extends to level 4. Development of the upper part led to the Big Twenty stope, where loose "sand carbonate" was tapped and, according to the late C. T. Brown, flowed down to level 3, where many tons of it had merely to be shoveled into mine cars. This ore, which was mined in the early eighties, contained about 20 ounces of silver to the ton-much more than the average lead carbonate ore of the district. The associated zinc carbonate was not mined until 1903, or later, after it had been recognized by Brown. The relative positions of the lead and zinc carbonate ores in and beneath the Big Twenty stope and in the lower Kelly limestone on either side of the Brown fault are shown in figure 16.

The stopes accessible in 1915 and 1916 are shown on plate 36. The oldest stopes, which extended for nearly 500 feet northward from the Kelly tunnel along level 3 , are filled and inaccessible; but, together with the stopes mapped, they represent an almost continuous replacement of the more permeable beds. Beyond the filled stopes on level 3 the sulphide ore appears.

The ore zone, which widens northward in accordance with the diverging trends of the Kelly-Graphic and Brown faults, has a general steplike or zigzag outline that has been influenced by cross faults, whose positions are indicated by branch stopes of southwest trend. For about 400 feet north of the Kelly tunnel the ore zone is almost entirely between the Kelly-Graphic and Brown faults. It is widest in the vicinity of southwesttrending cross faults near crosscut 4 on level 3, but farther north the ground between the two faults has not been very productive. The principal shoot north of crosscut 5 extends with north-northwest pitch along the west side of the Brown fault and ends abruptly between levels 4 and 6 against the Kelly-Graphic cross fault, whose footwall is argillite. Beneath level 6 a short west branch of the shoot extends southward from the Kelly-Graphic cross fault, and a veinlet follows the cross fault for a considerable distance. Farther south short branches of the ore shoot that have been mined along minor cross faults extend nearly down to level 6 .

The ore south of crosscut 4 on level 3 was entirely 


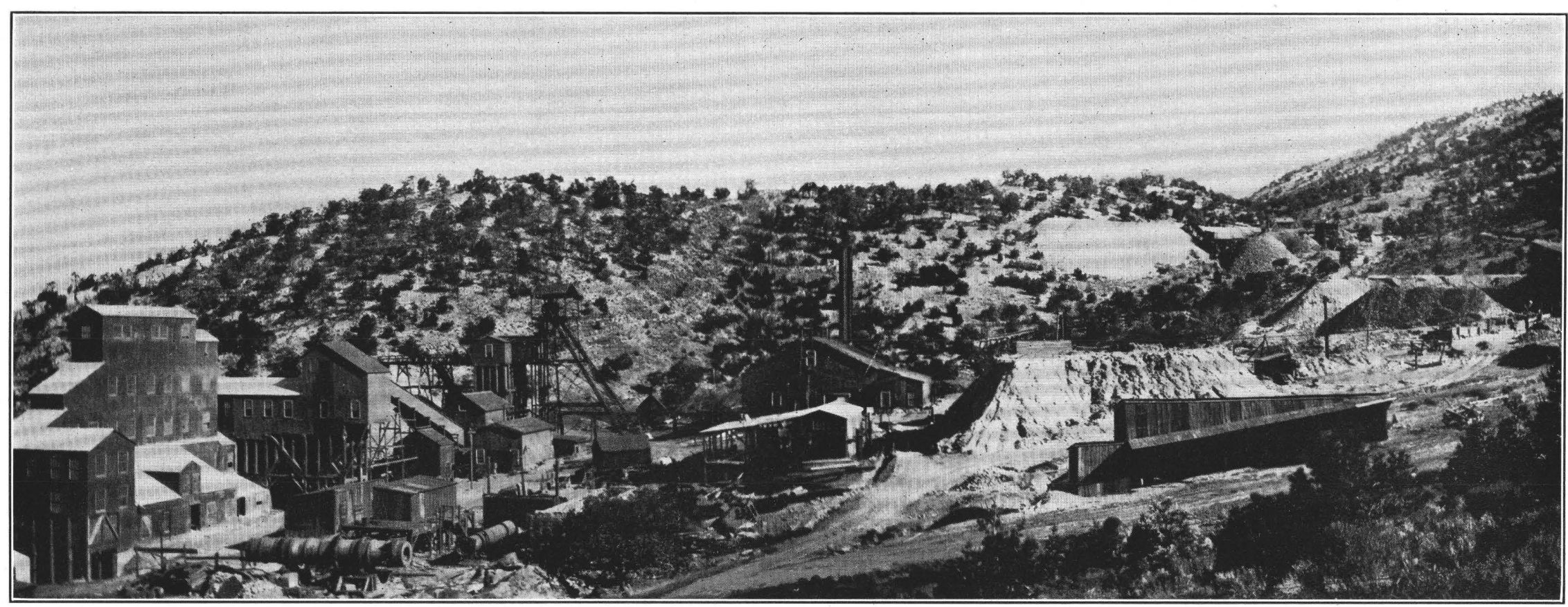

SURFACE PLANT OF KELLY MINE IN 1916, LOOKING NORTH. Traylor shaft in left foreground; ore bin and dump of Kelly tunnel in right foreground. High slope on left is capped with cliff-forming beds of Madera limestone. Lower quartzite member of Sandia formation crops out 
to

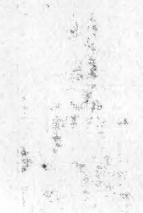

kat 1 
oxidized. In some places, particularly near the outcrop and in parts of the Big Twenty stope, considerable oxidized copper ore was mined near the Kelly-Graphic fault. The fault itself was filled with leached quartz, which had also replaced the adjacent limestone beds to some extent. Similar quartz, with some barite and calcite, was found along some of the minor cross faults. The only metallic minerals remaining are remnants of specularite-magnetite. The ore on the west side of the Brown fault and below level 3 is massive sulphide, largely zinc blende with minor amounts of galena, a little visible chalcopyrite and pyrite, and considerable specularite and magnetite. There is no change in its content of pyrite that corresponds to the change in the Nitt-Waldo workings. Any original pyritic ore was evidently near the quartz veins where the oxidized copper was found. Such a restricted position would strengthen the impression that the principal channels into which the solutions rose were along the shaken ground where the longitudinal and minor cross faults intersect. The stopes in the southwest branch east of the Paschal shaft and at the Kelly-Graphic cross fault show how far ore was deposited in commercial amounts west of the main zone of shaken ground.

Along the northern part of level 6 north of the Paschal shaft the upper Kelly limestone is somewhat impregnated with sulphides along minor fractures, and near the south end of level 6 (pl. 36 and fig. 14) a little ore has been mined near the junction of a vein of southerly trend and a fault of southeasterly trend. The north end of level 7 exposes a small mineralized fissure where the "silver pipe" bed reaches the Kelly-Graphic cross fault. A similar but more encouraging showing was found on level 8 about 400 feet northeast of the Traylor shaft, but water a few feet below the level had retarded its exploration prior to 1916. Farther south on level 8 a small amount of mineralized ground was exposed west and south of the main ore shoot. (See figs. 14 and 16.)

The large ore shoot on the highest levels ends southward against a dike-one of the "faulting dikes"-that follows a minor cross fault or fissure. A little ore has been found south of it along fissures on level 3 (fig. 16), which is there very close to the surface; but no continuous stopes had been found prior to 1916, although the ground was in line with the Juanita ore zone to the south. The "faulting dike" or its steplike continuations have been cut on levels $4,6,7,8$, and 9 (pl. 36), and the "silver pipe" bed has been followed for several hundred feet south of it on levels 7, 8, and 9. A quartz vein was found in the lower Kelly limestone near the south end of level 7, along a minor longitudinal fault; and some sulphides and calcite have been found in an oblique fissure along the "silver pipe" bed west of it. The structural setting of this ground is similar to that in the southern part of the main ore zone, but the ore-forming solutions that reached it were weak. A little oxidized ground with zinc carbonate was found along the fissure at the extreme south end of level 7. A little ore has also been found in the southern parts of levels 8 and 9 , but its character is that of ore deposited by solutions that have traveled rather far from their source.

The crosscut on level 10 was driven to explore the Waldo fault, along which the west ore zone of the Graphic-Waldo mine was formed. The fault had been cut in 1916 (fig. 15), showing purple andesite on its west wall, and the lower quartzite, shale, and limestone beds of the Sandia formation on the east wall. Since then a winze was sunk about 380 feet in the volcanic rock and a crosscut driven about 120 feet eastward, cutting the fault and entering the upper Kelly limestone; but no discovery of ore has been reported.

The development of the mine leaves little unexplored ground worthy of consideration. Work in the Kelly limestone shows no noteworthy ore zones except that near the Kelly-Graphic and Brown faults. The ore mined in 1929-39, so far as known, has come from that zone. The Sandia strata are largely eroded above this zone except in the northernmost part of the mine, where the wedge of ground near the junction of the Brown fault and Kelly-Graphic cross fault is rather favorably situated. It may be that solutions could rise above the Kelly limestone along the Brown fault or its branches and form small ore shoots in the overlying quartzite and limestone beds, as they did in the Graphic-Waldo mine. These beds, so far as known, remain unexplored, and the thick covering of shale above them may readily conceal any superficial evidence of ore deposition.

\section{JUANITA MINE}

The Juanita mine, owned by former Senator T. B. Catron, of Santa Fe, and leased from 1915 to 1928 to the Mines \& Metal Co., of Kelly, is in the Mamie Lode claim (pl. 36) in the southeast part of the Kelly fault block, south of Kelly Gulch. Although the mine has been active in almost every year for which records of output are available, its total output, shown in the accompanying tables, has been small. According to these tables the output has consisted almost entirely of lead ores, both oxidized and sulphide, and oxidized zinc ore, supplemented by a few small shipments of zinc-lead and zinc sulphide ores and dry silver ore. The grade of the oxidized zine ores is similar to that of the Kelly and Graphic-Waldo ores, but the lead and silver contents of the lead ores have been generally lower. The copper and gold credited to the mine in the first table has come from the lead ores. 
Ore produced at Juanita mine, $1905-37,{ }^{1}$ and its gross metal content

[Data collected by C. W. Henderson, Geological Survey and Bureau of Mines, U. S. Department of the Interior, Denver, Colo.]

\begin{tabular}{|c|c|c|c|c|c|c|}
\hline Year & $\begin{array}{l}\text { Short } \\
\text { tons }\end{array}$ & $\begin{array}{l}\text { Gold } \\
\text { (ounces) }\end{array}$ & $\begin{array}{c}\text { Silver } \\
\text { (ounces) }\end{array}$ & $\begin{array}{l}\text { Copper } \\
\text { (pounds) }\end{array}$ & $\begin{array}{c}\text { Lead } \\
\text { (pounds) }\end{array}$ & $\begin{array}{c}\text { Zine } \\
\text { (pounds) }\end{array}$ \\
\hline & $\begin{array}{r}750 \\
1,210\end{array}$ & & $\begin{array}{l}2,800 \\
2,515\end{array}$ & & $\begin{array}{l}321,160 \\
223,194\end{array}$ & $\begin{array}{l}175,000 \\
568,750\end{array}$ \\
\hline & $\begin{array}{l}200 \\
200\end{array}$ & & & & & $\begin{array}{l}152,000 \\
1\end{array}$ \\
\hline & $\begin{array}{l}100 \\
590\end{array}$ & & & 3 & 7 & \\
\hline & 4,468 & 0.24 & & & & \\
\hline & $\begin{array}{l}2,989 \\
1,617\end{array}$ & 2. & 2,341 & 3,197 & 333, & $\begin{array}{l}1,646,809 \\
1,135,682\end{array}$ \\
\hline & 1,313 & 7. 47 & 514 & 1,877 & 9 & 757,131 \\
\hline & 1,486 & & & & & \\
\hline & 1,047 & & 2,816 & & & \\
\hline & 1,073 & 3. 50 & & & & 38 \\
\hline & & & & & & \\
\hline & $\begin{array}{l}189 \\
623\end{array}$ & 1.40 & & & & $\begin{array}{l}43,444 \\
73,442\end{array}$ \\
\hline & & & & 3, & & $5,+46$ \\
\hline & 1,308 & .80 & 3,093 & 8,7 & & \\
\hline & 1,287 & .40 & 917 & 1,908 & & $\begin{array}{l}457,080 \\
43\end{array}$ \\
\hline & $\begin{array}{r}128 \\
25\end{array}$ & .70 & 172 & & 26,381 & $\begin{array}{l}\begin{array}{l}43,908 \\
15,000\end{array} \\
\end{array}$ \\
\hline & 537 & 3.09 & 1, & & & \\
\hline & & & & & & \\
\hline & 17 & .90 & 379 & 7 & & \\
\hline & 22,758 & 24.91 & 23,352 & 56,042 & 744,230 & $10,224,765$ \\
\hline
\end{tabular}

No returns on file for 1909 and 1910. Mine idle 1921-22, 1931-36.

2 May include 161 tons of oxidized zinc containing 91,448 pounds of zinc from Ambrosia mine in 1913; includes 121 tons of oxidized zinc ore from Ambrosia mine in 1914 and smali outputs of oxidized zine ore in 1915,1916 , and 1918 from same mine.

Classes and average gross metal content of ore shipped from Juanita mine, 1905-37

[Data collected and classified by C. W. Henderson, Geological Survey and Bureau of Mines, U. S. Department of the Interior, Denver, Colo.]

\begin{tabular}{|c|c|c|c|c|c|c|c|c|c|c|c|}
\hline \multirow[b]{3}{*}{ Year } & \multicolumn{6}{|c|}{ Sulphide ore } & \multicolumn{5}{|c|}{ Oxidized ore } \\
\hline & \multicolumn{3}{|c|}{ Lead ore ${ }^{2}$} & \multicolumn{3}{|c|}{ Zinc-lead ore } & \multicolumn{3}{|c|}{ Lead ore ${ }^{3}$} & \multicolumn{2}{|c|}{ Zine ore } \\
\hline & 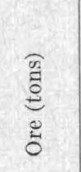 & 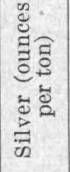 & 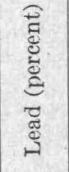 & 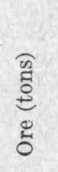 & 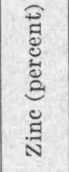 & 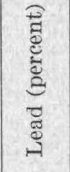 & 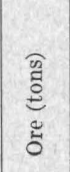 & 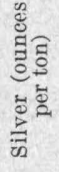 & 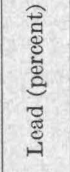 & 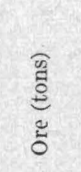 & 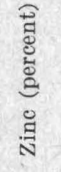 \\
\hline & & & & & & & $\begin{array}{l}500 \\
440\end{array}$ & $\begin{array}{l}5.6 \\
4.0\end{array}$ & $\begin{array}{l}32.1 \\
25.4\end{array}$ & $\begin{array}{l}250 \\
750 \\
700\end{array}$ & $\begin{array}{l}35.0 \\
37.9\end{array}$ \\
\hline 190 & & & & & & & & & & $\begin{array}{l}200 \\
100\end{array}$ & 38.0 \\
\hline & & & & & & & 23 & 3.6 & 18. 8 & & \\
\hline & & & $\ldots$ & & & & $\begin{array}{l}118 \\
576\end{array}$ & $\begin{array}{l}6 \\
0\end{array}$ & & & \\
\hline & & & & & & & & & & & \\
\hline & & & & 36 & 20.0 & 16.0 & 166 & $\begin{array}{l}3.1 \\
2.4\end{array}$ & $\begin{array}{l}32.2 \\
19.7\end{array}$ & & \\
\hline & & & & & & (10.0 & & 8 & & 301 & $\begin{array}{l}31.6 \\
31.0\end{array}$ \\
\hline & & & & 82 & 18.0 & 11.0 & 339 & 2. 3 & & 652 & 27.4 \\
\hline & & & & & & & & 0 & & $\begin{array}{l}475 \\
72\end{array}$ & 27.4 \\
\hline & 512 & 2.9 & & & & & & & & 111 & $\begin{array}{l}30.2 \\
33.1\end{array}$ \\
\hline & & & & & & & & & & & \\
\hline & $\begin{array}{l}1,039 \\
400\end{array}$ & $\begin{array}{l}3.0 \\
-1\end{array}$ & 19 & 879 & 200 & 0 & ${ }^{6} 269$ & 55 & 51.1 & & \\
\hline & 73 & 2.4 & 18.1 & & 20.0 & & & & & 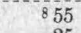 & 40.0 \\
\hline & & & & & & & & & -- & & \\
\hline & 397 & 1.3 & 12.5 & & & & & & & & \\
\hline & & & & & & & 175 & 2.2 & 19.3 & & \\
\hline & 3,658 & & & 997 & & & 3,920 & & & 14,186 & \\
\hline
\end{tabular}

${ }_{1}$ No returns on file for 1909 and 1910. Mine idle 1921-22, 1931-36. ${ }_{2}^{2}$ Lead sulphide ore contained from 0.001 to 0.01 ounce of gold to the ton and from 0.2 to 0.5 percent of copper.

3 Oxidized lead ore contained from 0.001 to 0.045 ounce of gold to the ton and from 0.02 to 0.8 percent of copper.

${ }^{4} 20$ tons of siliceous silver ore containing 37.7 ounces of silver to the ton also shipped n 1906.

${ }^{5}$ Mixture of crude ore and concentrates.

72 tons of dry silver ore credited with 14 ounces of recovered silver to the ton was also shipped in 1926 .

8 All zine sulphide ore in 1927 .

According to the company's tax report the net earnings during the 6 years $1915-20$ averaged about $\$ 7,400$ annually and in 1919 and 1920 they averaged only $\$ 666.83$

\footnotetext{
${ }^{83}$ Finlay, J. R., Report on appraisal of mines in New Mexico: New Mexico State Tax Commission, 1921-22, p. 53, 1922.
}

The Juanita mine workings are in the southerly continuation of the Kelly ore zone, and are entirely in the Kelly limestone except for the adit tunnel, or level 4 , which extends east-northeast for 365 feet in the Sandia formation before cutting the top of the Kelly limestone. Levels 4, 5, and 6, and some tunnels at higher levels (pl. 36) were accessible in 1915 and 1916. The limestone is cut by a zone of lamprophyre dikes that trend about parallel to the strike of the limestone and dip from $45^{\circ}$ to $80^{\circ} \mathrm{E}$. The limestone is cut off on the east by the Kelly-Graphic fault zone, which here includes three members that dip vertically to steeply east and step the limestone downward to the west. A parallel fault zone is exposed 130 to 160 feet west of the Kelly-Graphic zone and is essentially a steplike continuation of the Brown fault in the Kelly mine. These two zones are connected by at least three minor cross faults or fissures. Two of these, north of the adit tunnel, are followed by inclined winzes. They strike west-southwest, the more northerly one with downthrow on the north, and the other with downthrow on the soutn. The third fault is 370 feet south of the tunnel, and its downthrow is on the south. A bedding fault along the "silver pipe" bed is exposed on level 4 about 300 feet south of the adit tunnel. A lamprophyre dike is eut off by it on the roof of the drift, but the amount of displacement along it is not shown.

The early workings, which evidently include the upper three levels, were opened by tunnels along the Kelly-Graphic fault zone. Only small parts of them were accessible to us. The northernmost, in the Juanita North Lode claim, extends from Kelly Gulch along a spur of the main fault for about 50 feet, and a winze from it explores the same fault 35 feet lower. It opened ore that extended down to the fourth or main tunnel level. A second tunnel, not shown on plate 36, but 500 feet to the south, enters the fault zone near the northern cross fault. It was not accessible in 1916. The third and fourth tunnels, whose portals are in the small gulch 1,000 feet south of Kelly Gulch, explore a fault 100 feet or more west of the main fault. The northern of these two tunnels lies along and beneath old oxidized lead stopes near the junction of the middle cross fault with the Kelly-Graphic zone. The faults exposed in these upper tunnels contain quartz and barite, from which sulphides have been partly leached, although in places they contained enough galena to be mined in small leasing operations in 1916 . The uppermost beds, especially of the Kelly limestone, have been silicified along these faults, as is well shown in the Juanita North Lode claim. The oxidized lead ore lies beneath this silicified cap but does not extend far from the north-trending faults, except at their intersections with the two northern cross faults, where it extends the full width of the Kelly-Graphic zone 
and continues westward down the dip of the limestone along the cross faults. Narrow bands of cellular zine carbonate form the walls of the more upright stopes and the floors or down-dip extensions of the stopes along the bedding.

The main adit tunnel, or level 4 , reaches the bottoms of the old stopes in the upper Kelly limestone just south of the middle cross fault, and the floor of the stoped ground consists of a quartz-barite aggregate that rests on the "silver pipe" bed. The stopes extend for at least 170 feet south of the cross fault and have been reached by raises from level 4. East crosscuts in the lower Kelly beds have not disclosed any ore. About 350 feet south of the tunnel a small upright shoot has been stoped along a fissure that strikes north and dips $57^{\circ} \mathrm{E}$. This fissure crosses the bedding fault along the "silver pipe." An east crosscut a little farther south extends 90 feet, crossing a fault along a lamprophyre dike 50 feet east of the drift and continuing through iron-stained silicified limestone to a second member of the Kelly-Graphic fault zone, but no ore had been found in 1916.

The southern cross fault is a little south of this crosscut. Level 4 turns eastward for 80 feet, crossing this fault at a low angle and continuing southward for 270 feet. Near its south end a west crosscut has been driven completely through the Kelly limestone, which is there overlain by pebbly quartzite and shale. Nothing of promise was found in these workings. The southern cross fault evidently marks the south end of at least the western members of the KellyGraphic fault zone and has prevented ore-forming solutions from permeating the ground south of it.

North of the adit tunnel level 4 reaches the top of the Kelly limestone at the middle cross fault and curves eastward, crosscutting to the "marbleized lime" bed above which the old stopes are reached by raises. It extends northward for 220 feet, crossing the bottom of a stope that extends downward along the northern cross fault, and continues 170 feet farther to a raise that connects with the workings in the Juanita North Lode claim south of the tunnel mentioned on page 138.

Ore has been mined along inclines in the lower Kelly limestone that follow the northern and middle cross faults down to level 5. A little above level 5 pyritic quartz is present along the northern cross fault, and a raise along it disclosed some high-grade sulphide ore just below the "silver pipe" bed and along the intersection with a minor fault of northwest trend and northeast dip. The middle cross fault similarly contains quartz and galena just below the "silver pipe" and has been stoped to a slight extent above the "silver pipe." The incline along it crosses two closely parallel faults of north-northwest trend along which shale has been stepped down against the upper Kelly limestone. This fault zone, which is in steplike rela- tion to the fault cut at the south end of level 6 in the Kelly mine, is followed northward on level 5, and a few horizontal tubelike shoots have been mined along it. The shoots are floored by silicified limestone that rests on the "silver pipe" bed. The "silver pipe" bed is offset by two minor faults of north-northwest to northwest trend that join or cross the fault along the drift. The drift continues nearly to the north boundary line, where it turns eastward and completely crosscuts the lower Kelly limestone.

The confinement of relatively large ore shoots to that part of the Kelly-Graphic fault zone that is near the cross faults and the relative prominence of quartz and barite gangue indicate that the ore-forming solutions were farther from their source and had somewhat less penetrating power than in the Kelly and GraphicWaldo mines. Solutions that escaped from the KellyGraphic zone along the two northern cross faults and the adjacent parts of the west fault zone had practically no penetrating power and therefore formed veinlike shoots. The southern part of level 7 in the Kelly mine lies parallel to level 5 of the Juanita mine and 250 feet west of it; inclined raises from it extend eastward nearly to the property line without disclosing encouraging signs of ore. Downward exploration near the middle cross fault west of level 5 also failed to disclose any ore. The small shoots along level 5, therefore, appear to mark the west limit of ore deposition.

\section{SOUTH JUANITA (JUANITA EXTENSION) MINE}

The South Juanita mine, entirely within the Juanita Extension claim, is about a quarter of a mile south of the Juanita mine. Its small, intermittent output from 1907 to 1939 , recorded in the accompanying table, has consisted entirely of oxidized zinc and oxidized lead ore, both of which have been of lower grade than those of the three larger mines to the north.

Ore shipped from South Juanita mine, 190\%-39, ${ }^{1}$ and gross metal content

[Data collected by C. W. Henderson, Geological Survey and Bureau of Mines, U. S. Department of the Interior, Denver, Colo.]

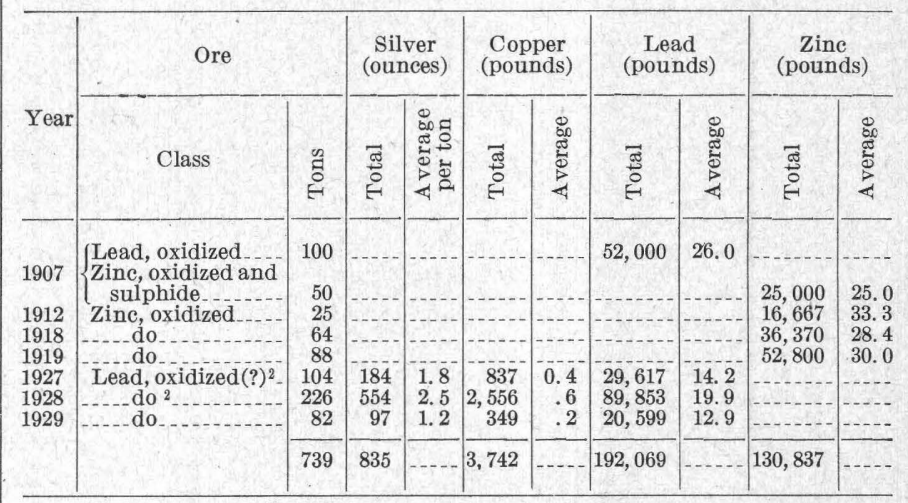

1 Mine idle 1908-11, 1913-17, and 1930-39; no shipments recorded 1920-26. Two carloads of lead ore were reported shipped in 1925, but metal content was not stated was reported in other years. 


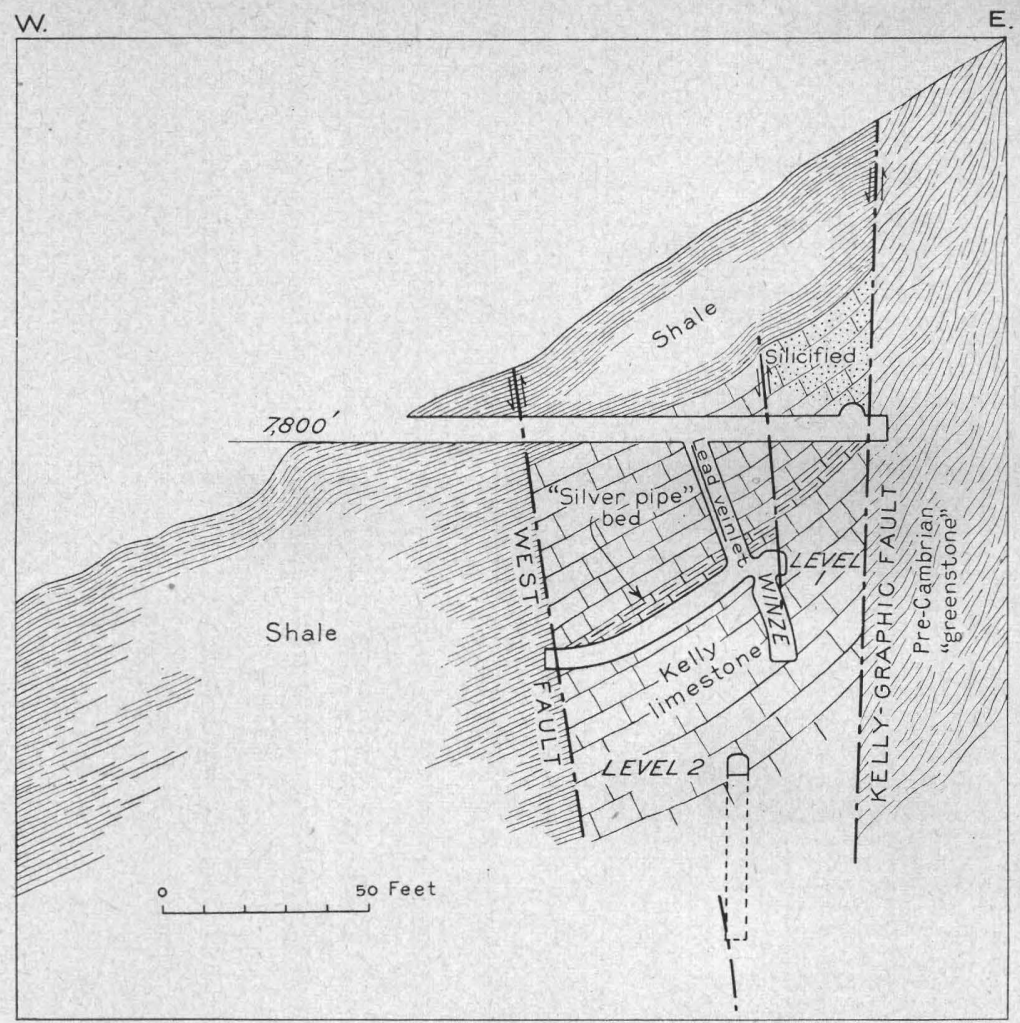

Figure 17.-Cross section ( $A-B$ on plate 37) of South Juanita (Juanita Extension) mine. After W. H. Paul. with minor additions.

The mine (pl. 37 and fig. 17) is opened by a 200 -foot vertical shaft along the Kelly-Graphic fault and by a 120 -foot adit tunnel that trends east-southeast and reaches the Kelly-Graphic fault 35 feet north of the shaft at a depth of 70 feet. Three levels have been driven - the adit level, the first level 35 feet lower, and the second level 50 feet below the first level. A third level and a long, lower adit tunnel whose portal would be 380 feet west-southwest of the present adit have been planned, according to mine maps, but so far as known no work has been done on them. The mine's geologic conditions are similar to those in the eastern part of the Juanita mine. The Kelly-Graphic fault with nearly vertical dip forms the east limit of the workings. It undulates in strike and in the southern part of the mine it curves from S. $15^{\circ}$ E. to S. $45^{\circ}$ E. as it approaches the Germany fault. The Kelly limestone with westerly dip pitches slightly northward along the workings except to the north of the adit level, where it becomes nearly horizontal. It is bounded by pre-Cambrian "greenstone" (gabbro or argillite) along this fault and is cut by two minor longitudinal faults conveniently called the middle and west faults. The middle fault, 15 feet west of the Kelly-Graphic fault, drops the limestone a few feet on the west; and the west fault, 45 feet farther west, drops it 60 feet or more also on the west. The only cross fissure noted is along the adit tunnel where the north pitch of the limestone is a little steeper than elsewhere. A few closely spaced lampro- phyre dikes parallel to the minor faults are exposed in the southern part of the mine; and one dike of latite porphyry, $21 / 2$ feet thick and similar to the latite porphyry in the large faulted sill south of Chihuahua Gulch, is exposed at the south end of level 2. This dike dips steeply east and is beveled off by a more steeply east-dipping fault that strikes N. $35^{\circ} \mathrm{W}$. and evidently corresponds to the middle fault.

The ore bodies include a small stope on the adit level, one along level 1 , and a few small pockets on level 2. The adit-level stope is along the bedding of the upper Kelly limestone and is capped by replacement quartz that underlies the upper "silver pipe" bed. The stope and the quartz cap are bounded on the west by the middle fault. The principal stope of the mine pitches northward at a small angle and crosses level 1 near the shaft. It extends 100 feet north and 270 feet or more south of the shaft. It underlies the main "silver pipe" bed, and for most of its length south of the shaft it is bounded on the west by a lamprophyre dike. It narrows toward its south end, where the strike of the country rock is northwest. There the Kelly-Graphic fault is tight but the "greenstone" and limestone along it are bleached and impregnated with pyrite and quartz. The ore mined has been largely lead carbonate, with minor quantities of zinc carbonate along the down-dip side of the lead shoots and along fractures below and also west of the lead shoots. On level 2 a few small bunches of ore have been stoped in 
lower Kelly limestone about 50 feet northwest of the shaft, and at the north end of the level ore containing pyrite, zinc blende, galena, and chalcopyrite in a quartz gangue has been followed by a winze for about 40 feet on the east side of the west fault. At the bottom of the winze "greenstone" appears on the east side of the fault, but the ore continues downward.

\section{BLACK CLOUD AND MISTLETOE MINES}

The consolidated property of the Black Cloud Mining \& Milling Corporation includes part of the main ore zone and extends eastward beyond the South Stonewall fault. It includes the Helen Cross group, from which small shipments of ore were reported in 1906-7 and 1917-18. The original Black Cloud and Mistletoe mines are near the South Stonewall fault between the heads of Chihuahua and Mistletoe Gulches. The Mistletoe or Gordon tunnel is down the slope to the west at an altitude of about 7,950 feet. The Mistletoe mine and the newly driven tunnel were both owned by the Mistletoe \& Magdalena Tunnel Co. in 1908. The Black Cloud mine ras opened about 1915. In 1926 it was acquired by the newly organized Black Cloud Mining \& Milling Corporation under a longterm lease with option to purchase for $\$ 24,500$. The same company acquired a lease on the Mistletoe mine and tunnel in 1927 or 1928 with an option to purchase them for $\$ 125,000 .^{84}$ The property then comprised about 400 acres. The Mistletoe mine was connected by an aerial tramway with the mill at the mouth of the tunnel. This mill, erected by the old company in 1908 (p. 79) was overhauled by the new company and operated during 1928 and 1929. According to the Mines Handbook, ${ }^{85}$ the value of the total output of the property by former operators was about $\$ 100,000$ and by the new operators $\$ 37,500$, whereas $\$ 150,000$ had been spent on development work. Reorganization to provide funds for additional development work and equipment was then being contemplated.

The oxidized ore shipped, according to the Mines Handbook, averaged between 7 and 10 percent of lead, and the average value of the silver and gold content of the ore was less than $\$ 2.00$ to the ton. Some ore of shipping grade contained as much as 25 percent of

\footnotetext{
${ }^{84}$ Mines Handbook, vol. 18, pt. 1, p. 1661, 1931.
}

Idem, p. 1661 . lead. The sulphide ore, presumably from the winze along the Mistletoe fault in the tunnel, was reported to average between 12 and 15 percent of lead and 20 percent of zinc and to contain minor amounts of copper, silver, and gold.

The recorded outputs of ore from the Helen Cross group, the Mistletoe tunnel, and the Black Cloud workings are shown in the accompanying tables. The copper and some of the lead ores from the tunnel were higher in silver than most of the ores shipped from the district since 1904. The lead sulphide ores from the Black Cloud workings were mostly of rather low grade and characteristic of the siliceous replacement ores east of the main ore zone, but the oxidized zinc ores formed through the replacement of unsilicified limestone beneath the lead deposits were of as high grade as those of the more productive mines in the main zone.

Ore shipped from Helen Cross group, $1906-18^{1}$ and its gross
metal content
[Data collected by C. W. Henderson, Geological Survey and Bureau of
Mines, U. S. Department of the Interior, Denver, Colo.]

1 No ore shipped during years for which no record is shown.

Ore shipped from Mistletoe tunnel, 1910-26, ${ }^{1}$ and its gross metal content

[Data collected and classified by C. W. Henderson, Geological Survey and Bureau of Mines, U. S. Department of the Interior, Denver, Colo.]

\begin{tabular}{|c|c|c|c|c|c|c|c|}
\hline \multirow{2}{*}{ Year } & \multicolumn{2}{|l|}{ Ore } & \multirow{2}{*}{$\begin{array}{c}\text { Gold } \\
\text { (ounces) }\end{array}$} & \multirow{2}{*}{$\begin{array}{c}\text { Silver } \\
\text { (ounces) }\end{array}$} & \multirow{2}{*}{$\begin{array}{l}\text { Copper } \\
\text { (pounds) }\end{array}$} & \multirow{2}{*}{$\begin{array}{c}\text { Lead } \\
\text { (pounds) }\end{array}$} & \multirow{2}{*}{$\begin{array}{c}\text { Zinc } \\
\text { (pounds) }\end{array}$} \\
\hline & Class & Tons & & & & & \\
\hline 1910 & $\begin{array}{l}\text { Zinc and lead, oxi- } \\
\text { dized }\end{array}$ & \multirow{5}{*}{$\begin{array}{r}2500 \\
330 \\
141 \\
20 \\
28\end{array}$} & \multirow[t]{2}{*}{ 3. 70} & \multirow[t]{2}{*}{955} & \multirow[t]{2}{*}{401} & \multirow[t]{2}{*}{84,091} & \multirow{2}{*}{11,871} \\
\hline \multirow{4}{*}{$\begin{array}{l}1911 \\
1916 \\
1917 \\
1918 \\
1924\end{array}$} & & & & & & & \\
\hline & $\begin{array}{l}\text { Lead } \\
\text { Copper }\end{array}$ & & 24.00 & $\begin{array}{r}1,249 \\
162\end{array}$ & 2,150 & 152,718 & \\
\hline & opper & & -... & 204 & $\begin{array}{l}2,201 \\
2,891\end{array}$ & & \\
\hline & Lead (ore and con- & & 7.83 & 1. 288 & 1. 990 & 57. & \\
\hline \multirow{3}{*}{$\begin{array}{l}1925 \\
1926\end{array}$} & Lead do & 316 & 2. 70 & 647 & 2,060 & 69,603 & \\
\hline & & 204 & 10.20 & 018 & 1,029 & 31,019 & \\
\hline & & 1,429 & 48.43 & 5,022 & 13,302 & 415,162 & 11,871 \\
\hline
\end{tabular}

1 No ore shipped during years for which no record is shown.

2500 tons of crude ore yielded 91 tons of lead concentrates and 16 tons of zinc con-

Ore treated in mill, but no shipment made. 
Ore mined at Black Cloud mine, 1915-38,1 and its gross metal content

[Data collected and classified by C. W. Henderson, Geological Survey and Bureau of Mines, U. S. Department of the Interior, Denver, Colo.]

\begin{tabular}{|c|c|c|c|c|c|c|c|c|c|c|c|c|}
\hline \multirow{2}{*}{ Year } & \multicolumn{2}{|c|}{ Ore } & \multicolumn{2}{|c|}{ Gold (ounces) } & \multicolumn{2}{|c|}{ Silver (ounces) } & \multicolumn{2}{|c|}{ Copper } & \multicolumn{2}{|c|}{ Lead } & \multicolumn{2}{|c|}{ Zinc } \\
\hline & Class & Tons & Total & Per ton & Total & Per ton & Pounds & Percent & Pounds & Percent & Pounds & Percent \\
\hline $\begin{array}{l}1915 \\
1916\end{array}$ & Zinc, oxidized 2 & $\begin{array}{r}2434 \\
191\end{array}$ & & & & & & & & & $\begin{array}{l}282,689 \\
128,784\end{array}$ & $\begin{array}{l}32.6 \\
33.7\end{array}$ \\
\hline 1917 & $\left\{\begin{array}{l}\text { Lead, oxidized }(?) \\
\text { Zinc, oxidized }\end{array}\right.$ & $\begin{array}{r}34,500 \\
15\end{array}$ & 27.23 & 0.006 & 1,713 & 0.4 & 6,494 & 0.06 & 176,944 & 1.7 & 10,320 & 34.4 \\
\hline 1923 & $\left\{\begin{array}{l}\text { Copper sulphide } \\
\text { Lead sulphide }\end{array}\right.$ & $\begin{array}{l}13 \\
91\end{array}$ & 3.00 & & $\begin{array}{l}152 \\
338\end{array}$ & $\begin{array}{r}11.7 \\
3.7\end{array}$ & $\begin{array}{l}1,090 \\
1,908\end{array}$ & $\begin{array}{r}44.0 \\
4.8\end{array}$ & $\begin{array}{r}671 \\
31,666\end{array}$ & $\begin{array}{r}41.3 \\
415.3\end{array}$ & & (n) \\
\hline 1925 & do do & & 1. 40 & .03 & 183 & 3.8 & 706 & 4.5 & 18,841 & ${ }_{4} 16.8$ & & \\
\hline 1927 & $\left\{\begin{array}{l}\text { Lead sulphide (?) } \\
\text { Lead sulphide }\end{array}\right.$ & $\begin{array}{r}51,000 \\
26\end{array}$ & $\begin{array}{r}29.00 \\
.49\end{array}$ & $\begin{array}{l}.03 \\
.02\end{array}$ & $\begin{array}{r}2,503 \\
118\end{array}$ & $\begin{array}{l}2.5 \\
4.5\end{array}$ & $\begin{array}{r}3,904 \\
249\end{array}$ & 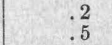 & $\begin{array}{r}248,966 \\
7,399\end{array}$ & $\begin{array}{l}12.4 \\
14.3\end{array}$ & & .... \\
\hline 1928 & $\left\{\begin{array}{c}\text { do } \\
\hdashline \ldots\end{array}\right.$ & $\begin{array}{r}62,000 \\
7\end{array}$ & 81.98 & .04 & $\begin{array}{r}4,505 \\
56\end{array}$ & $\begin{array}{l}2.3 \\
8.0\end{array}$ & $\begin{array}{r}6,850 \\
110\end{array}$ & $\begin{array}{l}.2 \\
.7\end{array}$ & $\begin{array}{r}572,802 \\
6,591\end{array}$ & $\begin{array}{l}14.3 \\
47.1\end{array}$ & $\begin{array}{r}34,746 \\
280\end{array}$ & 2.0 \\
\hline $\begin{array}{l}1933 \\
1937\end{array}$ & Lead sulphide & $\begin{array}{l}10 \\
15\end{array}$ & $\begin{array}{l}.20 \\
50\end{array}$ & .02 & $\begin{array}{l}72 \\
66\end{array}$ & 7.2 & $\begin{array}{l}243 \\
261\end{array}$ & 1.2 & $\begin{array}{l}6,447 \\
7,910\end{array}$ & 32.2 & & \\
\hline \multirow[t]{2}{*}{1938} & $\left\{\begin{array}{l}\text { Dry gold } \\
\text { Lead }\end{array}\right.$ & $\begin{array}{r}103 \\
9\end{array}$ & $\begin{array}{r}60.50 \\
.20\end{array}$ & 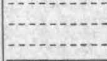 & $\begin{array}{r}111 \\
37 \\
\end{array}$ & & $\begin{array}{r}112 \\
64\end{array}$ & & $\begin{array}{r}413 \\
3,902\end{array}$ & & 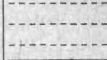 & \\
\hline & & 8,463 & 204.50 & 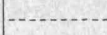 & 9,854 & & 21,991 & & $1,082,552$ & & 456,819 & \\
\hline
\end{tabular}

The workings near the South Stonewall fault are opened by several short tunnels. The two northernmost, not shown on the geologic map, are in Kelly limestone about 1,000 feet north of the aerial tramway and between the Stonewall fault and the minor fault 200 feet to the east. The upper Kelly limestone in their vicinity is almost completely silicified, and its outcrop between the two tunnels is marked by a small stope mainly just above the "silver pipe" bed. The upper tunnel extends southward along the east fault, which dips $76^{\circ}$ W. About 70 feet from its portal there is an old, filled winze that is said to extend 75 feet down the dip and to have exposed some good ore. The lower tunnel trends S. $20^{\circ}$ E. along an east-dipping fissure at its intersection with the "silver pipe" bed. A short raise 45 feet from its portal connects with a small stope just above the "silver pipe" bed. The ore shoot stoped is about a foot thick, parallels the bedding, and consists of streaks of galena in a gangue of replacement quartz. The stope extends to the upper tunnel at a point midway between the portal and the old winze. A little azurite or blue copper carbonate was found at a few places just above and below the stope. The lower tunnel continues 50 feet beyond its connection with the stope and exposes streaks of galena just above the "silver pipe" bed. It also exposes zine carbonate which has replaced the "silver pipe" bed for as much as a foot below its top. The zinc carbonate is underlain by soft, leached, ironstained limestone.

The principal Black Cloud workings are east of the east fault and about 800 feet south of the two tunnels just described. They include two levels opened by upper and lower tunnels and connected with an abandoned shaft, which is marked on plate 2 by the upper of two buildings. The principal work in 1916 was on level 2 under the direction of Paul B. Moore, of Magdalena. The north drift on that level lies in or just below the quartz that here also has almost completely replaced the upper Kelly limestone. The quartz had been mined in places for lead, and small bodies of zinc carbonate that had replaced remnants of limestone between the quartz and the "silver pipe" bed were being stoped in 1916. The ore was accompanied by streaks of soft black earthly material, and some rusty material, that lay just above the stope and along the sides of it and contained little or no zinc.

About 300 feet north of the shaft, and beyond the second crosscut, the north drift continues for a short distance along a fault that trends N. $25^{\circ}$ W., dips $80^{\circ}$ W., and has a downthrow of 6 to 8 feet on the west. It is apparently a branch of the east fault. A raise near the fault connects with a relatively large lead stope. This stope is also closely related to a fissure that in part nearly coincides with the bedding but steepens southward to a dip of $50^{\circ}$. The lead ore consists of partly oxidized galena in a gangue of replacement quartz. The galena is in part coarsegrained and is accompanied here and there by bunches of chalcopyrite. Such bunches are evidently the source of the small copper stains that are found throughout the siliceous ores in the southeast part of the district. The average content of the crude lead ore mined in 1916 was said by Mr. Moore to be 15 percent of lead and 2.25 ounces of silver and 0.05 ounce of gold to the ton. The concentrates, which in that year were produced in a mill at Magdalena, averaged 58 percent of lead and 9 ounces of silver and 1.8 ounces of gold to the ton. The tailings contained about 0.9 percent of lead and less than 1 percent of copper.

Zinc carbonate has been mined along the lower parts of the stope, and at several places beneath the stope small masses of brown "tallow clay" have replaced limestone immediately below the quartz mass. One of 
them also extends downward for about 10 feet into black earthy material along a steeply east-dipping fracture just east of the fault. The clay, which has fine horizontal banding even in the fissure, has slightly replaced the fissure walls. Although similar clays at Leadville, Colo., ${ }^{86}$ contain considerable zinc, a test on the clay from the Black Cloud mine showed little or no zinc. The clay, however, was regarded as a guide to zinc carbonate ore; in fact, veinlets and cavity linings of high-grade green botryoidal smithsonite and white hydrozincite cut the clay, and similar material coats the larger masses of zinc carbonate ore.

Another fairly large stope containing similar ore lies just above the tunnel level and extends southward from the shaft. An associated stope of zinc carbonate ore, below tunnel level, replaces part of the "silver pipe" and the limestone just above it. This stope in 1916 extended nearly 100 feet in a southerly direction and had a maximum width of 40 feet. Its height was very irregular and its cross section roughly $\mathbf{U}$-shaped, as if it had replaced the upper limestone for short disstances along parallel steeply dipping fissures leaving an intervening hanging mass of limestone, but completely replacing the underlying "silver pipe" and adjacent beds.

The lower tunnel near its north end penetrated about 25 feet of pyritic quartz that contained specks of native silver, but the relations of this material to the lead ore and to faults and fissures were not clearly defined.

The old Mistletoe mine was opened by two tunnels about 500 feet south of the main Black Cloud workings and a little east of the south end of the Stonewall fault. The principal work was done about 1911. The upper or main tunnel extends eastward about 50 feet to a narrow stope whose ore had replaced a limestone bed along a steeply east-dipping fissure. The stope extended for 90 feet north and 50 feet south of the tunnel. Low-grade ore left along the edges of the stope consists of galena in a gangue of leached quartz. The ore mined is said to have been of similar low grade and to have been milled. No associated zinc ore has been found.

The lower of the two tunnels cut a thin shoot of siliceous galena ore about 40 feet from the portal. The shoot, which did not exceed a foot in thickness, underlay a shale parting about 6 feet below the upper "silver pipe" bed. A little ore had been stoped from it.

The Mistletoe or Gordon tunnel, whose portal is on the north slope of Mistletoe Gulch at an approximate altitude of 7,950 feet, is 1,050 feet long. It extends in a general easterly direction but is slightly convex to the north. It was flooded in 1915 and 1916 but was mapped by Koschmann and Lasky in December 1929. It follows the general course of a much faulted lampro-

${ }^{86}$ Loughlin, G. F., The oxidized zinc ores of the Leadville district, Colorado: U. S. Geol. Survey Bull. 681, pp. 24-28, 1922. Emmons, S. F. Irving, J. D., and Loughlin, G. F., op. cit. (Prof. Paper 148), pp. $160-162$. phyre dike or sill for about 100 feet and continues in Madera limestone as far as the Mistletoe fault, east of which it cuts black shale and limestone as far as a second fault 190 feet east of the Mistletoe fault; and there it enters into the argillite for a few feet. The Mistletoe fault is represented by a crushed zone 10 feet thick, about 820 feet due east of the portal, and almost vertically below its position on the surface. Its dip in the tunnel, however, is $75^{\circ} \mathrm{W}$. The principal minor faults cut by the tunnel farther west conform in position to those mapped at the surface, and the same is true of the fault 190 feet east of the Mistletoe fault. Several other minor faults of vertical to steep westerly dip are cut. The shale and limestone east of the Mistletoe fault, however, have not been satisfactorily explained. According to the geologic map (pl. 2), displacement along the fault east of the Mistletoe is not very great, but the rocks in the tunnel, which are evidently parts of the shale and lower limestone members of the Sandia formation, imply a drop of at least 250 feet, sufficient to place the lower quartzite member and the Kelly limestone below the tunnel level. A recheck of the surface mapping by Koschmann and Lasky failed to account for the discrepancy, and it can only be inferred either that the principal displacement shifts from the Mistletoe to the eastern fault between the surface and the tunnel level or that the structure between the two faults is complicated by concealed minor faults and perhaps contorted bedding.

A little coarse-grained siliceous lead-zinc sulphide ore was noted on the tunnel dump in 1916. This ore evidently came from a winze along the Mistletoe fault, in which ore was reported at a depth of 50 feet below the tunnel level. The winze was full of water in 1929. This ore suggests that the Kelly limestone on the west side of the fault may be worthy of exploration. Drilling would doubtless be necessary to determine the position of the limestone. The comparative costs of pumping and driving of a lower drainage tunnel should also be considered.

\section{YOUNG AMERICA, IMPERIAL, AND ENTERPRISE CLAIMS}

The Young America mine is situated on the upper slope of the Magdalena Range, just east of the Water Canyon Trail and 11/5 miles southeast of Kelly. Its first owner since 1907, when annual reports of it began to be submitted to the United States Geological Survey, was H. W. Russell \& Co., who reported a shipment in 1909 of 22 tons of crude ore, from which 220 ounces of silver and 22,520 pounds of lead were recovered. The ownership passed to C. T. Brown in 1911 and to the Empire Zinc Co. in 1915. It was leased to Sim Exter in 1916, but his shipments were evidently included with those of the Empire Zine Co. for that year.

The workings are mainly in the Young America and Imperial claims and the unpatented Enterprise claim, which overlaps the eastern parts of the other two (see 
fig. 18). The workings include several short tunnels of easterly trend from which drifts extend northward and southward. Only two-here called the Young America and Enterprise tunnels-were accessible in 1916. The Young America tunnel is close to the north boundary of the Young America claim. Drifts from it follow the Young America fault, which separates the shale member of the Sandia formation on the west from silicified upper Kelly limestone on the east. The silicified part of the limestone is about 40 feet thick and should therefore include practically the entire upper member.

To the northeast, in the Imperial claim, the north drift from the tunnel whose altitude is 8,570 feet is said to have followed a streak of lead and copper carbonates. The south drift from this tunnel opened two small bodies of high-grade zinc carbonate that had evidently replaced unsilicified remnants of limestone. The Ellen tunnel, south of the Young America, was said to trend about N. $73^{\circ} \mathrm{E}$. and to connect with an old shaft that had been sunk along the fault and had disclosed a little high-grade copper ore.

The Enterprise tunnel extends east-northeast to the most westerly of two closely parallel minor faults of north-northwest trend. At the breast of the tunnel a raise along the bedding has followed a thin streak of lead carbonate across the two faults and for a short distance beyond without disclosing an ore shoot. A thin streak of zinc carbonate lies about 5 feet below the lead carbonate streak. The south drift from the tunnel follows the lead carbonate streak along the west side of the west fault, which is vertical at the tunnel but dips $70^{\circ} \mathrm{W}$. along the southern part of the drift. Lead carbonate was mined for a width of 2 feet along the fault and connected with a small stope 3 feet thick that extended westward or down-dip from the fault. The stope along the bedding was roofed and floored by silicified limestone. That in the floor was cellular and about 2 feet thick and connected downward with a vertical mass that had replaced limestone along a vertical fissure. Two elliptical bodies of zinc carbonate were mined, one along each side of the vertical quartz body. They were 12 to 15 feet long, as much as 5 feet wide, and about 4 feet thick.

The north drift from the tunnel turned east-northeast along a cross fissure close to the southeast boundary of the Imperial claim. The limestone on both sides of the cross fissure was replaced by a mass of coarse-grained high-grade galena, which was said to have an unusually high content of silver. The ore was accompanied by some quartz but ended abruptly against unaltered limestone. The cross fissure had been followed for about 20 feet in this ore in 1916; and at the breast of the drift, which was near a fault of northerly trend, it was turning to a more northerly course. This structural condition suggested that the ore shoot was controlled by the intersection of fissures.

\section{LINCHBURG TUNNEL}

The Linchburg tunnel (fig. 18) is about a mile southeast of Kelly. It was begun by the American Zine, Lead \& Smelting Co. in 1910, was taken over by C. T. Brown in 1912, and by the Empire Zinc Co. in 1915 or 1916.

It extends about 1,150 feet in an average N. $75^{\circ} \mathrm{E}$. direction to prospect the Kelly limestone on the west or downthrown side of the Young America fault. Its breast is along the middle of the northwest boundary of the Young America claim. A raise (fig. 19) had been put up into the limestone in 1916, but it was

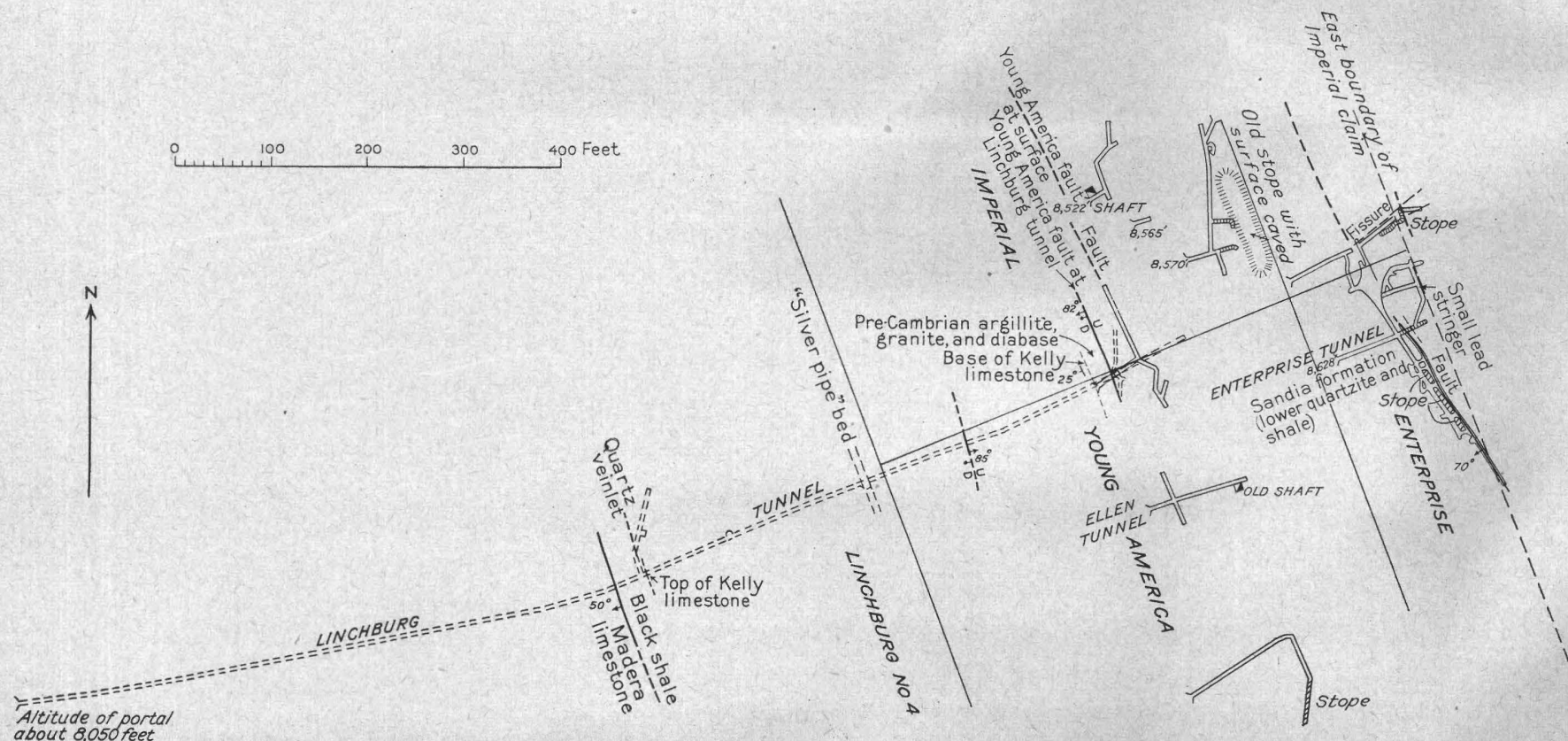

FIgURE 18.- Map of the Linchburg tunnel and shallow workings in the Young America, Imperial, and Enterprise claims. 

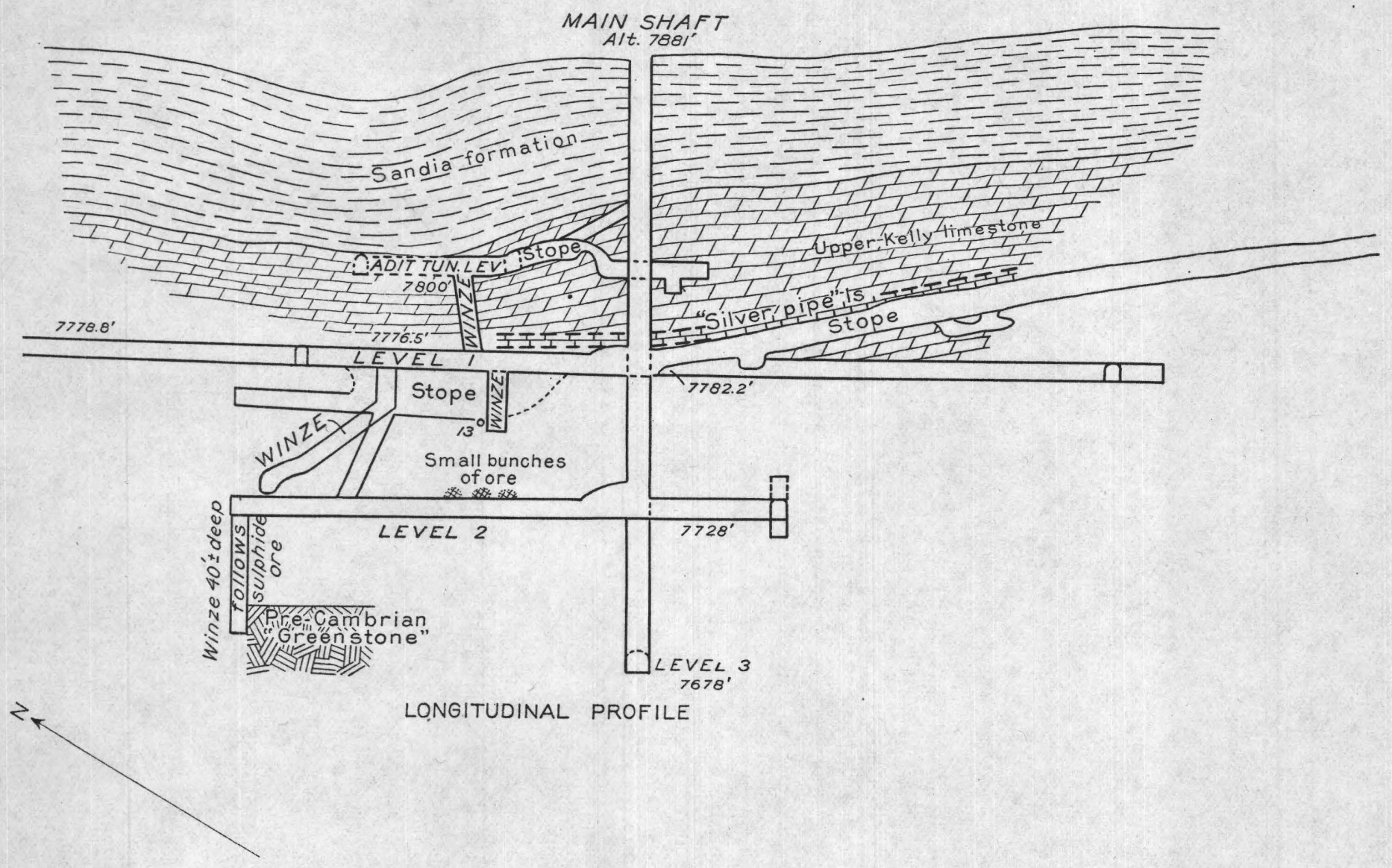

LONGITUDINAL PROFILE

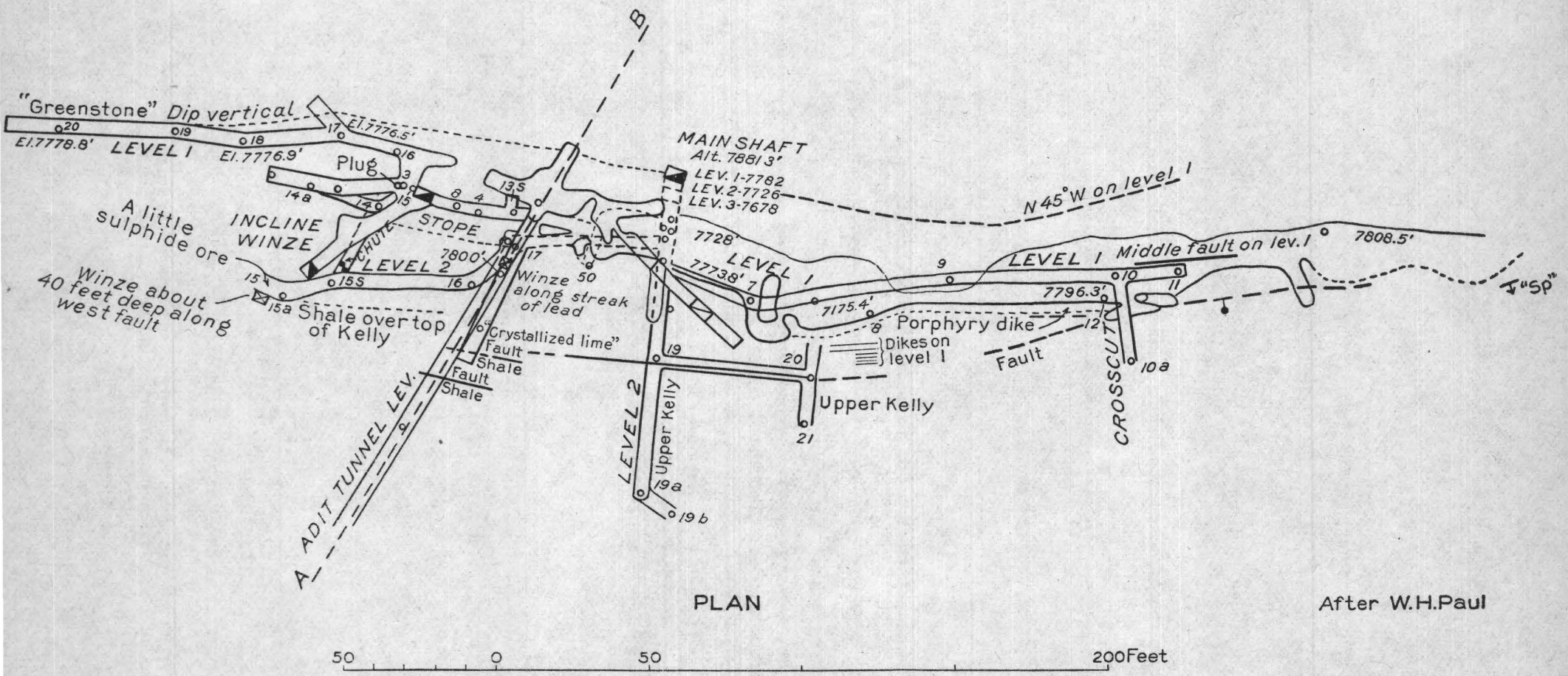

PLAN AND LONGITUDINAL PROFILE OF SOUTH JUANITA (JUANITA EXTENSION) MINE. 

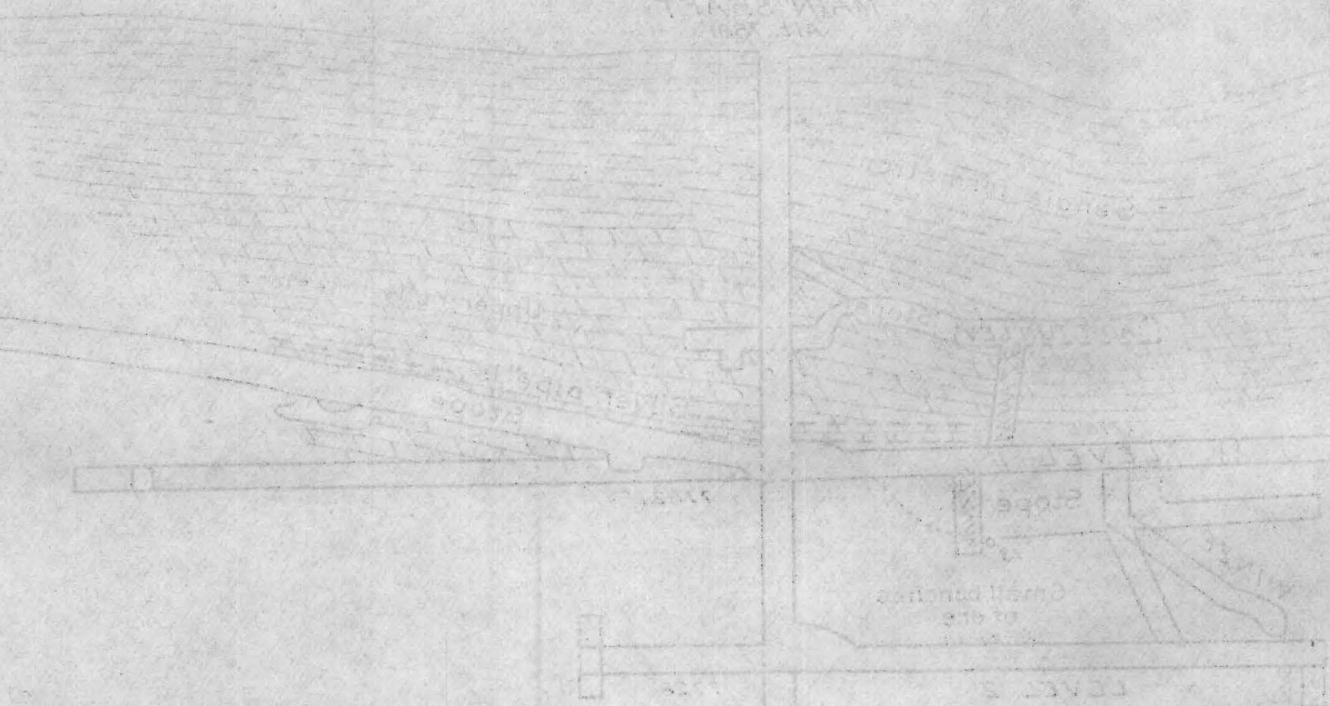

pas 8 


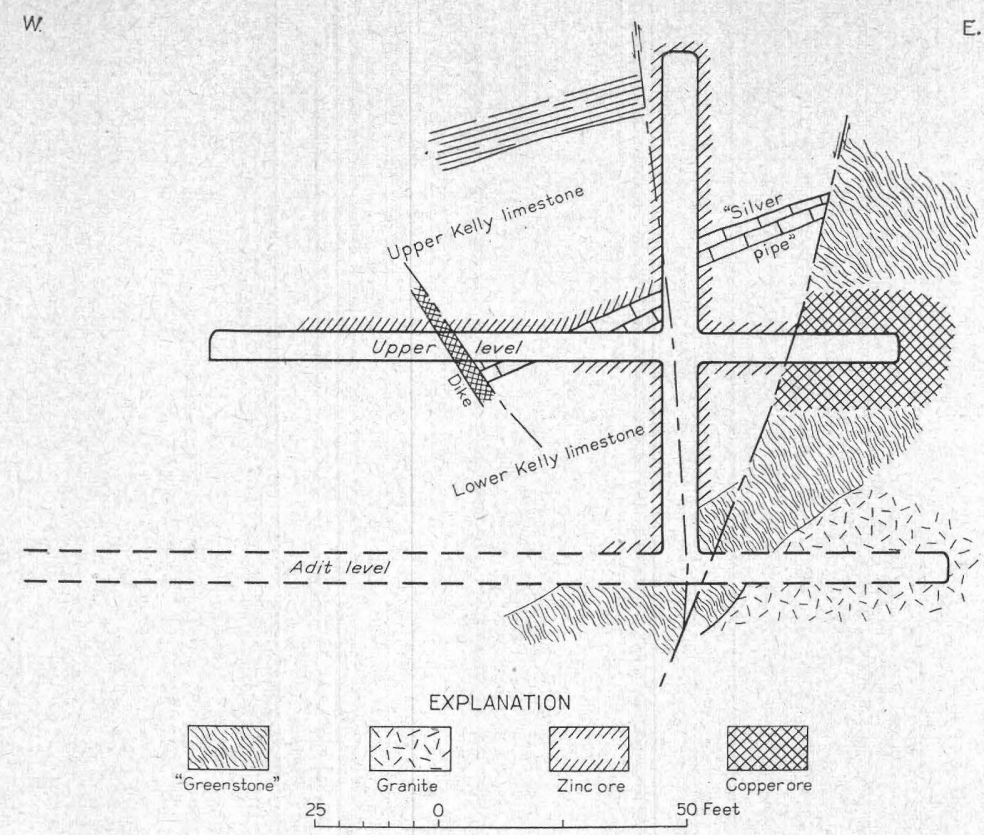

FiguRe 19.- Section through main raise near breast of Linchburg tunnel, looking N. $70^{\circ}$ E. After Soren Ringlund.

so full of gas when visited that observations were confined to the tunnel. The portal, at an approximate altitude of 8,050 feet according to plate 2 , is in purple andesite, which continues for a short distance. The tunnel then cuts a dike of latite porphyry with north strike and vertical dip. The dike is about 25 feet thick and is faulted against Madera limestone on the east. The Madera limestone continues to a point about 570 feet from the portal, where it is faulted against the lower beds of the Sandia formation. A short distance farther east the tunnel cuts the Kelly limestone, which dips west at a small angle and continues to a point about 100 feet from the end of the tunnel, where it is underlain by pre-Cambrian argillite or "greenstone." A short distance beyond the base of the Kelly limestone the Young America fault is exposed, and a little farther east the argillite is cut by granite, whose contact dips about $40^{\circ} \mathrm{W}$. The lower beds of the Kelly limestone, called the "Pinto limestone," are mineralized along the tunnel; and the main raise, put up along a west branch of the Young America fault (fig. 19) is said to have cut ore of low to moderate grade both below and above the "silver pipe" bed. The argillite or greenstone is also mineralized along the fault zone. Since 1916 drifts were extended to the north and the south on the tunnel level and considerable work was done through the raise; but the prevailing market for zinc has been such that no shipments of ore have been made, and the workings have probably been idle from 1921 to 1941 .

A specimen of the mineralized limestone collected on the tunnel level in 1916 contained about 50 percent of garnet, 30 percent of hedenbergite, 10 percent of quartz, 5 percent of calcite, and 5 percent of sulphides (galena, zinc blende, and chalcopyrite). The limestone also contains specularite in places. Specimens of the underlying argillite or "greenstone" were also found to contain the same sulphides and specularite, as well as epidote and colorless garnet. This association points to a more intense mineralization than has been indicated elsewhere in the southern part of the district. Its relation to the ore and gangue in the higher Young America and Enterprise workings implies that the oreforming solutions, locally at least, rose vertically. It also suggests that the Kelly limestone for a considerable distance along the west side of the fault may be more thoroughly replaced by ore than it is on the east side. The Kelly limestone west of the main fault zone has not been exposed at any other place south of the South Juanita mine, but it may be significant that the showing along the fault in the Mistletoe tunnel 1,800 feet to the north justified the sinking of a winze; in fact, the Kelly limestone throughout this distance is worthy of consideration.

\section{WOODLAND MINE}

The Woodland mine is near the summit of the range, due east of South Camp, with which it was once connected by an aerial tramway. It is opened by a short tunnel in silicified upper Kelly limestone. A short distance from the portal and a little above the "silver pipe" bed the tunnel cuts a streak of partly leached galena and quartz. The streak lies along the bedding and has been followed for short distances by north and south drifts and by a raise to the east. No evidence of stoping was found in these workings.

\section{CAVERN AND GRAND LEDGE MINES}

The Cavern and Grand Ledge claims are opened by two tunnels along the Water Canyon Trail east of 
South Camp and just southwest of the Woodland mine. The tunnels are connected by an inclined tram road with a small dismantled mill (p. 79) in the middle branch of Patterson Canyon. The claims were located in 1885 and were worked intermittently. The last mining done was in 1897 on the Grand Ledge and about 1904 on the Cavern claim, although assessment work was continued until 1919 . The property in 1915 and 1916 was in the care of Mr. F. A. Gordon, who guided Mr. Loughlin through the accessible workings of these and other properties in the southern part of the district. We are also indebted to Messrs. G. L. Brooks and B. A. Statz, of Albuquerque, president and engineer of the Cavern Gold Mining Co., for maps of the workings.

The claims are along a southerly continuation of the fault zone that extends through the Young America claim. The courses of the principal faults in the zone are irregular and partly concealed by an old landslide. The Young America fault evidently curves southeastward, is joined by a minor fault of southerly trend, and thence turns to the south and south-southwest. The fault west of the Young America curves even more southeastward. The two faults unite beneath the landslide and continue southward as the Grand Ledge fault, whose west wall at the surface consists of Madera and uppermost Sandia beds, and whose east wall is preCambrian argillite or "greenstone". The argillite is partly capped by silicified Kelly limestone, none of which extends down to the tunnel levels. The Grand Ledge fault is followed by a dike of white rhyolite in the Grand Ledge tunnel.

The Grand Ledge tunnel (fig. 20), which evidently corresponds to the first level of the workings, has an altitude of 8,761 feet and extends S. $83^{\circ}$ E. for about 175 feet. The first 90 feet is in Madera and Sandia beds which dip $20^{\circ}-25^{\circ} \mathrm{W}$. and are bounded on the east by the white rhyolite dike and the main fault. The remainder of the workings are in argillite. The rhyolite dike is followed by a vein composed of barite with a little quartz, fluorspar, and sulphides, which has been opened by a short north drift. Eighteen feet east of the vein, a south drift in argillite has explored a veinlet of barite and quartz with a little zinc carbonate and green copper carbonate. This veinlet strikes N. $20^{\circ} \mathrm{W}$., dips $65^{\circ} \mathrm{W}$., and evidently follows a small spur from the main fault. Twenty-one feet east of the south drift the main north drift follows a fault vein for about 50 feet in argillite and connects with an old stope that strikes N. $25^{\circ}$ E. and dips steeply east at the tunnel level but curves to $60^{\circ} \mathrm{W}$. above the level. According to a generalized blue print dated 1904, on which figure 20 is partly based, this stope has a horizontal length above the level of 100 feet and extends nearly to the surface. The average width of the stope where seen on the tunnel level is about 4 feet, though its horizontal projection in figure 20 is greater, and its maximum width is 15 feet. Remnants of the ore consisted of galena and cerussite in a honeycombed ironstained gangue. The ore shipped is said to have included "sand carbonate" and some low-grade copper carbonate. The north drift, according to the blue print, continues for about 200 feet, passing an abandoned shaft 25 feet north of the stope.

The Cavern tunnel is about 200 feet N. $10^{\circ} \mathrm{W}$. from the Grand Ledge tunnel and 30 feet or more lower. It trends N. $73^{\circ}-87^{\circ}$ E. for 290 feet, passing through Madera and upper Sandia beds and ending in the main fault zone. The beds dip about $35^{\circ} \mathrm{W}$. except in the eastern 60 feet of the tunnel, where black pyritic shale of the Sandia formation dips $65^{\circ} \mathrm{W}$. and is cut by many nearly vertical fractures that are essentially part of the fault zone. A south branch of the tunnel obliquely crosscuts the shale for about 60 feet and connects with the abandoned shaft, south of which an old stope extends upward and, according to the blue print, is essentially continuous with the stope on the Grand Ledge level. It is also apparently continuous with a downward tapering stope that was opened by short crosscuts from the old shaft 25 and 50 feet below the Cavern tunnel or second level. A winze inclined about $78^{\circ} \mathrm{W}$. followed the mineralized zone downward for 90 feet from the bottom level, but no drifting or stoping was done from it.

The appreciable size of the ore shoot and its mineral composition imply that ore deposition in this part of the main fault zone was rather intense, especially as the ore was deposited between walls of argillite and dense black limestone or shale, which are relatively resistant to replacement. The fact that the downthrow on the west side of the fault is greater than at any other place along the fault zone also favors the existence of minor faults and fractures in the Kelly limestone and other more brittle beds below the shale member of the Sandia formation, which could have served as circulation channels for ore-forming solutions just as those in the Graphic-Waldo and Kelly mines did. The presence of high-temperature minerals as well as promising shoots of sulphide ore in Kelly limestone along the same fault zone in the Linchburg tunnel, less than 2,000 feet to the north, is a strong indication of a local source of ore in the vicinity. Geologic conditions as a whole, therefore, favor the exploration of the Kelly limestone on the west side of the Grand Ledge fault. The irregularity of dip at and near the surface prevent a close estimate of the depth of the Kelly limestone, which should be determined by drilling. Calculation from available data places the base of the Kelly limestone at an average altitude of 7,600 feet and implies that the limestone could be drained by a tunnel 3,200 feet long with its portal in the north branch of Patterson Can- 
MINES IN THE MAIN ORE ZONE
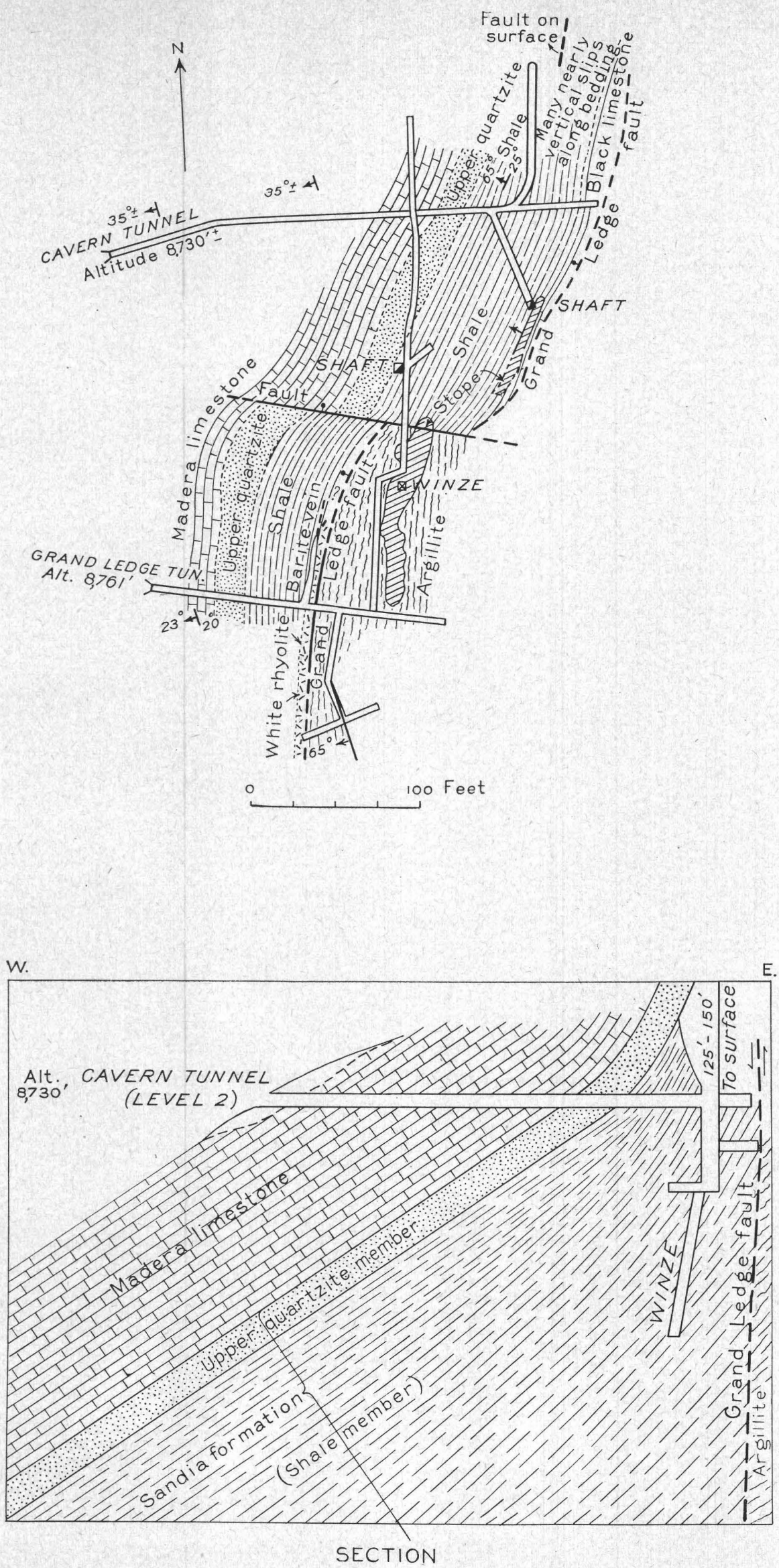

FIGURE 20.-Plan and cross section of Cavern and Grand Ledge tunnels. 
yon. Drilling, however, may prove that the base of the limestone is not quite so deep.

\section{CONNELLY TUNNEL}

The Connelly tunnel cuts the Grand Ledge fault 1,800 feet south of the Grand Ledge tunnel. There the shaly lower Madera limestone beds are faulted against argillite. A number of small quartz veins are present in the fault zone, accompanied in places by barite and a small quantity of ore minerals. The ground was partly eaved and was not explored thoroughly.

\section{WEST VIRGINIA TUNNEL}

The West Virginia tunnel, about 900 feet southeast of the Connelly tunnel, extends N. $55^{\circ}-60^{\circ}$ E. for about 160 feet in Madera limestone and ends at a reverse fault that strikes N. $25^{\circ} \mathrm{W}$. and dips about $60^{\circ} \mathrm{E}$. The east wall of this fault is pre-Cambrian argillite or "greenstone", and it therefore is the main fault of the zone, although it must be connected with the Grand Ledge fault by a sharp westerly deflection or a concealed cross fault a short distance north of the tunnel. No veins have been developed in the tunnel.

\section{VICTOR TUNNEL}

The Victor tunnel, beyond the south boundary of the area mapped but in the general direction of the main fault zone, follows a narrow pockety quartz vein in purple andesite breccia for about 100 feet in a S. $5^{\circ}$ W. direction. The breast of the tunnel exposes stringers of chalcopyrite, galena, and zinc blende in a gangue of calcite and quartz.

Other outcrops and "float" of vein material in the vicinity consist of quartz and barite with minor amounts of other characteristic minerals.

\section{MINES AND PROSPECTS EAST OF THE MAIN ORE ZONE}

Workings in the complexly faulted ground just east of the Germany fault are mostly on the Sampson, Legal Tender, and Grand Tower claims to the north of Kelly Gulch and in the Germany mines to the south of it. (See pl. 30.) The Sampson claim lies along the fault of northwesterly trend, referred to here as the Sampson fault, that separates the Madera limestone from the lower limestone and quartzite members of the Sandia formation. The Legal Tender and Grand Tower claims, which overlap, include the southern part of the Sampson fault and the network of short faults crossed by the Tip Top road.

The Sampson fault may be regarded as a steplike continuation of the Germany fault, as it marks the principal downthrow to the east that is marked farther south by the Germany fault. The intervening minor faults are in part branches of the Germany fault and in part transverse faults along which small blocks have undergone considerable subsidence. The greatest amount of subsidence is shown by the small rectangular block of Madera limestone bounded by Kelly limestone on the west and by the lower limestone of the Sandia formation on the other three sides.

\section{SAMPSON CLAIM}

Only shallow work has been done on the Sampson claim, where ore has been stoped along a fissure, which strikes N. $37^{\circ} \mathrm{W}$. and dips $70^{\circ} \mathrm{E}$. in the Sampson fault zone. The ore shoot, as seen in 1916 , had been followed about 80 feet and showed a northwesterly pitch of $20^{\circ}$. It consisted principally of oxidized lead ore that had replaced limestone between beds of shale in the Sandia formation. Bunches of zinc carbonate, said to average 35 percent of zinc, were found in the down-dip and down-pitch parts of the shoot, and zinc carbonate of lower grade-reported as 20 percent-was found along bedding planes and fractures in adjacent limy shale. The only reported shipment was of 33 tons of ore in 1917 from which 500 pounds of lead and 13,344 pounds of zine were recovered; but other small shipments may have been included with other shipments by the owner, the Ozark Smelting \& Mining Co.

\section{GRAND TOWER AND LEGAL TENDER CLAIMS}

In the northern part of the Grand Tower and Legal Tender claims, the second owned by the Tri-Bullion Smelting \& Development Co., a row of shallow shafts and prospects has been sunk along minor faults of north-northwest trend and steep west dip in the lower limestone and quartzite members of the Sandia formation. No production has been reported from these claims since 1904. The ore, as seen from the surface at one of these prospects, has replaced a limestone bed in the hanging wall of the fault where quartzite forms the footwall. At the southernmost opening of the group another small stope occurred similarly in a wedge of limestone faulted between two masses of quartzite. The limestone above the stope was silicified.

A few similar bunches of ore are exposed in shallow workings elsewhere on these claims. One of them, reached by a short tunnel that trends S. $80^{\circ}$ E., just northwest of the cable house on the Legal Tender claim, has replaced a slightly domed bed of Madera limestone just above a bed of quartzite that may mark the top of the Sandia formation. The stoped part of this shoot is circular, with a diameter of about 20 feet and a thickness of 4 feet. Southeast of this tunnel, short tunnels along faults in the Kelly limestone expose small irregular stopes capped by thoroughly silicified limestone.

The largest ore body in these claims is reached by the Grand Tower vertical shaft, which has been sunk a little west of the east boundary of the Legal Tender claim. (See fig. 21.) Between 10,000 and 15,000 tons of ore are said to have been milled and shipped from it, all prior to 1904 .

The mine, as shown on plate 2 , is in the midst of a 


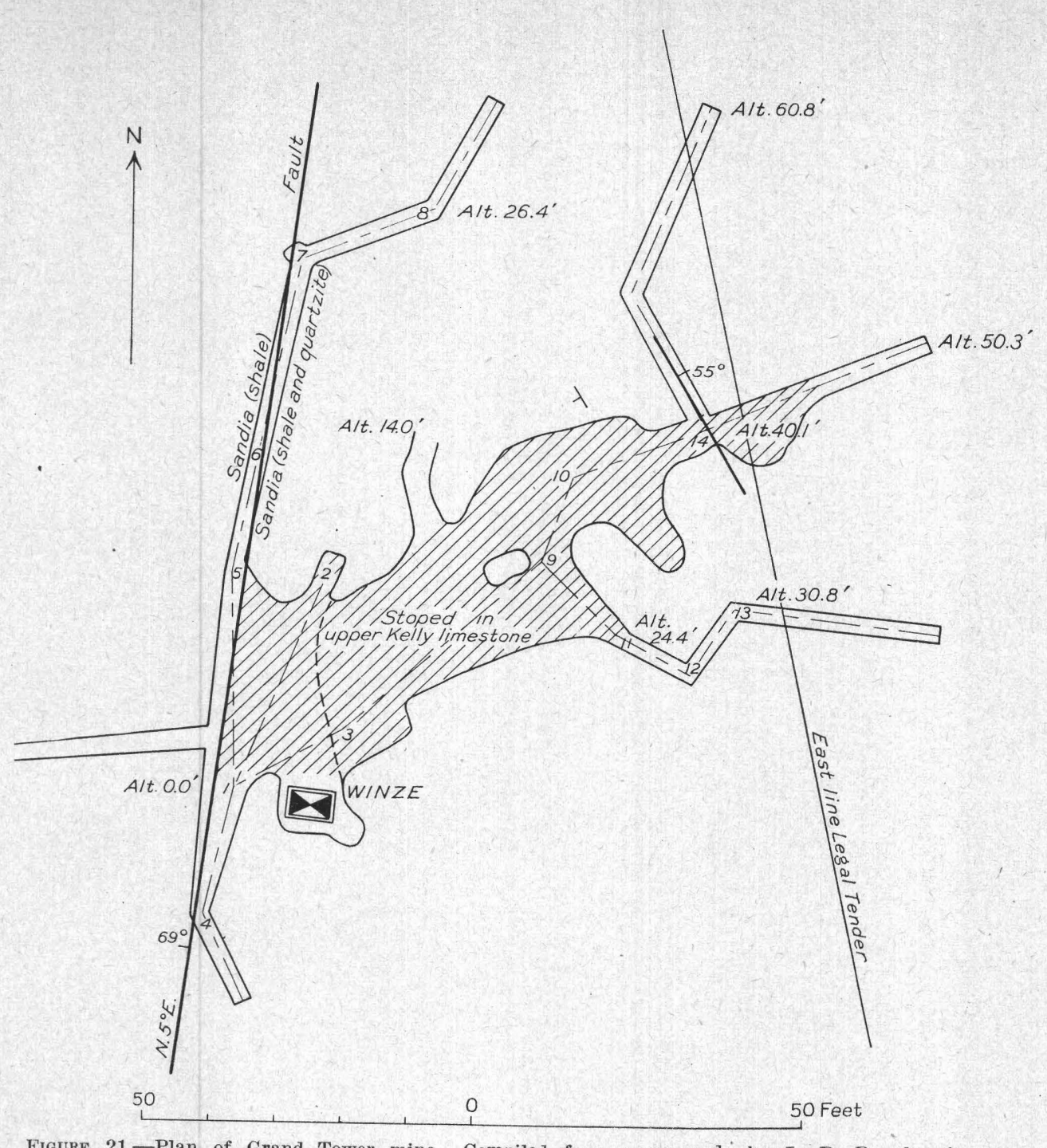

Figure 21.-Plan of Grand Tower mine. Compiled from maps made by L. P. Pressler for the Tri-Bullion Smelting \& Development Co, in 1911, and by R. L. Chase in 1912.

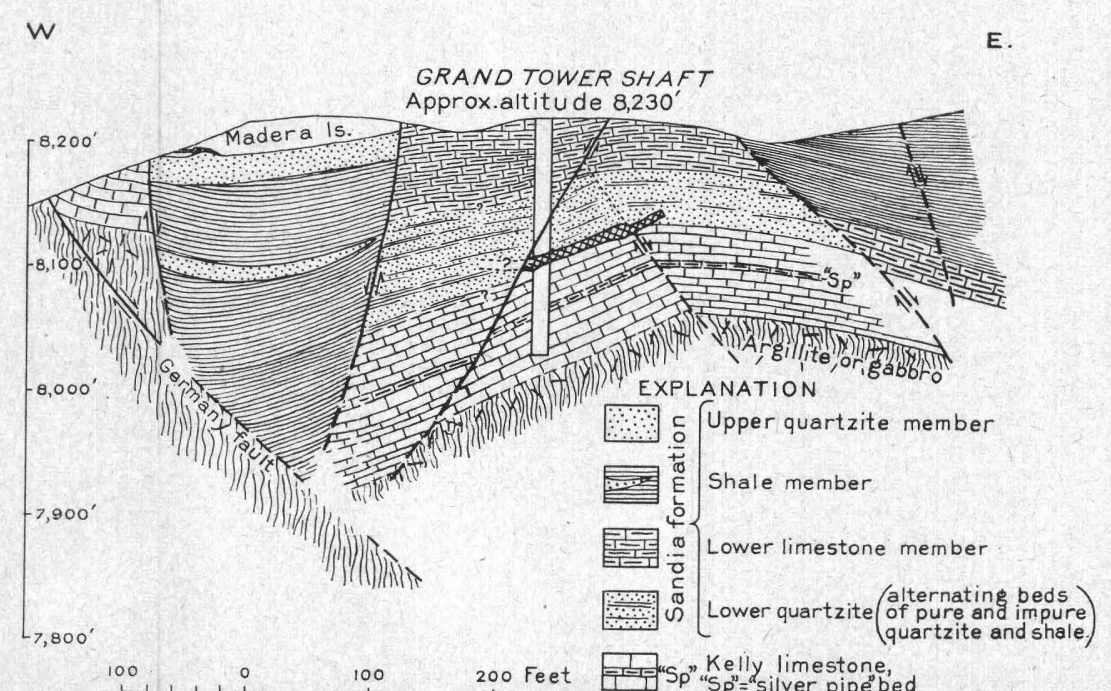

Frgurh 22.- Section from the Germany fault through the Grand Tower shaft, looking N. $74^{\circ} \mathrm{E}$. 
network of short longitudinal and cross faults that are east of the Germany fault and subsidiary to it and bound a group of small depressed blocks. The most depressed of these blocks is represented at the surface by Madera limestone, but the two blocks east of it, which contain the Grand Tower workings, are represented by the lower limestone of the Sandia formation. The gealogic structure, insofar as it can be interpreted, is shown in figure 22.

The workings opened by the shaft are within an area 250 feet square. The shaft is said to be about 190 feet deep, but water stood at a depth of 130 feet in 1916, and no information regarding conditions below that depth is available. The shaft cuts the top of the Kelly limestone at a depth of 120 feet. A fault is exposed just west of the shaft at that level. It strikes N. $5^{\circ} \mathrm{E}$, dips $69^{\circ} \mathrm{W}$., and corresponds rather closely to the fault that crops out just east of the shaft. This fault, which at the 120 -foot level brings the lower Sandia beds against upper Kelly limestone, forms the west boundary of an ore shoot just below the shale roof of the Kelly limestone. The shoot, which has an average width of 50 feet, has been stoped up the dip for 100 feet in a northeasterly direction. Near its northeast end, which is 80 feet above the southwest end, the limestone is cut by a small fault that dips $50^{\circ}-60^{\circ} \mathrm{E}$. and passes upward into a roll in the shale. The ore follows the roll and continues a few feet beyond the fault. The shape of the stope suggests that the ore shoot followed a cross fracture between the two faults, but no such fracture was noted in the roof or floor of the stope. Remnants of sulphide ore in and around the stope contain pyrite, zinc blende, galena, and chalcopyrite; and low-grade material along the walls and floor consists largely of quartz-barite gangue. A few small bunches of zinc carbonate, replacing coarsegrained limestone, were noted along the down-dip side of the stope; and it is therefore inferred that the main ore body was in part oxidized. The only development above water level outside of the stope are two inclines that rise northward at low angles. Only the western incline was accessible. It followed the west fault for 80 feet and showed shale and quartzite of the Sandia formation on both sides.

As the stope is much too small to account for the total reported tonnage of ore produced, it seems that some ore must have come from below the present water level. The bottom of the shaft should be near the bottom of the Kelly limestone, and a west crosscut from it might reach Kelly limestone beyond the fault. Ore could be expected at both of these places.

\section{GERMANY MINES}

The Germany mines, owned by the Germany Mining \& Development Co., comprise four sets of workings that have prospected the ground, half a mile and more east of Kelly, between the Germany fault and the north end of the Mistletoe fault. Development of this ground began in 1906, but, although a great deal of work was done, the output, as shown in the table on page 152 , has been relatively small. The average grade of the ores has been distinctly below that of the ores in the main ore zone in both lead and zinc, but several shipments of lead and dry ores have been much higher in silver. A few shipments have contained more gold than the average, but they may have included small quantities of gold ore from the Stonewall claim of the Tip Top and Key mines. The ground, explored by the Germany mines, as shown on plate 2 , is crossed by two faults of east-northeast trend with downthrow on the south that displace the Sandia and lower Madera formations on the surface. The northern cross fault is so compensated on its north side by faults of northerly trend that the displacement near its junction with the obscure northern part of the Mistletoe fault is small. The southern cross fault maintains a throw of about 400 feet throughout its length, thus compensating for most of the displacement along the Mistletoe fault. The lowest workings (figure 23) are opened through the main tunnel, whose portal is in Kelly Gulch at an approximate altitude of 7,840 feet. Tunnel No. 1 is 700 feet to the east in a tributary of the gulch, at an altitude of 8,020 feet, and the Alhambra tunnel and "old workings" are on opposite sides of the tributary gulch at altitudes of 8,060 feet and 8,080 feet.

The Alhambra tunnel was flooded and inaccessible in 1915 and 1916; but the distribution of its workings suggests that they have explored the Kelly limestone west of the northernmost part of the Mistletoe fault, where displacement along it is small. The eastern part of the No. 1 tunnel workings, which explore the same ground were also flooded. The western part of No. 1 tunnel and the "old workings" above it explore the Germany fault, where it curves from a southeasterly to a south-southwesterly course, and a branch fault that is essentially a continuation of the southeasterly course. A little ore was evidently stoped where this branch fault cut the top of the Kelly limestone in the old workings. Elsewhere the limestone was silicified but nonproductive.

The main or lower tunnel passes in a S. $72^{\circ} \mathrm{E}$. direction through argillite, granite, and dikes of pre-Cambrian diabase and felsite, but it was flooded east of the Germany fault in 1915 and 1916. It crosses the Germany fault 1,000 feet from the portal and continues for 350 feet farther, presumably to the Mistletoe fault. Workings extending southward from it have explored the ground in the vicinity of the Germany fault for about 1,600 feet. A little siliceous zine sulphide ore with a green copper stain was found along a minor fissure in Kelly limestone on the east side of the Germany fault. About 500 feet south of the tunnel, near 


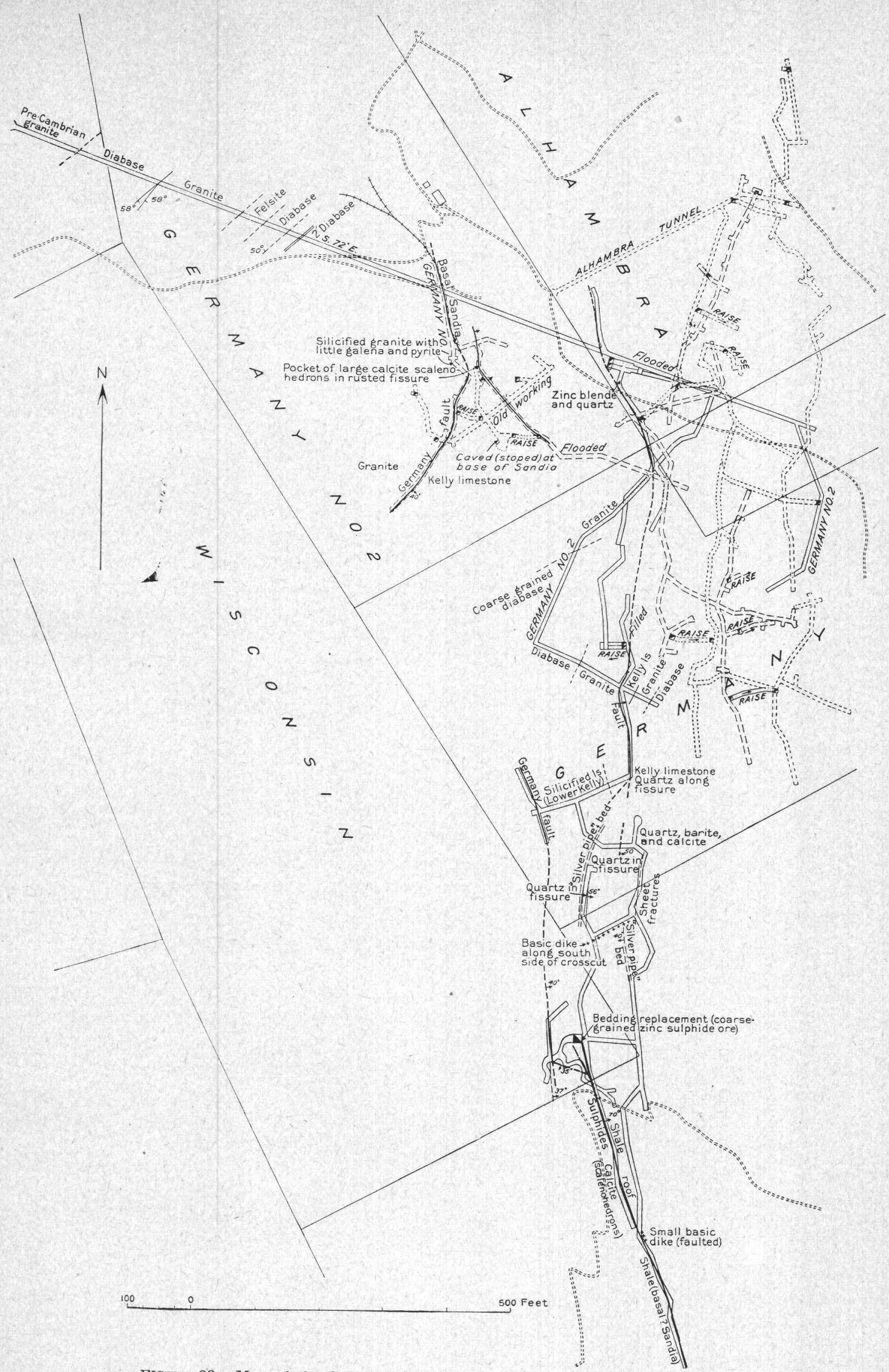

FIGURE 23.- Map of the Germany mines showing geology of accessible parts. 
Ore mined at Germany mines, $1906-39,1$ and its gross metal content

[Data collected and classified by C. W. Henderson, Geological Survey and Bureau of Mines, U. S. Department of the Interior, Denver, Colo.]

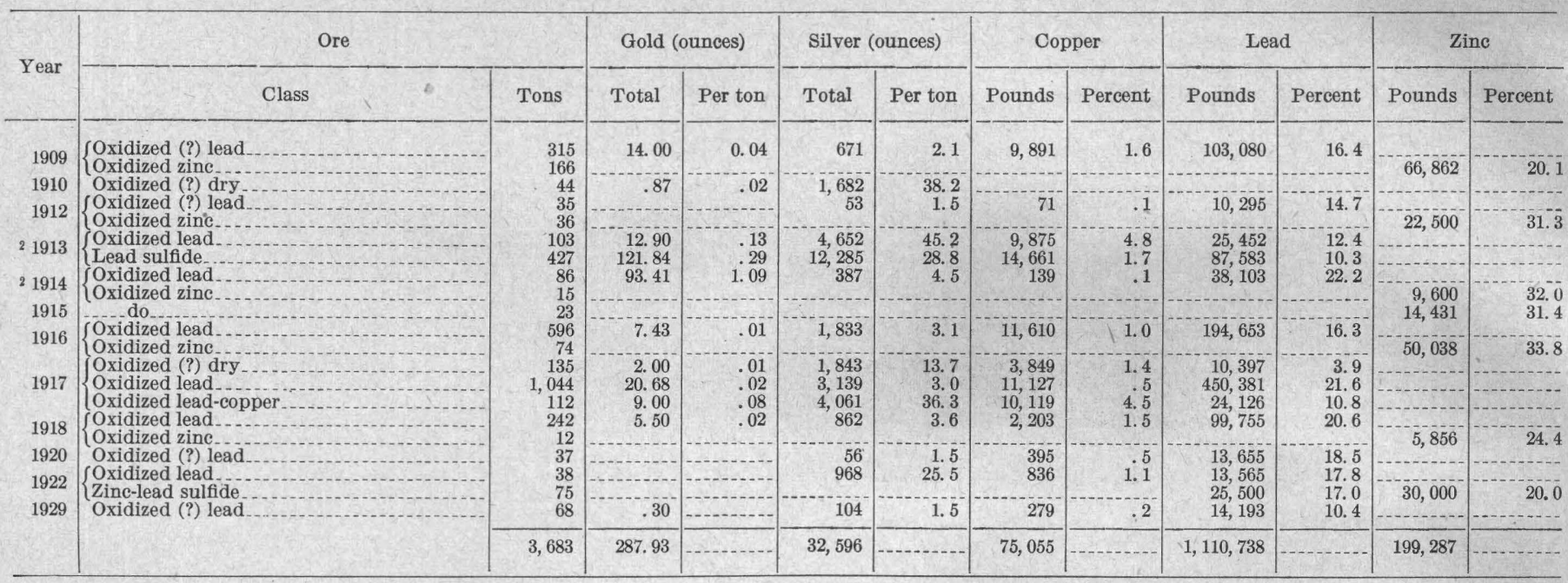

1 Development or assessment work but no production in 1906-8, 1911, 1919, and 1921. Mine idle in 1923-28 and $1930-39$.

2 Shipments for 1913 and 1914 may include those from the Tip Top and Key mines as well as the Germany mines.

the projected position of the northern cross fault, the Germany fault is either offset or bends abruptly westward and sends an east branch along the continuation of its regular course. The lower Kelly limestone along this branch fault is replaced by quartz, barite, and calcite, and minor fissures between the east branch and the main fault are filled with quartz. These fissures either end southward or are deflected along a lamprophyre dike that parallels the cross faults. A little farther south a replacement deposit of sulphide ore about 2 feet thick is exposed at the junction of the topmost Kelly bed and a minor fault that strikes southsoutheast and dips $70^{\circ} \mathrm{E}$. The deposit has been explored in a winze along the top of the Kelly limestone and another minor branch fault that follows a lamprophyre dike and has a small downthrow on the west. The ore is a coarse-grained mixture of galena, zinc blende, pyrite, and microscopic chalcopyrite in a gangue of quartz, calcite, barite, and siderite. It has been followed south-southeast along the branch fault and passes into a vein of calcite, whose scalenohedrons indicate the waning end of local mineral deposition. The fault and vein have been followed for 530 feet from the winze to the south end of the mine.

The evidence throughout the accessible parts of the mine indicates that, although early silicification took place rather continuously along and near the Germany fault, it was confined to fissures and the adjacent limestone; also that the later ore-forming stage supplied only small quantities of sulphide ore to minor tension faults near the main fault and was too weak to effect permeation along the bedding of the limestone.

\section{LITTLE LOELLA CLATM}

The Little Loella claim is on the upper west slope of the Magdalena Range about 4,000 feet due east of
Kelly and a little west of the South Stonewall fault. Kelly limestone, whose uppermost beds are completely silicified, crops out along its eastern part and dips westward beneath the basal Sandia beds. Accessible workings include three tunnels in the upper Kelly limestone.

The lowest tunnel extends for 65 feet in a N. $62^{\circ}$ E. direction, beginning in the silicified beds and passing into the underlying unaltered limestone. A drift extends north for 30 feet from the breast of the tunnel. At the north end it exposes a lamprophyre dike of northeast trend and also a little zinc carbonate that has replaced limestone just below the silicified top.

The two upper tunnels trend northward and follow the upper and lower sides of a stoped ore shoot that has replaced the limestone just below the silicified top for a maximum length of about 150 feet, a maximum width of about 25 feet, and a thickness of 3 or 4 feet. The maximum length is along the upper tunnel. The maximum width persists for about 60 feet and the down-dip side of the stope then turns northeastward and converges with the relatively straight up-dip side. The roof and floor of the stope consists of quartz and barite. Remnants of the ore consist of galena in a honeycombed quartz-barite gangue from which zinc blende and probably some pyrite and chalcopyrite have been leached. The ore is accompanied by yellow and red earthy material, probably plumbojarosite in part, and a few green copper-stained streaks. The ore is said to have averaged 16 percent of lead after careful sorting.

The lower of these two tunnels follows the down-dip side of the stope for 60 feet and continues 90 feet farther in a N. $6^{\circ}$ E. direction in the silicified top beds of the limestone. A filled winze at the north end of the tunnel may have reached some high-grade zinc carbonate, as carbonate was seen on the dump but nowhere in the main stope. It could also have come from a 
hole about 8 feet square in the floor of the main stope, but the quartz walls of the hole suggests that it contained lead ore.

\section{TIP TOP AND KEY MINES}

The Tip Top and Key mines are in Tip Top Mountain, a mile northeast of Kelly. They are in the Key group of 16 claims, but their workings, which are continuous, are confined to the Tip Top, Stonewall North, Key, and Key No. 2 claims. They were worked by the Mine Development Co. from 1900 to 1909 and were taken over by the Germany Mining \& Development Co. in 1910. The only recorded output, according to the Denver office of the Geological Survey, is shown in the following table:

Ore shipped from Tip Top and Key mines, 190\%-9, and its gross metal content

\begin{tabular}{|c|c|c|c|c|c|c|}
\hline \multirow{2}{*}{ Year } & \multicolumn{2}{|l|}{ Ore } & \multicolumn{2}{|c|}{ Silver (ounces) } & \multicolumn{2}{|c|}{ Lead } \\
\hline & Class & Tons & $\begin{array}{c}\text { Total } \\
\text { (gross) }\end{array}$ & $\begin{array}{l}\text { Per } \\
\text { ton }\end{array}$ & $\begin{array}{l}\text { Pounds } \\
\text { (gross) }\end{array}$ & Percent \\
\hline \multirow{3}{*}{$\begin{array}{l}1907 \\
1908 \\
1909\end{array}$} & Oxidized lead. & 1,000 & 2,000 & 2.0 & 309,600 & 15.5 \\
\hline & & $\begin{array}{l}50 \\
29\end{array}$ & $\begin{array}{r}100 \\
59\end{array}$ & $\begin{array}{l}2.0 \\
2.0\end{array}$ & $\begin{array}{l}15,477 \\
11,994\end{array}$ & $\begin{array}{l}15.5 \\
20.7\end{array}$ \\
\hline & & 1,079 & 2,159 & 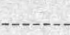 & 337,071 & .. \\
\hline
\end{tabular}

Shipments were reported to have been suspended in 1907 and limited to two carloads in 1908 and one carload in 1909 because of the low price of lead. The price did not improve appreciably until 1916, but even then the mine remained idle.

Some additional shipments from the Key group of claims may have been included in the output of the Germany mines (p. 152) in 1913 and 1914. They probably came from the Stonewall tunnels and were made because of their unusually high gold content. (See p. 155.)

The portal of the Tip Top tunnel is on the south slope of Tip Top Mountain at the end of the road on the upper north slope of Kelly Gulch at an approximate altitude of 8,520 feet. The portal of the Key tunnel is on the north slope on the east side of the main range about 2,000 feet north-northeast of the Tip Top portal at an approximate altitude of 8,540 feet. The two tunnels are connected (fig. 24) by a zigzag set of drifts and crosscuts that follow parts of the "silver pipe" member of the Kelly limestone and intervening cross faults. The Tip Top portal is connected by a short horizontal track with an ore bin just beyond the dump.

The workings are almost entirely in the Kelly limestone. The underlying granite and argillite are exposed at the Key portal and in a few crosscuts where faulting has brought them to the general level of the workings. The lower quartzite member of the Sandia formation has been similarly exposed at a few places.
The limestone member above this quartzite is cut at and near the Tip Top portal.

Three sets of faults are present-a dominant set with westerly trend, called the Tip Top fault zone; a subordinate set with northerly trend; and an obscure set of bedding faults, only one of which, a low-angle reverse or thrust fault within the "silver pipe" bed, has been mapped. Most of the west-trending faults in the northern two-thirds of the workings dip $50^{\circ}-75^{\circ} \mathrm{N}$. and have their downthrows to the north. The positions of the larger faults conform to those mapped at the surface. (See pl. 2.) A few minor west-trending faults, between 600 and 700 feet northeast of the Tip Top portal, dip south, have downthrows to the south, and appear to represent local settling of minor slabs within the steplike south border zone of the depressed block whose north side is in the vicinity of Oak Spring. The local north-trending faults are evidently the northernmost members of the Stonewall fault zone, but here they merely represent adjustments within the slabs between the larger west-trending faults. The thrust fault that nearly coincides with bedding within the "silver pipe" bed is exposed along a short, stub drift 900 feet south of the Key portal. Its only significance is to show that this kind of faulting took place in the eastern part of the district as well as elsewhere and to imply that similar slips have made minor openings along other beds and rendered them more susceptible to permeation.

The only ore shoots found have been small and scattered and with one exception have been in the lower and upper Kelly limestone at or near the intersections of west-trending and north-trending faults. The exception is along the short drift extending northward from the Tip Top tunnel, where the lower part of the lower limestone member of the Sandia formation contains small bunches of ore along or near an obscure west-trending fault. The same limestone, 130 feet farther east, has been replaced by a shoot of northerly trend that probably cropped out originally and was mined through a short tunnel. The Kelly limestone between some of the closely spaced productive and unproductive faults in the central part of the workings is considerably silicified, and one fault between the two most silicified areas contained coarsegrained calcite. Complete oxidation of such ore as could be seen prevented a thorough recognition of the original ore and gangue minerals, but they evidently represent deposition rather far from the source of supply.

\section{STONEWALL TUNNELS}

The Stonewall tunnels, all with easterly trend, have explored the Kelly limestone in the southern part of the Stonewall North claim. They were owned by this Germany Mines Co. in 1913-14, and small shipments from them were probably included in those from the 


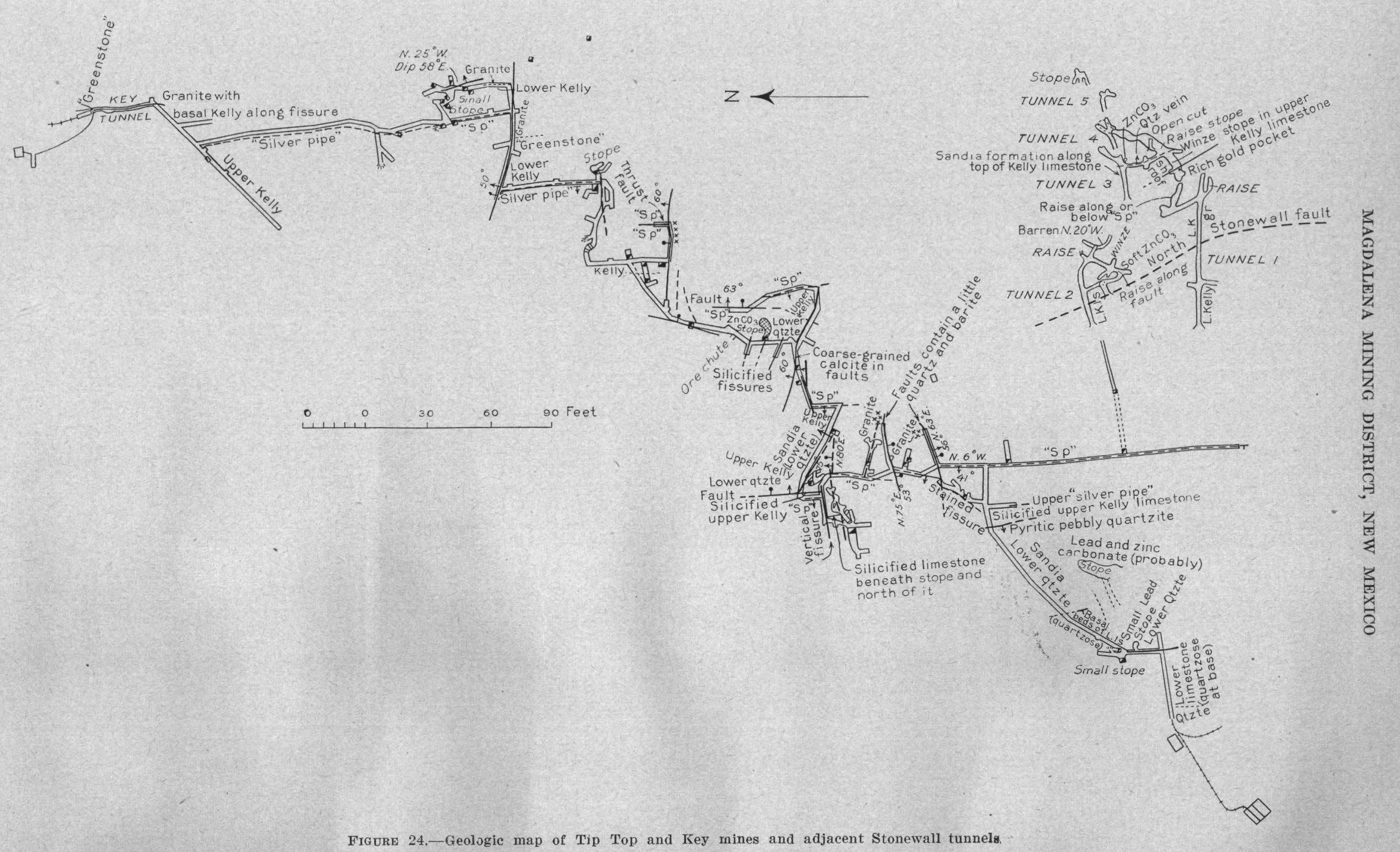




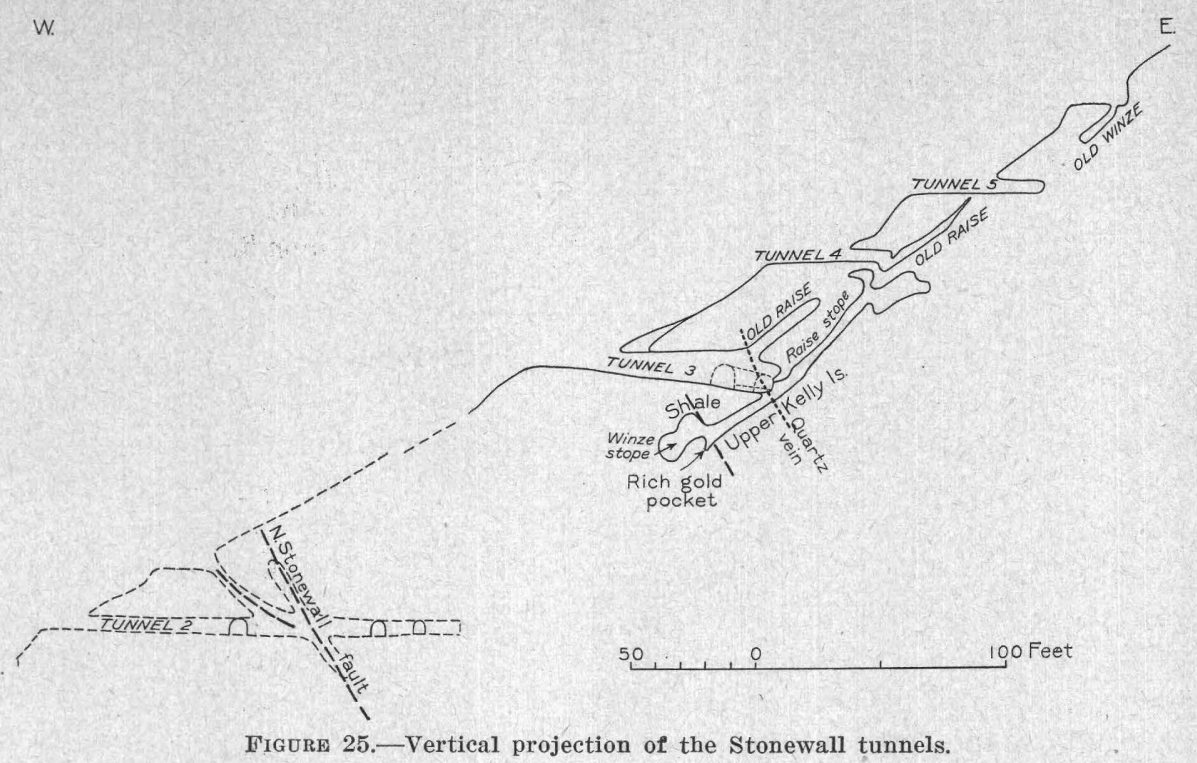

Germany mines in those years. (See p. 152.) No. 1 tunnel, 640 feet east of the portal of the Tip Top tunnel (fig. 24) begins at the lower "silver pipe" bed and crosses the base of the Kelly limestone, along which a thin streak of partly oxidized siliceous lead ore is exposed. The tunnel continues through pre-Cambrian granite as far as the North Stonewall fault, where the main "silver pipe" and upper Kelly limestone beds in the hanging wall lie against the granite footwall. .The fault there strikes N. $20^{\circ} \mathrm{W}$. and dips $37^{\circ} \mathrm{E}$. The fractured limestone and granite contain coarsegrained iron-stained calcite and clay, but no ore minerals were noted. The No. 2 tunnel, 200 feet north of No. 1, also begins in Kelly limestone and crosses the North Stonewall fault, which there dips $60^{\circ} \mathrm{E}$. (See fig. 25.) East of the fault it continues southeastward through upper Kelly limestone, which dips $20^{\circ}-30^{\circ} \mathrm{W}$. and has been replaced by soft clay stained by black manganese and brown iron oxides. The main "silver pipe" bed is exposed in the breast of the tunnel. A branch of the tunnel extends southward for 50 feet through the soft ground, and a short winze and two raises extend from it along the fault. The winze was said to have exposed partly leached quartz and rather low grade lead carbonate along the footwall side and some zinc carbonate ore averaging 35 percent of zinc along the hanging wall; but the only material noted in the winze in 1916 was soft porous material stained by the black manganese and reddishbrown iron oxides that commonly accompany zinc carbonate deposits.

A short distance south of No. 1 tunnel, the North Stonewall fault has been opened by a shallow, inclined shaft sloping $45^{\circ}$ E., along which pyritized shale at the base of the Sandia formation in the hanging wall has dropped to the level of the main "silver pipe" bed in the footwall. It discloses a thin streak of gold-lead ore just beneath the upper "silver pipe" bed or "west vein," which locally marks the top of the Kelly limestone. The streak was followed up the dip to the base of a local "roll," where the dip became nearly vertical and the bedding planes relatively impervious.

No. 3 tunnel, about 250 feet east-northeast of No. 1 tunnel, has also opened ore just below the "upper silver pipe" bed, which immediately underlies pyritized shale. The tunnel cuts an east-dipping quartz-galena vein 55 feet from its portal. This vein has been followed southward for 90 feet and bunches of partly oxidized lead ore and zinc carbonate ore have been exposed along its walls. The main ore shoot, found about 70 feet south of the tunnel, extends along the limestone bedding on both sides of the vein. It has been stoped for 190 feet up the dip and 40 feet down the dip from the tunnel level. It ends downward beneath a "roll" in shale similar to that described above. The limestone beneath the "roll" is cut by a minor, east-dipping fault and the ore shoot thickens along the fault and on its footwall side, as shown in figure 25.

Shipments of ore from the main shoot are said to have contained 18 to 20 percent of lead, too little copper to be paid for, and averages of 4 ounces of silver and 0.55 ounce of gold to the ton. The ore above tunnel level is said to have been high-grade lead carbonate with a small gold content. That below tunnel level, especially beneath the "roll," contained more gold, some sorted lots containing as much as 17 ounces to the ton. The gold occurred as minute grains in silicified limestone and was closely associated with barite, galena, cerussite, willemite, gypsum, kaolin, and black manganese and brown iron oxides. The 17 -ounce ore came from a small wedge-shaped depression at the bottom of the stope (fig. 25) where gold had evidently been concentrated by downward circulation, in a trough formed by the intersection of the west-dipping beds and an 
east-dipping fault that passed upward into the "roll." Small bunches of zinc carbonate have been found on both the hanging walls and footwalls of the lead-gold stope.

The small workings up the slope above No. 3 tunnel apparently opened ore along the uppermost beds of Kelly limestone.

\section{AMBROSIA MINE}

The Ambrosia mine, owned by former Senator T. B. Catron and under lease to the Mines \& Metals Co., of Kelly, in the years 1914-20, is situated on the crest of the range 1,500 feet north of the Key tunnel. No record of its early shipments is available. Small shipments of oxidized zinc ore made from its old stopes in 1914,1916 , and 1918 were included with those of the Juanita mine, which was leased to the same company. Its workings were too much caved to permit study, but they are evidently located along a fault that locally coincides with the steep westerly dip of the beds. The southern ore shoot, which crops out, has replaced the uppermost beds of the Kelly limestone on both sides of the fault. It has been worked through a shaft and a short tunnel. The stoped ground extends with twc interruptions for about 300 feet. Oxidized lead and oxidized zinc ores have been mined.

A lower tunnel, whose portal is along the trail 500 feet southwest of the Ambrosia shaft, has been driven in a N. $85^{\circ}$ E. direction for about 60 feet through the lower quartzite of the Sandia formation and 120 feet in Kelly limestone. Two short drifts extend from it along north-trending fissures but with no encouraging signs of ore.

The North Ambrosia or Ambrosia Extension workings are opened by two tunnels about 800 feet north of the Ambrosia shaft and a little west of the crest of the range. Its workings also are caved, but some zinc carbonate had been taken from them. They are in lower Kelly limestone to the north of a west-trending fault and to the west of a north-trending fault. These faults bring the lower Kelly limestone on the west against pre-Cambrian felsite. The upper Kelly limestone has been entirely eroded.

\section{SLEEPER TUNNEI}

The portal of the Sleeper tunnel is midway between the Key and Graphic tunnels, near the west edge of the large area of Madera limestone that is locally bounded by a northern continuation of the Germany fault. The tunnel (fig. 26) extends S. $80^{\circ}$ E. for 950 feet beginning in pre-Cambrian argillite, crossing the Germany fault about 250 feet from the portal, and continuing through the lower limestone and quartzite-shale members of the Sandia formation, the Kelly limestone, and a few feet of the underlying argillite.

Development has consisted mainly in following the "silver pipe" bed of the Kelly limestone. The north drift along this bed shows that the bed has been bleached, evidently an effect of weak contact-metamorphism, 1,500 feet away from the nearest exposure of the Nitt monzonite stock. The main workings, which are south of the tunnel, consist of drifts and cross cuts that follow the "silver pipe" and its westerly shifts along the south walls of two transverse faults. These faults strike S. $80^{\circ}$ W., dip $75^{\circ}-85^{\circ} \mathrm{N}$., and are approximately in line with the northernmost transverse faults that influenced ore deposition in the Tip Top and Key mines; but there is no positive indication of mineralization along them or adjoining north-trending fissures.

The only ore found in the mine, so far as we could see, was about 90 feet south of the second transverse fault, near the intersection of a north-trending fissure and a minor transverse fault whose south wall has shifted eastward. There a streak of partly oxidized galena from 1 to 2 inches thick, which lay just beneath the "silver pipe" bed, had been followed by a short raise. A small pile of galena seen on the dump presumably came from this raise. Another small pile of zinc carbonate with some green and blue copper carbonates may also have come from this raise or perhaps from a raise farther west along the top of the Kelly limestone. A short distance south of the galena raise, the north-trending fissure contains small scalenohedrons of calcite and brown iron oxide. The calcite is a characteristic product of the weakest ore-forming solutions and therefore may mark the approximate limit reached by solutions in this vicinity.

South of the calcite vein an irregular east crosscut has been driven among some intersecting faults of northeast and northwest trends along which the lower quartzite-member of the Sandia formation is in contact with Kelly limestone, but nothing encouraging has been found.

\section{PROSPECTS WEST OF THE MAIN ORE ZONE}

The only deposit that has been productive recently in the west ore zone is that along the Waldo fault cut by the Waldo tunnel of the Graphic-Waldo mine (p. 130). Exploration of the southerly continuation of the fault by a crosscut from the Traylor shaft of the Kelly mine (p. 137) was evidently not successful. The only workings farther south in this zone are shallow prospects along small veins in volcanic rocks, from two of which-the Iron Mask and Morning Star-a few tons have been shipped.

The Iron Mask at South Camp was one of the earliest claims to be worked, but evidently without much success, as the workings were left flooded in 1881 (p. 76). A little work was done on it in 1913 and 1914, but no output was reported. It was reopened again in 1928 but was closed again in 1929 without any output, although a small amount of ore was exposed containing chalcocite, other copper minerals, and 


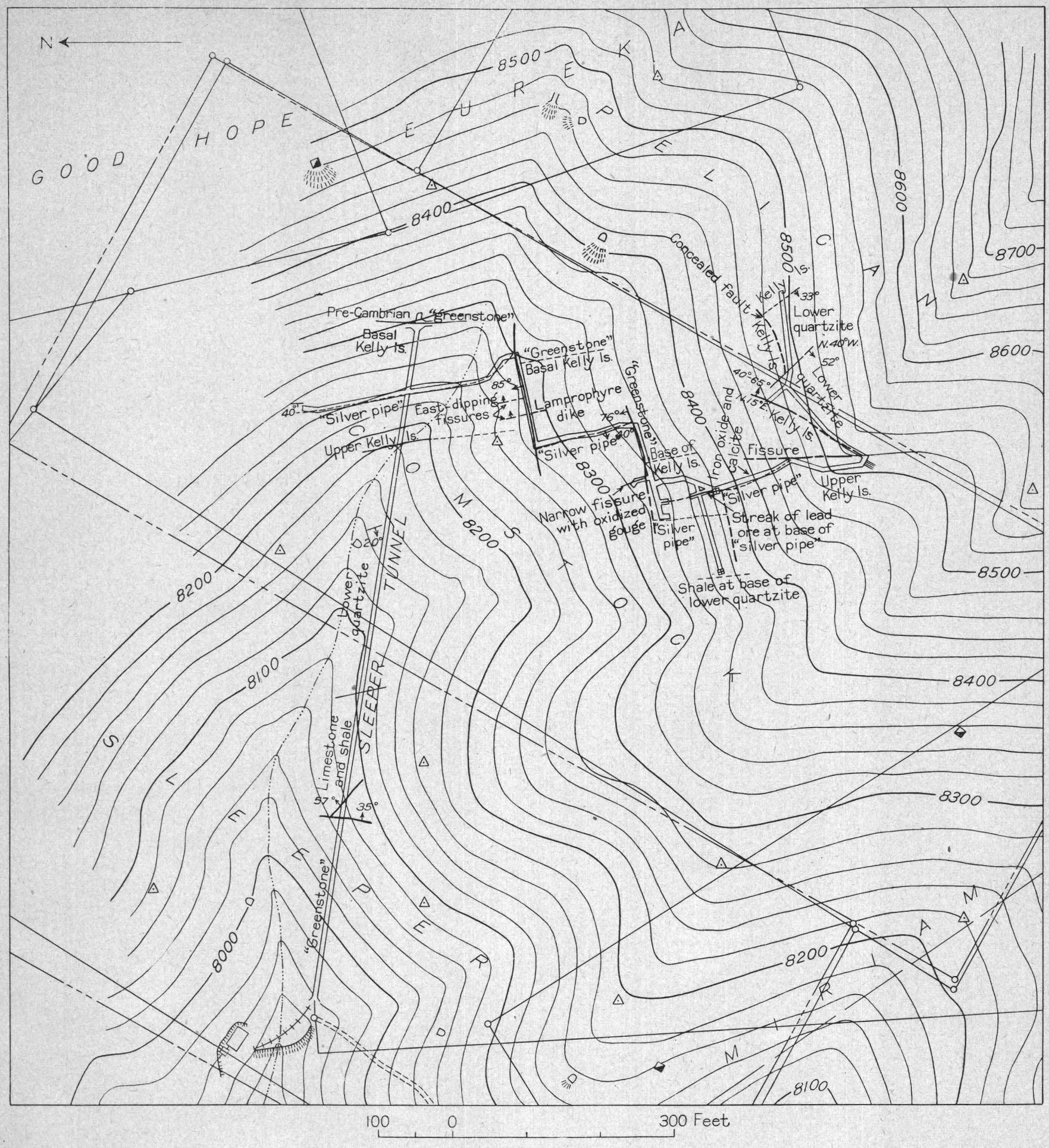

FIGURE 26.-Geologic map of the Sleeper tunnel workings. 
argentite (?), which have been described in the chapter on mineralogy.

The Morning Star group is just north of the Iron Mask. It was not accessible to us, but 1 ton of dry ore containing 0.5 ounce of gold and 18 ounces of silver was reported from it in $1922 ; 13$ tons containing a total of 5.8 ounces of gold and 3 ounces of silver was reported in 1934; 71 tons containing 58.0 ounces of gold, 32 ounces of silver, 248 pounds of copper, and 1,049 pounds of lead in 1935; and 34 tons containing 28.2 ounces of gold, 11 ounces of silver, and 37 pounds of copper in 1936.

\section{MINES NORTH OF THE NITT MONZONITE STOCK}

Mines and prospects north of the Nitt monzonite stock are few, small, and scattered, and only onethe Hardscrabble-has had any considerable production.

\section{HARDSCRABBLE MINE}

The Hardscrabble mine is situated on the upper west slope of the Magdalena Range, 4,000 feet east of Hardscrabble Camp. Although it is one of the older mines of the district, only incidental mention of it has been found in historical accounts of the district. It was owned by the Copper Ridge Mining \& Development Co. in $1915-16$ and by I. S. Mactavish of Magdalena in 1928.

No figures showing its earliest output are available. In 1905 the ore shipped was claimed to average 4 percent of copper, 30 percent of lead, 44 percent of zinc, and 12 ounces of silver and 0.05 ounce of gold to the ton. ${ }^{87}$ Its recorded intermittent output from 1909 to 1920 is shown in the accompanying table. The copper ores mined during this period were comparatively rich in both copper and silver, but the lead and zinc-lead ores were typically low in silver. No record of shipments before 1909 is available.

Ore shipped from Hardscrabble mine, $1909-39,{ }^{1}$ and its gross metal content

[Data collected and classified by C. W. Henderson, Geological Survey and Bureau of Mines, U. S. Department of the Interior, Denver, Colo.]

\begin{tabular}{|c|c|c|c|c|c|c|c|}
\hline \multirow{2}{*}{ Year } & \multicolumn{2}{|l|}{ Ore } & \multirow{2}{*}{$\begin{array}{c}\text { Gold } \\
\text { (ounces) }\end{array}$} & \multirow{2}{*}{$\begin{array}{l}\text { Silver } \\
\text { (ounces) }\end{array}$} & \multirow{2}{*}{$\begin{array}{c}\text { Copper } \\
\text { (pounds) }\end{array}$} & \multirow{2}{*}{$\begin{array}{c}\text { Lead } \\
\text { (pounds) }\end{array}$} & \multirow{2}{*}{$\begin{array}{c}\text { Zinc } \\
\text { (pounds) }\end{array}$} \\
\hline & Class & Tons & & & & & \\
\hline 1909 & Copper, sulphide & 4 & & & 655 & & \\
\hline \multirow[t]{2}{*}{1916} & $\left\{\begin{array}{l}\text { Copper sulphide } \\
\text { Zinc, sulphide and } \\
\text { oxidized. }\end{array}\right.$ & $\begin{array}{r}141 \\
72\end{array}$ & 1.00 & 1,651 & 15,542 & 7,931 & \\
\hline & Copper, oxidized..- & 112 & & 968 & 15,336 & & 43,802 \\
\hline${ }^{2} 1917$ & $\left\{\begin{array}{l}\text { Lead sulphide } \\
\text { Zinc-lead sulphide }\end{array}\right.$ & $\begin{array}{r}126 \\
43\end{array}$ & & 376 & & 30,388 & 9,100 \\
\hline \multirow[b]{2}{*}{1918} & Copper, oxidized & 107 & .30 & 2,536 & 16,298 & $\begin{array}{r}5,954 \\
10,277\end{array}$ & 22,620 \\
\hline & $\left\{\begin{array}{l}\text { Zinc-lead sulphide } \\
\text { Zinc sulphide..... }\end{array}\right.$ & $\begin{array}{l}85 \\
51\end{array}$ & & 270 & 1,012 & 1,350 & 50,181 \\
\hline 1919 & Copper sulphide. & 48 & & 1,056 & 8,160 & & \\
\hline \multirow[t]{2}{*}{1920} & Dry silver & $\begin{array}{r}60 \\
268\end{array}$ & $\cdots$ & 2,024 & 8,178 & 14,231 & 42,000 \\
\hline & Total & 1,117 & 1.30 & 8,944 & 65,181 & 70,111 & 190,567 \\
\hline
\end{tabular}

1 Mine 1910-1.5 changed ownership twice: some assessment work done. Idle 1921-39. 2. Assays of crude ore reported in 1917 ranged as follows: Copper ore from 8.2 to 9.8 ounces of silver to the ton and 8.30 to 16.47 percent of lead; zinc-lead ore, 6.9 to 10.77 of lead and 26.3 percent of zinc.

${ }^{87}$ Stevens, H. J., Copper handbook, vol. 5, p. 456, 1905.
We are indebted to Mr. Oscar Redemann, treasurer of the company in 1916, for a map of the mine made by $\mathrm{H}$. W. Kitson and for other information. The mine (pl. 38) is opened by two old glory holes separated by an interval of 25 feet and by three tunnels, the upper two of which connect with an inclined tramway that extends about one-third of the distance down to the camp. The camp has been deserted for many years, and operation of the mine has been intermittent.

The glory holes and the upper or No. 1 tunnel are in a large lenticular inclusion of metamorphic Kelly limestone in Tertiary (?) granite. The exposed contacts all show some effects of movement. The limestone mass is about 1,400 feet long, and as much as 150 feet wide, and extends northeastward beyond the crest of the range; but mining has been confined to its southwest part. The limestone beds in the eastern part of the big glory hole strike N. $65^{\circ} \mathrm{E}$. and $\operatorname{dip} 60^{\circ} \mathrm{SE}$., forming an acute angle with the boundary fault, which strikes N. $30^{\circ}$ E. and dips $60^{\circ}-70^{\circ}$ SE., and a nearly right angle with a set of fissures along which the southern ore shoots lie. For the most part they have been converted into light gray, coarse-grained marble, but some beds have been replaced by garnet and others by wollastonite. No cherty beds characteristic of the upper Kelly limestone were seen at the big glory hole, although they may be represented by wollastonite beds; but a bed resembling the metamorphosed "silver pipe" bed lies about in the middle of the exposed mass, which is 60 feet wide. The small glory hole has exposed beds containing quartz grains typical of the basal Kelly beds. These quartzose beds happen to lie along the northwest edge of the limestone mass. The northwest edge near the crest of the range is a dark greenish gray epidotized rock cut by white rock that contains small tourmaline crystals. This rock is bounded conformably on the southeast by garnetized limestone; and its position therefore suggests that it represents metamorphosed, impure, basal beds of the Kelly limestone.

The granite has been considerably altered to sericite, chlorite, and pyrite along faults and fissures. It is cut by a dike or linear group of dikes of white rhyolite, which trend S. $65^{\circ} \mathrm{E}$. up the slope from the portal of the lowest or No. 1 tunnel to the north wall of the larger glory hole.

The southeast boundary fault or crushed zone is not exposed in accessible underground workings. The principal fissure or fault in the mine trends S. $70^{\circ} \mathrm{E}$., dips $50^{\circ}-60^{\circ} \mathrm{NNE}$., and evidently cropped out in the area now represented by the smaller or northern glory hole. It has been followed by No. 2 tunnel and is also exposed 125 feet lower in No. 3 tunnel. It has not produced any conspicuous offset in the limestone, but the underlying granite along it has been considerably crushed and altered. Its granite hanging wall has also been cut by intersecting minor fissures of northeast and 
northwest trend, and the principal ore shoot reached by No. 2 tunnel is in this fractured granite. Other fissures trend northeast and essentially coincide with the bedding of the limestone. They are most conspicuous in the workings of No. 1 tunnel, where they are associated with a transverse fault of north-northwest trend and east-northeast dip, and along the southeast corner of the large glory hole.

The ore bodies for the most part have replaced limestone, but they have also replaced shattered granite beneath the limestone. The main ore shoot cropped out near the southwest end of the limestone; and remnants of its gossan, which contains considerable plumbojarosite, can be seen at the west end of the larger glory hole. The glory hole is so caved that its structural details are concealed, but the limestone along its west half has been largely replaced by honeycombed quartz; the "silver pipe" bed forms the hanging wall. The limestone between the "silver pipe" bed and the southeast boundary of the inclusion has not been conspicuously mineralized. The smaller circular glory hole is on the main cross fault. Its bottom connects eastward with an old stope that extends northeastward for at least 60 feet and has an average width of about 35 feet. The stope in granite opened by No. 2 tunnel is on the hanging-wall side of the main fault and directly down the dip of the fault from the glory hole and the connected stope. Boulders of limestone on the floor of the stope in granite show that some connection has been made with the overlying stopes. The stope in granite, which follows intersecting minor fissures of northeast and northwest trend, is very irregular in outline and contains pillars of pyritized granite.

The northern ore bodies, all of which cropped out, were worked through No. 1 tunnel. They are all in limestone and lie along fissures or bedding planes of southeasterly dip. The western body, or No. 1 vein, has a footwall of granite; and the eastern body, or No. 3 vein, has a hanging wall of granite. The ore shoot on the middle, or No. 2 vein, which extends upward to the southwest and reaches the surface, is also floored at least in part by a narrow mass of granite that apparently crosscuts the limestone.

No. 3 tunnel has evidently been driven to explore the ore zone at greater depth, but its breast in 1916 was still in granite and considerably west of the projected positions of the westernmost ore bodies.

The ore mined was mostly oxidized and rich in lead and silver, with some oxidized zinc ore in typical relationship; but mixed sulphide ore was found in the lowest part of the No. 3 vein in No. 1 tunnel and in the ore in granite in No. 2 tunnel. The sulphide ore was similar to that in the Graphic-Waldo and Kelly mines; and, like that ore, it was accompanied hy magnetite-specularite aggregates, which formed casings around at least one of the stopes. The shoots in lime- stone are accompanied by quartz, garnet, epidote, chlorite, and calcite, whereas those in granite are accompanied by quartz, sericite, and chlorite. The walls of oxidized ore bodies contain considerable brown iron oxide and green copper carbonate, and the walls of the stope in granite were coated with conspicuous amounts of blue copper sulphate. Some black-stained ore from an inclined winze along the main fault was said to have unusually large contents of copper and silver.

\section{ANCHOR MINE}

The Anchor mine is at the end of the road in Anchor Canyon, 11/4 miles east-northeast of Hardscrabble Camp. It was opened about 1885 and is said to have produced rich silver ore with a total value of about $\$ 60,000$, but it was abandoned about 1893 , when the price of silver declined. It was reopened in $1924 \mathrm{by}$ the C. \& M. Ores Co., of Magdalena, which assumed control, through lease and ownership, of seven claims with a total area of about 125 acres. This company operated the mine intermittently until 1926 and treated the ore in a mill designed for both gravitative concentration and flotation. A lead-silver concentrate was made, and about 20 tons of concentrates was shipped to the smelter in El Paso, Tex., but zinc blende went into the tailings. Operations ceased in 1926.

The workings (fig. 27) consist of an inclined shaft, from which two short levels have been driven, and a tunnel 900 feet long with an average trend of about S. $30^{\circ}$ E., from which a raise connects with the shaft whose collar is 125 feet above tunnel level. The tunnel and the lower part of the shaft were flooded in 1929, and the present description is based mainly on a report by J. A. Weir, which Mr. Ian E. Mactavish, of the C. \& M. Ores Co., kindly placed at our disposal.

The country rock is coarse-grained Tertiary (?) granite. It is cut by several dikes of lamprophyre and white rhyolite in the vicinity of the mine.

The ore occurs in a vein along a fault whose irregular walls are slickensided and lined with gouge. The strike of the vein is about S. $30^{\circ} \mathrm{E}$. and the average dip $50^{\circ} \mathrm{NE}$. It can be traced on the surface with interruptions, and its course to the south of the shaft is marked by prospect pits. Its average thickness is about 4 feet and its maximum thickness 6 feet. Its ore shoots are shown in figure 27 . Its ore is somewhat banded, in general quartz forming the outer parts and barite and fluorite the middle. Vugs are numerous, and some are lined with black manganese oxide. The quartz layer along the footwall is more massive and continuous than that on the hanging wall.

Between level 1 and the surface the ore was oxidized. Its content of gold and silver was rather constant, averaging about 0.02 ounce of gold and 12.5 ounces of silver to the ton. A little lead and zine were present.

The ore minerals in the sulphide ore are zine blende, 

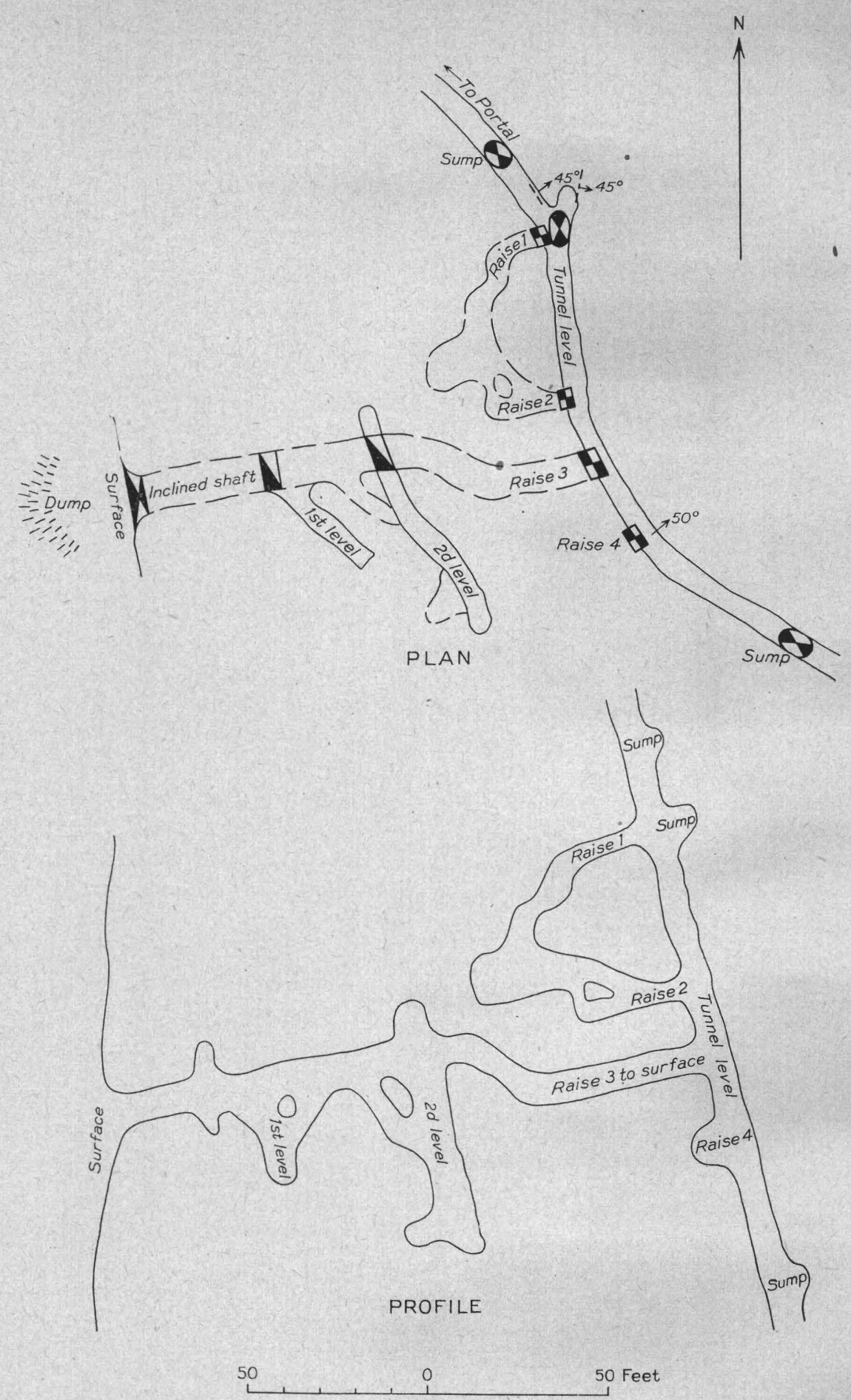

Figure 27.-Plan and profile of part of the Anchor mine, surveyed by J. A. Weir for the C. \& M. Ores Co. 
GEOLOGICAL SURVEY

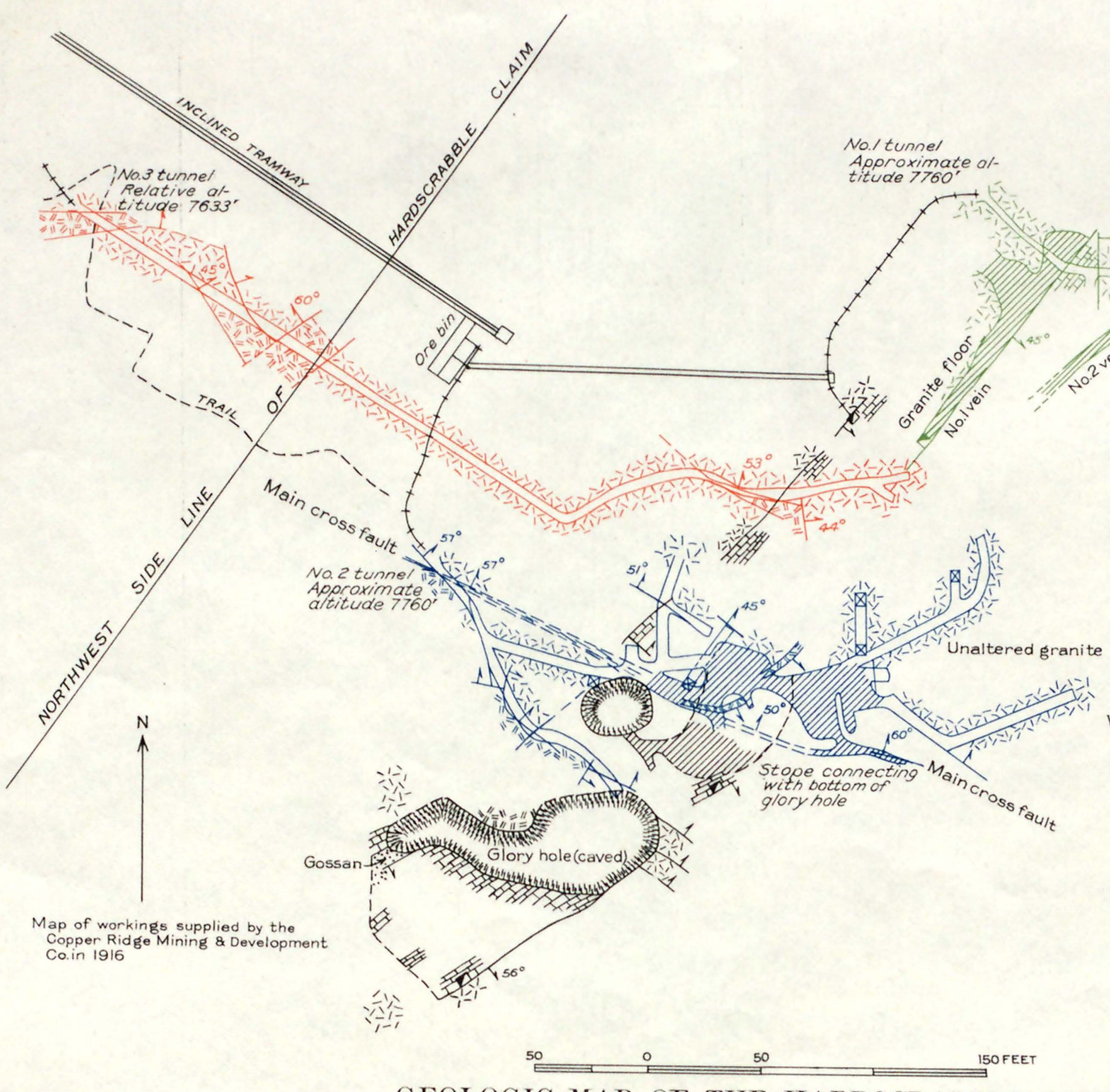

PROFESSIONAL PAPER 200 PLATE 38 
galena, and native silver, accompanied by small amounts of pyrite and chalcopyrite and a negligible quantity of gold. The silver, according to E. H. Wells, then president of the New Mexico School of Mines, ${ }^{88}$ cccurs chiefly as wire silver in the seams and crevices of both sulphides and gangue. It is apparently the result of some local enrichment in the transition zone between oxidized ore and sulphide ore. The crude ore mined contained about 3 percent of zinc and 2 percent of lead, and, in spite of evident enrichment, only 0.015 ounce of gold and 6.5 ounces of silver to the ton. Smelter returns on the two shipments of concentrates were as follows:

\begin{tabular}{|c|c|c|c|}
\hline Weight (tons) & $\begin{array}{l}\text { Gold (ounce } \\
\text { to the ton) }\end{array}$ & $\begin{array}{c}\text { Silver (ounces } \\
\text { to the ton) }\end{array}$ & $\begin{array}{c}\text { Lead } \\
\text { (percent) }\end{array}$ \\
\hline $\begin{array}{l}\text { 4. } 25 \\
8\end{array}$ & $\begin{array}{r}0.07 \\
.05\end{array}$ & $\begin{array}{l}56.8 \\
65.3\end{array}$ & $\begin{array}{l}41.6 \\
50.3\end{array}$ \\
\hline
\end{tabular}

Assays of the tailings showed that practically all the zinc, about half of the lead, and 60 percent or more of the silver ( 4 ounces to the ton) were lost.

\section{VINDICATOR MINE}

The Vindicator mine, on the east side of Hardscrabble Valley, northeast of Hardscrabble Camp, consists of nine claims that cover about 150 acres. These claims were purchased by the Grubnau Chemical Co. in 1924-27. They are an elongate group 7,400 feet long and from 600 to 1,200 feet wide. The mine was studied in 1929 by Koschmann, in company with Mr. V. Carl Grubnau, to whom we are indebted for much of the information.

The property is underlain by Tertiary (?) granite and Madera limestone, but the limestone is so extensively covered with alluvium, which is as much as 25 feet thick, that detailed study of the bedrock is impossible at the surface. Limestone is exposed only along the low ledge that adjoins the granite south of the shaft and in the arroyo southwest of the shaft. The limestone in the arroyo contains thin-bedded and thickbedded rock characteristic of the lower and upper parts of the Madera limestone. The thin-bedded member is considerably epidotized. The low ledge adjoining the granite is largely bleached and recrystallized and may at first be mistaken for metamorphosed Kelly limestone.

A dike of white rhyolite with steep easterly or vertical dip lies along the contact between granite and limestone and evidently fills a longitudinal fault along which some renewal of movement has taken place since the dike was intruded. Two transverse faults are indicated by offsets in the thick-bedded limestone-one, about 350 feet south of the shaft, between the two

\footnotetext{
${ }^{88}$ Oral communication.
}

southern exposures shown on plate 2, and another, based in part on underground evidence, between the mine workings and the northern exposure.

The Vindicator shaft, on the Vindicator No. 1 claim, is shown on plate 2 and figure 28. It is vertical for 100 feet and then inclined $45^{\circ} \mathrm{W}$. for an additional vertical depth somewhat more than 100 feet. Levels have been driven at depths of $65,100,150$, and 200 feet, the 150 -foot level being driven from a winze that connects the 100 - and 200 -foot levels along the rhyolite dike. The mine is thoroughly dry, in contrast to the shallow shafts in monzonite 3,500 feet to the south, where the water level is at least 200 feet higher than the collar of the Vindicator shaft. All the levels extend eastward to the rhyolite dike, which is 40 feet from the shaft on the 65 -foot level and 70 feet from it on the 200-foot level. Only the 65- and 200-foot levels extend appreciably west of the vertical part of the shaft.

The workings are entirely in thick-bedded limestone, which is thoroughly fractured and shows no distinct bedding planes. None of the limestone is bleached cr noticeably recrystallized, which is in contrast to the outcrops of metamorphic limestone south of the shaft.

Sulphide ore has replaced the limestone along the longitudinal fault and has the rhyolite dike for a hanging wall. The limestone footwall is very little shattered. The ore has been exposed on the 100-, 150-, and 200 -foot levels, as shown in figure 28. Two carloads, mined between the 100- and 200-foot levels and totaling 76 tons, were shipped to the El Paso smelter in 1929. Their assay contents were as follows:

Assay contents of sulphide ore from Vindicator mine

\begin{tabular}{l|r|r|r|r|r|r}
\hline & Tons & $\begin{array}{c}\text { Gold } \\
\text { (ounce to } \\
\text { the ton) }\end{array}$ & $\begin{array}{c}\text { Silver } \\
\text { (ounces to } \\
\text { the ton) }\end{array}$ & $\begin{array}{c}\text { Lead } \\
\text { (percent) }\end{array}$ & $\begin{array}{c}\text { Copper } \\
\text { (percent) }\end{array}$ & $\begin{array}{c}\text { Zine } \\
\text { (percent) }\end{array}$ \\
\hline Car 1 & 36 & $\begin{array}{c}0.015 \\
\text { Car 2 }\end{array}$ & 2.96 & 7.45 & 1.22 & $\begin{array}{r}13.8 \\
(1)\end{array}$ \\
\hline
\end{tabular}

1 Not determined.

Before the present ownership, some lead ore had been shipped from the Vindicator No. 8 (formerly the Jupiter) claim, but nothing is known of its quantity or metal content.

A considerable quantity of spongy brown iron oxide has been exposed. The principal exposure, which has been followed by the shaft for more than 100 feet from the surface, has an east-west extent of more than 115 feet on the 65-foot level. A second exposure, at the bottom of the shaft, extends more than 50 feet in both north-south and east-west directions; and a third, on the 150 -foot level, extends along the footwall of the vein for at least 50 feet and is as much as 25 feet in width. Assays of the iron oxide, according to $\mathrm{Mr}$. Grubnau, showed the following contents of lead and zinc: On the 100 -foot level, across the south side of the 


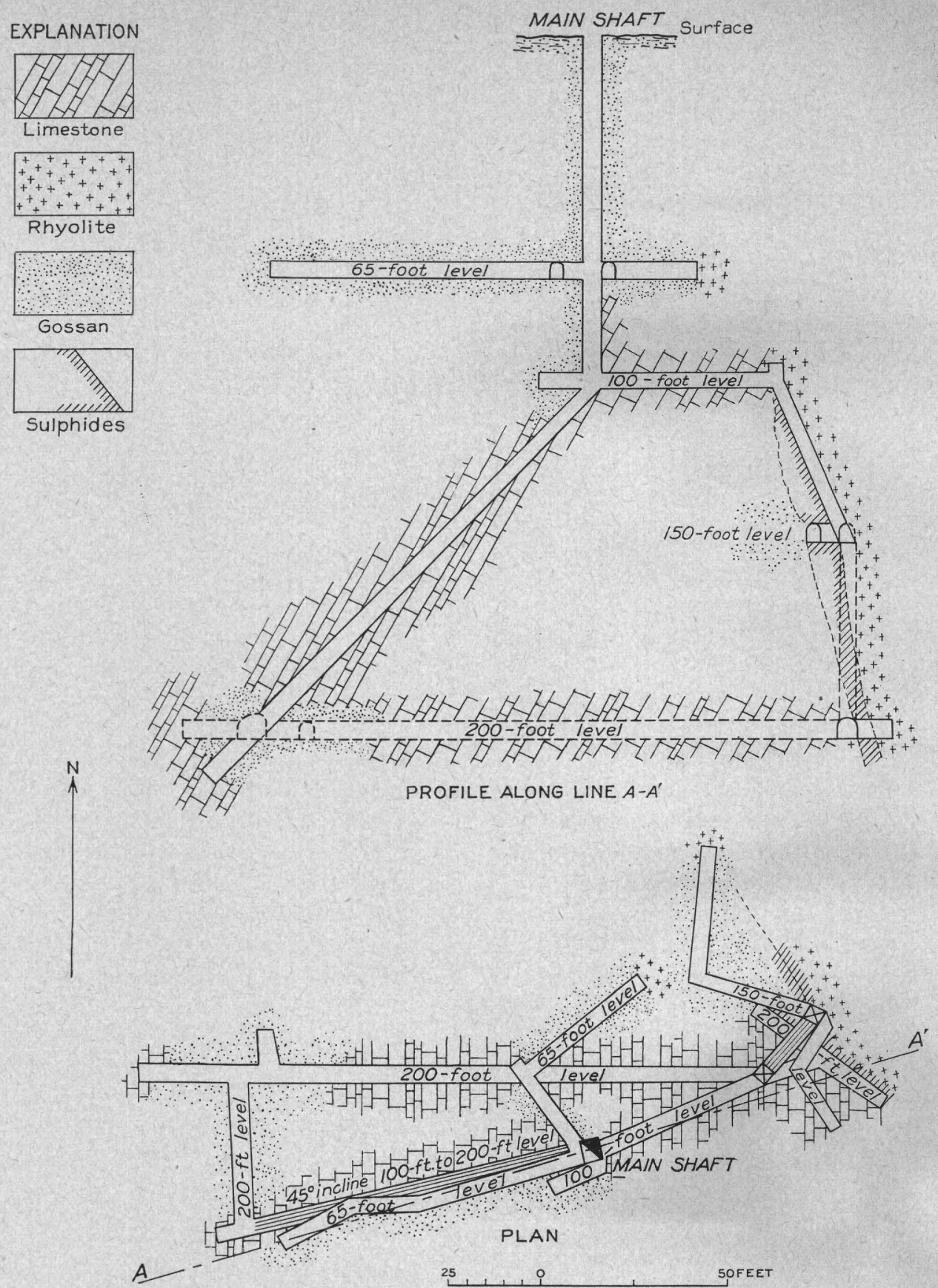

FIGURw 28.-Geologic map of the Vindicator mine and cross section looking S. $77^{\circ}$ W. By V. Carl Grubnau, with minor modifications.

shaft, 0.3 percent of lead and 0.8 percent of zinc; average on the 150 -foot level north of the winze, 1.0 percent of lead and 2.1 percent of zinc; grab sample at the crosscut north of the shaft, on the 200 -foot level, 0.8 percent of lead and 5.1 percent of zinc.

A chemical analysis of a sample submitted by $\mathrm{Mr}$. Grubnau in 1935 is quoted on page 116. This sample contained considerable barite and quartz and was evidently similar to the gangue of the main vein, but the iron oxide examined by us underground appeared for the most part to have resulted from the direct replacement of limestone. The spongy character and the local "box-work" structure of the iron oxide give it some resemblance to the gossan of leached zinc ore; but similar structure has been produced by the direct replacement of limestone by brown iron oxide along grain boundaries and minute fractures followed by the leaching of any unreplaced limestone.

The amount of iron oxide along the fault is too large to be interpreted solely as a gossan resulting from the partial replacement of limestone by zinc sulphide ore and its subsequent leaching, although such a process may have contributed to it. The source of the iron, therefore, is not clearly understood, but it was presumably above the present erosion surface in pyritized rock similar to the bleached volcanic rock 
to the southwest on Stendel Ridge. Volcanic rocks, shown in figure 2, undoubtedly once overlay the rocks of the Vindicator mine. They may have been strongly pyritized in the vicinity of the intersecting faults in and near the mine; and, together with the underlying limestone, they may also have been impregnated with small amounts of lead and zinc, which are reflected in the assays quoted above. According to this interpretation the iron oxide is not a reliable guide to zinc sulphide ore. Regardless of its significance, however, evidence in the district as a whole would favor exploration of the fault intersections south of the present workings. Ore bodies along such intersections elsewhere in the district have been of small to moderate size compared with those in the Kelly limestone. Because of the prevailingly steep dip of the Madera limestone, as shown by surface exposures, the Kelly limestone may be 1,000 feet or more below the present bottom of the mine, and ground-water level is doubtless considerably above it.

\section{OUTLYING PROSPECTS}

\section{CAVALIER CLAIM}

The Cavalier claim, owned in 1916 by the late E. A. Clemens, is located on a low spur due north of Magdalena Mountain and about half a mile south of the town of Magdalena. The vein zone on the claim is close to the vertical contact between a dikelike mass of monzonite and the volcanic rocks of Magdalena Mountain and is exposed in a shallow pit about 50 feet south of the shaft. The contact strikes northward and is closely paralleled by the vein zone, which is exposed for a width of more than 24 feet and consists of a set of closely parallel quartz veins. The exposed part of the zone cuts the volcanic rock, but the vein, according to $\mathrm{Mr}$. Clemens, could not be traced up the steeper part of the mountain. The quartz is gray and massive and contains a few streaks of barite. In some places it contains a sprinkling of zinc blende and galena and in other places a sprinkling of pyrite. The zone is somewhat shattered, especially near its east wall, and is partly leached and stained by iron and manganese oxides and green copper carbonate. According to Mr. Clemens assays of samples containing blende and galena showed some silver, and gold colors could be obtained from almost any part of the vein; but the total metal content evidently had not encouraged more than intermittent prospecting.

\section{MAGNETITE ON MEDLEY RANCH}

The low rolling ground on the Medley ranch west of the town of Magdalena consists largely of rhyolite and probably andesite, and the flat-topped hills in the area are capped by a brown weathering vesicular basalt. On the west and southwest slopes of one of these hills are thinly scattered fragments of magnetite used as flux in the old South Camp smelter in 1882-83, but no magnetite was ever found in place. One small fragment, noted during a brief visit in 1916, consisted of magnetite in contact with massive vein quartz. This association of magnetite with volcanic rocks is too unusual for an explanation of it to be offered without an opportunity to study the magnetite in place.

\section{HEISTER PROSPECT}

The Heister prospect is on the Mary Magdalena claim in low rolling ground about a mile north of the town of Magdalena. The surface around the prospect is covered with rhyolite and andesite debris, and the vein may be near the contact between the two rocks. The vein trends north and is said to be in a mineralized belt that extends a mile farther north. The vein material seen in 1916 consists of quartz with irregularly distributed barite and galena, but no assay record of it was obtained. Vanadinite and wulfenite were said to be found with it occasionally.

\section{FUTURE OF THE DISTRICT}

Comments regarding ore reserves and future developments in the district have been scattered at opportune places throughout this report and are summarized in the following paragraphs.

When a district reaches a dormant stage, after having actively produced large quantities of oxidized and sulphide ore as long as the Magdalena district has, its chances of substantial recovery, to the conservative mind, seem remote. It would be rash to predict that the Magdalena district can never attain its former activity, but a consideration of its known reserves and of related geologic conditions afford a basis for some encouragement, particularly along the main fault zone of the district, whenever the markets for zinc and lead justify development. Conditions along other zones are such that discouraging factors may outweigh any that are encouraging.

\section{MAIN ORE ZONE SOUTH OF NITT STOCK}

The cessation of milling in 1927 is said to have left a considerable quantity of low-grade sulphide ore in the Nitt and Graphic-Waldo mines without adequate means of treatment. As a large tonnage of ore was mined and milled in the Graphic-Waldo mine during the 10 years after our study, we have no estimate of the remaining tonnage or its grade. The main ore zone, as well as its east branch in the old Graphic workings, has been so thoroughly explored that no great amount of shipping ore can be expected from it, although small operations by lessees may continue indefinitely. The same inference applies to the Kelly mine. A systematic search in the Sandia and Madera formations along intersections of mineralized fissures in the main ore zones of these mines may disclose ore bodies similar to those mined through the Ida Hill and Cimarron tunnels. No 
information regarding tonnage and grade of ore from these workings is available, so no ratio of the costs of exploration and mining to the value of production can be expressed.

Further developments in the Juanita and South Juanita mines may disclose further small ore shoots, but as the variety of ore already mined is characteristic of that deposited rather far from its source and as no promising structural conditions have been noted that would suggest the presence of undiscovered ore shoots, no great contribution to output can be expected from these mines, although the Kelly limestone west of the west fault in the South Juanita has yet to be explored.

The composition of the vein along the Mistletoe fault in the Mistletoe tunnel indicates that it is nearer to its source of supply than are those of the Juanita and South Juanita mines. Its position in shale suggests that ore shoots along it may be small, and the amount of water present is an obstacle to development; but the possibility that the underlying Kelly limestone, capped by shale, may contain substantial ore bodies in shattered ground west of the fault is worthy of consideration. The difficulty in determining the exact stratigraphic position of the shale in the tunnel prevents an estimate of the depth to the Kelly limestone, but drilling may determine the depth and also the presence of appreciable quantities of ore. No deep development work has been undertaken between the Mistletoe and Linchburg tunnels, but the junctions of the Mistletoe fault with the Young America and Linchburg faults in the intervening area suggest favorable structural conditions; furthermore, the south-southeast trends and steep dips of the two faults are about parallel to that of the Kelly-Graphic fault to the north and suggests that the Kelly limestone along their west walls may have been as permeable as it was in the Kelly mine.

The Linchburg ore body with its accompanying hightemperature minerals along the Young America fault implies a center of mineralization nearby. Lack of data on development through the Linchburg tunnel prevents an expression of opinion regarding the strength of this center as compared with those of the Graphic-Waldo and Kelly mines, but the character of the ore seen by us lends support to the idea that Kelly limestone along the west side of the fault is worthy of further attention whenever the price of zinc and lead are sufficient to offset the costs of mining and milling. The shallow ore mined along the Grand Ledge fault, which is essentially a southern continuation of the Young America fault, encourages deep exploration of the Kelly limestone farther south. In short, the Kelly limestone along the main fault zone south of Chihuahua Gulch offers the best outlook for ore reserves in the district. The Linchburg tunnel affords drainage and haulageway at an altitude of about 8,050 feet, but drilling may show that a deeper outlet is desirable, primarily for drainage but also as a haulageway for a large amount of ground. Small ore bodies may be found above the Kelly limestone, but will hardly justify exploration unless incidental to the exploration of the Kelly limestone.

\section{AREA EAST OF MATN ORE ZONE}

In the area east of the main ore zone it is most convenient to trace conditions from south to north. East of the Grand Ledge, Young America, and Mistletoe faults the Kelly limestone is either at or near the surface and has been rather thoroughly explored. The ore found in it was evidently formed by solutions that rose through the shaly ground along these faults and became dispersed along minor faults. Other ore bodies similar to those in the Black Cloud mine may await discovery, but their expected extent and grade do not justify much outlay for exploration and development.

North of Chihuahua Gulch the east-dipping Germany fault was too tight to permit appreciable circulation of ore-forming solutions, and the small showings of ore along minor faults east of it in the accessible part of the Germany mine are discouraging. A greater output has been reported from the Germany mine than can be accounted for by these showings, and it is inferred that ore along minor faults was mined through the upper workings. The ore mined in the Grand Tower mine and in the Sampson claim also proves that the much-faulted ground east of the Ge:many fault was permeated by ore-forming solutions, but the character of the ore seen indicates remoteness from any center of mineralization and the improbability of finding sufficiently continuous ore shoots to justify costly exploration. It is a reasonable inference that the ore in this faulted ground was former by solutions that rose from the Kelly center, wormed their way through the pre-Cambrian block between the Kelly-Graphic and Germany faults or along cross fractures beneath the down-faulted shaly ground just north of it, and dispersed along the minor faults.

One cannot help wondering whether ore shoots of considerable size may exist in Kelly limestone beneath this down-faulted shaly area, but the facts that the ore shoots in the Kelly mine dwindled in this vicinity, where the associated faults curved from a northnorthwesterly to a northerly trend, and that faults east of the shale area have a northerly trend as well as dominantly low easterly dips discourage the expectation of anything more than small scattered shoots, some of which may be found along the transverse fault zone that connects with the Tip Top and Key ground.

The ground developed through the Sleeper tunnel north of this transverse fault zone has proved to be barren, and prospects still farther north around Oak Spring have been unproductive although they and the 
associated metamorphic rocks show the effects of considerable mineralization. One of the faults just south of Oak Spring strikes north-northwest, with downthrow on the west, and is therefore similar in attitude to the faults along the Kelly ore body. The fact that the Sandia strata along this and neighboring faults have been weakly mineralized suggests that ore bodies may be found in the underlying Kelly limestone. The weathered metamorphic shale effectively conceals evidence of transverse or other minor faulting that might help to localize ore shoots in this small area, and the suggestion of ore therefore is very speculative.

\section{WEST ORE ZONE}

The west ore zone, along the Waldo fault, has been explored in the westernmost parts of the GraphicWaldo and Kelly mines, but no information has been obtained regarding the quantity or grade of ore found. Considerable work was done on the east side of the fault in the Graphic-Waldo mine, and the fact that the mine was unwatered in 1928 implies the presence of an ore reserve that is awaiting more favorable market conditions. Workings in the Kelly mine reached the Kelly limestone on the east side of this fault but were soon abandoned. This fact, together with the interruption of the Waldo fault by one or more transverse faults between the two mines suggests that little mineralization took place along this zone as far south as the Kelly mine. The thickness of volcanic rock on the west side of the Waldo fault is roughly estimated to be 1,500 feet, and the vertical depth to its base close to the fault should accordingly be 2,000 feet or more, if its dip of $45^{\circ}-50^{\circ}$ persists. If the underlying Madera and Sandia formations are as thick here as they are east of the fault, they should increase the vertical depth to the Kelly limestone by another 1,500 feet. The total depth of 3,500 feet, together with the cost of pumping, seems prohibitive.

A fault equivalent to the Waldo fault in general position and attitude separates pink rhyolite and red rhyolite from purple andesite in the foothill area south of Kelly. Small veins along or near the fault have been opened by shallow prospects, but the Iron Mask and Morning Star claims at South Camp are the only ones, so far as known, that have been at all productive. The Iron Mask vein has much the same structural and special relations to the Linchburg center of mineralization as the vein along the Waldo fault has to the Graphic-Waldo center. It is reasonable to expect ore shoots similar to the Iron Mask at intervals along the fault zone, but the fact that the Iron Mask mine has been so little developed since the early ' 80 's implies that profitable mining below the shallow ground-water level is unlikely. The depth to underlying sedimentary rocks cannot be closely estimated because of unconformities in both the volcanic and sedimentary series. Rough calculation would place the top and bottom of the Madera limestone at depths of 1,000 and 1,500 feet and the top of the Kelly limestone at a depth of 2,300 feet or more. Whether the Kelly limestone, however, is appreciably mineralized along the fault is uncertain, because it is not known whether the shallow ore along the fault zone was introduced from a local deep center of mineralization or by solutions that worked their way upward and westward from the Linchburg center.

The zone of mineralization still farther west indicated by the bleached rhyolite on the isolated low hill $11 / 2$ miles west of Kelly is of little interest, as the evidence of mineralization other than bleaching is weak and the depths to strata that have been productive elsewhere are too great and obscure to encourage exploration.

\section{ORE ZONES NORTH OF NITT STOCK}

Deep exploration in the faulted ground along Hardscrabble Valley is entitled to more consideration than it has received, as the evidence of sulphide deposition both in the monzonite and in the Madera limestone of the Vindicator mine justify the inference that the Kelly limestone may contain ore bodies of considerable size. The ground-water surface, furthermore, may be so deep that underground drainage would be feasible and pumping from the Kelly limestone would be correspondingly reduced.

There is little more to expect from the vicinity of the Hardscrabble mine, as ore deposition in appreciable quantity has been restricted to the limestone inclusion in Tertiary (?) granite. The recent effort to work the Anchor mine offers little encouragement for prospecting in the granite area.

\section{GRANITE MOUNTAIN AREA}

Although the presence of magnetite and serpentine near the southeast base of Granite Mountain implies a local center of mineralization, the surrounding shaly and volcanic rocks and the small size and low grade of veins exposed by small prospects in them offer little encouragement to further exploration. The prevailingly steep dip of the formations renders the depth to the Kelly limestone too great to encourage sinking to it. Farther east, where the Kelly limestone is exposed, the evidence of mineralization is weak and the best that could be expected by further exploration would be small ore bodies with quartz-barite gangue. The water level in the area is so shallow that no great amount of oxidized or enriched ore seems likely. 



\section{INDEX}

A Page

Abo sandstone, description of

fossils in

near Patterson Canyon, section of

Abstract

Acknowledgments for aid

Actinolite, occurrence of

Alluvium, occurrence of

Alteration of rocks and ores

Ambrosia mine, features of

Analyses of rocks and ore

Anchor mine, description of

Andalusite, occurrence of

Andesite, analyses of .

occurrence and character of

Anglesite, occurrence of.

Antigorite, occurrence of -

Antlerite, occurrence of

Aplite dikes, description of

Aragonite, occurrence of

Argentite (?) occurrence of

Argillite, character and occurrence of

Augite andesite, description of -

20-22

$-21-22$

21

$1-3$
$3-4$

100

22

$\begin{array}{r}156 \\ \hline\end{array}$

$11,31,39,44,92,93,116$

159-161

99

31

$25,27,28-31$, pls. $10,11,12, A$

97

101

96

Augite andesite, description of

$40-41$, pl. 2

103

98
$7-8$

$35-36$, pl. 13

Azurite, occurrence of

B

Banded rhyolite, description of

Barite, occurrence of

Bibliography .

Biotitization of pre-Cambrian rocks

Black Cloud mine, description of

ore mined at.

Bornite, occurrence of

27-28

103

4-5

12-13

141-143

142

C

Cadmium mineral, greenockite, occurrence of

Calcite, occurrence of

Carboniferous system, description of

Cavalier claim, features of

Cavern mine, description of

Celadonite, occurrence of.

origin of

Cerargyrite, occurrence of

Cerussite, occurrence of

Chalcanthite, occurrence of

Chalcocite, occurrence of

Chalcophanite, occurrence of

Chalcopyrite, occurrence of

Chlorite, occurrence of

Chrysocolla, occurrence of

Clay minerals, occurrence of

Climate of the area

Connelly tunnel, features of

Copper, native, occurrence of

Copper minerals, occurrence of

Covellite, occurrence of

Crest fault, features of

Cuprite, occurrence of

Cyanotrichite, occurrence of

of

.

of

95

- 1 D

Datil formation, occurrence of

Diabase, occurrence and character of

Diopside, occurrence of

Dolomite, occurrence of

Drainage of the area.

E

East Slope fault, features of

Enterprise claim, features of

Epidote, occurrence of

145-148

30,104, pl. $12, A$

$55,103-104$

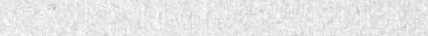

Faults, age of

Page

interpretation of

in the Granite Mountain area

north of the Nitt stock

south of the Nitt stock

Felsite, occurrence and character of

Felsite tuff, occurrence and character of

Field work in the area

Fluorspar, occurrence of

Folding in the area, age and general character of

Future development of the area

G

Gabbro, occurrence and character of _.....

Galena, occurrence of

Gangue minerals

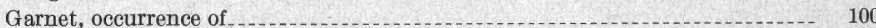

Geography of the area

Germany fault zone, features of ....

Germany mines, description of

ore mined at

Girty, G. H., fossils identified by

quoted $\ldots \ldots \ldots, 19,2$

Gold, occurrence of

Goslarite, occurrence of ............... 94

Grand Ledge fault, features of

Grand Ledge mine, description and section of ............................ 145-148

Grand Tower claim, description, plan, and section of ........ 148-150

Granite, pre-Cambrian Tertiary (?)

Granophyre, origin and character of . _ See also Hybrid granophyre.

Graphic-Waldo mine, description of _....... 124-132 generalized section in

ore shipped from

Greenockite, occurrence of $\ldots$

"Greenstone." See Argillite

Ground-water level in the area

Hardscrabble mine, description of

ore shipped from 158

Hedenbergite, occurrence of

Heister prospect, features of

Helen Cross group, ore shipped from

Hematitization in the southern area -----

Hemimorphite, occurrence of

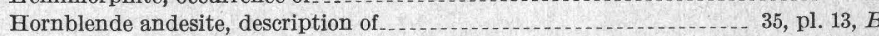

Hybrid granophyre, description of ....................... 41-42, pl. 18, $B$

Hydrozincite, occurrence of

Igneous rocks, pre-Cambrian ............ 8-12

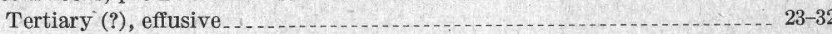

intrusive $32-47$

Imperial claim, features of

Intrusion of stocks, local faulting during .

Intrusive contacts, alteration far from $\ldots \ldots \ldots \ldots \ldots \ldots \ldots . . . \ldots 1-55$

alteration near 49-51

Iron Mask vein, features of

Iron minerals, occurrence of

\section{J}

Jarosite, occurrence of

Jarosite, occurrence

uanita mine, description of $\ldots \ldots \ldots$
ore produced at

K

Kelly fault block, diagram of .

Kelly-Graphic fault, features of

$60-61$ 
Kelly limestone, aqe and correlation of character and distribution of ore shipped from

Key mine, features of Kelly mine, description of

16

pls. $5,9.28$ 132-137

133

153,154

\section{L}

Lamprophyre dikes, occurrence and character of

Landslides, features of

Latite, occurrence and character of.

Latite dikes, character of

Latite porphyry, occurrence and character of

Lead minerals, occurrence of

Legal Tender claim, features of

Limestone, alteration of

Limonite, occurrence of

Linchburg tunnel, features of

Little Loella claim, features of

Location of the area

M

Madera limestone, description of fossils in

Magdalena group, description of fossils in

Magdalena Range, columnar section of sedimentary rocks in general features of

Magnetite, occurrence and character of

Malachite, occurrence of

Manganese minerals, occurrence of

Melanterite, occurrence of

Mineral deposits, distribution and elassification of formed at high temperatures

formed at low temperatures

formed at moderate temperatures

Minerals of the area

alphabetical list of

Mines of prospects, descriptions of

See also names of individual mines and prospects.

Mining in the area, historical sketch of-

Mississippian rocks, occurrence and character of

Mistletoe fault, features of

Mistletoe mine, description of ore shipped from

Mitchell tunnel, features of

Monzonite group, description of

Morning Star vein, features of

(1............ 4

24-25, 25-26, pl. 7, A

$32-33$

$9 \overline{7}-98,116$

148
$50-51$

91

144-145

$152-153$

5

18-19, pl. 9

20

$16-20$
$19-20$

pl. 8

5-6, pl. $5, B$ 90-91, 163, pl. 23

96
9116

99,116

92
-105

$105-106$

110

$106-110$

87-104

88

$123-163$

75-82

14-16

61

141-143

131-132

$36-39$, pl. $2,14,15,16$

156-15

Natrojarosite, possible occurrence of

Nitt mine, description of

generalized section through

ore shipped from

N

re, production of

O

Ore deposits, alteration of

distribution and classification of

formation of

historical sketch of

oxidized, occurrence and character of

Outlying prospects

Pegmatitic material, occurrence of

Pennsylvanian rocks, occurrence and character of

Permian rocks, occurrence and character of

Physiographic development of the area

Pitchstone, occurrence of

Plumbojarosite, occurrence of

Pre-Cambrian rocks, alteration of

correlation of

description of

Production of metals in Socorro County and Magdalena mining district, summary of

Prospects. See names of mines and prospects.

Psilomelane, occurrence of

Pyrite, occurrence of

Pyrolusite, occurrence of

Pyrrhotite, occurrence of

$$
\text { Q }
$$

Quartz, occurrence of

$123-124$

127
124

$82-87$

$118-123$

104-105

105-115

$75-82$

115-118

163

$16-20$

20-2

$73-75$, pls. 21,22

42

49-50

13-14

7-13

$82-87$

-99
$8-109$

91, 108-109

89
91

Quaternary formations, character and distribution of
Relief of the area

R

Page

Rhyolite, analysis of

occurrence and character of

44

porphyry, description of . ............................. 33-35, pls. 12, 13

magnetic facies in $34-35$

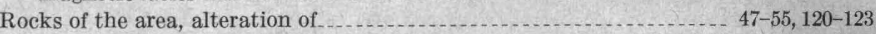

character and distribution of

claim, features of

Sandia formation, description of $\ldots . . .16-18$, pl.

fossils in $\ldots . . . .19-20$

Sandstone, replacement of ................

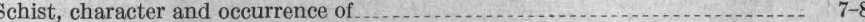

Sericite, occurrence 102

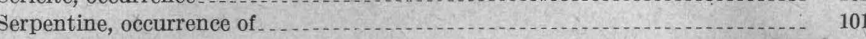

Shale, alteration of

Siderite, occurrence of

Silicification of the rocks

Silver, native, occurrence of _............ 98

Silver minerals, occurrence of . ............

"Silver pipe" beds, occurrence and character of _... 14-16

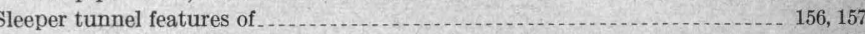

Smithsonite, occurrence of ................

South Juanita mine, description of ........

ore shipped from

Spangolite, occurrence of

Specularite, occurrence of ....

Sphalerite, occurrence of ........................................ 92, 109-110

Stendel fault, features of $\quad 64-65$

Stonewall fault zone, features of

Stonewall tunnels, description of

Structure in the area, Laramide and Tertiary _.......... $57-73$

Laramide and Tertiary, interpretation of ........... $65-73$

Mesozoic ....

Paleozoic _...

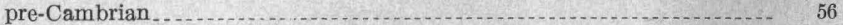

summary of $\ldots 55-56$, pls. $2,4,20$

Sulphide deposits, alteration of ... character and occurrence of _......................

See also under individual minerals.

$\mathrm{T}$

"Tallow clay." See Zinc-bearing clay.

Talus, occurrence of

Tenorite, occurrence of

Tertiary (?) structure

Thaumasite, occurrence of

Tip Top mine, features of

Topography of the area

Tourmaline, occurrence of

Tremolite, occurrence of.

Tuff, occurrence and character of

Vanadinite, occurrence of

Vegetation of the area

Victor tunnel, features of

Vindicator fault, features of

Vindicator mine, assay of ore from

description of

Wad, occurrence of

Waldo fault, features of

West Virginia tunnel, features of

White, David, fossils identified by quoted.

Willemite, occurrence of

Wollastonite, occurrence of

Woodland mine, features of

Y

Young America fault, features of

Young America mine, features of

61

Zinc-bearing clay, occurrence of

Zine blende ores, occurrence of

Zinc minerals, occurrence of

Zones of alteration.
(1)

rar

